\title{
Systemwide Plan
}

N.C. STATE LIBRARY RALEIGH

\section{for the}

\section{North Carolina State Parks System}

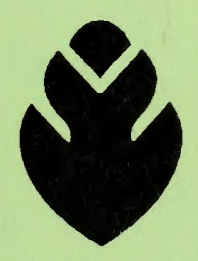

\section{December 1988}

Division of Parks and Recreation

NC Department of Natural Resources and Community Development

PO Box 27687

Raleigh, NC 27611-7687

The preparation of this report was financed in part through a Planning Grant from the National Park Service under the provisions of the Land and Water Conservation Fund Act of 1965 (Public Law 88-578).
The Division of Parks and Recreation does not discriminate against anyone on the basis of race, sex, color, national origin, age or handicap and is an equal opontuntity employer. If anyone foels that they been discriminated against, a complaint may be filed with either NRCD or the Equal Opportunity Otfice, U.S. Department of the Interior, Washington. D.C. 20240. 



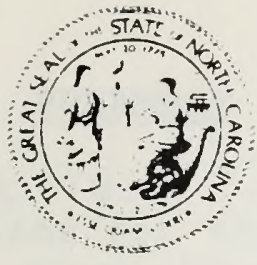

\section{STATE OF NORTH CAROLINA \\ OFFICE OF THE GOVERNOR \\ RALEIGH 27603-8001}

\section{JAMES G. MARTIN \\ GOVERNOR}

To The Citizens of North Carolina:

It is our pleasure to present the Systemwide Plan for the North Carolina State Parks System. This plan provides the foundation and framework upon which the state Parks System can be improved over the next five years. The report has been written in response to the 1987 State Parks Act which directs that the Systemwide Plan is to evaluate the resources of the existing system, identify duplications and deficiencies in the system and make recommendations for correction, and describe anticipated trends in usage of the system and detail what impacts these trends may have.

The Systemwide Plan is written at a time of great need to bring greater support to our state Parks System. An aging physical plant, inadequate staffing levels, and urban encroachment threaten the significant values preserved by our state parks. The system needs to be expanded in order to adequately protect the State's natural heritage and decent facilities should be provided in order to serve rapidly expanding use.

The State Parks Act charges the system with promoting pride and understanding in the State of North Carolina. We invite you to join us in our goal to make the North Carolina state Parks System the best in the nation.

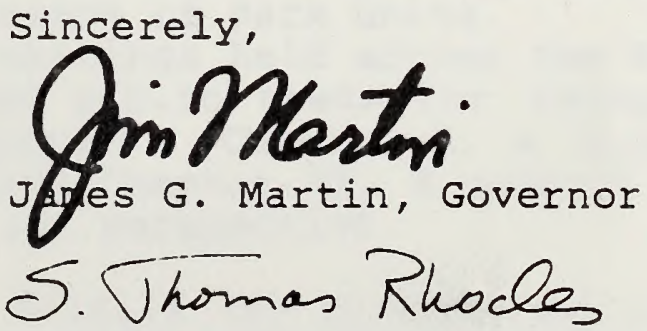

S. Thomas Rhodes, Secretary Department of Natural Resources and Community Development 
Digitized by the Internet Archive in 2016

https://archive.org/details/systemwideplanfo00nort 


\section{PREAMBLE}

The 1987 state Parks Act (G.S. 113-44.7 through 113-44.14) mandates that systemwide plans for the North Carolina state Parks System are to be prepared every five years. This report, the first systemwide plan, has been developed in direct response to that Act. The Act stipulates that systemwide plans are to:

1) Outline a method whereby the mission and purposes of the state Parks System as defined in G.S. 113-44.8 can be achieved in a reasonable, timely, and cost-effective manner;

2) Evaluate existing parks against these standards to determine their statewide significance;

3) Identify duplications and deficiencies in the current state Parks system and make recommendations for correction;

4) Describe the resources of the existing state Parks system and their current uses, identify conflicts created by those uses, and propose solutions to them; and

5) Describe anticipated trends in usage of the state Parks system, detail what impacts these trends may have on the state Parks system, and recommend means and methods to accommodate those trends successfuliy.

The Plan is to be developed with full public participation including a series of public meetings to collect views and information on the needs of the public for recreational resources in the state Parks system and views and information on the manner in which these needs should be addressed.

Chapter II within this report describes the resources of the existing state Parks system and proposes solutions to existing problems. Chapter III details anticinated trends and recommends means and methods to respond to those trends. Chapter IV identifies duplications and deficiencies within the system and determines the statewide significance of park units. Chapter $V$ reports the results of public meetings held across the state to collect views and information on public needs for recreational resources in the state parks system. Chapter I, a history of the development of the system, and chapter VI, a summary of the benefits of parks, are included for perspective.

In order to outline a method to fulfill the mission and purposes cf the state Parks system, recommendations are made throughout the report. The recommendations are logical outgrowths of information contained within the chapters. These recommendations should drive budget requests and, if support is made available, Division workplans. 
In order to develop an action plan, recommendations are grouped into nine logical categories in chapter VII. The categories include: capital development, expansion of the system, natural resources, programming, repair and maintenance, expansion of staff, staff training, policy implementation and planning, and increased funding. Actions are listed for each category which will boldly move the North Carolina State Parks System into tine next decade. 


\section{TABLE OF CONTENTS}

$\underline{\text { Topic }}$

$\underline{\text { Page }}$

I. THE DEVELOPMENT OF THE NORTH CAROLINA STATE PARKS SYSTEM. 1

A. Introduction.

B. I ounding of the State Parks System: 1891-1933.

1. Establishment of Mt. Mitchell State Park.

2. Fort Macon State Park.

3. Creation of a New Department.

4. Statutory Authority for Parks.

5. Rendezvous Mountain Transfer.

6. Lakes Act.

7. Conclusion.

C. Federal Public Works Programs: 1934-1941.

1. Civilian Conservation Corps Camps.

2. State Park Guidelines and Demonstration Parks.

3. Park, Parkway, and Recreation Area Study.

4. Conclusion.

D. Post World War II Developments: 1945-1955.

1. North Carolina Recreation Commission Created. 6

2. Division of State Parks Created.

3. Cape Hatteras and Historic Sites Transferred. 7

4. Kerr Reservoir Established.

5. State Park Principles.

6. Conclusion.

E. Growth Through Donations and LWCF Assistance: 1956-1970. 8

1. Natural Areas.

2. Land and Water Conservation Fund.

3. First State Park Study Commission.

4. Conclusion.

F. Program and Park Expansion: 1971-1979. 10

1. Additional Park Donations. 10

2. Merger of Kerr Lake, State Parks, and the Recreation Com. 11

3. Natural and Scenic Rivers Act.

3. Constitutional Amendment to Conserve and Protect North Carolina's Natural Resources. 12

4. State Trails Act. 12

5. Major State Appropriations. 13

6. Development of Master Plans. 14

7. North Carolina Environmental Policy Act 14

8. Natural Heritage Program. 14

9. Second State Park Study Commission. 15

10. Conclusion. 16

G. Reservoirs, Re-Evaluation, and New Initiatives: 1980-Present. 16

1. Jordan Lake and Falls Lake Opened. 16

2. Decline of the Land and Water Conservation Fund. 16

3. Drop in Appropriations.

4. Third State Park Study Commission. 17

5. The $1985 \$ 25$ Million Appropriation. 18 
Development of the North Carolina State Parks System (cont.)

6. Community Service Worker Program.

7. Adopt a Park Program. 20

8. State Goals and Policy Board Report of 1986.

9. Six-Point Plan. 21

10. Division Reorganization. 22

11. Fourth State Park Study Commission. 23

12. State ?arks Act. $\quad 24$

13. State Auditor's Report. 25

14. Conclusion. 27

H. Chapter Summary Conclusions $\quad 27$

II. EVALUATION AND DESCRIPTION OF SYSTEM.

A. Introduction. $\quad 42$

B. Description of the System. $\quad 42$

1. State Trails. 43

2. The Natural and Scenic Rivers System. $\quad 44$

C. Recreational Opportunities. $\quad 45$

1. Conclusion. 51

D. A Profile of the Typical State Park Visitor. 51

1. Conclusion. $\quad 54$

E. Description of the Physical Plant. 55

1. Capital Improvement Funding History. 57

2. Contributions of the Land and Water Conservation Fund. 59

3. Physical Plant Funding Needs. 60

4. Capital Improvement Project Cost Savings. 61

5. Maintenance and Repair Program. 62

6. Conclusion. $\quad 65$

F. External and Internal Threats. $\quad 67$

$\begin{array}{ll}\text { 1. Park Boundaries. } & 68\end{array}$

2. Land Acquisition Program. $\quad 70$

3. Rising Land Values. 71

4. Conclusion. $\quad 72$

G. Administration. $\quad 73$

1. Attendance Trends. $\quad 73$

2. Budget Versus Attendance. $\quad 77$

2. Budget and Attendance Comparisons. 77

3. Staffing. $\quad 80$

4. Concessions Management. 89

5. Volunteer Initiatives. 92

6. Conclusion. 93

H. The State of Planning for the State Parks System. 94

1. Conclusion. 96

I. State Fragmentation of Preservation and Interpretation. 97

J. Interpretation and Education Program. 98

K. Chapter Summary Conclusions. 99 
III. TRENDS AFFECTING THE STATE PARK SYSTEM.

A. Introduction. 101

B. Changing Social and Demographic Conditions. 101

1. Population.

101

2. Demographics.

102

3. Social Changes.

105

4. Technological Changes. 106

C. Activity Trends. 106

D. Management Implications. 107

E. Economic Changes. 112

F. Management Implications. 113

G. Changes in Transportation Systems. 114

H. Management Implications. 116

I. Political Trends. 117

1. Organized User Groups. 117

2. Environmental Change. 117

3. Senior Citizens. 118

4. Federal Government Role. 119

J. Management Implications. 119

K. Chapter Summary of Management Implications. 121

IV. DUPLICATIONS, DEFICIENCIES, AND STATEWIDE SIGNIFICANCE. 124

A. Introduction. 124

B. Methodology. 124

1. Overview. 124

2. Definition of Resource Themes. 125

3. Significance of Themes Within Regions. 125

4. Protection of Themes by State Park System Units. 126

5. Protection of Themes Within Geographic Regions. 126

6. Ranking of Park Units. 126

C. Duplications and Deficiencies in the State Parks System. 126

1. Archaeologic Theme Representation. 128

2. Biologic Theme Representation. 136

3. Geologic Theme Representation. 142

4. Recreation Theme Representation. 147

5. Scenic Theme Representation. 152

E. Statewide Significance of Parks. 157

F. Chapter Summary Conclusions. 160

V. PUBLIC MEETING RESULTS. 161

A. Introduction. 161

B. Methodology. 162

C. Analysis. 163

1. Increase Funding for Parks. 163

2. Expand Recreational Opportunities. 163

3. Increase Park Acreage. 164

4. Increase Staffing. . 164

5. Natural Resource Protection. 167

6. Increase Information/Awareness. 168

7. Interpretation and Education. 168

8. Improve Maintenance. 169

9. Other Topics. 169

D. Chapter Summary Conclusions. 169 
VI. BENEFITS AND VALUES OF THE STATE PARKS SYSTEM.

A. Introduction. 177

B. Preserving and Protecting Natural Resources. 177

C. Recreational Benefits and Values. 179

D. Social Benefits and Values. 180

E. Economic Contributions of the State Parks System. 182

1. Introduction. 182

2. Public Area Recreation Visitors Survey. 183

3. Implan Model. 183

4. Economic Effects of Recreational Expenditures by State Parks System Visitors. 185

5. Case Study: Economic Effects of a New State Park. VI-13 189

F. Chapter Summary Conclusions. 190

$\begin{array}{ll}\text { VII. RECOMMENDATIONS AND PROPOSED ACTIONS. } & 191\end{array}$

A. Introduction. 191

B. Action Plan. 211

1. Capital Development Program. 211

2. Expansion of the North Carolina State Parks System. 212

3. Natural Resource Protection. 214

4. Programming. 215

5. Repair and Maintenance. 216

6. Expansion of Field Staff. 217

7. Staff Training Needs. 218

8. Policy Implementation and Planning. 219

9. Increased Funding for the State Parks System. 220

VIII. SYSTEMWIDE PLAN CONCLUSIONS. 222

$\begin{array}{lr}\text { LITERATURE CITED } & 225\end{array}$

$\begin{array}{lr}\text { LIST OF ABBREVIATIONS } & 230\end{array}$

APPENDICES : $\quad 233$

Appendix I: Public Comment on the Draft of the Systemwide Plan and Response 234

APPENDIX I-1: The State Parks Act. 243

APPENDIX II-1: Park Profiles. 247

Bald Head Island 248

Bay Tree Lake State Park 249

Boones Cave State Park 251

Bushy Lake Natural Area 255

Carolina Beach State Park 256

Chowan Swamp Natural Area 261

Cliffs of the Neuse State Park 262

Crowders Mountain State Park 267

Dismal Swamp Natural Area 271

Duke Power State Park 272

Eno River State Park 277

Falls Lake State Recreation Area 283 
APPENDIX II-1: Park Profiles (Continued).

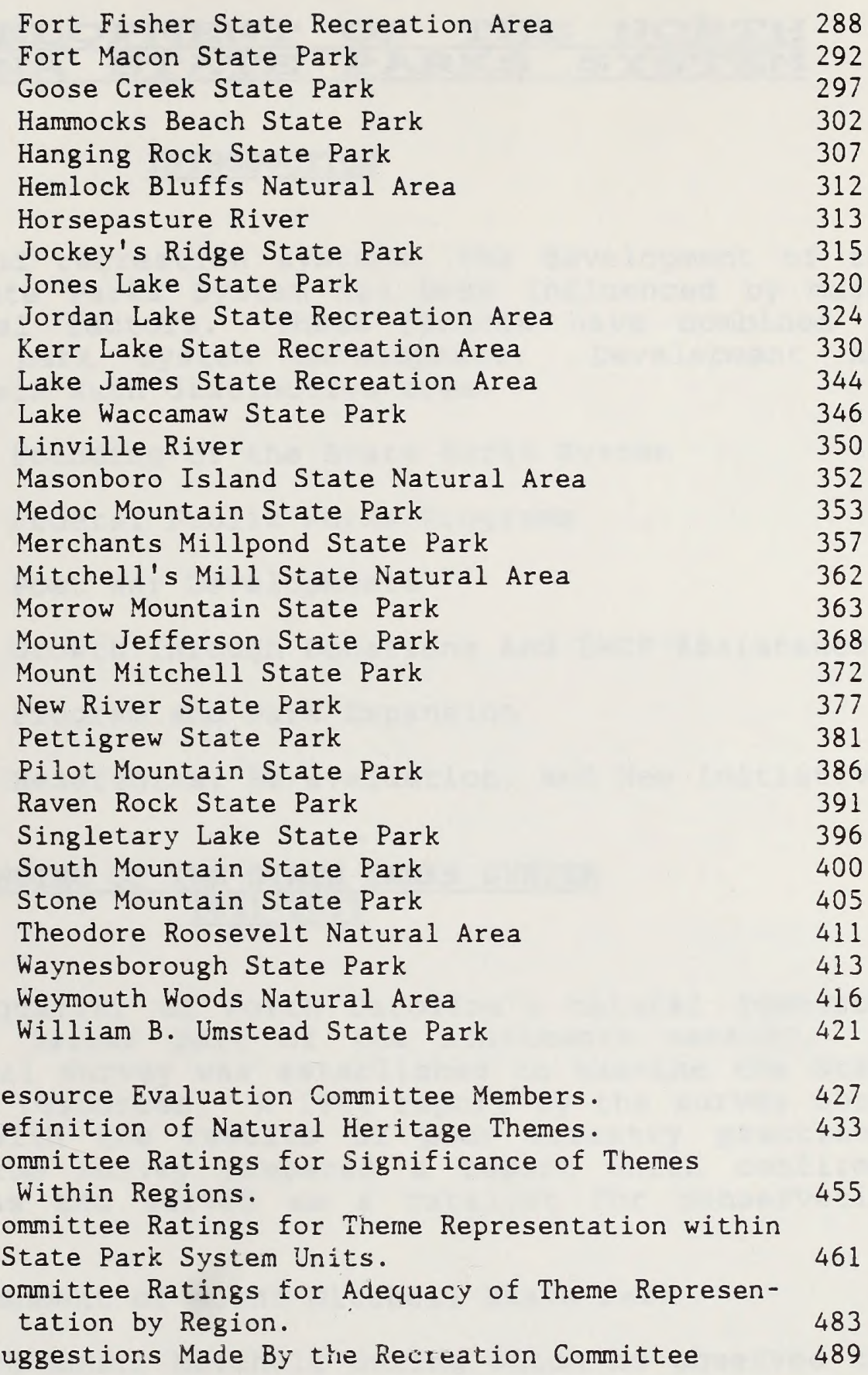

APPENDIX IV-1: Resource Evaluation Committee Members. 427

APPENDIX IV-2: Definition of Natural Heritage Themes. 433

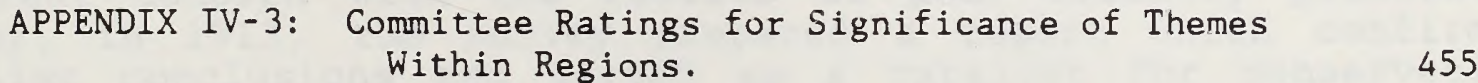

APPENDIX IV-4: Committee Ratings for Therne Representation within

APPENDIX IV-5: Committee Ratings for Adequacy of Theme Represen-

APPENDIX IV-6: Suggestions Made By the Recreation Committee 489 

CHAPTER I

\section{THE DEVEIOPMENT OF THE NORTH CAROIINA STATE PARKS SYSTEM}

\section{INTRODUCTION}

Like other park and recreation systems, the development of the North Carolina state Parks system has been influenced by major economic and social factors. These factors have combined to pattern eras of park system development. Development has proceeded through six such distinctive eras.
$1891-1933$
Founding of the state Parks system
$1934-1941$
Federal Public Works Programs
$1945-1955$
Post War Developments
$1956-1970$
Growth Through Donations and LWCE Assistance
$1971-1979$
Program and Park Expansion

1980-Present Reservoirs, Re-evaluation, and New Initiatives

\section{FOUNDING OF THE STATE PARKS SYSTEM}

$$
\underline{1891-1933}
$$

Concern with the quality of North Carolina's natural resources heightened in the latter part of the nineteenth century. In 1891, the Geological Survey was established to examine the state timber and mineral resources. A 1903 report by the survey noted a great concern with the results of poor forestry practices. Later, in 1913, the survey prepared a report which confirmed earlier conclusions and served as a catalyst for conservation efforts.

\section{Establishment of Mount Mitchell state Park}

Following a trip to Mount Mitchell during which he observed the devastation resulting from poor timbering practices, Governor Locke Craig encouraged the General Assembly to appropriate $\$ 20,000$ in 1915 to establish Mount Mitchell as the first State park. Reasons for the acquisition were cited in Chapter 76 of the Public Laws of 1915:

Whereas the summit of Mount Mitchell in Yancey County is the greatest altitude east of the Rocky Mountains, and whereas the headwaters of many of the important 
streams of the state are at, or near the said summit, and the forest is being cleared, which tends to damage and injure the streams flowing through the said state from the mountains to the Atlantic Ocean; and whereas it is deemed desirable that this beautiful and elevated spot shall be acquired and permanently dedicated as a state park for the use of the entire state seeking health and recreation; and whereas, unless the said land is acquired by the state at this time, the cost of acquiring it at a later date will be greatly increased and the watercourses may be damaged, and the beauty of the scenery destroyed by removing the growth therefrom, and irreparable damage accrue; ....

Mount Mitchell became North Carolina's first state park the next year with the acquisition of 795 acres. The park was administered under the Geological and Economic Survey from 1916 until 1925, when the Department of Conservation and Development was created (Figure I-1).

Fort Macon State Park

By 1923, Fort Macon was considered surplus property of the Federal Government and was listed for sale. The North Carolina General Assembly directed acquisition of the property, and 390 acres of the Fort Macon Military Reservation were acquired for one dollar in June of 1924, creating the state Parks System's second park (Table I-1).

\section{Creation of a New Department}

The Department of Conservation and Development, created in 1925 by the General Assembly, provided the first guidelines for management of the parks. The broad range of powers in the Department included fire prevention, reforestation, and maintenance of the state's parks and forests.

\section{Statutory Authority for Parks}

In 1925, the General Assembly passed G.S. 113-22, "Control of Mount Mitchell Park and other state parks." Its passage gave State parks their first statutory authority. The statute directed that "The Department of Conservation and Development shall have the control and management of Mount Mitchell Park and any other parks which have been or may be acquired by the state as state parks." While authorizing state parks, the statute did not offer any management direction or policy. State parks continued to be operated primarily under this authorization for many years. 
Rendezvous Mountain Transfer

During 1926, Rendezvous Mountain was donated to the state to become a park. Legend had it that the mountain was the campsite of the over-the-Mountain troops just before the historic battle of Kings Mountain. The history of the mountain was questionable and the park acreage small, so the Department transferred it to the State Division of Forestry in 1956.

\section{Lakes Act}

In 1927, the General Assembly directed the Department of Conservation and Development to "investigate and locate bodies of marsh and swampland, title of which is now rested in the state Board of Education, with the object of determining whether such parcels of land are suitable for state Parks, State Forests, State Game Refuge or Shooting Grounds" (Chapter 83, Public Laws of 1927). Seven Coastal Plain lakes (Bay Tree Lake, Lake Phelps. Lake Waccamaw, Jones Lake, Salters Lake, Singletary Lake, and White Lake) came under the Department's jurisdiction at this time. (Euller, 1977).

Chapter 165 of the Laws of 1929 specified that "all lakes now belonging to the state having an area of 50 acres or more" should be "administered as provided for other recreational areas now owned by the State". This allowed the Department of Conservation and Development to assume management authority for Black (now Bay Tree), White, Jones, Salters, and Singletary lakes. Although the State took control of these unique Carolina bay lakes, the land around the lakes was not acquired.

Also in 1929, the General Assembly enacted a law (Chapter 282) which established a majority policy for park land acquisition. Rather than park acquisition being funded by the state, "public spirited citizens" would henceforth purchase or donate land for such purposes.

\section{Conclusion}

Establishment of North Carolina's first state park, Mount Mitchell, came in response to threats to its natural resources. While this initial acquisition was completed with appropriated State funds, subsequent expansion in the number and size of park units was accomplished without such appropriations (Table I-1). Fort Macon was a gift of Federal surplus property, and the lakes came into the system through transfer of management and authority. This initial era of State park development ended with establishment of a policy which relied upon citizen action for future expansion of the State Parks System (Table I-2). While no management direction was given, the first statutory authority did direct the newly formed Department of Conservation and Development to operate Mount Mitchell and other State parks. 
FEDERAL PUBLIC WORKS PROGRAMS

1934-1941

The major growth period of 1934-1941 was influenced by the economic circumstances of the thirties. In response to the Great Depression, the Roosevelt administration placed millions of dollars into public works programs. The federally assisted programs created nine state parks in North Carolina.

\section{Civilian Conservation Corps Camps Built and Work Begins}

In the spring of 1933, new opportunity for state parks development was supported by the establishment of the civilian conservation corps (CCC). The first CCC camps were located at Fort Macon in 1934. Other detachments of the CCC were established by 1935 at Hanging Rock, Cape Hatteras, Mount Mitchell, Stanly County, and Morrow Mountain, where 1981 acres were donated by park support groups.

The CCC constructed recreation facilities such as lakes, picnic areas, trails, and roads and restored historical structures on State park lands. Over $\$ 2.25$ million in Federal funds went into the acquisition and development of nine North Carolina parks. The nine parks that were constructed by the work program included:

\author{
Fort Macon \\ Morrow Mountain \\ Hanging Rock \\ Cape Hatteras \\ Mount Mitchell
}

\author{
Jones Lake \\ Singletary Lake \\ Crabtree Creek (later renamed \\ Umstead) \\ pettigrew
}

In addition to state park development, the CCC was involved in reforestation and soil erosion projects including tree planting, fire fighting, timber stand improvement, erosion control, and recreational development outside of state park areas. More than 75,800 men from North Carolina were enrolled in the CCC, and more than 76,600 men served in North Carolina. An average of 45 camps a year were operated with a total financial obligation within the State of over $\$ 82,000,000$. (Cohen, 1980).

In order to administer the larger park system, the Branch of State Parks was created under the Division of Forestry in 1935. Mr. Thomas Morse was appointed the first Superintendent of Parks in order to oversee the development being done by the CCC.

State Parks Guidelines and Demonstration Parks

The new organization prompted a study of the recreational needs of the state of North Carolina in 1936. In cooperation with the 
State Planning Board and the National Park Service (NPS), official guidelines for the concept of a state Parks system were produced. The guidelines stated that areas to be acquired for State parks must:

- Have sufficient natural beauty and recreation possibilities;

- Preserve areas of natural beauty;

- Have sufficient historic or scientific value for statewide interest; and

- Preserve typical natural scenery near population centers.

These guidelines were considered by the NPS when it began development on Crabtree creek and Singletary Lake, two recreational demonstration projects. The crabtree creek area was chosen to rehabilitate worn out farmland located near Raleigh, Durham, and Chapel Hill and to demonstrate that such land could be made into useful recreational land. After establishing a CCC camp on the site, day use and camping area facilities were developed. Four thousand nine hundred and sixty-seven $(4,967)$ acres were turned over to the state in 1943. In 1955, Crabtree Creek State Park and the adjacent Reedy Creek State Park were combined and renamed to William B. Umstead State Park.

The Singletary Lake area, also submarginal farmland, was known as the Bladen Resettlement Administration from 1936-1939. The area was built for group camping with a recreation center which included an office, maintenance area, and other recreational facilities. The park was leased to the state in 1939, and deeded to the state in 1954.

Pettigrew State Park was established in 1947 in order to restore and preserve the historic plantations of Bonarva and Somerset and to provide for recreational use of Lake Phelps. (Fuller, 1977). The Work Projects Administration (WPA) helped in the restoration of the buildings on the plantation. The WPA also supplied funds and labor for construction of the swimming pool, bathhouse and lodge at Morrow Mountain, as well as funds and labor for bathhouse and beach development at Fort Macon. (Cohen, 1980).

Park, Parkway and Recreation Area Study

Working in cooperation with the NPS and the work Projects Administration, the Board of Conservation and Development approved the Park, Parkway, and Recreation Area Study. This study provided the first comprehensive plan for the state Parks system. The beginning of World War II halted the study and also marked the end of the CCC and WPA programs. 
Conclusion

State parks in North Carolina benefited greatly from the economic circumstances of the thirties (Table I-2). The civilian Conservation Corps, work Projects Administration and other Federal programs poured significant funds into the field of conservation to create jobs. These programs significantly expanded the State Parks System (Table $I-1$ ), and a separate State agency for parks was established for the first time. State financial commitment to its parks, however, remained minimal.

\section{POST WORLD WAR II DEVELOPMENTS}

1945-1955

In 1945, the impetus to create a well-rounded park system resurfaced. The initial land for Cliffs of the Neuse state Park ( 321 acres) was donated in 1945, and the General Assembly in 1947 made the first state park capital improvement appropriation, $\$ 500,000$. Cliffs of the Neuse state Park, which had recently opened, received $\$ 57,000$ of the appropriations in support of capital improvements.

\section{North Carolina Recreation Commission Created}

North Carolina, in 1945, created the first state Recreation Commission in the country. The Recreation Commission would operate separately from state Parks until 1971, when it was merged into the office of Recreation Resources. The Recreation Commission was to (1) study and appraise recreation needs of the State, (2) assemble and disseminate information, (3) promote and organize local recreation systems, (4) aid in recruiting, training, and referring recreators, (5) promote recreation institutes and conferences, (6) aid in establishing and promoting approved recreation standards, and (7) cooperate with public, private, and commercial recreation interests and individuals.

\section{Division of State Parks Created}

An increase in the demand for parks spurred the creation of the Division of State Parks in 1948 (Figure I-1). Separated from State Forestry, the Division immediately started to prepare a detailed study of its purpose and objectives.

In 1949, an appropriation of $\$ 1,074,144$ was made to the Division of State Parks to acquire lands within existing parks and to make improvements such as parking lots, bathhouses, and campgrounds. However, the infrequent and small appropriations over the years did very little to expand park system growth. This view was reflected in a statement by Mr. Ralph J. Andrews, former Director of State Parks, in 1952: 
Had it not been for these federal agencies, the development of the North Carolina state parks would now be little better than it was when Mount Mitchell was established 37 years ago. (Tilden, 1962).

Cape Hatteras and Historic Sites Transferred

Later in 1949, Cape Hatteras, the recipient of extensive CCC efforts, was leased to the Department of Defense for military purposes, and in 1952 it was deeded to the Federal government to become part of the Cape Hatteras National Seashore Recreation Área.

In order to allow the Division of State Parks to concentrate on developing recreational and scenic parks, the General Assembly in 1955 transferred historic sites to the newly formed Department of Archives and History.

\section{Kerr Reservoir Established}

The U.S. Corps of Engineers began construction of the Kerr Reservoir in 1946. The reservoir, completed in 1953, was designed for flood control and hydroelectric power generation. Recreational use was also authorized, and in 1951 North Carolina created the Kerr Reservoir Development Commission to manage recreation areas leased from the Corps of Engineers. The reservoir immediately became a popular recreation spot.

\section{State Parks Principles}

In January of 1955, the Board of Conservation and Development adopted new principles for the establishment and management of state parks. According to the Principles, "the purpose of the North Carolina State Parks System shall be -- to serve the people of North Carolina and their visitors by:

- Preserving and protecting natural areas of unique or exceptional scenic value;

- Establishing and operating state parks that provide recreational use of natural resources and outdoor recreation in natural surroundings;

- Portraying and interpreting plant and animal life, geology, and all other natural features; and

- Preserving, protecting, and portraying scientific sites of statewide importance. 


\section{Conclusion}

The post-war period was followed by increased park usage and the State's first appropriations for capital improvements in state parks. The North Carolina Recreation Commission was created in 1945, and its work was instrumental in the establishment of an extensive system of local government park and recreation programs. In 1951, the Rerr Reservoir Development Commission was established to manage the popular Kerr Lake recreation areas. A Divisiun of State Parks was established, separating parks from State Forestry, and a few years later, historic sites were transferred from state Parks to Archives and History. The Division focused on park development; and the era ended with the adoption of principles to govern the establishment, extension, and development of the state Parks System (Table I-2). State financial commitment during this period remained minimal.

\section{GROWTH THROUGH DONATIONS AND LWCF ASSISTANCE}

$$
\text { 1956-1970 }
$$

Beginning in 1956, a series of gifts served to add additional park units to the system. Mount Jefferson resulted from a donation by citizens of Ashe county arranged by a park support group. Hammocks Beach followed in 1961, a gift from the Hammocks Beach Corporation; and Duke Power Company donated land along Lake Norman in 1962 for Duke Power State Park (Table I-1).

\section{Natural Areas}

Because some of the areas being donated did not meet state park criteria and because of the growing importance of unique natural areas, in 1963 the Board of Conservation and Development adopted principles for natural areas. The principles stated that the purpose of natural areas was "To serve the people of North Carolina and their visitors by (1) preserving and protecting natural areas of scientific, aesthetic or geologic value. . . and (2) portraying and interpreting plant and animal life, geology, and all other natural features and processes in the various natural areas. That same year, the state's first natural area, Weymouth woods, was donated as a Sandhills Nature Preserve.

\section{Land and Water Conservation Fund}

In 1965, the Federal Government created the Land and water Conservation Fund (LWCF) which provided up to 50 percent matching funds for acquisition and/or development of outdoor recreation areas. The LWCF has been a primary funding source for state parks since 1965, with approximately $\$ 15.5$ million in assistance going into acquisition and development projects at 30 state parks, recreation areas, and natural areas. By matching state appropriations and donated land and money, the state has been able to purchase lands and construct new park facilities at a substantial discount. Pilot Mountain was one of the first parks to receive a large amount of LWCF assistance, receiving $\$ 682,711$ 
in the Federal funds in 1968. Stone Mountain and other parks followed with subsequent LWCF grants.

\section{First State Parks Study Commission}

The State Parks and State Forests Study Commission was created in 1967 by the General Assembly to examine outdoor recreation in North Carolina. Findings were related in a letter to the Governor and the General Assembly that stated:

In examining outdoor recreation in North Carolina and assessing the desires and needs of the populace, it became glaringly obvious that a bold new concept in the development of State parks would be necessary to meet these needs. As real property becomes more valuable and desirable, the state must undertake, now, a broad and realistic program for acquiring new parks and expanding existent parks. At today's economic values, we can no longer afford to sit idly by and wait for public spirited citizens to donate the entire state's responsibilities. Neither do we have the right to expect it.

The Study commission recommended a program with specific objectives to:

- Enlarge the State Parks System to accommodate an additional 2.1 million visitors per year;

- Create new state parks so most of the State's population will be within a one-hour drive;

- Improve and expand existing park facilities;

- Provide an equitable location of areas across the state that is consistent with area functions and classifications;

- Encourage advanced planning and land acquisition in areas of major water impoundments;

- Expand State park staff to administer site planning and development; and

- Insure access to public waters.

Most of the Study Commission's recommendations were never implemented or only partially followed as sufficient funding never materialized. However, as a direct result of the study, an 
immediate search for potential state park property began. Through the efforts of local supporters, naturalists, and the Conservation and Development Board, Carolina Beach State Park was purchased in 1969. This milestone marked the first park purchased by the state since Mount Mitchell in 1916. State funds were also used to match LWCF assistance in 1970 to acquire Raven Rock State Park. Appropriations for land acquisition, however, were short lived, and the state Parks system returned to its reliance on donations. Through 1970, gifts to the state Parks System accounted for crer 440 percent more land than the state had purchased.

\section{Conclusion}

The number of units in the State Parks System almost doubled from 1956-1970 (Table I-1). Most of the growth came about through donations of land and money. Such donations, after the advent of the LWCF in 1965, were often used as the state match for LWCF grant assistance for park acquisition and development purposes.

The first state Parks Study Commission recognized that more aggressive state action was needed and made recommendations for such action. Implementation of the recommendations, however, languished.

\section{PROGRAM AND PARK EXPANSION 1971-1979}

\section{Additional Park Donations}

Through the efforts of special interest groups and LWCF assistance, the size of the state Parks system continued to grow. In 1971, Boones Cave was donated by the Daniel Boone Historical Association. In 1973, land adjacent to Crowders Mountain was donated by local citizens (Crowders Mountain was acquired later). That same year, Merchants Millpond was donated by A. B. Coleman and the Nature Conservancy, and beginning acreage for Eno River State Park was donated by the Eno River Association.

The Eno River Association--a tax exempt, non-profit corporation--was organized in 1965 to prevent the Eno from being dammed for a water supply reservoir. The Association was to continue to play a vital role in continued state land acquisition efforts at Eno River through its success in obtaining legislative appropriations and through its fund raising efforts which provided the match for federal LWCF assistance. 
Merger of Kerr Lake, State Parks, and the Recreation Commission

Since 1951, the Kerr Reservoir Development Commission had been managing recreation areas at the 50,000 acre man-made kerr Lake. In 1971, State Parks, Kerr Reservoir, and the North Carolina Recreation Commission (which had been in existence since 1945) were merged as the Office of Recreation Resources under the newly formed Department of Natural and Economic Resources (DNER) (Figure I-1). The new office vas organized to serve as a focal point for the promotion, development, and administration of a recreation and park system.

With the addition of a new type of park unit, principles to guide the development and operation of recreation areas were developed by state park staff and adopted by the Park and Recreation Council. The principles, developed in 1974, stated "the purposes of the North Carolina State Recreation Areas shall be to serve the people of North Carolina and their visitors by:

- Providing areas where outdoor recreation pursuits shall be the dominant or primary objectives;

- Locating areas demographically to serve the State's growing population;

- Providing quality recreational experiences in the out-of-doors through recreational facilities of high-quality design and construction and through information and interpretive programs; and

- Operating and maintaining the recreation resource in such a manner as to insure standards of quality and to insure the health, safety, and welfare of its users.

Natural and Scenic Rivers Act

The Natural and Scenic Rivers system was created by the 1971 General Assembly to preserve and protect certain free flowing rivers, their water quality, and their adjacent lands for the benefit of present and future generations. The Act seeks to protect rivers with outstanding natural, scenic, educational, geological, recreation, historic, fish and wildlife, scientific and cultural values. The General Assembly recognized the "necessity for a rational balance between the conduct of man and the preservation of the natural beauty along the many rivers of the state." "The New River Scenic River and the Linville River became the first rivers included in the system through legislation passed in 1976. The New River was designated to stop a proposed impoundment. The New River Scenic River designation has been amended three times; the first to increase the length of river from four miles to 26.5 miles, the second to increase the fee simple limits from 400 to 550 acres, and the third to 
increase the fee simple limits. from 550 to 700 acres. The Linville River designation required no additional state action, for the segment designated flows through U.S. Forest service land.

Over the years, numerous rivers have been studied and found to qualify for designation. Lack of funding, as well as opposition to designation by local landowners, however, has prevented expansion of the system. Only the Horsepasture River, in 1986, has been added to the system.

\section{Constitutional Amendment to Conserve and Protect North Carolina's Natural Resources}

In the general elections held November 7,1972 , the citizens of North Carolina overwhelmingly approved a constitutional amendment to conserve and protect North Carolina's natural resources. The amendment, which broadly defined the conservation and protection of natural resources as a proper function of state and local governments, reads as follows:

It shall be the policy of this state to conserve and protect its lands and waters for the benefit of all its citizenry, and to this end it shall be a proper function of the State of North Carolina and its political subdivisions to acquire and preserve park, recreational, and scenic areas, to control and limit the pollution of our air and water, to control excessive noise, and in every other appropriate way to preserve as a part of the common heritage of this state its forests, wetlands, estuaries, beaches, historical sites, open lands, and places of beauty.

To accomplish the aforementioned public purposes, the state and its counties, cities and towns, and other units of local government may acquire by purchase or gift properties or interests in properties which shall, upon their special dedication to and acceptance by resolution adopted by a vote of three-fifths of the members of each house cf the General Assembly for those public purposes, constitute part of the "State Nature and Historic Preserve", and which shall not be used for other purposes except as authorized by law enacted by a vote of three-fifths of the members of each house of the General Assembly. The General Assembly shall prescribe by general law the conditions and procedures under which such properties or interests therein shall be dedicated for the aforementioned public purposes. (Article XIV, Section 5: Conservation of Natural Resources).

\section{State Trails Act}

The North Carolina Trails System Act was passed in 1973 to provide for a statewide trails system. The system included 
scenic trails, recreation trails, and connecting or side trails.

Volunteer efforts have been paramount in the success of the Mountains-to-sea Trail and other trail efforts.

State scenic trails are defined as extended trails so located as to provide maximum potential for the appreciation of natural areas and for the conservation and enjoyment of the significant scenic, historic, natural, ecological, geological or cultural qualities of the areas through which such trail= may pass. State recreation trails are defined as trails plannel principally for recreational value and may include trails for foot travel, horseback, non-motorized bicycles, non-motorized water vehicles, and two-wheel and four-wheel drive motorized vehicles. Connecting or side trails provide additional points of public access to state recreation or state scenic trails or provide connections between such trails.

\section{Major State Appropriations}

Three years following the report of the state Parks and state Forests study Commission, in 1971 a publication titled "Now or Never" was produced by DNER. It highlighted state Park establishment and acquisition needs.

Heightened awareness of the State's outdoor recreation needs resulted in state parks becoming a priority item of the Governor and the General Assembly in the early 1970s. The General Assembly responded in 1974 by appropriating $\$ 11.5$ million for land acquisition and $\$ 2.5 \mathrm{million}$ to improve existing facilities. In 1975, an additional $\$ 5.5$ million for land and $\$ 3$ million for capital improvements were appropriated. Although smaller in amount, appropriations continued through the end of the decade.

Growth of the system mushroomed as a result of the state appropriations. The state appropriations continued to be matched, where possible, with LWCF monies, thus allowing the State funds to have an even larger impact. Twenty-two thousand one hundred and seventy-three $(22,173)$ acres of land were acquired to establish new parks and to provide key expansions of several existing parks in the six years from 1974 through 1979, a 21 percent increase in total state Parks system acreage. Jockey's Ridge, South Mountains, Goose Creek, Medoc Mountain, Lake Waccamaw, Eno River, Crowders Mountain, and Merchants Millpond State Parks and the natural areas Dismal Swamp, Chowan Swamp, Hemlock Bluffs, Masonboro Island, Mitchells Mill, and Baldhead Island all received funding during the middle to late 1970 s (Table I-1).

In addition to the large appropriations of 1973, the General Assembly also passed a reorganizational act which split the Office of Recreation Resources into two divisions: the Division of Parks and Recreation and the Division of Resource Planning and Evaluation (Figure I-1). The separation ended in 1977 when the 
two divisions were reunited as the Division of Parks and Recreation.

\section{Development of Master Plans}

The early 1970's, with the establishment of the Master Planning Unit, represented the first time since the $1930^{\prime} \mathrm{s}$ (when the National Park Service master planned several of the parks) when a comprehensive and professional review of park land acouisition, development, and management needs was completed. The cesultant master plans were based on public input, recreation demand, and the "Principles." Private firms completed the first plans for Pilot Mountain, Stone Mountain, and Duke Power state Parks. The remaining plans were prepared by "in-house" staff who were supported by capital improvement appropriations. When the funds were depleted, the staff was deleted. The master plans that were prepared continue to guide the land acquisition and capital improvement programs. Some of the plans need major revision and parts of other plans require updating. The last state park to have a master plan developed was Hanging Rock in 1981, although the plan was never printed or publicly destributed.

\section{North Carolina Environmental Policy Act}

Through passage of the North Carolina Environmental Policy Act in 1971, the General Assembly declared that " ... it shall be the continuing policy of the state of North Carolina to conserve and protect its natural resources and to create and maintain conditions under which man and nature can exist in productive harmony." The purposes of the article are:

To declare a state policy which will encourage the wide, productive, and beneficial use of the natural resources of the state without damage to the environment, maintain a healthy and pleasant environment, and preserve the natural beauty of the State; to encourage an educational program which will create a public awareness of our environment and its related programs; to require agencies of the state to consider and report upon environmental aspects and consequences of their actions involving the expenditure of public moneys; and to provide means to implement these purposes.

The Environmental Policy Act had a direct affect on the way parks were master planned, developed, and operated.

\section{Natural Heritage Program}

During the 1970s, the preservation of outstanding natural areas became a major issue, and as an outgrowth of such concern, the Natural Heritage Program was created in 1976 with seed money from the Babcock Foundation and the Reynolds Foundation and technical 
assistance from the Nature Conservancy. The Natural Heritage Program's goals are to preserve the natural heritage of the State; to create a statewide inventory of natural diversity including exemplary and unique natural ecosystems, or endangered and rare species; and to make recommendations for the protection of outstanding areas and rare species habitats.

The Theodore Roosevelt Natural Area, donated by the heirs of Theodore Roosevelt in 1971, became the State's second naturpl area. Other natural areas and the years they came into the system are: Bushy Lake (1970), Dismal Swamp (1974), Chowan Swamp (1974), Hemlock Bluffs (1976), Masonboro Island (1976), Mitchells Mill (1976), and Baldhead Island (1979) (Table I-1).

\section{Second State Parks Study Commission}

In December of 1973, the Fiscal Research Division of the General Assembly completed a study of state Parks. The report noted that park facilities, many of them quite old, were not well maintained, and summarized park conditions by saying that "somewhere along the line, we [the state] have missed the boat." The report recommended consideration of a thorough upgrading and modernization of existing facilities.

A few years later in 1977, legislation was passed creating a second State Parks study Commission to prepare a report on the needs for parks and recreation in North Carolina. In response to that mandate, "New Directions", a five-year (1979-1984) plan for the state parks and recreation system was developed. The recommendations called for the acquisition of 11,447 acres at 25 sites to complete $35 \%$ of the master planned proposed acquisition; extensive capital improvements to increase recreational opportunities; 88 new staff positions; development of the state Natural Heritage Program; establishment of a Mountains-to-sea trail and emphasis on trails; cabin and marina development to increase revenues; designation of at least five natural or scenic rivers; and increased assistance to other recreation providers. In response to the North Carolina Environmental Policy Act, the report recommended that environmental impact statements be completed for all parks and recreation areas. The recommendations were many and far sighted. Unfortunately, few of them would be implemented (Table I-3) because limited funds were appropriated.

"New Directions" reflected a policy shift away from expansion in the number of park units. Instead, focus was placed on improving existing units through capital improvements and additional staffing and finishing of land acquisition at existing parks. 


\section{Conclusion}

The decade of the seventies witnessed many changes in the organization and development of the state Parks System. New program responsibilities broadened the scope of the State Parks System, starting with the addition of Kerr Lake, the North Carolina Recreation Commission, and the Natural and Scenic Rivers System in 1971. Further expansions came with the addition of State trails and the Natural Heritage Program (Table I-2). By the end of the decade, these programs were united administratively under the Division of Parks and Recreation (Figure $I-1$ ).

Not only did the decade see a doubling in the number of state Parks System units, but the acreage of many existing units also increased. Total acreage had increased from 55,173 acres at the beginning of 1970 to 116,978 in 1980 , a 112 percent increase in just ten years. The growth resulted primarily from the first significant appropriations ever made to the system, starting in 1974. Gifts and LWCF assistance also continued to be major factors in system growth (Table I-1).

In 1972, North Carolina citizens overwhelmingly approved a constitutional amendment to conserve and protect natural resources. The decade also ended on a promising note. Master plans had been developed for 22 parks. Appropriations for acquisition and capital improvement needs had been made for six straight years, and the second state Parks Study Commission had highlighted many needs still to be addressed.

\section{RESERVOIRS, RE-EVALUATION, AND NEW INITIATIVES \\ 1980-PRESENT}

\section{Jordan Lake and Falls Lake Opened}

Jordan Lake, opened in 1981, and Falls Lake, opened in 1983, were added to the State Parks system as recreational areas. Both of the recreational areas have been leased to the state by the Army Corps of Engineers for 50 years. The popular and heavily used facilities at both lakes greatly increased total visitation as well as visibility for the system. Fort Fisher became the fourth State Recreation area in 1986 after its transfer from the Department of Cultural Resources, Division of History and Archives.

Decline of the Land and Water Conservation Fund

The Land and Water Conservation Fund, which had been a significant outdoor recreation funding source for both local governments and the state since 1965, began to experience a decline in its funding. In 1982, for the first time since 
passage of the LWCF ACt, North Carolina received no annual apportionment. The cutback was a drastic reduction from the $\$ 7.2$ miliion received just three years earlier. In 1983, annual apportionments resumed, but on a much smaller scale than what was available during the seventies.

Through 1987, approximately $\$ 15.5$ million in LWCF assistance had gone into acquisition and development projects at 29 state parks, recreation areas, and natural areas. However, future use of LWCF assistance for the State Parks system is likely to offer only minimal help. The 1988 apportionment makes only $\$ 107,872$ available to the state for outdoor recreation projects.

\section{Drop in Appropriations}

The momentum of the seventies, which was built upon several years of steady appropriations and the "New Directions" report, stalled. Implementation of most of the recommendations from "New Directions" failed to materialize for lack of funding (Table I-3). During the five-year period from 1979-1984, \$2,272,000 was appropriated for both land acquisition and capital improvements. Only $\$ 465,000$ was appropriated for land acquisition of which $\$ 215,000$ was legislatively directed to Eno River state Park. By contrast, "New Directions" had listed $\$ 49,577,000$ in similar needs for the same period. Lack of State appropriations also prevented maximum use of LWCF assistance. LWCF funds and donations comprising the state's share of the IWCF projects carried the land acquisition program through this 5-year period. Staffing increases recommended by "New Directions," 88 positions in five years, also failed to materialize. Instead, State Parks system staffing increased by 15 positions. Staffing, at best, only held the status quo, for three new park units--including Jordan and Falls Reservoirs--were opened from 1979-1984.

\section{Third State Parks Study Commission}

Needs facing the state Parks system continued to receive publicity, and a third state Parks study Commission was created by the General Assembly in 1983. The report of the commission, as had the previous two study Commission reports in 1968 and 1979, noted many deficiencies in the state Parks system. As a result, it made numerous recommendations, including:

- Entry level pay increases and upward salary range revision for park personnel;

- Increased staffing, with a minimum of three rangers and a half-time clerk year-round; addition of a Trails

Coordinator; two staff persons for river protection; and two staff persons for natural heritage; 
- Purchase of 9,559 "critical" acres to complete the purchase of the primary resources for which a park or natural area was established to protect a park's scenic quality, to protect a park's watershed, to provide land for development, to eliminate inholdings, to protect important natural and geologic features, to protect habitat, to provide important buffer, and to protect park entrances at an estimated cost of $\$ 23$ million;

- Designation of the Horsepasture River as a State Scenic River;

- State acquisition of lands adjacent to the Horsepasture River for establishment of a State Park;

- Completion of the Mountains-to-Sea Trail ( $\$ 3.8$ million);

- Additional acquisition and protection of natural heritage areas $(\$ 160,000$ per year for five years);

- Additional capital improvement funds (\$43 million over six years);

- Endorsement of master plans and updating of plans;

- Purchase of two-way radios for rangers;

- Addition of telephone answering equipment at parks;

- Establishment of park support groups;

- A $\$ 50$ million bond referendum for land acquisition; and

- Establishment of a permanent dedication procedure for owners of natural heritage areas.

As shown, the third State Parks Study Commission made numerous recommendations for improving the state Parks System. While a few of these recommendations were acted upon, most have never been implemented (Table I-3) due to limited funding. The report did, however, emphasize many of the problems facing the state Parks System. Spurred by this emphasis, the General Assembly made a significant appropriation for park land acquisition.

\section{The $1985 \$ 25$ Million Appropriation}

The 1985 General Assembly authorized an appropriation of $\$ 25$ million to acquire critical park acreage to be split in half over a two-year period. Critical acres are those areas necessary to complete the purchase of the resource itself, acquire inholdings, provide areas for facility development, and acquire access and buffer zones. This large appropriation exceeded the total of prior state appropriations over the entire history of the state Parks System. 
While welcomed and needed, the $\$ 25$ million, which came after years of low or no land acquisition appropriations, did present some initial administrative problems for the Division. Priorities had to be set, tracts identified, property owners contacted, appraisals performed, surveys completed, and State acquisition procedures followed. The appropriated funds did not include personnel to implement the land acquisition, and Division personnel shifts had to be made to administer the funds. Early work consisted of re-evaluating acquisition needs for each park, prioritizing these needs, performing preliminary property title and tax work, and contacting landowners. The Division has control over less than one-half the 24 major steps needed to complete a land acquisition.

These steps resulted in the acquisition program starting slowly. By the time acquisition began to take place, the General Assembly--perceiving progress to be too slow--reacted with a series of changes and adjustments to the original $\$ 25$ million appropriation. Acquisition, development, and operations funds for the newly created Lake James state Park used \$2,655,000. A program to place community service workers in the parks used $\$ 1.2$ million. An additional $\$ 2.6$ million went towards park repairs and maintenance, and $\$ 2,265,000$ was designated for uses outside of the state Parks system. Funds were also diverted to acquire park acreage which had not been deemed critical. After these adjustments, $\$ 15,780,000$ remained to support acquisition of critical acres, leaving approximately $\$ 9.2$ million in critical acres which had been identified by the third state Parks study Commission still to be funded. In spite of these adjustments, the appropriation was a great boost to Division land acquisition efforts, allowing acquisition of approximately 175 parcels consisting of 7,601 acres.

\section{Community Service Worker Program}

With $\$ 1.2$ million taken from the 1985 Land Acquisition appropriation, $\$ 800,000$ for materials and $\$ 400,000$ for staffing, the 1986 short session of the General Assembly created the Community Service Worker Program to help address the pressing maintenance needs of the system. This program allowed offenders assigned by the courts to fulfill their sentences by performing labor to benefit the state Parks system. Projects performed by the workers ranged in scope from repairing trails and painting to complex reconstruction projects and costly surveys. At time of enactment of the Community service worker Program, park maintenance for the state Parks system consisted of seven maintenance personnel and an annual budget of $\$ 60,000$ for repairs.

Inadequate staffing of parks created some problems in administering work performed by community service workers. Although funding for peak load supervisors to oversee the work effort was eventually provided, often seasonal and experienced 
park professionals were needed to guide the work activities. Thus, ranger staffs were further stretched to oversee the program. The problems were sometimes exacerbated when workers did not report to parks at their scheduled times leaving peak load supervisors and park staff wondering where they were. Like the experience the federal land management agencies have had with increased volunteer efforts, there is a point of diminishing returns when the additional staff effort expended to oversee volunteer activities is not surpassed by the work accomplished. While the community service worker Program was no substitute for a professional maintenance staff, the program did significantly boost both the manpower and budget for maintenance.

Subsequent sessions of the General Assembly did not appropriate funds to continue the program, so it terminated in september of 1988. During its two-year existence, 5,907 community service workers performed 105,130 hours of labor in 55 of the park units. These projects represented an estimated savings of $\$ 841,040$ in labor costs.

\section{Adopt a Park Program}

In response to a proposal from the Department of Natural Resources and Community Development, the $Z$. Smith Reynolds Foundation awarded a $\$ 35,000$ grant to the Department on May 10 , 1985, to fund an Adopt-a-Park Program. The purpose of the program was to encourage citizen participation in the stewardship of the unique natural resources within the state Parks, and to provide an opportunity for the development of long-term support groups for the State Parks and Recreation Areas by establishing a mini grant program for groups interested in adopting a park.

In the fall of 1985, the Adopt-a-Park grants were advertised, and 45 groups applied for grants. In the spring of 1986 , a grant awards committee made up of six Department staff members and three citizens awarded thirteen grants for a total of $\$ 9,318$. A second funding cycle was advertised in January of 1987 and on March 19, 1987, 28 grants were awarded out of 33 applications for a total of $\$ 25,682$.

Projects developed by Adopt-a-Park groups ranged from trails improvements to construction of an amphitheater and preparation of educational materials and exhibits.

In August 1988, the Department submitted a grant proposal to. the Z. Smith Reynolds Foundation for $\$ 35,000$ for further development of the Adopt-a-Park Program. The proposal will be considered by the Foundation's Board of Directors at their meeting in May, 1989 .

\section{State Goals and Policy Board Report of 1986}

In its "Report to the Governor, May 1986," the State Goals and Policy Board made several recommendations for action relating to 
State parks (Table I-3). The six recommendations--developed after study, citizen testimony, and site visits--were as follows:

- Immediate emergency funding to elevate existing capital facilities to satisfactory condition. Top priority needs of $\$ 2.9$ million were listed. Other capital improvement needs were also noted;

- A one-time appropriation for two-way radio equipment;

- Interagency cooperation was possible and cost effective, including the use of Department of Corrections labor and Department of Transportation maintenance of roads and entrances;

- Preparation of a system plan for the state Parks System;

- Develop a guideline formula for capital improvements and operations funding. \$1.50 per visitor suggested; and

- Establishment of a trust fund to provide for future acquisition of recreational lands.

The report stated that "North Carolina's parks and recreation system is in generaliy deplorable condition, is a burden to the full development of the state's tourism industry, and is inarguably a worst-case example of abuse of public trust and abdication of responsibility." It noted that the system suffered "from deterioration of aging capital facilities, inadequate staffing, lack of preventive maintenance, absence of emergency services and procedures, and a limited plan for protective acquisition of new lands."

The State Goals and Policy Board did have some optimistic comments regarding the state Parks System. It recognized that of all the institutional needs the Board addressed, "...The parks system may represent one of the greatest opportunities to make immediate and lasting improvements at the least cost." It also saw state Parks System investment as aiding natural resource protection, quality of life, tourism, and business recruitment efforts.

\section{Six-Point Plan}

In 1986, the Department of Natural Resources and Community Development and the Division perceived the state Parks system to be at a crossroads. Both internal and external studies had 
identified many problems: no enabling legislation and strategy for the future; new parks added without study; existing parks without adequate support; only 31 of 51 units with facilities or staff; major maintenance and repair needs without a reliable source of funds; under three full-time employees per park; rangers performing daily maintenance instead of resource management and interpretation; only eight permanent maintenance personnel; critical acres not acquired; no park brochures, maps, or literature for the public; needed training in search and rescue, emergency medical services, fire fighting, law enforcement, and disaster preparedness; no communication equipment; poor ranger housing; declining LWCF assistance; and sporadic and inconsistent funding support for the state Parks System.

To address these critical problems facing the State Parks System, the Department developed six goals and corresponding actions which collectively represented a pathway for the future. The goals were:

- Parks for Tomorrow: develop a strategy for parks and recreation for the future.

- Capital Improvement/Maintenance: make necessary improvements and establish a secure foundation to maintain and manage park resources.

- Resource Protection: protect precious limited natural resources.

- Land Acquisition: complete the State Parks System, as quickly as possible.

- Visitor Programs/Activities: expand park education programs and insure visitor health and safety.

- Funding Methods: develop a consistent funding source to manage, maintain, and expand the State Parks System.

The Six-Point Plan, along with proposed legislation which would specify the purpose of the state Parks System and statutorily establish the System, were presented in 1986 to the fourth State Parks Study Commission.

\section{Division Reorganization}

Significant reorganization of the Division took piace in september of 1986. As a result, four of the seven regional office positions were eliminated along with two consulting positions in the Raleigh office. In an effort to improve both the quality and efficiency of consulting services to the general public, the Division contracted for these services with the University System. 
At the same time, a visitor services branch was created within the operations section. The overall impact of the realignment was to increase capabilities to provide services to visitors, train staff, and become more responsive in strategic planning. The new branch of Visitor Services included an interpretation and education group, consisting of a Head of Interpretation and Education, an exhibits specialist, a publications editor/writer, and a volunteer services coordinator. Other new positions focused on public safety and concessions management. The statewide trails cosrdinator and chief of maintenance were reorganized into the Jisitor Services Branch.

Other changes included creation of a District superintendent position for the three reservoirs, and a training coordinator's position staff development specialist's position.

\section{Fourth State Parks Study Commission}

The General Assembly recognized that the State Parks System faced continuing problems and needs and that the system needed further attention. As a result, a fourth study commission was authorized in 1985 .

By this time, annual visitation had increased to over six and one-half miliion visitors. Fifty-two units, covering over 123,000 acres of land and water, were managed by the Department of Natural Resources and Community Development's Division of Parks and Recreation. The value of these lands and waters were then conservatively estimated at $\$ 350$ million. These fifty-two units included twenty-eight parks, nine natural areas, two scenic rivers, one natural river, four recreation areas, seven state lakes, and one state trail. Not all of the fifty-two units were staffed and operated by the Division. Due to inadequate support, the Division was able to operate only 33 of the units.

The fourth study Commission met nine times in 1985-87, addressing a variety of topics and concerns including developing a long-term strategy, capital improvement and maintenance needs, resource protection, land acquisition, visitor programs and activities, and funding methods. The study commission Report, made to the General Assembly, contained ten recommendations. Several of these were acted upon by the 1987 General Assembly, including:

- An act to establish the purposes of the state Parks System;

- Funding for park radios of $\$ 600,000$;

- Four trail coordinators and Adopt-a-Trail funds; and

- Unfreezing of $\$ 5,000,000$ frozen from the 1985 appropriation for the purchase of "critical areas." 
While the General Assembly did remove the freeze on $\$ 5,000,000$ in land acquisition funds, only $\$ 545,000$ of it went towards the purchase of critical acres specified in the original act.

Funding for park radios marked an important moment for state Parks System management. Without communication equipment, field staff was hampered in its ability to effectively and efficiently operate. With the radios, staff were better able to provide for the safety of park staff and visitors, increase operations and maintenance efficiency, and provide better law enforcement capability.

Trail legislation passed in 1987 created four regional trail coordinator positions to enable the Division to work effectively in establishing and maintaining trails and coordinating volunteer efforts. Adopt-a-Trail legislation was also passed to coordinate with the Trails Committee and local groups or persons on trail development and maintenance.

The General Assembly rejected the Study Commission's recommendation to appropriate $\$ 25$ million over the 1987-89 biennium for land acquisition and capital improvements. Instead, a capital improvement appropriation of $\$ 3.8 \mathrm{million}$ was made. The General Assembly also failed to act on the commission's recommendation that a trust fund be established from private funds matched by public money to endow the land acquisition, operations, and capital improvement programs. It did, however, create a recreation and natural heritage fund for state agencies. An initial appropriation of $\$ 275,000$ funded three acquisition projects (one within the Division) and two natural heritage inventory projects. Additional recreation and natural heritage funds were not appropriated by the 1988 General Assembly.

\section{State Parks Act}

The most important outgrowth of the fourth study commission was the passage of an act to establish the purpose of the state Parks system. Prior to its passage, North Carolina's state parks were operated primarily under G.S. 113-23, originating from 1915 legislation, which states that "The Department of Natural Resources and Community development shall have the control and management of Mount Mitchell Park and any parks which have been or may be acquired by the state as State Parks."

Since its origin in 1916, the state Parks system sought to protect North Carolina's natural resources while also providing outdoor recreation opportunities. However, no law existed which defined the purpose of the system and, therefore, policies and direction were subject to change as administrations, personnel, and public opinion changed. Since the "Principles" were not legally binding, adherence to them was subject to change. The Study Commission and the General Assembly saw the need to have the system protected by a legal mandate, and the state Parks Act resulted in 1987 . 
The State Parks Act defined the purpose of the state Parks system as protecting representative examples of North Carolina's unique biological, recreational, geological, scenic, and archaeological resources for future generations and providing for the public's enjoyment of those resources. The Division was directed to carry out the mission and to prepare a state Parks Systemwide PIan.

The Act makes the preservation of unique resources and the provision of appropriate outdoor recraation opportunities a legal requirement. It further outlines the process for adding or deleting parks. Additions of individual parks must be associated with adequate authorization and appropriation for operation, development, and acquisition through majority vote of the General Assembly. Deletions of park units also require majority vote of the General Assembly. Park, as defined by the Act, means any tract of land or body of water comprising the state Parks system including existing state Parks, State Natural Areas, State Recreation Areas, State Trails, State Rivers, and State Lakes.

The Act mandates the preparation of a system Plan, of which this chapter is a part, which must be developed by December 31, 1988 . The plan is to serve as an overall strategy for the future. It is to evaluate existing parks; identify deficiencies or duplications in the current system; describe the resources of the system and the current uses and conflicts of uses in the parks; and describe anticipated trends in the use of the parks, the impacts of the trends and recommend ways to accommodate the trends. Designed to be a working document, it must be reviewed and revised every five years.

The State Parks Act also directs that every park shall have a general management plan. The plan shall include a statement of purpose for the park based upon its relationship to the system Plan and its classification as to its purpose or purposes. An analysis of the major resources and facilities on hand to achieve those purposes shall be completed along with a statement of management direction. The general management plans shall be revised as necessary.

State Auditor's Report

In December of 1987, the office of State Auditor completed an extensive performance audit of the Division of Parks and Recreation. The purpose of the audit was to examine the management and operation of the state Parks system and report findings and recommendations relative to operational areas where improvements might be achieved. The audit included examination of study commission reports and the state Goals and Policy Board's report, visits to 24 parks, discussions with central office and field staff, examination of national and state data on park operations, and reviewed internal management initiatives. 
Findings and recommendations of the audit included the following:

Staffing -

Management units with no staff or little staffing were found, along with heavy reliance on peak load and seasonal staff. The audit recommended top priority for basic field support and that the 1988 state Parks Study Commission evaluate the issue of appropriate staffing. A need for basic staffing to cover ranger responsibilities, general maintınance work, and clerical support was noted.

Ranger Classifications -

Park Ranger classifications were found to be low, and review by State Personnel was recommended.

Housing -

Inequitable compensation exists between rangers with housing and those without. Establishment of adequate housing should be a top priority.

Land, Physical Plant, and Funding -

Needs for repairs, renovation, and park development remain significant. The major challenge confronting the State Parks System is how to meet these needs. The audit recommended study by the 1988 Study Commission. The need for "...future funding strategies should be long term and comprehensive, and multiple needs should be recognized to provide for balance in addressing deficiencies. Legislation which would establish the General Assembly's long-range funding proposal was recommended.

Preservation and Interpretation -

The audit noted that several state agencies are

involved in the preservation and interpretation of public resources, which may result in fragmentation and duplication. A study of whether consolidation might be more efficient and effective was recommended.

The audit report also addressed a course of action should the necessary resource commitment not surface. In that event, the serious consideration of ..."transferring current management units to local governmental entities or closing parks and consolidating existing resources at the parks with the greatest statewide significance" should be made by the Department and General Assembly.

The effect of the State Auditor's report is still to be determined (Table I-3). Many of its recommendations for further study were made to the fifth State Parks Study Commission which will be reporting to the 1989 General Assembly. 
After a retrenchment in appropriations for land acquisition and capital improvements from 1980-1985, the State Parks System again became a priority. A large appropriation for land acquisition resulted from recommendations of the third state Parks study Commission and General Assembly action. The need to develop a continuous planning process which would evaluate the existing system and provide guidance for the future was recommended by the fourth study Commission. The General Assembly s usequently passed the State Parks Act. The act established the purposes of the State Parks System, directed the Division to complete a state Parks Systemwide Plan, and called for the development of general management plans.

Recent state Parks study Commissions have achieved success in gaining increased support for the state Parks System. Even with increased support, many needs remain unmet. Over the last ten years, studies by Legislative Study Commissions in 1979, 1985, and 1987, as well as studies by the state Goals and Policy Board and State Auditor, have consistently reported on the needs for land acquisition, improvements to the physical plant, adequate staffing, and increased and steady funding.

\section{CHAPTER SUMMARY CONCLUSIONS}

Federal funding and private donations have played a major role in the expansion of the state Parks system. Public works programs during the 1930s assisted in the creation of nine state parks. Donations and LWCF assistance supported major park system expansion from 1960-1980. LWCF assistance has significantly declined since 1982. Through reliance on donations, federal assistance, and sporadic funding, the State has not developed the state Parks System in response to priority needs. Rather, the development of the system has been piecemeal and reactive.

- -RECOMMENDATION I-1: New, expanded, and constant sources of support for the system must be developed to supplement declining federal funding.

--RECOMMNDATION I-2: Expansion of the system must follow priorities set by the State through professional analyses in order to make the best use of the public's investment.

- With the exception of two time periods, 1974-1979 and 1985-1987. State financial commitment to development, acquisition, and operation of the state Parks System has been relatively weak. After acquiring the first state parks in 1916 and 1924, State policy prohibited park acquisition through appropriations until 1969. When appropriations were made, major improvements occurred in the system. 
--RECOMARDATION I-3: The State should increase its financial commitment to the State Parks System.

- Statutorily patterned policy for operation and expansion of the system has been weak. Meaningful statutory policy for State parks did not exist until 1987. Administration of State parks has gone through several reorganizations. Shifting emphases have detracted from the efficient development of a comprehensive state park system.

--RECOMENDATION I-4: Development and administration of the State Parks System must follow a consistent, steady course of action following a well-defined, fixed policy grounded in statutory law.

- The State Parks System has undergone many examinations. Since 1936, three comprehensive plans have been developed for the State Parks System. Since 1967, four Legislative Study Commissions have examined the system and made recommendations for improvements and emphasized the need for additional funding, and a fifth Study Commission will report in 1989. These examinations of the system, along with studies by the state Goals and Policy Board and state Auditor, have consistently emphasized funding needs for land acquisition, capital improvements, and staffing. These studies have gained attention, and some significant advancements have been made.

--RECOMMENDATION I-5: Legislative study commissions should continue to be appointed until adequate improvements have been made in the system. 


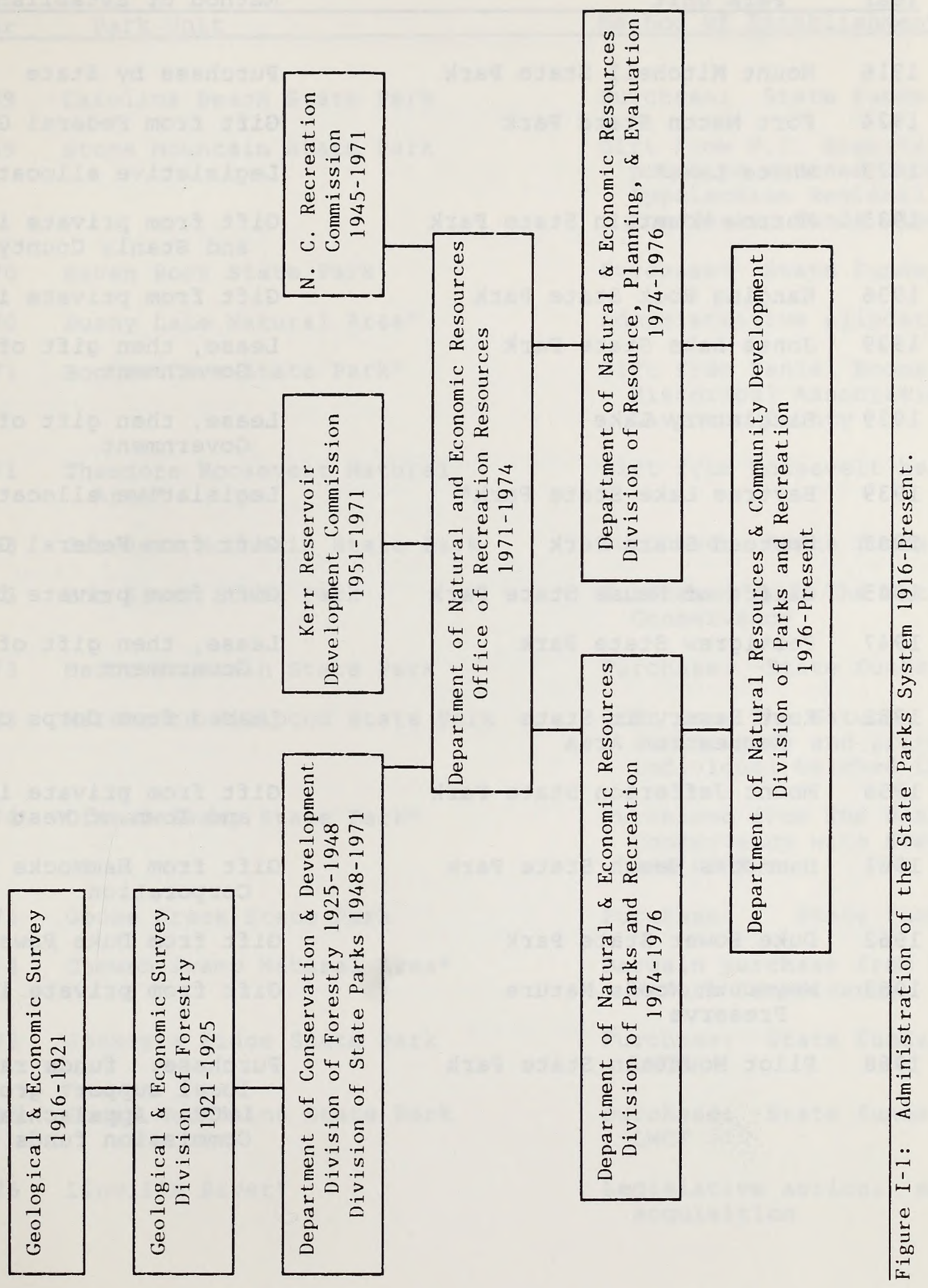


Table I-1. Year and Method of Park Establishment.

Year Park Unit

1916 Mount Mitchell state Park

1924 Fort Macon State Park

1929 White Lake*

1935 Morrow Mountain State Park

1936 Hanging Rock State Park

1939 Jones Lake State Park

1939 Singletary Lake

1939 Baytree Lake State Park*

1943 Umstead State Park

1945 Cliffs of Neuse State Park

1947 Pettigrew State Park

1951 Kerr Reservoir State Recreation Area

1956 Mount Jefferson State Park

1961 Hammocks Beach State Park

1962 Duke Power State Park

1963 Weymouth Woods Nature Preserve

1968 Pilot Mountain State Park
Method of Establishment

Purchase by state

Gift from Federal Government

Legislative allocation

Gift from private individuals and stanly county

Gift from private individuals

Lease, then gift of Federal Government

Lease, then gift of Federal Government

Legislative allocation

Gift from Federal Government

Gift from private individuals

Lease, then gift of Federal Government

Leased from Corps of Engineer

Gift from private individuals and Town of West Jefferson

Gift from Hammocks Beach Corporation

Gift from Duke Power Company

Gift from private individual

Purchase: funds raised by local support group matched LWCF. Appalachian Regional Commission funds also used. 
Table I-1. Year and Method of Park Establishment. (Continued)

Year Park Unit

1969 Carolina Beach State Park 1969 Stone Mountain State Park

1970 Raven Rock State Park

1970 Bushy Lake Natural Area*

1971 Boones Cave State Park*

1971 Theodore Roosevelt Natural Area *

1973 Crowders Mountain State Park

1973 Eno River State Park

1973 Medoc Mountain State Park

1973 Merchants Millpond State Park

1974 Dismal Swamp State Park*

1974 Goose Creek State Park

1974 Chowan Swamp Natural Area*

1975 Jockey's Ridge State Park

1975 South Mountains State Park

1976 Linville River*
Method of Establishment

Purchase: State funds

Gift from N.C. Granite Corporation matched LWCF. Appalachian Regional Commission funds also used.

Purchase: State funds and LWCi

Administrative allocation

Gift from Daniel Boone Historical Association and Davidson County

Gift from Roosevelt heirs

Purchase: State funds

Purchased from The Nature Conservancy

Purchase: State funds

Gift from The Nature Conservancy and private individual matched LWCF.

Purchased from The Nature Conservancy with state funds and LWCF

Purchase: State funds

Bargain purchase from the Nature Conservancy

Purchase: State funds and LWCE

Purchase: State funds and LWCF

Legislative action: no acquisition 
Table I-1. Year and Method of Park Establishment. (Continued)

Year Park Unit

1976 Hemlock Bluffs Natural Area*

1976 Lake Waccamaw State Park

1976 Masonboro Island Natural Area *

1976 Mitchelis Mill Natural Area*

1977 New River Scenic River

1979 Baldhead Island Natural Area*

1979 Waynesborough Park

1982 Jordan Reservoir State Recreation Area

1983 Falls Reservoir State Recreation Area

1986 Fort Fisher Recreation Area

1986 Horsepasture River*

1987 Lake James State Park
Method of Establishment

Purchase: State funds and LWCE

Purchase: State funds

Purchase: State funds

Gift from Martin Marietta Corporation

Gift of easements and state and LWCF purchases

Gift from The Nature Conservancy

Gift from City of Goldsboro

Leased from Corps of Engineers

Leased from Corps of Engineers

Purchase: State funds and LWCF. Transferred from Department of Cultural Resources to the Division.

Legislative action. No acquisition

Purchase: State funds

*No permanent/full-time staff 


\section{1-1933 FOUNDING OF THE STATE PARKS SYSTEM}

1891 Geological survey for North Caroiina established: examined the nature and extent of mineral and timber resources.

1905 Geological survey reorganized into the North Carolina Geological and Economic Survey: examined mineral, forest, fish, and all other material resources of the State.

1915 Bill passed to establish Mount Mitchell state Park. Initial land acquisition of 795 acres took place in 1916.

1921 Division of Forestry created within the Geological and Economic Survey. Parks administered under Forestry.

1924 Fort Macon acquired. Gift of Federal surplus property.

1925 Creation of the Department of Conservation and Development: charged with fire prevention, reforestation, state forests and parks.

1925 General statute 113-22 gives the Department of Conservation and Development control of Mount Mitchell and other state parks.

1927 Chapter 83: Directed Department of Conservation and Development to investigate bodies of swampland and determine suitability for state parks.

1929 Chapter 165: Directed that state owned lakes of 50 acres or more be administered, as provided for other recreational areas, by the Department of Conservation and Development.

1929 Chapter 282: Established policy that new park land would not be purchased by the state, but that "public spirited citizens" would purchase or donate land for park purposes. 


\section{4-1941 FEDERAL PUBLIC WORKS PROGRAMS}

1934-1941 Civilian Conservation Corps and other federal public works expended $\$ 2.25$ million for park development. Resulted in the establishment of Morrow Mountain, Hanging Rock, Jones Lake, Singletary Lake, Pettigrew, and Umstead State Parks.

1936 The Recreation Area Study: Formed a list of requirements for establishing areas to be state parks. Requirements included natural beauty, recreation possibilities, statewide historic or scientific values, natural scenery, and location near population centers.

1940 Park, Parkway and Recreation Area Study: Prepared a comprehensive plan for establishing the administration and operations of a state Parks system. It was not funded, as World War II directed attention from parks.

\section{5-1955 POST WAR DEVELOPMENT}

1945 Cliffs of the Neuse donated to the State.

1945 The North Carolina Recreation Commission, the country's first, was established.

1947 General Assembly appropriated $\$ 50,000$ for the construction of public facilities. Marked the first state park capital improvement appropriation.

1948 State Parks elevated to divisional status within the Department of Conservation and Development.

1949 General Assembly appropriated $\$ 1,074,144$ to the Division of Parks for the purchase of small tracts of land within park boundaries and for the construction of roads, parking areas, and other types of facilities.

1951 Kerr Lake Reservoir opened under the Kerr Reservoir Development Commission.

1955 General Assembly transferred historic sites from the Division of Parks to the newly formed Department of Archives and History. Legislature wanted the Division of Parks to concentrate on recreational and scenic values.

1955 Board of Conservation and Development adopted State Parks Principles. 
Table I-2. Development of the State Parks System. (Continued)

\section{6-1970 GROWTH THROUGH DONATIONS AND LWCF ASSISTANCE}

1956 Mount Jefferson donated by Ashe County citizens.

1961 Hammocks Beach donated by North Carolina Teachers' issociation.

1962 Duke Power State Park donated by Duke Power Company.

1963 The Board of Conservation and Development adopted principles for state natural areas.

1963 Weymouth woods Nature Preserve donated.

1965 Land and Water Conservation Fund, a federally funded program to provide matching funds for park land acquisition and development, was created.

1967 State Parks and State Forest Study Commission: Created by the General Assembly to examine outdoor recreation. The study recommended purchasing new parks, upgrading existing facilities, and expanding staff.

1968 Pilot Mountain purchased with private assistance and LWCF.

1969 Stone Mountain donated.

1969 Carolina Beach State Park, the first state park to be purchased with state funds since 1915, was purchased.

1970 Raven Rock State Park acquired by the State using matching LWCF federal funds.

1970 Bushy Lake Natural Area allocated to State Parks.

\section{1-1979 PROGRAM AND PARK EXPANSION}

1971 Boones Cave and Theodore Roosevelt Natural Area donated.

1971 "Now or Never": Report identified potential park lands, lost opportunities, and highlighted the need for action.

1971 State Parks, Kerr Reservoir, and Recreation Commission merged under the Department of Natural and Economic Resources as the office of Recreation Resources. 
1971 Natural and Scenic Rivers System Act passed.

1971 North Carolina Environmental Policy Act passed.

1972 A constitutional amendment to conserve and protect North Carolina s natural resources was passed.

1973 North Carolina Trails System Act passed.

1973 Appropriation of $\$ 11.5$ million for new park lands and $\$ 2.4$ million to improve existing facilities.

1973 Crowders Mountain, Eno River, Medoc Mountain, and Merchants Millpond were established.

1974 Dismal Swamp, Goose Creek, and Chowan Swamp established.

1974 The Division of Planning and Evaluation established principles for State recreation areas.

1974 Master Planning Unit established.

1975 General Assembly appropriated $\$ 5.5$ million for park lands and $\$ 3$ million for capital improvements.

1975 Jockey's Ridge and South Mountains established.

1976 Natural Heritage Program established. Hemlock Bluffs, Lake Waccamaw, Masonboro Island, and Mitchells Mill established. Linville River designated as a component of the Natural and Scenic Rivers System.

1977 New River State Park established.

1979 "New Directions": Report from the second State Park study commission (created in 1977) recommended expanding existing parks, increasing recreational activities and staffing, and increasing revenues generated by parks. A five-year plan was outlined.

1979 Baldhead Island Natural Area and Waynesborough Park established.

1980-PRESENT RESERVOIRS, RE-EVALUATION, AND NEW INITIATIVES

1982 Jordan Reservoir State Recreation Area opened. Leased from the Corps of Engineers.

1983 Falls Reservoir State Recreation Area opened. Leased from the Corps of Engineers. 
Table I-2. Development of the State Parks System. (Continued)

1984

Third State Parks Study Commission concluded that insufficient funds existed for acquiring critical lands; that fifty-year-old park buildings needed repairs; and that the system was understaffed and rangers were underpaid.

1985 State Goals and tolicy Board made six recommendation for action to reverse deplorable condition of parks.

1985 General Assembly appropriated $\$ 25$ million for land acquisition. Subsequent adjustments in the appropriations diverted some funds to other purposes.

1986 Department proposed a Six-Point Plan which listed goals and actions.

1986 Fort Fisher transferred from the Division of Archives and History to Parks and Recreation. Horsepasture River designated as a component of Natural and Scenic Rivers System.

1986 Division reorganized Consulting Services were contracted and a new Visitor Services Branch, master planning, and District Superintendent for reservoirs added.

1987 Fourth State Parks and Recreation Area Study Commission recommended establishing the purposes of the State Park System; having fee collection at State parks adding to the budget; establishing a trust fund to purchase and manage land; limiting the liability of landowners for the trails system; and purchasing a two-way radio system for parks.

1987 State Parks Act - The Act defines the mission and purpose of the State Parks System and calls for the preparation of a system plan to be submitted to the General Assembly by December of 1988 .

1987 State Auditor's Report makes recommendations which included staffing, funding, housing, land acquisition, and capital improvements. 
Table I-3. Major Study Report Recommendations, 1979-1988

Recommendations

Status

Report of the second State Parks Study Commission to the 1979 General Assembly. "New Directions." January, 1979.

- Expand existing parks by acquiring 20,617 acres at 28 sites during 1979-1984.

Estimated cost: $\$ 17.85$ million

- Develop 156 capital improvement projects at 31 sites during 1979-1984 to complete $40 \%$ of needed development. Estimated cost: $\$ 31.7$ million.

- Increase staffing by 88 persons during 1979-1984.

$\$ 465,000$ or $2.6 \%$ of recommended amount appropriated for land acquisition from 1979-1984.

$\$ 1,807,000$ or $5.7 \%$ of recommended amount appropriated for capital improvements from 1979-1984.

Staffing increased by 15 persons from 1979-1984, but Waynesborough, Falls Lake, and Jordan Lake opened.

Report of the Third State Parks Study Commission made to the 1985 General Assembly. February, 1985.

- Upward revision of salary range for park personnel.

- Minimum staffing of three rangers and a half-time clerk for all park areas.

- Establish trail coordinator position.

- Establish two staff positions for rivers.

- Establish two staff positions for natural heritage.

- Purchase 9,559 critical acres. Estimated cost: $\$ 23$ million.

Entry level revisions made, but but most classifications unchanged.

Less than half of the operated units meet this minimum.

Implemented.

Not implemented.

Implemented as part of N.C. Nature Preserve Act in 1985.

$\$ 15,780,000$ or $69 \%$ appropriated for critical acres. Approximately 1900 critical acres remain. $\$ 2,725,000$ appropriated for lands not on priority list.

- Acquire land along the Horsepasture River

No land acquired along Horsepasture.

- Complete Mountains-to-Sea Trail. Estimated cost: $\$ 3.8$ million.

No funds appropriated for trail.

- Acquisition and protection of natural areas. Estimated cost: $\$ 800,000$ over

No funds appropriated.

5 years.

- Fund capital improvements. Estimated cost: $\$ 43$ million over 6 years. 
Table I-3. Major Study Report Recommendations, 1979-1988 (Continued)

Recommendations

Status

\section{Report of the Third State Parks Study Commission made to the 1985 General Assembly. February, 1985.}

- Updating of master plans for parks.

- Purchase of two-way radios.

- Purchase of telephone answering equipment at park and recreation areas.

- Create a State funded LWCF

- Up to a $\$ 50$ million bond referendum for State parks.

- Inclusion of the Horsepasture River into the Natural and Scenic Rivers System.

- Legislation to establish a permanent registration and dedication for natural areas.
Nc progress. Planning staff significantly reduced with LWCF reductions.

Implemented. Radios purchased with $\$ 600,000$ appropriation in 1987 .

Not implemented.

Not implemented.

Not implemented.

Implemented. Horsepasture designated a Scenic River in 1985 . No support for acquisition, operation, or development.

Implemented. The N.C. Nature Preserve Act passed in 1985.

\section{State Goals and Policy Board, Report to the Governor, May 1986.}

- Emergency capital improvement funding of $\$ 2.9$ million. Other capital improvement needs were noted.

- \$600,000 for two-way radio/telephone equipment.

- DOT maintenance of park roads; DOC labor used in parks.

- Preparation of a system plan.

- Develop a capital improvements and operations guideline formula.

- Establishment of a trust for land acquisition.
$\$ 5,110,000$ for capital improvements appropriated since the recommendation. Many capital improvements needs remain unfunded.

Implemented. Radios purchased with $\$ 600,000$ appropriation in 1987 .

Not implemented.

Completed December, 1988.

Not implemented.

Not implemented. 
Table I-3. Major Study Report Recommendations, 1979-1988 (Continued)

Recommendations

Status

\section{Report of the Pourth State Parks Study Commission made to the 1987 General Assembly.} February, 1987.

- Legislation to establish the purposes of the State Parks System and procedure for additions and deletions to the system.

- Establishment of a trust fund for 1 and and capital improvements, with a 2-1 (privateState) basis.

- Fees collected at State parks be added to budgetary appropriations.

- Limit the liability of landowners for persons using their land for trails.

- Purchase of uniforms for seasonal field staff.

- Purchase of two-way radio system.

- Unfreezing land acquisition funds in reserve.

- \$25 million for biennial land acquisition ( $\$ 10$ million) and capital improvements (\$15 million).

- Establish four regional trail coordinators.

- Create a fifth State Parks Study Commission.
Implemented. State Parks Act.

Not implemented.

Not implemented.

Implemented. Bill limiting liability passed in 1987.

Partial funding. $\$ 45,000$ reduced to $\$ 20,000$, uniforms to vests.

Implemented. Bill authorizing purchase passed in 1987.

Funds unfrozen, but majority went to needs other than critical acres.

$\$ 3,570,000$ or $36 \%$ appropriated for 1 and; $\$ 5,110,000$ or $35 \%$ appropriate for capital improvements.

Implemented. Bill passed in 1987.

Implemented. Commission to report to 1989 General Assembly.

\section{Performance Audit Report of the Office of State Auditor. December, 1987.}

- Basic staffing to cover ranger responsibi-

*Pending

lities, general maintenance, and clerical

support.

- Review of ranger classification for possible *Pending upgrade.

- Establishment of adequate housing for *Pending rangers. 
Table I-3. Major Study Report Recommendations, 1979-1988 (Continued)

Recommendations

Status

\section{Performance Audit Report of the Office of State Auditor. December, 1987.}

- Long term, comprehensive funding to

*Pending meet multiple needs of land acquisition and the physical plant.

-- Study Natural and Scenic Rivers legislation to see if protection mechanism is appropriate.

$\star$ Pending

-- Eliminate State agency fragmentation and duplication in the preservation and interpretation of public resources.

*The State Auditor's Report was completed in December of 1987. Recommendations contained in the report will be studied by the fifth State Parks Study Commission and considered in its report to the 1989 General Assembly. 



\title{
CHAPTER II
}

\section{EVAIUAIION AND DESCRIRTION OE SYSTEM}

\author{
"Describe the resources of the existing State Parks System \\ and their current uses, identify conflicts created by those \\ uses and propose solutions to them;" (GS 113-44.11.4)
}

\section{INTRODUCTION}

Since its establishment in 1915, the state Parks system has grown to consist of 53 management units and approximately 125,000 acres of land and water. Total 1987 attendance was $7,580,232$, an increase of $2.75 \mathrm{million}$ in the last ten years. The increased size of the state Parks system and the increased visitation have created challenges in preserving natural resources while allowing for public use. Inadequate appropriations for operations have limited administration of most units to custodial management. Lack of funding for development, repair, renovation, and maintenance has resulted in a state parks system infrastructure which is in decline. Inadequate land acquisition appropriations has caused loss of critical lands to incompatible private development, loss of important buffers and lands proposed for park development.

This chapter details the state Parks System. Trends in budgeting, staffing, and visitation are examined. Conclusions are drawn describing the condition of the system. Recommendations are made for addressing the operational and development needs of the system. Profiles detailing each park unit are included in appendix II-1.

\section{DESCRIPTION OF THE SYSTEM}

The North Carolina State Parks System composes the six classes of units cited in the state Parks Act. The management classifications are state Parks, State Natural Areas, State Recreation Areas, State Trails, State Rivers, and State Lakes (Table II-1). Park units have been designated as State Lakes, State Rivers, and State Trails according to legislation pertaining to those specific resources. Five state Lakes became units of the system according to Chapter 165 of the Laws of 1929. The State Trail System was created according to the provisions of GS 113A-83, "The North Carolina State Trails System Act." State Rivers are designated according to the provisions of GS 113A-30, "The Natural and Scenic Rivers Act of 1971."

\section{Parks Merit Priority}

\footnotetext{
"North Carolina's system of state parks is second to none in natural endowments. From seacoast to mountains, the parks represent examples of scenic wonders worth preserving for posterity, as well as resources of recreation and enjoyment for the present generation."
} 
"The increasing stresses of our modern lifestyle underscore the importance of the parks as places of refuge and recreation. Our obligation to future generations is to develop and maintain state parks in harmony with our environmental resources.

"We are richly blessed with a wide range of natural resources between our coastline and mountains. Parks, wisely developed and maintained, hold little pieces of these natural treasures in trust for all people. Through the park system, access to the ocean front, the deep woods and the mountain top is available to everyone, not just the favored few who can afford to purchase costly real estate."

Letter to the Editor, News and Observer, 1987

\section{State Trails}

The 1973 North Carolina Trails System Act established a statewide system of scenic and recreation trails to and within public parks, forests and recreation areas for hiking, bicycling, horseback riding, and canoeing. The first state Recreation Trail, the Lumber River Canoe Trail in Scotland County, was designated in May, 1978. The Lumber River Canoe Trail and subsequent units added to the system were local government endeavors with little direct financial support from the state.

The Mountains-To-Sea Trails (MST) was initiated in 1978 using 15 volunteer task forces to sponsor segments across North Carolina. The fifteen segments are in varying stages of the construction process; planning, construction, and dedication. The MST effort benefited from two pieces of 1987 legislation. First, the state Parks Act designated state Trails as units in the state parks System. The Mountains-To-Sea Trail is the first state Trail in the State Parks system. The state Parks Act stipulates that all additions to the system will be accompanied by adequate appropriations for operations, development and land acquisition. Second, the General Assembly created a state trails coordinator position and four district trails coordinators. The positions are essential for supporting the volunteer task forces as work on the trail segments progress. However, when the trail coordinator positions were created support was not given for travel, office supplies and furniture, and equipment. Only their salaries were appropriated.

The MTS is currently 505 miles long including 200 miles of hiking trails, 293 miles of river trails, and 12 miles of urban trails. A recent hiking trail guide, Hiking Trails in North Carolina, identifies 760 hiking trails statewide totaling 2,400 miles. The standard for trail mileage in North Carolina, one mile per 1,000 population, is present in only twelve out of 100 counties (Avery, Gates, Graham, Harnett, Haywood, McDowell, Macon, Madison, Scotland, Swain, Transylvania, and Yancey). Most of the existing trails are within the mountain regions where less than 13 percent of the population resides. 
--RECOMPNDATION II-1 : The State Trails System should be expanded to help achieve the standard of one mile of trail per 1,000 population.

Rails-To-Trails Programs (The National Rails to Trails Program, in the National Trails system Lands Act of 1983, P.L. 98-11) offer potential for significantly increasing trail opportunities in North Carolina. Although legal hurdles exist, other states have initiated successful Rails-To-Trails Programs. These programs are funded with land acquisition reserves that are available when attractive trail corridors become available. Normal budget processes are too slow to be useful in purchasing rail corridors because abandonments are completed too quickly.

--Recommendation II-2 : Create a land acquisition reserve fund for purchasing valuable trail corridors when they become available.

--Recommendation II-3 : Provide adequate support for the trails coordinator positions.

\section{The Natural and Scenic Rivers System}

The North Carolina Natural and Scenic Rivers System was created by the 1971 General Assembly to preserve and protect outstanding free flowing rivers for the benefit of present and future generations. In 1975, the New River and the Linville River became the first rivers to be included in the system, and the Horsepasture was added in 1985.

Minimum criteria have been legislatively established for designation into the system. River segment length must be at least one mile, minimum and maximum boundaries are specified, water quality of at least class $C^{*}$ is required, water flow must be continuous, and only limited public access is allowed. While some rivers may have both natural and scenic features, in general a natural river is less accessible and more primitive than a scenic river.

A river segment may become a part of the system in either of two ways, by direct action of the General Assembly or through a study process which concludes with designation by the General Assembly. Over the years, a number of rivers have been studied and found to qualify for inclusion in the system. These included the Waccamaw River, Uwharrie River, South River, Black River, Bennetts Creek, Green River and Jacob Fork. Designation was not forthcoming for these rivers, however, as sufficient local support did not exist. opposition to designation increases when multiple landowners become involved.

* Class C waters are suitable for secondary recreation; such as boating and fishing; and fish propagation. 
The recent report by the State Auditor's Office raised the question of whether the current laws regulating the Natural and Scenic Rivers System are appropriate to provide adequate protection and management of designated rivers. The report recommended that the laws be critically reviewed to determine if adequate protection for the rivers exist and if limits on the acquisition of land and the use of easements represent the best management strategy for the land owners and the state.

--RECOMIFIDATION II-4 : Additional river segments should be added to the Natural and Scenic Rivers System to create a viable river protection program.

--RBCOMMENDATION II-5 : Natural and Scenic Rivers System legislation should be reviewed and amended, if necessary, to adequately protect the visual corridor of designated rivers and resolve problems created by the existing designation process.

\section{RECREATIONAL OPPORTUNITIES}

The State Parks System provides opportunities for outdoor recreation activities in natural settings. Thirty-three of fifty-three park units are staffed and open to the public. The quality, quantity, and variety of recreation available varies according to management category, the amount of federal or state assistance the park has received, and natural constraints addressed in the master plans. More developed recreation facilities are located at the State Recreation Areas, particularly at the three federal reservoirs; Kerr Lake, Jordan Lake and Falls Lake. Campgrounds, swimming beaches and boating facilities at these sites were built by the US Army Corps of Engineers and the Kerr Lake Commission before the facilities were transferred to the Division of Parks and Recreation for operation.

State Parks with more visitor services and facilities were given to the state nearly fifty years ago by the National Park Service (NPS). These parks offer swimming lakes, large group camps, boat rentals and tent campgrounds. Hanging Rock State Park and Morrow Mountain state Park have the only vacation cabins in the system with six cabins being located in each park. Morrow Mountain State Park contains the only swimming pool in the system. 
Table II-1. State Parks System Units by Management Category.

\section{PARK AREAS}

1. Bay Tree Lake

2. Boone's Cave

3. Carolina Beach

4. Cliffs of the Neuse

5. Crowders Mountain

6. Duke Power

7. Eno River

8. Fort Macon

9. Goose Creek

10. Hammocks Beach

11. Hanging Rock

12. Jockey's Ridge

13. Jones Lake

14. Lake Waccamaw

15. Medoc Mountain

16. Merchants Millpond

17. Morrow Mountain

18. Mount Jefferson

19. Mount Mitchell

20. New River

21. Pettigrew

22. Pilot Mountain

23. Raven Rock

24. Singletary Lake Group Camp

25. South Mountain

26. Stone Mountain

27. Waynesborough

28. William B. Umstead

\section{TOTALS}

28 Park Areas

5 Recreation Areas

3 State Rivers

1 State Trail

9 State Natural Areas

7 State Lakes

\section{$\overline{53}$ Units}

\section{STATE RECREATION AREAS}

1. Falls Lake

2. Fort Fisher

3. Jordan Lake

4. Kerr Lake

** 5. Lake James

\section{STATE RIVERS}

$\begin{aligned} * \star 1 & \text { Linville River } \\ \star \star \star 2 & \text {. New River } \\ \star \star 3 & \text { Horsepasture River }\end{aligned}$

STATE TRAILS

** 1. Mountains-to-Sea

STATE NATURAL AREAS

** 1. Baldhead Island

** 2. Bushy Lake

** 3. Chowan Swamp

** 4. Dismal Swamp

** 5. Hemlock Bluffs

** 6. Masonboro Island

** 7. Mitchells Mill

8. Theodore Roosevelt

9. Weymouth Woods

\section{STATE LAKES}

* ** 1. Bay Tree Lake

* ** 2. Lake Phelps

$* * * 3$. Lake Waccamaw

* $* * 4$. Jones Lake

** 5. Salters Lake

*** 6. Singletary Lake

** 7. White Lake

* Units of Park Areas

** Non-operated Units 


\section{Tennessee's Roan Mountain State Park}

Roan Mountain State Park, which is classified as a Rustic State Park, offers a visitor center, museum, twenty cabins, 110 campsites, a 50-seat restaurant, a picnic area with 30 tables and four pavilions and a swimming pool. The park, which remains popular year round, has eight hiking trails ranging in distance from .5 to 4.7 miles and cross country ski trails totaling 8.5 miles.

By contrast, state park units that have been acquired solely by the State have emphasized land acquisition over visitor services and facilities. Many of these units offer only minimal recreation opportunities for hiking, primitive camping, fishing, and picnicking. Unfortunately, these opportunities are provided simply because no funding has been available for other visitor services. Park unit master plans call for greatly increased recreation opportunities. Master plans have only been completed for 23 units. Although many of the master plans were developed over ten years ago, not a single park unit has been completed. Over $\$ 96$ million is needed to build the facilities identified by the master plans or to renovate worn out campgrounds, picnic areas, trails and bathhouses. Pressing needs for land acquisition have taken priority over development when funds have been available. The result is that the variety, amount and quality of recreation opportunities are not equivalent to services offered at National Parks in North Carolina or other state park systems in the southeast.

--RECOMMNDATION II-6: The variety, amount, and quality of recreation activities supported by the State Parks System should be increased.

Figure II-1 presents a listing of the recreational facilities at each state park unit. Self-guided nature study is available at nearly all state parks system units. Primitive camping is available at eleven park units. Singletary lake state Park is one of four state parks and state recreation areas with barracks and dining facilities for organized groups. Tent and trailer camping is available at ten state Parks and two state Recreation Areas. Electrical hookups for trailers are only offered partially at Kerr Lake and Jordan Lake State Recreation Area campgrounds. 
CENTRAL DISTRICT

\begin{tabular}{|c|c|c|c|c|c|c|c|c|c|c|c|c|c|}
\hline & \multicolumn{4}{|c|}{ Camping } & \multirow[t]{2}{*}{ Plenicking } & \multirow[t]{2}{*}{ Swimming } & \multirow[t]{2}{*}{ Bathhouse } & \multirow[t]{2}{*}{ Concession Stand ${ }^{*}$} & \multirow[t]{2}{*}{ Boat Rental } & \multirow[t]{2}{*}{ Boat Ramp } & \multirow[t]{2}{*}{ Fishing } & \multicolumn{2}{|c|}{ Trails } \\
\hline & Family & Primitive & Group & Canoe & & & & & & & & Foot & Bridle \\
\hline Eno River & & - & - & & - & & & & & & $R$ & - & \\
\hline Jones Lake & - & & & & - & $L$ & $\bullet$ & - & - & - & L & - & \\
\hline Lake Waccamaw & 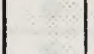 & & $\bullet$ & & - & $\mathrm{L}$ & & & & & $\mathbf{L}$ & & \\
\hline Medoc Mountain & & $\bullet$ & - & & - & & & & & & $R$ & - & - \\
\hline Raven Rock & & - & - & - & - & & & & & & R & - & - \\
\hline Singletary Lake & . & & $\bullet^{\sim}$ & & & c & & & & & L & - & \\
\hline Weymouth Woods & 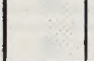 & & & & & & & & & & & - & \\
\hline William B. Umstead & - & & - & & - & c & & & - & & $L$ & - & - \\
\hline
\end{tabular}
C Swimming for campers only
L Lake
O Ocean
P Pool
R River

\section{EAST DISTRICT}

\begin{tabular}{|c|c|c|c|c|c|c|c|c|c|c|c|c|c|}
\hline & \multicolumn{4}{|c|}{ Camping } & \multirow{2}{*}{ Picnicking } & \multirow[t]{2}{*}{ Swimming } & \multirow[t]{2}{*}{ Bathhouse } & \multirow[t]{2}{*}{ Concession Stand ${ }^{*}$} & \multirow[t]{2}{*}{ Boat Rental } & \multirow[t]{2}{*}{ Boat Ramp } & \multirow[t]{2}{*}{ Marina } & \multirow[t]{2}{*}{ Fishing } & \multirow[t]{2}{*}{ Trails } \\
\hline & Family & Primitive & Group & Canoo & & & & & & & & & \\
\hline Carolina Beach & - & & - & & $\bullet$ & & & $\bullet$ & & $\bullet$ & - & R & $\bullet$ \\
\hline Cliffs of the Neuse & $\bullet$ & & - & & $\bullet$ & $L$ & - & - & $\bullet$ & & & R & - \\
\hline Fort Fisher & & & & & & 0 & - & - & & & & 0 & - \\
\hline Fort Macon & & & & & $\bullet$ & 0 & - & & & & & 0 & - \\
\hline Goose Creek & & - & - & & - & $\mathrm{R}$ & & & & - & & $R$ & - \\
\hline Hammocks Beach & & - & - & & - & 0 & - & $\bullet$ & & & & 0 & - \\
\hline Jockey's Ridge & & & & & $\bullet$ & & & & & & & & $\bullet$ \\
\hline Merchants Millpond & - & - & - & $\bullet$ & - & & & & - & & & L & - \\
\hline Pettigrew & - & & - & & - & & & & & - & & L & - \\
\hline Theodore Roosevelt & & & & & & & & & & & & & - \\
\hline Waynesboro & & & & & - & & & & & & & R & - \\
\hline
\end{tabular}

Figure II-1. Recreational Opportunities in the North Carolina State Parks System. 
Figure II-1 continued

RESERVOIR DISTRICT

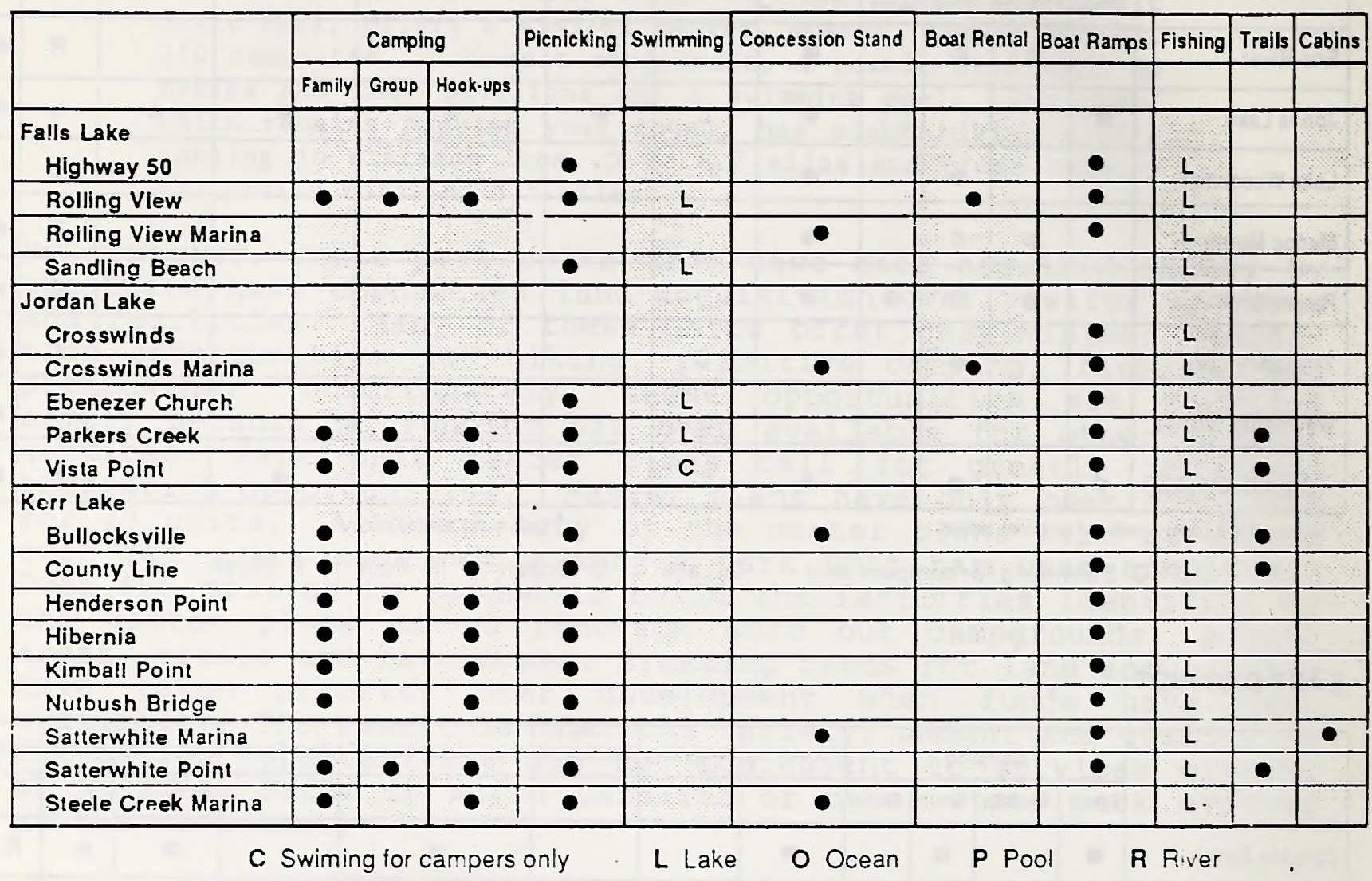

Figure II-1. Recreational Opportunities in the North Carolina State Parks System 
Figure $\| 1-1$ continued

WEST DISTRICT

\begin{tabular}{|c|c|c|c|c|c|c|c|c|c|c|c|c|c|c|}
\hline & \multicolumn{4}{|c|}{ Camping } & \multirow{2}{*}{$\begin{array}{ll} & \text { Picnicking } \\
& \end{array}$} & \multirow[t]{2}{*}{ Swimming } & \multirow[t]{2}{*}{ Bathhouse } & \multirow[t]{2}{*}{ Concession Stand } & \multirow[t]{2}{*}{ Boat Rental } & \multirow[t]{2}{*}{ Boat Ramp } & \multirow[t]{2}{*}{ Fishing } & \multicolumn{2}{|c|}{ Trails } & \multirow[t]{2}{*}{ Cabins } \\
\hline & Family & Primitive & Group & Canoe & & & & & & & & Foot & Binde & \\
\hline Boone's Cave & & & & & $\bullet$ & & & & & & $L$ & $\bullet$ & & \\
\hline Crowders Mountain & & - & - & & - & & & & & & $L$ & $\bullet$ & - & \\
\hline Duke Power & - & & - & & - & L & - & - & - & - & L & - & & \\
\hline HangIng Rock & $\bullet$ & & - & & - & L & $\bullet$ & - & $\bullet$ & & L & $\bullet$ & & - \\
\hline Lake James & & & & & - & L & & . & & & $L$ & - & & \\
\hline Morrow Mountain & $\bullet$ & $\bullet$ & - & & - & $P$ & - & - & - & - & $L$ & - & - & - \\
\hline Mount Jefferson & & & & & - & & & & & & & - & & \\
\hline Mount Mitchell & & - & & & - & & & - & & & . & - & & \\
\hline New River & & - & & - & $\bullet$ & & & & & - & $R$ & & & \\
\hline Pilot Mountain & - & & - & & $\bullet$ & & & & & & $R$ & $\bullet$ & - & \\
\hline South Mcuntains & & - & $\bullet$ & & - & & & & & & $R$ & - & $\bullet$ & \\
\hline Stone Mountairı & - & - & - & & & & & $\bullet$ & & & R & - & & \\
\hline
\end{tabular}

L Lake F Pool R Rives

Figure II-1. Recreational Opportunities in the North Carolina State Parks System.

Family Camping : Areas provide bathhouses and running water. Accommodations are for tent and trailer camping.

Primitive Camping : Areas provide toilets and running water. Accommodations are for tent camping.

Group Camping :

Areas reserved for groups only. Facilities vary by park from primitive tent sites to sites with barracks and mess halls.

Canoe Camping : Campsites accessible only by water. Accommodations are for tent camping only. 
Picnic tables and trails are available at nearly all state Parks and State Recreation Areas. Bridle trails serve horseback enthusiasts at eight state Parks. Water-based recreation activities are available in many state Parks and, state Recreation Areas, State Lakes and State Rivers. Fishing is the most widely available activity with trout streams in the west, reservoirs in the piedmont, and surf fishing on the coast. Swimming is offered at ten state parks and all three state recreation areas. Five state Parks and three state Recreation Areas provide motor-boat launching facilities. Canoeists can visit nine state Parks and one state Recreation Area to experience boating at a slower pace. Sailing is available at three State Parks and three State Recreation Areas.

Conclusion

The passive activities available at nearly all system units such as nature study, hiking, and fishing are offered because they are relatively inexpensive. visitor centers, interpretative exhibits, and recreation opportunities requiring capital development are usually absent except where the facilities were built with federal assistance. Except for recreation area users, the current recreation opportunities appeal to specialized visitors who can enjoy the natural resources through independent study. State parks in other states offer a much broader range of recreation opportunities while maintaining an emphasis on natural resource protection that is supported through information and education programs. Master plans that have been completed for 23 of the units call for $\$ 135,136,850$ million of park development.

\section{A PROFILE OF THE TYPICAL NORTH CAROLINA STATE PARR VISITOR}

In order to identify the characteristics of park visitors, the Division of Parks and Recreation contracted with the United States Forest Service (USFS) to survey visitors to North Carolina State Parks. The survey was part of the Public Area Recreational Visitor Study (PARVS) project, a cooperative effort between six federal agencies and eleven state park systems. Interviews were conducted at eight state parks during 1986 and 1987.

Results from this survey indicate that the typical North Carolina State Park visitor is a 38-year-old white male who attended but did not graduate from college; is employed full time; has an annual family income of between $\$ 30,000$ and $\$ 34,999 ;$ and drove 75 miles one way with his family, which includes 1.5 children, to visit the park. He is familiar with the state park because he visits it approximately 10 times a year. He spends $\$ 2.23$ for each hour of visit and spends more than $\$ 915.00$ each year on recreation. 
He visits the State Park because it's convenient and the other areas available to him are too crowded. If asked to rank his satisfaction with his recreation experience at the State Park, he will, on a scale of 1 to 10 where a ranking of 10 indicates a completely enjoyable experience, rate his experience slightly better than an 8. While at the park, he is likely to walk, swim, camp at a developed site, sightsee or picnic. His favorite recreation activities throughout the year are walking, dining, swimming in a pool, bicycle riding, and running or jogging.

North Carolina State Park visitors are younger than the general population. Seventy-nine percent of park visitors are younger than 45 years old as compared to 68 percent of the general population (Table II-2). Clearly, the system falls short in offering the kinds of opportunities and facilities that will support older age groups.

The vast majority of visitors to North Carolina state Parks come with their families or with family and friends (Table II-3). Groups consisting of one family, family and friends or more than one family make up seventy-one percent of all groups visiting the parks. Groups of friends visiting the parks together account for over 15 percent of all groups. Persons visiting the parks alone account for 10 percent of all visitor groups. 
Table II-2. Age Distribution of State Park Visitors as Compared to all North Carolinians.

\begin{tabular}{ccc}
\hline AGE & & \\
\hline GROUP & $\begin{array}{c}\text { PERCENTAGE OF } \\
\text { PARK VISITORS }\end{array}$ & $\begin{array}{c}\text { NC } \\
\text { POPULATION* }\end{array}$ \\
12 years and under & $18 \%$ & $18 \%$ \\
$13-25$ years & $24 \%$ & $20 \%$ \\
$26-45$ years & $37 \%$ & $31 \%$ \\
66 years and above & $16 \%$ & $20 \%$ \\
\hline
\end{tabular}

* Source: North Carolina Population Projections, 1984 Edition office of State Management and Budget

Table II-3. Distribution of Visitors by Social Group.

Social Group Percentage of

All Visitor Groups

Family

Friends

Person Alone

Family and Friends

Multi-Family

Organized Group
$60.6 \%$

$15.6 \%$

$10.0 \%$

$7.3 \%$

$3.4 \%$

$2.2 \%$ 
North Carolina residents out number out-of-state visitors to North Carolina state Parks by three-to-one (Table II-4). In surrounding states, out-of-state visitors comprise a higher percentage of state park attendance. PARVS interviews identified 42 percent of all groups at South Carolina state parks as being tourists. Overnight accommodations and recreation opportunities in North Carolina state parks do not measure up to the facilities in these surrounding states and therefore tourists are attracted elsewhere.

Table II-4. Distribution of Visitors Between In-State and Out-of state Residence by State.

\begin{tabular}{lcc}
\hline \multicolumn{1}{c}{ STATE } & PERCENTAGE OF & \\
\hline Georgia & IN-STATE VISITORS & $\begin{array}{c}\text { PERCENTAGE OF } \\
\text { OUT-OF-STATE VISITORS }\end{array}$ \\
North Carolina & $68 \%$ & $32 \%$ \\
South Carolina & $76 \%$ & $24 \%$ \\
Tennessee & $58 \%$ & $42 \%$ \\
Virginia & $69 \%$ & $31 \%$ \\
\hline
\end{tabular}

\section{Conclusion}

A young, educated family characterizes the typical state park user group. Favoring an uncrowded park experience and the convenience of traveling to a North Carolina State Park unit, the typical park user visits approximately ten times per year. North Carolina residents outnumber tourists three-to-one.

In surrounding states, out-of-state visitors comprise a higher percentage of state park attendance. South Carolina state parks attract almost twice as many tourists as North Carolina. 
DESCRIPTION OF PHYSICAL PLANT

The State Parks system physical plant consists of the man-made improvements required to open a park unit to visitors and provide the services necessary to promote public enjoyment and understanding of park resources while offering a safe park experience. The physical plant also helps protect the natural resource base by creatil: $j$ areas that are more suited for accommodating recreation uses and directing traffic away from more sensitive areas. Minimum standards for appropriate facilities have not been developed.

Physical plant development and renovation of state parks has been underfunded. Only 33 of 53 units provide public access and many well-attended parks feature aging facilities built by the federal government fifty years ago. Many parks have inadequate water and sewer systems. Some are potential health hazards. Few parks have visitor centers to provide information about park opportunities and interpret the natural resources. Until recently, no inventory of park buildings and repair needs existed.

The Division of Parks and Recreation has developed two computerized systems to document physical plant status and needs. The systems are the Project Evaluation Program (PEP), and the Facility Inventory and Inspection Program (FIIP).

The Project Evaluation Program ranks projects proposed for new construction, renovation, or cyclic maintenance. The priorities are established according to the objectives to be achieved by the projects such as public safety, protecting the natural environment, and fulfilling legal obligations. The system also stores information on the type of project being built, whether the project is new construction or renovation, and how many visitors will benefit annually. The Division has identified 270 capital improvement projects needed to develop decent park units.

The Facility Inventory and Inspection Program is a computerized system to track the condition, repair needs, and costs for every building in the state Parks system. Information gathered by engineers identifies deficiencies in each building's structure and appearance based on architectural standards. The costs of bringing each building back to safety standards are then estimated, using construction cost estimation information. FIIP represents the first time condition and repair costs for 880 state Parks buildings have ever been systematically studied. The results identify repair needs for eight structural categories (site; exterior envelope; interior envelope; fire and life safety; handicapped access; heating, ventilation, and air conditioning; plumbing; and electrical) in terms of three levels of urgency. Similar inventories of rad and utilities need to be conducted. 


\section{"The State of our Parks"}

"Of the nearly 1,000 campsites in seven camping areas at Kerr Lake, only 13 are built correctly, with raised platforms for the tents and iron grills to contain campfires.

The old electrical outlets at the campsites will not adequately handle motor home and trailer campers, whose microwave ovens, t.asters and hair dryers put heavy loads on the old 1960 syst $\epsilon$.

Worn water lines spring leaks frequently, according to rangers at the park sites. Some older wells have been shut down.

At Bullocksville Park, eaves are sagging on the wash house; sinks are rusty; makeshift toilet tank covers are made of wood and some of the drinking fountains no longer work.

The Bullocksville baseball field is an antique, its fence lines overgrown with grass, the metal numbers from its old scoreboard strewn about on the ground. The field itself is kept mowed, but no stripes mark the running lanes. The backstop is made of wood and chicken wire. The benches are sagging, with nails sticking out at the ends."

\section{Lenoir News-Topic, February 8, 1987}

The road system in the state Parks system is primarily used for site access instead of travel within the parks. While over 120,000 acres of land and water are contained in the system, less than 90 miles of paved road exist - less than one mile per 1,000 acres of park land. As with land acquisition and building, state park units with more developed road systems have been developed by federal agencies and then donated to the state. Morrow Mountain State Park contains 6.5 miles of paved roads which were originally built by the CCC. Jordan Lake state Recreation Area has over ten miles of paved road constructed by the U.S. Army Corps of Engineers.

The majority of state park roads are unpaved; over 158 miles of the 248 total miles in the system (Table II-5). The state parks with the greatest total road mileage are properties that contained unpaved roads when they were added to the system. For example, South Mountains State Park and Stone Mountain State Park have almost sixty miles of roads within the boundaries but only five miles at stone Mountain are paved. South Mountains state Park has completely unpaved roads that can become impassable except with four-wheel drive. The unpaved roads compromise natural resource protection, park aesthetics, and visitor safety. The Division is in the process of contracting an intensive road and bridge inventory in order to identify repair and renovation. needs. 
Table II-5. Road Mileage by Pavement Type.

Pavement Type

Mileage

Low grade/unpaved

Soil surfaced/Clay

Gravel

108.2

22.2

27.9

Paved

89.7

TOTAL

248.0

\section{Capital Improvement Funding History}

The physical plant has been funded sporadically during the 73 year history of the State Parks System (Table II-6). Much of the physical plant in more developed state parks was built in the 1930 's by the Civilian Conservation Corps. Falls, Kerr, and Jordan Lake State Recreation Areas were constructed by the US Army Corps of Engineers and leased to the Division of Parks and Recreation. State appropriations to renovate and expand the physical plant have increased from an average of $\$ 34,000$ per year in the 1960's to average $\$ 1.1$ million per year in the 1970 's to average $\$ 1.2$ million per year in the $1980^{\prime} \mathrm{s}$.

Although the trend shows an increase during each decade, the funding from year-to-year has fluctuated greatly. Money was allocated each year during the 1970's but funding levels ranged from $\$ 400,000$ to $\$ 3$ million within three years.

\section{Top Five State Park Capital Improvement Budgets}

In 1986, the California State Park System capital improvement budget for new construction was $\$ 25.5$ million, in Minnesota $\$ 25 \mathrm{million}$, in Illinois $\$ 18.6 \mathrm{million}$, in Louisiana $\$ 13$ million and in Ohio $\$ 12.8 \mathrm{million}$. The national median was $\$ 1.45$ million.

North Carolina has spent $\$ 27$ million on capital improvements in the entire 73-year history of the State Parks System. 
Table II-6. Capital Improvements and Land Acquisition Appropriations History.

\begin{tabular}{|c|c|c|c|c|}
\hline YEAR & & $\begin{array}{c}\text { CAPITAL } \\
\text { IMPROVEMENTS }\end{array}$ & $\begin{array}{c}\text { LAND } \\
\text { ACQUISITION }\end{array}$ & $\begin{array}{l}\text { TOTAL CAPITAL } \\
\text { APPROPRIATIONS }\end{array}$ \\
\hline $\begin{array}{l}1915-47 \\
1947-48 \\
1948-49 \\
1949-50 \\
1950-57 \\
1957-58 \\
1958-59 \\
1959-60 \\
1960-63 \\
1963-64 \\
1964-65 \\
1965-66 \\
1966-67 \\
1967-68 \\
1968-69 \\
1969-70 \\
1970-71 \\
1971-72 \\
1972-73\end{array}$ & $\begin{array}{l}\text { * } \\
\text { * } \\
\text { * } \\
\text { * }\end{array}$ & $\begin{array}{r}47,664 \\
500,000 \\
- \\
1,074,144 \\
- \\
608,000 \\
- \\
480,500 \\
- \\
714,220 \\
714,220 \\
429,460 \\
429,460 \\
319,740 \\
319,740 \\
424,350 \\
400,000 \\
500,000 \\
500,000 \\
\end{array}$ & $\begin{array}{r}57,845 \\
0 \\
- \\
0 \\
- \\
0 \\
- \\
0 \\
- \\
0 \\
0 \\
0 \\
0 \\
0 \\
0 \\
0 \\
250 \\
0 \\
0 \\
\end{array}$ & $\begin{array}{r}105,509 \\
500,000 \\
- \\
1,074,144 \\
- \\
608,000 \\
- \\
480,500 \\
- \\
714,220 \\
714,220 \\
429,460 \\
429,460 \\
319,740 \\
319,740 \\
424,350 \\
424,250 \\
500,000 \\
500,000 \\
\end{array}$ \\
\hline $\begin{array}{l}\text { SUBTOTAL } \\
(58 \text { YEAR }\end{array}$ & S ) & $\$ 7,461,498$ & 82,095 & $\$ 7,543,593$ \\
\hline $\begin{array}{l}1973-74 \\
1974-75 \\
1975-76 \\
1976-77 \\
1977-78 \\
1978-79 \\
1979-80 \\
1980-81 \\
1981-82 \\
1982-83 \\
1983-84 \\
1984-85 \\
1985-86 \\
1986-87 \\
1987-88 \\
1988-89\end{array}$ & 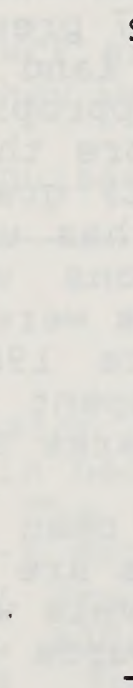 & $\begin{array}{r}\$, 500,000 \\
3,000,000 \\
1,000,000 \\
750,000 \\
1,200,000 \\
1,200,000 \\
500,000 \\
500,000 \\
100,000 \\
-0,- \\
707,000 \\
329,000 \\
1,137,000 \\
2,750,000 \\
3,800,000 \\
1,310,000 \\
\end{array}$ & $\begin{array}{r}\$ 11,500,000 \\
5,500,000 \\
500,000 \\
500,000 \\
500,000 \\
500,000 \\
-0- \\
250,000 \\
-0- \\
-0- \\
215,000 \\
-0- \\
11,435,000 \\
3,800,000 \\
3,020,000 \\
250,000 \\
\end{array}$ & $\begin{array}{r}14,000,000 \\
8,500,000 \\
1,500,000 \\
1,250,000 \\
1,700,000 \\
1,700,000 \\
500,000 \\
750,000 \\
100,000 \\
-0,0 \\
922,000 \\
329,000 \\
13,072,000 \\
6,550,000 \\
7,120,000 \\
1,560,000 \\
\end{array}$ \\
\hline $\begin{array}{l}\text { SUBTOTAL } \\
\text { ( } 16 \text { YEAR }\end{array}$ & & $\$ 20,783,000$ & $\$ 37,970,000$ & $\$ 58,753,000$ \\
\hline $\begin{array}{l}\text { TOTAL } \\
\text { ( } 74 \text { YEAR }\end{array}$ & & $\$ 28,244,498$ & $\$ 38,052,095$ & $\$ 66,296,593$ \\
\hline
\end{tabular}

* Data Not Available 
Lack of a consistent funding base has greatly affected the Division's capability to maintain an effective, ongoing capital improvement program.

--RECOMMNDATION II-7: A consistent, increased funding base is needed to maintain an effective capital improvement program.

During the $1980^{\prime} \mathrm{s}$, state parks received $\$ 3.8$ million for the capital improvement budget in fiscal ytar 1988 following no allocation in 1983. In addition to wide variation in funding levels, appropriations have been earmarked for specific projects instead of being available for Division priorities.

--RECOMMENDATION II-8: Funding for capital projects should follow the Division's Project Evaluation Program - a professionally prepared, prioritized listing of capital needs.

Twenty-five percent of all capital improvement funding occurred during the last three years. Although funding has increased, the real concern is whether sufficient funds have been available to provide appropriate levels of visitor services to North Carolina citizens. Sporadic and inadequate funding for capital improvements and repair needs have resulted in a state parks System which is inadequately developed and in a serious state of disrepair.

\section{Contributions of the Land and Water Conservation Fund}

Since 1969, the Land and Water Conservation Fund has contributed significantly to the State Parks System. Table II-7 presents the history of federal LWCF grants to state parks for land acquisition and capital improvements compared to state appropriations. From 1967 through 1988, LWCF grants contributed more than state appropriations for seven fiscal years. Because LWCF grants must be matched on a one-to-one basis, North Carolina has used land donations as the state match when appropriations were not available. In 1982, almost $\$ 1 \mathrm{million}$ in LWCF funds were awarded to the state and matched by donated land. Since 1967, LWCF grants have provided 18 percent of all funds spent on land acquisition and capital improvements in the state Parks system.

It is important to note that LWCF allocations have been dropping since the early 1980 s and long-term funding patterns are still in doubt. If federal LWCF grants remain at current levels which are low, then the state must replace a significant source of state park acquisition and development funding.

--RECOMIENDATION II-9: New and expanded sources of support for the system must be developed to supplant declining federal funding. 
Table II-7. Contributions of LWCF Grant to State Park Acquisition and Development Projects.

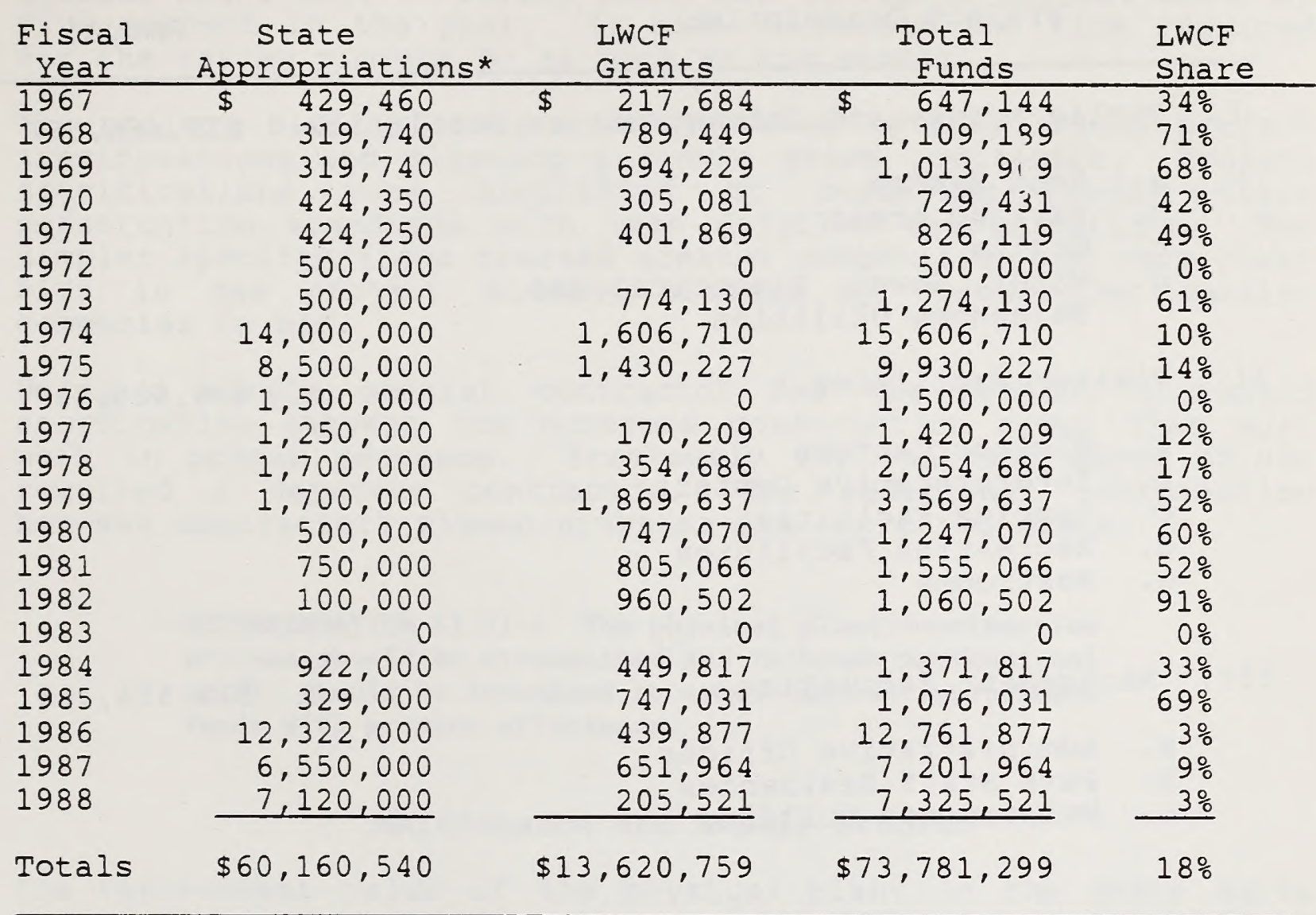

Note: LWCF grants are allocated to the fiscal year in which they were approved.

* For acquisition and development.

\section{Physical Plant Funding Needs}

The Division of Parks and Recreation has documented over $\$ 135$ miliion in needed capital improvement projects in the state Parks system. The needs exist in every facet of the physical plant. Table II-8 details a capital improvement program to address these needs by project categories. As increased appropriations are received, additional staff will be needed for administration as well as for environmental documention, permitting, and monitoring.

Table II-9 shows the repair needs identified by the Facility Inspection Improvement Program system. The inspection covered 880 buildings. Over one million dollars of critical repairs are needed to correct threats to public health, fire hazards and major structural damage. The problems were caused by years of inadequate maintenance resources. 
Table II-8. Needed Capital Improvements Identified Through PEP Process.

Project Description

Amount

I. Public Access and Infrastructure Facilities. $\$ 23,466.067$
a. Road System
b. Parking Areas
c. Trails
d. Water, Sewer, Electrical and Telephone Utilities

II. Visitor Facilities. $\$ 96,086,517$
a. Visitor Centers
b. Interpretative Centers
c. Camping Facilities
d. Recreation Facilities
e. Restrooms

III. Management Facilities.
a. Administrative Offices
b. Park Staff Residences
c. Maintenance Building

\section{--RECOMENDATION II-10: Significant increases in funding are needed to address the $\$ 135$ million backlog in capital improvement needs.}

\section{Capital Improvement Project Cost Savings}

The Division of Parks and Recreation has been able to realize significant cost savings while building the Waynesborough Park ranger's residence through modifying the state construction process and using in-house professional services. The residence was built for $\$ 98,500$ as compared to an average of $\$ 132,500$ for two residences built by the U.S. Army Corps of Engineers at Falls Lake and Jordan Lake.

Modifying the state construction process streamlined the normal schedule; reducing the project period from two years to nine months. The shortened time period decreased the effects of inflation which are estimated by the state construction office at six percent annually. 
The Division of Parks and Recreation shifted the review and approval of construction plans to a staff architect. Relying on outside architects to review plans had increased project costs by five percent in the past. It also increased the time required for the review process by as much as six months.

The project bidding process was improved by simplifying project specifications and allowing a single prime contractor. Project specifications were simplified by replacing normal state construction standards with less detailed specifications. The simpler specifications created greater competition and thus lower bids in the project bidding process by encouraging smaller companies to bid.

Using a single general contractor for the project increased coordination between the numerous construction crews that must work in proper sequence. Previously any contract above $\$ 5,000$ required a separate contractor. The additional coordination between contractors slowed progress and increased costs.

--RECOMMENDATION II-11: The physical plant construction process should be streamlined and in-house professional staff should be increased to spend capital improvement funds with greater efficiency.

\section{Maintenance and Repair Program}

The replacement value of the physical plant in the state Parks system is currently estimated to be $\$ 330,000,000$. In the 1985-87 Biennium, the maintenance repair and reserve fund for state Parks was $\$ 250,000$, or about seven tenths of one percent $(.7 \%)$ of its value. The Facility Inventory and Inspection program has identified over $\$ 3$ million of repair needs classified as critical or serious (Table II-9). The magnitude of these repairs are attributable to the lack of maintenance resources available as well as the lack of a cyclic preventative maintenance system. Current maintenance resources are only able to address emergency needs. To move from crisis management to preventative maintenance, a new program has been initiated.

The Maintenance and Operations Management system (MOMS) provides the Division of Parks and Recreation with the ability to schedule routine and cyclic maintenance jobs effectively. MOMS allows park staffs to plan, schedule and control the maintenance work process. It identifies the 
labor, equipment and supplies necessary to complete each task. Cyclic maintenance is scheduled to prevent repair needs from becoming crisis situations. Without proper maintenance, park buildings are at best a disservice to the citizens who use them. At worse, they are potentially harmful.

Significant additions to staffing and equipment will be necessary to perform the critical and serious repairs identified by the FIIP system and to implement the cyclic Maintenance and Operations Management System. The exact proposal for additional staffing and equipment requires further study to convert the labor and materials needs described by FIIP into maintenance positions and support estimates.

For major repair needs, contracting for specialized services and equipment may be more efficient than purchasing equipment and training park staff. Finally, MOMS is designed to be a centralized information system requiring computer capabilities and communications at each park unit which are currently unavailable.

--RECOMMENDATION II-12 : A comprehensive repair and maintenance program must be supported to address the backlog of needs, protect the public's investment, and assure safe park facilities.

Road repair and maintenance is the responsibility of the Division of Parks and Recreation within park boundaries. Park roads are not part of the state highway system and any maintenance performed by the Department of Transportation is performed on a cost reimbursement basis. An inventory of road, bridge, and culvert conditions and repair needs for bridges has not been available due to lack of resources. The Division is contracting such a survey and, given the limited resources allocated to the road system, repair needs will probably be significant. 
TABLE II-9. Building Repair Needs Summary.

\begin{tabular}{|c|c|c|c|c|c|}
\hline Repair Category & & Critical & Serious & Minor & Total \\
\hline Site & $\$$ & 6,306 & 438,392 & 556,799 & $1,001,497$ \\
\hline Exterior Envelope & $\$$ & 882,481 & 441,890 & 153,628 & $1,477,999$ \\
\hline Interior Envelope & $\$$ & 213,744 & 256,259 & 58,825 & 528,828 \\
\hline Fire/Life Safety & $\$$ & 25,492 & 11,053 & 383 & 36,928 \\
\hline Handicapped Access & $\$$ & 799 & 658,945 & 24,569 & 684,313 \\
\hline $\begin{array}{l}\text { Heat, Ventilation, } \\
\& \text { Air Conditioning }\end{array}$ & $\$$ & 6,447 & 27,743 & 1,162 & 35,762 \\
\hline Plumbing & $\$$ & 9,346 & 21,677 & 7,739 & 38,762 \\
\hline Electrical & $\$$ & 11,295 & 37,044 & 5,115 & 53,454 \\
\hline TOTALS & & $, 155,910$ & $\overline{1,893,003}$ & $\overline{808,220}$ & $\overline{3,857,133}$ \\
\hline
\end{tabular}

Critical- Deficiencies which are a threat to fire and life safety, or the health of an individual, or could cause major damage to the structure.

Serious- Deficiencies which are not a threat to life and life safety, but, if left uncorrected, could cause further damage to the structure.

Minor- Deficiencies requiring general maintenance or repair. 
--RECOMMENDATION II-13: Critical and serious repair needs totalling $\$ 3,048,913$ must be addressed immediately to avoid further deterioration of park facilities.

\section{Conclusion}

Traditionally low, sporadic funding for development, and a reliance on federal construction programs, has created underdeveloped park units. Lacking cyclic maintenance, existing facilities have fallen into disrepair. Inadequate repair and renovation reserves have limited the Division's ability to address and correct the crisis situations created. The Division has identified significant repair-renovation needs but, without a significant increase in funding, does not have the resources necessary to address even critical needs. Recent inventory and inspection programs have identified over $\$ 135$ million in needed projects for new construction, renovations, and repairs. These projects are necessary to protect the $\$ 330$ million public investment in park facilities, create new opportunities for public use, and protect natural resources by directing visitor use. 


\section{N.C. PARKS EMBARRASS STATE}

"North Carolina's public parks are a refutation of the state's motto: to be rather than to seem. Visitors to one of the woefully under-funded recreation sites are likely to find a park that exists on paper, but not in reality.

Consider Duke Power State Park, on the south Iredell County shores of Lake Norman near Troutman. Picnic tables installed at the park's opening more than 10 years ago are still there, sagging from age and rot. Brush a hand over one of the benches to clear it of dust and it is likely to break under the touch. You wouldn't dare sit on it - or bring your family back for a picnic.

Or consider the state park on Morrow Mountain northeast of Albemarle, overlooking Lake Tillery. A stone lodge damaged by fire 10 years ago still has not been repaired. Erosion threatens the bare slopes that lead down to the lake.

Similar neglect can be found in state parks all across North Carolina: Toilets are stopped up, shower heads are clogged, hiking trails are overgrown, picnic facilities are rotting or nonexistent. Though North Carolina was the first state in the Southeast to establish a state park, if is now next to last in spending for park maintenance.

One problem is that North Carolina's national parks, forest and seashores are so superior, they attract most of the 7.5 millions park users. State parks remain relatively out of sight and out of mind. State park officials claim N.C. travel and tourism agents don't promote state parks because they're afraid users will be disappointed at what they find. It isn't that North Carolina doesn't spend money on parks.

Since 1985, the legislature has appropriated $\$ 28.1$ million for park acquisition, maintenance and repair - about twice what the Governor requested. But much of the money went to expand existing facilities or buy new ones ...., not to improve what the state already owns.

Though many studies have pointed up the problems, there is still no consensus, no sense of legislative commitment to what needs to be done. The costs will be high, but so are the costs - and the embarrassment - of letting existing parks go to ruin.

The Charlotte Observer, Editorial, August 11, 1988 


\section{EXTERNAL AND INTERNAL THREATS}

In recent years, pressures upon the lands and waters of the state Parks System have grown intense, diverse, and contentious. High population growth, heavy development pressures, and rapid technological advances have brought with them a host of threats to public resources. Chemical pollution, heavy visitor use, and the activities of adjacent landowners are just a few of the many kinds of threats facing the lands and resources of the state ?arks system.

\section{Concerns Grow Over Development Near Umstead}

Noise and dust from a nearby rock quarry invade a wooded picnic site. The dull roar of a passing jet briefly drowns out bird songs on a nature trail. Water flowing in a creek is a little muddy.

William B. Umstead State Park, just northwest of Raleigh, is fighting intrusions at its borders by the growing RaleighDurham Airport, new office construction and other development along two busy highways. State park officials have fought for the past decade to maintain Umstead's natural aura as the Research Triangle builds up around it.

Donated to the state by the federal government in 1944, the 5,221 -acre park is an oasis in the middle of one of the nation's development meccas.

U.S. 70 and Interstate 40 border the park on the north and south, linking it to Raleigh, Durham and Research Triangle Park. On the park's northwest side is RDU, which is undergoing a major expansion as part of American Airlines' decision to add 180 daily flights there by 1989 .

Raleigh annexed the park last summer along with 1,750 acres planned for development west of it. Cary's corporate limits nudge Umstead's southern border.

The New and Observer, Monday, May 26, 1986.

Many internal threats to the parks are obvious to the most casual visitor. Antiquated and malfunctioning sewage treatment at Mount Mitchell state Park, eroding trails at Hanging Rock state park, aquatic weeds in the lakes of William B. Umstead State Park, and deteriorating water quality of park swimming areas are examples of the internal threats to the system's resources and visitors. 
Perhaps the most alarming current threats to the state Parks System are derived from external sources. The effects of activities on lands adjacent to the parks often directly and adversely impact the Park's resources as well as the enjoyment visitors derive while at the parks. Over the last 5 years, many adjacent land use activities have threatened the parks including:

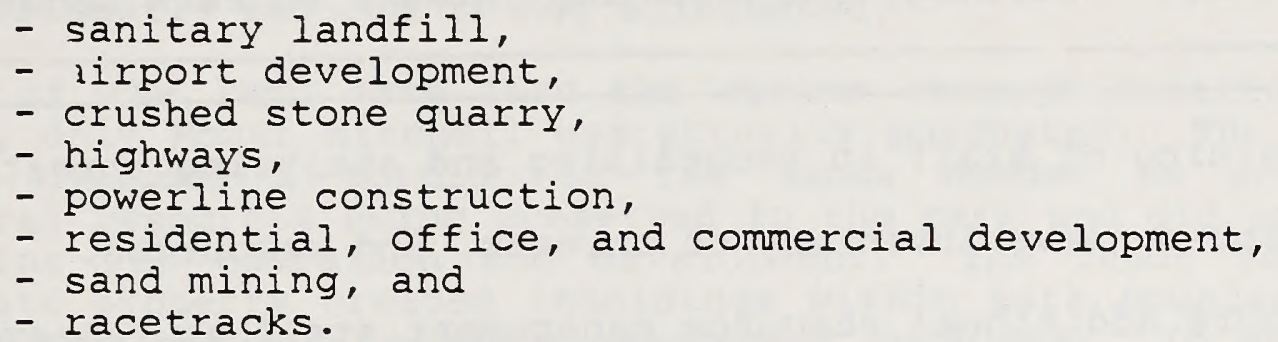

These activities damage the parks by creating traffic congestion at park entrances, causing air pollution, increasing noise levels, creating visual intrusion, eliminating wildlife habitat and travel corridors, causing sedimentation of surface waters, and myriad other adverse effects. Specific internal and external threats to park units are listed in park profiles (Appendix II-1).

Both internal and external threats must be managed, mitigated, and even prevented through resource management techniques, existing resource protection regulations, zoning and development controls, and coordination and cooperation with those with jurisdiction over various land use activities (Table II-10).

The first step in addressing internal and external threats is to develop resource management plans which identify threats to the unit, evaluate the significance of the threats, and propose actions in response. Field staff must be kept up-to-date in resource management through comprehensive training programs. The Division of Parks and Recreation has not been able to develop resource management plans due to inadequate staffing. In many instances, field staff can only watch in frustration as park resources are degraded.

\section{--RECOMENDATION II-14: Resource management plans should be prepared for every park unit and be periodically updated.}

\section{Park Boundaries}

One problem in addressing threats to the park resources is the lack of clearly defined and marked boundary lines. In locations where park boundaries are unknown or poorly marked, encroachment activities that are against park regulations or cause damage can occur without the knowledge of park staff or the public. The State Parks system is currently identifying and marking boundary lines that are not marked. Table II-11 presents the status of the boundary marking project for the state Parks system. 
--RECOMENDATION II-15: All park boundaries should be marked in a standardized way. Markings should be current and visible for use by the public and park staff.

Table II-10. Strategy for Managing Threats to Park Lands.

1. Training of staff in recognizing and analyzing threats.

2. Comprehensive inventory of threats, and resources.

3. Secure additional resource management staff to research threats and develop protection strategies.

4. Develop resource management policies and guidelines.

5. Train staff to conduct resource management and protection strategies.

6. Secure continuing source of land acquisition funding.

7. Arrange local and state-level protection agreements for State Parks.

8. Secure changes in legislation and administrative codes.

Table II-11. Park Boundary Marking Status.

STATUS (December, 1987)

Mileage

Well marked

Poorly marked

Unknown or Unidentified

Total
195.8

218.1

97.5

511.4 


\section{Land Acquisition Program}

Land acquisition is the most expedient and practical method to prevent many external threats to the parks. Through the acquisition of critical natural resource lands and adequate buffers, the magnitude of impacts to the park's resources and to park visitors emanating from activities on adjacent lands can be significantly reduced if not eliminated.

Most of the land came into the system through donations. Until 1971, only Mount Mitchell was actually purchased. The donations only included a portion of the lands needed to protect the natural resources being preserved in the park and did not include funding for operation and development. The lands retained as private property created inholdings within park boundaries which can cause natural resource management problems. In some parks, the primary resource is not totally under public ownership, such as the millpond shoreline at Merchants Millpond state Park.

Land acquisition to secure critical lands from potential incompatible land use activities is only effective when there are funds available for land purchases. Table II-6 presents the land acquisition funding history of the state Parks system. It illustrates the degree to which the system has been created through a combination of donations and transfers from other agencies. The subtotal for years 1915-1973 shows that land acquisition spending totaled $\$ 82,095$. Although this is extremely low funding, consider that twenty three units had already been added to the system. These park units include many popular parks such as Morrow Mountain State Park, Hanging Rock State Park, William B. Umstead State Park, Duke Power State Park and Carolina Beach state Park. Land acquisition funds were used to purchase only one unit, Carolina Beach state Park, during this fifty-eight year period.

Funding for land acquisition has increased dramatically, though sporadically, since the first purchase in 1971. More than $\$ 37$ million has been spent since 1971. Legislative study commissions have recommended and won support for nearly half of all land acquisition funding, $\$ 18.3 \mathrm{million}$ during the last three fiscal years $1986-1988$

Current inventories indicate that 23,000 more acres are needed to complete land acquisition at existing park units as currently planned. Using an estimated $\$ 5,000$ per acre cost, \$115 million will be needed to purchase park land. The 1985 legislative State Park study Commission recommended $\$ 50$ miliion to address remaining land acquisition needs. The $\$ 15.7$ million subsequently spent for park lands acquired 7,600 acres. A constant funding source for land acquisition is needed to administer a more efficient program. Reliable funding provides a basis for planning, purchase of land from willing sellers, and the ability to react to emergencies that threaten park resources and aesthetics. 
A Landbase Inventory has been developed to store accurate deed and survey information on current park lands. When complete, the inventory will inform park staff exactly what lands are under park management. Land management requires a major commitment of staff resources. Responsibilities include researching land rights involved in encroachments, accessess, and easement requests. Additional staffing is needed to develop and implement land management plans. Land Management Plans (LMP) identify protection needs for park rysources and propose solutions. Although land acquisition is th? most effective means of protection, the LMP considers the full range of protection strategies. These strategies include fee simple acquisition, zoning, purchased or donated easements, restrictive covenants, and life-time leases.

Each LMP should be updated on a planning cycle to identify changing land use patterns surrounding the park and other conditions affecting park resource protection. Previous land acquisition appropriations have not included staff support which impedes progress toward purchasing important land.

--RECOMMENDATION II-16: Land Management plans should be prepared and implemented for all park units.

--RECOMMENDATION II-17: A significantly increased and stable funding base is needed to acquire the 23,000 acre backlog of land essential to protect existing parks.

\section{Rising Land Values}

Rising land values, especially those in the urban areas of the State, are limiting land acquisition efforts. As land values increase, the State's buying power is diminished. Higher land values can encourage a landowner to subdivide property. More staff time per acre goes into acquiring small lots, and these small lots have a higher per acre value than the larger block of land from which they were derived.

Table II-12 presents four examples of land values that have increased significantly through time. Savings to the state would have been dramatic if land acquisition funds were available when prices were lower. In 1971 the Division emphasized the need to acquire lands before land values further escalated in a report entitled "Now or Never." In 1989 some critical lands are now so costly that the de facto answer has become "never." 
Table II-12. Examples of Increasing Land Values.

COST PER ACRE

PARK

$1974-1976$

1980-1982

$1986-1988$

Eno River

Stone Mountain

W. B. Umstead
$\$ 1,252$

658

3,504
$\$ 2,807$

1,657

4,968
$\$ 10,000$

2,011

21,289

\section{Conclusion}

The representative examples of North Carolina's natural heritage protected in the state Parks System are threatened by an assortment of pressures including adjacent land uses, pollution, and worn out, overused visitor use facilities. These threats have accelerated in recent years as North Carolina becomes a more urban state. Inadequate resources exist for resource management, staffing, training, inventories, and protection programs. Land acquisition, the most effective resource protection program, has recently received significant funding after decades of neglect. More land, 23,000 acres with an estimated value of $\$ 115$ million, is needed to complete existing parks. Delaying funding will increase per acre costs as land values rise and will cause important resource, buffer, and facility development lands to be lost to incompatible development. 


\section{ADMINISTRATION}

The North Carolina state Parks System has traditionally been managed with extremely limited operating funds, a trend that is similar to land acquisition and capital improvement funding. New park units have been added to the system through donation and transfer of land and water without increased appropriations to support staffing and development. Some units have remained unstaffed and unmanaged for many years after becoming part of the State Parks System. No parks have sufficient management capabilities to manage the park natural resources, interpret those resources to the public, protect public health and safety, and provide park maintenance. Even funding for park brochures is not available at many units. Meanwhile, attendance continues to increase.

--RECOMIENDATION II-18: Standards must be developed which prescribe adequate operation (e.g., staffing levels), development, and acquisition for each management category. These standards must be met when adding new park units.

\section{Attendance Trends}

State Parks System attendance has grown rapidly in the past decade from 4.8 million visitors in 1978 to 7.6 million visitors in 1987. Fiscal year 1987-1988 attendance passed 8 million. The upward trend is marked by wide fluctuations from 1978 through 1982 and consistent increases since 1982 (Figure II-2). Though limited information explaining these sharp swings in attendance is available, expansion of park facilities appears to be a contributing factor. From 1973 through 1979, \$9.5 million was appropriated for capital improvements. Several parks reported low attendance years when construction was occurring followed by increased attendance when new park facilities opened.

A sharp decrease from 1980 to 1981 occurred when the Division of Parks and Recreation began using traffic counters at Kerr Lake to measure attendance rather than using U.S. Army Corps of Engineers estimates. The decrease of 405,000 visitors was nearly $10 \%$ of total system attendance and $24 \%$ of Kerr Lake attendance in 1980.

Since 1982, total system attendance has grown each year with the smallest increase, 5\%, occurring in 1982 and the largest increase occurring in 1985, 11\%. In the recent years, the North Carolina State parks system has been the third fastest growing in attendance in the United States. A considerable portion of attendance increases since 1984 has occurred at the State Recreation Areas. At Jordan Lake and Falls Lake state Recreation Areas, the U.S. Army Corps of Engineers built water-based recreation facilities and campgrounds opening in 1984 and 1986 (Figure II-3). Fort Fisher state Recreation Area opened in 1986 offering an ocean beach day use area. State Recreation Area 
attendance has increased 19 percent annually since 1984 as compared to 3 percent annually at state Parks. The trend toward State Recreation Areas accounting for a greater share of total system attendance will continue. New recreation opportunities have increased the percentage of total attendance occurring at State Recreation Areas from under $30 \%$ in 1984 to nearly $40 \%$ in 1987 (Figure II-4). Major overnight and day use areas being added at Jordan lake will attract greater numbers of visitors from the growing Research Triangle. Without simnificant appropriations for visitor use facilities in state Parks, attendance should continue to grow slowly or perhaps level off.

\section{Federal Construction at Jordan Lake State Recreation Area Provides More Recreational Opportunities and More Headaches}

Recreation facilities being constructed by the U.S. Army Corps of Engineers at Jordan Lake State Recreation Area will provide more campgrounds and day use areas than at any other unit in the system. By the summer of 1989, 1,070 individual campsites and 11 group camping areas will be available at four sites around the lake. Jordan Lake State Recreation Area is already extremely popular because of its proximity to the Research Triangle and numerous water-based recreation opportunities. Unfortunately, current park staffing is minimal and completely incapable of managing the new additions.

Seven rangers are assigned to the three areas that are now open; Vista Point, Parkers Creek, and Crosswinds. On holiday weekends, nearly 2,000 campers occupy the 305 campsites and overflow areas; nearly 300 per ranger. However, no rangers are available after the park closes until the next morning because no on-site ranger residences are provided or planned. During the day, attendance increases as swimmers and picnickers arrive at day use areas. Large groups find the picnic shelters attractive and recently a company picnic brought 4,000 employees to Parkers Creek. Fortunately, the company was able to manage the group because only three rangers are available to oversee the picnic area, 250 campsites, six group campsites, and a swimming beach. The popularity for these functions will only increase as more companies and organizations discover the park. 


\section{Percentage Change In Total Attendance 1978-1987}

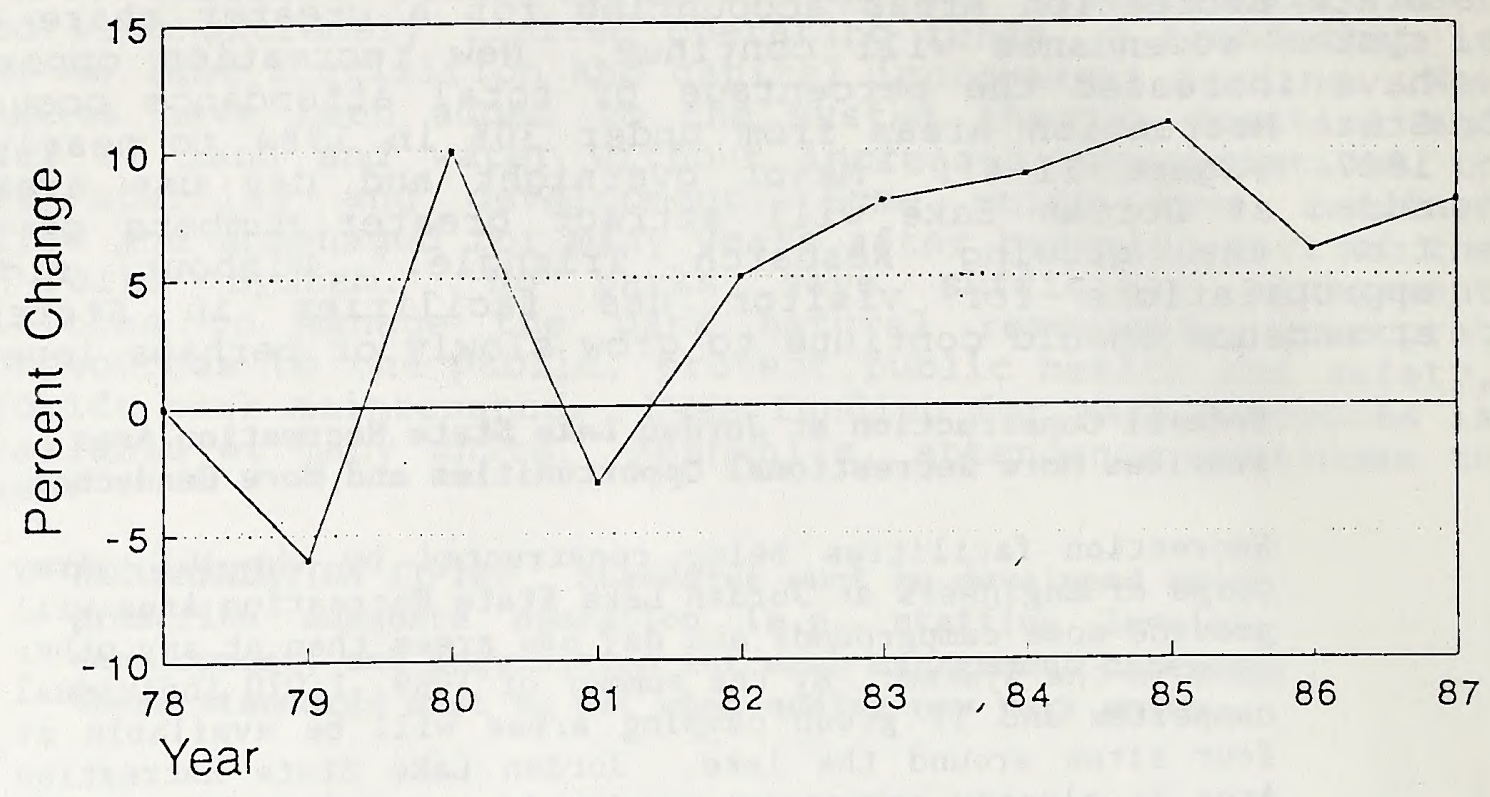

Figure II-2 Percentage Change In State Park Attendance 1978-87

Visits in Millions

STATE PARK AND RECREATION AREA VISITS

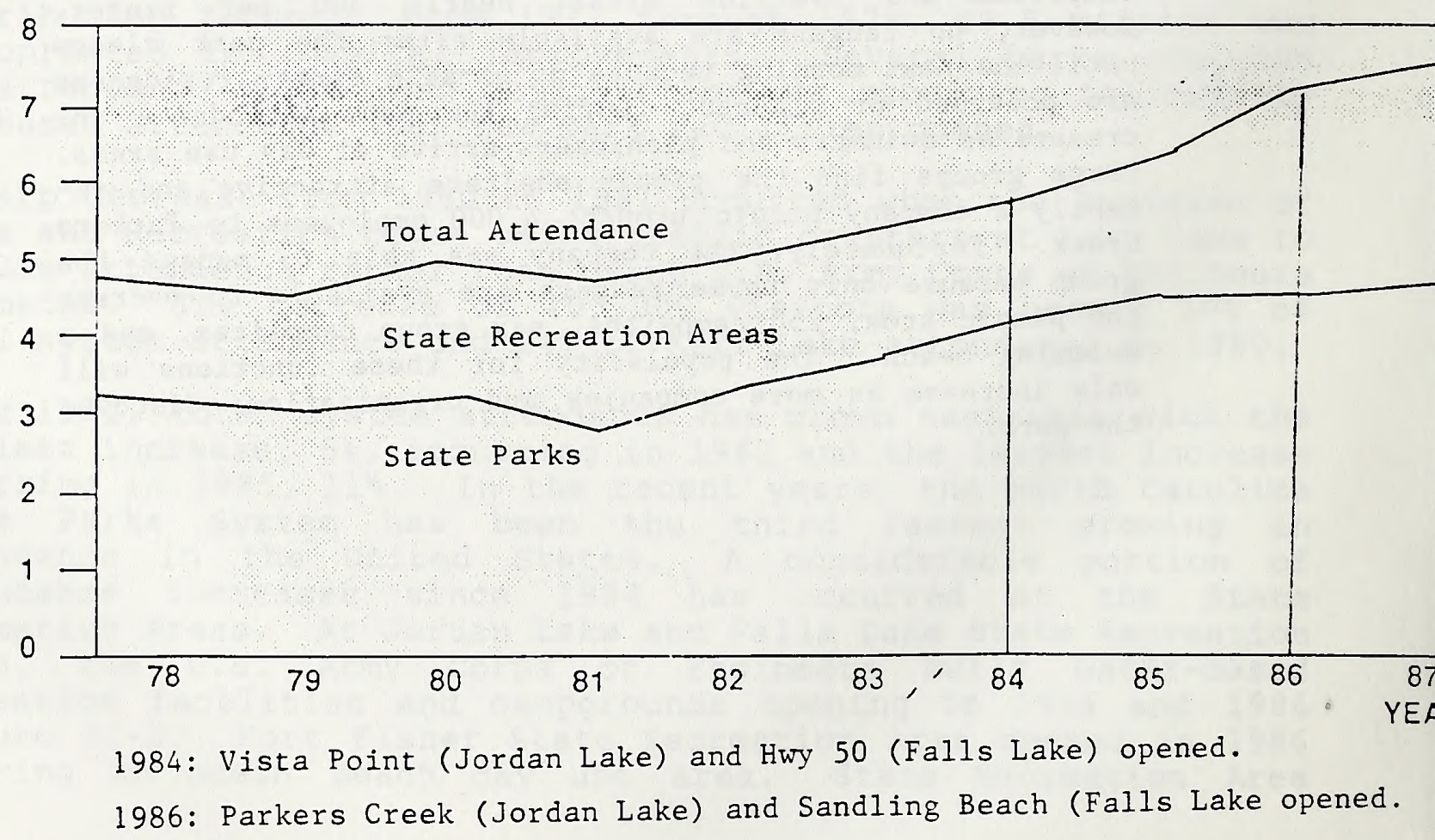

Figure II- 3. Recreation Areas Significantly Increase Attendance at State Parks System. 
By the summer of 1989, the Corps of Engineers will complete construction of the largest campground (580 campsites) at Poplar Point and the largest day use area (swimming, picnicking, and boating) at Seaforth on Jordan Lake. To support these sites as existing areas, a waste water treatment plant with a larger capacity than many small cities will aiso come on-line. Instead of adding ranger support staff to prepare for additional attendance, Jordan Lake lost one ranger position last year due to a budget cutback. The result is that one ranger will be available for each of the seven areas. Only one on-site ranger residence is included in the new construction.

--RECOMMINDATION II-19: Immediate attention must be given to supporting adequate staffing levels at state recreation areas where use has been rising and is expected to continue to significantly increase.

\section{Percentage of Total Attendance \\ By Management Cateḡory}

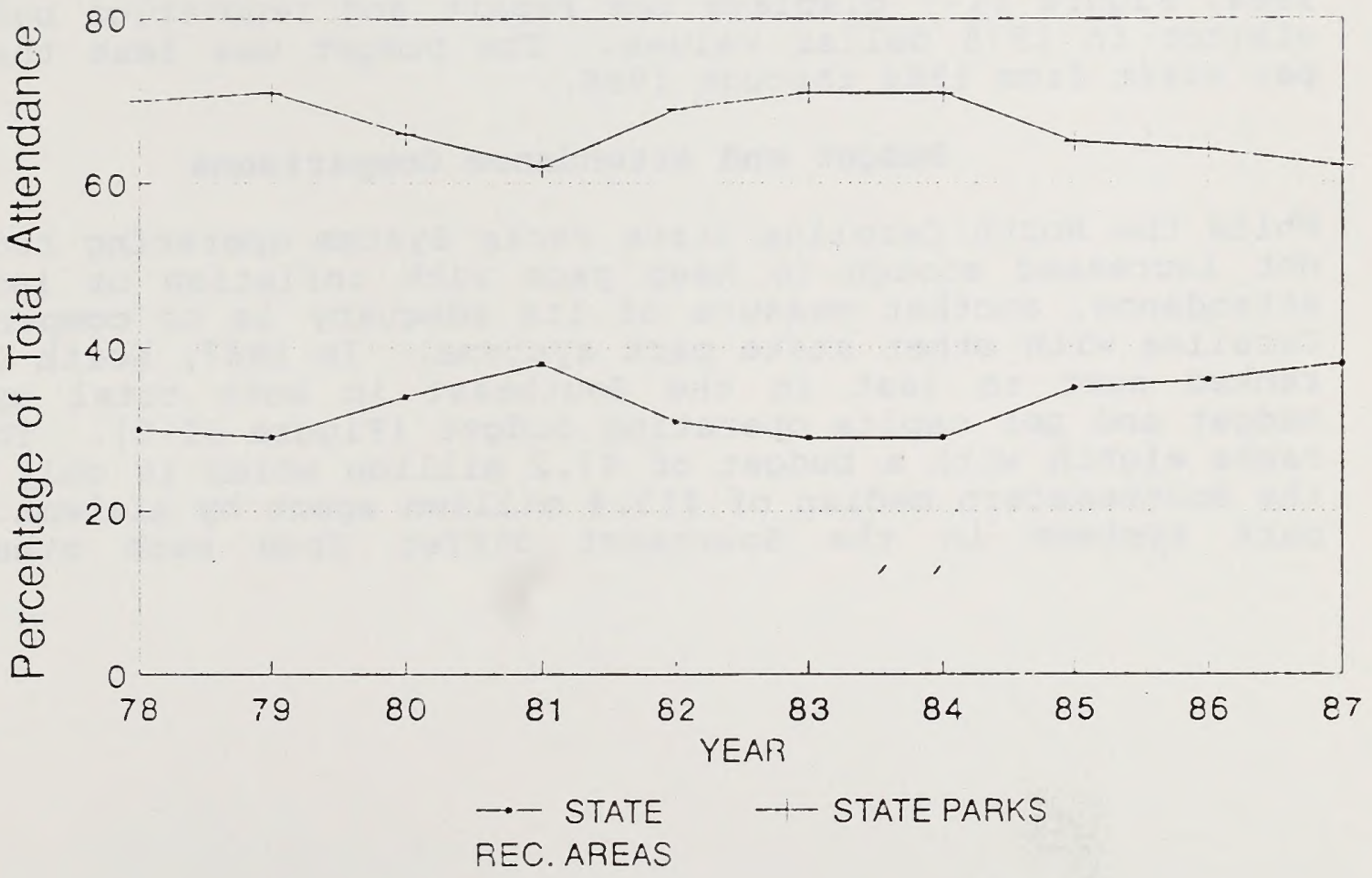

Figure II-4 Percentage of Total Attendance By Managemen: Category 


\section{Budget Versus Attendance}

Operating budgets for the State Parks System have not kept pace with attendance and inflation increases in the past decade. Total attendance rose from 4.8 million visitors in 1978 to 7.6 million visitors in 1987; a sixty percent increase. During the same period, the operating budget grew only twenty-nine percent over inflation (Figure II-5). In 1978 dollar values, the operating budget increased from $\$ 2.68$ million in 1978 to $\$ 3.45$ million in 1987. An increase in actual purchasing power of less than $\$ 800,000$ occurred as attendance increased by 2.7 million visitors.

During the ten years from 1978 to 1987, operating budget per visitor decreased from $\$ 0.56$ to $\$ 0.45$ in 1978 dollar values; a decrease of nearly $20 \%$ (Figure II-6). Except for 1980, operating budget per visitor decreased every year from 1979 through 1985 in actual purchasing power. This trend shows the limited resources available to accomplish the mission of the State Parks System were shrinking as steadily increasing attendance created greater pressures on natural resources and visitor services.

--RECOMMENDATION II-20: Increased operating and development budgets are needed to meet increasing use of the system.

Minimal funding has been available for repairs and renovation. Although budget information is not available for years prior to 1984, Figure II-7 displays the repair and renovation budget per visitor in 1978 dollar values. The budget was less than $\$ 0.10$ per visit from 1984 through 1986.

\section{Budget and Attendance Comparisons}

While the North Carolina State Parks System operating budget has not increased enough to keep pace with inflation or increasing attendance, another measure of its adequacy is to compare North Carolina with other state park systems. In 1987, North Carolina ranked next to last in the southeast in both total operating budget and per capita operating budget (Figure II-8). The State ranks eighth with a budget of $\$ 7.2$ million which is only half of the Southeastern median of $\$ 15.4$ million spent by Alabama. State park systems in the southeast differ from each other with 
STATE PARK OPERATING BUDGET \& ATTENDANCE ('Jsing 1978 Dollars)

\section{Millions}

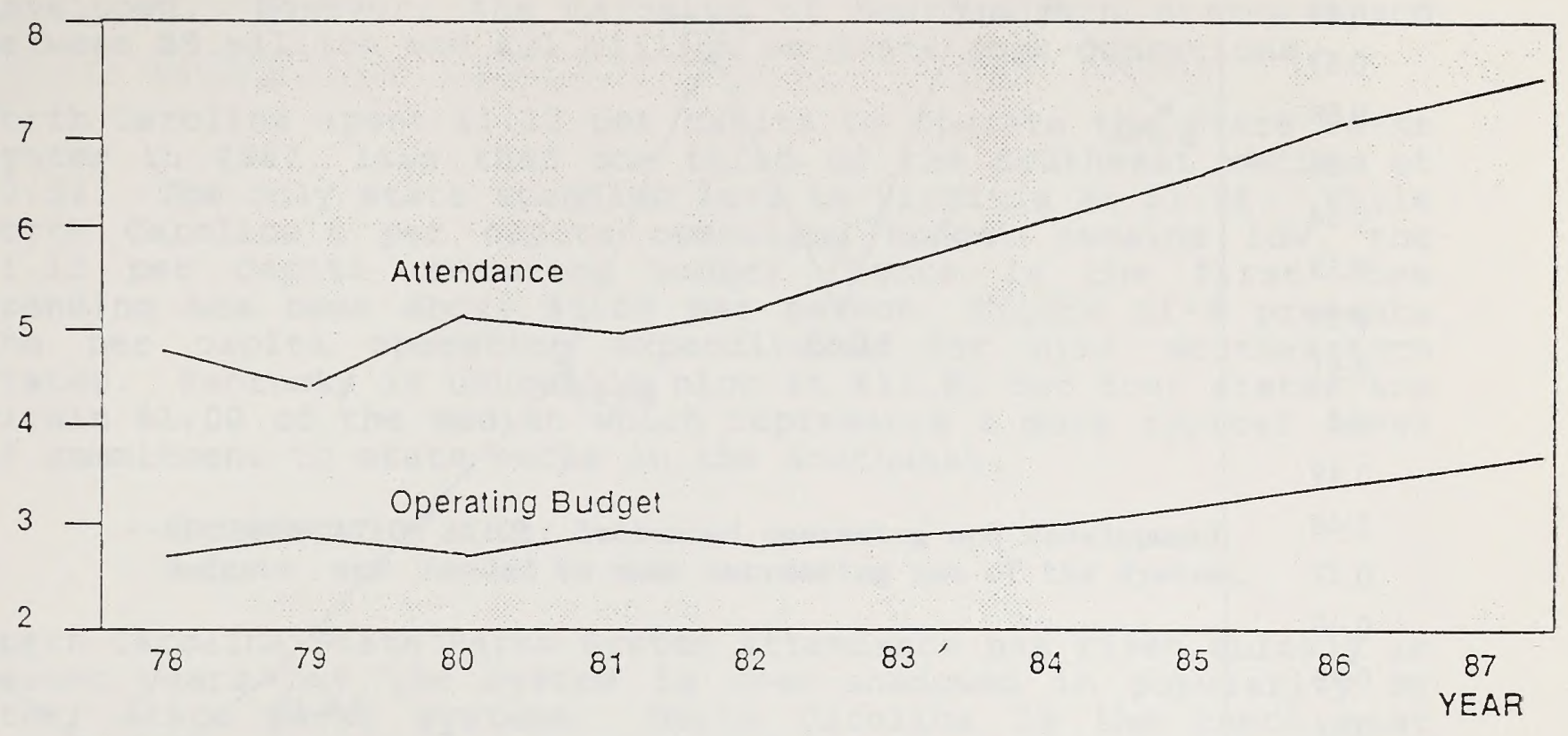

Figure II-5. State Parks System Operating Budget and Attendance. 
1978 Dollars

(Using 1978 Dollars)

\subsection{9 \\ 0.58 \\ 0.57 \\ 0.56 \\ 0.55 \\ 0.54 \\ 0.53 \\ 0.52 \\ 0.51 \\ 0.5 \\ 0.49 \\ 0.48 \\ 0.47 \\ 0.46 \\ 0.45 \\ 0.44 \\ 0.43 \\ 0.42}

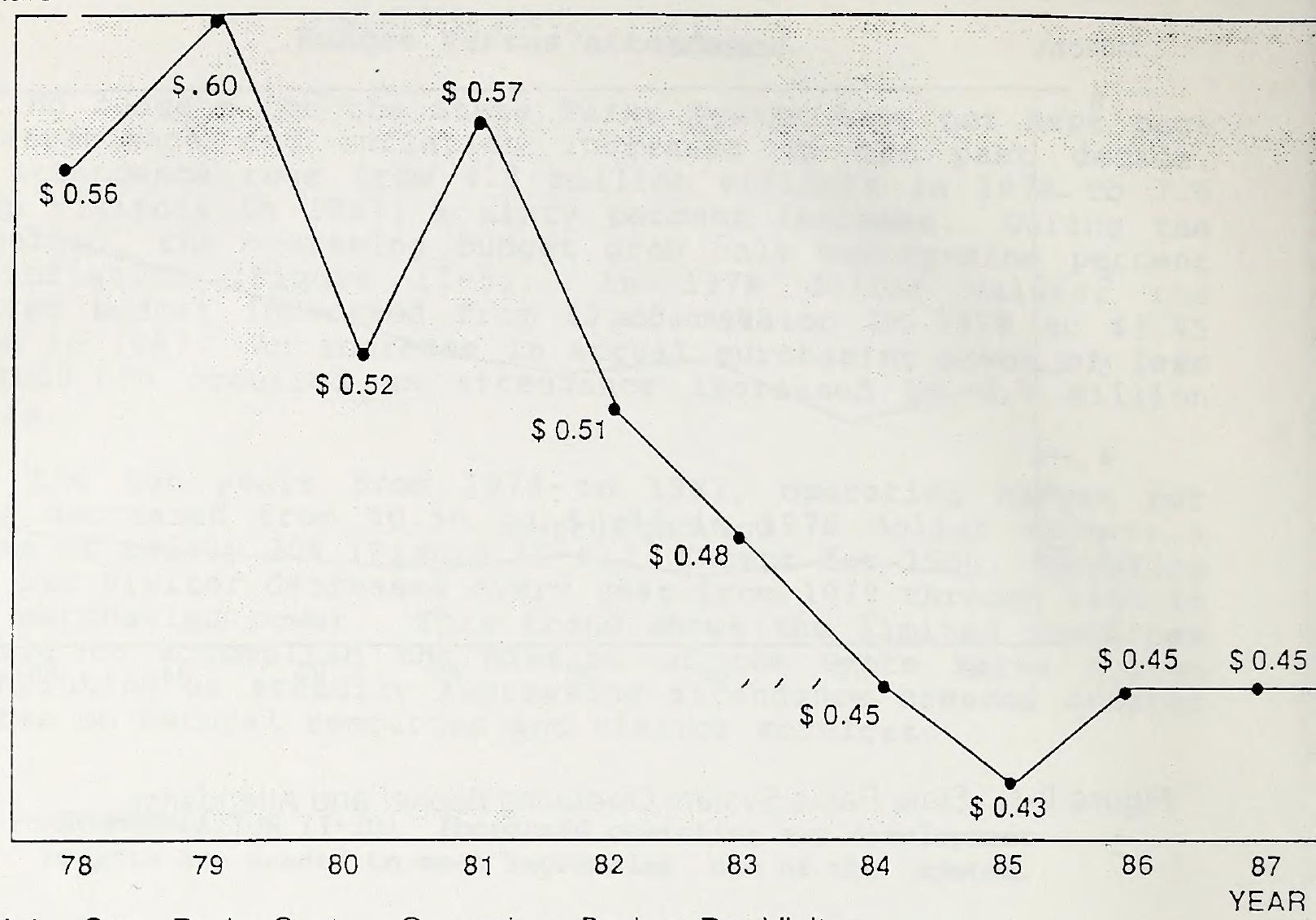

Figure II-6. State Parks System Operations Budget Per Visitor.

REPAIR \& RENOVATIONS BUDGET PER VISITOR

1978 Dollars (Using 1978 Dollars)

0.19

0.18

0.17

0.16

0.15

0.14

0.13

0.12

0.11

0.10

0.09

0.08

0.07

0.06

0.05

0.04

0.03

0.02

0.01

0.00

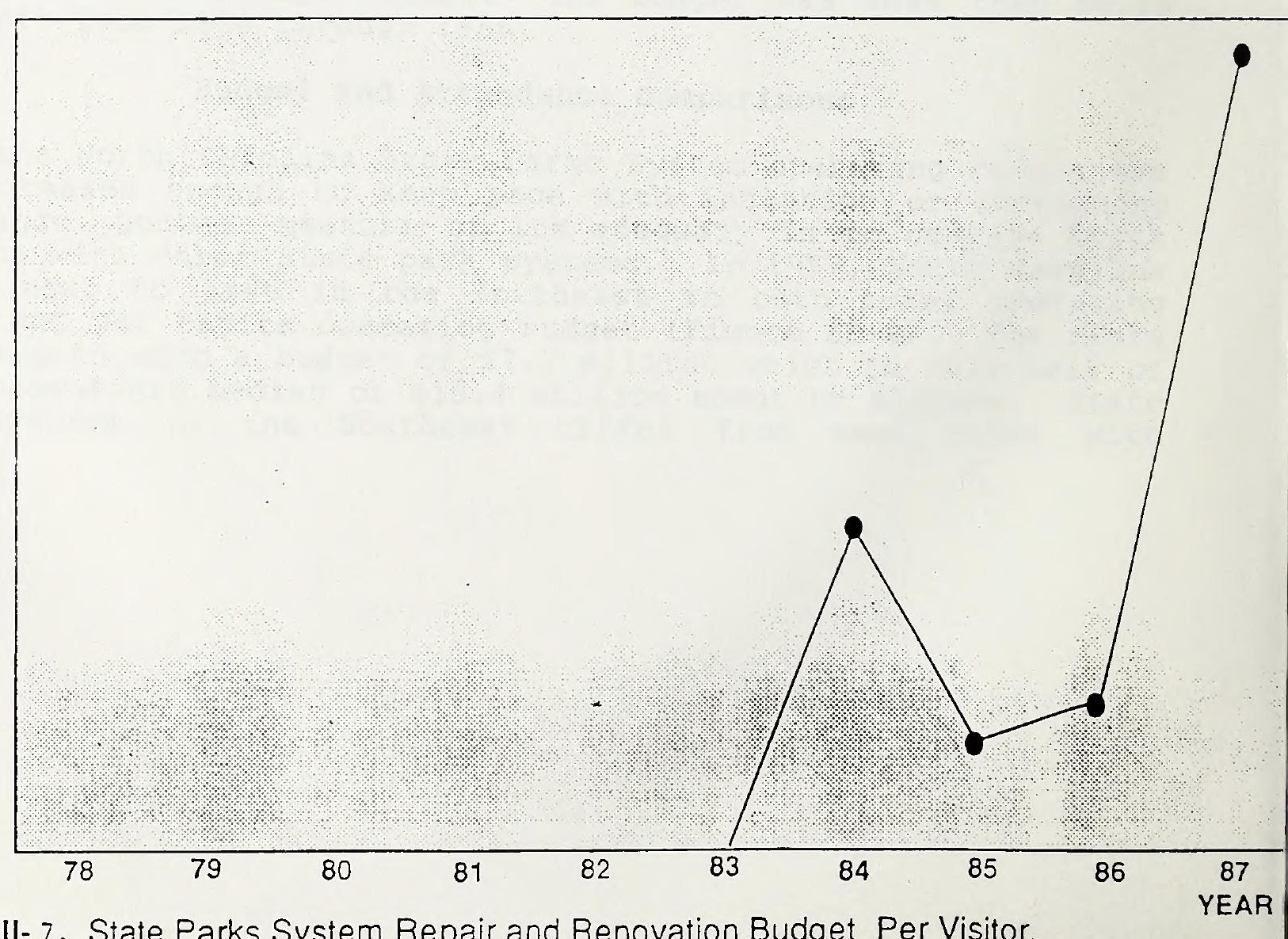

Figure II- 7. State Parks System Repair and Renovation Budget Per Visitor. 
Kentucky's tourism-oriented resort parks being the most developed. However, the majority of southeastern states spend between $\$ 9$ million and $\$ 21$ million on state park operations.

North Carolina spent $\$ 1.12$ per capita to operate the State Parks System in 1987, less than one third of the southeast median of $\$ 3.52$. The only state spending less is Virginia at $\$ 1.06$. While North Carolina's per capita operating budget remains low, the $\$ 1.12$ per capita operating budget figure is the first time spending has been above $\$ 1.00$ per person. Figure II-9 presents the per capita operating expenditures for nine southeastern states. Kentucky is unusually high at $\$ 13.91$ but four states are within $\$ 1.00$ of the median which represents a more typical level of commitment to state parks in the southeast.

\section{--RECOMIENDATION II-21: Increased operating and development budgets are needed to meet increasing use of the system.}

North Carolina State Parks System attendance has risen quickly in recent years but the system is over-shadowed in popularity by other state parks systems. North Carolina is the tenth most populated state in the country, yet its state park attendance lags behind the top ten states. Figure II-10 shows both population and state park visitation for the ten most populated states. While North Carolina compares favorably with three states; Florida, Texas, and New Jersey; the other six park systems are far more popular. For example, Pennsylvania and Illinois have populations between 11.5 million and 12 million while their state park systems draw between 35 million and 36 million visitors; over three visitors per resident. North Carolina state Parks receive just over one visitor per resident.

Because North Carolina is ranked 49 th in operating expenditures per capita, it's not surprising that it ranked last among the ten most populated states. The median per capita operating expenditure for these ten states is $\$ 2.37$ compared to $\$ 1.12$ for North Carolina. New York spends $\$ 5.61$ per capita or about $\$ 85$ miliion annually on operating its state parks to rank first among the most populated states.

\section{Staffing}

Staffing in state park field units has increased in the past ten years, but has not increased sufficiently to match rising attendance figures. As with the operating budget, North Carolina State Parks System staffing levels have been traditionally lower than in other states. The combination of continued low staff levels and increased use pressures have reduced staff activities to a custodial level of management. 


\section{"Beach Week" at Jockey's Ridge Strains Park Staff}

Jockey's Ridge State Park provides a spectacular view of a North Carolina barrier island from the highest active sand dune on the east coast. However, for at least one week per year, this scenic attraction becomes a management nightmare. "Beach Week" brings over 1,000 William and Mary College students to Nags Head after final exams. The students congregate on Jockey's Ridge sand dune each night around 7 p.m. to watch the sunset and "blow off steam".

This tradition, which began in the early 1980s, created problems that the ranger staff was not capable of handling. Jockey's Ridge, like many State Parks, has one ranger on duty to close the park. The first year that "Beach Week" occurred, the students refused to leave when the park closed at $9 \mathrm{p} . \mathrm{m}$. Widespread consumption of alcohol fueled the unruly crowd. The only ranger on duty, pregnant at the time, was ignored by the crowd as she tried to disperse them. Students remaining in the park simply ran away from the ranger who had no law enforcement authority or training. When the students finally left, they also left a pickup truck load of beer cans littering the park. The scene was repeated each night for a week.

As "Beach Week" continues each year, the State sends up to five park superintendents and experienced rangers to Jockey's Ridge to enforce park rules on closing hours and prohibiting alcohol consumption. The park only has two full time rangers and does not have a superintendent. Rangers must be posted in the park until midnight to prevent vandalism. Not only is the operation expensive, it causes other eastern North Carolina parks to be short staffed as well. 


\section{Southeast State Park Operating Budgets 1987}

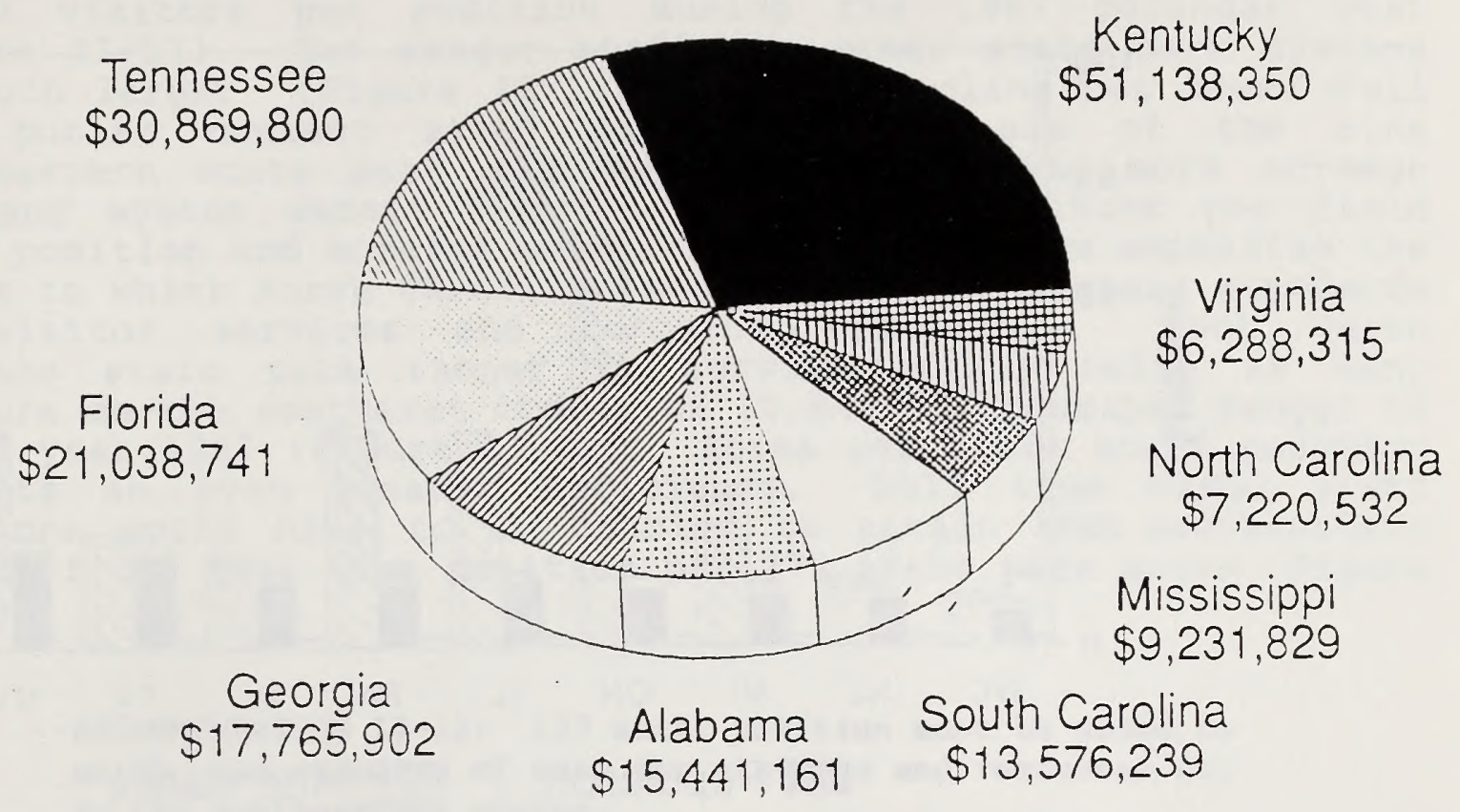

Figure 11-8 Southeast State Park System Operating Budgets by State

\section{Southeast State Park Per Capita Operating Budgets 1987}

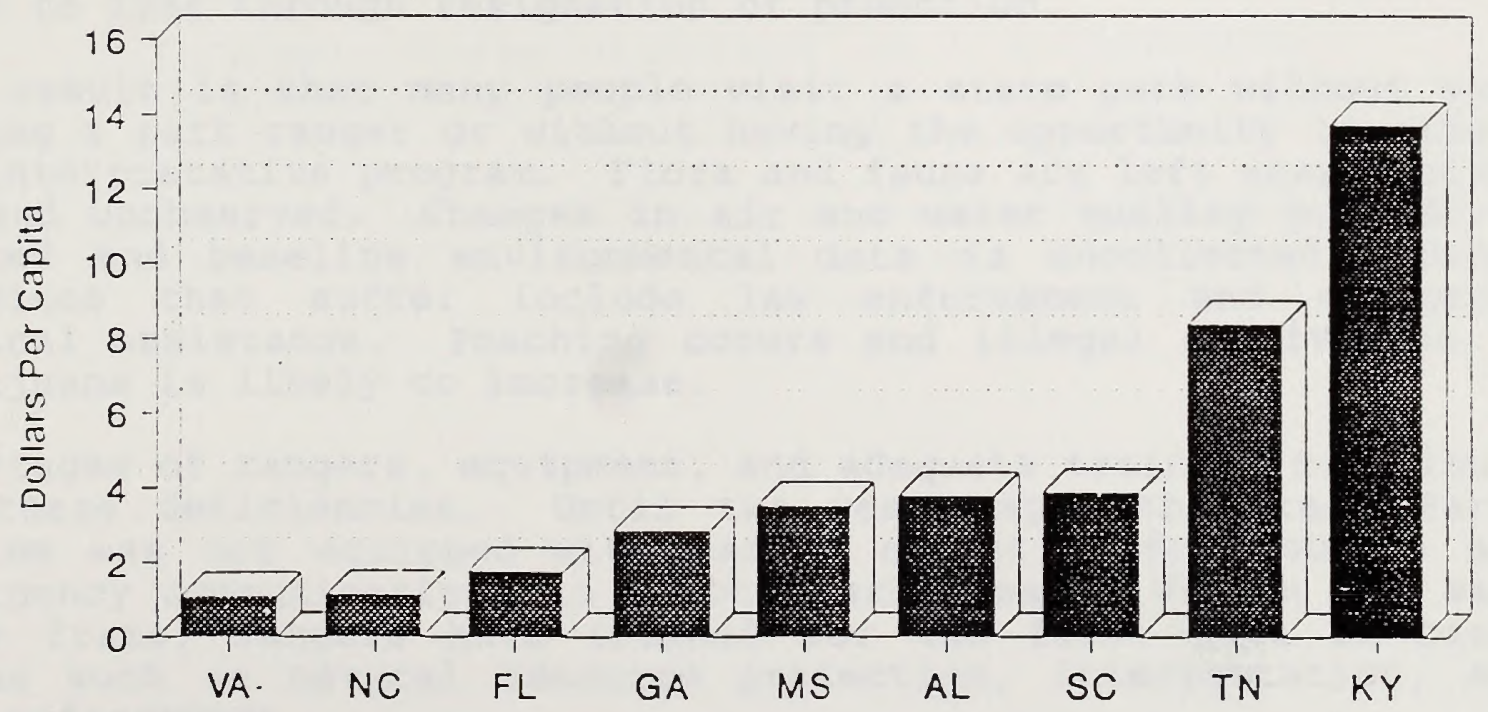

Figure II-9 Per Capita Operating Budget for Southeast State Park System 


\section{Popuation And State Park Visitation}

In The Ten Most Populous States In the Nation

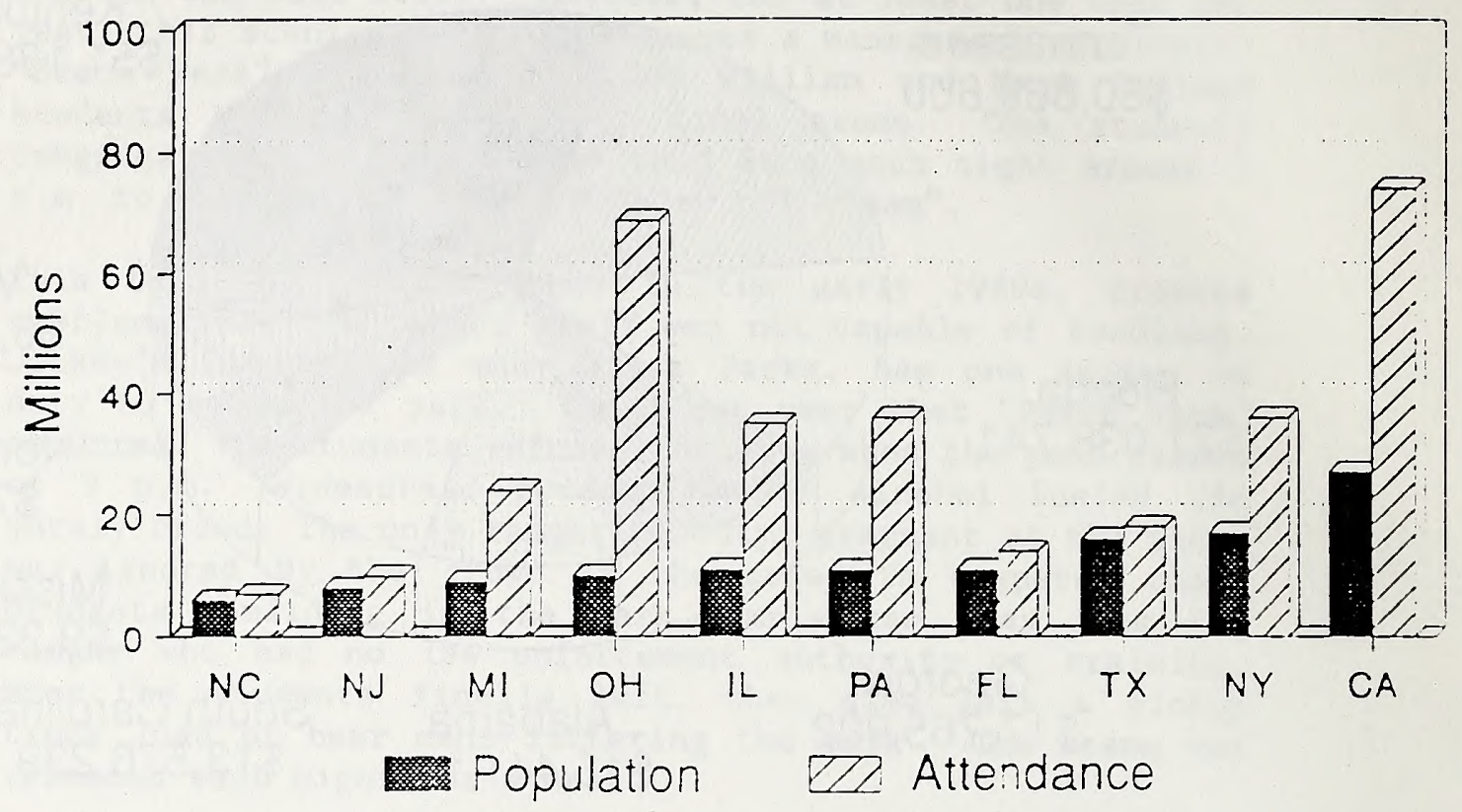

Figu:e Il-10 State Park Attendance In The Ten Most Populous States 
There are 110 public contact staff positions in the park units currently to serve over 7.6 million visitors annually; over 60,000 visitors per position during the 1987 calendar year (Figure II-11). The ranger staffs in other state park systems are much larger (Figure II-12). North Carolina has fewer full time public contact staff positions than six of the nine southeastern state park systems despite managing more acreage than any system except Florid1. Ratios for visitors per field staff position and acreage per field staff position emphasize the extent to which North Carolina lags behind southeastern standards for visitor services and resource protection. Each North Carolina state park ranger is serving nearly twice as many visitors as the southeast median of 30,844 visitors per ranger in fiscal year 1987 (Figure II-13). Acres per field staff position presents an even greater deficiency. Full time field staff positions would have to be doubled to attain the southeastern median of one full time position per 372 state park acres (Figure II-14).

--RECOMMENDATION II-22: 123 staff position must be added to match the standard of care for visitors and resources set by the southeastern states.

The system is without maintenance employees except at the federal reservoirs and seven parks (DUPO, FOMA, HABE, HARO, PETT, STMO, and WIUM), making rangers responsible for inappropriate, routine janitorial chores. Park rangers are forced to become primary maintenance workers without sufficient time to handle more appropriate responsibilities including interpretation, natural resource management, and protecting public safety. As a result of frustration with inappropriate job responsibilities and low pay, fifty percent of all Ranger I positions were vacated from 1986 to 1988 through resignation or promotion.

The result is that many people visit a state park without ever seeing a park ranger or without having the opportunity to attend an interpretative program. Flora and fauna are left unappreciated and unobserved. Changes in air and water quality go undocumented and baseline environmental data is uncollected. Other services that suffer include law enforcement and emergency medical assistance. Poaching occurs and illegal cultivation of marijuana is likely to increase.

Shortages of rangers, equipment, and adequate training contribute to these deficiencies. Until two years ago, the state Parks System was not equipped with radios essential for routine and emergency communications in remote park areas. Within the same time frame, rangers have trained for the first time in basic areas such as natural resource protection, interpretation, and law enforcement. 
Specific staffing needs for each unit are listed in park profiles (Appendix II-1). A minimum of three permanent staff are necessary in each unit to assure that someone is available to provide assistance to visitors during all operating hours. Ten of the operated units do not meet this critical minimum standard. The units include: Fort Fisher, Hammocks Beach, Jockey's Ridge, Lake Waccamaw, Medoc Mountain, Pettigrew, New River, Mount Jefferson, Waynesborough, and Weymouth woods. There is an immediate, critical need to provile park superintendents at Jockey's Ridge, Lake Waccamaw, Fort Fisher, and New River.

Insufficient clerical positions are allocated to state park field units. Only twelve of the thirty-three operational units have a clerk-typist position; ten being half-time positions (full-time: Jordan Lake, Kerr Lake; half-time: Eno River Falls Lake, Fort Macon, Hanging Rock, Morrow Mountain, Pilot Mountain, Singletary Lake, stone Mountain, weymouth woods, william Umstead). The four district offices have clerk-typists although only one is a full-time position. Without sufficient clerical staff, basic services such as greeting the public and providing park information are unavailable when rangers are away from the office.

In the absense of clerical staff, rangers and superintendents must perform routine clerical duties. These tasks take time away from appropriate ranger duties such as interpretation and education, and resource management. A full time clerical position in each operational unit and district office is needed to relieve rangers of clerical duties and provide basic park information to visitors.

--RECOMMENDATION II-23: A critical need exists to provide park superintendents at Jockey's Ridge, Lake Waccamaw, Fort Fisher, and New River.

--RECOMMENDATION II-24: Staffing at tem parks should be increased immediately to meet the minimum standard of three rangers in each operated unit.

--RECOMMENDATION II-25: A minimum of one full time clerical and one full time maintenance position must be available for all operated units. 


\section{Visitors PerFull Time Position \\ 1978-1987}

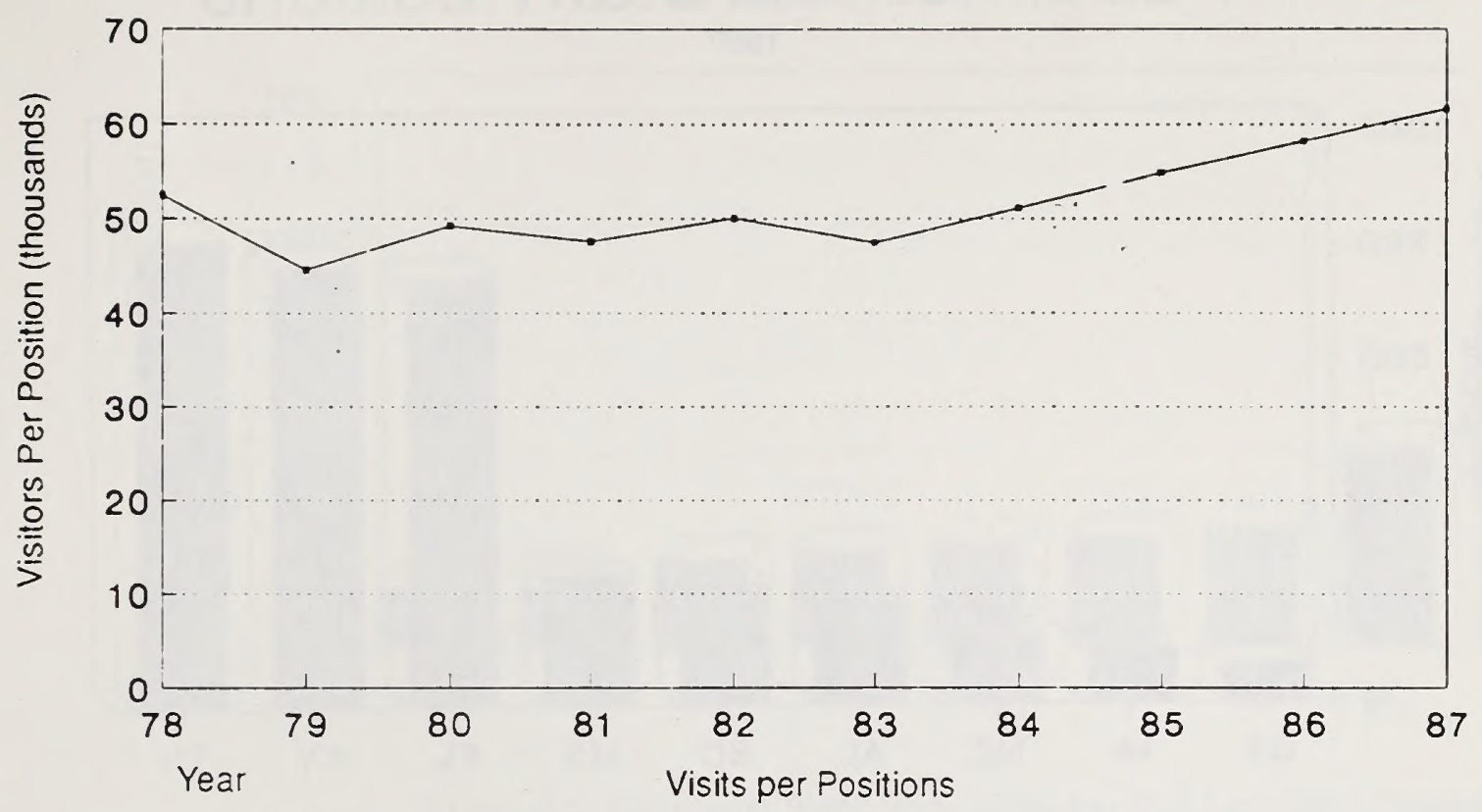

Figure II-11 State Park System Visitors Per Position 


\section{Full Time Field Staff Positions 1987}

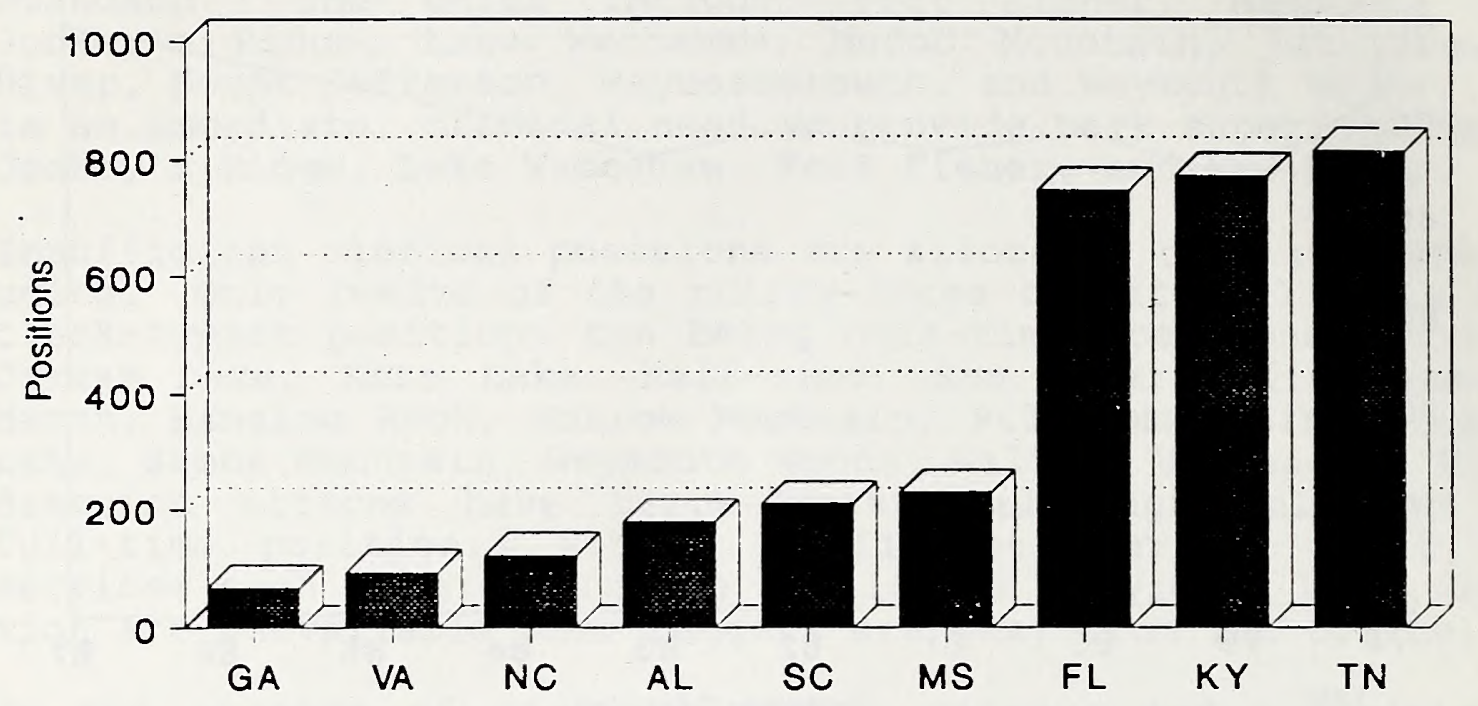

Figure II-12 Full Time Staff Positions for Southeastern State Park Systems 


\section{Southeast State Park Visits Per Full Time Field Staff Position 1987}

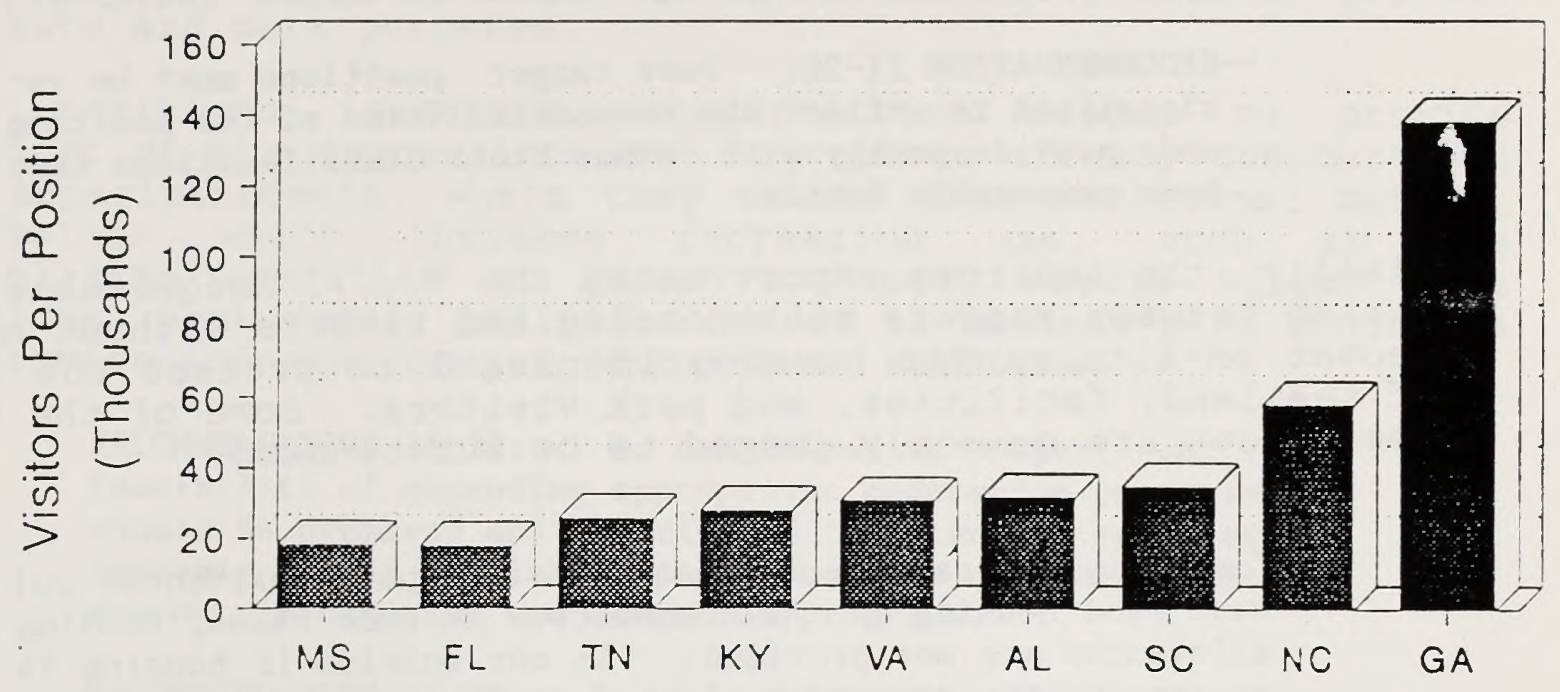

Figure II-13 Southeast State Park Visits Per Full Time Staff Position

\section{Southeast State Park Acres Per Full Time Field Staff Position 1987}

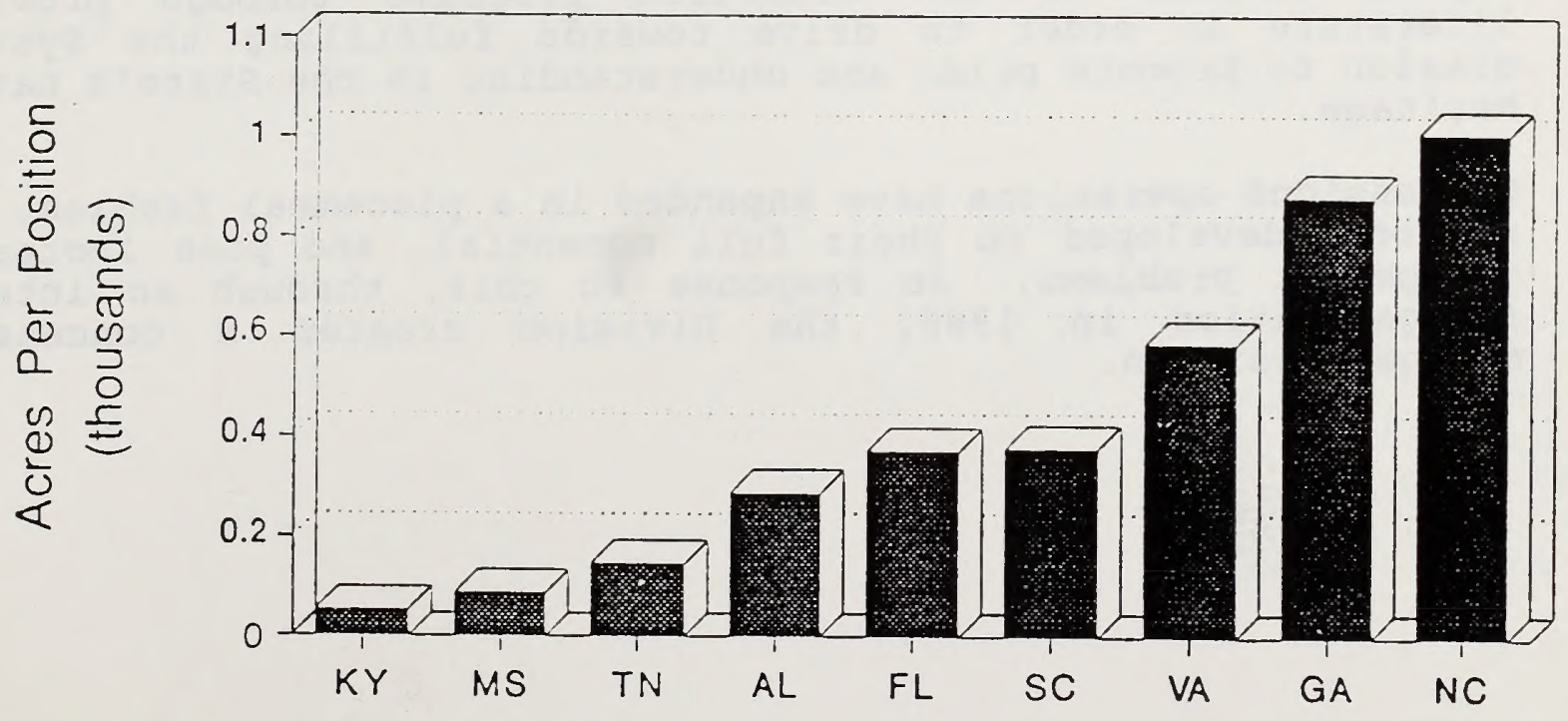

Figure II-14 Southeast State Park Acres Per Full Time Staff Position 
The Auditor's report goes on to note the disparity between classifications for park rangers and field staff in the Division of Forestry, Wildlife Resources Commission, and state Historic Sites. Relatively low classification for ranger positions has been a long standing concern of the Division and undoubtedly contributes to unacceptably high rates of staff turnover.

--RECOMENDATION II-26: Park ranger positions must be reclassified to reflect the responsibilities of the position and provide parity with other State classifications that have comparable duties.

Finally, the Auditors report notes the ".... inequitable compensation between rangers with housing and rangers without housing." Decent on-site ranger housing is needed to protect the security of the land, facilities, and park visitors. Some of the existing residences are commonly judged to be substandard.

Currently, 28 rangers are not provided park residences and must find housing in the community. In such cases, housing allowances are not provided. In our opinion if housing is an appropriate component of the system, all rangers should be provided with a residence

$$
\text { - } 1987 \text { State Auditors Report }
$$

--RECOMMNDATION II-27: Decent housing must be provided for park rangers. Twenty eight residences should be constructed. Inadequate housing must be renovated or replaced to reduce staff turnover.

\section{Concessions Management}

Expansion of concessions operations provides needed recreational opportunities and local economic development. In particular, concessions and/or cooperative agreements offer an opportunity to expand information and education programs through providing literature in order to drive towards fulfiliing the system's mission to promote pride and understanding in the state's natural heritage.

Concessions operations have expanded in a piecemeal fashion, have not been developed to their full potential, and pose increasing management problems. In response to this, through an internal reorganization in 1986, the Division created a concessions manager position. 
Public versus private ownership issues are central to an expanded concessions agreements in the state Parks system. The private concessioner should provide an appropriate service which achieves park goals and objectives. Public ownership and control of all park facilities is therefore desirable. Privately owned facilities create greater potential for conflict between private interests and park purposes.

Staff positions (contract managers) are needed to provide oversight of the concessions and to relieve already overburdoned park superintendents, where they exist, from additional duties. concessions which increase recreation use, such as the hang-gliding operation at Jockey's Ridge, should support the additional park ranger positions needed to protect park resources and provide information and educational services.

--RECOMMENDATION II-28: A comprehensive report on the feasibility of expanding appropriate concession operations should be prepared and distributed to potential operators. Emphasis should be placed upon concession operations which support information and education programs.

--RECOMIENDATION II-29: In a self-perpetuating system, a portion of the receipts realized from expanded concessions should support staff positions necessary for oversight of the operations.

--RECOMMENDATION II-30: A concessions contract manager position should be immediately created for the Reservoir district in order to provide needed oversight of operations. 
Table II-13. Revenue from Concessions Operations for Southeastern State Parks and Recreation Systems*.

South Carolina

Alabama

West Virginia

Georgia

Florida

Kentucky

North Carolina

Virginia

Tennessee
$\$ 2,692,971$

$1,546,744$

$1,287,232$

930,985

760,386

620,075

204,850

134,155

91,879

* Source: State Park Directors Information Exchange for the 1987 Fiscal Year.

Relative to other state park systems, the North Carolina System has a very limited number of concession arrangements (Table II-13). Eight concession agreements are in operation including a restaurant at Mt. Mitchell, four marinas at Kerr, Jordan, and Falls Lake, beach chairs at Ft. Macon, hang gliding at Jockey's Ridge, and a snack bar at Kerr Lake.

At Fort Macon, the Eastern National Park and Monument Association (ENPMA) operates a bookstore selling park-related literature. The association, a non-profit organization, has similar working agreements with the National Park Service and and other state park systems. The bookstore is operated at no cost to the Division and enhances the information and education resources at the park. Similar agreements with ENPMA should be explored at other park units where feasible.

Revenues realized from concessions become a part of the Division budget through the state budgeting process. State appropriations are reduced by estimated park concessions revenues. In state Parks, overcollections must be anticipated and spent or they revert to the State General Fund at the end of the fiscal year. Potential exists for directing more concessions revenues to park purposes by returning the revenues to a non-profit foundation, such as North Carolina Recreation and Park Foundation. The foundation could then support state park funding needs through a grants process. 


\section{Volunteer Initiatives}

Volunteers have traditionally been a source of labor and support for state and national parks. The Appalachian Trail exemplifies a comprehensive volunteer program. Trail segments are assigned to volunteer organizations for maintenance. These groups are kept involved and informed through awards, newsletter communications and conferences.

In North Carolina, school teachers volunteered to give nature talks in state parks over forty years ago. Citizen groups have organized to purchase and donate land for state parks. However, the Division of Parks and Recreation has only recently begun coordinating volunteer efforts in order to attract more volunteers and use their skills more efficiently. A volunteer coordinator position was created through a 1986 internal reorganization.

Recent volunteer programs have provided valuable contributions to the State Parks System. A Z. Smith Reynolds Foundation grant created an Adopt-A-Parks Program. The $\$ 35,000$ grant provided up to $\$ 1,000$ to groups interested in doing hands-on projects in state parks. Adopt-A-Park projects ranged from trail construction projects to creating interpretive brochures. A total of forty-one grants were awarded over the life of the program.

Although the Community Service workers Program was not strictly a volunteer program, it provided the state Parks system with a significant labor force for maintenance projects. People convicted of criminal offenses could be sentenced to performing community service work. During the two years that the program was in operation, 105,103 hours of service were performed creating $\$ 840,824$ in savings to the state Parks System. The program ended in 1988 when all funding was expended. While the Adopt-APark and Community Service workers programs made contributions, both programs were only in effect a short time. The state parks System must support a consistent, continuing program to more effectively use volunteer talent and energy.

\section{--RECOMIENDATION: II-31: Develop consistent support for the volunteer program to effectively use volunteers on a continuing basis.}

The State Trails system provides one example of a successful volunteer program in which efforts have been focused on completing the Mountains-To-Sea Trail. Fifteen task forces are responsible for completing a multi-use trail across North Carolina. Over 500 trail miles have been dedicated through volunteer efforts. The creation of a state trails coordinator position and four district trails coordinators is expected to provide even greater accomplishments. 
Recognizing volunteer contributions is an essential, yet inexpensive aspect of a successful program. Awards help improve volunteer interest and motivation. Typical awards recognize milestones in length of volunteer service or outstanding contributions on specific projects.

--RBCOMANDATION II-32: Develop an incentives program to recognize volunteer achievements.

--RECOMMENDATION II-33: Develop and administer a comprehensive volunteer program without decreasing support for other Division programs.

--RECOMENDATION II-34: Provide adequate field staff to supervise volunteer activities.

\section{Conclusion}

North Carolina State Parks have been traditionally managed with minimal staff and operating resources. As parks were added to the system, no standard existed for adding sufficient operations and management funding support. Many units are left unoperated and therefore subject to abuse from unmonitored uses. The system lacks the resources to protect park natural features, interpret these features to the public, protect public safety, and provide maintenance. Increasing attendance and minimal funding has produced a custodial level of management that does not protect the public's investment in state parks. Inadequate staffing levels lead rangers to perform inappropriate custodial activities rather than providing adequate information and education services. Comparisons with other state park systems reveals the degree to which operating budgets and staff levels fall short of more successful park systems. In recent years, the North Carolina state Parks System has been the third fastest growing in attendance in the United States. Attendance at Falls Lake and Jordan Lake State Recreation Areas has grown 19 percent per year since 1984. The trend will continue as more recreation facilities open at these reservoirs. North Carolina must triple its per capita operating budget to reach the southeast state park median of \$3.52. Full time field positions would need to nearly double to reach the southeast median of 211 positions. Concession operations have expanded in a piecemeal fashion, have not been developed to their full potential, and pose increasing management problems. The Division of Parks and Recreation has only recently begun coordinating volunteer efforts in order to attract more volunteers and use their skills more efficiently. 


\section{THE STATE OF PLANNING FOR THE STATE PARKS SYSTEM}

No legal mandate existed for state Park systemwide planning until the State Parks Act was passed by the 1987 General Assembly. State policy for the State Parks System began as early as 1929 when the General Assembly approved a policy stating that land acquisition would occur through donations rather than appropriationi. For the next fifty-eight years, state park planning developed administrative guidelines, principles, and recommendations that presented changing goals for the system but were usualiy not implemented. Legislative study commission recommendations, beginning in 1969, have received the greatest support for implementation.

As described in chapter I, numerous efforts have been made to shape the mission of the state Parks system. The earliest planning produced guidelines in 1936 developed by the state Planning Board and National Park Service (NPS). The guidelines balanced preservation and recreation priorities by stating that parks should have natural beauty and recreation possibilities, statewide scientific value, or typical scenery near population centers. These guidelines were considered when NPS donated demonstration parks like William B. Umstead. In 1955, the Board of Conservation and Development adopted new guidelines for the system, the state Park Principles. The principles established the purpose of the system as preserving scenic and scientific resources of statewide importance and providing recreation in natural surroundings. The principles established three site classifications including standards for minimum size and significance. State Natural Area Principles, following a similar format, were adopted in 1963.

These guidelines and principles have several shortcomings for state park planning. First, none were established with a legislative mandate and therefore did not provide a consistent mission for the state Parks system. The principles could be ignored by administrative or legislative decision makers with opposing viewpoints. Second, the guidelines and principles provided no actions or recommendations for achieving a mission. From 1929 to 1969, the state Policy prohibited park land acquisition and therefore no resources for initiating system expansion existed. Finally, no operations standards for staffing, maintenance, resource protection or interpretation were described.

The first state Park Study Commission, 1967-69, produced a system plan and recommendations for expanding the system. The commission approved a recreation-oriented approach to selecting new parks by recommending that a state park be located within fifty miles of most of the state's population. The recommendation produced the first priority listing for park expansion needs. 
New acquisitions were intended to double park system acreage and provide 20 acres per 1,000 population by 1980 . Other recommendations for development, staffing, planning, and administration were given less emphasis than land acquisition priorities.

The second State Park Study Commission, 1977-79, found that the goal of locating a state park within 50 miles of most of the state's population had been accomplished by the new units added in the previous decade. Recommendations in the 1979 plan "New Directions" :ocused on improvements to existing parks including land acquisition, capital improvements and staffing. Addition of a recreation area in the Triad was recommended. State trails and state rivers expansion needs were also endorsed.

Implementation of recommendations from both state Park study Commissions emphasized land acquisition over capital improvements, visitor services, or staffing. No standard for facilities, services, maintenance, or staffing were established and land acquisition continued to receive highest priority when appropriations became available. A mission statement driving the system forward was not developed.

State park planning has not been a continuous process. Park master plans, completed from 1970-1981 for 23 parks, exemplify this deficiency. Parks without master plans include Fort Macon, Carolina Beach, and Hammocks Beach. Funding was never available to produce master plans for all park units and completed master plans were never updated. The planning staff, funded with capital improvement money, was eliminated when appropriations were reduced. The master plans are therefore based on population trends, surrounding land use patterns, and preservation priorities that have significantly changed since the plans were finished. Without review and updating, the master plans propose solutions from the $1970^{\prime} \mathrm{s}$ to the conditions of the 1990's.

The Department of Natural Resources and Community Development endorsed a Six Point Plan for Parks and Recreation in 1986 which addressed the deficiencies of previous planning efforts. The plan proposed enabling legislation to provide the system's first legislatively mandated mission statement. The legislation, the State Parks Act, stipulates that additions to the system must be accompanied by adequate authorization and appropriation for acquisition, development, and operations. A systemwide plan is to be updated on a continuous five year cycle. And, general management plans are required for each unit describing 'it's purpose, classification, and management direction based on the systemwide plan.

Future needs include definitions for each management category. The definitions should include a prescription of adequate 
operation, development, and acquisition needs necessary to be a unit of statewide significance meeting stipulations of the state Parks Act. These management category definitions should be legislatively approved policy to consistently guide management decisions and the consideration of future additions to the system.

--RECOMMENDATION II-35: Definitions for each management category should be produced and should include a prescription if adequate operation, development, and acquisition needs to be a unit of statewide significance meeting stipulations of the State Parks Act.

--RECOMMNDATION II-36: Definitions for each management category should be approved by the General Assembly to guide management decisions and the addition of new units.

--RECOMMENDATION II-37: Master plans should be produced for a11 State Parks System units that do not have an existing plan.

--RECOMENDATION II-38: All existing master plans should be updated to reflect changes occurring since the plans were completed.

\section{Conclusion}

Until 1987, no legal mandate existed for state Parks System Planning. Administrative guidelines and principles were adopted describing park purposes and standards which could be reinterpreted or ignored. No operation standards for staffing, maintenance, development, resource protection or interpretation were described. While the 1955 state Park Principles emphasized preservation of natural resources, a 1969 State Park Study Commission recommended a recreation-oriented standard of locating a state park within fifty miles of most citizens. Master plans were produced for 23 units but none have been updated or implemented. The state Parks Act mandates the first continuous planning process evaluating whether the state Parks System is accomplishing its mission. Future planning should include legislatively approved policies for each management category to guide administrative decisions and the consideration of future additions to the system. 


\section{STATE FRAGMENTATION OF PRESERVATION AND INTERPRETATION PROGRAMS}

Several state agencies have responsibilities for preservation and interpretation in addition to the state Parks System. These include the Division of Forest Resources, the Department of Cultural Resources, the wildlife Resources commission, the Department of Administration (aquariums), the State $Z 00$, and the Division of Coastal Managemert. The Division of Forest Resources administers four small state forests to demonstrate uses of woodlands such as wildlife protection, timber products, education, and recreation. The Department of Cultural Resources administers twenty-four historic sites interpreting historic towns, homesteads, residences, and battlegrounds significant to North Carolina history. The Wildlife Resources Commission manages approximately two million acres of game lands of which 201,000 are State owned. The Department of Administration maintains three state aquariums. And the Division of Coastal Management preserves examples of significant coastal natural areas as well as establishing beach access areas for public use.

The 1987 State Auditors Report made the following recommendation addressing preservation and interpretation in the state:

"During the course of our audit we noted that several state agencies are involved in the preservation and interpretation of public resources. In our opinion, the management of comparable activities through multiple agencies results in unnecessary fragmentation and may result in duplication of administrative structures and services. Accordingly, one of our recommendations is for the Governor to have his staff identify all agencies involved in the preservation and interpretation of public resources to examine the current management structures and to consider whether consolidation of some or all of the programs would provide a more efficient management structure."

--RECOMIENDATION II-39: Identify all agencies involved in preservation and interpretation of park resources, examine the current management structures, and consider whether consolidation of some or all of the programs to provide a more efficient management structure. 


\section{INTERPRETATION AND EDUCATION PROGRAM}

The State Parks system contains outstanding opportunities for educating North Carolinians about the State's natural and cultural heritage and the consequences of their actions on the environment. However, inadequate staffing and facilities leave this opportunity largely unfulfilled. The Division of Parks and Recreation should take the initiative in environmental education across the state.

Since its creation in 1915, the North Carolina State Parks System has provided visitors with opportunities for quality recreation and learning about the unique natural resources of the State through interpretive and education programs. Increasing demands for these dwindling resources place an even greater emphasis on education as a sound management tool for natural resources agencies.

The State Parks System manages park units throughout the state. This land resource puts most school systems and the general public within easy access of an environmental learning opportunity at State Park and Recreation Areas.

No other single agency can duplicate the land and staff resources in the state Parks system, nor are they charged with providing the level of services and programs to schools, organizations, and the public-at-large.

The State Parks System should serve as a model for environmental education and for promoting a sense of stewardship toward North Carolina's natural and cultural heritage. Park visitors must be involved in the educational process and learn how each park's features contribute to the values of the state Parks System and to enhancing the quality of life for all North Carolinians. This also provides the necessary foundation to maintain a quality State Parks System for present and future generations. Management strategy must emphasize the importance of educating the public about the needs for public open space and about the wise use of the State's resources.

\section{--RECOMmDATION II-40: The State Parks System should serve as a model for environmental education and for promoting a sense of stewardship towards North Carolina's natural and cultural heritage.}

The Division of Parks and Recreation has recently made big strides in tying the Basic Education Program to park interpretive activities. Programs are being developed which relate park themes to school curricula. Superintendents of operated units have been charged with developing one activity to serve curricula needs by 1989. Increasing staff and providing adequate support will greatly increase the state Parks system's ability to serve as outdoor laboratories for environmental education. 


\section{CHAPTER SUMMARY CONCLUSIONS}

RECREATIONAL OPPORTUNITIES - The passive activities available at nearly all system units; such as nature study, hiking, and fishing; are offered because they are relatively inexpensive. Visitor centers, interpretative exhibits, and recreation opportunities requiring capital development are usually absent except where the facilities were built with federal assistance. Except for recreation area users, the current recreation opportunities appeal to specialized visitors who can enjoy the natural resources th ough independent study. State parks in other states offer a much broader range of recreation opportunities while maintaining an emphasis on natural resource protection that is supported through information and education programs.

A PROFILE OF THE TYPICAL NORTH CAROLINA STATE PARK VISITOR - A young, educated family characterizes the typical state park user group. Favoring an uncrowded park experience and the convenience of traveling to a North Carolina State Park unit, the typical park user visits approximately ten times per year. North Carolina residents outnumber tourists three-to-one. State park systems in all surrounding states attract a higher percentage of tourists.

PHYSICAL PLANT - Traditionally low, sporadic funding for development, and a reliance on federal construction programs, has created underdeveloped park units. Lacking cyclic maintenance, existing facilities have fallen into disrepair. Inadequate repair and renovation reserves have limited the Division's ability to address and correct the crisis situations created. The Division has identified significant repair-renovation needs but without, a significant increase in funding, does not have the resources necessary to address even critical needs. Recent inventory and inspection programs have identified over $\$ 114$ million in needed projects for new construction, renovations and repairs. These projects are necessary to protect the $\$ 330$ million public investment in park facilities, create new opportunities for public use, and protect natural resources by directing visitor use.

EXIERNAL AND INTERNAL THRRATS - The representative examples of North Carolina's natural heritage protected in the State Parks System are threatened by an assortment of pressures including adjacent land uses, pollution, and worn out, overused visitor use facilities. These threats have accelerated in recent years as North Carolina becomes a more urban state. Inadequate resources exist for resource management staffing, training, inventories, and protection programs. Land acquisition, the most effective resource protection program, has recently received significant funding after decades of neglect. More land, 23,000 acres, is needed to complete existing parks. Delaying funding will increase per acre costs as land values rise and will cause the important resource, buffer, and facility development lands to be lost to incompatible development.

ADMINISTRATION - North Carolina State Parks have been traditionally managed with minimal staff and operating resources. As parks were added to the system, no standard existed for adding sufficient operations and management funding support. Many units are left unoperated and therefore subject to abuse from unmonitored uses. The system lacks the necessary resources to protect park natural features, interpret these features to the public, protect public safety, and provide maintenance. Increasing attendance and minimal funding 
has produced a custodial level of management that does not protect the public's investment in state parks. Inadequate staffing levels lead rangers to perform inappropriate custodial activities rather than providing adequate information and education services. Comparisons with other state park systems reveal the degree to which operating budgets and staff levels fall short of more successful park systems. In recent years, the North Carolina State Parks System has been the third fastest growing in attendance in the United States. Attendance at Falls Lake and Jordan Lake State Recreation Areas has grown 19 percent per year since 1984. The trend will continue as more recreation facilities open at these reservoirs. North Carolina must triple its per capita operating budget to reach the southeast state park median of $\$ 3.52$. Full time field positions would need to nearly double to reach the southeast median of 211 positions. Concession operations have expanded in a piecemeal fashion, have not been developed to their full potential, and pose increasing management problems. The Division of Parks and Recreation has only recently begun coordinating volunteer efforts in order to attract more volunteers and use their skills more efficiently.

PLANNING: Until 1987, no legal mandate existed for State Parks System Planning. Administrative guidelines and principles were adopted describing park purposes and standards which could be reinterpreted or ignored. No operation standards for staffing, maintenance, development, resource protection or interpretation were described. While the 1955 State Park Principles emphasized preservation of natural resources, a 1969 State Park Study Commission recommended a recreation-oriented standard of locating a state park within fifty miles of most citizens. Master plans were produced for 23 units but none have been updated or implemented. The State Parks Act mandates the first continuous planning process evaluating whether the State Park System is accomplishing its mission. Future planning should include legislatively approved policies for each administrative category to guide management decisions and the consideration of future additions to the system. 

"Describe anticipated trends in usage of the State Parks System, detail what impacts these trends may have on the State Parks System, and recommend means and methods to accommodate those trends successfully." G.S. 113-44.11.5.

\section{INTRODUCTION}

The State Parks Act requires that the systemwide Plan describe anticipated trends in the usage of the state Parks system, detail what impacts these trends may have on the state Parks system, and recommend means and methods to accommodate trends successfully. In legislating this task, the General Assembly has recognized the important role that an accurate prediction of North Carolina's future outdoor recreation needs plays in the ability of the state to establish a positive and practical future direction for the State Parks System.

From the vast, cloud-draped peaks of Mount Mitchell in the west to the windy, shifting dunes of Jockey's Ridge in the east, nowhere is North Carolina's unique landscape better represented than in its state parks. However, as the state's population increases over time, increasing demand for natural resources and an ever-decreasing rural landscape will force difficult decisions for the state which will affect where we live, work and play. Much of what we as citizens can do today about the quality of our future lives is dependent upon government's ability to anticipate the future needs of ourselves and our children.

\section{CHANGING SOCIAL AND DEMOGRAPHIC CONDITIONS IN NORTH CAROLINA}

The North Carolina populace is becoming more cosmopolitan. It is aging, urbanizing, better educated, more technologically astute, and characterized by two wage earner families and single parent families. The proportion of young children and older adults is increasing.

\section{Population}

At the turn of the next century, 7.26 million North Carolinians will be seeking outdoor recreation opportunities in the Tarheel State. Sixty-three years later (2063), at the current rate of growth, the number will have reached the ten-million mark. In each instance, the active outdoor recreation participant will represent a smaller proportion of the overall population as the state's citizens age, travel less, seek fewer athletic opportunities, and recreate closer to home. 


\section{Demographics}

In $1987,20.5$ percent of North Carolina's citizens were younger than 14 years of age. By the year 2000, this percentage will have dropped to 18 percent. However, the number of children under five years of age will have increased from 1987 levels by slightly more than three percent as shown in Figure III- 1 . This trend reflects the decision of many "baby-boom" couples to begin families after delaying having children for careers and signals the reversal of a 14-year downward trend. The percentage of college graduates in the year 2000 will have declined in size, down nine percent from 1987 levels, thus reversing a steady growth which has existed since 1970 .

At the turn of the next century, almost 37 percent of North Carolina's population will be 45 years of age or older. In fact, slightly less than a million North Carolinians will be of retirement age by the year 2000. Consequently, the median age of the State's citizens will have risen from 29.6 in 1980 to 36.5 in the year 2000. The aging trend will continue to increase, with the median reaching 39.4 in the year 2010 .

Nowhere is this trend more significant than in the Mountain Region of the Tarheel state. Already known as a retirement haven, North Carolina's mountain counties will continue to lead the state in median age through the year 2000 (Figure III-2). For instance, by the turn of the century 25 percent of Polk County's population will be 65 years old or older. In contrast, the percentage of the population of retirement age in wake county will only be nine and seven tenths, or four percent less than that for the entire state (Figure III-3). In addition, the state's racial composition will essentially be unchanged, and the proportion of males in the year 2000 will have declined slightly from 1987 levels, down from 47.9 percent to 47.3 percent.

The character of North Carolina households is changing rapidly as families are characterized by two wage earners, or single parent families, and pursue an urban lifestyle. New residents who have migrated from other parts of the country continue to introduce new lifestyles which significantly impact traditional southern values. Twenty percent of all households consist of people who live alone, and the number of single-parent households has risen dramatically. According to the North Carolina office of State Budget and Management, 19 percent of all families with children under eighteen years of age were single-parent families in 1980. This proportion has increased from 12.5 percent of all families in 1970 .

The State's population will continue to grow slightly faster from migrating populations than from natural increases (i.e., births 


\section{Population Demographics for The Years 1987-2000}

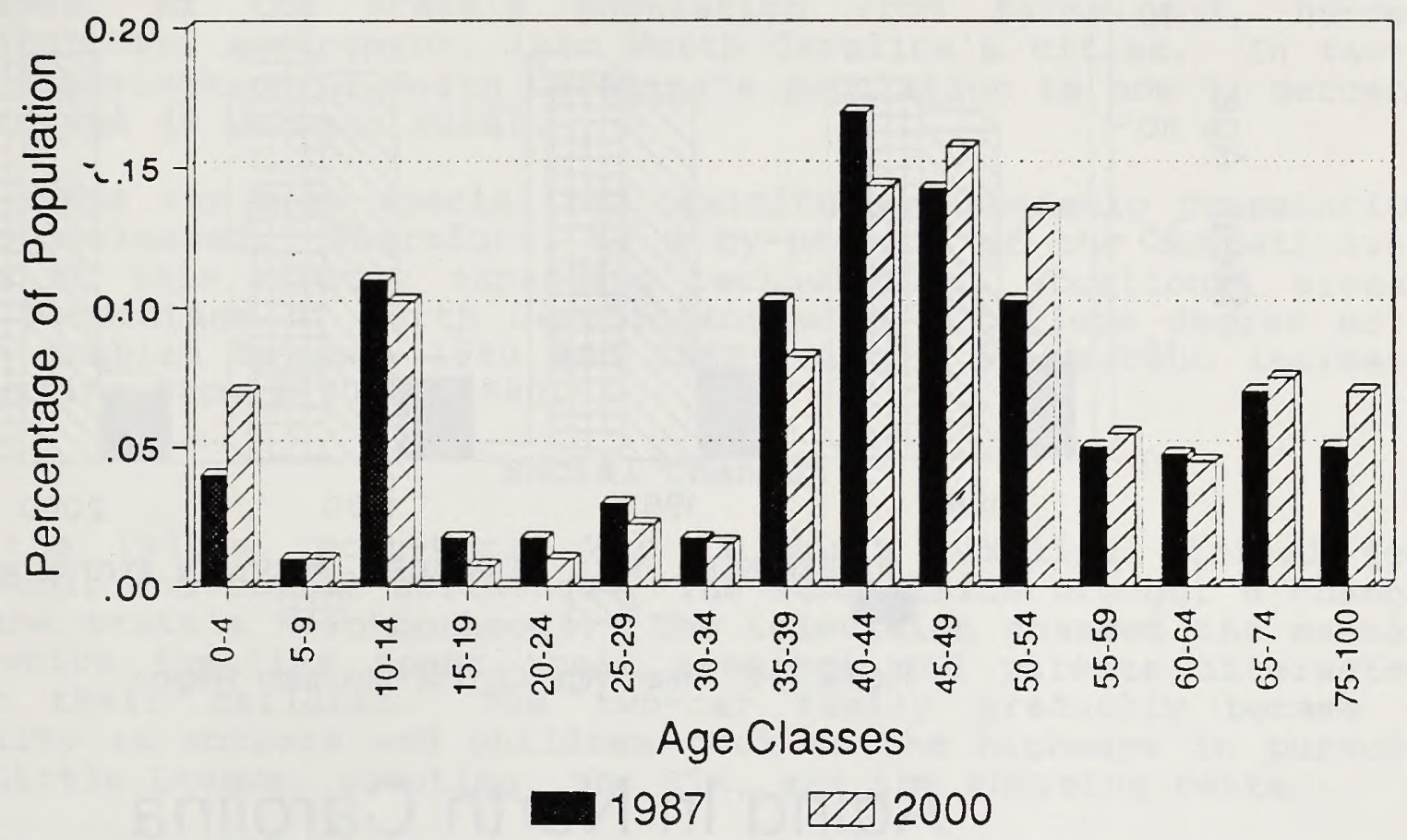

Figure III-1. Population Demographics for The Years 1987 and 2000 


\section{Mean Age Of The Mountain Region 1987-2000}

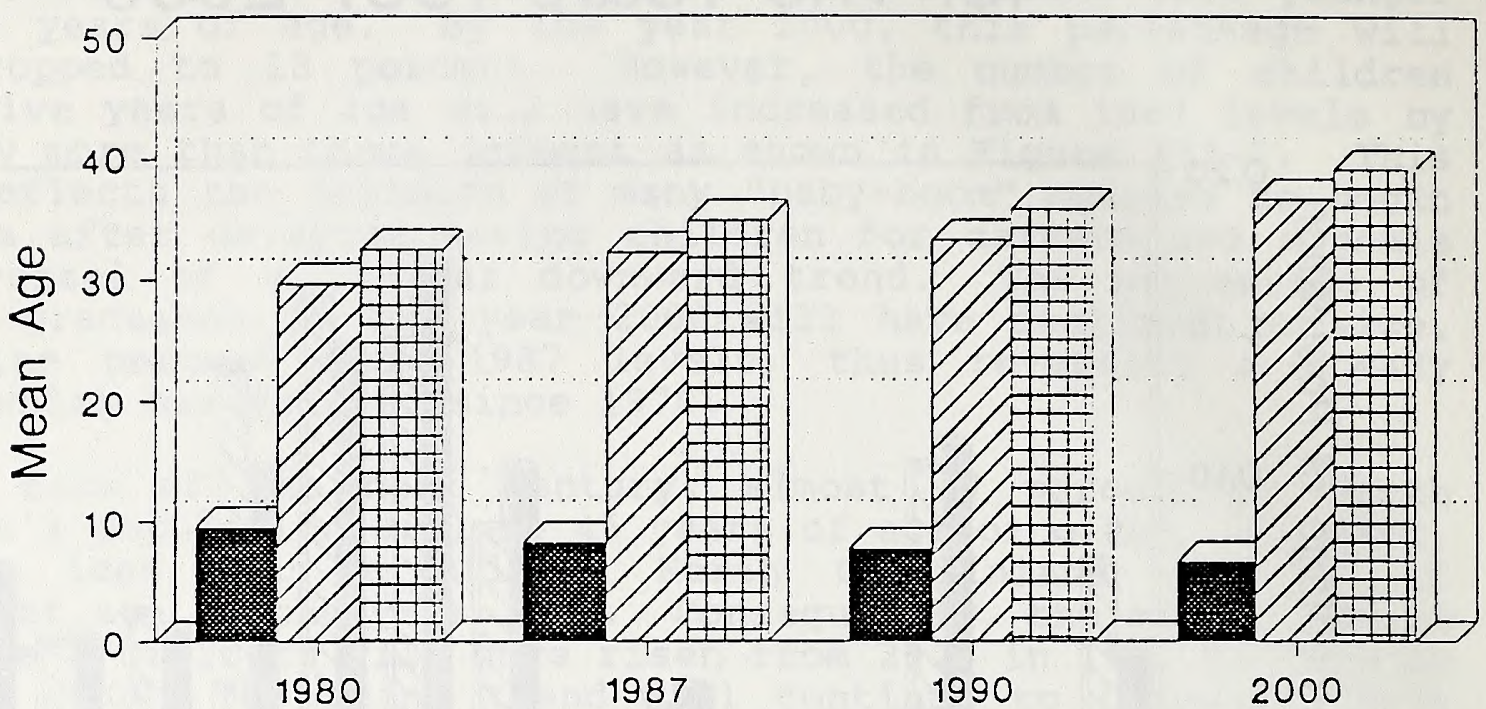

\% DIFFERENCE N.C. MEAN AGE MOUNTAIN REGION MEAN AGE VZ

Figure III-2. Mean Age Of The Mountain Region

\section{Aging In North Carolina 1987-2000}

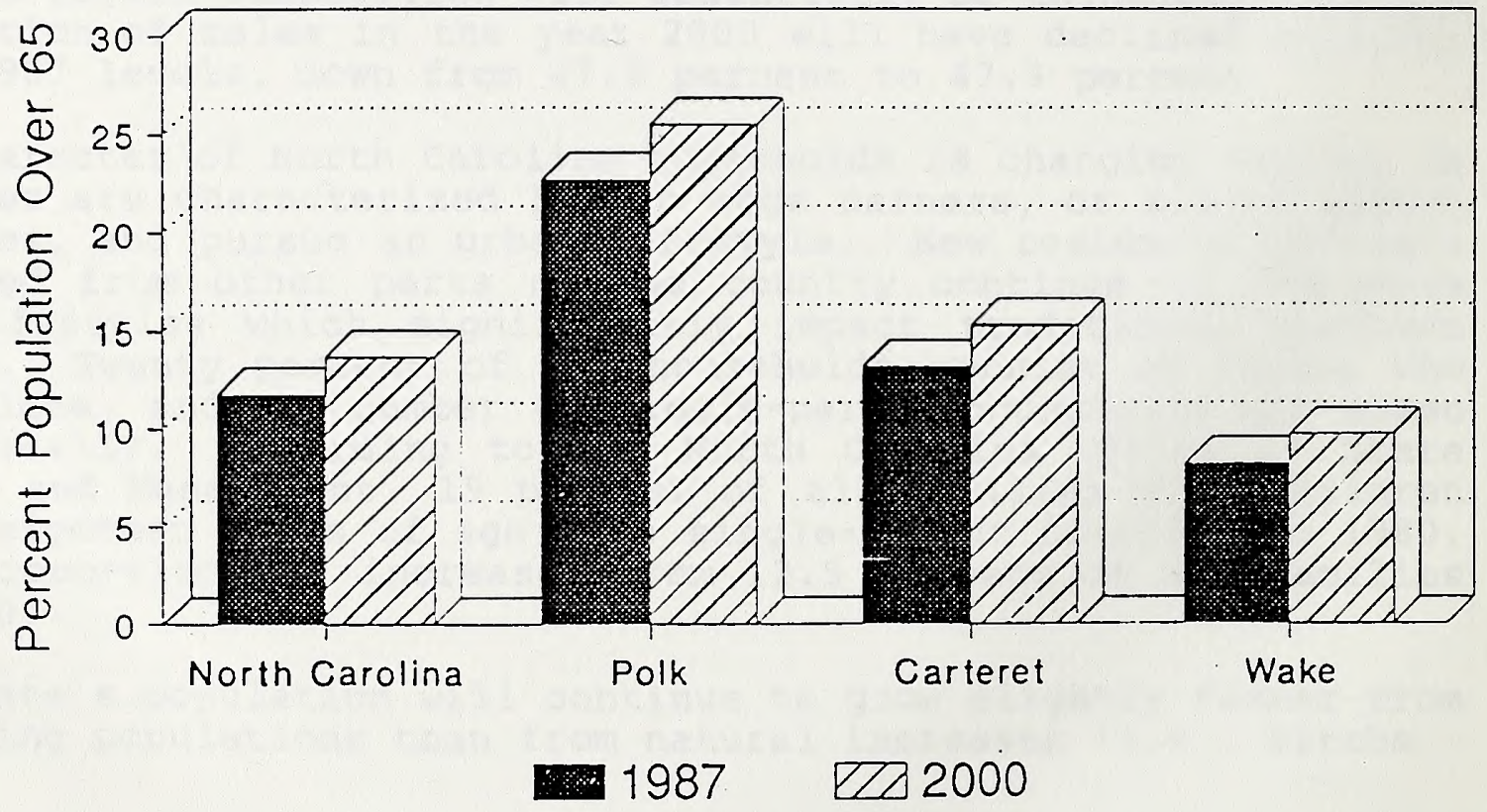

Figure III-3 Aging In North Carolina: 1987-2000 
minus deaths). This trend began in the 1970's as new industries moved from the North into urban areas in North Carolina. These new light industries, (e.g., high-technology computer, electronic equipment assembly plants, etc.) are gradually replacing some of the State's traditional industries (e.g., textiles, furniture manufacturing, etc.). The influx of new urban jobs increased the movement of the state's population from farms and, hence, agricultural employment, into North Carolina's cities. In fact, the distribution of North Carolina's population is now 51 percent urban and 49 percent rural.

The needs for both specialized training and academic preparation also increased. Therefore, as a by-product of the competitiveness of this rapidly expanding technological vocational arena, the percentage of North Carolinians with a college degree more than doubled between 1960 and 1980, with a 57 percent increase occurring from 1970 to 1980.

\section{Social Changes}

In the 1950's, post-World War II North Carolina strived for economic and social affluence. The subdivision brought a change to the state's neighborhoods. The television changed the manner in which families spent their evenings and parents interacted with their children. The two-car family gradually became a reality as mothers and children took to the highways in pursuit of Little League, scouting, the PTA, and the shopping center.

During the $1960^{\prime} \mathrm{s}$, a new social conscience permeated America's institutions. Initiated by the civil rights movement and the tragic loss of a President, North Carolina and the rest of the country rebelled. The traditionally socratic arena of higher learning toyed with the drug culture, free love, Haight-Ashbury, and woodstock. A new fraternity composed of students who protested, marched and picketed against the war exploded on the state's campuses. The conflict in Vietnam was broadcast in the living rooms of the middle class during the six o'clock news.

In the 1970's, as disillusionment with the country's leadership grew to new levels, America sought and achieved an end to the war. The nation watched on television as a senator from North Carolina and a daily newspaper in our nation's capital toppled a President. Inflation, economic uncertainty, and the price of gasoline brought an end to social protest and reawakened the pragmatic, upwardly mobile consumer.

North Carolina looked to the 1980's with one eye on profits and the bottom line and the other on the competition. The United States no longer looked for new markets, but became, for the Japanese, the koreans and the emerging third world, the marketplace of choice. Today, discussion about import quotas, trade imbalances and unfair competition are commonplace in the board rooms of industry, in the halls of Congress, and between Presidential candidates. The world economy affects Americans in businesses from agriculture to banking. 
A new emphasis on ethics and morality has emerged in society and fused with a strong existing commitment to ecological values. While the country has less time for leisure, quality experiences, whether in search of personal excellence through physical fitness or the adrenal high of adventure sports, dominate the demand for recreation opportunities. The home has become the source of many leisure activities to help reduce the stress and pressures of high technology and a fast-paced existence. The use of the video cassette recorder (VCR) and the microwave as essential appliances illustrate this trend.

\section{Technological Changes}

As industries strive to remain competitive in shrinking global markets, innovation in the laboratory has produced a wide range of new products and materials. Fiberglass laminated skis, snowmobiles, reflective clothing, fabrics which efficiently whisk away moisture, alloy-framed bicycles, fipstop nylon tents, freeze-dried food, full-time four-wheel drive vehicles, wedgesoled running shoes, and portable electric generators all have changed the way Americans recreate.

What future role will the personal computer and the modem play in future outdoor recreation opportunities? Will, by the year 2000, North Carolinians be able to reserve a tennis court, select a tee-off time, order tickets to the symphony or the neighborhood cinema, and select a favorite entree for dinner at a nearby restaurant by telephone, days, even weeks, in advance? Will single parents program both the automated preparation of tonight's dinner and the television channels available for their children's viewing while still at work?

Changes in technology and consumer preferences continue to make the homeplace an increasingly important source of leisure experiences. Active and passive recreational pursuits can now be supported by home gyms, video exercise programs, hot tubs, audio/video centers, and other high-tech toys.

\section{ACTIVITY TRENDS}

North Carolinians will demand greater quantities of water-based outdoor recreation opportunities in the future. By increasing the opportunities for water-based recreation, a clientele will be attracted to the system who will be different in tastes and preferences than that of the typical 1988 state park visitor. Consequently, the rate of growth for future state park visitation may increase dramatically as additional segments of the population become state park visitors. Weekend trips are replacing the two-week summer vacation as people seek more frequent participation closer to home. 
From 1960 to 1983, the outdoor recreation activities which exhibited the greatest growth nationwide, based upon the percentage of increased participation, were:

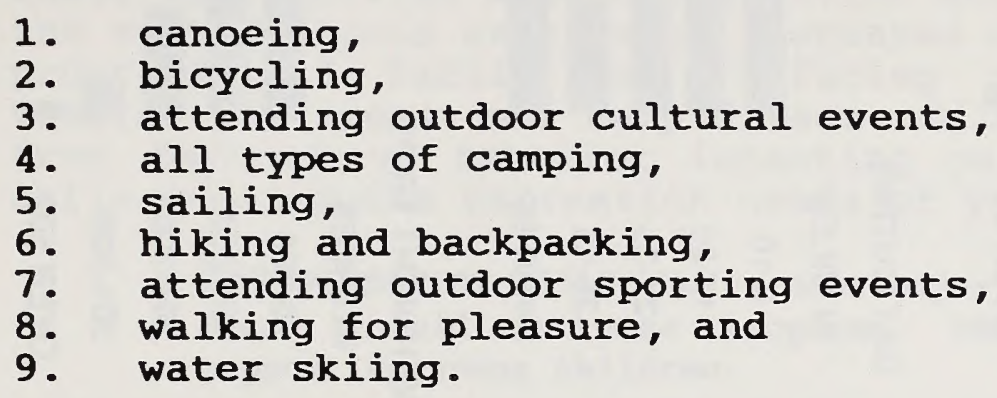

A recent survey of North Carolina state Park visitors found, based upon participation during the last 12 months, that the activities most frequently participated in were:

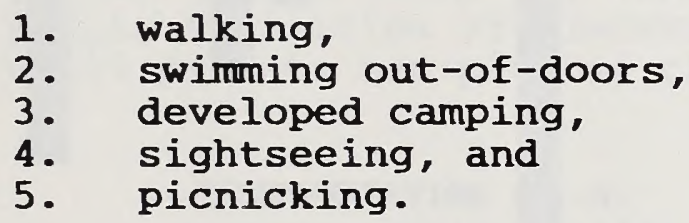

The nature of recreational trips and vacations have changed in the last twenty years as presented in Figures III-4 and III-5. National trends indicate that more people are now choosing to recreate closer to home and more frequently. The two-week summer vacation to a distant destination has been replaced by a number of weekend trips to primarily day-use areas.

\section{MANAGEMENT IMPLICATIONS}

(1) State Parks System recreational opportunities are not adequate to meet public demand for many popular activities. The aging and overused facilities currently available often fall short of visitor expectations for quality, quantity and variety. Visitors are unable to find visitors centers, park maps or opportunities beyond hiking and picnicking in many parks. Without additional recreational opportunities in state parks, unmet demand will only increase.

--RECOMMENDATION III-1: Recreational opportunities should be expanded in many parks to meet increasing demand.

--RECOMMENDATION III-2: Information and education programs must be implemented and emphasized in all park units. 
๙ั
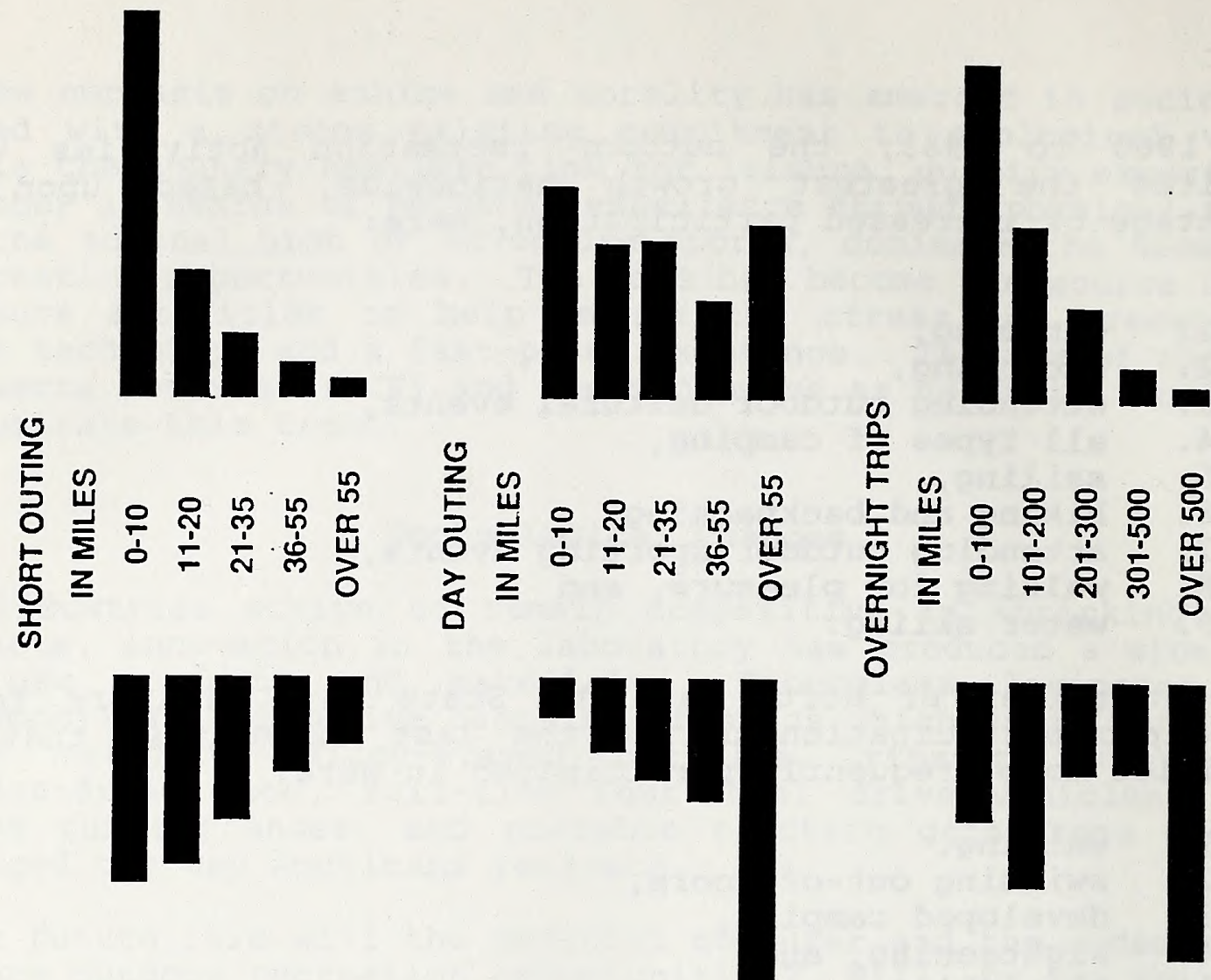

ह

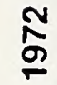
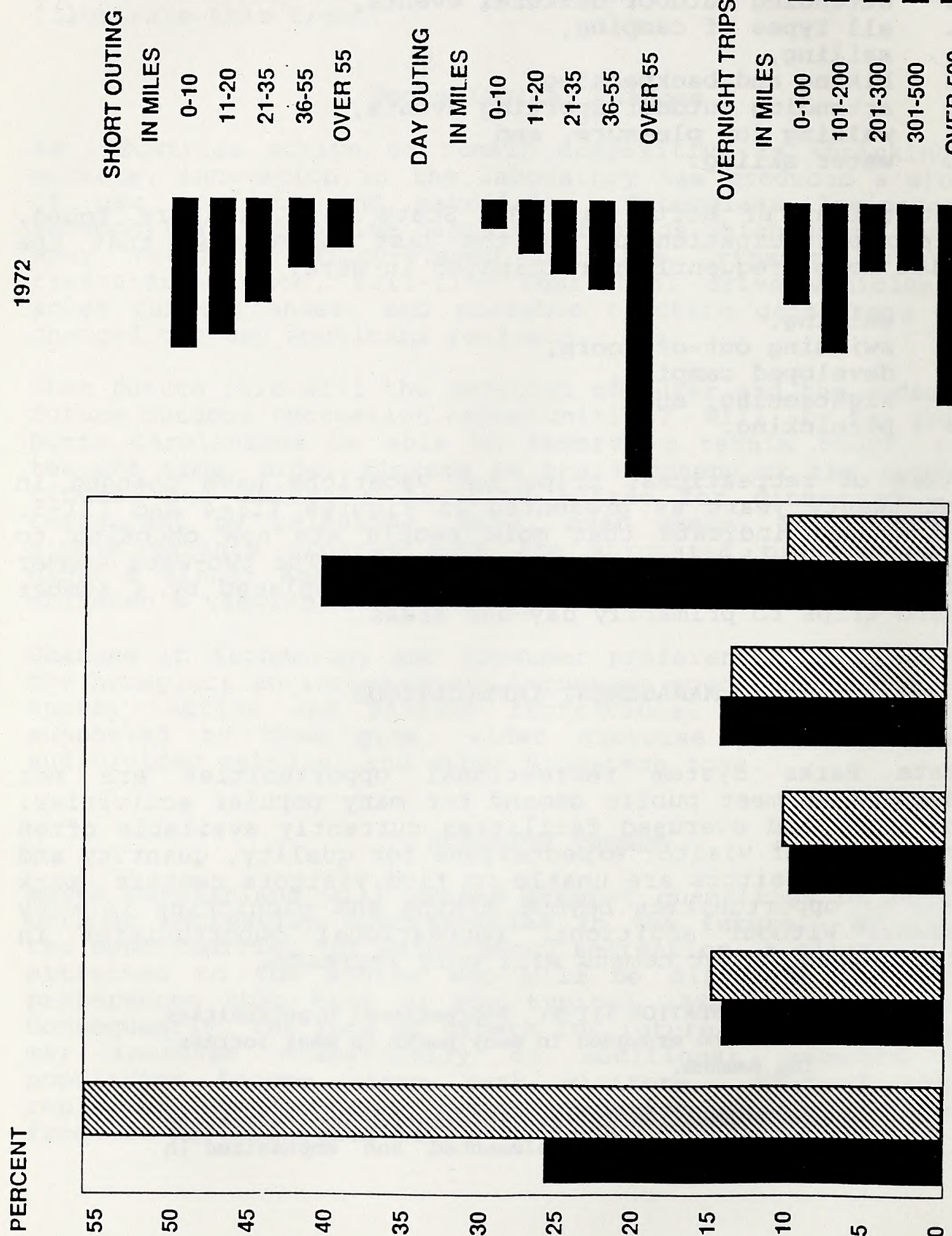

$n$
2
5
0
0

ลे

(4)

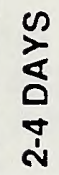

कृ

บ 8

ㄷํㅇ 8

है

88 8

n 280

웅

8.8

पू है

m!

फे है

5 년

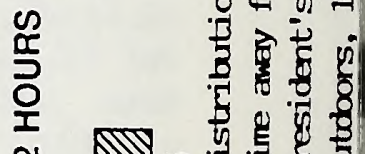

ॠ o M

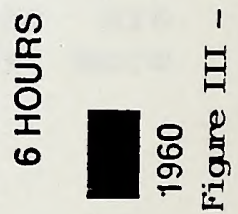


(2) Families constitute sixty percent of the groups visiting the State Parks System, according to the 1986 Public Area Recreation Visitor Study (PARVS) survey in North Carolina. Population projections predict that the birth rate will continue to increase through the end of the century. As these new families demand recreation and park opportunities, the system should experience increased demand for children's programs and facilities. Offering play equipment near visitor-use areas can help direct children's energies away from destructive behavior impacting park natural resources while meeting the recreation needs of young families.

\section{--RECOMMENDATION III-3: Units near major metropolitan areas should increase programs and facilities supporting young children.}

3) The growing child population emphasizes the importance of developing interpretative centers and environmental education to promote an environmental ethic and promote public health with the new generation. Across the nation public facilities are becoming surrogates for the homeplace until parents can pick up children after the work day.

--RECOMMENDATION III-4: Interpretative centers and environmental education programs should be provided in all park units.

--RECOMMENDATION III-5: Park units should serve to promote environmental quality and public health.

(4) The growing elderly population has more leisure time but participates in active leisure activities less frequently than younger age groups. Declining health is the most frequent reason cited for giving up an activity. The elderly are therefore more concerned with the safety, quality, and accessibility of park facilities. Bus tours which provide greater mobility and opportunities for sociaizing for the elderly are becoming increasingly popuiar. State parks should be capable of accommodating bus tours and large school groups with adequate facilities and appropriate information and education programs.

--RECOMMENDATION III-6: The safety, quality, and accessibility of park resources should be increased to serve the aging population.

--RECOMRENDATION III-2: Information and education programs must be implemented and emphasized in all park units. 
(5) An increasing cosmopolitan and educated proportion of the North Carolina population participates in outdoor recreation more frequently, usually on weekends and close to home. This pattern creates a greater demand for higher quality leisure delivery systems near population centers. College graduates participate in the following activities at a rate double that of non-graduates: golf, tennis, canoeing/ kayaking, sailing, backpacking, day hiking, ice skating, and cross-crunty skiing.

--RECOMMRNDATION III-7: Water-based recreation areas should be provided in proximity to major metropolitan areas. These units must be diverse enough to support a broad spectrum of outdoor recreational activities.

(6) As two-wage earner families become more common and urban lifestyles predominate, these families will have less time to plan leisure outings. Better information systems about state parks will help increase public awareness of park opportunities available and reduce public frustration in accessing park resources.

--RECOMMENDATION III-2: Information and education programs should be implemented and emphasized in all park units.

(7) Most, if not all, emerging social groups will expect more and better services at state park units, such as concessions, decent toilets, and visitor centers.

--RECOMMENDATION III-8: A greater number of higher quality visitor services must be provided by appropriate units to meet the expectations of emerging social groups.

(8) State park attendance, particularly at attractive parks near large urban areas, will continue to grow because of the trend toward frequent trips to nearby parks for one-day or weekend visits.

--RBCOMMENDATION III-7: Water-based recreation areas should be provided in proximity to major metropolitan areas. These units must be diverse enough to support a broad spectrum of outdoor recreational activities.

(9) Increased leisure spending during less leisure time indicates a demand for quality experiences and opportunities to use recreation equipment. Many state park units that are currently underdeveloped or need renovation are not likely to satisfy this demand. 
--RECOMIENDATION III-1: Recreational opportunities should be expanded in many parks to meet increasing demand.

(10) Greater attendance at popular parks will increase inappropriate behavior and require greater management resources.

--RECOMENDATION III-9: Increased staffing is needed to accommodate increasing use.

--RECOMMENDAIION III-2: Information and education programs must be implemented and emphasized in all park units.

--RECOMMENDATION III-10: Al1 field staff should receive adequate training in visitor management and safety protection including law enforcement, emergency response, and search-and-rescue.

(11) Technological changes in recreation equipment occur quickly and could create fads in park use. Large capital improvements should be able to support a variety of activities.

--RECOMIENDATION III-11: Through the general management planning process, appropriate uses for each unit must be identified.

--RECOMENDATION III-12: The Division should identify appropriate recreation uses and capital development for each management category addressed in the State Parks Act.

--RECOMMENDATION III-7: Water based recreation areas should be provided in proximity to major metropolitan areas. These units must be diverse enough to support a broad spectrum of outdoor recreational activities.

(12) The State Parks system may have a role in providing physically active recreation in areas where none is available from local providers.

--RECOMENDATION III-13: Through its SCORP process, the State should identify where local authorities are not capable of supplying needed recreation facilities and take action to meet that cemand. 
(13) The State Parks System should experience a continued demand for dispersed use opportunities which are threatened by greater visitation, encroaching development, and environmental degradation.

--RECOMMENDATION III-14: Increasing visitor use should be accommodated in a manner that does not degrade significant natural resource values and compromise the quality of visitor experiences.

--RECOMMENDATION III-15: All park system units should continue to provide opportunities for primitive and unconfined activities which offer an opportunity for solitude and are dominated by the forces of natures.

\section{ECONOMIC CHANGES}

North Carolina's employment is shifting away from traditional light manufacturing industries such as textiles and furniture manufacturing to high technology and service-oriented employers. While real personal income is predicted to increase at a rate of 2.1 percent through the year 2000, farm-generated income will not keep pace with inflation.

North Carolina's economy will have undergone tremendous changes by the year 2000. Industrial output will grow an average of two percent per year during the 12 -year span. The textile, apparel, lumber and tobacco industries will show slowing or declining growth rates, while machinery, rubber and plastics, instruments and printing and publishing will grow an average of four percent per year. The State's non-manufacturing sector will be the principal source of new jobs, accounting for 75.2 percent of all non-farm jobs by the year 2000. Of these non-farm jobs, trades and services will produce 317,000 new employment opportunities in the next 12 years.

After adjusting for inflation, the State's average manufacturing wage will increase only one percent annually through the turn of the century. North Carolina's real personal income should rise at an annual rate of approximately two and one-tenth percent during the same period. This is down from a three and threetenths percent annual growth rate which occurred in the period between 1973 and 1987. In addition, the agricultural sector is not expected to improve in its economic health during the next 12 years because the projected annual increase through the year 2000 in farm income is only four and seven-tenths percent, or three tenths of a percent less than the five percent projected annual inflation rate for the same period.

This decline in real income and the projected slow-down in the economy will affect the projections for housing starts as well. 
Housing will drop from a projected 88,500 starts in 1988 to between 75,000 and 80,000 in the $1990^{\prime} \mathrm{s}$. However, the overall cost of housing is not expected to decline, since the competition for urban housing will increase. In 1980, the median value of a private home in North Carolina was $\$ 36,000$, with values in the larger cities ranging from $\$ 50,400$ in the Raleigh-Durham-Research Triangle area to $\$ 39,600$ in the Greensboro-Winston-Salem area. By the year 2000, those values are projected to be: $\$ 127,260$, $\$ 178,164$ and $\$ 139,986$ respectively.

\section{MANAGEMENT IMPLICATIONS}

(14) The growing number of service sector jobs are relatively lower paying and will create an economic class limited in its ability to afford private and commercial recreation opportunities. Public parks will have an important role in providing inexpensive recreation opportunities.

--RECOMMENDATION III-13: Through its SCORP process, the State should identify where local providers are not capable of supplying needed recreation facilities and take action to meet that demand.

(15) Higher-income, two-wage earner families will have more disposable income to spend on recreation, but tend to have leisure interests not found in state parks. Country clubs, fitness centers, and vacation resorts offer the amenities this group desires. Families with annual incomes above $\$ 50,000$ participate in nearly all types of boating, nature study, and day hiking more frequently than lower-income groups.

--RECOMIENDATION III-7: Water-based recreation areas should be provided in proximity to major metropolitan areas. These units must be diverse enough to support a broad spectrum of outdoor recreation activities.

(16) "Baby-boomers," born 1946-1964, spend 25 percent above average on recreation and leisure, 35 percent above average on dining out, and 55 percent above average on cars, boats and recreation vehicles. Recreation vehicles are being designed and marketed to appeal to this group. Increasing recreation vehicle sales should translate into greater demand for campsites and dump stations to accommodate RV's and opportunities to use specialized vehicles (such as four wheel drives) on public resources.

--RECOMIENDATION III-11: Through the general management planning process, appropriate uses for each unit must be identified. 


\section{CHANGES IN TRANSPORTATION SYSTEMS}

With the exception of North Carolina's rail system, the statewide transportation network is expected to expand to meet the needs of the population in the next century. The regions expected to benefit the greatest from this expansion are the Tidewater and Mountain.

Through the late 1990 's, the North Carolina Jepartment of Transportation intends to focus its highway devel(pment program on 19 strategic corridors which crisscross the state (Figure III-6). These corridor improvement projects will extend I-40 from Raleigh to Wilmington; produce an interstate link between Asheville and Johnson City, Tennessee; produce an interstate link between Charlotte and wilmington; and produce an interstate link between Virginia Beach, Virginia, and Myrtle Beach, South Carolina, through North Carolina's coastal counties.

Because North Carolina's transportation infra-structure is multifaceted, a number of other developments will facilitate the State's emergence into the next century. Since 1982, the number of commercial aircraft based in North Carolina has more than doubled (Figure III-7). The location of two commercial aviation hubs in North Carolina, Piedmont's in Charlotte and American's in Raleigh-Durham, has significantly increased the number of domestic and international flights available to North Carolina's citizens.

An annual commitment through 1996 of $\$ 2.5$ million in state and federal funds for public transportation should help reduce the current problems of traffic congestion in North Carolina's metropolitan areas. Also, a commitment to alternative forms of transportation should assist in the reduction of urban traffic problems. For example, since 1984, the number of independent and incidental bicycle projects has increased over 800 percent, up from less than 10 in that year to more than 80 in 1988 .

of all the transportation infra-structures in the state, only the railroad system appears to be facing a downward trend as railway corridors continue to be abandoned. In fact, 1,535 miles of track were candidates for abandonment in 1986 alone (Figure III-8). However, these abandonments may produce an expansion of the state's outdoor recreation opportunities in the near future as government agencies and concerned private citizens take advantage of a new federal program The National Rails to Trails Program, to convert these abandoned railroads into expansive recreation trails. 


US-23-441
US-19\&64
US-23
US-421
US-74\&I-85
US-74

US - 23-441

Mountain

Mountain

Mountain

Mountain

piedmont

Piedmont/

Coastal

Plain/

Tidewater

US-321\&NC-16

$$
\text { US }-52
$$$$
\text { US }-220 \& 74
$$$$
\text { US }-64
$$$$
I-40 \& I-85
$$$$
\text { US }-421 \& \mathrm{NC}-87
$$

US-1

$I-40$

US -70

$$
\text { US }-264
$$

Piedmont/

Mountain

\section{piedmont}

Piedmont

piedmont

Piedmont

Piedmont/

coastal

Elain

Tidewater

piedmont

Piedmont/

Coastal

Plain/

Tidewater

Piedmont/

Coastal

Plain/

Tidewater

Pieamont/

Coastal

Plain/

Tidewater

US- $64 \&$ US -17

US 17

US- $158 \&$

NC- 168

Piedmont/

Coastal

plain

Tidewater

Tidewater
Tennessee Iine to Georgia Line

Tennessee Iine to I40 in Haywood Co.

Asheville to Tennessee Line

Wirston-Salem to Tennessee

Charlotte to I26 in Polk Co.

charlotte to wilmington

Gastonia and Charlotte to Boone

Mount Airy to Lexington

US-74 in Richmond Co. to Virginia

Lexington to Raleigh

Winston-Salem to Raleigh

Greensboro to Wilmington

Raleigh to Henderson

Raleigh to wilmington

Raleigh to Morehead City

Raleigh to Washington

Raleigh to Plymouth \& Plymouth to Virginia Line

Williamston to South Carolina

Virginia Line to Roanoke Island

\section{Figure III-6. Interstate and Strategic Corridors: North Carolina Transportation Improvement




\section{Aircraft Trends

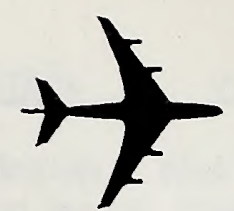

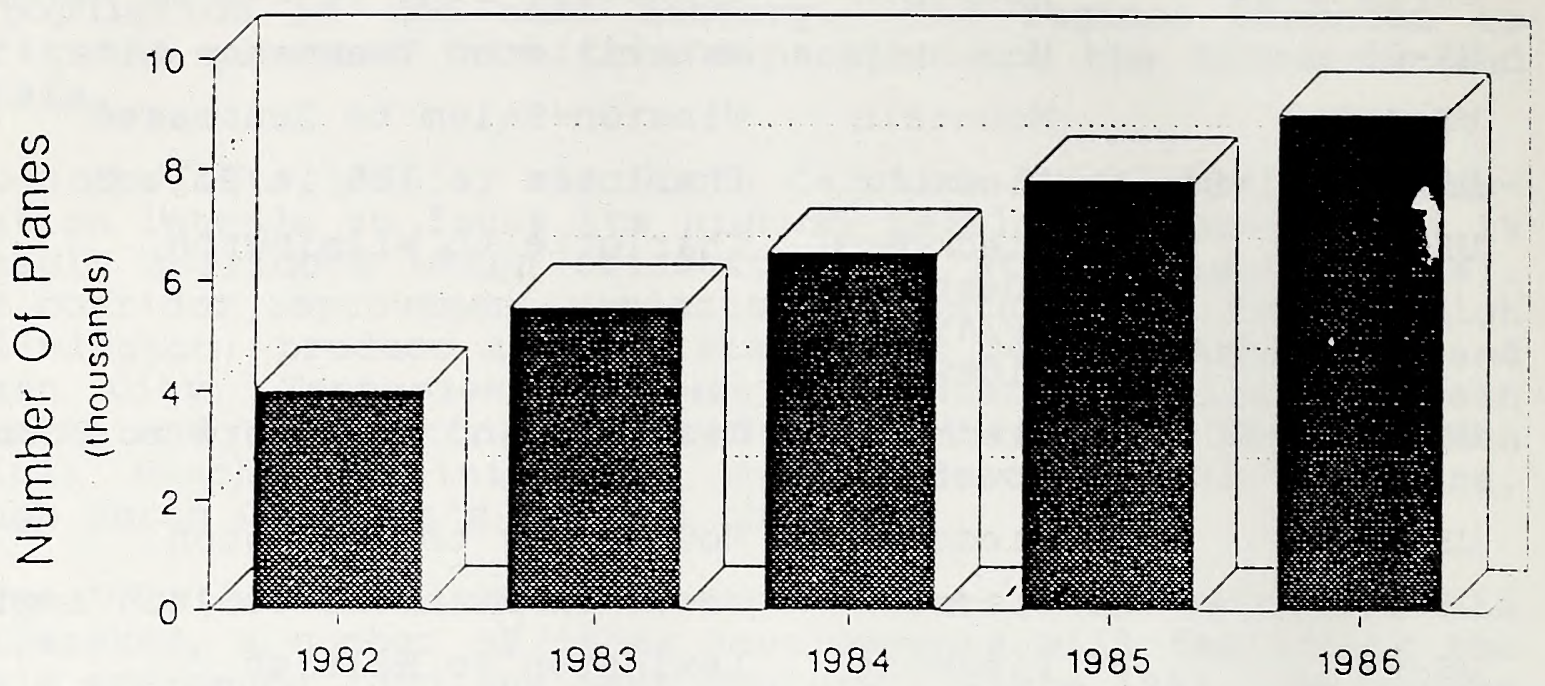

Figure 111-7. Aircraft Trends

North Carolina Railway Trends

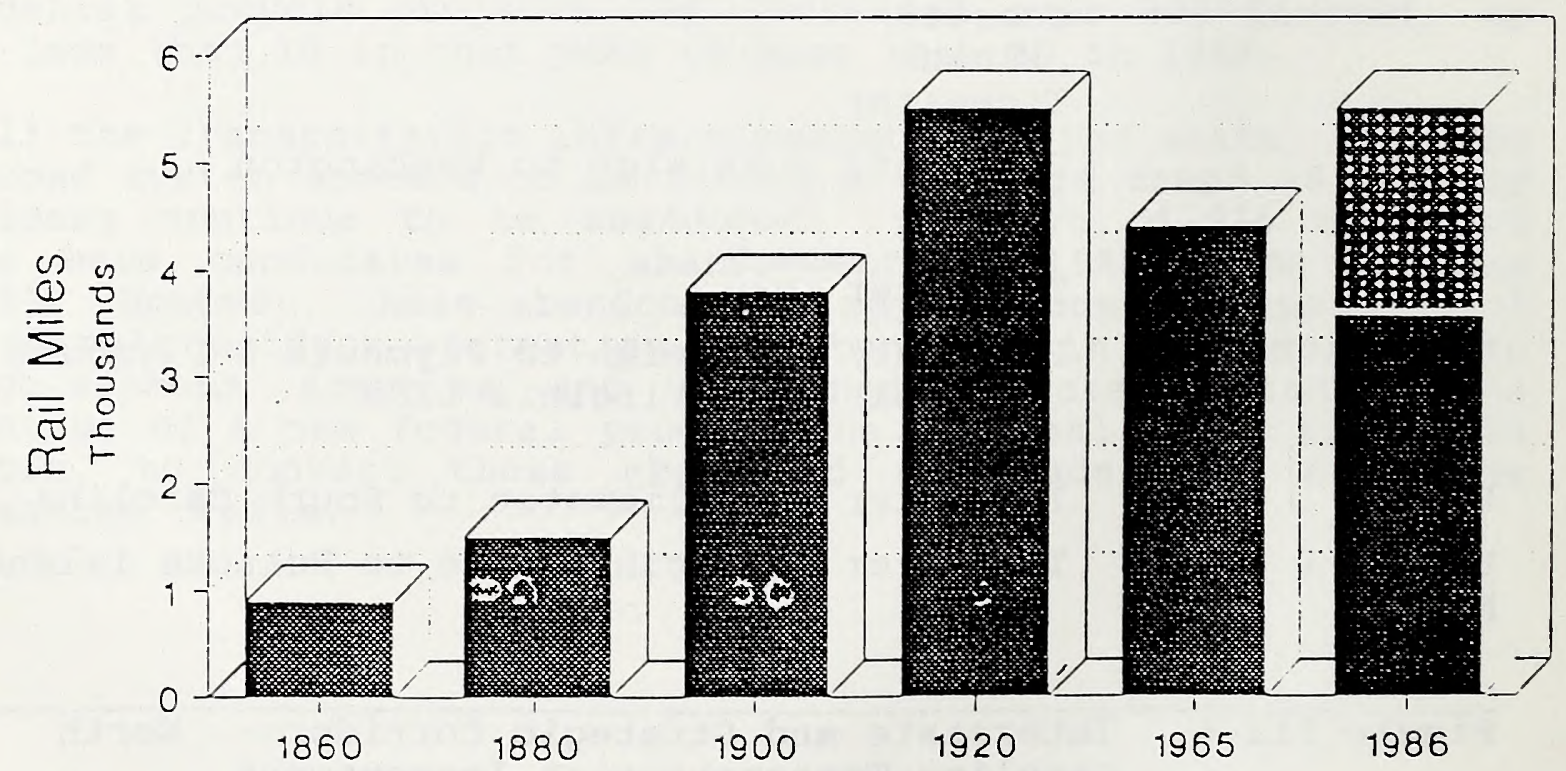

1535 Miles :Proposed Abandonment

Figure III-8. North Carolina Railway Trends 


\section{MANAGEMENT IMPLICATIONS}

(17) Road system improvements in eastern North Carolina will create a demand for more overnight opportunities in the region. All forms of camping have enjoyed increased popularity, nearly doubling between 1965 and 1980 .

--RECOMMENDATION III-11. Through the general management planning process, appropriate uses for each unit must be identified.

(18) Day trips to coastal beaches will continue to increase in popularity as roads improve to Morehead City and Wilmington.

--RECOMMENDATION III-9: Increased staffing is needed to accommodate increasing use.

--RECOMMIINDATION III-10: All field staff should receive adequate training in visitor management and safety protection including law enforcement, emergency response, and search-and-rescue.

--RECOMMENDATION III-11: Through the general management planning process, appropriate uses for each unit must be identified.

--RECOMMENDATION III-15: All park system units should continue to provide opportunities for primitive and unconfined activities which offer an opportunity for solitude and are dominated by the forces of nature.

(19) Bicycling is the second fastest-growing recreational activity in the united States, and more park visitors will be bringing bicycles to the parks. State parks are logical camping areas and attractions for the tour biking routes identified by the Department of Transportation Bicycling Highways Program. Bike parking and storage facilities will make state parks more attractive. Off-road bikes will create a demand for suitable trails that do not conflict with other trail users or damage the natural resource base.

--RECOMMENDATION III-16: Creation of a rails-totrails acquisition fund is needed to convert abandoned rail corridors to recreation trails.

(20) Rail abandonment is a major source of recreation trails in states with trail acquisition funding and the proper legal authority. The Mountains-to-sea Trail in North Carolina would benefit greatly if abandoned rail corridors could serve as trail segments.

-RECOMMENDATION III-16: Creation of a rails-totrails acquisition fund is needed to convert abandoned rail corridors to recreation trails. 
(21) The expanding road system will bring many more out of state visitors to the mountains and beaches of North Carolina. These visitors will look to state parks to provide primary and ancillary recreational opportunities.

\section{POLITICAL TRENDS}

The number, organization and lobbying abilities of interest groups will continue to increase as North Carolina becomes more cosmopolitan. Groups representing park users, environmentalists, and the elderly are likely to have well-defined and sometimes conflicting demands on park and recreation resources. Meeting these requests will be more difficult due to reduced federal funding and greater reliance on state resources.

\section{Organized User Groups}

People are specializing in recreation pursuits by participating in fewer activities but with increasing frequency. As the leisure-ethic continues to replace the work-ethic, leisure activities become sources of self-expression and self-identity. Large urban centers bring together sufficient numbers of people with similar recreation preferences that user groups form and grow in both membership and sophistication. These groups can become effective proponents for specific park opportunities to satisfy their demands. The North Carolina Trails Association is the most effective user group currently and has been active in the designation and development of the Mountains-To-Sea Trail. Windsurfing, rock climbing, and hang gliding have growing constituencies in the North Carolina State Parks System as well.

\section{Environmental Change}

The North Carolina landscape continues to change rapidly as urban centers expand to encompass surrounding rural areas. Condominiums, second homes, hotels and resorts turn natural vacation areas into bustling communities. Private lands are closing to public use over liability concerns. Water shortages have become an annual summer concern, triggering conservation measures in some cities. Collectively, these growth-related pressures create a greater awareness of natural resource protection needs.

The membership and organizational sophistication of the environmental movement in the state appears to be increasing. The combined influence of these organizations was effective in promoting the recently approved ban on phosphate detergents. The trend indicates a renewed emphasis on environmental concerns as headlines address the deterioration of the ozone layer, contamination of ground water, waste on beaches, and the spruce/fir dieback in the western mountains. 
A majority of Americans, 65 percent, agree that "protecting the environment is so important that requirements and standards cannot be too high and continuing environmental improvements must be made regardless of cost," according to a 1988 New York Times-CBS News Poll. The percentage of respondents who agreed has increased since 1981 when the question was first asked and 45 percent agreed that protecting the environment is important.

The News \& Observer, Raleigh, NC 8-22-88

Individual parks in developing areas are likely to serve as magnets for development and thus will experience escalating encroachment problems. Umstead State Park is the most seriously effected by this trend, with population on the east side expected to increase to 20,000 over the next two decades. A crushed stone quarry and RDU International Airport border the Western side. Many other parks face encroachment from residential and vacation-home development.

\section{Senior Citizens}

The elderly are becoming a more influential group as they increase in numbers, affluence, and education. North Carolina is one of eleven states where the population above age 65 increased by more than $20 \%$ from 1980 - 1986. The increase is the result of migration to North Carolina by retirees as well as longer life spans which have increased by 2.5 years since 1960 . The elderly population is not only growing, it is more affluent than younger age groups. The national median for household net worth (assets minus liabilities) was $\$ 32,700$ in 1984. By contrast, median household net worth for senior citizens (age 65 and above) was nearly double that amount at $\$ 60,300$. The formal education for the elderly population has increased from 8.7 years to 11.8 years since 1970 . Almost 10 percent are now college educated.

The largest organization of Americans age 50 and above is the American Association of Retired Person (AARP). With over 27 million members, AARP represents the interests of the elderly in federal and state legislatures. It promotes educational and community service programs as well as direct membership benefits. The organization's success in obtaining benefits for its membirship can be attributed to the elderly's voting and purchasing power.

The trend toward a larger, more affluent and more educated elderly population will increase in the 21 st century as "Baby Boomers" move toward retirement. Their expectations and demand for quality services are greater than previous generations. This new generation of retirees will have even greater education and 
affluence to communicate their demands. These trends indicate that the influence of the elderly in society will continue to increase.

\section{Federal Government Role}

A significant decrease has occurred in federal funding support of outdoor recreation with the assumption that states will assume greater responsibility. The land and water conservation Fund (LWCF), which funds parks and recreation acquisition and development, reflects this trend. Through the 1970 's, LWCF appropriations grew steadily and peaked at $\$ 805$ miliion nationally. Reduced appropriations in the $1980^{\prime}$ 's have averaged less than $\$ 200$ million annually.

North Carolina received an average of $\$ 5.32$ million per year for fiscal years 1976-80. In recent years the funding has averaged $\$ 350,000$. While several trust funds for parks and recreation have been established in North Carolina, none have received significant funding. Recent federal legislation proposing the American Heritage Trust would significantly improve federal funding; however, North Carolina will not be able to take full advantage of the funding without a state-level trust fund.

Many states have established successful trust funds dedicated to parks and recreation. The key in each state has been to identify and tap a stable funding source. Four categories of funding sources currently in use are taxes, licenses, bonds, and lotteries. Florida and Michigan have mineral or oil severance taxes generating up to $\$ 35$ miliion annually. Florida and Maryland use a percentage of the real estate transfer document tax to provide $\$ 25$ million per year. Ohio collects $\$ 3$ million each year for boat licenses although these taxes are usually earmarked for improving boating facilities. The state of New Jersey passed bond issues to acquire and protect open space totalling $\$ 675$ miliion. Finally, Colorado targeted parks and recreation projects for lottery revenues and has raised about $\$ 12$ million a year.

\section{MANAGEMENT IMPLICATIONS}

(22) More citizen groups with increasing influence will advocate an expansion of specific recreation opportunities. For example, the North Carolina Trail Association has provided the momentum for the Mountains-To-Sea Trail. Wind surfing organizations have already requested improved and expanded facilities at the State Recreation Areas. New activity-specific groups will be established and become active in the future.

--RECOMIENDATION III-17: Improvement of the State Parks System should be made in a systematic manner in adherence to provisions within the State Parks Act. 
(23) The influence of the environmental lobby will increase as a result of increased public attention focused on problems such as air pollution, acid rain, devastating droughts, and accelerating development. Donations and memberships in environmental organizations have been steadily increasing and expanding the base of support for action on environmental issues. These environmental problems do not have short term solutions and will continue to generate public concern and support for government action.

--RBCOMMENDATION III-18: Park units should serve as examples of environmental quality and governmental integrity in protecting valuable natural resources.

--RECOMMRDATION III-5: Park units should serve to promote environmental quality and public health.

(24) The elderly are potentially the most influential interest group in the 21st Century. Their growing numbers, education, and organization as well, as their voting and spending power, will be a dominant factor in public decisions. The expectations for park and recreation areas and facilities will be for improved quality, accessibility, and safety. Responding to these expectations and developing an elderly constituency will be advantageous.

--RECOMMRNDATION III-8: A greater number of higher quality visitor services must be provided by appropriate units to meet the expectations of emerging social groups. 


\section{CHAPTIR STMERY OP \\ MAMGGIBTI DIPLICATIONS}

(1) State Parks System recreational opportunities are not adequate to meet public demand for many popular activities. The aging and overused facilities currently available of ten fall shart of visitor expectations for quality, quantity and variety. Visitors are unable to find visitors centers, park maps or opportunities beyond hiking and picnicking in many parks. These visitors must either go to other parks or do without. Without additional recreational opportunities in state parks, unmet demand will only increase.

(2) Families constitute sixty percent of the groups visiting the State Parks System, according to the 1986 Public Area Recreation Visitor Study (PARVS) survey in North Carolina. Population projections predict that the birth rate will continue to increase through the end of the century. As these new families demand recreation and park opportunities, the system should experience increased demand for children's programs and facilities. Offering play equipment near visitor-use areas can help direct children's energies away from destructive behavior impacting park natural resources.

(3) The growing child population emphasizes the importance of developing interpretative centers and environmental education to promote an environmental ethic and promote public health with the new generation. Across the nation public facilities are becoming surrogates for the homeplace until parents can pick up children after the work day.

(4) The growing elderly population has more leisure time but participates in active leisure activities less frequently than younger age groups. Declining health is the most frequent reason cited for giving up an activity. The elderly are therefore more concerned with the safety, quality and accessibility of park facilities. Bus tours which provide greater mobility and opportunities for socializing for the elderly are becoming increasingly popular. State parks should be capable of accomodating bus tours and large school groups with adequate facilities and appropriate information and education programs.

(5) An increasing cosmopolitan and educated proportion of the North Carolina population participates in outdoor recreation more frequently, usually on weekends and close to home. This pattern creates a greater demand for higher quality leisure delivery systems near population centers. College graduates participate in the following activities at a rate double that of non-graduates: golf, tennis, canoeing/ kayaking, sailing, backpacking, day hiking, ice skating, and cross-county skiing.

(6) As two-wage earner families become more comon and urban lifestyles predominate, these families will have less time to plan leisure outings. Better information systems about state parks will help increase public awareness of park opportunities available and reduce public frustration in accessing park resources.

(7) Most, if not all, emerging social groups will expect more and better services at state park units, such as concessions, decent toilets, and visitor centers.

(8) State park attendance, particularly at attractive parks near large urban areas, will continue to grow because of the trend toward frequent trips to nearby parks for one-day or weekend visits. 
(9) Increased leisure spending during less leisure time indicates a demand for quality experiences and opportunities to use recreation equipment. Many state park units that are currently underdeveloped or need renovation are not likely to satisfy this demand.

(10) Greater attendance at popular parks will increase inappropriate behavior and require greater management resources.

(11) Technological changes in recreation equipment occur quickly and could create fads in park use. Large capital improvements should be able to support a variety of activities.

(12) The State Parks System may have a role in providing physically active recreation in areas where none is available from local providers.

(13) The State Parks System should experience a continued demand for dispersed use opportunities which are threatened by greater visitation, encroaching development, and environmental degradation.

(14) The growing number of service sector jobs are relatively lower paying and will create an economic class limited in its ability to afford private and commercial recreation opportunities. Public parks will have an important role in providing inexpensive recreation opportunities.

(15) Higher-income, two-wage earner families will have more disposable income to spend on recreation, but tend to have leisure interests not found in state parks. Country clubs, fitness centers, and vacation resorts offer the amenities this group desires. Families with annual incomes above $\$ 50,000$ participate in nearly all types of boating, nature study, and day hiking more frequently than lower-income groups.

(16) Baby-boomers, born 1946-1964, spend 25 percent above average on recreation and leisure, 35 percent above average on dining out, and 55 percent above average on cars, boats and recreation vehicles. Recreation vehicles are being designed and marketed to appeal to this group. Increasing recreation vehicle sales should translate into greater demand for campsites and dump stations to accommodate RV's and opportunities to use specialized vehicles (such as four wheel drives) on public resources.

(17) Road system improvements in eastern North Carolina will create a demand for more overnight opportunities in the region. All forms of camping have enjoyed increased popularity, nearly doubling between 1965 and 1980 .

(18) Day trips to coastal beaches will continue to increase in popularity as roads improve to Morehead City and Wilmington. visitors will be bringing bicycles to the parks. State parks are logical camping areas and attractions for the tour biking routes identified by the Department of Transportation Bicycling Highways Program. Bike parking and storage facilities will make state parks more attractive. off-road bikes will create a demand for suitable trails that do not conflict with other trail users or damage the natural resource base.

(20) Rail abandonment is a major source of recreation trails in states with trail acquisition funding and the proper legal authority. The Mountains-to-Sea Trail in North Carolina would benefit greatly if abandoned rail corridors could serve as trail segments. 
(21) The expanding road system will bring many more out of state visitors to the mountains and beaches of North Carolina. These visitors will look to State parks to provide primary and ancillary recreational opportunities.

(22) More citizen groups with increasing influence will advocate an expansion of specific recreation opportunities. For example, the North Carolina Trail Association has provided the momentum for the Mountains-To-Sea Irail. Wind surfing organizations have already requested improved and expanded facilities at the State Recreation Areas. New activity-specific groups will be established and become active in the future.

(23) The influence of the environmental lobby will increase as a result of increased public attention focused on problems such as air pollution, acid rain, devastating droughts, and accelerating development. Donations and memberships in environmental organizations have been steadily increasing and expanding the base of support for action on environmental issues. These environmental problems do not have short term solutions and will continue to generate public concern and support for government action.

(24) The elderly are potentially the most influential interest group in the 2lst Century. Their growing numbers, education and organization as well as their voting and spending power will be a dominant factor in public decisions. The expectations for park and recreation areas and facilities will be for improved quality, accessibility, and safety. Responding to these expectations and developing an elderly constituency will be advantageous. 


\title{
CHAPTER IV
}

\section{DUPIICATIONS, DEEICIENCIES
AND STATEWIDE SIGNIEICANCE}

\author{
"Evaluate existing parks against these \\ standards to determine their statewide \\ significance." \\ --G.S. $113-44.11 .2$ \\ "Identify duplications and deficiencies in \\ the current State Parks System and make \\ recommendations for corrections."
}

--G.S. $113-44 \cdot 11.3$

\section{INTRODUCTION}

The significant archaeologic, geologic, scenic, recreational, and biologic resources of North Carolina should be represented ultimately in a completed state Parks system. The General Assembly has recognized this through passage of the state Parks Act, which stipulates that the systemwide plan is to:

1. Identify duplications and deficiencies in the current state Parks system and make recommendations for correction.

2. Evaluate existing parks against these standards [i.e., unique archaeologic, geologic, recreational, scenic, and biologic resources] to determine their statewide significance.

In order to fulfill these mandates, five committees were formed to represent each of the unique resource categories cited in the act. Committees were composed of academic experts, representatives from relevant citizen groups, and state experts. Committee chairs were asked to use their judgement in recruiting members having recognized expertise. The Parks and Recreation Council reviewed committee membership and made recommendations for two additional members who were added. A roster of committee members is included in Appendix IV-1.

\section{METHODOLOGY}

Overview

The approach used by the committees in identifying duplications and deficiencies in the state Parks system was a modification of one developed by the National Park Service (1972) when it was faced with a similar charge. To supplement the Park service approach, consensus building was attempted by including academic experts and citizen group representatives on each committee. All committee members were provided with copies of the state Parks Act and Park Principles. 
Committees were charged with fulfilling each of the objectives listed below:

1. Definition of resource themes.

2. Determination of significance of themes within geographic regions.

3. Identification of protection of themes by state Parks system units.

4. Evaluation of protection of themes within geographic regions.

5. Development of a ranking describing the relative amount of protection park units provide to significant biologic, geologic, recreation, scenic, and archaeologic resources.

\section{Definition of Resource Themes}

Within reasonable limits, each committee defined the full spectrum of themes which occur within each unique resource. Resource themes are categories encompassing all the natural phenomena within the unique resource cited by the state Parks Act. For instance, the committee concerned with biological resources developed 19 themes to cover the significant plant communities which exist in North Carolina.

In total, committees identified 92 themes which should be protected in order to preserve representative examples of unique biologic, geologic, scenic, recreational, and archaeologic resources in a comprehensive state Parks system. Themes identified by the five committees are listed in Table IV-1. A definition of each theme is included in Appendix IV-2.

\section{--RECOMMnDATION IV-1: The State Parks System should preserve representative examples of 92 unique biologic, geologic, scenic, recreational, and archaeologic themes.}

\section{Significance of Themes Within Regions}

After deriving resource themes, the committees rated the significance of the themes within four natural regions (i.e., Tidewater, Coastal Plain, Piedmont, and Mountain) which were suggested by the Parks and Recreation Council. Figure IV-1 displays approximate regional locations. A theme which is significant to that region (i.e., an important example of the natural heritage of that region based on a consideration of quality, quantity, and diversity) was assigned a value of three. A theme of moderate significance to that region was assigned a value of two. A theme 


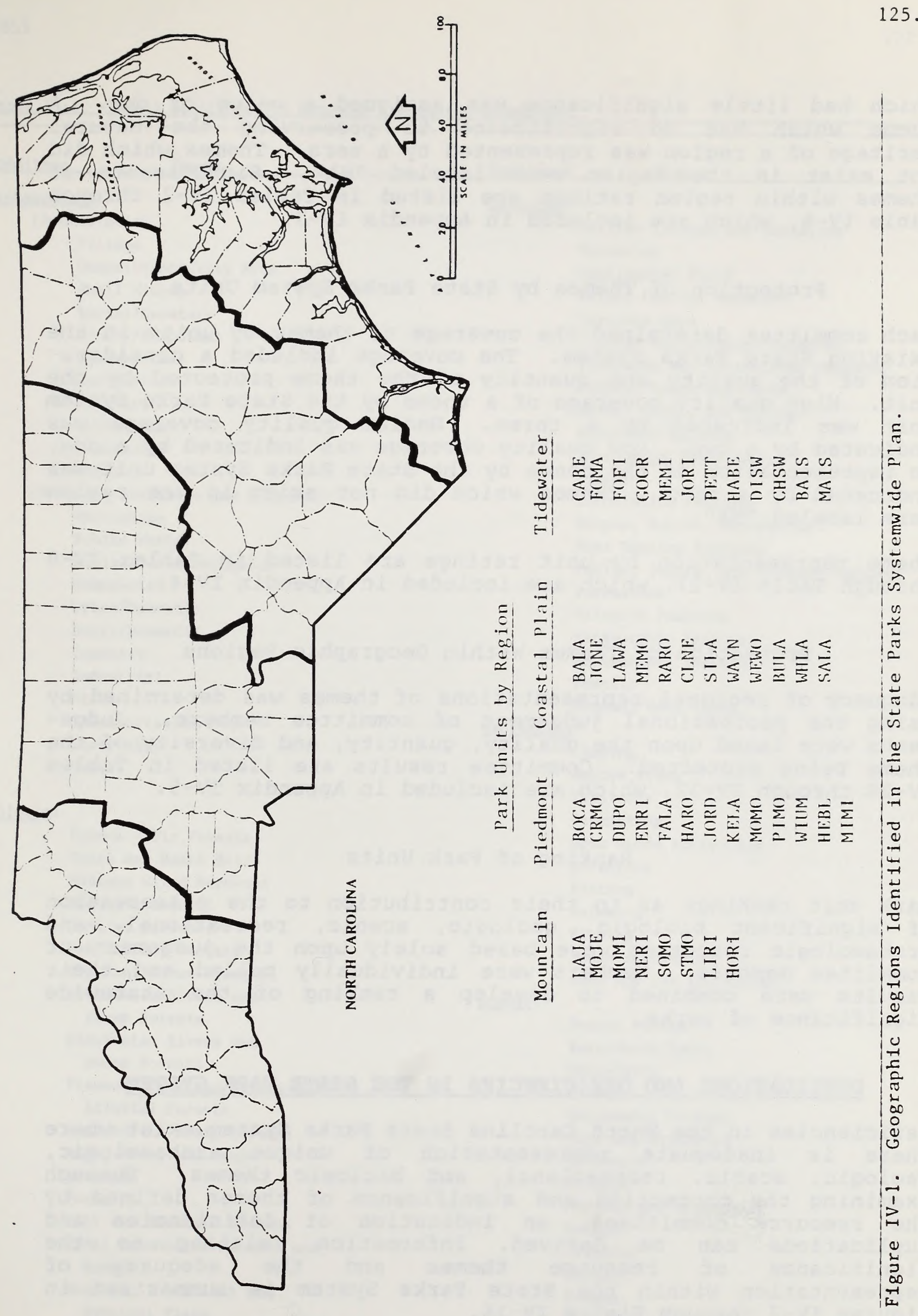


which had little significance was assigned a value of one. A theme which had no significance to preserving the natural heritage of a region was represented by a zero. Themes which did not exist in the region were labeled "NA". Significance of themes within region ratings are listed in Tables IV- 2 through Table IV-6, which are included in Appendix IV-3.

\section{Protection of Themes by State Parks System Inits}

Each committee determined the coverage of themes by units in the existing state Parks System. The coverage included a consideration of the quality and quantity of the theme protected by the unit. High quality coverage of a theme by the state Parks system unit was indicated by a three. Medium quality coverage was indicated by a two. Low quality coverage was indicated by a one. No representation of the theme by the state Parks system unit was indicated by a zero. Themes which did not exist in the region were labeled "NA".

Theme representation by unit ratings are listed in Tables IV-8 through Table IV-27, which are included in Appendix IV-4.

\section{Protection of Themes Within Geographic Regions}

Adequacy of regional representations of themes was determined by using the professional judgement of committee members. Judgements were based upon the quality, quantity, and diversity of the theme being protected. Committee results are listed in Tables IV-28 through IV-32, which are included in Appendix IV-5.

\section{Ranking of Park Units}

Park unit rankings as to their contribution to the preservation of significant biologic, geologic, scenic, recreational, and archaeologic resources were based solely upon the judgement of committee members. Members were individually polled and their results were combined to develop a ranking of the statewide significance of parks.

\section{DUPLICATIONS AND DEFICIENCIES IN THE STATE PARK SYSTEM}

Deficiencies in the North Carolina state Parks system exist where there is inadequate representation of unique archaeologic, geologic, scenic, recreational, and biologic themes. Through examining the protection and significance of themes defined by the resource committees, an indication of deficiencies and duplications can be derived. Information relating to the significance of resource themes and the adequacy of representation within the state Parks system is summarized in Figures IV-2 through Figure IV-16. 
Table IV-1. Themes Identified by Resource Evaluation Comittees.

Comittee Themes

Archaeologic:

(Prehistoric)

Village

Campsite/Activity Area

Shell Midden

Burial/Cemetery

Quarry/Soapstone

Quarry/Other

Shelter/Cave

Rock Art

Trail/Path

Underwater

other

(Standing Structure and Historic)

Recreation

Public Works

Public/Civic Religious

Commercial

Urban/Domestic

Rural/Domestic

Cemetery

Industrial

Mills

Transportation

Underwater

other

Biologic:

Spruce - Fir Forests

Grass and Heath Balds

Montane Mixed Hardwood

Piedmont/Coastal

Mixed Hardwood

Oak Hickory Forests

Dry Coniferous Forests

Brownwater Rivers and

Swamp Forests

Blackwater Rivers and Swamp Forests

Piedmont/Mountain Rivers and

Alluvial Forests

Nonriverine Swamp Forests

Bogs, Fens, and Seeps

Savannas

Pocosins "

Salt and Brackish Marshes

Tidal Freshwater Marshes and Swamps

Beaches, Intertidal and

Subtidal Flats

Rock Outcrops

Maritime Grasslands

Maritime Forests
Comittee

Themes

Geologic:

Barrier Islands and Shoreline

Estuaries

Continental Shelf

Relect Coastal Features

Carolina Bays

Fluvial Depositional Features

Peatlands and Interstream Wetlands

Natural Lakes and Ponds

Caves, Sinks, and Springs

Dissected Uplands

Inselbergs (Monadnocks)

Cliffs

Exfoliation Features

Gorges, Rapids, Waterfalls

Mass Wasting Features

Faults, Joints, and Related Features

Intrusions

Volcanic Features

Metamorphic Features

Sedimentary Features

Fossils

Unusual Rock Types

Recreation:

Camping

Nature Study

Trail Use

Picnicking

Open Space Activities

Adventure

Boating

Swimming

Fishing

Beach Activities

Snow and Ice Activities

Scenic:

Scenic Vistas

Reservoirs/Lakes

Waterfalls

Rivers

Whitewater Streams

Bays and Estuaries

Seashores

Forests

Meadows and Grasslands

Swamps

Pocosins

Marshes

Gorges

Rock Outcroppings

Is lands

Caves and Cliffs

Scenic Highways 
Preservation quotients reflecting relative amounts of theme coverage by the State Parks System are presented in Figures IV-3, IV-4, IV-6, IV-7, IV-9, IV-10, IV-12, IV-13, IV-15, and IV-16. The quotients were determined by dividing summed regional theme coverage values by summed regional theme significance values. Although the values are not statistical equivalents, they do provide some indication of theme representation by the state Parks System. Committee recommendations provide further insight into protection needs.

Archaeologic Theme Representation

Five archaeologic themes have high protection needs: prehistoric village (Coastal Plain, Piedmont), prehistoric burial/cemetery (all regions), standing structure mills (Mountain), historic industrial (Piedmont, Mountain), and historic commercial (Piedmont, Mountain). The most duplicated themes include prehistoric campsite/activity areas, historic rural-domestic, and standing structure rural-domestic.

As defined by the Archaeologic committee, archaeologic themes are relatively well covered by the State Parks System (Figures IV-2 through Figure IV-4). This is not to state that they are well preserved or interpreted, but simply that most archaeologic themes exist, or likely exist, within the State Parks System.

High quality protection of themes provided by more than one unit is identified in Table IV-33.

Expansion needs to protect significant archaeologic themes are listed, by priority order, in Table IV-34. The State should move to preserve inadequately protected themes before further duplicating themes with high quality protection. Themes with lower relative coverage quotients and no duplications represent the highest priority acquisition needs to protect archaeological values. 
Table IV-33. High Quality Protection of Archaeologic Themes by Region.

Theme

Park Unit*

\section{$\underline{\text { Tidewater }}$}

Prehistoric Archaeological

Campsite/Activity Area

Historic Archaeological:

Rural-Domestic

Cemetery

Transportation

Military

Underwater

GOCR, MEMI, PETT, HABE, BAIS, MAIS

Standing Structures:

Military GOCR, MEMI FOMA, FOFI, GOCR FOMA, MEMI FOMA, FOFI FOFI, PETT FOMA, FOFI

Coastal Plain

Prehistoric Archaeological:

Campsite/Activity Area Underwater

BALA, LAWA, MEMO, RARO, WHLA

Historical Archaeological

Rural-Domestic LAWA, WHLA

RARO, SILA

\section{Piedmont}

Prehistoric Archaeological:

Campsite/Activity Area

CRMO, DUPO, ENRI, FALA, JOLA

KELA, MOMI, PIMO, WIUM, MIMI

Underwater FALA, JOLA, KELA

Historic Archaeological:

Recreation

HARO, WIUM

Public Works

Rural-Domestic

DUPO, WIUM

Mills

Standing Structures:

Recreation

Public Works

Rural-Domestic

HARO, WIUM
DUPO, WIUM
CRMO, DUPO, ENRI, FALA, JOLA
KELA, MOMI, PIMO, WIUM
WIUM, MIMI
HARO, WIUM
DUPO, WIUM
DUPO, ENRI, FALA, JOLA, KELA
MOMI, PIMO

Mountain

Prehistoric Archaeological:

Campsite/Activity Area

Historical Archaeological:

Recreation

Rural-Domestic

Standing Structures:

Recreation

NERI, SOMO, STMO

CAJA, MOMI

NERI, SOMO, STMO

LAJA, MOMI

* Codes for park units are explained in the list of abbreviations. 
Table IV-34. Relative Coverage of Expansion Needs to Protect Significant Archaeologic Thees.

\begin{tabular}{|c|c|c|c|c|c|}
\hline Theme & $\begin{array}{l}\text { Relative } \\
\text { Coverage* }\end{array}$ & $\begin{array}{l}\text { Quality of } \\
\text { Protection }\end{array}$ & $* *$ & $\begin{array}{l}\text { Region } \\
\text { Coverage } \\
\text { Needed In*tw: }\end{array}$ & $\begin{array}{c}\text { Relative } \\
\text { Expansion } \\
\text { Need }\end{array}$ \\
\hline Prehistorical Village & .67 & -- & & $C, P$ & High \\
\hline Prehistorical Burial/Cemetery & .67 & -- & & Al1 & High \\
\hline Standing Structures Mills & .67 & -- & & M & High \\
\hline Historical Industrial & .67 & -- & & $\mathrm{P}, \mathrm{M}$ & High \\
\hline Historical Commercial & .67 & -- & & $P, M$ & High \\
\hline Historical Public Works & .67 & 2 Units & & M & Moderate \\
\hline Historical Transportation & .67 & 2 Units & & $P, M$ & Moderate \\
\hline Prehistorical Underwater & .67 & 5 Units & & M & Moderate \\
\hline Prehistorical Rock Art & .83 & -- & & $P, M$ & Moderate \\
\hline Standing Structures Cemetery & .83 & -- & & $P, M$ & Moderate \\
\hline Standing Structures Transportation & on .83 & -- & & $P, M$ & Moderate \\
\hline Standing Structures Industrial & 1.0 & - & & M & Low \\
\hline Prehistorical Trail/Path & 1.0 & -- & & M & Low \\
\hline Prehistorical Quarry-Soapstone & 1.0 & -- & & M & Low \\
\hline Standing Structures Commercial & 1.0 & -- & & M & Low \\
\hline Prehistorical Quarry-Other & 1.0 & -- & & M & Low \\
\hline Prehistorical Shelter/Cave & 1.0 & -- & & -- & Low \\
\hline $\begin{array}{l}\text { Standing Structures Public/ } \\
\text { Civic/Religious }\end{array}$ & 1.0 & -- & & -- & Low \\
\hline Historical Urban Domestic & 1.0 & -- & & -- & Low \\
\hline $\begin{array}{l}\text { Historical Public/Civic/ } \\
\text { Religious }\end{array}$ & 1.0 & -- & & -- & Low \\
\hline Prehistorical Shell Midden & 1.0 & -- & & -- & Low \\
\hline Prehistorical-other & 1.0 & -- & & -- & Low \\
\hline Historical Other & 1.0 & -- & & -- & Low \\
\hline Standing Structures Other & 1.0 & -- & & -- & Low \\
\hline Standing Structures Military & 1.0 & 2 Units & & -- & Very Low \\
\hline Historical Mills & 1.0 & 2 Units & & M & Very Low \\
\hline Historical Military & 1.0 & 2 Units & & -- & Very Low \\
\hline Standing Structures Public Works & 1.0 & 2 Units & & M & Very Low \\
\hline Historical Underwater & 1.0 & 2 Units & & $P$ & Very Low \\
\hline Historical Cemetery & 1.0 & 3 Units & & - & Very Low \\
\hline Historical Recreation & 1.0 & 4 Units & & -- & Very Low \\
\hline Standing Structures Recreation & 1.0 & 5 Units & & -- & Very Low \\
\hline $\begin{array}{l}\text { Standing Structures Rural/ } \\
\text { Domestic }\end{array}$ & 1.0 & 7 Units & & -- & Very Low \\
\hline Historical Rural-Domestic & 1.0 & 16 Units & & -- & Very Low \\
\hline Prehistorical Campsite/Activity & 1.0 & 23 Units & & -- & Very Low \\
\hline
\end{tabular}

\footnotetext{
*Adequacy of Coverage/Significance of Coverage.

***Number of Units with High Quality Protection.

***: $\mathrm{T}=$ Tidewater, $\mathrm{C}=$ Coastal Plain, $\mathrm{P}=$ Piedmont, $\mathrm{M}=$ Mountain
} 


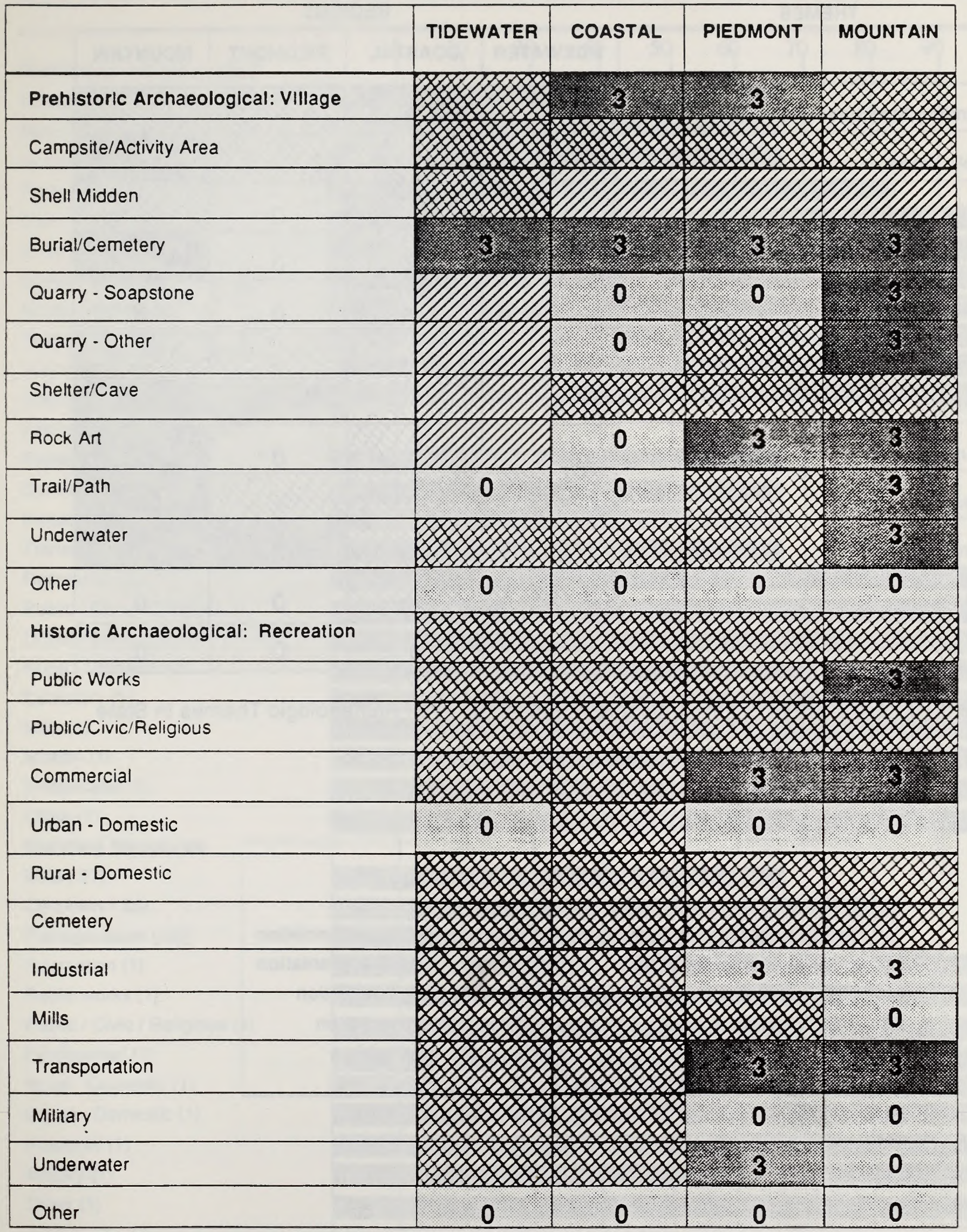

Figure IV-2. Summary of Significance and Representation Of Archaeologic Themes in State Parks System. 
THEMES

REGIONS

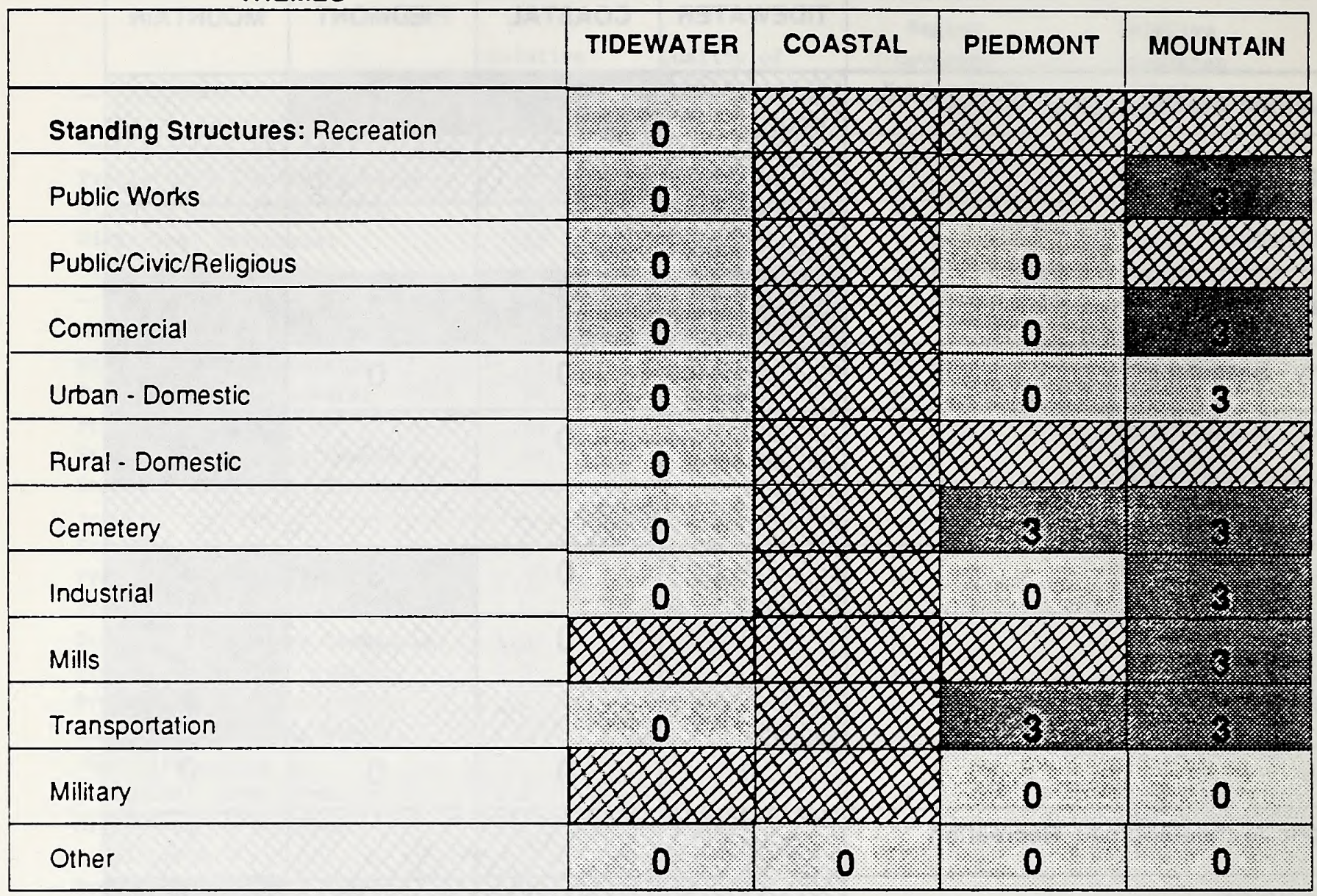

Figure IV-2. Summary of Significance and Representation Of Archaeologic Themes In State Parks System.

KEY

3 Prime Significance

2 Moderate Significance

1 Little Significance

o No Significance
Adequate Representation

Moderate Representation Littie Representation No Representation Not Applicabie 
Prehlstorlc Archaeological

\section{Percent}

Village (.67)

Burial / Cemetery (.67)

Underwater (.67)

Rock Ant (.83)

Cam., Isite / Activity Area (1)

Shell Midden (1)

Quarry - Soapstone (1)

Quarry - Other (1)

Shelter / Cave (1)

Trail / Path (1)

Other (1)

Historlc Archaeologlcal

Public Works(.67)

Commercial (.67)

Industrial (.67)

Transportation (.67)

Recreation (1)

Public / Civic / Religious(1)

Urban - Domestic (1)

Rural - Domestic(1)

Cemetery (1)

Mills (1)

Military (1)

Underwater (1)

Other (1)

\section{Standing Structures}

Mills (.67)

Cemetery (.83)

Transportation (.83)

Recreation (1)

Public works (1)

Public / Civic / Religious (1)

Commercial (1)

Rural - Domestic (1)

Urban - Domestic (1)

Industrial (1)

Military (1)

Other (1)
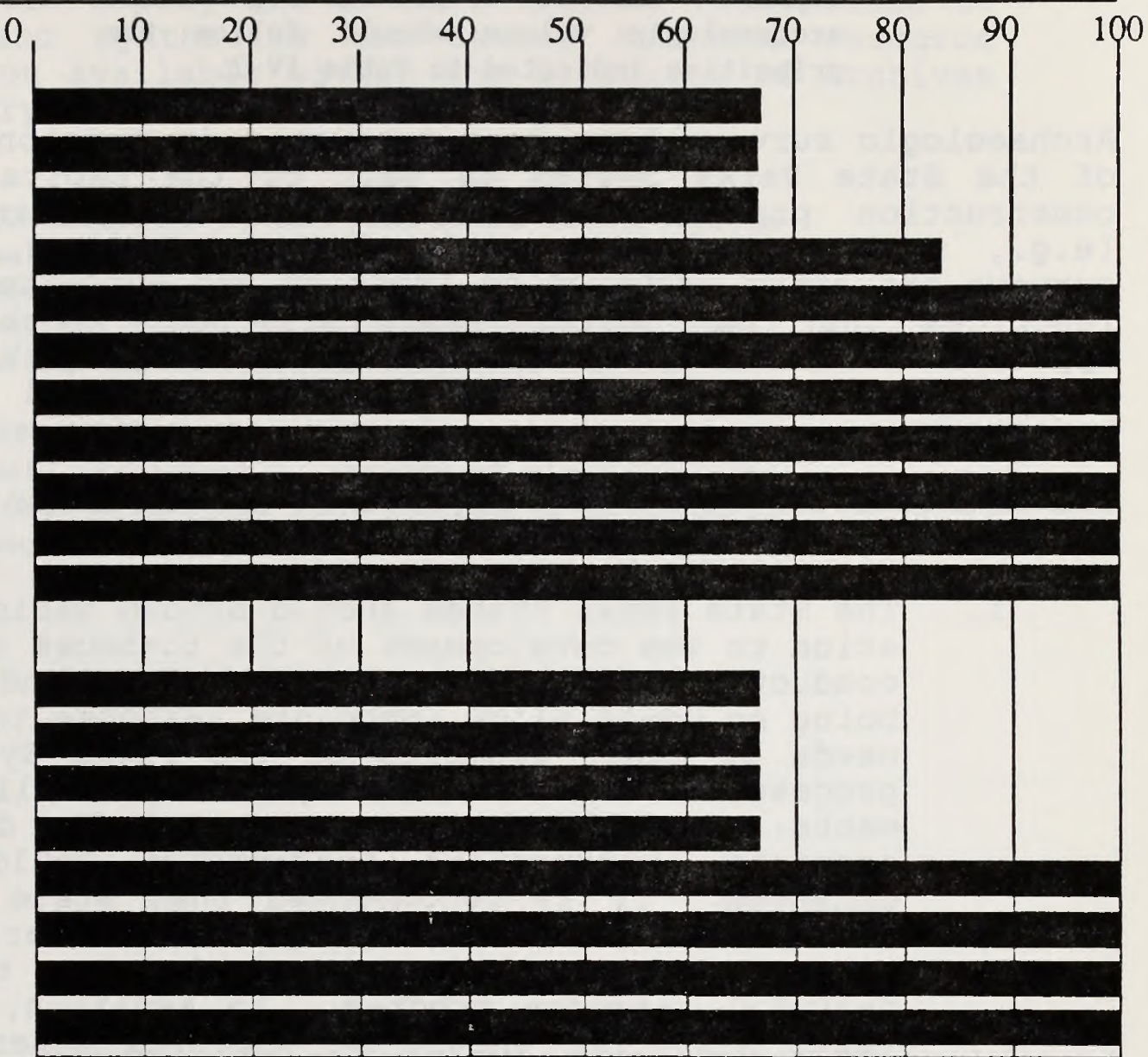

Other (1)

Figure IV-3. Adequacy of Archaeologic Theme Representation in State Parks System by Theme. 
--RECOMRENDATION IV-2: State Parks System expansion intended to protect significant archaeologic values should follow the priorities indicated in Table IV-2.

Archaeologic surveys have been conducted in portions of 19 units of the state Parks system as part of the capital development construction process. Prior to ground-disturbing activities (e.g., road construction, capital improvements), archaeologic surveys are often required to identify and evaluate any cultural resources that may be adversely affected. Such a piecemeal approach to identifying archaeologic values within the state parks system has resulted in an inadequate and uncoordinated inventory.

The Archaeologic Committee urged that the Division of Parks and Recreation pursue the following recommendations:

1. The State Parks system should afford serious consideration to the development of the in-house capability for conducting cultural resource surveys and evaluations. Doing so would allow immediate response to the planning needs of other segments of the Parks system planning process, as well as the regulatory compliance requirements. In addition, the potential for development of accurate interpretive information would be greatly enhanced. It is recommended that state Parks employ two professional archaeologists (master's degree or better) and one laboratory technician to manage the cultural resource program. In addition, an architectural historian should be employed under contract to conduct a comprehensive inventory and evaluation study of all standing structures in the parks.

2. It is recommended that state Parks initiate a program

of staff training on the overall principles and procedures of cultural resource management. Included among the proposed program topics are:

a. Current state cultural resource protection laws (e.g., the Archaeological Resources Protection Act; the Unmarked Human Burial and Human Skeletal Remains Act);

b. The general prehistory and history of North Carolina;

c. Identification and treatment of cultural materials;

d. The proper approaches to the recording and interpretation of cultural resources in general; and

e. Cultural resource preservation and management procedures. 
3. For immediate and near-term planning purposes, State Parks should employ one or more trained individuals to compile and synthesize the extant cultural resource information available within the Divisions of Archives and History and Parks and Recreation.

\footnotetext{
-RECOMMENDATION IV-3: The State Parks System should develop an "in-house" capability to ronduct cultural resource surveys and evalua$t$ ions and assist in developing accurate interpretive and information programs.

--RECOMMINDATION IV-4: The State Parks System should implement a program of staff training on the principles and procedures of cultural resource management.
} 


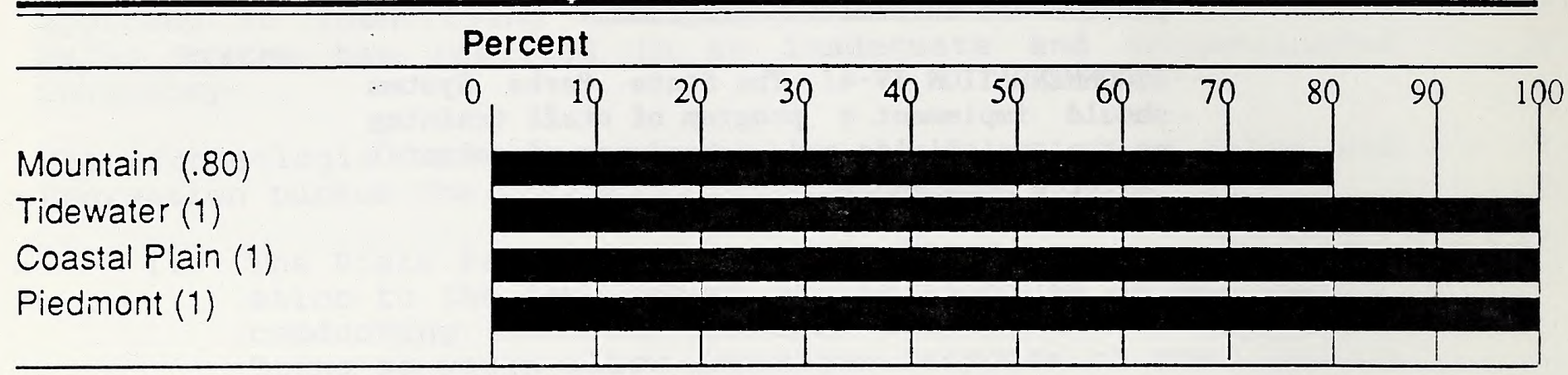

Figure IV-4. Adequacy of Archaeologic Theme Representation in State Parks System by Region.

\section{Biologic Theme Representation}

Eleven biological themes are recognized as very high expansion needs. These themes include oak-hickory forests (Tidewater), non-riverine swamp forests (Coastal Plain, Tidewater, Piedmont), brown water rivers and swamps (Coastal Plain), rock outcrops (Tidewater and Mountain), grass and heath balds (Mountain), dry coniferous forests (Tidewater and Mountain), bogs-fens-seeps (Piedmont, Mountain), savannas (Tidewater, Coastal Plain), pocosins (Tidewater), Piedmont/Coastal Plain mixed hardwood forests (Mountain, Tidewater), and black water river swamp forests (Tidewater, Coastal Plain). Duplications include beaches/subtidal/intertidal flats and salt-and-brackish marshes.

Several significant biologic themes are not represented in the state Parks System (Figures IV-5 through Figure IV-7). The piedmont region offers the greatest protection of existing biological themes. The Tidewater and coastal Plain regions have the most themes remaining uncovered.

Table IV-36 lists a prioritization of expansion needs to cover significant biological themes. 
Table IV-3s. High Quality Protection of Biological

Themes by Region.

Theme

Park Unit*

$\underline{\text { Tidewater }}$

Maritime Grasslands

Salt and Brackish Marshes

Natural Ponds, Pools, and Lakes

Beaches, Subtidal, and Intertidal Flats
HABE, BAIS

FOMA, HABE, BAIS, MAIS

CABE, MEMI, PETT

FOFI, DISW, BAIS, MAIS

\section{Coastal Plain}

Piedmont and Coastal Plain Mixed

Hardwood Forests

Rock Outcrops

Dry Coniferous Forests

Oak-Hickory Forests

Black Water Rivers and Swamps

Pocosins

Natural Ponds, Pools, and Lakes

MEMO, RARO, CLNE

RARO, CLNE

JOLA, SILA, WEWO, SALA

MEMO, RARO, CLNE

LAWA, SILA, WEWO

JONE, BULA, SALA

JONE, LAWA, SILA, BULA, SALA

\section{$\underline{\text { Piedmont }}$}

Piedmont and Coastal Plain Mixed

Hardwood Forests

BOCA, ENRI, WIUM

Rock Outcrops

CRMO, HARO, PIMO, MIMI

Oak Hickory

BOCA, ENRI, FALA, HARO,

JOLA, MOMO, PIMO, WIUM

\section{Mountain}

Rock Outcrops

Oak-Hickory Forests
MOJE, STMO

MOJE, STMO

Codes for park units are explained in the list of abbreviations. 
Table IV-36. Relative Coverage of Bxpansion Heeds to Protect Significant Biologic The es.

\begin{tabular}{|c|c|c|c|c|c|}
\hline Theme & $\begin{array}{l}\text { Relative } \\
\text { Coverage* }\end{array}$ & \multicolumn{2}{|c|}{$\begin{array}{l}\text { Quality of } \\
\text { Protection }\end{array}$} & $\begin{array}{l}\text { Region } \\
\text { Coverage } \\
\text { Needed In*wis }\end{array}$ & $\begin{array}{c}\text { Relative } \\
\text { Expansion } \\
\text { Need } \\
\end{array}$ \\
\hline Oak-Hickory Forests & 0.0 & & Units & $\mathbf{T}$ & Very High \\
\hline Non-Riverine Swamp Forests & .22 & & -- & $\mathrm{C}, \mathrm{T}, \mathrm{P}$ & Very High \\
\hline Grass and Heath Balds & .33 & & -- & M & Very High \\
\hline Dry Coniferous Forests & .33 & 4 & Units & $\mathrm{T}, \mathrm{M}$ & Very High \\
\hline Bogs, Fens, Seeps & .33 & & -- & $P, M$ & Very High \\
\hline Savannas & .33 & & -- & $\mathrm{T}, \mathrm{C}$ & Very High \\
\hline Spruce-Fir Forests & .67 & & -- & M & High \\
\hline Maritime Forests & .67 & & -- & $\mathbf{T}$ & High \\
\hline Piedmont/Mountain Rivers and & & & & & \\
\hline Alluvial Forests & .67 & & -- & $P, M$ & High \\
\hline Natural Ponds, Pools, Lakes & .67 & 8 & Units & $\mathrm{T}$ & High \\
\hline Maritime Grasslands & 1.0 & 2 & Units & $-\ldots$ & Very Low \\
\hline Salt and Brackish Marshes & 1.0 & 4 & Units & $-\cdots$ & Very Low \\
\hline Beaches, Subtidal, and Intertida & & & & & \\
\hline Flats & 1.0 & 4 & Units & --- & Very Low \\
\hline
\end{tabular}

\footnotetext{
*Adequacy of Coverage/Significance of Coverage.

**Nomber of Units with High Quality Protection.

***T $=$ Tidewater, $\mathrm{C}=$ Coastal Plain, $\mathrm{P}=$ Piedmont, $\mathrm{M}=$ Mountain
} 
THEMES

REGIONS

\begin{tabular}{|l|l|}
\hline & \\
\hline Spruce-Fir Forests & TIDEWATER \\
Grass and Heath Baids \\
Montane Mixed Hardwood Forests \\
\hline Pdmnt./Cstl. Piain Mixed Hardwoood Forest \\
\hline Rock Outcrops
\end{tabular}

Figure IV-5. Summary of Significance and Representation Of Biologic Themes In State Parks System.

KEY 3 Prime Significance 1 Little Significance Adequate Representation 2 Moderate Significance 0 No Significance Moderate Representation

Little Representation $\square$ No Representation ZZ Not Applicable 


\section{Percent}

Oak-Hickory Forests (0)

Non-Riverine Swamp (.22)

Brown Water River Swamp (.25)

Rock Outcrops (.33)

Grass \& Heath Balds (.33)

Dry Conifer Forests (.33)

Bogs, Fens, Seeps (.33)

Savannas (.33)

Pocosins (.33)

Pdmnt. /Cstl. Mxd Hardwood (.40)

Black Water River Swamp (.50)

Spruce-Fur Forests (.67)

Maritime Forests (.67)

Pdmnt ./ Mtn. Alluvial (.67)

Natural Ponds, Pools, Lakes (.67)

Montane Mixed Hardwood (.80)

Tidal Fresh Marshes, Swamps (1)

Maritime Grasslands (1)

Salt \& Brackish Marsh (1)

Beach Subtidal \& Intertidal Flat (1)

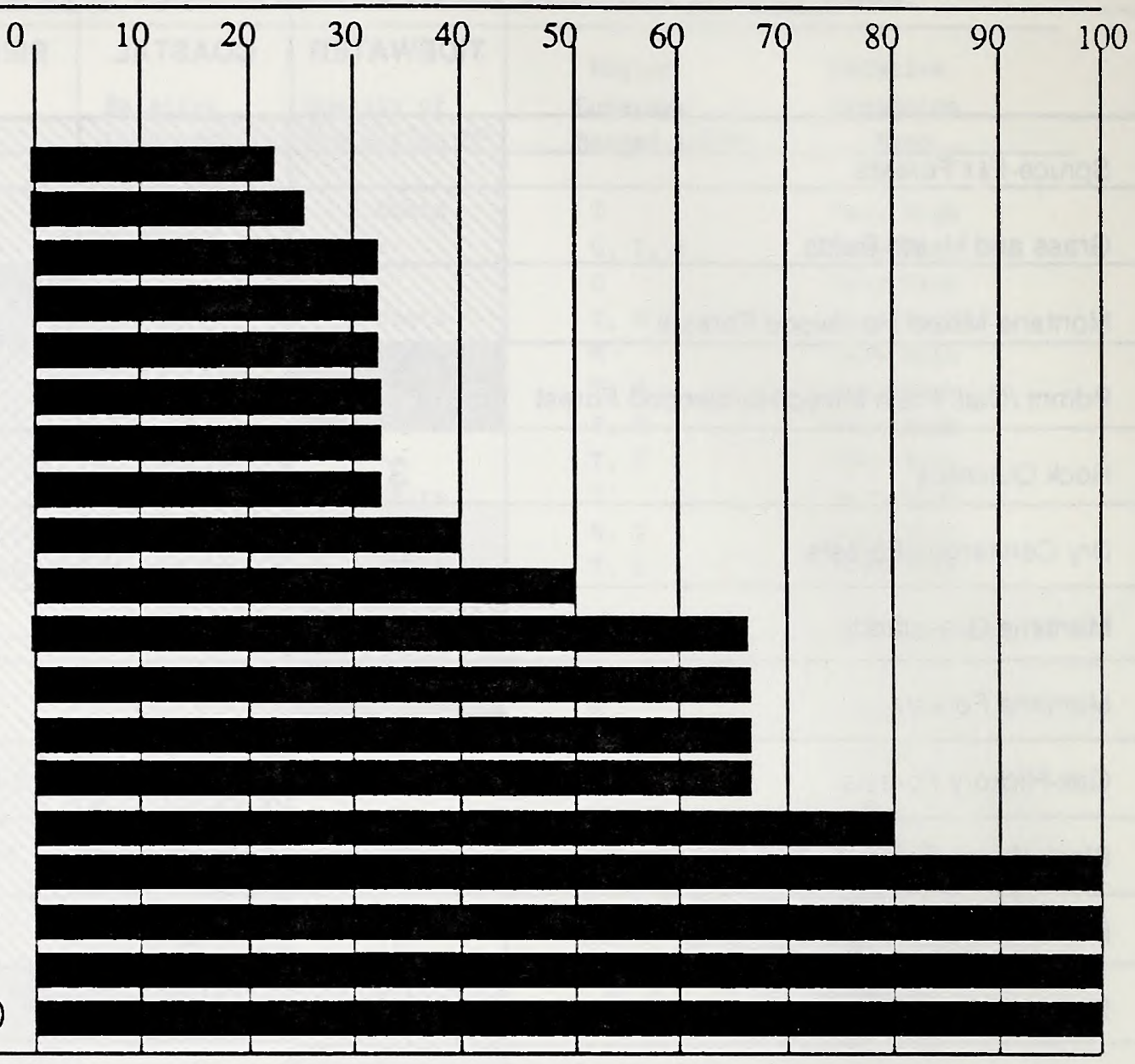

Figure IV-6. Adequacy of Biologic Theme Representation in State Parks System by Theme.

Coastal Plain (.31)

Tidewater (.35)

Mountain (.46)

Piedmont (.55)

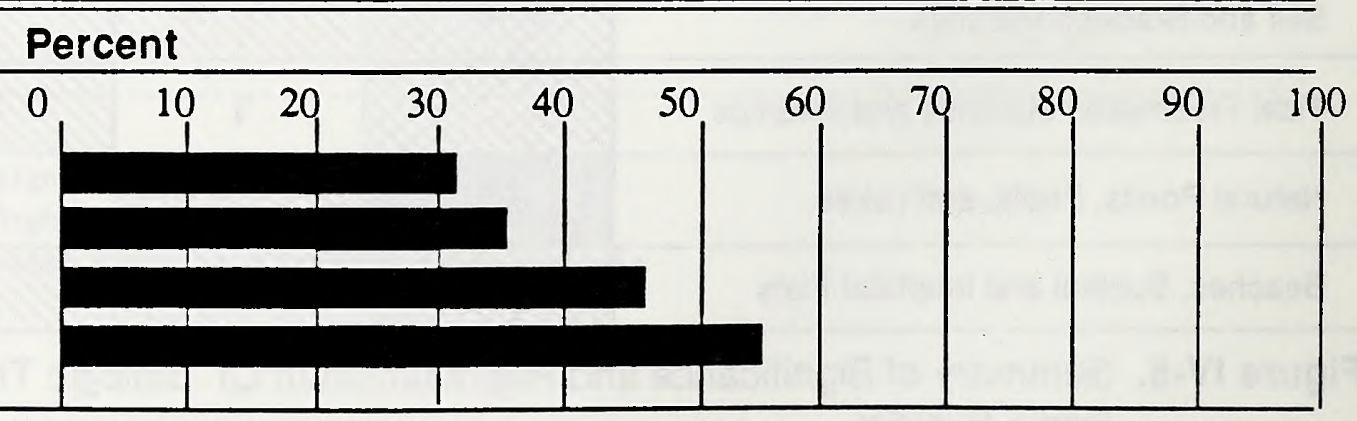

Figure IV-7. Adequacy of Biologic Theme Representation in State Parks System by Region. 
In addition to the results from the numeric rating process, the Biologic Committee suggested that the themes listed below are high-priority additions.

Blackwater Rivers and Swamps (Coastal Plain and Tidewater): Large blackwater rivers are poorly represented. Excellent examples of blackwater rivers include (but are not limited to) the Black, Northeast Cape Fear, Lumber, Waccamaw, and Scuppernong Rivers.

Bogs, Fens, and Seeps (Mountain and Piedmont): Only a very limited part of the range of diversity of this theme occurs on State Parks land. These endangered ecosystems are poorly protected in the state.

Dry Coniferous Forests (Tidewater and Coastal Plain): This threatened system is a highly significant and diverse part of the state's heritage. Old-growth longleaf pine forests and woodlands are poorly represented.

Grass and Heath Balds (Mountain): These interesting systems are very poorly represented in the state Parks System. Most remaining examples are in U.S. Forest service or National Park service ownership.

Maritime Forests (Tidewater): Maritime Forests are endangered by rapid coastal development; very few good examples remain. Additional representation of this important ecosystem would be desirable.

Montane Mixed Hardwood Forests (Mountain): The diverse and attractive mesophytic forests of the mountains are not well represented in the State Parks system. Better representation in State Parks is needed for interpretation and protection.

Natural Ponds, Pools, and Lakes (Tidewater): Limesink ponds are rare and threatened features of the Tidewater Region, almost entirely unprotected on or off of state Parks lands.

Nonriverine Swamp Forests (Piedmont): Nonriverine Swamp Forests in the Piedmont, generally occurring in upland depressions developed over mafic rocks, are very rare and unprotected on state or other lands.

Piedmont/Mountain Rivers and Alluvial Forests (Piedmont and Mountain): Rivers and alluvial forests are poorly represented in the Mountain and Piedmont Regions, aside from a few examples such as Eno River state Park.

Pocosins (Tidewater): White cedar swamps, here considered a part of the pocosins Theme, are threatened throughout their range. They are a distinctive and significant part of North Carolina's natural heritage not sufficiently protected in the state. 
Rock Outcrops (Tidewater and Mountain): The great geologic diversity of North Carolina is reflected in a diversity of rock outcrop communities. Much of this diversity is not contained in the state Parks system. The unusual limestone areas of the Tidewater and Mountain Regions have distinctive natural communities which are poorly protected in the state.

Savannas (Coastal Plain and Tidewater): This important and diverse theme is essentially unrepresented in the state parks System. Throughout the Southeast, savannas are being destroyed by conversion to pine plantation, lack of adequate fire management, and other factors. High quality examples occur on the Nature Conservancy's Green Swamp Preserve, on Croatan National Forest, and on. Holly shelter Game Land, but the diversity of soils and moisture regimes is not protected. High quality savannas in State Park ownership would help protect this declining and highly significant community type.

--RECOMMENDATION IV-5: State Parks System expansion intended to protect significant biological values should follow the priorities indicated in Table IV-36 and Figure IV-5.

Geologic Theme Representation

Fourteen geologic themes were rated as very high expansion needs. These include: continental shelf (Tidewater), cliffs (Tidewater), volcanic features (Mountain), fossils (Tidewater, Piedmont, Coastal Plain), caves/sinks/springs (Mountain, Coastal Plain, Piedmont), relict coastal features (Coastal Plain, Tidewater), unusual rock types (Tidewater, Mountain, Piedmont), mass wasting features (Coastal Plaiń, Mountain), unusual rock types (Tidewater, Mountain, Piedmont), folds and related features (Mountain, Coastal Plain), faults/joints/related features (Mountain, Coastal Plain), sedimentary features (Mountain, Piedmont), gorges/rapids/waterfalls (Coastal Plain), and fluvial depositional features (Piedmont, Mountain). Themes which are duplicated include: barrier islands/seashores, natural lakes/ponds, carolina bays, peatlands and interstream wetlands, estuaries, and inselbergs.

Ten significant geologic themes have no representation in the State Parks System (Figure IV-8). Fossils, caves/sinks/springs, and unusual rock types have little coverage across all regions. on the other hand, geologic themes, which include barrier islands, carolina bays, exfoliation outcrops, intrusions, and metamorphic features, have adequate representation. The Piedmont offers the most protection of geologic themes within the State Parks System, whereas the Tidewater offers the least.

A prioritization of expansion needs is listed in Table IV-38. 
Table IV-37. High Quality Protection of Geologic

Themes by Region.

Theme

Park Unit*

\section{Tidewater}

Barrier Islands and Shoreline Estuaries

Natural Lakes and Ponds

FOMA, FOFI, JORI, HABE, BAIS, THRO, MAIS FOMA, GOCR, HABE, BAIS, THRO, MAIS CABE, PETT

\section{Coastal Plain}

Carolina Bays

Fluvial Depositional Features

Peatland and Interstream Wetlands

Natural Lakes and Ponds

Cliffs

Sedimentary Features
JONE, LAWA, SILA, BULA, SALA

LAKA, CLNE

JONE, SILA, BULA, SALA

JONE, LAWA, SILA, SALA

LAWA, RARO, CLNE

LAWA, CLNE, WEWO

$\underline{\text { Piedmont }}$

Dissected Uplands

Inselbergs (Monadnocks)

Cliffs

Gorges, Rapids, and Waterfalls

Faults, Joints, and Related Features

Intrusions

Volcanic Features

Metamorphic Features

Sedimentary Features

Unusual Rock Types
ENRI, WIUM

CRMO, HARO, MOMO, PIMO

CRMO, HARO, PIMO, HEBL

ENRI, HARO, MIMI

BOCA, CRMO, HARO, KELA, PIMO

ENRI, MIMI

ENRI, MOMO

CRMO, HARO

HARO, MOMO, PIMO

CRMO, HARO

\section{Mountain}

Dissected Uplands

Inselbergs

Cliffs

Gorges, Rapids, Waterfalls

Metamorphic Features
SOMO, STMO

MOJE, STMO

NERI, STMO

SOMO, STMO, LIRI, HORI

MOJE, MOMI, NERI, SOMO, STMO

* Codes for park units are explained in the list of abbreviations. 


$\begin{array}{lllll} & & \text { Region } & \text { Relative } \\ \text { Theme } & \text { Relative } & \text { Quality of } & \text { Coverage } & \text { Expansion } \\ \text { Coverage* } & \text { Protection } * * * & \text { Needed In*⿲:* } & \text { Need }\end{array}$

\begin{tabular}{|c|c|c|c|c|}
\hline Continental Shelf & 0.0 & - & $\mathrm{T}$ & Very High \\
\hline Cliffs & 0.0 & 9 Units & $\mathrm{T}$ & Very High \\
\hline Volcanic Features & 0.0 & 2 Units & M & Very High \\
\hline Fossils & .10 & -- & $\mathrm{T}, \mathrm{P}, \mathrm{C}$ & Very High \\
\hline Caves, Sinks, and Springs & .11 & -- & $\mathrm{M}, \mathrm{C}, \mathrm{P}$ & Very High \\
\hline Relict Coastal Features & .17 & -- & $\mathrm{C}, \mathrm{T}$ & Very High \\
\hline Unusual Rock Types & .17 & 2 Units & $\mathrm{T}, \mathrm{M}, \mathrm{P}$ & Very High \\
\hline Mass Wasting Features & .17 & -- & $\mathrm{C}, \mathrm{M}$ & Very High \\
\hline Folds and Related Features & .25 & -- & $M, C$ & Very High \\
\hline \multicolumn{5}{|l|}{ Faults, Joints, and Related } \\
\hline Features & .25 & 5 Units & $\mathrm{M}, \mathrm{C}$ & Very High \\
\hline Sedimentary Features & .33 & 3 Units & $M, P$ & Very High \\
\hline Gorges, Rapids, Waterfalls & .33 & 4 Units & $\mathrm{C}$ & Very High \\
\hline Fluvial Depositional Features & .50 & 2 Units & $P, M$ & Very High \\
\hline
\end{tabular}

$\begin{array}{lcccc}\text { Dissected Uplands } & .99 & 2 \text { Units } & \text { T } & \text { Very Low } \\ \text { Inselbergs } & .99 & 6 \text { Units } & \mathrm{C} & \text { Very Low } \\ \text { Estuaries } & .99 & 6 \text { Units } & \mathrm{C} & \text { Very Low } \\ \text { Exfoliation Outcrops } & 1.0 & -- & -- & \text { Very Low } \\ \text { Intrusions } & 1.0 & 2 \text { Units } & -- & \text { Very Low } \\ \text { Metamorphic Features } & 1.0 & 2 \text { Units } & & \text { Very Low } \\ \text { Peatlands and Interstream } & & & -- & \text { Very Low } \\ \quad \text { Wetlands } & 1.0 & 4 \text { Units } & -- & \text { Very Low } \\ \text { Carolina Bays } & 1.0 & 5 \text { Units } & -- & \text { Very Low } \\ \text { Natural Lakes and Ponds } & 1.0 & 6 \text { Units } & -- & \text { Very Low } \\ \text { Barrier Islands and Shorelines } & 1.0 & 7 \text { Units } & & \end{array}$

*Adequacy of Coverage/Significance of Coverage.

**Number of Units with High Quality Protection.

$* * * \mathrm{~T}=$ Tidewater, $\mathrm{C}=$ Coastal Plain, $\mathrm{P}=$ Piedmont, $\mathrm{M}=$ Mountain 


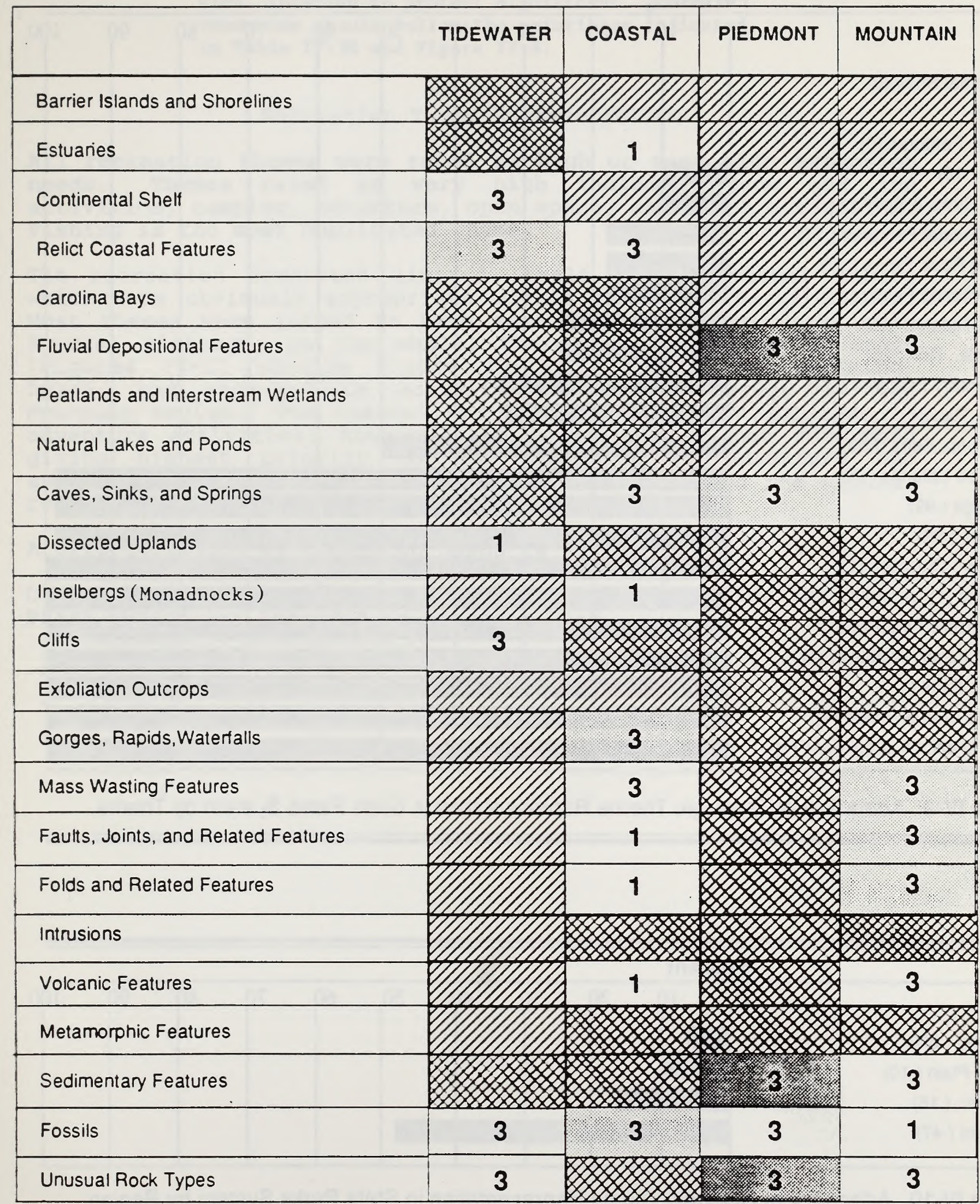

Figure IV-8. Summary of Significance and Representation Of Geologic Themes In State Parks System.

$\begin{array}{lllll}\text { KEY } & 3 & \text { Prime Significance } & 1 & \text { Little Significance Adequate Representation } \\ 2 & \text { Moderate Significance } & 0 & \text { No Significance }\end{array}$


Continental Shelf $(0)$

Cliffs (0)

Volcanic Features (0)

Fossils (.10)

C:aves, Sinks \& Springs (.11)

Re!ict Coastal Features (.17)

Unusual Rock Types (.17)

Mass Wasting Features (.17)

Folds \& Related (.25)

Flts., Jnts., Rel. (.25)

Sedimentary Features (.33)

Gorges, Rapids, Waterfalls (.33)

Fluvial Dep. Fetrs. (.50)

Dissected Uplands (.99)

Inselbergs (.99)

Estuaries (.99)

Exfoliation Outcrops (1)

Intrusions (1)

Metamorphic Features (1)

Ptlds. \& Intrstr. Wetlands (1)

Carolina Bays (1)

Natural Lakes \& Ponds (1)

Barrier Islands \& Shorelines (1)

\section{Percent}

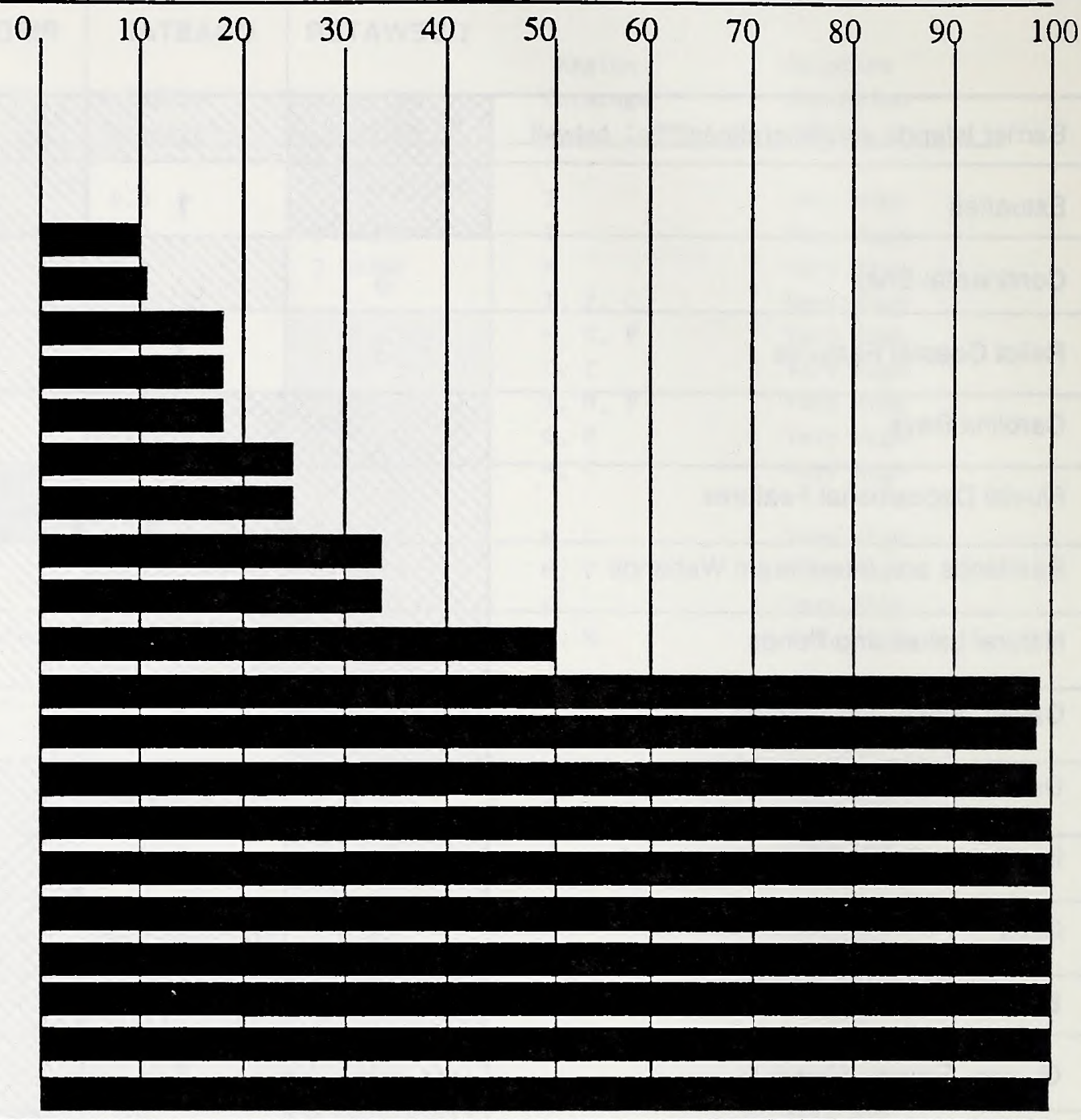

Figure IV-9. Adequacy of Geologic Theme Representation in State Parks System by Theme.

Tidewater (.063)

Coastal Plain (.10)

Mountain (.16)

Piedmont (.47)

\section{Percent}

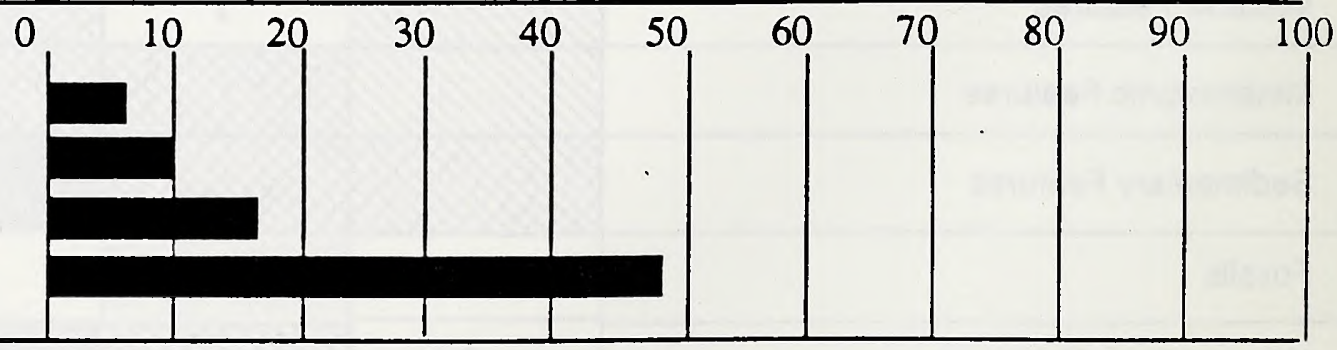

Figure IV-10. Adequacy of Geologic Theme Representation in State Parks System by Region. 
--RBCOMmENDATION IV-6: State Parks System expansion intended to protect significant geologic resources should follow the priorities indicated in Table IV-38 and Figure IV-8.

\section{Recreation Theme Representation}

All recreation themes were rated as high or very high expansion needs. Themes rated as very high include: snow and ice activitiı:s, camping, adventure, open space, and beach activities. Fishing is the most duplicated theme.

The recreation Committee limited itself to traditional themes which were obviously appropriate within the state Parks system. Most themes were judged to have some representation within the System, although, on the whole, there was inadequate coverage (Figures IV-11 through Figure IV-13). Significant swimming, beach, and snow-and-ice activities had no coverage in the Mountain Region. The Coastal Region offers no representation of adventure activities; however, the committee did not recommend giving highest priority to the provision of adventure and snow-and-ice activities due to associated impacts on the natural resource and high development costs.

A prioritization of expansion needs is listed in Table IV-40.

Other suggestions made by the committee for improving the state Parks system are included in appendix IV- 6 . 
Table IV-39. High Quality Protection of Recreation

Themes by Region.

\section{Tidewater}

Nature Study

Open Space Activit es

Swimming

Fishing

Beach Activities
FOMA, GOCR

FOMA, FOFI

FOMA, FOFI, HABE

CABE, FOMA, FOFI, GOCR, HABE

FOMA, FOFI, HABE

Coastal Plain

Open Space Activities

MEMO, SILA

Swimming

CLNE, SILA

\section{Piedmont}

Nature Study

Picnicking

Boating

Swimming

Fishing

Beach Activities
ENRI, HARO

FALA, JOLA, KELA

DUPO, FALA, JOLA, KELA

FALA, HARO, JOLA, KELA

FALA, JOLA, KELA, MOMO, WIUM

FALA, HARO, JOLA, KELA

\section{Mountain}

Fishing

NERI, SOMO, STMO

$\varpi$ Codes for park units are explained in the list of abbreviations. 
Table IV-40. Relative Coverage of Expansion Needs to Protect Significant Recreation Themes.

\begin{tabular}{|c|c|c|c|c|}
\hline Theme & $\begin{array}{l}\text { R lative } \\
\text { Coverage* }\end{array}$ & $\begin{array}{c}\text { Duplication of } \\
\text { Coverage rot }\end{array}$ & $\begin{array}{l}\text { Region } \\
\text { Coverage } \\
\text { Needed In'rids }\end{array}$ & $\begin{array}{l}\text { Relative } \\
\text { Expansion } \\
\text { Need }\end{array}$ \\
\hline Snow and Ice Activities & 0.0 & -- & $M$ & Very High \\
\hline Camping & .44 & -- & A11 & Very High \\
\hline Adventure & .44 & -- & $C, T, P, M$ & Very High \\
\hline Open Space & .44 & 4 Units & All & Very High \\
\hline Beach Activities & .45 & 7 Units & $M, T, C, P$ & Very High \\
\hline Swimming & .50 & 9 Units & $M, C, T, P$ & High \\
\hline Boating & .52 & 4 Units & All & High \\
\hline Trail Use & .54 & -- & Al1 & High \\
\hline Picnicking & .54 & 3 Units & A11 & High \\
\hline Nature Study & .58 & 4 Units & $\mathrm{T}, \mathrm{C}, \mathrm{P}$ & High \\
\hline Fishing & .67 & 13 Units & $\mathrm{T}, \mathrm{C}, \mathrm{M}$ & High \\
\hline
\end{tabular}

*Adequacy of Coverage/Significance of Coverage.

*'Number of Units with High Quality Protection.

*** $\mathrm{T}=$ Tidewater, $\mathrm{C}=$ Coastal Plain, $\mathrm{P}=$ Piedmont, $\mathrm{M}=$ Mountain 
THEMES

REGIONS

\begin{tabular}{|c|c|c|c|c|}
\hline & TIDEWATER & COASTAL & PIEDMONT & MOUNTAIN \\
\hline Camping & 3. & 3 & $x<$ & 4 \\
\hline Nature Study & 3) & & & \\
\hline Trail Use & 3. & 3. & $x$ & 桨泫 \\
\hline Picnicking & 3. & \% & 6 & 流 \\
\hline Open space & 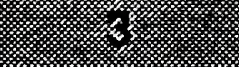 & 级 & 3. & 3. \\
\hline Adventure & 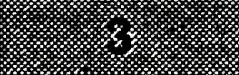 & 3 & 4 & \% \\
\hline Boating & 3 & & 纱 & 3 \\
\hline Swimming & 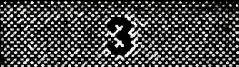 & 4 & s. & 3 \\
\hline Fishing & & $x$ & & 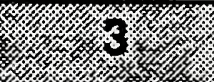 \\
\hline Beach Activities & $z_{2}^{x}$ & 3 & 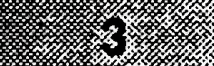 & 3 \\
\hline Snow and Ice Activities & DIIIs & & 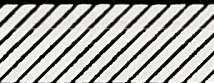 & 3 \\
\hline
\end{tabular}

Figure IV-11. Summary of Significance and Representation Of Recreation Themes In State Parks System.

\begin{tabular}{|c|c|c|c|}
\hline & & KEY & \\
\hline 3 & Prime Significance & 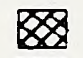 & Adequate Representation \\
\hline 2 & Moderate Significance & 裂 & Moderate Representation \\
\hline 1 & Little Significance & $\square$ & Little Representation \\
\hline 0 & No Significance & $\square$ & No Representation \\
\hline & & $\mathbb{Z}$ & Not Appllcable \\
\hline
\end{tabular}


Snow \& Ice Activities (0)

Camping (.44)

Adventure (.44)

Open Space (.44)

Beach Activities (.45)

Swimming (.50)

Boating (.52)

Trail Use (.54)

Picnicking (.54)

Nature Study (.58)

Fishing (.67)

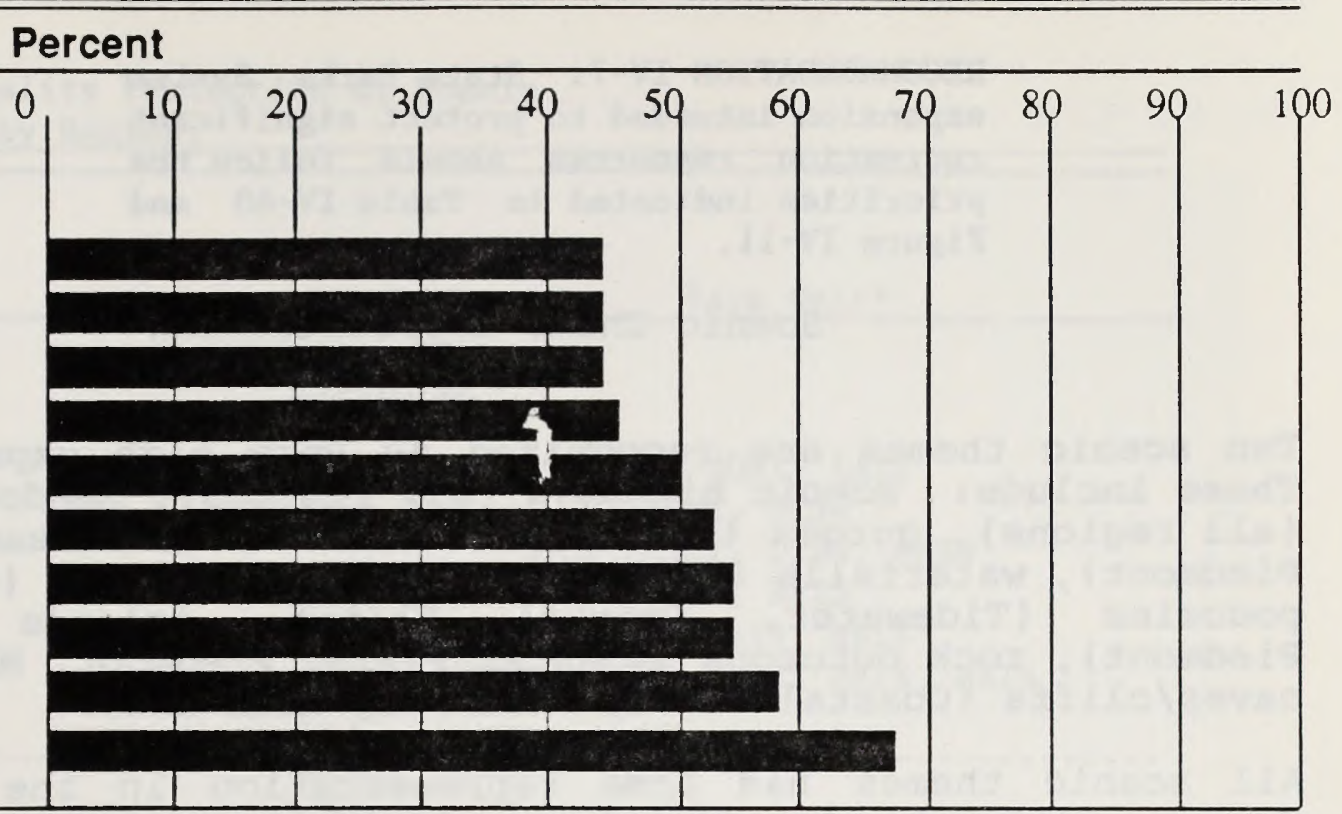

Figure IV-12. Adequacy of Recreation Theme Representation in State Parks System by Theme.

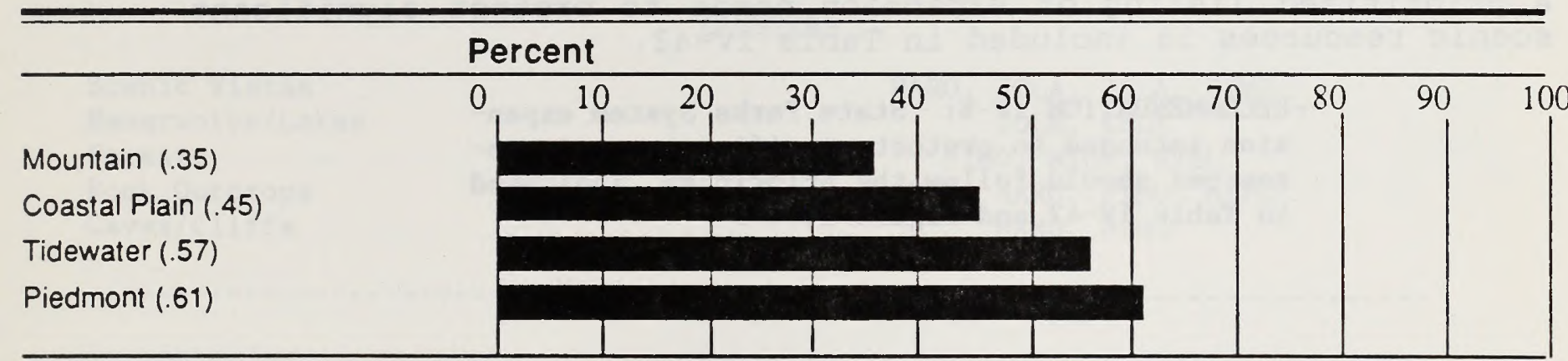

Figure IV-13. Adequacy of Recreation Theme Representation in State Parks System by Region. 


\section{--RECOMENDATION IV-7: State Parks System expansion intended to protect significant recreation resources should follow the priorities indicated in Table IV-40 and Figure IV-11.}

Scenic Theme Representation

Ten scenic themes are recognized as very high expansion needs. These include: scenic highways (all regions), meadows/grasslands (all regions), gorges (Mountain), white water streams (Mountain, Piedmont), waterfalis (Piedmont, Mountain), rivers (all regions), pocosins (Tidewater, Coastal Plain), islands (Tidewater, Piedmont), rock outcrops (Coastal Plain, Piedmont, Mountain), and caves/cliffs (Coastal Plain, Piedmont, Mountain).

All scenic themes had some representation in the state Parks System, although significant scenic highways had no representation within the Tidewater and Coastal plain Regions (Figures IV-14 through Figure IV-16). Across all regions, approximately one half of scenic themes are represented by the system. The Committee advocated adding additional units in the piedmont Region to serve a rapidly expanding population, and adding units in the Mountain region to preserve significant resources.

A prioritized listing of expansion needs to protect significant scenic resources is included in Table IV -42 .

--RECOMMNDATION IV-8: State Parks System expansion intended to protect significant scenic resources should follow the priorities indicated in Table IV-42 and Figure IV-14. 
Table IV-41. High Quality Protection of Scenic Themes by Region.

\section{Tidewater}

Scenic Vistas

Forests

Swamps

Marshes

Islands

Seashores
MEMI, JORI, BAIS

MEMI, DISW

GOCR, MEMI, DISW, CHSW

CHSW, BAIS

HABE, BAIS, MAIS

FOMA, FOFI, HABE, BAIS, MAIS

Coastal Plain

Scenic Vistas

Reservoirs/Lakes

Caves/Cliffs
RARA, CLNE

JONE, LAWA, SILA, WHLA, SALA RARO, CLNE

\section{Piedmont}

Scenic Vistas

Reservoirs/Lakes

Forests

Rock Outcrops

Caves/Cliffs
HARO, JOLA, KELA, PIMO JOLA, KELA PIMO, WIUM, HEBL
CRMO, HARO, PIMO, MIPO
HARO, PIMO

$\underline{\text { Mountain }}$

Scenic Vistas

MOMI, NERI, STMO, LIRI, HORI

* Park unit codes are explained in the list of abbreviations. 
Table IV-42. Relative Coverage of Expansion Needs to Protect Significant Scenic Thenes.

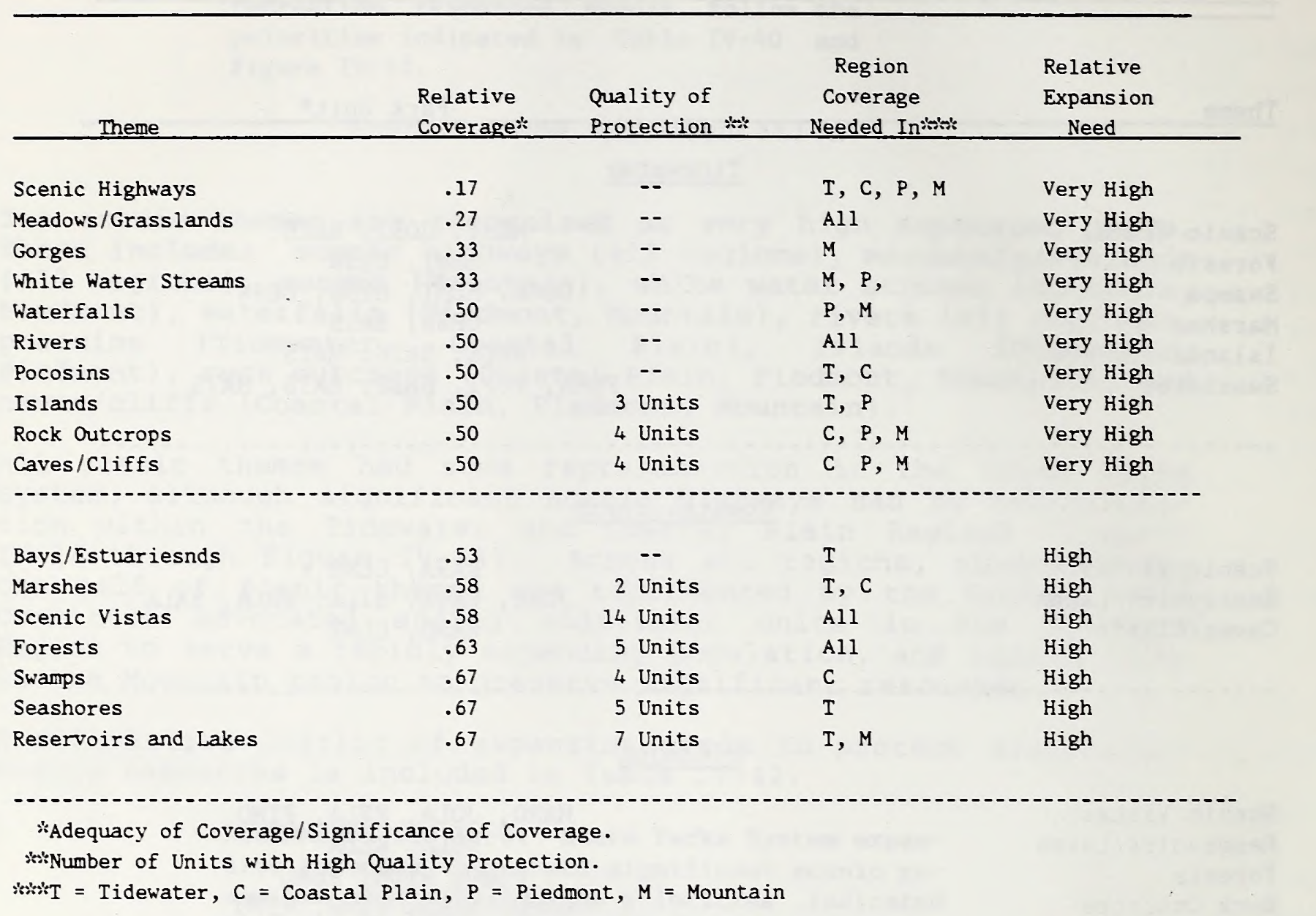


THEMES

REGIONS

\begin{tabular}{|c|c|c|c|c|}
\hline & TIDEWATER & COASTAL & PIEDMONT & MOUNTAIN \\
\hline Scenic Vistas & & 3 & & 3. \\
\hline Reservoirs/Lakes & (8. & & & , \\
\hline Waterfalls & Ola & & 3 & 8 \\
\hline Rivers & 3 & 6 & 3 & . \\
\hline White Water Streams & UnIIII & & 3 & 3 \\
\hline Forests & , & & s & 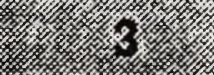 \\
\hline Meadows/Grasslands & 3 & 3 & 3 & 3 \\
\hline Swamps & $\infty$ & 8 & 7 & \\
\hline Pocosins & 6. & $x$ & 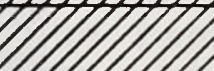 & \\
\hline Marshes & 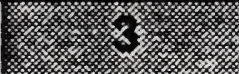 & & DIDOD= & \\
\hline Gorges & UnDIIIs & M & Olla & 3 \\
\hline Rock Outcrops & ¿-IIIII & 3 & 3. & 3. \\
\hline Islands & 3 & Ella & 3 & \\
\hline Caves/Cliffs & IAlala & 3 & 3 & 3 \\
\hline Scenic Highways & 3 & 3 & 3 & 3 \\
\hline Bays/Estuaries & 3 & & & \\
\hline Seashores & & & & \\
\hline
\end{tabular}

Figure IV-14.

Summary of Significance and Representation Of Scenic Themes In State Parks System.

\begin{tabular}{|lll|}
\hline & KEY & \\
3 & Prime Significance & Adequate Representation \\
2 & Moderate Significance \\
1 & Littie Significance & $\begin{array}{l}\text { Moderate Representation } \\
\text { Littie Representation } \\
\text { No Representation } \\
\text { Not Applicable }\end{array}$ \\
\hline
\end{tabular}




\section{Percent}

Scenic Highways (.17)

Meadows \& Grasslands (.27)

Gorges (.33)

White Water Streams (.33)

Waterfalls (.50)

Rivers (.50)

Pocosins (.50)

Islands (.50)

Rock Outcrops (.50)

Caves / Cliffs (.50)

Bays / Estuaries (.53)

Marshes (.58)

Scenic Vistas (.58)

Forests (.63)

Swamps (.67)

Seashores (.67)

Reservoirs / Lakes (.67)

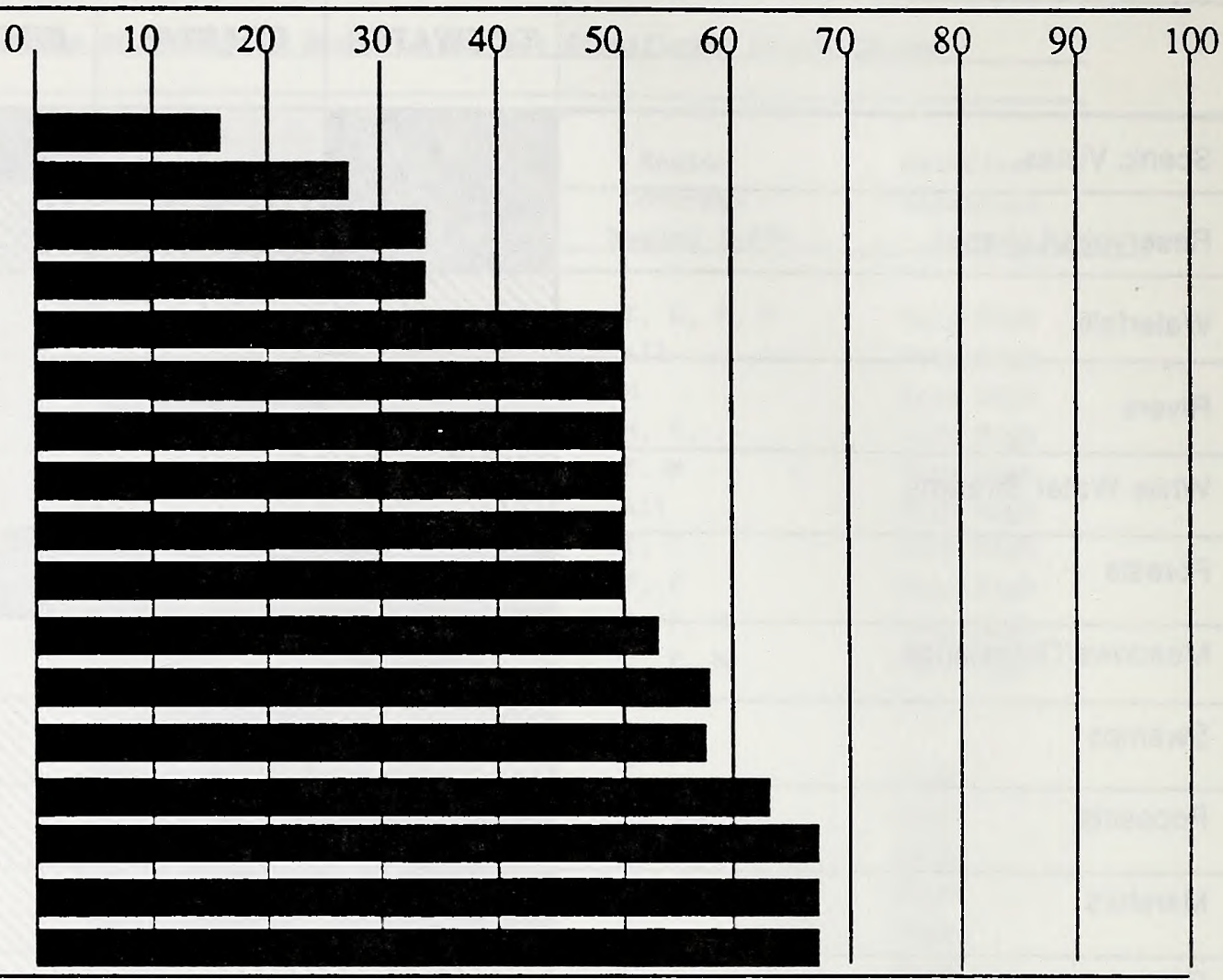

Figure IV-15. Adequacy of Scenic Theme Representation in State Parks System by Theme.

Piedmont (.42)

Coastal Plain (.51)

Mountain (.52)

Tidewater (.56)

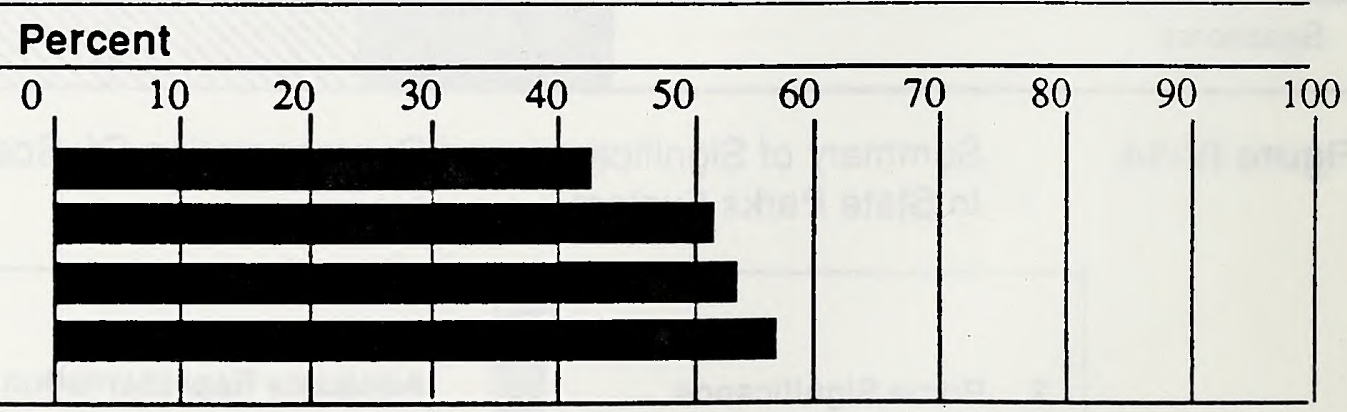

Figure IV-16. Adequacy of Scenic Theme Representation in State Parks System by Region. 


\section{STATEWIDE SIGNIFICANCE OF PARRS}

Committee rankings provide an indication of the statewide significance of parks. Units ranked at the top of the list (Hanging Rock, Pilot Mountain, Stone Mountain) provide a model of the level of significance parks should have.

The statewide significance of parks was determined through a two-step process. First, in a systematic manner, for each park unit the sum of each committee's ratings was determined (Tables IV-8 through Table IV-27). This sum for the unit was used to identify the rank order for units listed in Table IV-43. Second, this rank order information was presented to committee members who were asked to use their judgement in developing a ranking of the statewide significance of parks. Table IV-44 lists the results from this process.

In interpreting Tables IV-43 and IV-44, some considerations should be kept in mind. In determining their original ratings, committees only evaluated the acreage owned, and therefore protected, by the state. Therefore, units such as Iinville River, Horsepasture River, and white Lake would be ranked low, since little if any acreage is owned. Also, time and funding limitations prevented committees from conducting in-depth site analyses.

The statewide ranking of parks in Table IV-44 may be used as a guide in shaping the future of the system. In order to upgrade the system, new units added to the system should be of a level of statewide significance indicative of the units ranked higher in Table IV 44 .

--RECOMMENDATION IV-9: New units added to the system should be of a level of significance indicative of the highest ranked parks (Table IV-44). 


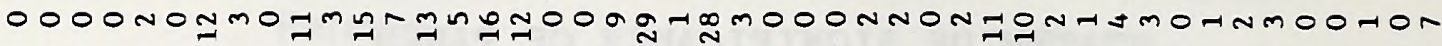

芯

芯

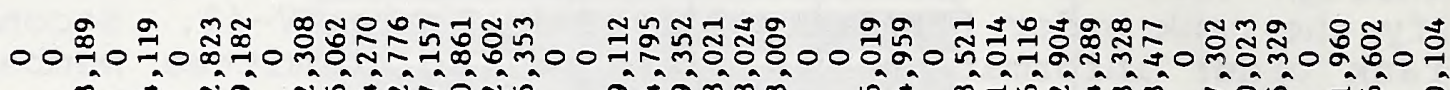

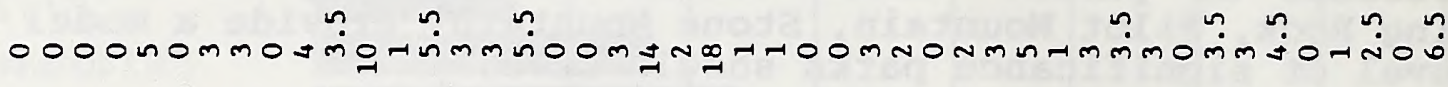

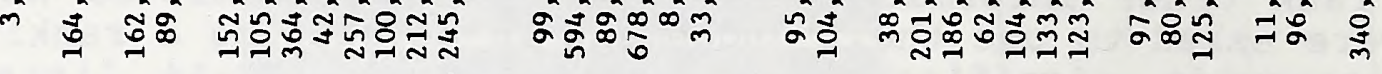

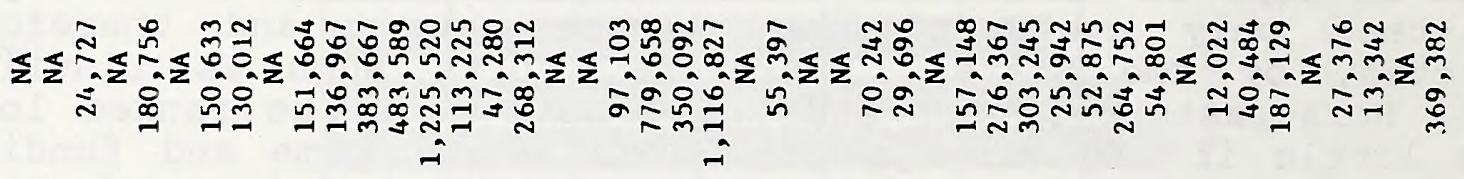

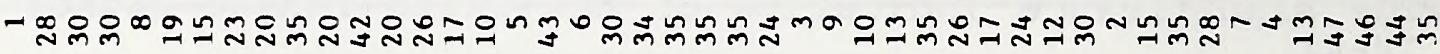

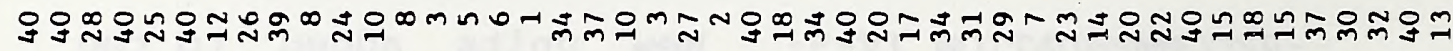

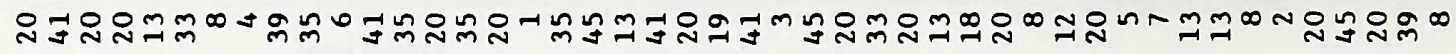

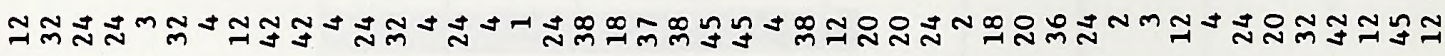

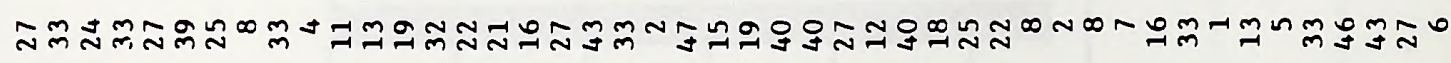


Table IV-44. Ranking of Park Units Derived from Subjective Committee Ratings.

\begin{tabular}{|c|c|c|c|c|c|c|}
\hline \multirow{2}{*}{$\begin{array}{l}\text { Park } \\
\text { Code }\end{array}$} & \multirow{2}{*}{ Park Name } & \multicolumn{5}{|c|}{ Committee } \\
\hline & & Archaeologic & Biologic & Geologic & Recreation & Scenicl \\
\hline BAIS & Baldhead Island & 11 & 8 & 17 & 39 & 4 \\
\hline BALA & Baytree Lake & 35 & 37 & 45 & 39 & 33 \\
\hline $\mathrm{BOCA}$ & Boone's Cave & 30 & 30 & 23 & 28 & 34 \\
\hline BULA & Bushy Lake & 42 & 14 & 26 & 39 & 39 \\
\hline $\mathrm{CABE}$ & Carolina Beach & 12 & 6 & 13 & 25 & 13 \\
\hline CHSW & Chowan Swamp & 25 & 32 & 35 & 39 & 22 \\
\hline CLNE & Cliffs of Neuse & 17 & 15 & 7 & 12 & 21 \\
\hline CRMO & Crowders Mountain & 4 & 20 & 6 & 26 & 18 \\
\hline DISW & Dismal Swamp & 3 & 33 & 43 & 38 & 23 \\
\hline DUPO & Duke Power & 1 & 41 & 42 & 9 & 27 \\
\hline ENRI & Eno River & 5 & 22 & 5 & 24 & 24 \\
\hline FALA & Falls Lake & 6 & 36 & 39 & 10 & 42 \\
\hline FOFI & Fort Fisher & 36 & 35 & 30 & 8 & 25 \\
\hline FOMA & Fort Macon & 41 & 26 & 27 & 3 & 29 \\
\hline GOCR & Goose Creek & 13 & 29 & 40 & 5 & 20 \\
\hline HABE & Hammocks Beach & 29 & 12 & 8 & 6 & 11 \\
\hline HARO & Hanging Rock & 20 & 4 & 1 & 1 & 5 \\
\hline HEBL & Hemlock Bluffs & 7 & 18 & 38 & 34 & 37 \\
\hline HORI & Horsepasture River & 39 & 43 & 28 & 36 & 8 \\
\hline JONE & Jones Lake & 37 & 21 & 14 & 11 & 36 \\
\hline JORD & Jordan Lake & 22 & 38 & 41 & 4 & 40 \\
\hline JORI & Jockey's Ridge & 46 & 39 & 16 & 27 & 7 \\
\hline KELA & Kerr Lake & 23 & 44 & 33 & 2 & 41 \\
\hline LAJA & Lake James & 8 & 45 & 44 & 39 & 43 \\
\hline LAWA & Lake Waccamaw & 38 & 2 & 9 & 19 & 31 \\
\hline LIRI & Linville River & 40 & 40 & 31 & 33 & 9 \\
\hline MAIS & Masonboro Island & 14 & 28 & 18 & 39 & 12 \\
\hline MEMI & Merchants Mill & 18 & 13 & 37 & 20 & 2 \\
\hline MEMO & Medoc Mountain & 26 & 31 & 29 & 17 & 16 \\
\hline MIMI & Mitchells Mill & 24 & 11 & 22 & 35 & 38 \\
\hline MOJE & Mount Jefferson & 31 & 3 & 19 & 31 & 14 \\
\hline MOMI & Mount Mitchell & 32 & 1 & 25 & 29 & 1 \\
\hline MOMO & Morrow Mountain & 9 & 27 & 12 & 7 & 28 \\
\hline NERI & New River & 33 & 34 & 21 & 23 & 15 \\
\hline PETT & Pettigrew/Phelps & 27 & 25 & 32 & 14 & 26 \\
\hline PIMO & Pilot Mountain & 10 & 5 & 2 & 21 & 6 \\
\hline RARO & Raven Rock & 16 & 17 & 10 & 22 & 19 \\
\hline SALA & Salters Lake & 43 & 19 & 4 & 39 & 44 \\
\hline SILA & Singletary Lake & 2 & 16 & 15 & 16 & 35 \\
\hline SOMO & South Mountains & 28 & 24 & 20 & 18 & 10 \\
\hline STMO & Stone Mountain & 34 & 7 & 3 & 15 & 3 \\
\hline THRO & Theodore Roosevelt & 15 & 9 & 24 & 37 & 17 \\
\hline WAYN & Waynesborough & 45 & 46 & 46 & 30 & 46 \\
\hline WEWO & Weymouth Woods & 19 & 10 & 34 & 32 & 30 \\
\hline WHLA & White Lake & 44 & 42 & 36 & 39 & 45 \\
\hline WIUM & William B. Umstead & 21 & 23 & 11 & 13 & 32 \\
\hline
\end{tabular}


Archaeologic: Five archaeologic themes have high protection needs: prehistoric village (Coastal Plain, Piedmont), prehistoric burial/cemetery (all regions), standing structure mills (Mountain), historic industrial (Piedmont, Mountain), and historic commercial (Piedmont, Mountain). The most duplicated themes include prehistoric campsite/activity areas, historic rural-k.mestic, and standing structure rural-domestic.

Biologic: Eleven biological themes are recognized as very high expansion needs. These themes include oak-hickory forests (Tidewater), non-riverine swamp forests (Coastal Plain, Tidewater, Piedmont), brown water rivers and swamps (Coastal Plain), rock outcrops (Tidewater and Mountain), grass and heath balds (Mountain), dry coniferous forests (Tidewater and Mountain), bogs-fens-seeps (Piedmont, Mountain), savannas (Tidewater, Coastal Plain), pocosins (Tidewater,) piedmont/coastal plain hardwood forests (Mountain, Tidewater), and black water river swamp forests (Tidewater, Coastal Plain). Duplications include beaches/subtidal/intertidal flats and salt-and-brackish marshes.

Geologic: Fourteen geologic themes were rated as very high expansion needs. These include: continental shelf (Tidewater), cliffs (Tidewater), volcanic features (Mountain), fossils (Tidewater, Piedmont, Coastal Plain), caves/ sinks/springs (Mountain, Coastal Plain, Piedmont), relict coastal features (Coastal Plain, Tidewater), unusual rock types (Tidewater, Mountain, Piedmont), mass wasting features (Coastal Plain, Mountain), unusual rock types (Tidewater, Mountain, Piedmont), folds and related features (Mountain, Coastal Plain), faults/joints/related features (Mountain, Coastal Plain), sedimentary features (Mountain, Piedmont), gorges/rapids/waterfalls (Coastal Plain), and fluvial depositional features (Piedmont, Mountain). Themes which are. duplicated include: barrier islands/seashores, natural lakes/ponds, carolina bays, peatlands and interstream wetlands, estuaries, and inselbergs.

Recreation: All recreation themes were rated as high or very high expansion needs. Themes rated as very high include: snow and ice activities, camping, adventure, open space, and beach activities. Fishing is the most duplicated theme.

Scenic: Ten scenic themes are recognized as very high expansion needs. These include: scenic highways (all regions), meadows/grasslands (all regions), gorges (Mountain), white water streams (Mountain, Piedmont), waterfalls (Piedmont, Mountain), rivers (all regions), pocosins (Tidewater, Coastal Plain), islands (Tidewater, Piedmont), rock outcrops (Coastal Plain, Piedmont, Mountain), and caves/cliffs (Coastal Plain, Piedmont, Mountain).

Significance of Parks: Committee rankings provide an indication of the statewide significance of parks. Units ranked at the top of the list in Table IV-44 (Hanging Rock, Pilot Mountain, Stone Mountain) provide a model of the level of significance parks should have. 


\title{
CHAPTER
}

\section{PUBIIC MEETING RESUITS}

\begin{abstract}
"The Plan sha11 be developed with full public participation, including a series of public meetings held on adequate notice under rules which shall be adopted by the Secretary. The purpose of the public meetings and other public participation shall be to obtain $f$-om the public:
\end{abstract}

(1) Views and information on the needs of the public for recreational resources in the State Parks System.

(2) Views and information on the manner in which these needs should be addressed."

-- G.S. $113-44.11 . b$

\section{INTRODUCTION}

The State Parks Act stipulates that the Division of Parks and Recreation is to develop the systemwide Plan with full public participation which includes a series of public meetings designed to collect:

1. Views and information on the needs of the public for recreational resources in the state Parks system; and

2. Views and information on the manner in which these needs should be addressed.

Recognizing the importance of meaningful public involvement in development and success of the plan, the Division sought public input in a variety of ways. Examples included ongoing review and suggestions by the Park and Recreation Council; citizen group representation on committees identifying shortfalls in protection of unique geologic, biologic, scenic, and recreational resources; ongoing communications with the most active support groups; and presentations to and discussions with various interested individuals and groups.

In addition, during the spring of 1988, seven public meetings were held to collect ideas for improving the state Parks system. These meetings, held in Asheville, Charlotte, Fayetteville, Greensboro, Greenville, Raleigh, and Wilmington, were attended by 229 people. Attendance at the meetings was promoted by mailings 
to recreation professionals, civic leaders, key contacts identified by Division consultants and district superintendents, conservation groups, university faculty, and citizens that had contacted the Division over the past six months requesting park information. Press releases, public service announcements, and notices posted in the parks were also used to promote attendance.

\section{METHODOLOGY}

Following a slide presentation which offered an overview if the existing state Park System, participants divided into small groups varying in size from five to eleven persons where suggestions were obtained using the nominal group process. The nominal group process was used so that all individuals who attended had a full opportunity to express their ideas.

Participants were asked to respond to the question, "What are your needs for recreation resources in the state Parks System?" Participants were informed that "park", as defined in the state Parks Act, means any tract of land or body of water comprising part of the States Park System including existing state parks, State natural areas, State recreation areas, state trails, State rivers, and State lakes.

At the end of each nominal group meeting, individuals were asked to review their group's entire list of suggestions and to select the three most important items, independently ranking them from three (most important) to one (third most important).

Table $V-1$ contains a summary of the 675 suggestions made at the seven meetings. Suggestions have been grouped into 15 topics and are arranged in descending order according to the scoring obtained (column 3). Scores were obtained by adding all the individual rankings of suggestions in a topic area. Weights (column 4) were obtained by dividing the sum of each topic area by the total sum of all the rankings. The weights give an indication of the importance of a particular topic to meeting participants.

For example, for the topic area "park land acquisition," the total of individual rankings was 274 . When this is divided by the total sum of all the rankings, 1935, on a scale of 1 percent to 100 percent, the importance of park land acquisition to meeting participants was 14.2 percent.

Table $\mathrm{V}-1$ also indicates the number of suggestions obtained in each topic area (column 1), the percentage of total suggestions in each topic area (column 2), and points per suggestion (column $5)$. Points per suggestion were obtained by dividing the score for each topic area by the number of suggestions for each topic area.

Such figures should only be used as a guide in determining the true meaning of the public input. Topic areas were defined by 
Division staff. There are also many areas of obvious overlap in the topic areas. For example, "more natural swimming areas" could be categorized as a recreation need or as a need for park land acquisition; "access to nature" could be categorized as natural resource protection, park land acquisition, or as a recreation need. Finally, 229 people may not represent an adequate sampling of the total state population. However, these results do reveal a "snapshot" of what North Carolinians expect their state Parks system to be.

\title{
ANALYSIS
}

\section{Increase Funding for Parks}

\author{
"Raise the priority of the State Parks System \\ funding in the minds of the state Legisla- \\ ture."
}

- Greenville Resident

Inadequate funding ranked as the number one concern of meeting participants, when judged by score or weight and points per suggestion. As most of the other topic areas are dependent upon funding, additional funding for the state Parks system becomes even more important. Funding suggestions were also mentioned 64 times, the third highest number of times for a topic area.

In addition to general calls for increased funding, many suggestions for alternative funding sources were also received. For a brief listing of typical suggestions for funding and other topic areas, refer to Table $\mathrm{V}-2$ at the end of this chapter.

--RECOMMENDATION V-1: Funding for the State Parks System should be increased. This should include an increase in appropriations and use of alternative funding sources.

\section{Expand Recreational Opportunities}

\author{
"Develop and maintain areas in a quality manner \\ for recreation purposes as well as preservation." \\ - Asheville Resident
}

Recreation was the second most important topic area when judged by score and weight, and it was the topic area which received the greatest number of suggestions. The 167 suggestions received were almost twice the number received supporting park land acquisition, the next largest topic area in terms of number of suggestions. It becomes clear that meeting participants desire additional development of recreational facilities in the state Park System. 
Interestingly, when ranked according to points per suggestion, recreation fell below twelve other topic areas. While meeting participants strongly desired additional recreation, suggestions from many other topic areas were judged to be more important.

Funding, for example, accounted for 9.5 percent of the suggestions made, and 16.8 percent of the total points. Recreation, by contrast, accounted for almost 25 percent of the total suggestions and 16 percent of the total points.

--RECOMmENDATION V-2: The State Parks System should provide more recreational opportunities.

\section{Increase Park Acreage}

"We need more acreage in the state Parks system in existing and new parks."

\section{- Greensboro Resident}

Park land acquisition is the third ranking topic area shown on Table V-1. Suggestions typically included finishing existing parks, eliminating inholdings, expanding existing parks, creating new parks, and additional access to the ocean, rivers, and lakes. Thirteen percent of suggestions made and 14.2 percent of the total points fell into the topic area. Points per suggestion for this topic area is slightly above average.

--RECOMMENDATION V-3: Land acquisition is needed to protect existing parks and expand the State Parks System in order to adequately protect the State's natural heritage.

\section{Increase Staffing}

"Increase State Park staff, especially for maintenance, clerical, rangers, and naturalists."

- Fayetteville Resident

The fourth ranking topic area, personnel, received 10.5 percent of the total points and 8.6 percent of all suggestions. The majority of comments in this topic area dealt with the need for additional personnel. Some of the suggestions were general in nature, such as "more staff", while others were more specific, such as requesting additional staff for interpretation or maintenance. Other personnel related comments dealt with better pay for rangers and other staff, career growth, housing, and ranger duties.

--RECOMMENDATION V-4: Staff should be increased at existing parks. Greater support (e.g., salary increase, improved housing, career growth) for staff should be provided. 
Table V-1. Public Meeting Results: Topic Areas and Scoring.

\begin{tabular}{|c|c|c|c|c|c|c|}
\hline & $\begin{array}{r}\text { Numb } \\
\text { Sugge } \\
\end{array}$ & $\begin{array}{l}\text { ber of } \\
\text { estions } \\
\end{array}$ & $\begin{array}{l}\% \text { of Total } \\
\text { Suggestions }\end{array}$ & $\begin{array}{l}\text { Score: } \\
\text { Number of } \\
\text { Points }\end{array}$ & $\begin{array}{l}\text { Weight: } \\
\% \text { of Total } \\
\text { Points }\end{array}$ & $\begin{array}{l}\text { Points Per } \\
\text { Suggestion } \\
\end{array}$ \\
\hline \multirow[t]{3}{*}{ I. } & FUNDING & 64 & 9.5 & 325 & 16.8 & 5.1 \\
\hline & General & 27 & 4.0 & 171 & 8.8 & 6.3 \\
\hline & Alternative Funding & 37 & 5.5 & 154 & 8.0 & 4.2 \\
\hline \multirow[t]{10}{*}{ II. } & RECREATION & 167 & 24.7 & 309 & 16.0 & 1.9 \\
\hline & Trails & 38 & 5.6 & 78 & 4.0 & 2.1 \\
\hline & Camping & 37 & 5.5 & 81 & 4.2 & 2.2 \\
\hline & Accommodations & 14 & 2.1 & 21 & 1.1 & 1.5 \\
\hline & Support Facilities & 10 & 1.5 & 12 & .6 & 1.2 \\
\hline & Picnic & 7 & 1.0 & 9 & .5 & 1.3 \\
\hline & Swimming & 4 & .6 & 4 & .2 & 1.0 \\
\hline & Boating/Fishing & 13 & 1.9 & 17 & .9 & 1.3 \\
\hline & Sports \& Playfields & 10 & 1.5 & 11 & .6 & 1.1 \\
\hline & Other & 34 & 5.0 & 76 & 3.9 & 2.2 \\
\hline \multirow[t]{7}{*}{ III. } & PARK LAND & 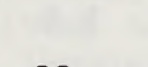 & & & & \\
\hline & ACQUISITION & 88 & 13.0 & 274 & 14.2 & 3.1 \\
\hline & Finish Existing Units & 18 & 2.7 & 51 & 2.6 & 2.8 \\
\hline & More Park Land & 49 & 7.3 & 186 & 9.6 & 3.8 \\
\hline & Access to Public & & & & & \\
\hline & Waters & 15 & 2.2 & 28 & 1.4 & 1.9 \\
\hline & Other & 6 & .9 & 9 & .5 & 1.5 \\
\hline \multirow[t]{3}{*}{ IV. } & PERSONNEL & 58 & 8.6 & 203 & 10.5 & 3.5 \\
\hline & Increase Staffing & 41 & 6.1 & 147 & 7.6 & 3.6 \\
\hline & Other & 17 & 2.5 & 56 & 2.9 & 3.3 \\
\hline \multirow[t]{2}{*}{ v. } & NATURAL RESOURCE & & & & & \\
\hline & PROTECTION & 41 & 6.1 & 165 & 8.5 & 4.0 \\
\hline \multirow[t]{4}{*}{ VI. } & INFORMATION/AWARENESS & 45 & 6.7 & 130 & 6.7 & 2.9 \\
\hline & Public Information & 14 & 2.1 & 30 & 1.6 & 2.1 \\
\hline & Market/Promote & 27 & 4.0 & 87 & 4.5 & 3.2 \\
\hline & Other & 4 & .6 & 13 & .7 & 3.3 \\
\hline VII. & $\begin{array}{l}\text { INTERPRETATION/ } \\
\text { EDUCATION }\end{array}$ & 52 & 7.7 & 123 & 6.4 & 2.4 \\
\hline
\end{tabular}


Table V-1. Public Meeting Results: Topic Areas and Scoring. (Continued)

\begin{tabular}{|c|c|c|c|c|c|c|}
\hline & $\begin{array}{r}\text { Number } \\
\text { Suggest }\end{array}$ & $\begin{array}{l}\text { r of } \\
\text { tions }\end{array}$ & $\begin{array}{l}\% \text { of Total } \\
\text { Suggestions } \\
\end{array}$ & $\begin{array}{l}\text { Score: } \\
\text { Number of } \\
\text { Points }\end{array}$ & $\begin{array}{l}\text { Weight: } \\
\% \text { of Total } \\
\text { Points } \\
\end{array}$ & $\begin{array}{l}\text { Points Per } \\
\text { Suggestion }\end{array}$ \\
\hline VIII. & $\begin{array}{l}\text { MAINTENANCE/REPAIR } \\
\text { RENOVATION }\end{array}$ & 27 & 4.0 & 118 & 6.1 & 4.4 \\
\hline IX. & POLICY CONSIDERATIONS & 23 & 3.4 & 78 & 4.0 & 3.4 \\
\hline $\mathrm{x}$. & PLAANNING & 23 & 3.4 & 48 & 2.5 & 2.1 \\
\hline XI. & $\begin{array}{l}\text { INTERRGOVERNMENTAL/ } \\
\text { INTERAGENCY }\end{array}$ & 23 & 3.4 & 45 & 2.3 & 2.0 \\
\hline XII. & $\begin{array}{l}\text { ADMINISTRATION/ } \\
\text { MANAGEMENT }\end{array}$ & 25 & 3.7 & 41 & 2.1 & 1.6 \\
\hline XIII. & $\begin{array}{l}\text { HANDICAPPED } \\
\text { ACCESSIBILITY }\end{array}$ & 13 & 1.9 & 31 & 1.6 & 2.4 \\
\hline XIV. & VOLUNTTEER SERVICES & 15 & 2.2 & 30 & 1.6 & 2.0 \\
\hline xv. & SAFETY & 9 & 1.3 & 13 & .7 & 1.4 \\
\hline XVI. & MISCEILLANEOUS & 2 & .3 & 2 & .1 & 1.0 \\
\hline TOTAL & S/AVERAGE & 675 & 100.0 & 1935 & 100.0 & 2.87 \\
\hline
\end{tabular}


The second, third, and fourth ranking topic areas--recreation, park land acquisition, and personnel--all relate to funding, the top ranking concern of public meeting participants. Additional park development, land acquisition, and staffing cannot take place without increased funding. Many of the other topic areas also relate to increased funding. Meeting participants realized this tie between funding and many of the suggestions, and this helps explain why calls for general funding increases averaged 6.3 points per suggestion, significantly higher than any other suggestion grouping.

\section{Natural Resource Protection}

"Protect our unique natural resources for present and future generations."

\section{- Wilmington Resident}

Natural resource protection, the fifth ranking topic area according to score and weight, received 8.5 percent of the total points. While natural resource protection suggestions were not received as frequently as six other topic areas, the suggestions which were received were judged by meeting participants to be relatively more important than most of the other topic areas. The four points per suggestion received reflect this concern of meeting participants. Suggestions such as "Protect our unique natural resources for present and future generations", "Insure protection of parks' natural features", and "Preserve our state's natural habitat" were judged to be particularly important.

Most of the suggestions grouped in the natural resource protection category were general in nature, like the illustrations above. It should be noted that approximately one-quarter of the natural resource protection suggestions emphasized natural resource protection as opposed to recreational development in the state parks. "Keep parks as undisturbed, natural settings with a minimum of development" was one such suggestion.

--RECOMMENDATION V-5: Valuable natural resources in parks must be protected. Natural resources within parks should be maintained in a high quality condition. 


\title{
Increase Information/Awareness
}

"Increase public awareness of State Parks through local programs, brochures, maps, and visitor center information."

- Asheville Resident

Topic area VI, Information/Awareness, focuses on marketing and promoting the state Park system to the public and to the General Assembly. This topic area also includes calls for an increase in brochures and maps. Information/Awareness received 6.7 percent of both the suggestions made and the total points. The 2.9 points per suggestion roughly equaled the median for all suggestions.

--RECOMMENDATION V-6: State leaders and the public should be made aware concerning the condition and needs of the State Parks System.

\section{Interpretation and Education}

\author{
"Every State Park should be an environmental \\ education center for adults, children, and \\ all ages." \\ - Raleigh Resident
}

Interpretation/Education ranked as the seventh most important topic in terms of score and weight, receiving 6.4 percent of the total points. The 52 suggestions received in this topic area actualiy exceeded the number received for the topic areas Information/Awareness and Natural Resource Protection, but participants judged the category to be relatively less important.

It should be noted that this category has a strong tie with the personnel category, for interpretive programs often depend upon staff. grams should be expanded. 


\section{Improve Maintenance}

"We need improved maintenance of existing facilities."

- Charlotte Resident

Maintenance/Repair/Renovation, topic area VIII, was the remaini'g topic area which received over 5 percent of the total points. While this category ranked eighth both in scoring and number of suggestions, it surprisingly ranked second in points per suggestion. Meeting participants did not often mention maintenance, repair, or renovation needs, but when suggestions were made, participants ranked them high in importance. Comments in this category tended to be general in nature, such as: "facility improvements; well-maintained, well-managed parks; better maintained parks and facilities; upgrade facilities; adequate funding for maintenance and repair; renovate, repair, and maintain recreation facilities"; and "improve maintenance".

--RECOMMENDATION V-8: Park resources must be better maintained.

\section{Other Topics}

Policy Considerations, topic area XIV, deals with suggestions covering areas like where parks should be located, who manages property, night operation, senior citizen discounts, park system composition and emphasis, and development versus preservation.

Topic areas $X$ through $X V$ received 2.5 percent or less of the total points. The low scoring does not mean that these topic areas are not important, just that their importance, relative to the other categories previously discussed, was less. Handicapped accessibility, the use of volunteers, intergovernmental cooperation, planning, and administrative/management considerations are crucial components of a fully developed state park system. Refer to Figure $V-2$ for a sampling of suggestions received in the various topic areas.

\section{CHAPTER SUMMARY CONCLUSIONS}

During the seven public input meetings, the citizens of North Carolina expressed a strong interest in and concern with their State Park System. While the suggestions offered were many and varied, the chief concern of the public is that the state Park system needs additional funding. The areas identified as most in need of additional funding were recreational development, park land acquisition, additional personnel, natural resource protection, public information and awareness, interpretation and education, and maintenance, repair, and renovation of the parks and their recreational facilities. 
Participants at the public meetings often asked why other states have better state parks and how North Carolina's state Parks have fallen so far behind. It became obvious from nominal group discussions and post meeting comments that citizens desire and expect an expanded and upgraded State Parks System. 
Table V-2. Suggestions Made at Public Meetings: Sample Comments by Topic Area.

FUNDING:

General - Sufficient funds to upgrade and maintain; increase per capita funding to southeast average; recognize funding needs; more legislative support; higher legislative priority; more money; increase budget; more development money; and more money for maintenance and staffing.

Alternative - Bond issue; user fees; no user fees; sales tax; income tax checkoff; private sector gifts; trust fund for acquisition and maintenance; develop alternative funding sources; return fees to parks; and land transfer tax.

\section{RECREATION :}

Trails - Provide well-marked trails; well maintained; back country trails; regional trail system; trail networks; more hiking trails; more water fountains along trails; trails of varied lengths; bicycle trails; improve existing trails; expand trail system; complete Mountain-to-sea trail; interpretive trails; well-marked, mapped, and maintained trails; more water trails; and more canoe trails.

Camping - More camping areas; full service campgrounds; group camp in the west; better reservation system; separate RVs from tents; need well-maintained campgrounds; additional camping at specific parks; well-designed campgrounds; campgrounds sensitive to resource; remote camping areas; wilderness camping; more and better campground amenities; and RV campgrounds.

Accommodations - More cabins; restaurants and cabins; rustic cabins; lodges in selected parks; and youth hostels.

Support Facilities - More and better restrooms and bathhouses; water fountains; clean restrooms; hot showers; and more concessions.

Picnic - Better picnic areas; more picnic areas; more picnic shelters; picnicking near parking; improved picnic areas.

Swimming - Swimming beaches near population; more natural swimming areas; improved swimming areas; and more supervised swimming. 
Table V-2. Suggestions Made at Public Meetings: Sample Comments by Topic Area. (Continued)

Boating/Fishing - Canoe rentals; sailboat rentals; boat rentals; increase canoeing opportunities; more boating and fishing opportunities; more ponds with fish; stocked areas; and sell fishing licenses.

Sports and Playfields - Play areas for children; active areas for recreation; playgrounds near campgrounds; ballfields; and active play equipment.

Other - Develop areas in quality manner for recreation; facilities for school groups; wider variety of facilities; family recreation; day use areas; opportunity to botanize; more programs at rivers and lakes; water opportunities; more equipment rental; more recreation events; senior citizen opportunities; teenage activities; large aquarium; more zoos; rock climbing; cross-country skiing; and hunting in parks.

\section{PARR LAND ACQUISITION:}

Finish Existing Units - Complete land acquisition according to master plans; complete parks; complete New River; complete Mountains-to-sea trail; more land at Mount Mitchell; acquire inholdings; and acquire buffer areas.

More Park Land - More land; more wilderness areas; acquire "rails-to-trails" areas; larger park areas; more parks; identify and acquire unique historical and cultural areas; land acquisition in Charlotte area, in Cape Fear/Fayetteville area, in the west, near urban areas, at Roan Mountain, at Catawba Falls, in the Piedmont, along the Mayo River, near Greenville, at Outer Banks; more water-based parks; establish more river parks; more natural rivers; more coastal parks; more natural areas; acquire wetlands; acquire land for greenways; establish historical and small farm parks.

Access to Public Waters - Aggressively push rivers program; increase canoeing opportunities through new river parks; develop and expand Natural and Scenic Rivers system; more canoeing access on lakes and rivers; additional access to pubiic waters; estuarine access; more beach parks and parking; public beach access areas; fishing and canoeing access. 
Table V-2. Suggestions Made at Public Meetings: Sample Comments by Topic Area. (Continued)

PERSONNEL :

Increase staffing - Hire more maintenance staff; more professional staff; more supervisory staff; add staff; need properly staffed parks; add personnel to increase safety and visitor access to information; more staff; more interpretive staff; more staff for naturalist activities; more rangers; more naturalists; more staff at Kerr Lake; more operations personnel; clerk in each park; and more personnel for more programs.

Other - Better pay for rangers; establish a competitive pay scale; upgrade salaries to southeast average; encourage promotion from within; more emphasis on ranger duties versus janitorial; and housing or housing allotment for all rangers.

NATURAL RESOURCE PROTECTION:

Protect our natural resources for present and future generations; insure protection of parks' natural features; preserve state's natural habitat; protect scenic quality and resource; acquire buffers; emphasize natural resource protection; more floodplain/watershed control; improve protection of fragile biological communities; need sedimentation/erosion control measures; protection and management of rare plants and natural communities; keep parks natural with minimum development; emphasis on preservation versus tourism; minimize human impact; controlled access to natural areas; and rehabilitate natural areas.

\section{INFORMATION/AWARENESS :}

Market/Promote - Need citizen participation with General Assembly for State Parks; increase awareness of legislature regarding state Park needs and importance; educate public and legislature with an aggressive media campaign; better marketing of parks; market opportunities to promote awareness; educate public on needs, uses, values of state Parks; develop a marketing plan; increase visibility; promote system better; better and more promotion of parks; and increase media coverage.

Public Information - More and better brochures; need information on Mountains-to-Sea Trail; more and better park maps; better location maps; brochures and maps for all parks; more and better printed material; and need high quality publications. 
Table V-2. Suggestions Made at Public Meetings: Sample Comments by Topic Area. (Continued)

\section{INTERPRETATION/EDUCATION :}

More nature centers; increased interpretation/education opportunities; provide environmental educat: on centers; more rangers for interpretation and education; $p$ :ograms for kids and schools; nature programs for schools; more printed educational material; mark nature trails and more interpretive signs; more led nature hikes; stress interpretation; more summer naturalists; give interpretation priority with rangers; more museums and guided tours; expand environmental education programs with schools; expand interpretive programs; additional interpretive staff; and need environmental education materials and facilities.

\section{MAINTENANCE/REPAIR/RENOVATION :}

Facility improvements; need well-maintained and managed parks; need upkeep on existing facilities; better maintained parks and facilities; more maintenance workers; more equipment for maintenance; need trail repair; update facilities (sewage, water, restrooms); upgrade and maintain facilities; improved trail maintenance; adequate funding for maintenance; renovate and repair existing facilities; upgrade existing park and recreation areas; and increase overall maintenance.

\section{POLICY CONSIDERATIONS:}

Insure a State Park within one hour's drive of every citizen; retain management of all Division lands; provide access to parks after dark; senior citizen discounts; maintain a variety of parks, recreation areas, natural areas, trails, rivers; inciude natural areas, recreational opportunities, and resort parks; emphasis on low impact recreation; separate recreation areas from State Parks; develop a dual system (parks/nature and recreation areas); recreational development should keep parks as natural as possible; resort parks should not be a part of the system; develop resort parks; reassess preservation philosophical perspective; and upgrade and market system as a tourist attraction.

\section{PLANNING:}

Locate parks for short travel times; careful planning and design to leave parks natural; more comprehensive system design; implement the state Parks Act; leave some park lands undeveloped; develop parks to provide natural areas and 
Table V-2. Suggestions Made at Public Meetings: Sample Comments by Topic Area. (Continued)

PLANNING: (Continued)

developed areas; more opportunities for citizen input; more public meetings and dialogue; respond to public meetings; update park plans; stronger central office for planning and administration; adequate planning staff; and on-site planning for all facilities.

\section{INTERGOVERNMENTAL/INTERAGENCY :}

Publicize Recreation Resources' Consulting Services; encourage local governments to provide greenways; give smaller towns funds for parks; coordinate public information about needs for natural preservation with other agencies and individuals; coordinate park support groups; connect urban trails to Mountains-to-Sea Trail; use Raleigh and wake County assistance at Umstead; consider partnerships with local governments; develop public/private partnerships; improve interagency cooperation; coordinate with local park and recreation facilities to avoid duplication; increase intergovernmental cooperation; and more state and local government cooperative agreements.

\section{ADMINISTRATION/MANAGEMENT :}

Need process for rails-to-trails initiatives; take leadership role with rails to trails; evaluate community Service Program in parks; thoroughly investigate major decisions; consistent line of authority; written criteria for land acquisition priority; spend park funds efficiently; monitor overuse; regulate crowds; better enforcement of coastal management plans; provide more equipment and support for field; manage parks correctly or close parks; restock wildife; and identify and mark boundaries.

\section{HANDICAPPED:}

Include handicapped accessibility information in mainstream park publications; more handicapped access; accessibility for physically impaired to natural environments and facilities; improve handicapped accessibility; handicapped involvement in planning process; better and more facilities for seniors and handicapped; and upgrade handicapped facilities. 
Table V-2. Suggestions Made at Public Meetings: Sample Comments by Topic Area. (Continued)

\section{VOLUNTEER SERVICES:}

Better utilize volunteers; need active involvement and support of volunteer groups; encourage volunteer/student workers to improve parks; separate volunteers from Community Service workers; more volunteer programs; establish a volunteer campground host program; establish special outings for volunteer groups to work; identify support groups and develop volunteer program; and emphasize use of volunteers for trail support and development.

\section{SAFETY :}

All parks should be safe for public use; stiffer fines for violations of park rules; enforce park regulations; more frequent safety patrols; proper signs and railing at Hanging Rock; need to feel safe (more rangers and increased visibility); and secure bicycle parking. 


\section{CHAPTER VI}

\section{BENEEITS AND VAIUES \\ OF THE STATE PARKS SYSTEM}

\section{INIRODUCTION}

The North Carolina state Parks system is composed of fifty three units which include state parks, state natural areas, state recreation areas, state rivers, State trails, and state lakes. The benefits which the system offers include natural resource preservation, public outdoor recreation opportunities, social benefits, and economic benefits from visitor expenditures.

\section{PRESERVING AND PROTECTING NATURAL RESOURCES}

The tendency nowadays to wander in wilderness is delightful to see. Thousands of tired, nerve-shaken, over civilized people are beginning to find out that going to the mountains is going home; that wilderness is a necessity; and that parks and reservations are useful not only as fountains of timber and irrigating rivers, but as fountains of life.

- John Muir

In the general elections held November 7, 1972, the citizens of North Carolina - by a more than six-to-one margin - approved a constitutional amendment to conserve and protect North Carolina's natural resources. The amendment declares that:

It shall be the policy of this state to conserve and protect its lands and waters for the benefit of all its citizenry, and to this end it shall be a proper function of the state of North Carolina and its political subdivisions to acquire and preserve park, recreational, and scenic areas, to control and limit the pollution of our air and water, to control excessive noise, and in every other appropriate way to preserve as a part of the common heritage of this state its forests, wetlands, estuaries, beaches, historical sites, openlands, and places of beauty.

- Article 14, Section 5 N.C. Constitution

The State Parks System plays an important role in attempting to carry out this strong mandate by seeking to preserve and protect unique natural resources of statewide significance. The parks, recreation areas, natural areas, rivers, lakes, and trails comprising the state Parks system contain outstanding examples of biological, geological, cultural, scenic and recreational resources. Many of the resources protected by inclusion in the system would have been destroyed or permanently altered if not protected by the state Parks system. 
The outdoors, which is often taken for granted, may ultimately depend on our actions for its continued vitality. At one time North Carolina consisted of small islands of civilization surrounded by wilderness. Now, however, the reverse is becoming increasingly common as islands of natural areas are often found surrounded by a sea of development. In the face of such change, the preservation and protection of natural resources is becoming increasingly important and contentious.

Preservation of the various natural areas under the State Parks System contributes to species preservation by providing habitats. Preservation helps to prevent erosion of topsoil and depletion of forests, it preserves rare and endangered plant and animal species, it protects scenic vistas, and it helps protect water quality. The state Parks system is an investment in natural systems.

While protection and preservation of natural resources is an obvious benefit of the state Parks system, unfortunately no satisfactory system exists for assigning a monetary value to such natural resource preservation. Because the value of natural areas is difficult to calculate, and because their value doesn't fit into the normal development formula that maximizes return on investment, natural areas are often lost or altered. Open space is lost, wetlands are altered, river corridors are developed, pollution threatens, scenic areas are developed, and wildlife habitat diminishes.

Establishment of units within the State Parks System recognizes that some areas are priceless and that their preservation is necessary. It also ensures that these areas will be available for present and future generations to enjoy.

It is difficult to put a dollar value on the areas acquired as State park units, but can there be any doubt that the $\$ 38$ million of State funds appropriated for state park land acquisition over the past 74 years has been money well spent? The $\$ 38$ million investment works out to approximately $\$ 6.00$ for each current citizen of the state, less than the cost of one night's dinner. 


\section{RECREATIONAL BENEFITS AND VALUES}

The fundamental truth that recreation is essential to the cultural, moral, physical, and spiritual well being of our people has been reaffirmed... The challenge to use leisure time effectively and constructively demands full development of our national, state, and local recreational resources.

- John F. Kennedy

The North Carolina State Parks System and its diverse units offer a setting from which a wide variety of recreational uses take place. Picnicking, hiking, jogging, nature study, sightseeing, family and group camping, fishing, sailing, boating, swimming, bird watching, and canoeing are some of the many activities in which people participate.

The opportunity to participate in such recreation pursuits in settings of outstanding natural beauty obviously appeals to citizens and visitors of the state. In 1987 total annual attendance reached an all time high of $7.5 \mathrm{million}$.

People want to pursue outdoor recreation in pleasant surroundings. The President's Commission on Americans Outdoors found that natural beauty is the most important criteria which people use in choosing park and recreation areas, followed by the amount of crowding. The state Parks system attempts to offer scenic, uncrowded settings. The President's commission also found that built amenities such as developed picnic areas, restrooms, and parking are also important criteria people use to choose favorite recreation places. While not all of the units of the state Parks system offer these built amenities, many units are so equipped, and plans call for additional development at other units of the system if capital development funds are received.

In its 74 year existence, the state Parks system has received approximately $\$ 28.2$ million in state funds for capital improvement projects. Such projects have included roads, parking, picnicking, visitor centers, restrooms, trails, boat ramps, camping areas and other development which has allowed increased recreational use of system units. Per capita, this investment comes to approximately $\$ 4.40$, about what it would cost one person to attend a movie.

The benefit of recreational use of the State Parks system is hard to calculate. Recreation is a basic necessity of life, and the promotion of recreation is a component of general welfare specified in the United States constitutional right to "the pursuit of happiness." No doubt most state park visitors are there for leisure time enjoyment and their own pursuit of happiness. 
Such pursuit of happiness may take the form of relaxation, of feeling a part of nature, of feeling awe or appreciation of beauty, of seeking challenge or achievement, of seeking escape, of finding time for the family, or of just being alone.

The recreational benefits are many, and their value is high. Unfortunately, no adequate dollar measure can be obtained for the value of recreational experiences which the state Parks system affords. As high as such a dollar value might be, the real value of the system is its vitality and the way it enhances lives. When families learn to appreciate one another on a camping trip, when a person enjoys a solitary walk along a beach, or when someone escapes from the daily grind of pressure and stress and finds relaxation, how can a price be placed on such an experience? And as the state loses undeveloped beachfronts, natural and scenic river corridors, and forests and wetlands, the value of such recreational experiences - while still difficult to calculate - only increases. The value of intimate contact with nature, of enhancement of appreciation for beauty, and of having fun in a beautiful setting cannot be measured in dollars or on any yardstick yet devised. To know these values is to experience them.

\section{SOCIAL BENEFITS AND VAIUES}

Clearly the problem of man and nature is not one of providing a decorative background for human play, or even ameliorating the grim city. It is the necessity of sustaining nature as a source of life, milieu, teacher, sanctum, challenge and most of all, of rediscovering nature's corollary of the unknown in the self, the source of meaning.

- from Design with Nature by Ian McHarg

The President's Commission on Americans Outdoors reports that health is the primary reason American adults say they engage in outdoor recreation. Exercise has been shown to reduce health costs. The Public Health Service's 1986 report, "Annual Review of Public Health", cites 43 studies finding positive links between regular physical activity and the prevention of heart disease. Various clinical studies have also demonstrated that physical fitness activities are effective in controlling depression, anxiety, and other psychiatric ailments.

Stress relief is also important to good health. Stress has been shown to be a forerunner of many illnesses, including cancer and cardiovascular disease. A frequently expressed motivation in outdoor recreation is the chance to get away, to relax, to find a change of pace and routine. The state Parks system provides settings which are often in sharp contrast to everyday life. These settings are often more open, quieter, less demanding, and more natural. They allow time for personal reflection, stimulate 
introspection, and allow personal control instead of being continually confronted with demands or needs to respond to others. By providing settings for exercise and for relaxation, the State Parks system contributes to the physical and mental health of its users.

The poet Robert Frost no doubt experienced the rejuvenating effect of the outdoors when he wrote:

The way a crow

Shook down on me

The dust of snow

From a Hemlock tree

Has given my heart

A change of mood

And saved some part

of a day I had rued.

- from "Dust of Snow" by Robert Frost

The State Parks System also provides settings which can help people accomplish personal goals such as better physical fitness, more time with the family or friends, increased knowledge and appreciation of nature and beauty, and learning to swim. State park settings also allow for positive contact with government.

Another benefit of the State Parks System is the learning environment it provides. The interpretive programs which the Division offers serve as a bridge to conservation and environmental awareness. Teaching people about the outdoors is a solid long term investment in the future quality of our natural environment and the health of our citizens. Outdoor education will help to create an active and informed citizenry which can then be more effective at preserving environmental quality and protecting natural resources, resulting in reduced costs of problems such as litter, stream pollution, vandalism, and illness.

The State Parks System benefits society by providing settings and activities for positive uses of leisure time. There is much evidence that society faces many problems such as drugs, poverty, poor physical fitness, and family instability. The state Parks System offers safe, available, and affordable places to roam, explore, play together, and learn. Parks afford opportunities for families, groups, and individuals to enjoy varied recreation pursuits in natural settings.

Families comprise the bulk of State Parks System visitation. A recent survey of state park visitors found that 64 percent of visitors were in family groups, 5 percent in multiple family groups, and 10 percent with family and friends, for a total family oriented visitation of over 79 percent.

The State Parks System also provides enrichment to our culture. 
The outdoors has long been recognized fof stimulating creative expression. Poetry, photography, novels, essays, symphonies and paintings often result from artists' desires to portray what they feel as well as what they see. Inspiration for much of our culture has come from the outdoors. The beauty and majesty of the State Parks system offer settings which enhance "...pride and inspirttion..." in the State of North Carolina.

\section{ECONOMIC CONTRIBUTIONS OF THE STATE PARKS SYSTEM}

\section{Introduction}

The value of the state Parks system is often only considered in terms of its contributions to preserving and protecting unique natural resources while providing recreational opportunities for North Carolina citizens and visitors to the state. The system does protect natural resources, and it does provide many social benefits such as settings for positive use of leisure time, for physical fitness and mental health, for family and group activities, and for environmental education. Although the provision of state parks and recreation areas is considered important in providing such social payoffs, all too often the state Parks system is thought of as a loss in economic terms, a write-off from productive use, and a locking-up of land that could otherwise be productive.

Nothing could be further from the truth. The state Parks system makes a real contribution to the state and local economies in terms of income, jobs, tax revenues, and expenditures.

The park system's economic impact, because of its diversity and fragmentation, is not easily measured. Many businesses that serve the park user-whether a traveler, tourist, or a local resident - are affected by people using parks. Such businesses include hotels, motels, campgrounds and other lodging facilities; airlines, buslines, and railroads; restaurants, gift shops, and service stations; amusement, golf courses, and other recreation facilities; and a host of other businesses. Since most of these businesses also serve local area residents, the impact of spending by park users can easily be overlooked or under estimated. 


\section{Public Area Recreation Visitors Survey}

In order to obtain the data needed to develop credible and comparable estimates of the economic impact of the State Parks System, a Public Area Recreation Visitors Survey (PARVS) was undertaken. The survey, conducted under contract with the Southeastern Forest Experiment Station of the U.S. Forest Service, permitted development of detailed information about recreational fatterns in North Carolina state park units. It also provides estimates of the direct monetary value derived from public area users.

The PARVS study, based upon on-site surveys conducted and mailback questionnaires received in 1986 and 1987, represented the Division's first attempt to study the economic impact of State park visitor expenditures on the North Carolina economy. The study collected expenditure, activity, travel, and demographic information from randomly selected visitors at eight representative park units of the State Parks System.

The PARVS produced some interesting information. For example, $85.6 \%$ of groups surveyed by the PARVS indicated that the park area they were visiting was their sole destination for their trip, and $78 \%$ of the groups were return visitors. Out-of-state visitors traveled an average of 8.09 hours to reach the park, while in-state visitors took 2.15 hours. Approximately three quarters of visitation originated in-state, and one quarter came from out-of-state. The state Park units were obviously a major draw for these travelers, as $93 \%$ of these groups indicated that they started from home.

In order to determine the economic effect of visitation to state parks, information collected by the PARVS was subsequently analyzed using the IMPLAN model.

\section{IMPLAN Model}

The IMPLAN-PARVS data combination is the most credible system currently available for analyzing the economic interdependence and impact of outdoor recreation. The computer based economic impact model IMPLAN was developed by the U.S. Forest Service to assist in its land management planning efforts.

From the IMPLAN analysis, a snapshot of the economic impact of recreational expenditures associated with the state Parks System can be obtained. Economic impact mostly concerns the distribution of spending and production that results as a by product of recreation visits. It is the magnitude of gains or losses which occur among industries within an area where a recreation site is located that results from a change in recreation visitation. 
The IMPLAN model examines the direct, indirect, and induced effects of such recreation spending. "Direct effects" are simply the value of the increased purchase of inputs used to manufacture or produce the final goods and services purchased by State Park visitors and State Parks System. "Indirect effects" refer to the value of the inputs used by additional firms which are called upon to produce goods and services for those firms first impacted directly by consumer spending. "Induced effects" are caused by or result from the direct and indirect effects of recreation spending. Induced effects are the flows of income to persons and businesses who may neither directly or indirectly be involved in the sale of recreation products and services, but who receive income as a result of local spending by employees and managers of the firms and plants which were impacted by direct and indirect effects.

The total economic impact of expenditures related to recreational visits is the sum of direct, indirect, and induced effects. Typicaliy, the total effects are between one half to two times more than the amount which the recreationists originally spent in the local or state economy.

In summary, the IMPLAN analysis measured the total economic impact State Parks System visitation has on the state economy. This total economic impact is composed of the direct, indirect, and induced effects of the change in consumer demand. The direct effects are the "first round" purchases on inputs from the firms experiencing the increase in demand. The indirect effects are purchases made in the "second round," "third round," "fourth round," and so forth in order to support the production of inputs purchased in the "first round". The induced effects are increased purchases of goods and services in the region which result from increased income to households and owners of firms.

The IMPLAN analysis was performed in two ways. First, analysis was performed to determine the interdependence of state park recreation within the state economy. This interdependence analysis indicates the effects of spending stimulated by park units on the magnitude and distribution of economic activity among businesses, industry, and workers in the state. It is not a true measure of economic growth because resident spending is included in the analysis. Expenditures by residents of the region are not new dollars, and if a recreation site did not exist, the assumption usually adopted is that residents would spend their dollars on other goods and services within the state economy.

Secondly, the classic economic impact analysis is also performed. This simply means that only nonresident expenditures are allocated to IMPLAN sectors, and so a measure of the effects of external dollars coming into the state economy is obtained. 


\section{Economic Effects of Recreational Expenditures by State Parks System visitors}

The economic effects of recreational expenditures by resident and non-resident visitors to the North Carolina State Parks System are shown in Table VI-1. The table shows figures for the 29 state park units, for the trree reservoirs (Kerr Lake, Jordan Lake, and Falls Lake), and tetals which include reservoirs and park units.

Table VI -1. Summary of Statewide Economic Effects of Resident and Non-resident Recreation Expenditures for the North Carolina State Parks System*

TOTAL GROSS OUTPUT
TOTAL INCOME

EMPLOYMENT

(NUMBER OF JOBS)

29 Parks

$\$ 190,582,984$

$\$ 77,421,560$

5,989

3 Reservoirs

$\$ 270,035,295$

$\$ 105,627,611$

7,244

Systemwide

Totals

$\$ 460,618,279$

$\$ 183,049,171$

13,233

* IMPLAN analysis was performed for two representative park units, Hanging Rock state Park and Kerr Lake state Recreation Area. Table data was developed from the individual park analysis using annual attendance figures.

Table VI-1 considers three major economic activities: total gross output, total income, and employment. They are defined as follows:

Total Gross output: The annual value of outputs produced by all sectors of the economy which result from state Park visitor expenditures. For example, when a visitor purchases a lunch, the expenditure would have ripple effects on agriculture, packing plants, wholesalers, retailers, bottlers, and so on. The effects of such expenditures are allocated to various sectors of the economy using Bureau of Economic Analysis production function relationships. 
Total Income: The sum of employee compensation (wages and salaries) which results from expenditures made by state Parks System visitors. It includes all firms affected by visitor expenditures. It also includes profits, rents, royalties, interests, etc. that are accruing to the owners of the affected property and firms.

Employment: The number of jobs ri:quired to produce the output for all the firms affected by state Parks system visitor expenditures.

The overall economic effect of resident plus non-resident recreation expenditures by visitors to the state Parks system is summarized in Table VI-1. Because the effects of resident expenditures are included, the totals do not represent new economic growth resulting from recreation expenditures. These figures do, however, indicate the interdependence of state Park related expenditures within the North Carolina economy.

This interdependence means that expenditures stimulated by state Parks system units contribute to the support of many firms and industries throughout North Carolina. As shown in Table VI-1, 13,233 jobs throughout the state are related to expenditures stimulated by the State Parks System. The figures also indicate that total income payments of $\$ 183,049,171$ result. In general, these figures suggest that state Parks stimulated expenditures are an interdependent and important component of the state economy.

Table VI-2 focuses on new dollars which induce economic growth. The table again summarizes three major economic activities: total gross output, total income, and employment. Table VI-2, however, only contains the impacts of non-resident expenditures on the economic growth of the state economy.

When nonresidents travel to a unit of the state Parks system, new dollars are brought into the state economy. Another way of expressing this is to say that the state economy "exports" recreation opportunities. These new dollars induce economic growth. For example, 3,054 jobs in the state economy result from nonresident state parks visitor expenditures. 
Table VI-2. Summary of Statewide Economic Effects of Non-resident Recreation Expenditures for the North Carolina State Parks System.*

TOTAL GROSS OUTPUT
TOTAL INCOME

$\$ 18,181,049$

$\$ 21,117,029$

$\$ 39,298,078$
EMPLOYMENT

(NUMBER OF JOBS)

\section{Parks}

$\$ 43,949,387$

$\$ 51,806,667$

$\$ 95,756,054$

Totals

3 Reservoirs

Systemwide

*IMPLAN analysis was performe

Hanging Rock State Park and Ker

Table data was developed from this individual park analysis using annual attendance figures.

Table VI-2 provides measures of the economic activity in the state economy which can be directly attributed to out of state visitation to the state Parks System. If the park system were to cease to exist, then this economic activity would be completely lost since non-residents would most likely reallocate expenditures to other parks outside of the state economy.

Similarly, if park management or changes in visitation patterns result in nonresidents reallocating their trips away from state park units, then the resulting decrease in economic activity would represent a net economic loss to the state economy. Alternatively, if park management or changes in visitation patterns resulted in increased trips from nonresidents to parks within the state, the resulting increase in economic activity would represent a net economic gain to local economics and the state economy.

As shown in Table VI-1 and Table VI-2, the three reservoirs contribute more to the State's economy than all the other state park units. In light of the recreational focus, more intensive development, and water sport orientation, this is not surprising. High attendance is also a major factor, with the three recreation areas accounting for 30 percent of the systemwide visitation:

The number of jobs created as a result of out-of-state visitation to the North Carolina State Parks System - 3,054 - while a large and significant number, is only a small portion of total statewide employment. Out of state visitation accounted for 0.001 percent of the total 1984 statewide employment of $2,826,000$. 
When the 3,054 jobs created by the expenditures of out-of-state visitors is compared with the State's investment in staffing for the State Parks System, a quite different picture emerges. There are currently only 215 permanent full time administrative and field staff, so a 14 to one ratio of jobs created to staff positions exists. Likewise, when the total income resulting from expenditures by out-of-state visitors is compared with the annual operating budget for the State Parks System, a similar result is found. Approximately $\$ 4.50$ in income is generated for each State dollar invested in the system's annual operating budge'.

Table VI-3 lists the percentage of visitor expenditures by expenditure category. As shown, the food and drink sector of the economy is most effected, capturing 36.3 percent of expenditures. Lodging, transportation, activities, and miscellaneous expenditures are grouped closely together with 18.7 percent, 16.3 percent, 15.6 percent, and 13.1 percent of visitor expenditures.

Table VI-3. Average Trip Expenditures By Expenditure Category.*

EXPENDITURE CATEGORY

PERCENTAGE OF EXPENDITURES
AVERAGE \$ PERSON

(PER 12 HOURS OF ON-SITE RECREATION ACTIVITY).

Food and Drink

$36.3 \%$

$\$ 9.54$

Lodging

$18.7 \%$

4.92

Transportation

$16.3 \%$

4.30

Activities

$15.6 \%$

4.08

Miscellaneous

$\underline{13.1 \%}$

3.44

Totals

$100 \%$

$\$ 26.28$

*Table developed from PARVS data. 
Case Study: Economic Effects of a New State Park

The economic data generated from the PARVS-IMPLAN model will allow economic estimates to be made regarding the addition of new State park units. During the 1980's, there has been considerable interest in protecting the Lumber River. One option for protection might be the establishment of a State fark on the river.

Such a park would focus on the major resource, the meandering blackwater river. It would be a linear park which would seek to protect and preserve the river corridor while allowing well designed and maintained places for public access to the river. Various access points would allow an individual canoer or groups such as the boy scouts to choose the length of time and distance of an outing. A park office and interpretive center as well as other facilities such as camping, trails, and picnicking areas would likely be developed along the middle of the protected corridor.

Such a park could be acquired and developed for approximately $\$ 4$ million. Once developed, what economic effects might such a park have on North Carolina? Assuming that the park would have an attendance which would approximate the median State park attendance, 113,225 visitors per year, the following economic effects could be expected from nonresident (out-of-state) expenditures:

Total Annual Gross Output: \$938,836

Total Annual Income: \$388,400

Employment (Number of Jobs): 30.48

The above numbers exclude any economic effect from the expenditures of residents of North Carolina. They are based only upon one-quarter of the anticipated annual visitation, the typical amount of visitation which originates from outside the State. Thus the figures represent the effects of external dollars which would be coming into the State economy, dollars which induce economic growth.

Development of a State park may also serve to redistribute dollars from one region of the state to another. While much State park visitation (75\%) originates in-state, in-state visitation often comes from outside of the local economic area. Spending by in-state visitors would add significantly to the local economy; therefore, the economic effects of such a State park on the local economy would be greater than the effects shown above. 


\section{CHAPTER SUMMARY CONCLUSIONS}

The benefits of the state Parks System are many and its value is high. The system makes significant contributions toward preserving and protecting natural resources for present and future generations. It offers settings and facilities which provide for a wide variety of both active and passive recreational uses. It also contributes social benefits and values in a variety of ways such as by aiding physical and mental health, by providing educational opportunities, by providing settings for positive uses of leisure time, and by providing recreation for families.

While these benefits are often recognized, their value is often overlooked. While the value of benefits such as the preservation of a rare plant species or a walk on an undeveloped beach are impossible to calculate, lack of quantitative dollar figures does not lessen their value.

Recent economic data obtained through visitor surveys and analysis of those surveys reveals that the state Parks System makes a significant contribution to the state's economy. It is estimated that expenditures by out-of-state visitors to 29 parks and three recreation areas generate annually $\$ 95.756$ million in total gross output and $\$ 39.298 \mathrm{million}$ in total income which induces economic growth in the state. These expenditures provide jobs for 3,054 citizens of North Carolina, jobs which would not otherwise exist.

The economic benefits provided by expenditures made by out-of-state visitors to the state Parks System outweigh the state's investment in the system, as shown below:

Investment

$\$ 38$ million for land acquisition in 74 years

$\$ 28.2$ million for capital development in 74 years

$\$ 7.2$ million current annual operating budget. versus

Economic Benefits

$\$ 95.756$ million annual gross output

$\$ 39.298$ million annual income

3,054 jobs 


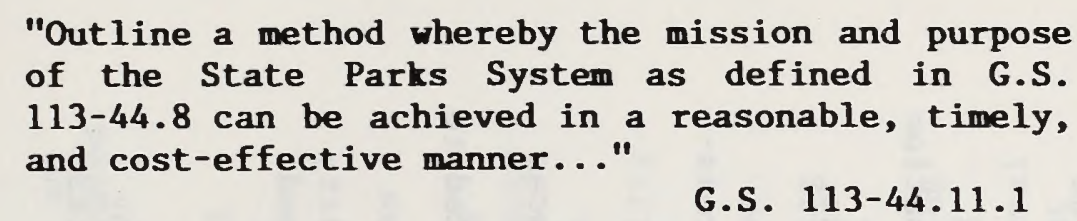

\section{INTRODUCTION}

A bold action plan is suggested for improving the system. Emphasis should be placed upon the needs of the existing system. Adequate capital development in one half of the units is called for over the next five years. An increase of 60 staff positions will allow the system to meet on-half of the standard set by the median of southeastern state park systems. An increase of staffing levels in ten operated units is essential. One quarter of the backlog of land needed to protect existing parks should be acquired.

This systemwide plan has been developed in direct response to stipulations in the state Parks Act. Following a thorough review of the development of the system, Chapter II describes the resources of the existing system. Chapter III details anticipated trends which may impact the system, and Chapter IV identifies duplications and deficiencies in the system and notes the statewide significance of park units. Within each chapter, recommendations are made as logical outgrowths of the information presented. The recommendations (Table VII-I) should serve to guide the state Parks system forward over the current five-year systemwide planning cycle. The recommendations should be used to drive budget requests and, if additional support is realized, Division workplans.

This chapter proposes a bold action plan to fulfill these recommendations. Proposed actions were developed in direct response to recommendations which were grouped into nine action categories (Table VII-1): capital development program, expansion of system, natural resources protection, programing, repair and maintenance, expansion of staff, staff training, policy implementation/planning, and increased funding. The proposed actions to fulfill the state Parks Act mandate will require a significant and stable increase in support for the state Parks system. 


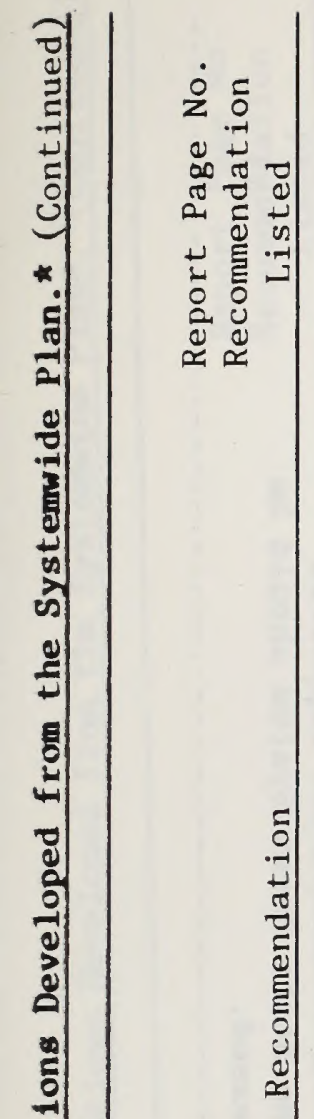

$\cong \stackrel{\Xi}{\Xi}$

$\bar{\sigma}$

$\vec{a} \quad \vec{a}$

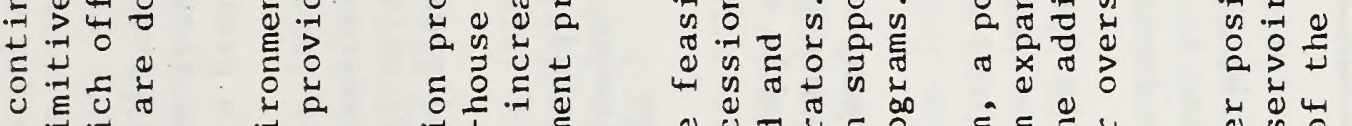

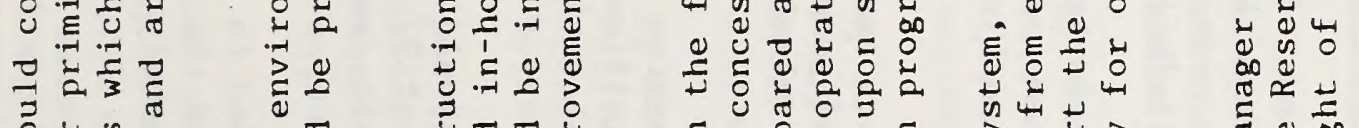

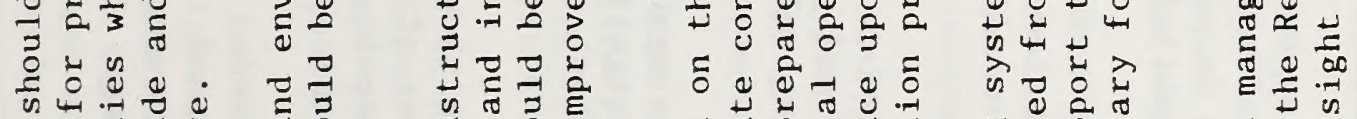

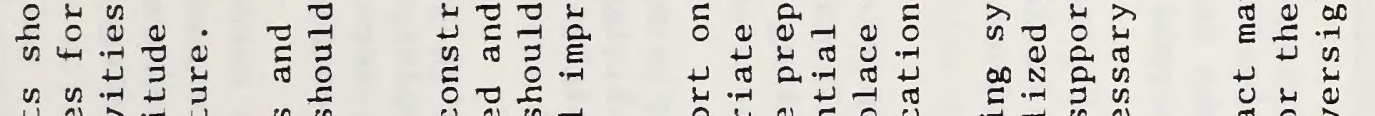

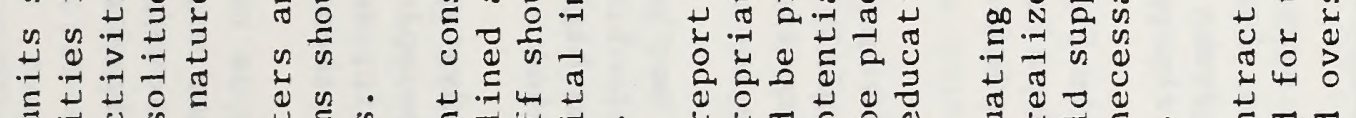

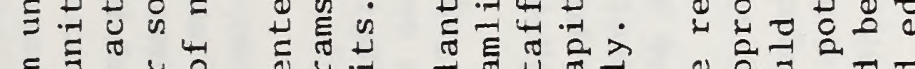

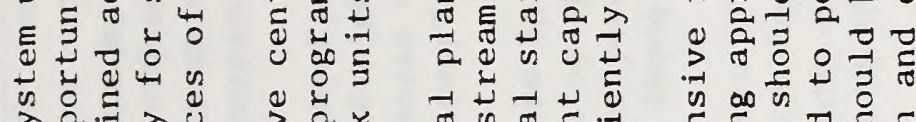

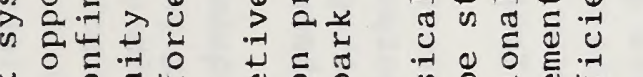

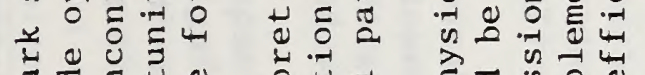

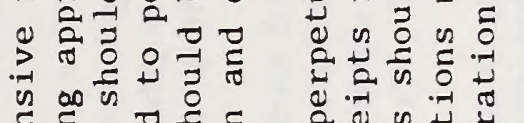

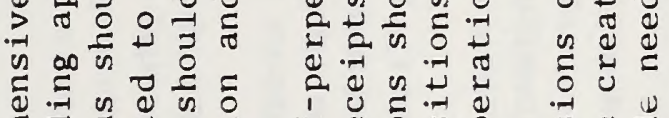

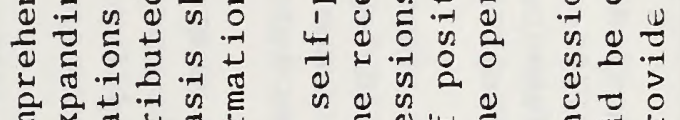

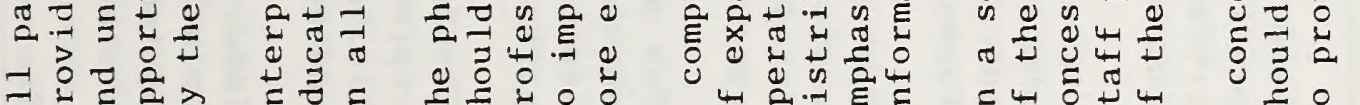

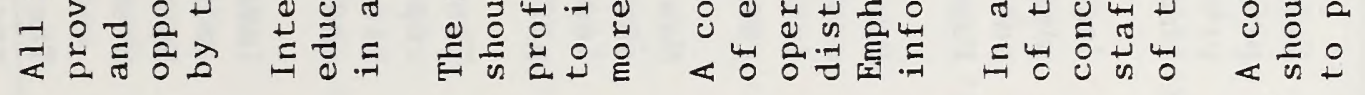
$\stackrel{\ddot{G}}{\ddot{H}}$
苛苛
$\stackrel{\ddot{\infty}}{\stackrel{\perp}{\leftrightarrows}}$
$\underset{\stackrel{\sim}{\lrcorner}}{\stackrel{\leftrightarrow}{H}}$

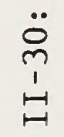

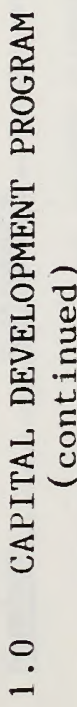




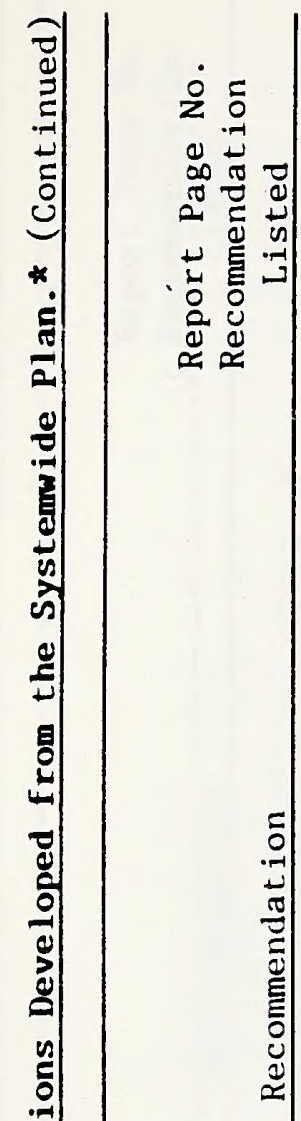

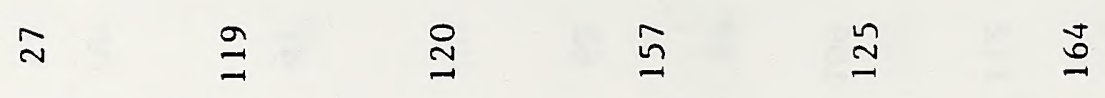

\&

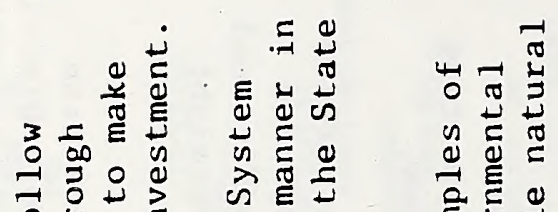

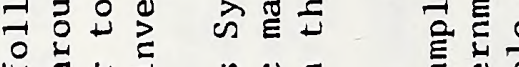

纯

范节

芚

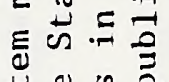

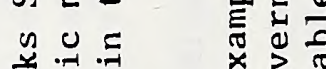

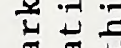

ค. 药

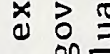

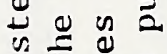

$\stackrel{0}{\pi}$

i 0

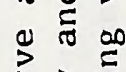

तेป

in के

$\stackrel{n}{=}=$

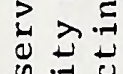

in $=0$

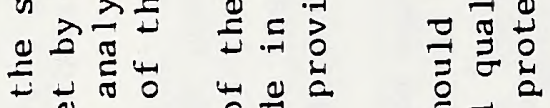

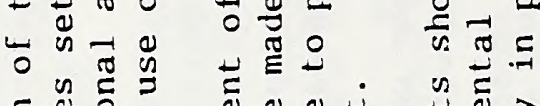

$\therefore \& \frac{\pi}{0}$

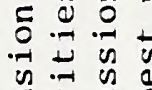

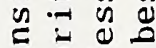

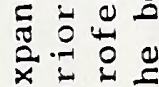

害哭递

$\sum_{0}^{0}$ 엄

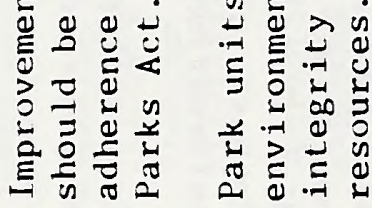

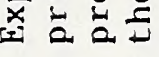

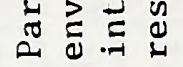

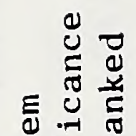

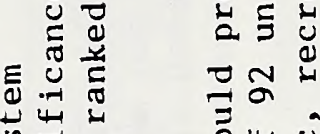

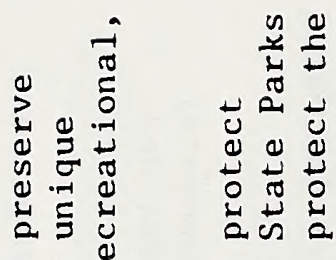

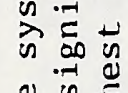

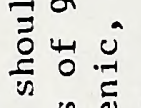

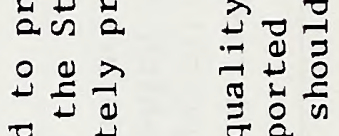

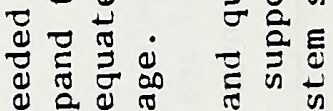

E气

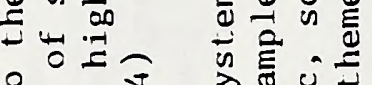

$=x \rightarrow \pi$ on

$\rightarrow \rightarrow 0$

$\stackrel{\infty}{\oplus \infty}$

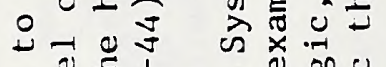

=

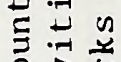

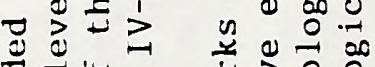

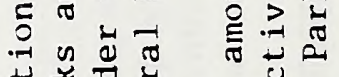

矛㟧。

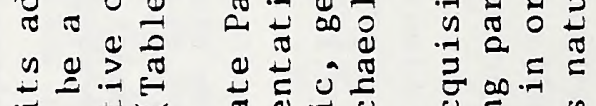

$\lambda$ 实

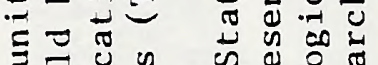

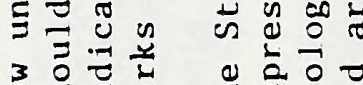

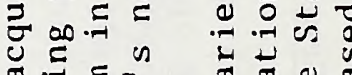

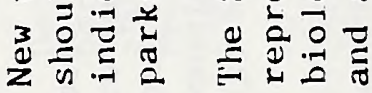

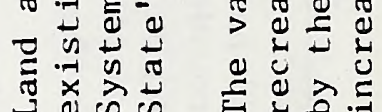

तथ

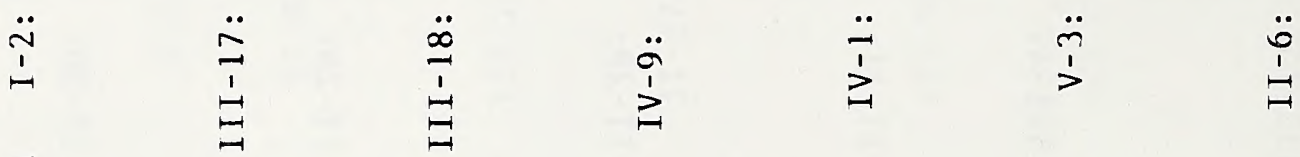

起

중

돌

㧒

$z$

恣鼠

胥 


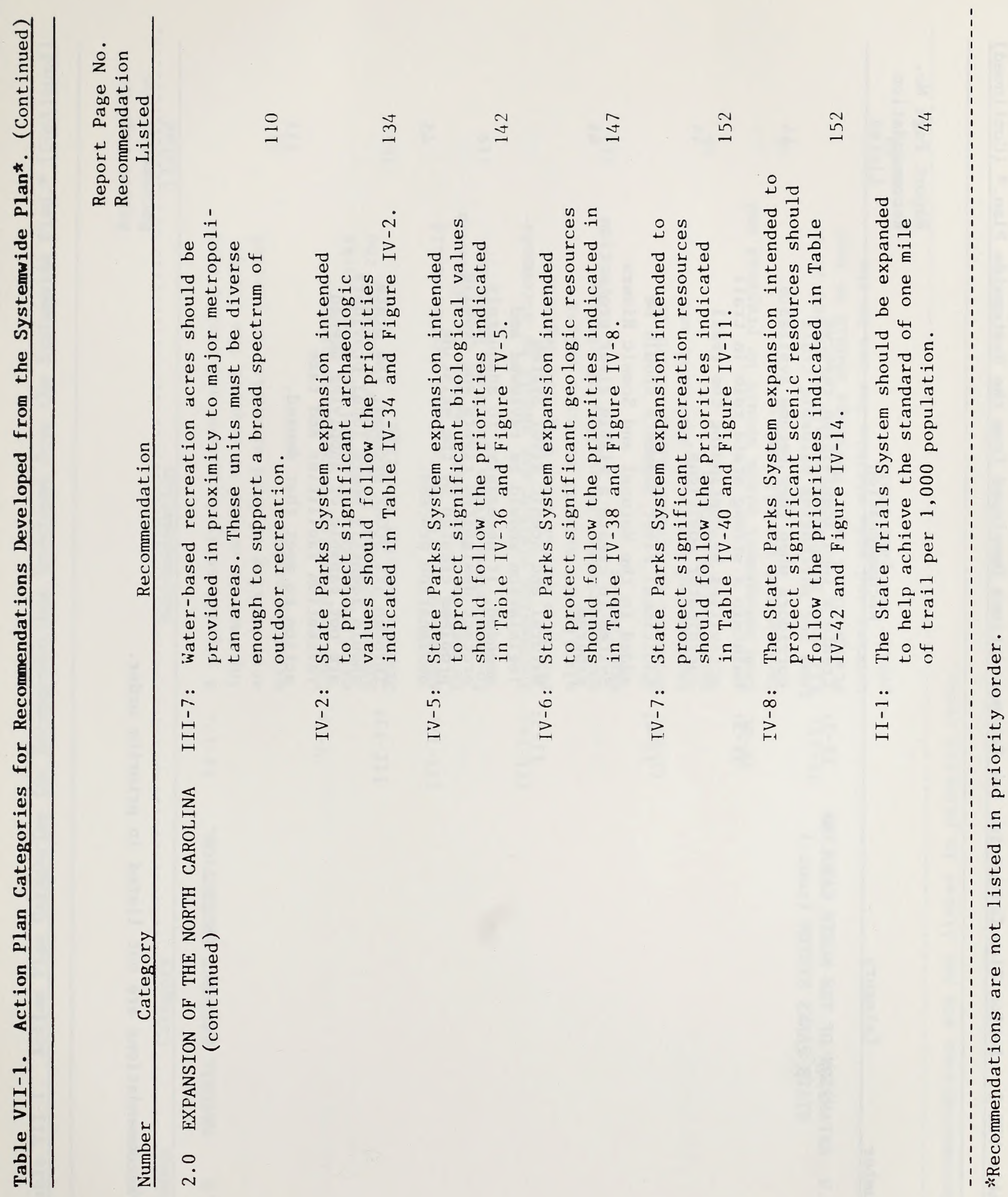




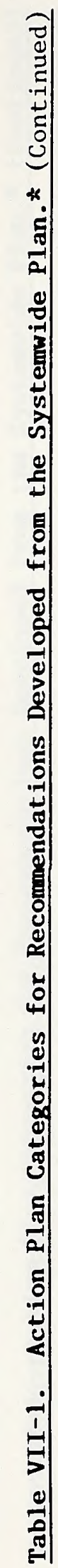

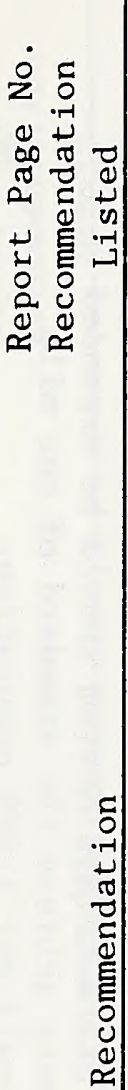

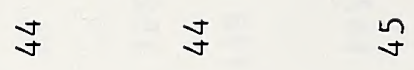

in

$\exists$

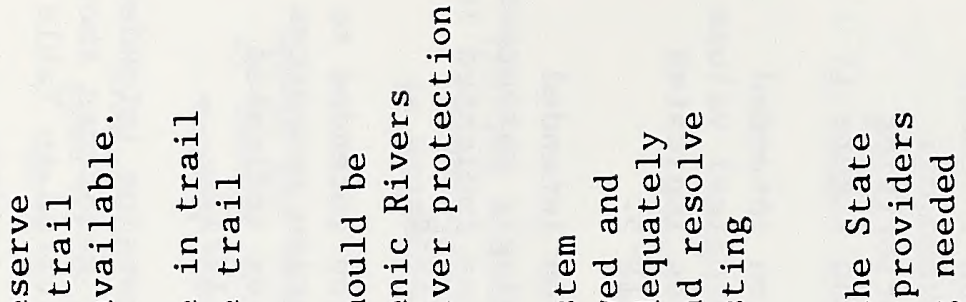

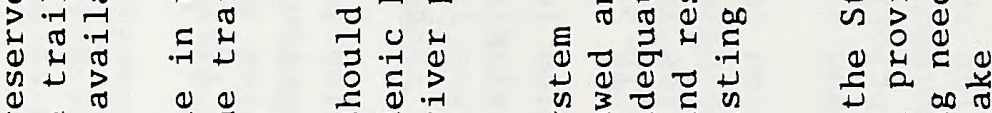

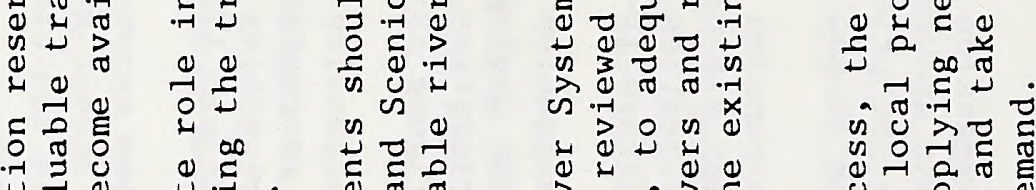

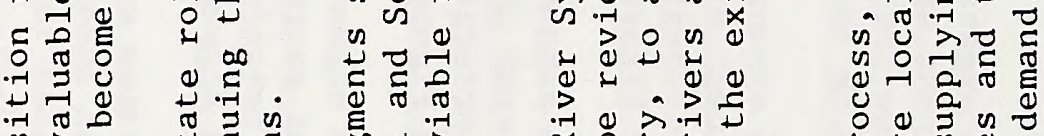

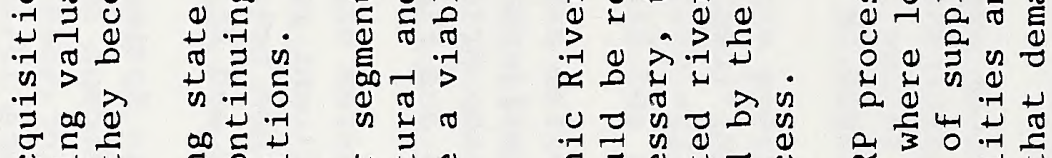

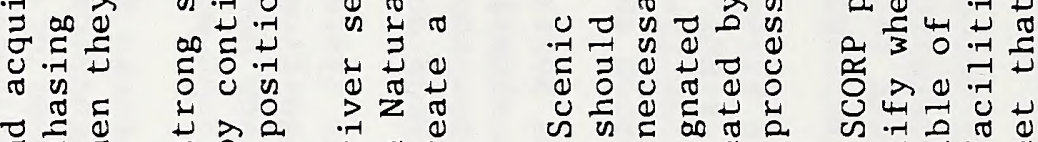

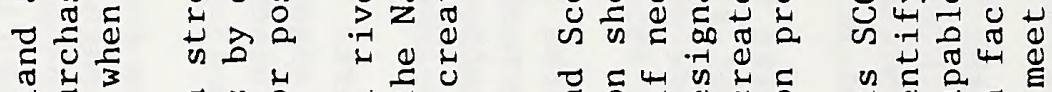

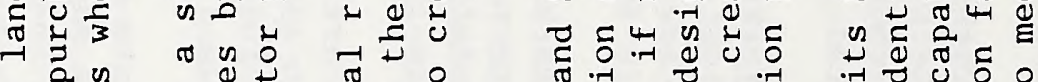

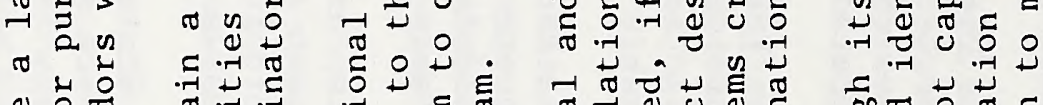

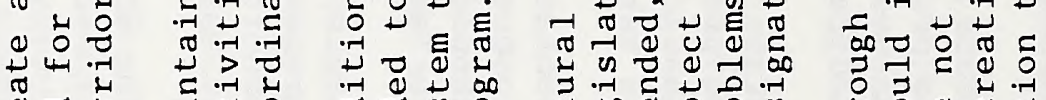

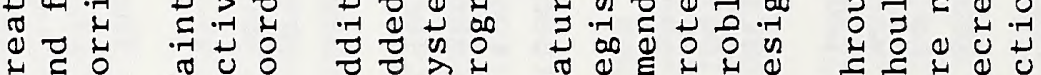

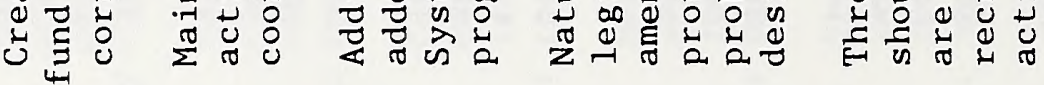

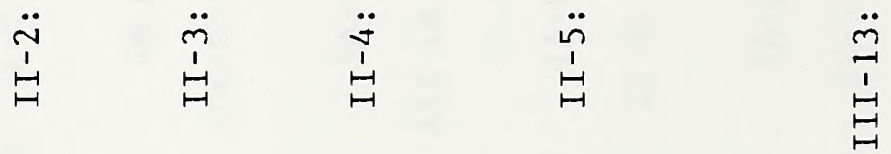

$\sum_{1-1}^{\mathbb{1}}$

完

U

胥

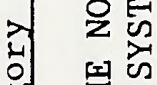

哭 焉

ง

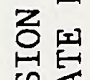

茇鼠

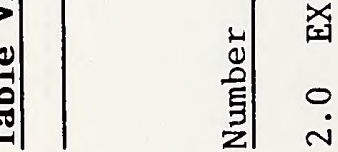




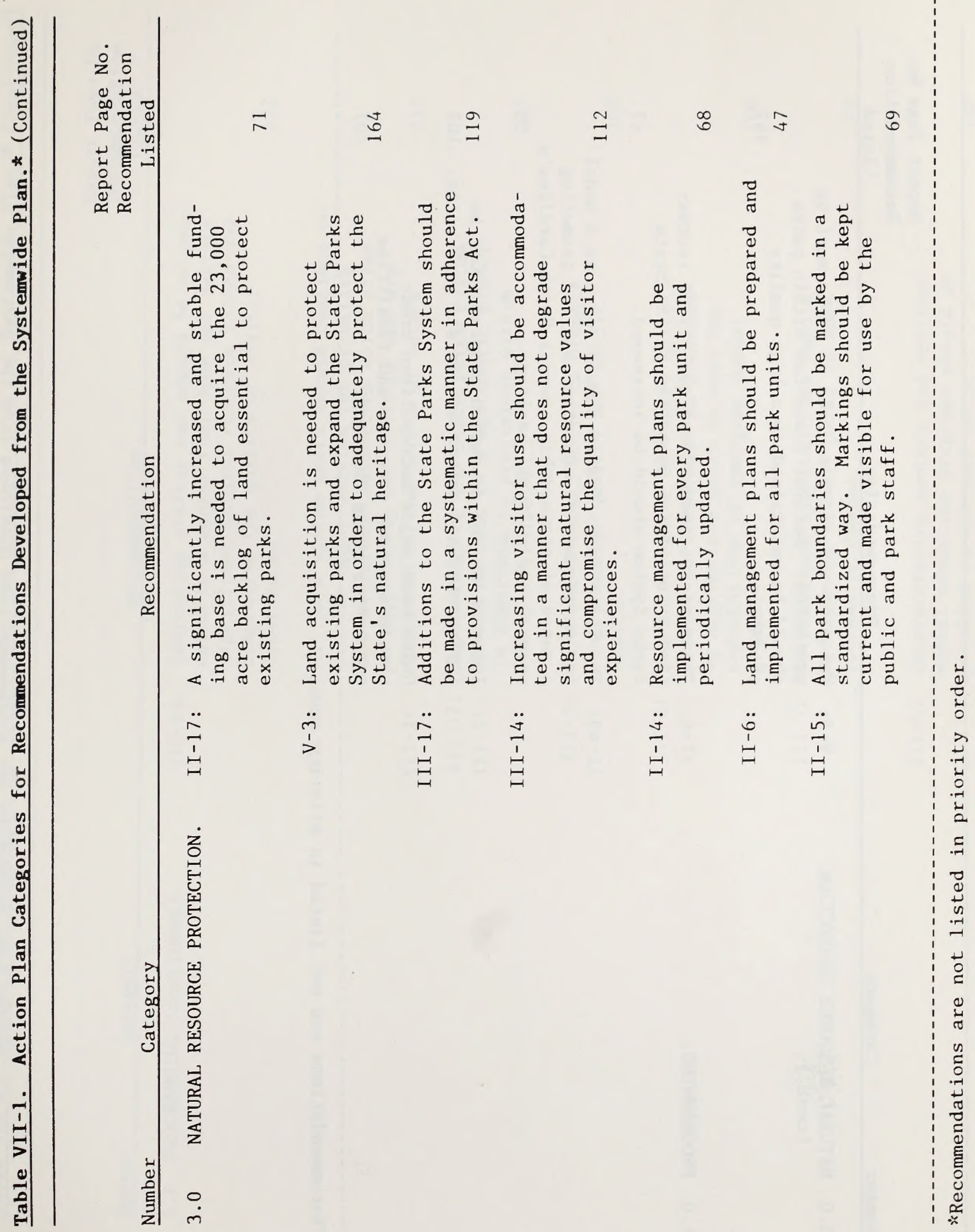




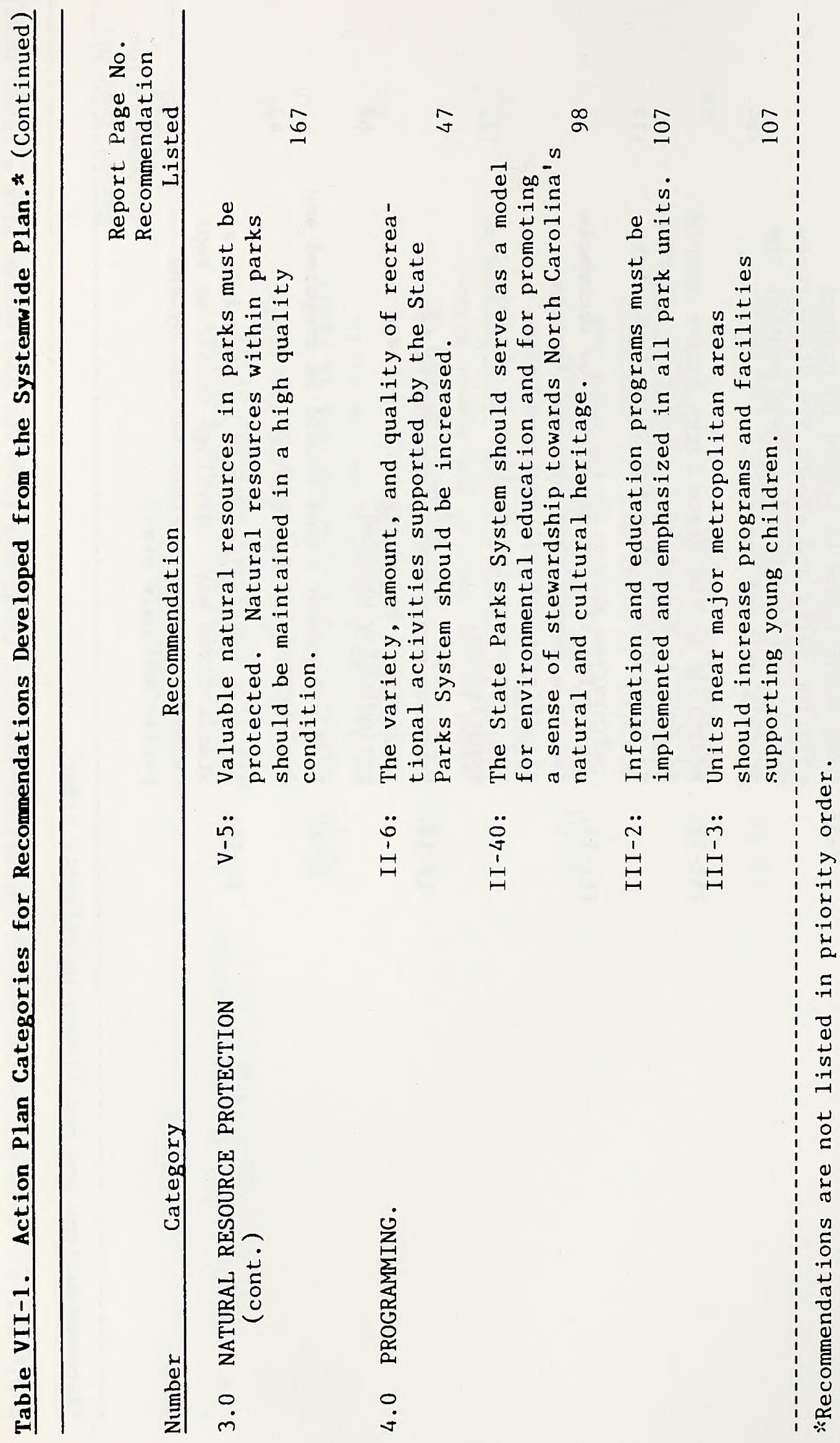




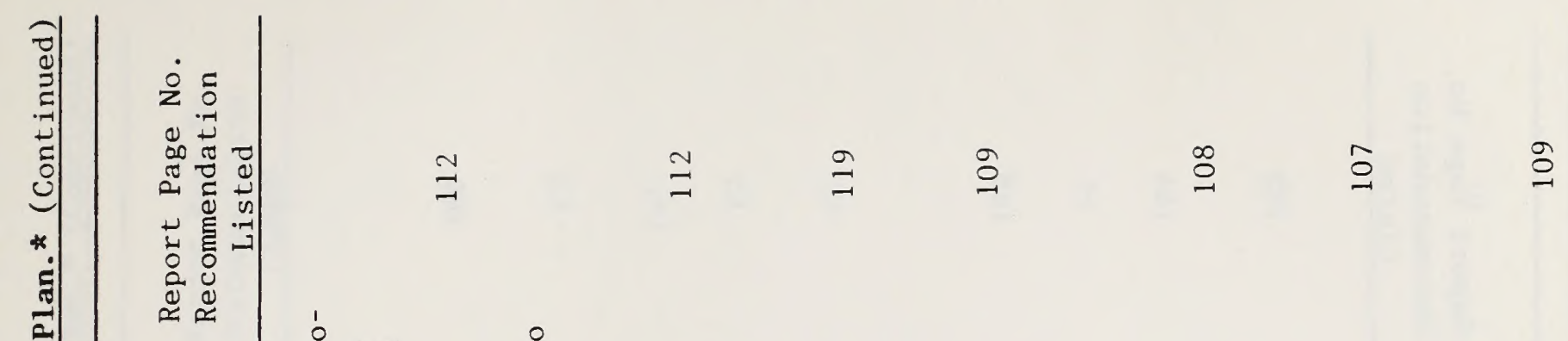
官 ๑

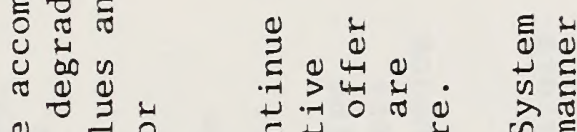

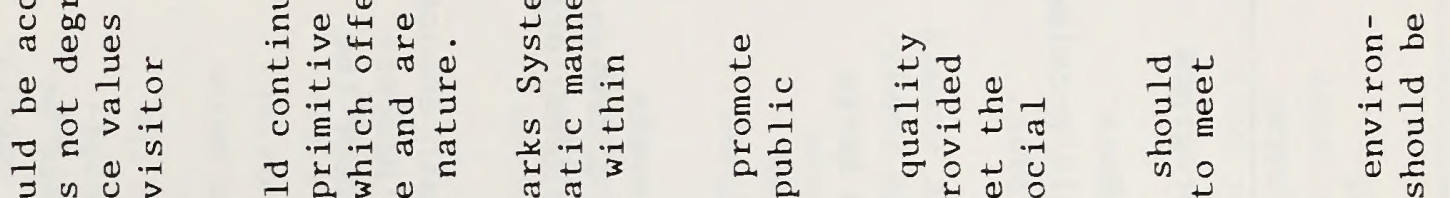

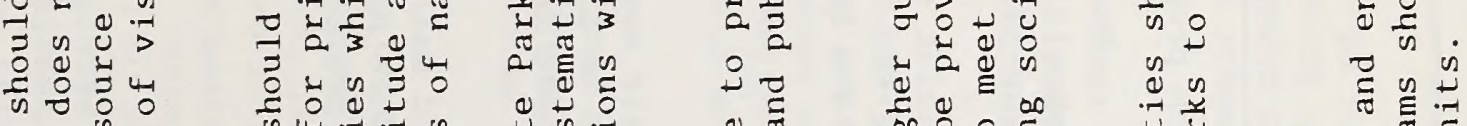

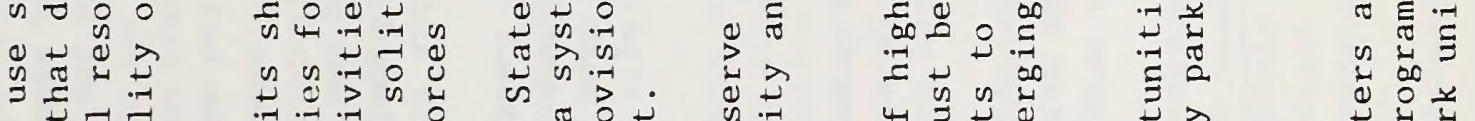
म न त

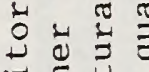

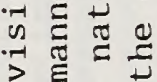

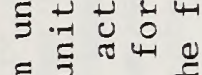

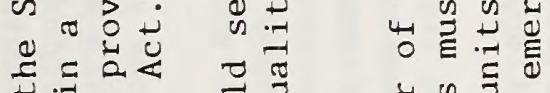
बृ

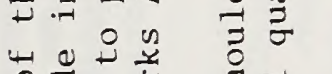
过 ป艹

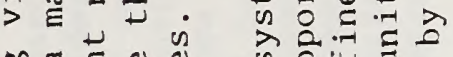

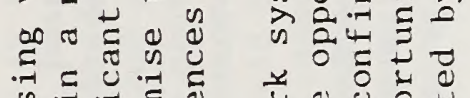

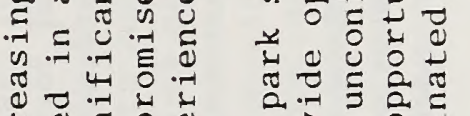

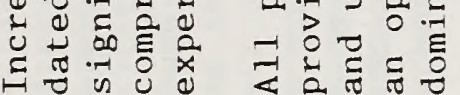
○茎

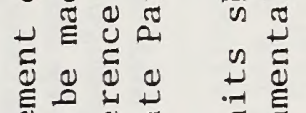

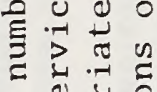

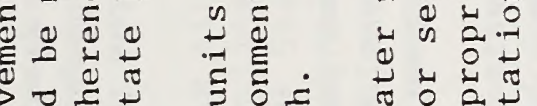

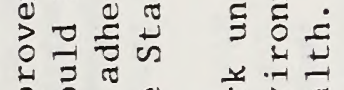
$x \cdot \frac{1}{2}=$

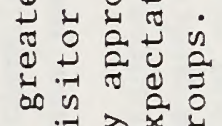

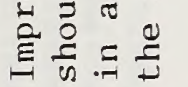

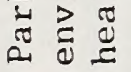

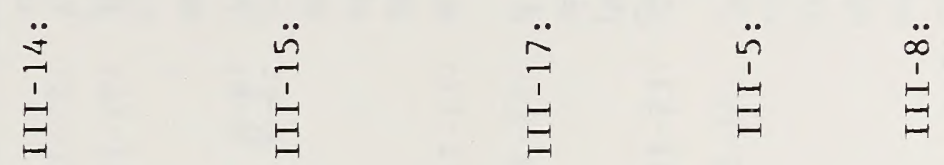

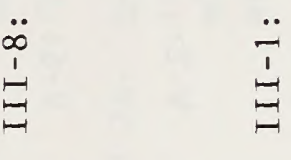

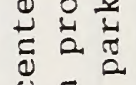
๑ 0 ¿ $\sum_{\pi}^{10} \sqrt{\pi}$ $\therefore$ ఝ̃ $\overbrace{0 \rightarrow 0}^{0} 0$ 党 可 Е芯这 


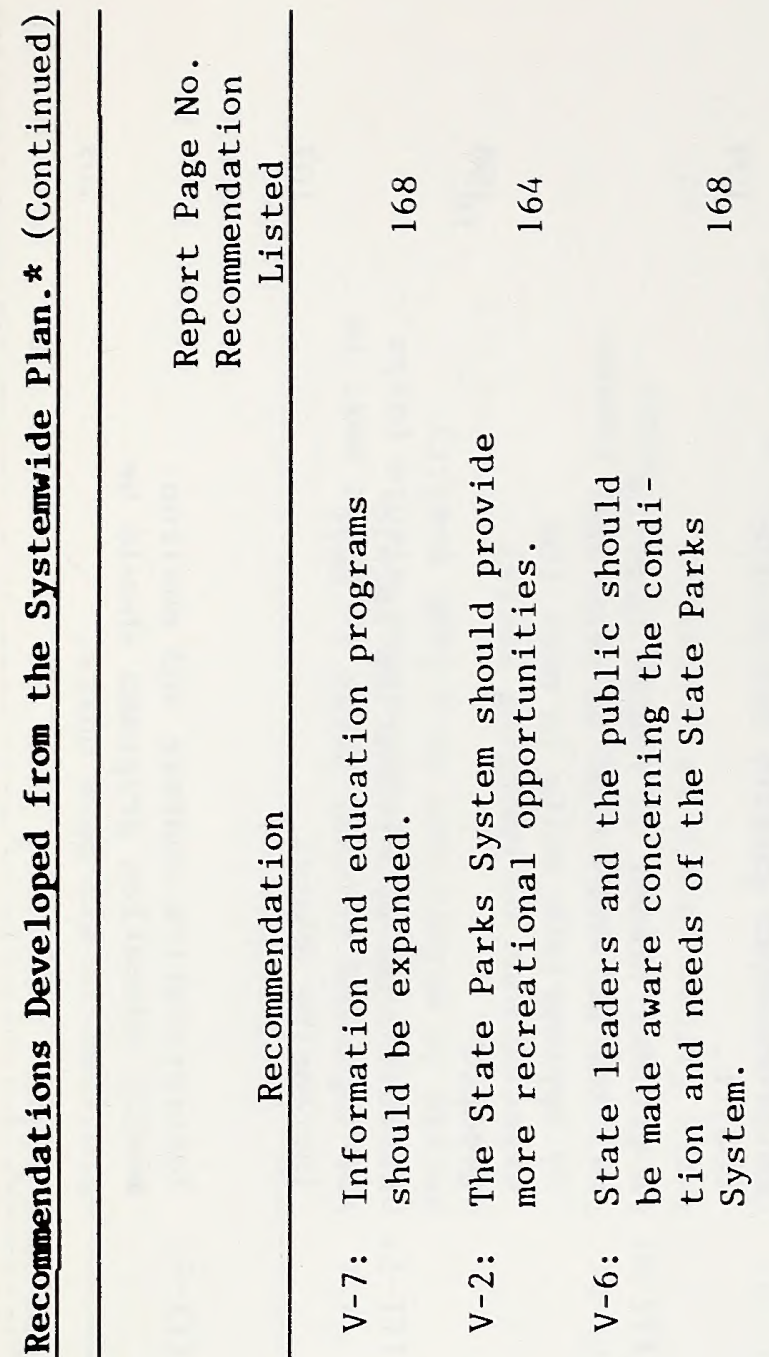

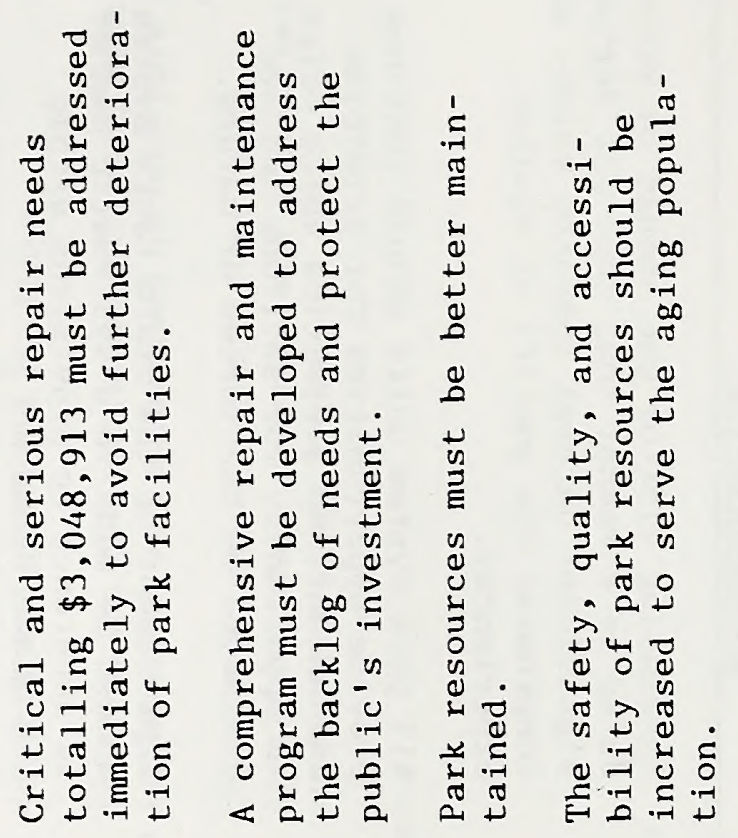

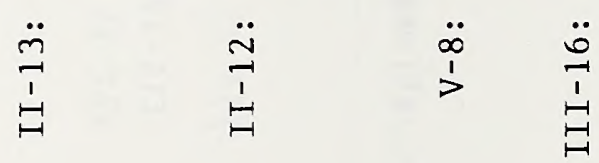

我

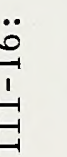




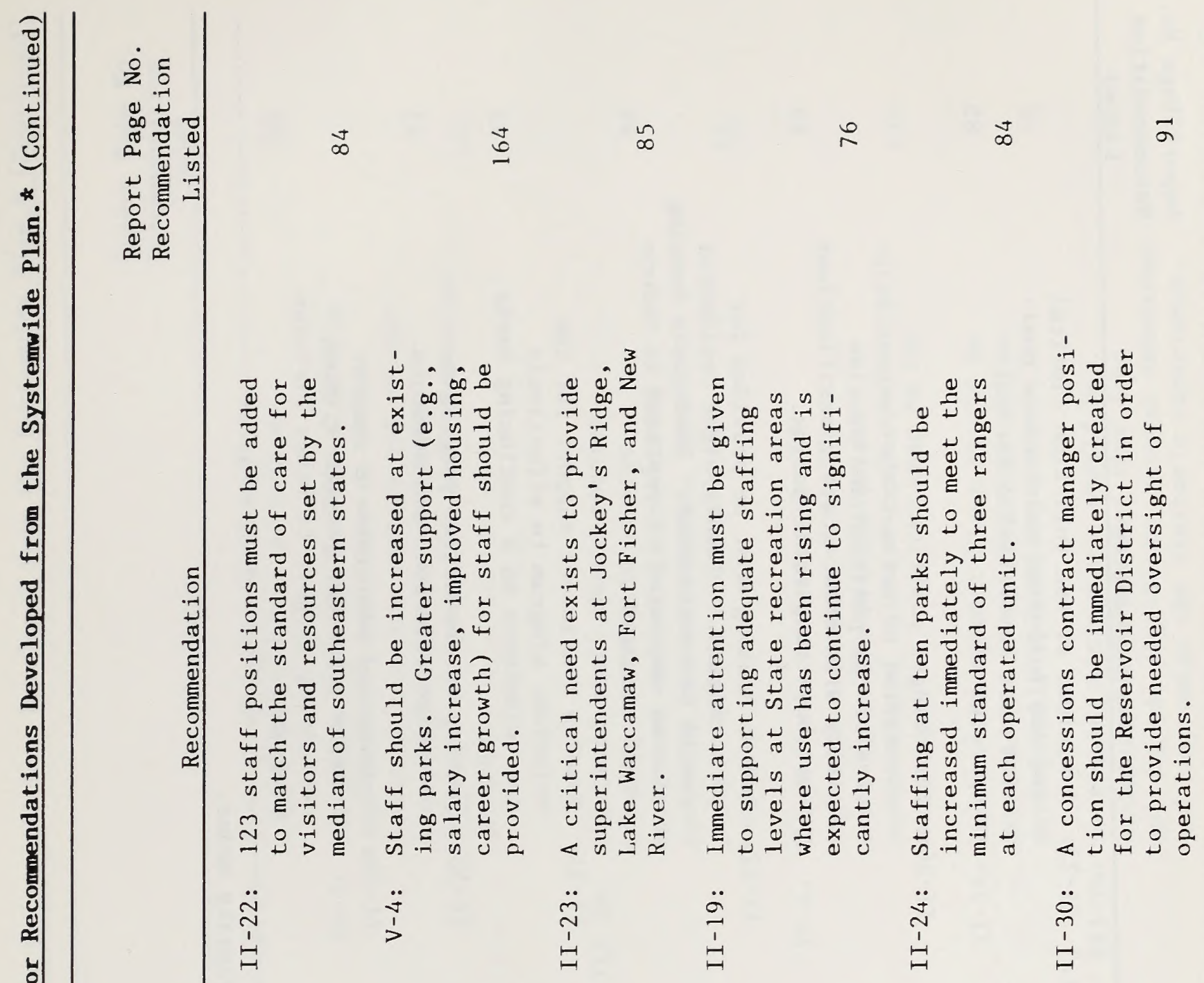

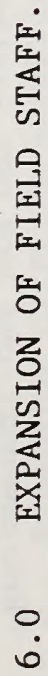




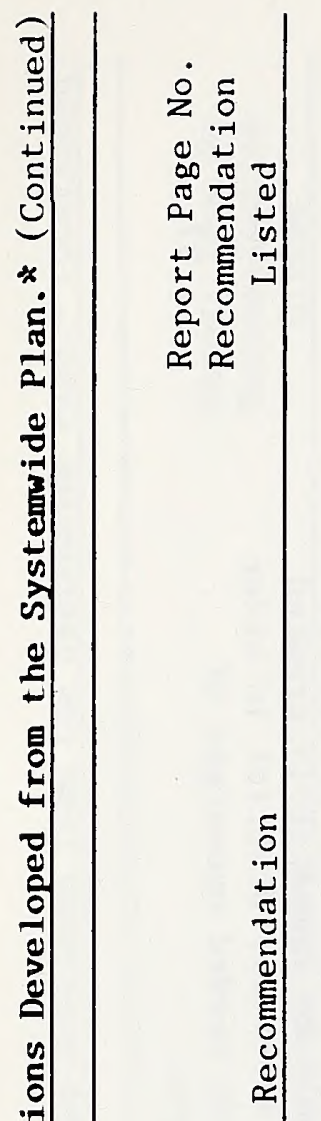

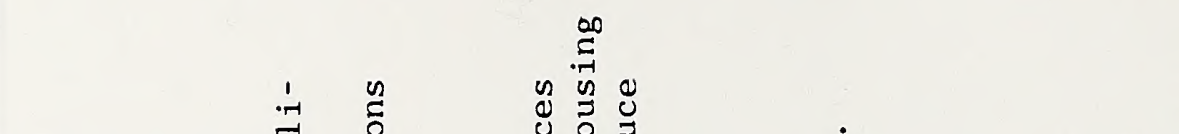

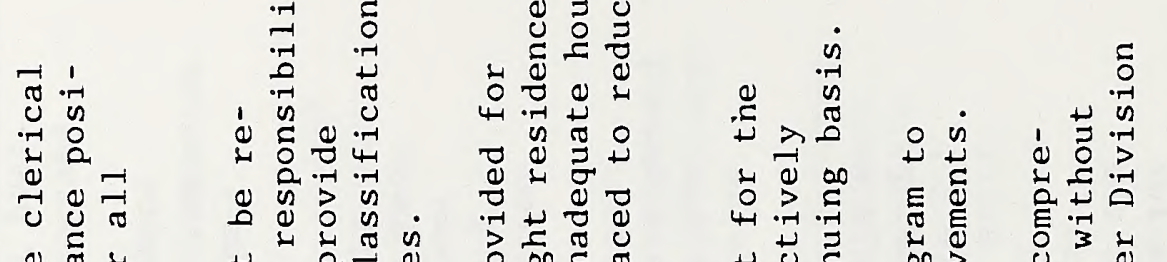

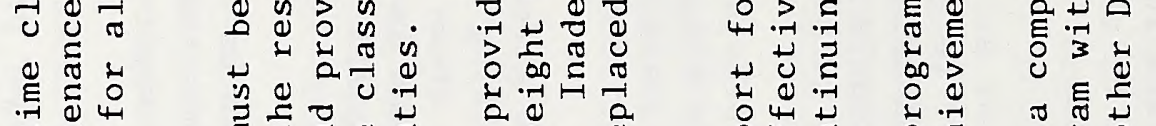

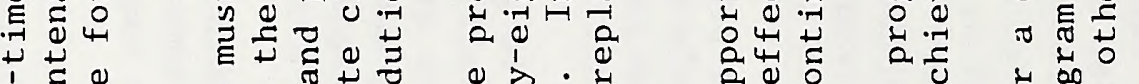

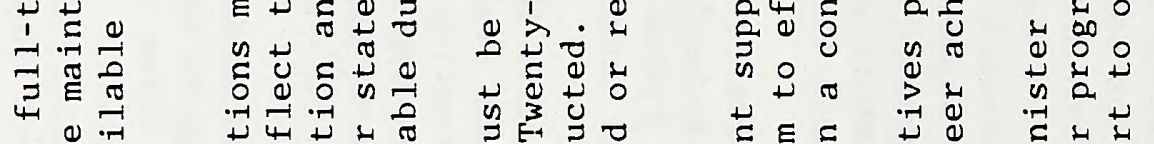

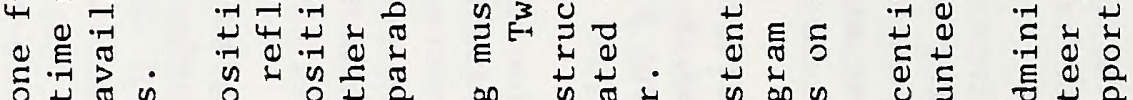

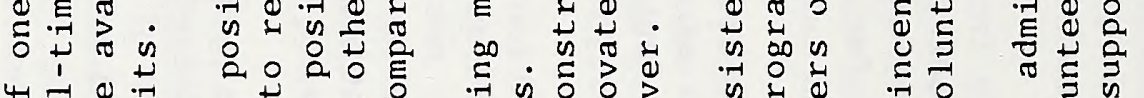
出光菏

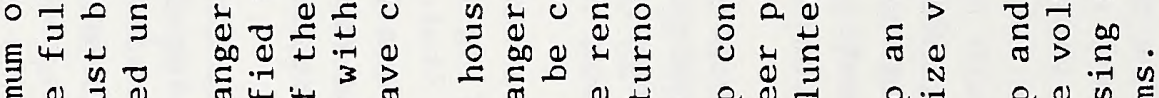

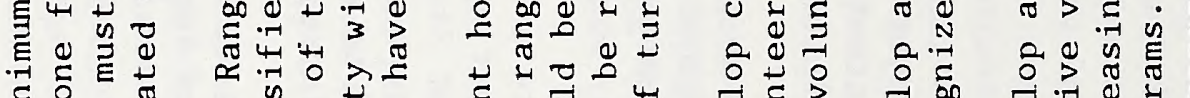

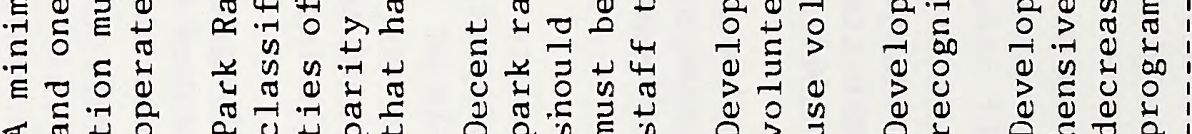
ฟ

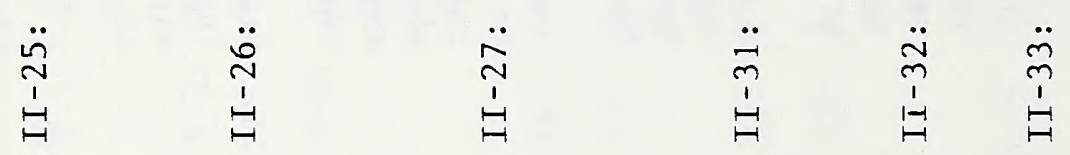



疍

돈

경 氠

$\stackrel{\infty}{\infty}$

ঞ

$\infty$

a 


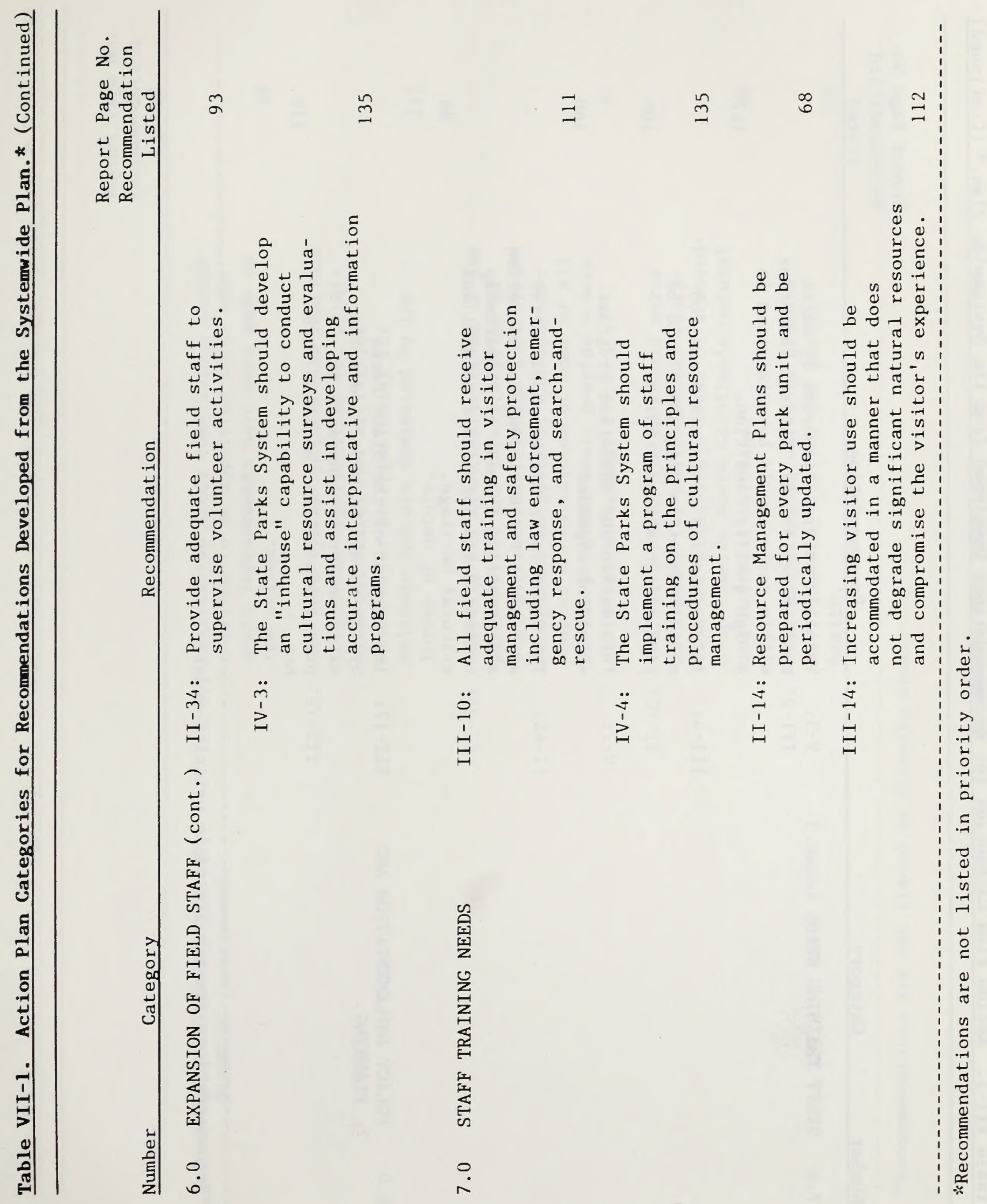




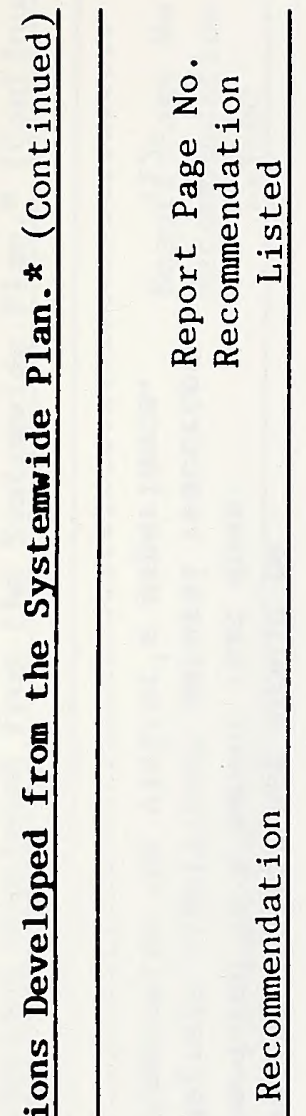

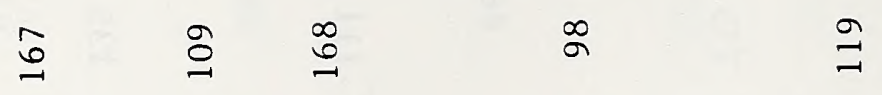

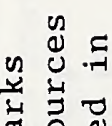

范

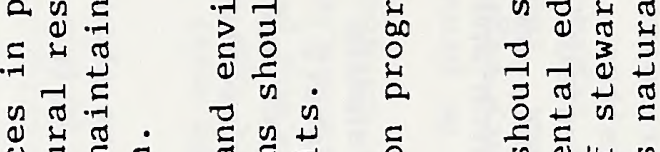

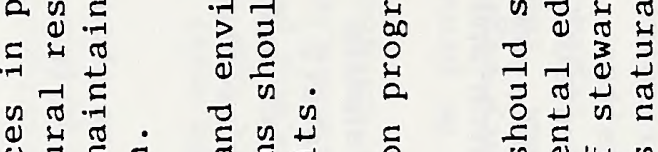

Uี

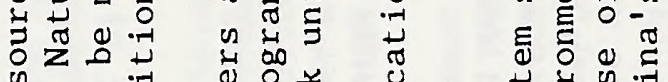

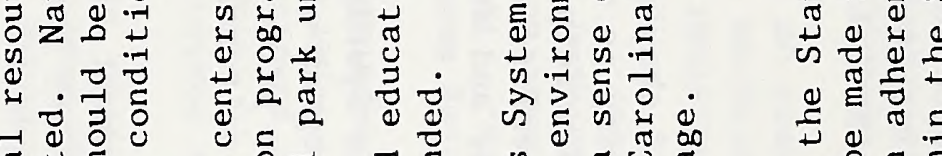

न

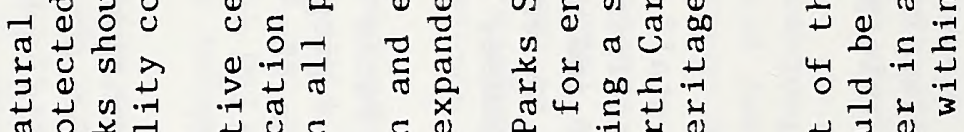

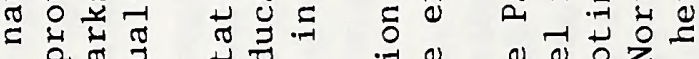

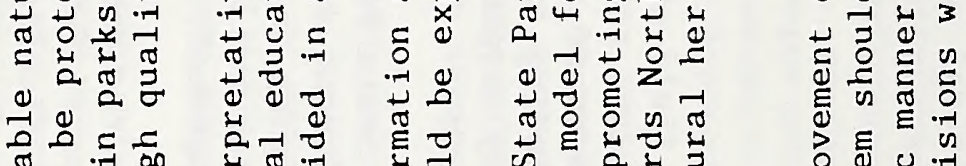
त.

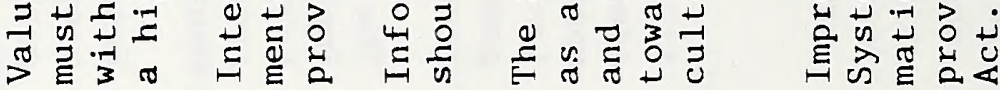

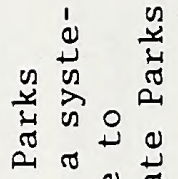

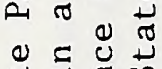

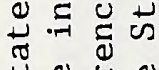

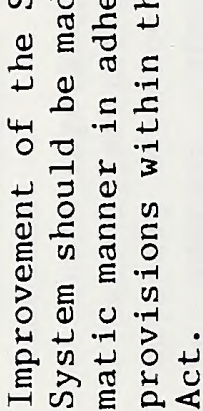

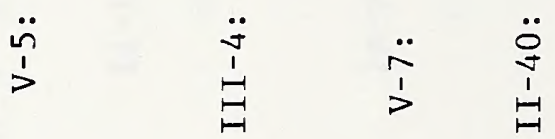

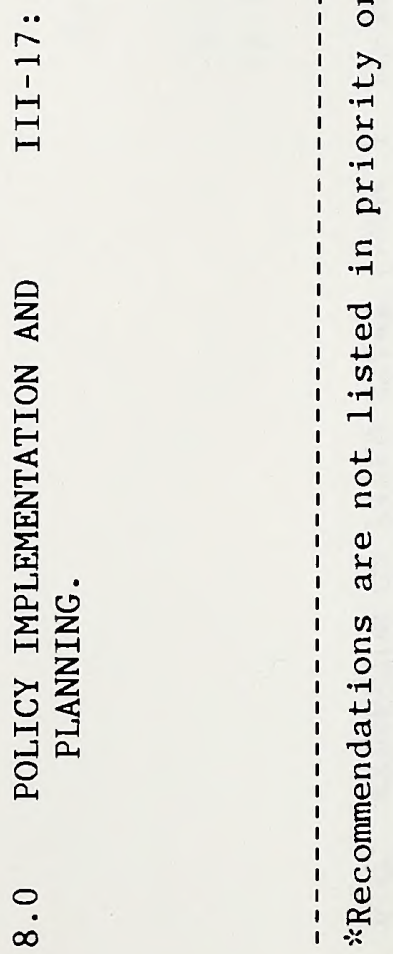




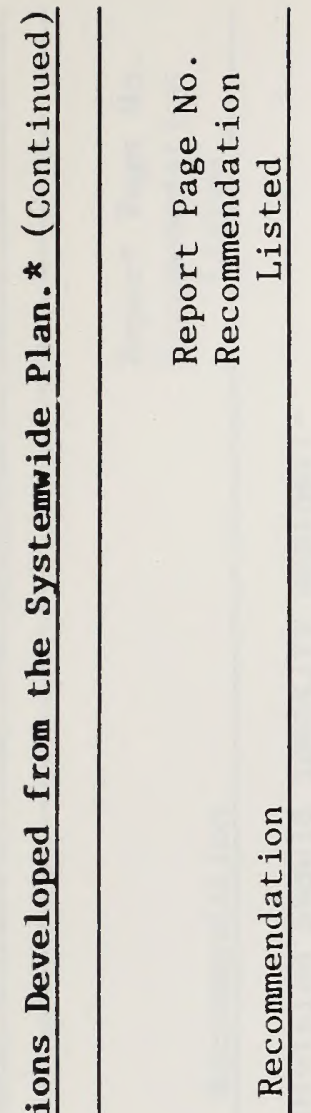

$\stackrel{\infty}{v}$

$$
\cong
$$

สิ

$\infty$

g

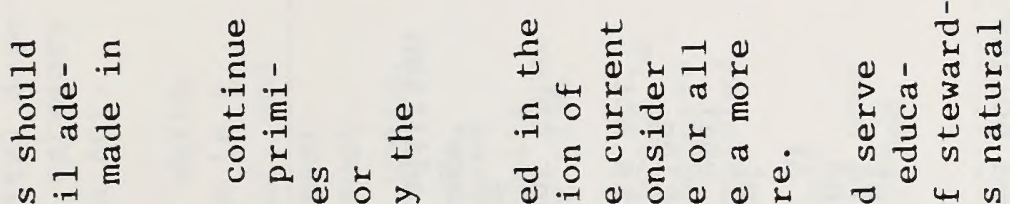

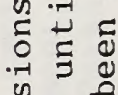

in 0

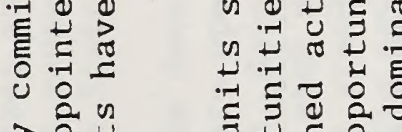

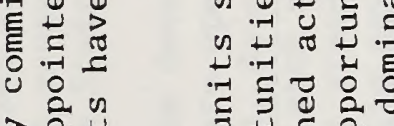

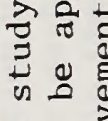

5

㝴命

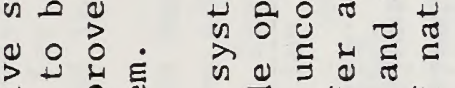

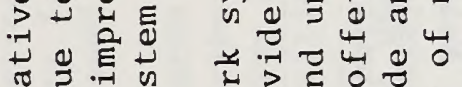

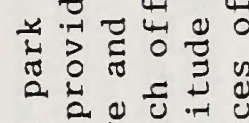

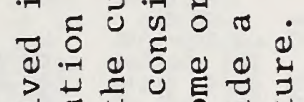

구요

至步

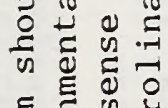

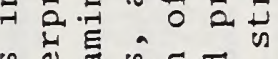

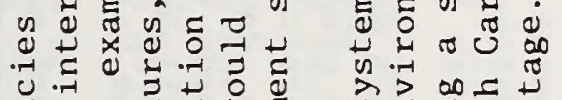

政.

$\lambda>\infty$ 舟

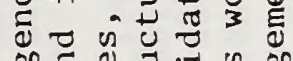

๘

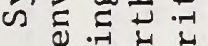

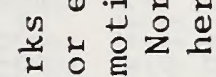

$\exists$ Э

तथ

๙

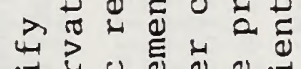

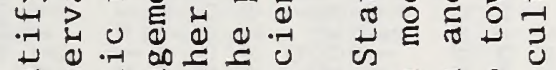

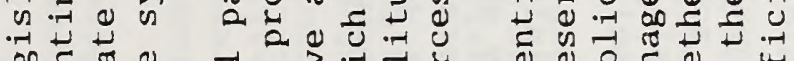

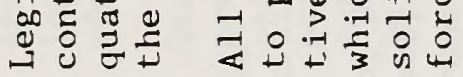

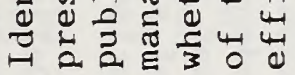

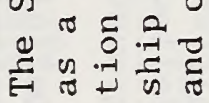

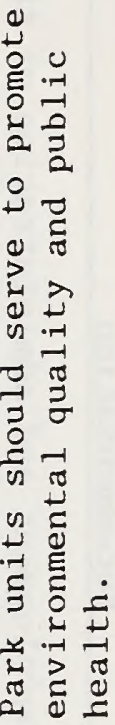

$\stackrel{\ddot{n}}{\oplus}$

$\ddot{n}$
$\stackrel{1}{ت}$
$ت$

$\stackrel{a}{m}$

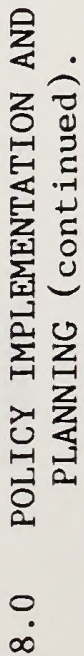

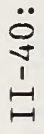

$\stackrel{\ddot{n}}{\stackrel{H}{ت}}$ 


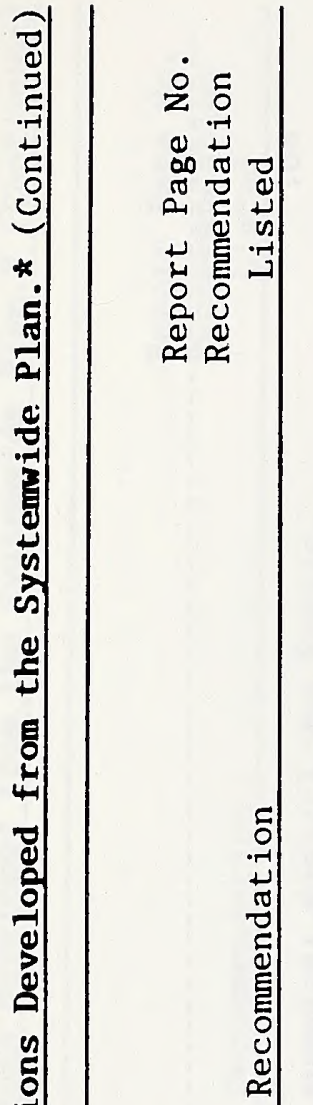

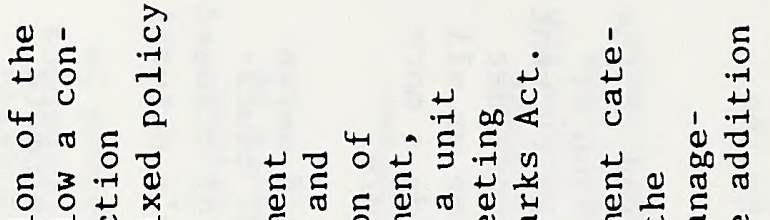

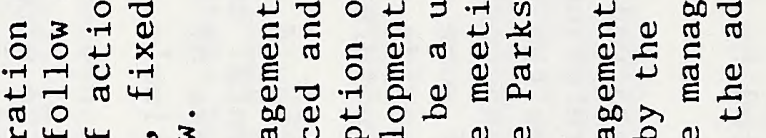
出

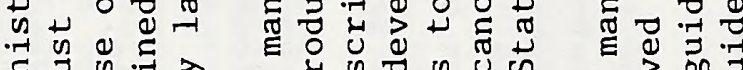
ह गु हE ๙ ठ

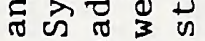
$4=000$

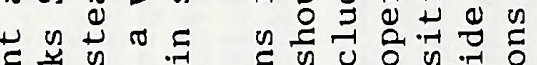

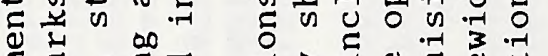

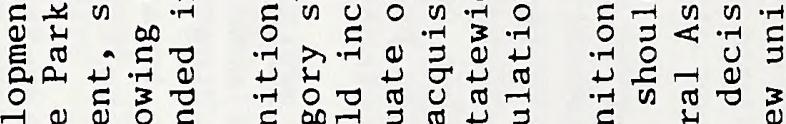
0

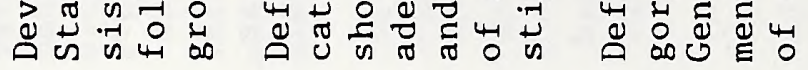
$\stackrel{\ddot{n}}{\stackrel{n}{\mapsto}}$

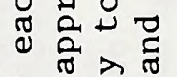

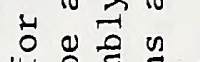
(1) ¿ $\exists$ 舟

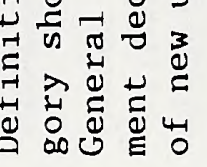
$\ddot{\stackrel{i}{n}}$

严 $\stackrel{\ddot{0}}{\ddot{1}}$

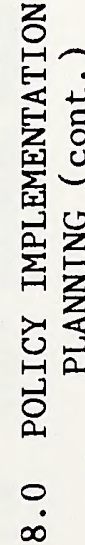


$\stackrel{\infty}{\sim}$

$\underset{n}{n}$

an

$\overrightarrow{6}$

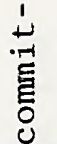

$\stackrel{0}{0}$

离司

छ் ते

$\rightarrow \rightarrow$

ฯ $\backsim$ 范?

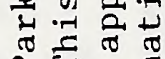

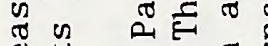

选 $\frac{x}{\pi}$

D. . .

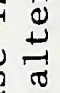

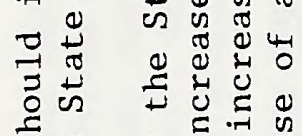

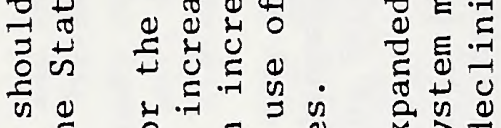

ป

出

岃

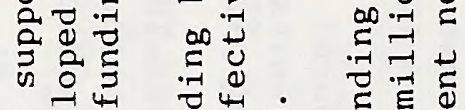

出出 出 出出

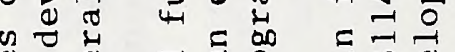

ब 0 व

\&

כू

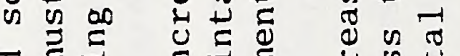

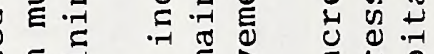

앙

गृ

స్

ช

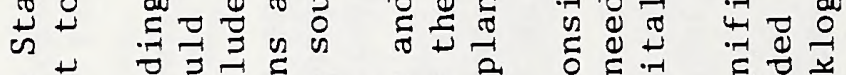

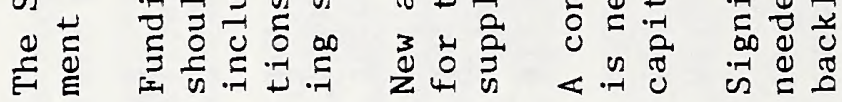

$\begin{array}{lllll}\ddot{r} & \ddot{1} & \ddot{r} & \ddot{T} & \ddot{0} \\ \dot{1} & > & \stackrel{1}{H} & \ddot{H}\end{array}$

惥

잉

겅 烝

空䆨

芠

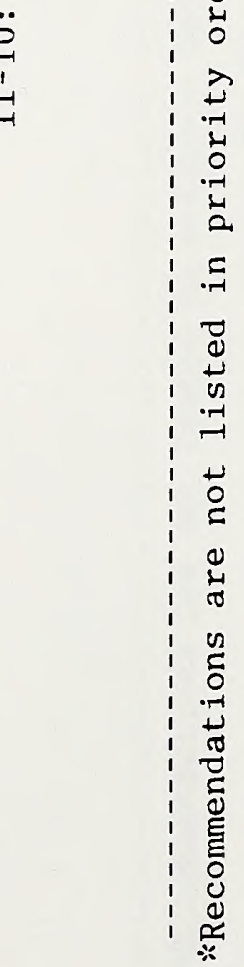




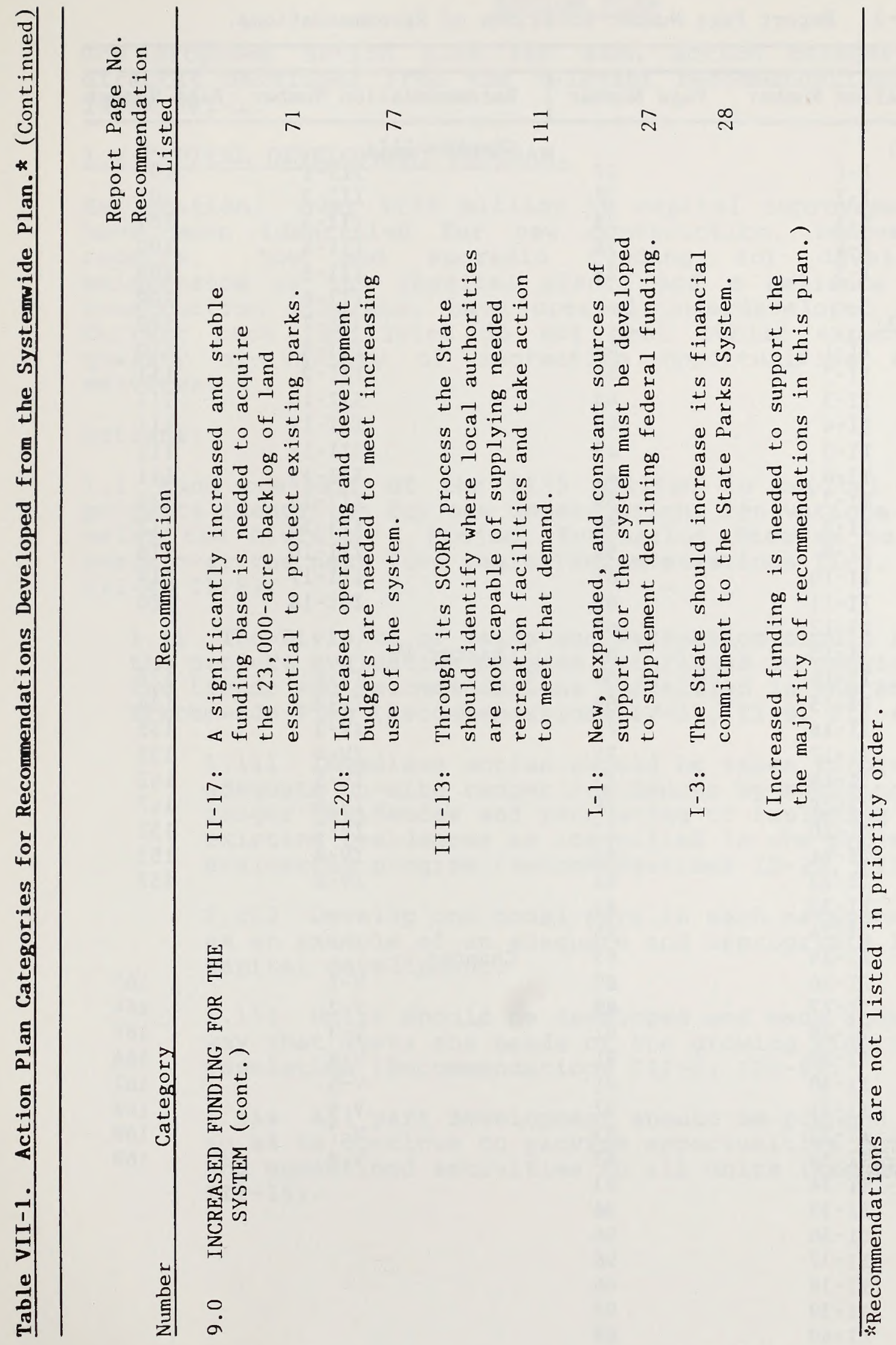


Table VII-2. Report Page Number Locations of Recommendations.

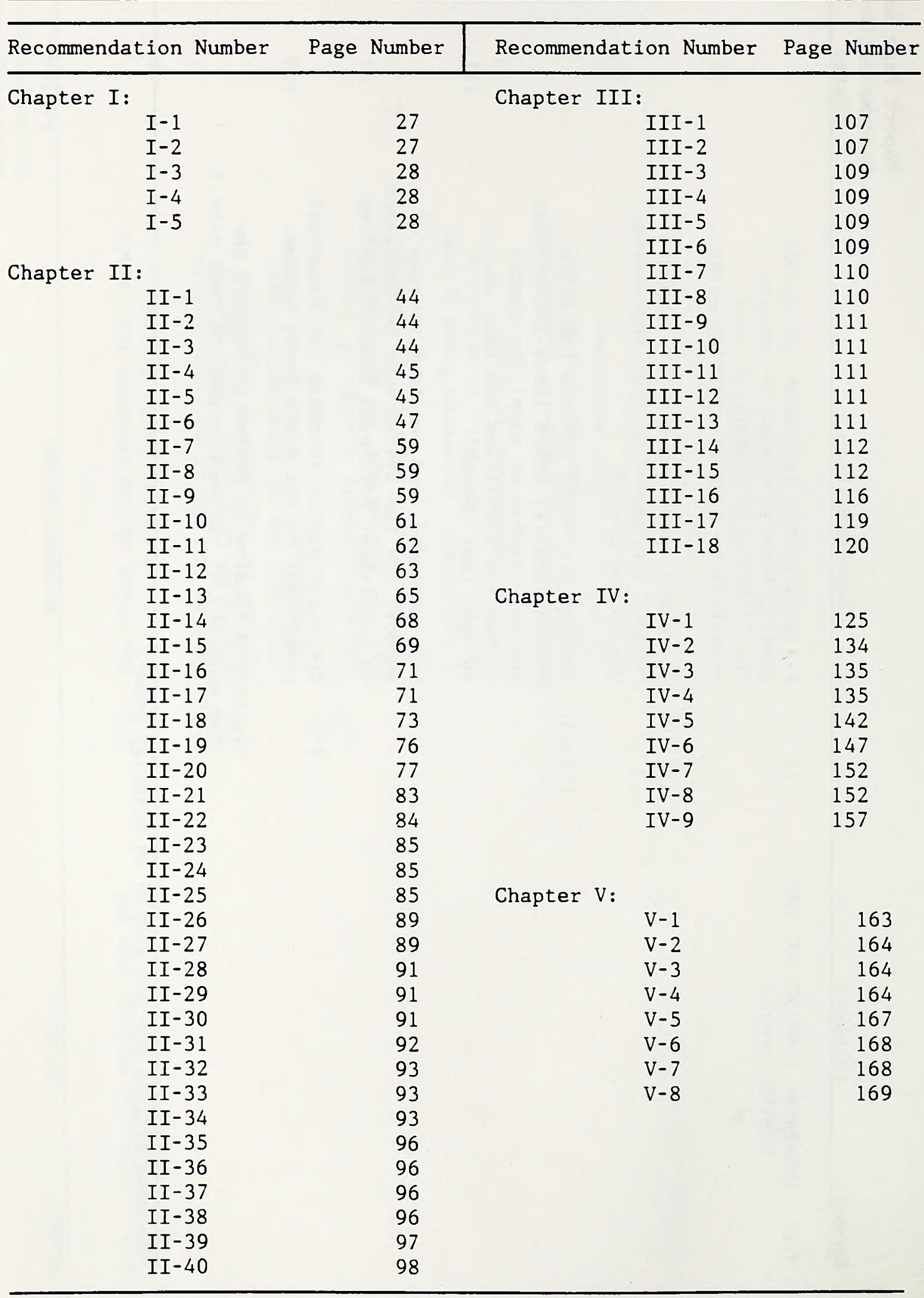




\section{ACTION PLAN}

The proposed action plan for each action category has been directly developed from the relevant recommendations listed in Table VII-1.

\subsection{CAPITAL DEVELOPMENT PROGRAM.}

Explanation: Over $\$ 135$ million in capital improvement projects have been identified for new construction, renovations, and repairs. Low and sporadic funding for development and maintenance of the physical plant, and a reliance on federal construction programs, have created underdeveloped park units. Current park facilities do not meet public expectations for quality or variety of recreation opportunities and visitor services.

Actions :

1.1 Fund one-half of the $\$ 135$ million in capital improvement projects identified for new construction, renovations and repairs using the Division's Project Evaluation Program to prioritize needs over the next five years (Recommendations II-6, V-2, III-1, III-4, II-8).

1.11 The Division of Parks and Recreation should re-evaluate the project evaluation program priorities in consideration of the trends and recommendations identified in the state Parks Systemwide Plan (Recommendations IV-13, II-8, III-4).

1.111 Immediate action should be taken to provide adequate on-site ranger residences by building 38 new ranger residences and renovating or replacing inadequate existing residences as identified in the project evaluation program (Recommendations II-27, III-8, II-8).

1.112 Develop one model park in each management category as an example of an adequate and appropriate level of capital development.

1.113 Units should be developed and made accessible in a way that meets the needs of the growing elderly population (Recommendations III-6, III-8).

1.114 All park development should be planned and built so as to continue to provide opportunities for primitive and unconfined activities in all units (Recommendation III-15). 


\subsection{CAPITAL DEVELOPMENT PROGRAM. (Continued)}

1.115 Park use areas such as campground and picnic areas should serve the growing number of families with young children by providing play areas and equipment located unobtrusively and built to blend in with the natural setting. (Recommendations II-6, V-2, III-1, III-8).

1.116 Recreation areas should be designed to support opportunities for a wide range of recreation activities and equipment (Recommendations II- $6, \mathrm{~V}-2$, III-1).

1.12 Increase design and development staffing to support the accelerated capital development program.

1.13 Increase the efficiency of the capital improvement process by eliminating expensive and timely review requirements of the State Construction Process and increasing in-house professional staff and technical resources

(Recommendation II-11).

1.2 Encourage concessions to operate appropriate recreation facilities (Recommendations II-28, II-29, II-30).

\subsection{Prepare a systemwide feasibility study of potential} concession operations. Emphasis should be placed upon activities supporting information and education that promotes pride and understanding in the natural heritage of the state (Recommendations II-28, II-29, II-30).

\subsection{EXPANSION OF THE NORTH CAROLINA STATE PARKS SYSTEM.}

Explanation: The system must be approximately doubled in size to fulfill its legislated mandate to protect representative examples of unique archaeologic, geologic, recreational, scenic, and biological resources. Some of the most recent additions to the system have been of questionable statewide significance. Future additions should follow recommendations developed from professional analysis, be subject to legislative approval, and be associated with adequate authorization and appropriation for operation, development, and acquisition. Expansion of the system should follow the realization of adequate support for operation, development, and acquisition of the existing system as recommended by the state Auditor's Report, the Third state Park Study Commission, and existing Park Principles.

Actions:

2.1 Expansion of the system must adhere to stipulations of the State Parks Act including an evaluation of the proposed unit's contribution to preserving significant resources, legislative approval for the addition, and adequate authorization and appropriation for operation, development, and acquisition (Recommendations I-2, III-17, III-18,). 


\subsection{EXPANSION OF THE NORTH CAROLINA STATE PARK SYSTEM. (cont.)}

2.11 The Division should prepare a report on the process and study items to be included in feasibility studies of proposed additions to the State Parks System (Recommendations I-2, III-17, III-18).

2.12 In order to improve the system, new units must be of a level of significance indicative of the existing units having the greatest statewide significance (Recommendations IV-10, III-18, I-2).

2.13 The system should be expanded to preserve, at a minimum, representative examples of 92 unique biologic, geologic, scenic, recreational, and archaeologic themes (Recommendation IV -1$)$.

2.14 Water based recreation areas should be provided in proximity to major metropolitan areas. The greatest current deficiency exists in the Triad area. These units must be diverse enough to support a broad spectrum of outdoor recreation activities (Recommendation III-7, II-6).

2.15 State Parks System expansion intended to protect significant archaeologic values should follow the priorities listed in Table IV-34 (Recommendation IV-2).

2.16 State Parks System expansion intended to protect significant biologic values should follow the priorities Iisted in Table IV-36 (Recommendation IV-5).

2.17 State Parks System expansion intended to protect significant geologic resources should follow the priorities Iisted in Table IV-38 (Recommendation IV- 6 ).

2.18 State Parks System expansion intended to protect significant recreation resources should follow the priorities Iisted in Table IV-40 (Recommendation IV-8).

2.19 State Parks System expansion intended to protect significant scenic resources should follow the priorities Iisted in Table IV-42 (Recommendation IV-8).

2.2 Through its SCORP process, the state should identify where local authorities are not capable of supplying needed facilities and take action to meet that demand (Recommendation III-13).

2.21 The recommendations of the President's Commission on Americans outdoors to establish an LWCF trust fund should be advocated by the state.

2.211 To fully benefit from matching funds proposed by the President's Commission on Americans outdoors, the state should establish a program similar to the LWCF program to support municipal and county recreation and conservation needs as recommended by the Fourth State Park Study Commission. 


\subsection{EXPANSION OF THE NORTH CAROLINA STATE PARK SYSTEM. (cont.)}

2.3 The state Trail system should be expanded to meet the southeastern states' standard (Recommendations II-1, II-2, II-3).

2.31 Establish a land acquisition reserve fund to support immediate response to opportunities provided by railway abandonments (II-2).

2.32 Complete the Mountains to Sea Trail (Recommendation (I -3$)$.

2.4 Double the number of units within the Natural and Scenic Rivers Program (Recommendation II-4).

2.41 Review Natural and Scenic Rivers legislation and make recommendations for revision (II-5).

2.42 Prepare a statewide assessment of rivers with

a prioritization of river segments to be included in the system.

2.43 Provide staffing and support for the Natural and Scenic Rivers Program.

\subsection{NATURAL RESOURCE PROTECTION.}

Explanation: Existing parks are threatened by inholdings, lack of access, overuse of inadequately developed facilities, insufficient buffers, and inadequate land to protect park resources. Such critical acres need to be acquired expeditiously. Other land acquisition is also needed at existing parks to finish the parks. Outstanding resources not adequately protected by the system need to be identified and targeted for acquisition. Additions to the system should be adequately funded. Trained staff should implement sound resource management programs. Adequate resource management and planning personnel are needed.

Actions :

3.1 Acquire sufficient land to protect the State's outstanding biologic, archaeologic, recreational, scenic, and geologic resources (Recommendations $\mathrm{V}-3, \mathrm{~V}-5$, III-17).

3.11 Complete acquisition of critical acres for existing park units (Areas acquired to complete the purchase of primary resources for which a park was established, to protect a park's scenic quality, to protect a park's watershed, to provide land for development, to eliminate inholdings, to protect habitat, to provide buffer, and to protect park entrances) (Recommendations II-17, V-3, V-5).

3.12 Complete acquisition of one quarter of the land needed to complete existing park units as per master plan

(Recommendations II-17, V-3). 


\subsection{NATURAL RESOURCE PROTECTION. (continued)}

3.2 Develop a comprehensive resource management program which would include adequate staffing, resource management training, identification and marking of park boundaries, and implementation of resource management plans (Recommendations V-5, II-14, II-6, III-14).

3.21 Develop park by park resource management plans on a 5-year cycle. (Recommendation V-5, II-14, II-6, III-14).

3.22 Provide staffing and support necessary to provide one full-time natural resource scientist in three of the district offices (Recommendations II-14, V-5).

3.23 Develop and increase resource management training. (Recommendations V-5, III-14).

3.231 Provide basic resource management training to all new personnel and existing staff over biennium.

3.232 Provide advanced natural resource management training to park superintendents.

3.233 Provide training in boundary management to all field staff.

3.24 Identify and mark park boundaries. (Recommendation II-15).

3.241 Contract Surveys.

3.242 Update and mark boundaries.

\subsection{PROGRAMMING.}

Explanation: One of the primary missions of the state Parks System is to promote pride and understanding in the state's natural heritage. Lack of facilities, park information, interpretative supplies and equipment, exhibits and displays, and interpretative staff have severely limited interpretative and educational programs.

Actions:

4.1 Initiate a long term capital improvement program aimed at providing basic visitor services facilities for all units following needs as they are identified on the Project Evaluation Program (Recommendations III-5, III-4, IV-20, II-40, III-2).

4.11 Immediately construct one environmental education center in each district (Recommendations III-4, V-7, III-3).

4.2 Develop and print complete and accurate park information brochures for all units (Recommendations IV-20, V-7, III-2). 
4.0 PROGRAMMING. (continued)

4.21 Develop and print a general information brochure for each park unit (III-2, V-7).

4.22 Develop and print specialized brochures such as trail maps and program schedules for each unit (Recommendations IV-20, V-7, III-2).

4.3 Add adequate numbers of maintenance and clerical staff (at least one for every operated unit) so rangers can concentrate on visitor services and natural resource management (Recommendations III-4, V-2, III-2).

4.4 Expand trailside and museum exhibits.

4.41 Upgrade and add trailside exhibits at five parks annually (Recommendations V-7, III-2, III-14).

4.42 Renovate six existing museum exhibits (Recommendation III-8).

4.43 Provide exhibits with newly constructed environmental education centers (Recommendations V-7, III-2, III-14)

4.5 Provide visitors and school classes with increased interpretative programming in parks (Recommendations II-6, II-40, $\mathrm{V}-2)$.

4.51 Provide expanded training for rangers in interpretative and educational skills, techniques, and programs

(Recommendations IV-20, V-7, III-2).

4.52 Provide each park with adequate interpretative and educational supplies and equipment (Recommendations III-4, $\mathrm{V}-7)$.

4.53 Encourage teacher training opportunities on how to best use the State Parks System as outdoor environmental classrooms (III-5, II-40).

\subsection{Repair and Maintenance.}

Explanation: Inadequate preventative maintenance staffing and funding has resulted in a $\$ 3.8$ million backlog in building repair and maintenance needs. Support for a comprehensive repair and maintenance program is necessary to protect the public's $\$ 330$ million investment in the existing State Parks System.

Actions :

5.1 Perform all repair and maintenance projects necessary to immediately correct the $\$ 3,048,913$ backlog of critical and serious needs (Recommendations II -13 , III-16). 
5.2 Implement a comprehensive preventative maintenance program to eliminate the backlog of repair needs and protect the public's investment (Recommendations II-12).

5.21 Place a minimum of one full time maintenance position in each operational unit (Recommendations II-12, III-16).

5.22 Stable and adequate funding must be provided to support preventative maintenance. Units with greater development will need more than one maintenance position (II-12, V-8, III-16).

\subsection{EXPANSION OF FIELD STAFF.}

Explanation: Park staff levels are below minimum standards necessary to provide visitor services and resource management. Rangers are forced to perform inappropriate primary custodial duties in lieu of providing information/education programs, safeguarding the public safety, and protecting park resources. Staff levels at other southeastern state park systems have twice as many rangers. Field staff positions have job classifications and pay scales which do not reflect their skill, level of responsibility, and commitment.

\section{Actions:}

6.1 Add approximately 60 staff positions in order to move halfway toward the standard of care set by southeastern state park systems over the next five years (Recommendations II-22, $V-4$, II-23, II-19).

6.11 Immediate action should be taken to provide park superintendents at Jockey's Ridge, Lake Waccamaw, Fort Fisher, and New River (Recommendation II-23).

6.12 Immediate action should be taken to provide at least three rangers in every operational unit. (Recommendation II -24 ).

6.13 Over the next five years one full time clerical and one full time maintenance worker should be provided in all operational units (Recommendation II-25).

6.14 Increase staff positions at state Recreation Areas to meet rising attendance levels (Recommendation II-19, II-30).

6.2 Provide increased support to field staff by reclassifying positions, increasing salaries, improving and providing housing, and promoting career growth (Recommendations II-26, II-27).

6.3 Provide adequate support to expand volunteer efforts (Recommendations II-31, II-32, II-33). 


\subsection{EXPANSION OF FIELD STAFE. (continued)}

6.31 Administer program without decreasing support to other Division programs--provide an appropriated position

(Recommendation II-33).

6.32 Develop an incentives program to recognize volunteer achievements (Recommendation II-32).

6.33 Promote consistent rather than sporadic volunteer support programs.

6.4 Support two staff positions to conduct comprehensive cultural resource surveys and assist in developing accurate interpretative and information programs (Recommendation IV-3).

\subsection{STAFE TRAINING NEEDS.}

Explanation: Adequate staff training must be provided to support the ranger's four major responsibilities: information/education, natural resource management, ranger duties $(e . g .$, wildland and structural fire fighting, law enforcement, search and rescue, first responder), and maintenance.

\section{Actions :}

7.1 Implement a comprehensive training program for state Parks system field staff (Recommendations III-10, IV-11, IV-4).

7.1 Continue current staff training programs in law enforcement (Recommendation III-10). AII new field staff should be required to be certified.

7.2 Continue and expand visitor safety training programs including emergency response and search and rescue. Park superintendents in heavily used parks should receive EMT training (Recommendation III-10).

7.3 Expand the natural resource management training program to provide comprehensive introductory and intermediate courses (Recommendations II-14, III-14, V-4).

7.5 Expand interpretation and education training program for all field staff. Implement a basic, intermediate, and advanced course for completion by all staff over the next five years (Recommendations III-4, V-7, II-40, III-2).

7.6 Implement a staff training program on the principles and procedures of cultural resource management (Recommendation IV -4 ).

7.7 Provide a division training facility in order to support ongoing training programs (Recommendations III-10, IV-11, IV-4). 


\subsection{POLICY IMPLEMENTATION AND PLANNING.}

Explanation: Lacking an overall strategy for the future, new parks have been added to an already overburdened, underdeveloped system without sufficient forethought while existing parks suffer from inadequate support. Comprehensive, systematic planning is needed to drive a consistent and effective improvement in the state parks system. The systemwide plan must be followed by completed and updated master plans, general management plans, resource management plans, and land protection plans for all units.

Actions:

8.1 Legislative study commissions should continue to be appointed until the needs of the existing system are met (Recommendation I-5).

8.2 As part of the current reorganization proposal, all state agencies involved in the preservation and interpretation of public resources should be examined to consider whether consolidation of some or all of the programs would provide a more efficient management structure (Recommendation II-39).

8.3 The systemwide plan should be revised and updated on a five year cycle through thorough analyses incorporating on-going public involvement (Recommendations III-17, I-4,).

8.31 Systemwide management policies must be developed through updating and expansion of the existing principles as a part of this systemwide planning cycle (Recommendations IV-8, II-35, II-36, III-12).

8.311 Policies, including an identification of appropriate recreation uses, must be developed for each management category cited in the state Parks Act (Recommendations III-12, II-18).

8.312 Standards must be developed which prescribe adequate operation, development, and acquisition for each management category cited in the state Parks Act (Recommendation II-18).

8.313 The feasibility of resort parks should be examined in a report submitted to the Governor.

8.314 Legislative approval should be obtained for these policies and standards through amendment to the state Parks Act (Recommendations I-4, II-36). 


\subsection{POLICY IMPLEMENTATION AND PLANNING. (continued)}

8.4 Master plans should be completed and updated for all units (Recommendations II-37, II-38).

8.5 General management plans should be completed for every unit on a five year cycle. The plans should include, at a minimum, a statement of management direction, an analysis of the major resources and facilities on hand, an identification of the unit's relationship to the system, and an identification of appropriate uses (Recommendations III-1, IV-9).

8.51 Operational analyses should be conducted while developing general management plans.

8.6 Provide additional staffing to support development and updating of systemwide plans, master plans, and general management plans.

\subsection{INCREASED FUNDING FOR THE STATE PARKS SYSTEM.}

Explanation: Traditionally low, sporadic funding has resulted in an underdeveloped and poorly maintained state parks system. Funding for park operations is ranked 49 th in the nation on a per capita basis. Pressures from increased attendance and threats to park natural resources cause degradation that goes unmonitored and unresolved. Recommendations from four legislative study commissions and a state auditor's report agree on the critical need for increased and stable funding. Increased support is necessary to fulfill the overall majority of recommendations and actions in this plan.

Actions :

9.1 The commitment to the North Carolina State Parks System should be increased though increased and stable funding of park acquisition, development, and operations (Recommendations I-3, $V-1, I-1$, II-7, II-10, II-17, II-20).

9.11 Create a $\$ 67$ million capital improvement funding source sufficient to build one-half of the projects identified in the Project Evaluation Program. The fund should also support the necessary increase in staff (and staff support) to implement its objectives (Recommendations II-7, II-10, V-1).

9.12 Triple the current operating expenditure per capita of $\$ 1.12$ to match the standard of care and commitment set by southeastern state park systems. Use these funds to support adequate staffing (and staff support) for operation, administration, maintenance, and planning (Recommendation II -20 ). 
9.0 INCREASED FUNDING FOR THE STATE PARKS SYSTEM. (continued)

9.13 Create a land acquisition fund sufficient to purchase one quarter of the 23,000 acres ( $\$ 115$ million estimated value) backlog in land needed to complete and protect existing parks. The funds should also support the necessary increase in staff (and staff support) to implement its objectives (Recommendations II-17, V-1).

9.14 Create a stateside LWCF fund to support expansion of the system and fill municipal and county recreation needs

(Recommendations I-1, III-13, IV-12, V-1). 

The North Carolina State Parks System serves the fourth fastest growing state in the nation. It is charged with protecting the natural heritage of one of the most diverse states in the country. It accommodates over seven million visitors annually. And, it is a state parks system which is in serious trouble.

Historically, the State has never made a strong, continuing commitment to its park system. Following the establishment of the first state park in 1915, North Carolina went for 58 years before appropriating significant funds for expansion, operation, and development of the system. Over sixty percent of the park units within the system have been added in a piecemeal, unplanned fashion through donation and federal government assistance. This assistance, in itself, created significant problems as it supported land acquisition without continuing funding for operation, renovation, repair, and maintenance. As new units have been added without adequate support, either operational budgets were further stretched to cover them or the additional acreage has been left unmanaged and forgotten.

Until recently, statutory law establishing policy for the development of a comprehensive state park system did not exist. Rather, with each new administration, policies, direction, and personnel have been subject to change. The system has suffered from a lack of definition of what it is and what it should be. A consistent course of action for expansion and improvement of the system has not be chartered and followed.

As a result of inadequate and sporadic funding, the backlog of needs for the North Carolina State Parks System staggers the uninitiated. Capital improvements totaling $\$ 135$ miliion are needed for new construction and renovation in order to complete existing units as they were planned. There is a backlog of $\$ 4$ million in repair needs with $\$ 3$ million of that being labelled "critical" and "serious" by independent, professional engineers. Land acquisition needs to complete and protect the current system reach into the tens of millions of dollars.

Most pressing is the day-to-day operation of park units. Field staff are often overwhelmed and frustrated by the number of park visitors and the inability to protect park resources from internal and external threats. Many of the operated units do not have enough staff to meet minimum standards. Several units are left without park superintendents. Some units have no staffing at all. What should be proactive management protecting the state's significant natural heritage while providing education-and-information programs has degenerated into custodial management which attempts to "keep the lid on" often impossible situations. 
Meanwhile, trends indicate that use and public expectations of the state Parks system will continue to escalate. An aging population will want better quality facilities with easier park access. "Baby-boomer" couples will expect appropriate outdoor recreation opportunities for their young children. An increasingly cosmopolitan population will demand higher quality parks providing recreational opportunities close to home. Special interest groups representing activity-specific park uses, environmentalists, and the elderly are likely to become more influential in advocating well-defined, sometimes conflicting, demands upon park and recreation resources. All of this will be occurring in the face of significantly decreasing federal assistance, something the state has relied upon in the past.

With the State's rapidly expanding development, adequate protection of the natural heritage of North Carolina is still lacking. The majority of significant archaeologic, geologic, recreational, scenic, and biologic themes remain unprotected. On average, an analysis of these themes indicates that the State Parks system is approximately $50 \%$ complete. In the meantime, land values continue to escalate at a rate that puts some significant acquisition needs beyond the reach of adequate protection.

Through public input and comment on this systemwide plan, North Carolinians have indicated that they want more parks. They want parks which provide a greater amount of recreational opportunities with information-and-education programs. They ask for adequate protection of the State's natural heritage, increased staffing levels, and decent park facilities. More than anything else, the citizens of North Carolina demand better parks.

Over the last two decades several significant efforts have been made to promote the needs of the State Parks System. The hopes and aspirations of these efforts become clear in the report titles such as "Now or Never" and "New Directions." Five legislative study commissions have examined the state Parks System and made recommendations for improvements. Although these efforts have met with some success, in particular two major land acquisition appropriations, the majority of their recommendations have languished. Without a stable and adequate funding base, the public investment cannot be adequately protected. Responsible management should not allow this to continue.

There is a building momentum for dramatic, definitive action. Jokes about "selling off" one unit to support the remainder of the system now gain more serious attention. Management recognizes that it cannot provide the protection of park resources and support visitor services that, from a professional perspective, are essential. Dramatic actions are called for.

In the near future two scenarios for the system may be drawn. 
Scenario one -- Current Funding Levels Maintained: The system will continue in decline. Custodial management will degrade into minimal operations necessary to protect vital public safety concerns. The aging physical plant, piece by piece, will be closed as liability concerns pattern park operation decisions. Increasing encroachment will compromise park units, particularly unoperated units or those near urban areas. Staff turnover rates will continue to accelerate. Responsible management will be forced to consider closure or transfer of some park units in order to provide increased operational budgets for the remainder.

Scenario Two -- Increase Operational Funding to Meet the Southeastern Average and Provide a Major Capital Improvement Program: Funding the North Carolina state Parks System at the southeastern per capita average would provide a nearly threefold increase in the Division's annual budget. This would support a steady and continual improvement in the existing system by providing adequate staffing (approximately double the current number) and sufficient repair and maintenance budgets. Five million dollars would be available annually to address the $\$ 115$ million backlog in land acquisition needed to protect existing parks. A major capital improvement funding package of $\$ 70$ million would provide decent facilities in one half of the parks. Funds for expansion of the system would not be available.

...We believe future funding strategies should be long term and comprehensive. The funding process should recognize the relative importance of the system's multiple needs in order to provide for balance in addressing deficiencies. Under such a program, management could annually identify the priority needs for each area of the system and work with the General Assembly on the allocation of available funds....

\section{State Auditors Report}

North Carolina is an exciting state with a bright future. Many components of its natural heritage are internationally recognized. Protection of the vast majority of the state's natural heritage is left to the state Parks System--a system which is commonly recognized as one of the poorest supported in the nation by any number of measures including per capita funding, staffing ratios, and expenditures per visitor. Significant increases in support are necessary to bring the system up to a level of operation indicative of the pride of North Carolinians. Realization of the actions developed by this plan will enable the state Parks System to boldly move into the next century. 

LITERATURE CITED 



\section{IITERATURE CITED}

Americans Outdoors: The Report of the President's Commission. Island Press, Washington, D.C., 1987.

Annual Information Exchange 1987. National Association of State Park Directors. Printed by the National Park Service Denver Service Center. 1987.

Annual Information Exchange 1988. National Association of State Park Directors. Printed by the National Park Service Denver Service Center. 1988.

Cohen, Stan. The Tree Army: A Pictorial History of the Civilian Conservation Corps, 1933-1942. Pictorial Histories Publishing Company, Missoula, Montana, 1980.

de Hart, Allen. North Carolina Hiking Trails, Second Edition. Appalachian Mountain Book Club, Boston, Massachusetts. 1988.

Fuller, Kirk. History of North Carolina State Parks: 1915-1976. Association of Southeast State Park Directors. Histories of Southeast State Park Systems. October, 1977.

McLellan, Gina. "The Future of Outdoor Recreation: What The Trends Tell Us". Parks and Recreation. May, 1986.

North Carolina Board of Transportation, Planning and Research Branch, Transportation Improvement Program, 1988-1996, Department of Transportation, Raleigh, N.C. 1988.

North Carolina Department of Conservation and Development. Biennial Reports from 1926-28 through 1968-70. Raleigh, North Carolina.

North Carolina Department of Conservation and Development. North Carolina State Parks at the Crossroads. Division of State Parks. Raleigh, North Carolina, 1961.

North Carolina Department of Natural Resources and Community Development. Five-Year Plan: 1979-1984. Report for the State Parks Study Commission. Raleigh, North Carolina, Fall, 1978 .

North Carolina Department of Natural Resources and Commuity Development. North Carolina State Parks. NOW or NEVER. Division of State Parks. Raleigh, North Carolina, 1971.

North Carolina Department of Natural Resources and Community Development. Parks and Recreation in North Carolina: 1984. Division of Parks and Recreation, Raleigh, North Carolina. 
North Carolina General Assembly. Study of North Carolina's Use of Federal Land and Water Conservation Funds for Outdoor Recreation: 1973-1978. Fiscal Research Division. Raleigh, North Carolina, July, 1978.

North Carolina General Assembly. Study of State Parks. Fiscal Research Division. Raleigh, North Carolina, December, 1973.

Office of State Budget and Management, North Carolina Long Term Economic-Demographic Projections, Management and Information Services, Raleigh, N.C. 1987.

Office of State Budget and Management, Profile, North Carolina Counties, Update Fall 1987, Management and Information Services, Raleigh, N.C. 1987.

Office of State Budget and Management, 1987 Projection Series, Management and Information Services, Raleigh, N.C. 1987.

Office of State Budget and Management, North Carolina State Government Statistical Abstract, Management and Information Services, Raleigh, N.C. 1984.

Proceedings: 1985 National Outdoor Recreation Trends Symposium II. Sponsored by National Sea Grant College Program, U.S. Forest Service, National Park Service. 1985.

Profile of Older Americans: 1987. American Association of Retired Persons and U.S, Administration on Aging. 1987.

Public Area Recreation Visitor Survey: IMPLAN Economic Analysis Report. U.S. Forest Service, Outdoor Recreation and Wilderness Assessment Group, Southeastern Forest Experiment Station, Athens, Georgia. 1987.

Public Area Recreation Visitor Survey: Standard Descriptive Report. U.S. Forest Service, Outdoor Recreation and Wilderness Assessment Group, Southeastern Forest Experiment Station, Athens, Georgia. 1987.

The President's Commission on Americans outdoors, A Literature Review, U.S. Government Printing office:

1987-175-425/60207, Washington, D.C., December, 1986.

The President's Commission on Americans Outdoors, Report and Recommendations to the President of the United States, U.S. Government Printing Office, Washington, D.C., December, 1986 .

The President's Commission on Americans Outdoors, Working Papers, U.S. Government Printing office: 1987-175-425/6207, Washington, D.C., December, 1986. 
Runkle, John. A Guide to North Carolina State Parks. Tread Softly, 1983.

State Parks and Recreation Areas Study Commission. Report of the State Parks and Recreation Areas Study Commission to the 1987 General Assembly. Raleigh, North Carolina. February, 1987 .

State Parks and State Forests Study Commission. North Carolina State Parks for the Future. Raleigh, North Carolina, January, 1969.

State Parks Study Commission. New Directions: A Plan for the North Carolina State Parks and Recreation System, 1979-1984. Raleigh, North Carolina, January, 1979.

State Parks Study Commission. Report to the 1985 General Assembly of North Carolina. Raleigh, North Carolina, 1985.

Tilden, Freeman. The State Parks: Their Meaning in American Life. Alfred A. Knopf. New York. 1962.

Office of the State Auditor. Performance Audit Report. The Management and Operation of the State Parks System. December, 1987.

State Goals and Policy Board. Report to the Governor. May, 1986. 

IIST OF ABBREVIATIONS 
- 


\section{LIST OF ABBREVIATIONS}

Code Park Unit

BAIS: Baldhead Island

BALA: Baytree Lake

BOCA: Boones Cave

BULA: Bushy Lake

CABE: Carolina Beach

CHSW: Chowan Swamp

CLNE: Cliffs of the Neuse

CRMO: Crowders Mountain

DISW: Dismal Swamp

DUPO: Duke Power

ENRI: Eno River

FALA: Falls Lake

FOFI: Fort Fisher

FOMA: Fort Macon

GOCR: Goose Creek

HABE: Hammocks Beach

HARO: Hanging Rock

HEBL: Hemlock Bluffs

HORI: Horsepasture River

JORI : Jockey's Ridge

JONE: Jones Lake

JORD: Jordan Lake

KELA: Kerr Lake

LAJA: Lake James

LAWA: Lake Waccamaw

LIRI: Linville River

MAIS: Masonboro Island

MEMO: Medoc Mountain

MEMI : Merchants Millpond

MIMI: Mitchells Mill

MOMO: Morrow Mountain

MOJE: Mount Jefferson

MOMI: Mount Mitchell

NERI: New River

PETT: Pettigrew

PIMO: Pilot Mountain

RARO: Raven Rock

SALA: Salters Lake

SILA: Singletary Lake

SOMO: South Mountain

STMO: Stone Mountain

THRO: Theodore Roosevelt

WAYN : Waynesborough

WEWO: Weymouth Woods

WHLA: White Lake

WIUM: William B. Umstead 


\section{List of Abbreviations (Continued).}

CCC: Civilian Conservation Corps.

FIIP: Facility and Inspection Improvement Program. An inventory of buildings in park units to identify maintenance, repair, and renovation needs. Does not include water, sewer, and road systems.

LWCF: Land and Water Conservation Fund.

MOMS: Maintenance and Operations Management System. A computerized system which inventories all maintenance needs and reports out daily maintenance work elements for staff to complete.

MST: Mountains to Sea Trail.

NPS: National Park Service.

PARVS: Public Area Recreation Visitor Survey. An intergovernmental cooperative research project which identified expenditure, travel, activity, and demographic characteristics of State Park System visitors.

PEP: Project Evaluation Program. Uncompleted capital improvement projects identified on existing master plans were ranked by need.

SCORP: State Comprehensive Outdoor Recreation Plan.

System: The North Carolina State Parks System which includes State parks, State lakes, State recreation areas, State natural areas, State trails, and state rivers.

WPA: Work Projects Administration. 

APPENDICES 
- nan 
Appendix I

Public Comment on the Drait of the Systemwide Plan and Response 


\section{PUBLIC COMMENT PROCESS}

The State Parks Act stipulates that the plan be developed with full public participation including a public meeting to review the draft plan prepared by the secretary before he adopts the plan. A public hearing to obtain comments regarding the draft plan was held on November 30,1988 in Raleigh. All comments, statements, and information submitted in writing prior to, during, or within seven days after the hearing or presented orally at the hearing were accepted. The comments were reviewed and summarized for inclusion in the plan. Responses were developed for all comments and the plan was amended as needed.

To initiate the public comment process, the Division of Parks and Recreation distributed 300 copies of the draft plan. The draft was available for public review at all operated state Parks System units as well as the seven NRCD regional offices. Statewide press releases announced the public hearing and the location of review copies. Every person attending one of the seven public workshops held in the Spring, 1988 was mailed an individual notification of the hearing. Review copies of the draft were also mailed to the following groups: the state Park and Recreation Area Study Commission, the Park and Recreation Council, the Trails committee, interested groups or individuals, Systemwide Plan Resource Evaluation Committees, and related public agencies. 
I. PUBLIC TESTIMONY SUMMARIZED FROM THE NOVEMBER 30,1988 PUBLIC HEARING.

\section{Comments of Mr. Charles Norwood}

1. Comment: I was surprised and shocked with the report on waynesborough Park which contained inaccurate information on a recommendation to delete the park.

Response: Recommendation IV-10 which referred to Waynesborough Park has been deleted. While the recommendation was based on the ranking of committees, responding to the critical lack of support for the system should have proposed a more comprehensive strategy.

\section{Comments of $\mathrm{Mr}$. John Dees}

1. Comment: Waynesborough Park has historic significance because Waynesborough was incorporated in 1787, served as a stagecoach stop, and a steamboat landing. The plan is incorrect in stating the size of Waynesborough Park as 138 acres; the park includes 205 acres.

Response: The state currently has deeds for 142 acres at waynesborough Park. The park profile has been corrected to reflect the historical importance of the area.

2. Comment: The landfill encompasses only 50 acres of the park site.

Response: The Waynesborough Park profile has been corrected to state the size of the landfill.

3. Comment: We object to the comment that the park has no buffer from urban development. The four lane highway bordering the park provides easy access for visitors.

Response: Park "Principles" call for natural settings that are buffered from man-made activities such as four lane highways.

4. Comment: We are distressed that our views weren't sought in the preparation of this report.

Response: Seven public hearings were held during Spring, 1988 to receive public input on the recreation needs of the public to be met by the State Parks system. The meetings were advertised 
statewide and are reported in Chapter $V$.

\section{Comments of $\mathrm{Mr}$. Bob Conner}

1. Comment: There is no clear definition of recreation.

Response: Recreation themes used in Chapter IV are defined in the Appendix IV-2. Action 8.311 recommends that a policy on appropriate uses for each management category in the state Parks Act must be developed. Action 8.314 states that this policy should be approved by the legislature.

2. Comment: "Management area" should be defined and clarified.

Response: "Management area" or "category" refers to the different types of sites identified in the State Parks Act as comprising the system: State parks, State natural areas, state recreation areas, state trails, state rivers, and state lakes.

3. Comment: The need for water activities near urban areas is overemphasized and ignores the current resources available to most major cities in the state.

Response: Water-related activities continue to be among the most popular outdoor recreation activities. The variety of popular water-related activities is growing as well. Three of the ten activities that have experienced the greatest increases in popularity in the past twenty-five years are canoeing, sailing, and water skiing. Trend information also demonstrates that most families recreate close to home during weekends rather than traditional two-week summer vacation to a distant location.

4. Comment: The state Parks system should be designed and promoted to serve North Carolina residents instead of tourists. The parks are already over used.

Response: Surrounding states provide greater support for their state parks and attract park users from other states. Degradation of park resources is recognized in the report. 


\section{Comments of Gus Anderson}

1. Comment: The emphasis on interpretation and education in the State Parks System should not take precedence over land acquisition and improving facilities.

Response: The State Parks Act states that the parks are to be used "to promote pride and understanding in the natural heritage of this State." The system must provide interpretation and education to fulfill its legal mandate.

2. Comment: Locate park development on the park perimeter and save large natural areas undisturbed.

Response: The plan does not address the location of facilities but does recommend that all units offer opportunities for primitive experiences (Recommendation III-15).

3. Comment: Locate new reservoirs and active recreation facilities only where a need exists instead of in parks currently preserving natural features. Natural areas are becoming more scarce as North Carolina becomes more urban.

Response: Recreation facility needs presented in the plan are based on master plan recommendations for current parks which largely consist of camping, picnicking, and interpretive facilities. Recreation needs will be considered in locating future facilities

\section{Comments of Jeff Smith}

1. Comment: State parks should preserve natural areas and not provide active recreation such as ballfields. Important natural areas that are critical to existing parks should not remain in private ownership. These areas should be purchased before they are lost.

Response: The plan recommends the purchase of nearly 6,000 acres of additional park land in the next five years. This represents one-fourth of the land currently needed to complete existing park units according to current master plans (Action 3.12).

\section{Comments of Jim Stevens}

1. Comment: The plan should make more reference to 
the American Heritage Trust Fund which was recommended by the President's Commission on Americans Outdoors.

Response: The American Heritage Trust Fund is still being considered by the U.S. Congress. The plan does review the history of LWCF grants to the State Parks System and recommends a similar fund in North Carolina to replace reduced federal funding of the program. The systemwide plan action plan calls for support of the Trust Fund initiative.

\section{Comments of Al Radford}

1. Comment: Don't forget about land acquisition priorities in relation to development priorities. The limited funding available should be directed toward our most outstanding parks as well as filling gaps in the system like in the Uwharrie Mountains and the Roanoke River bottom.

Response: The plan provides a ranking of all current park units based on an evaluation of the resources specified in the state Parks Act. These rankings can be used to identify parks with the most outstanding resources in the system but whether the ranking will be used to establish budget priorities is a policy decision. Chapter IV presents the expansion of the system needed to preserve resource themes described in the plan. The Roanoke River bottom is a brown water river and swamp in the coastal plain region which is identified as a very high expansion need. The Uwharrie region represents the Piedmont/Mountains Rivers and Alluvial Forests theme which is rated as a high priority expansion need.

\section{Comments of Ron Tietgen}

1. Comment: The plan recommends locating recreation facilities only where they are needed. The plan states that the parks are in a shambles and indicated to the legislature how to proceed. The next step is where to get the money. The recreation committee (which evaluated recreation resources for the plan) is saying the same thing you folks are saying here. Don't put a lake where one is not needed and don't build a building in a natural area. Keep parks natural and take those parks that are reported to be disaster areas and repair them. 
Respurse: Park master plans identify $\$ 135$ million worth of new construction and renovation projects for the existing park units. Professional engineers and architects surveyed state Parks System buildings and identified $\$ 3$ million in critical and serious repair needs.

\section{WRITTEN COMMENT SUMMARY}

\section{Synopsis of Comments of Mrs. Lib and Mr. Bob Conner}

1. Comment: We are concerned that recreation and development are mentioned more than acquisition and preservation. We are happy to see the "state Park Principles" included and hope they remain paramount.

Response: Chapter II documents both capital improvement and land acquisition needs. It also indicates that nearly twice as much money has been spent on land acquisition than on capital improvements during the last 15 years. The State Parks Act contains the legal mandate of the state Parks System.

2. Comment: We are concerned by Action 1.115 recommending playground equipment and Action 1.2 encouraging concessions. Children should learn about nature early in their lives through experiences in State Parks. Concessions should emphasize education and interpretation as stated in Action 1.21 .

Response: Playground equipment is currently provided in State recreation areas. Play equipment made of natural materials can be located unobtrusively and can help direct the energy of children away from harming natural resources. Action 1.115 will be amended to read, "Park use areas such as campground and picnic areas should serve the growing number of families with young children by providing play areas and equipment located unobtrusively and built to blend with the natural setting." The Eastern National Park and Monument Association operates a bookstore at Fort Macon State Park selling park-related literature which enhances the interpretation and education program at the park. Action 1.2(page VII-21) will be changed to read "Encourage concessions to operate appropriate recreation facilities while retaining public ownership and control of all park facilities."

3. Comment: Do not develop Recreation Vehicle (RV) facilities as described on page III-23, \#16. 
Response: Recreation vehicles are currently provided electric hookups at two state recreation areas and dump stations are provided at five state parks. However, no recommendation or action in the plan mentions RV facilities specifically.

4. Comment: We oppose resort parks in the state Parks system because private enterprise will develop them where they are feasible.

Response: Resort parks were both supported and opposed in the public workshops. The plan does not make a specific recommendation about resort facilities but Action 8.311 states "Policies, including an identification of appropriate recreation uses, must be developed for each management category cited in the state Parks Act." A report investigating the feasibility of resort parks is called for in the plan.

5. Comment: We support recommendation III-15 stating the need to provide parks preserving beautiful and scientifically important land.

Response: This concurs with legislative mandate stated in the state Parks Act.

\section{Comments of Ed Kelly, Waynesborough Task Force}

1. Comment: I was distressed to read the discussion of Waynesborough Park in the plan. Specifically, a master plan for Waynesborough Park was developed in 1985 and revised in 1988 .

Response: The last master plan developed and approved by the Division of Parks and Recreation was developed for Hanging Rock State Park in 1981. The Waynesborough master plan was produced and approved outside the Division of Parks and Recreation.

2. Comment: The evaluation of Waynesborough Park presented in chapter IV is not accurate. Mr. Kelly supplied his own evaluation of the park's significance based on 26 resource themes.

Response: An evaluation of each park was performed by experts on archaeologic, geologic, biologic, recreation and scenic resources. The expert evaluations based on six months of committee analysis are presented in the plan.

Comments of Mr. John Lawrence

1. Comment: A summary of the systemwide Plan highlighting its major conclusion should be produced and widely distributed. 
Response: An executive summary will be drafted in 1989. The State Parks Act mandating the systemwide plan did not give additional staff and support to the Division. Publication of the executive summary is dependent on additional support.

2. Comment: The state should act promptly to implement the actions described in the systemwide Plan to continue North Carolina's high quality of life.

3. Comment: I would like to volunteer to support the implementation of the plan.

\section{Comments of Mr. Edmund McCaffray}

1. Comment: The tidewater region deserves greater attention than the other three regions because it receives only $15 \%$ of the system's operating budget while attracting one-third of all visitors; four Tidewater region park units are not operated; improved transportation routes will attract more visitors to the region; only three units offer popular ocean beaches; and three of the fastest growing counties are in the Tidewater (Dare, Carteret and Brunswick).

Response: Needs for expanding the State Parks System are identified for all four geographic regions in Chapter IV. Specific recommendations are included for adding a superintendent position for two Tidewater parks; Jockey's Ridge and Fort Fisher. The Morehead City and Wilmington areas are identified in Chapter III as receiving greater recreational use in the next five years.

\section{Synopsis of Comments of Mr. Ted Alden Williams}

1. Comment: Mr. Williams supplied numerous comments and questions about the Kerr Lake State Recreation Area park profile.

Response: The comments were taken into consideration in updating the Kerr Lake park profile. 
APPENDIX I-1

STATE PARKS ACT 


\title{
GENERAL ASSEMBLY OF NORTH CAROLINA 1987 SESSION \\ RATIFIED BILL
}

\section{CHAPTER 243 \\ SENATE BILL 425}

\section{AN ACT TO ESTABLISH THE PURPOSES OF THE STATE PARKS SYSTEM.}

The General Assembly of North Carolina enacts:

Section 1. Subchapter II of Chapter 113 of the General Statutes is amended by adding a new Article $2 \mathrm{C}$ to read:

\author{
"Article 2C.
}

"State Parks Act.

"§ 113-44.7. Short title.--This Article shall be known as the State Parks Act.

"§ 113-44.8. Declaration of policy and purpose.--(a) The State of Vorth Carolina offers unique archaeologic. geologic. biological. scenic, and recreational resources. These resources are part of the heritage of the people of this State. The heritage of a people should be preserved and managed by those people for their use and for the use of their visitors and descendants.

(b) The General Assembly finds it appropriate to establish the State Parks Sistem. This system shall consist of parks which include representative examples of the resources sought to be preserved by this Article, together with such surrounding lands as may be appropriate. Park lands are to be used by the people of this State and their visitors in order to promote understanding of and pride in the natural heritage of this State.

(c) The tax dollars of the people of the State should be expended in an efficient and effective manner for the purpose of assuring that the State Parkis Sistem is adequate to accomplish the goals as defined in this Article.

(d) The purpose of this Article is to establish methods and principles for the planned acquisition, development, and operation of State parks.

"§ 113-44.9. Definitions.--As used in this Article, unless the context requires otherwise:

(1) 'Department' means the Department of Natural Resources and Community Development.

(2) 'Park' means any tract of land or body of water comprising part of the State Parks System under this Article, including existing State parks. State natural areas, State recreation areas, State trails, State rivers, and State lakes.

(3) 'Plan' means State Parks System Plan.

(4) 'Secretary' means the Secretary of the Department of Natural Resources and Community Development.

(5) 'State Parks System' or 'system' mean all those lands and waters which comprise the parks system of the State as established under this Article.

"§ 113-44.10. Powers of the Secretary.--The Secretary shall implement the provisions of this Article and shall be responsible for the administration of the State - Parks System. 
"§ 113-44.11. Preparation of a System Plan.--(a) The Secretary shall prepare and adopt a State Parks System Plan by December 31, 1988. The Plan, at a minimum. shall:

(1) Outline a method whereby the mission and purposes of the State Parks System as defined in G.S. 113-44.8 can be achieved in a reasomable. timely. and cost-effective manner:

(2) Evaluate existing parks against these standards to determine their statewide significance;

(3) Identify duplications and deficiencies in the current State Parks System and make recommendations for correction:

(4) Describe the resources of the existing State Parks System and their current uses, identify conflicts created by those uses, and propose solutions to them: and

(5) Describe anticipated trends in usage of the State Parks System, detail what impacts these trends may have on the State Parks System, and recommend means and methods to accommodate those trends successfully.

(b) The Plan shall be developed with full public participation. including a series of public meetings held on adequate notice under rules which shall be adopted by the Secretary. The purpose of the public meetings and other public participation shall be to obtain from the public:

(1) Vieus and information on the needs of the public for recreational resources in the State Parks System:

(2) Vieus and information on the manner in which these needs should be addressed:

(3) Revieu of the draft plan prepared by the Secretary before he adopts the Plan.

(c) The Secretary shall revise the Plan at intervals not exceeding five years. Revisions to the Plan shall be made consistent with and under the rules providing public participation in adoption of the Plan.

"§ 113-44.12. Classification of parks resources.--After adopting the Plan. the Secretary shall identify and classify the major resources of each of the parks in the State Parks System. in order to establish the major purpose or purposes of each of the parks, consistent with the Plan and the purposes of this Article.

"§ 113-44.13. General management plans.--Every park classified pursuant to G.S. 113-44.12 shall have a general management plan. The plan shall include a statement of purpose for the park based upon its relationship to the System Plan and its classification. An analysis of the major resources and facilities on hand to achieve those purposes shall be completed along with a statement of management direction. The general management plan shall be revised as necessary to comply with the System Plan and to achieve the purposes of this Article.

"§ 113-44.14. Additions to and deletions from the State Parks System.--(a) If, in the course of implementing G.S. 113-44.12 the Secretary determines that the major purposes of a park are not consistent with the purposes of this Article and the Plan. the Secretary may propose to the General Assembly the deletion of that park from the State Parks System. On a majority vote of each house of the General Assembly. the General Assembly may remove the park from the State Parks System. No other agency or governmental body of the State shall have the power to remove a park or any part from the State Parks System.

(b) New parks shall be added to the State Parks System by the Department after authorization by the General Assembly. Each additional park shall be authorized only by an act of the General Assembly. Additions shall be consistent with and shall address the needs of the State Parks System as described in the Plan. All additions 
shall be accompanied by adequate authorization and appropriations for land acquisition, development, and operations."

Sec. 2. This act is effective upon ratification.

June, 1987.

In the General Assembly read three times and ratified this the 2 nd day of

ROEERT R. JORDAN III

Robert B. Jordan III

President of the Senate

LISTON B. RAMSEY

Liston B. Ramsev

Speaker of the House of Representatives 
APPENDIX II-1 PARK PROFILES 
Location: Brunswick County

Size: 10,000 acres of State-owned marshes and upland include Battery Island (55 acres), Bluff Island (65 acres), and East and Bay Beach (240 acres).

\section{Reason for Establishment:}

Smith Island, popularly known as Bald Head, is an island complex containing 12,000 acres of beaches, dunes, maritime forest, salt marshes, fresh water ponds, tidal creeks, bays, and mudflats lying at the mouth of the Cape Fear River. This semi-tropical island, constituting the most southern extent of the State, is also of historical importance. The island is important for its maritime live oak forest and varied fauna and flora which include rare and endangered species.

\section{History of the Natural Area:}

Several proposals for development of Bald Head have been proposed over the years. In the mid-1970s, a compromise settlement of the Bald Head development controversy permitted development of the bulk of the maritime forest by the Bald Head Island Development Corporation. The remainder of the island complex, north of Bald Head and Bald Head Creek to New Inlet, became a State nature preserve and wildlife management area in 1979 with assistance from The Nature Conservancy.

\section{Existing Recreation Opportunities:}

The salt marshes are open to traditional hunting and fishing regulated by the Wildlife Resources Commission. The natural areas receive minimal use with only seasonal visitation by hikers, fishermen, or hunters. The beach area is traditionally used by fishermen during the fall, and campers use Bluff Island sporadically throughout the warm seasons. Battery Island receives very little use except by persons interested in observing bird populations. Its use is probably mainly by residents of the development.

\section{Threats :}

Possible disturbance of colonial nesting birds by visitors on Battery Island. Loss of breeding bird habitat by spoil deposition from maintenance dredging operations by the Army Corps of Engineers. Littering and damage to maritime forest and dune communities by public overuse. Disturbance of nesting loggerhead turtles by visitors. Damage to vegetation by feral animals.

\section{Land Acquisition:}

None planned.

\section{Staffing :}

None

\section{Budget:}

None 


\section{BAY TREE LAKE STATE PARK}

Location: Bladen County

Size: 609 acres of land; ownership claim to 1,418 acres of water.

\section{Reason for Establishment:}

Bay Tree Lake is one of the largest of North Carolina's natural lakes and also one of the shallowest. With its size and location, it is a good recreational resource. It was established to alleviate heavy use pressures and demands from White Lake and Jones Lake.

\section{History of the Park:}

The lake was formerly known as Black Lake. In 1965 the state granted permission to the Bay Lakes Corporation who owned 4,000 acres surrounding the lake to drain it and remove debris from the bottom, making it suitable for swimming, fishing, and boating.

Three thousand units and a marina were planned for the area. A breach in the lake rim rapidly caused it to return to its original condition and color. The state maintains a corridor from the highway to the lake's northwest edge. Bay Tree Lake was added to the system in 1939.

\section{Facilities: None}

\section{Existing Staff:}

Permanent:

No staff
Seasonal:

No Seasonal Staff

\section{Additional Staff Needs:}

Superintendent

Ranger (2)

Clerk Typist

Maintenance Mechanic

Staffing Over Last 10 Years: Park has never been staffed.

\section{Internal Threats:}

Unmarked Boundaries:

Boundaries need to be marked.

Water Quality:

The water quality is being affected by the boat use. 
Bay Tree Lake State Park (Continued)

Fire:

Lack of a control burn program hurts the longleaf pine communities and increases the threat of wildfires. The control of wildfire in the region threatens the natural integrity of the pocosin and sand rim communities which would otherwise be naturally maintained by fire. Fuels are building to dangerous levels in the area. A draft prescribed burning plan has been prepared.

Uncontrolled Access:

The park suffers from indescriminate use due to uncontrollable access.

\section{Externa1 Threats:}

Adjacent Development:

The Bay Tree Lake Corporation is a housing development that provides lake front property for its residents. Since its existence, there has been more development which may increase future problems.

Additional acquisition is needed in order to provide staff with the ability to efficiently and effectively manage the park.

Facility Condition: No data available

\section{Capital Improvements:}

Current Projects: None

Documented Needs: $\$ 335,165$

Projects: Boat access and road improvements

Boundary Marking Status: Approximately 3 miles have been clearly established and marked.

Operating Budget and Attendance Over Last 10 Years: No data available

Repair/Renovation: No data available

1987 Total Park Revenue: No data available 


\section{BOONES CAVE STATE PARK}

Location: Davidson County

Size: 110 acres

\section{Reason for Bstablishment:}

The cave is supposed to have been used as a hideout for Daniel Boone during an Indian attack.

\section{History of the Park:}

It is claimed that Daniel Boone lived nearby at a homesite on US 64 west of Mocksville, and his parents are buried in the Joppa Cemetery of Davie County. Boone married a local girl whose family owned land directly across from the cave. The so-called Squire Boone cabin is located in the park, although it has not been proven that Daniel Boone ever resided there. The area was given to the State by the local historical society and became a State park in 1971 .

\section{Pacilities :}

Canoe reststop for Yadkin River Trail

Picnic area ( 6 tables, 1 shelter)

Trail (1/2 mile, hiking)

\section{Existing Staff:}

Permanent:

No staff
Seasonal

No staff

Minimum Additional Staff Needs:

Ranger (2) 
Boones Cave State Park (Continued)

\section{Staffing Over Last Ten Years:}

Permanent

Seasonal

1977 No data available

No data available

1978 General Laborer

General Laborer was dis-

1979 continued.

Added:

Park Ranger I

1980-82 No change

No change

1983 Park Ranger transferred

1984-86 No change

No change

\section{Internal Threats:}

Thefts:

Due to the lack of staff, there have been many break-ins and thefts at the park buildings.

Vandalism:

The most destruction has occurred to the picnic shelters and the picnic tables in the form of carvings, painting and graffiti.

Trash:

Visitors and local residents ignore the garbage cans and insist on dumping their trash inside the cave.

Top 3 Visitor Impacts Identified by Superintendent:

1. Thefts

2. Vandalism

3. Trash

\section{External Threats:}

None identified. 
Boones Cave State Park (Continued)

\section{Facility Condition:}

There are 5 structures located on the park all needing repair. Safety related problems are:

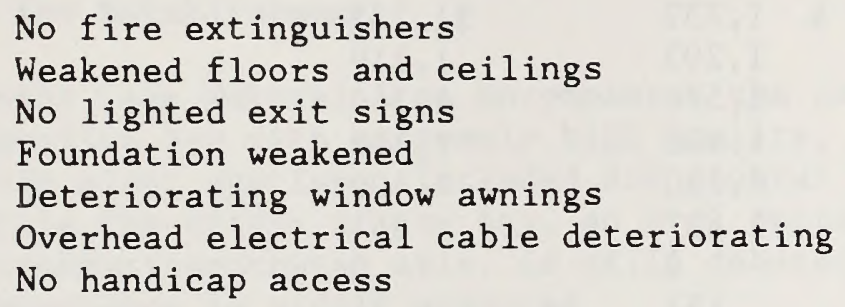

\section{Capital Improvements:}

Current Projects: None

Documented needs: $\$ 93,597$

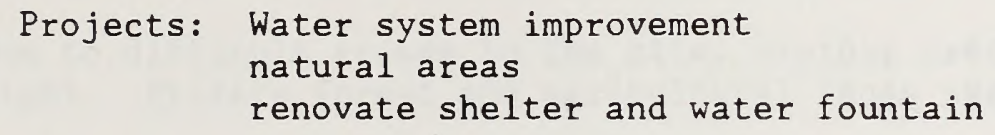

\section{Land Acquisition:}

No current acquisition in progress.

\section{Boundary Marking Status:}

No data available.

\section{Expenditures and Attendance:}

\begin{tabular}{|c|c|c|c|c|}
\hline Year & Attendance (Calendar Yr.) & Current \$ & $\$($ Fiscal Yr.) & $1977 \$ *($ Fiscal \\
\hline 1977 & 0 & & 3,323 & $\$ 3,323$ \\
\hline 1978 & 0 & & 4,544 & 4,227 \\
\hline 1979 & 0 & & 6,567 & 5,589 \\
\hline 1980 & 5,923 & & 5,110 & 3,319 \\
\hline 1981 & 19,446 & & 19,579 & 13,856 \\
\hline 1982 & 19,315 & & 18,479 & 12,222 \\
\hline 1983 & 19,823 & & 18,757 & 11,849 \\
\hline 1984 & 21,670 & & 18,757 & 11,286 \\
\hline 1985 & 24,084 & & 20,589 & 11,799 \\
\hline 1986 & 27,067 & & 22,076 & 12,237 \\
\hline 1987 & 24,727 & & 23,380 & 12,390 \\
\hline 1988 & & & 3,189 & 1,620 \\
\hline
\end{tabular}


Boones Cave State Park (Continued)

Repair and Renovations:

\begin{tabular}{|c|c|c|}
\hline Fiscal Year & Current \$ & $1977 \$ *$ \\
\hline 1977 & 1,232 & $\$ 1,232$ \\
\hline 1978 & 1,203 & 1,119 \\
\hline 1979 & 1,574 & 1,340 \\
\hline 1980 & 1,908 & 1,463 \\
\hline 1981 & 6,230 & 4,409 \\
\hline 1982 & 1,307 & 864 \\
\hline 1983 & 0 & 0 \\
\hline 1984 & 157 & 94 \\
\hline 1985 & 32 & 18 \\
\hline 1986 & 48 & 26 \\
\hline
\end{tabular}

*1977 budget figures are adjusted to reflect inflation and are shown in 1977 dollars. Source: Office of State Budget.

Total Park Revenue: FY 1987: \$0

FY 1988: \$0 


\section{BUSHY LAKE NATURAL AREA}

Location: Cumberland County

Size: 1,341 acres

\section{Reason for Establishment:}

Bushy Lake Natural Area encompasses the central section of a large Carolina Bay with extremely high quality, rare natural communities and rare plant species. Included are several rare plant and animal species. While the origin of the bay, an oval depression oriented on a northeast-southwest axis, is still debated, the geological and biological importance is widely accepted.

\section{History of the Natural Area:}

Bushy Lake became a State natural area in 1970. The area, owned by the State, was allocated to State Parks in 1977.

\section{Existing Recreation Use:}

Due to difficult access to the site, visitor use of the area is very light. Private forest and agricultural lands surround the natural area.

\section{Threats:}

Selective cutting around the lake margin on private land and pesticide/herbicide drift from adjacent agricultural fields threaten water quality and aesthetics. A variety of private owners own much of the protective sand rim. As presently constituted, the Bushy Lake Natural Area provides limited protection to the vegetation and rare species found there.

\section{Land Acquisition:}

Land acquisition needs at Bushy Lake are currently being evaluated. Two hundred and ten critical acres have already been identified in the current land acquisition program. Additional acquisition, estimated at 800 acres, will be needed to complete protection of the sand rim.

\section{Staffing:}

None

\section{Budget:}

None 


\section{CAROLINA BEACH STATE PARK}

Location: New Hanover County

Size: 1,773 acres

\section{Reason for Establishment:}

The area is known for its many insectivorous plants including the Pitcher Plant, Bladderwort, Sundew and the Venus Fly Trap. The park was established as an intra-coastal waterway park that would be both a natural area and allow public recreation along the intra-coastal waterway. The ocean beach, while not a part of the park, is nearby, and it attracts visitors to the park.

\section{History of the Park:}

Carolina Beach State Park marked a milestone in the development of the State Park System. In 1969, for the first time since Mount Mitchell was purchased in 1915, State funds were used to purchase land for a new State park. The establishment of the park came about through the efforts of ardent local supporters, naturalists, the Corps of Engineers, and the then existing Conservation and Development Board.

\section{Facilities:}

Family campground ( 83 sites, no hookups, restrooms/showers)

Marina (60 slips, fuel dock, 2 launching ramps, and sales area, restrooms/showers)

Park office/maintenance building

Picnic area (19 tables, no shelter)

Trails (5 miles, hiking)

\section{Existing Staff:}

\section{Permanent:}

Park Superintendent III

Park Ranger II

Park Ranger I (3)

\section{Seasonal:}

Park Attendant

General Utility Worker

\section{Minimum Additional Staff Needs:}

Clerk-Typist

Maintenance Mechanic III 
Carolina Beach State Park (Continued)

Staffing Over Last Ten Years:

Permanent

Park Superintendent III

Park Ranger II

Park Ranger I (2)
Seasonal

No data available

1977

Park Attendant

$1978 \quad$ No change

Added:

1979 Park Ranger I No change

1980-86 No change No change

\section{Internal Threats:}

Management Limitations:

The Division currently leases approximatley 1,300 acres from the U.S. Department of the Army. This area contains many unique resources, but due to the language of the lease, the Division does not have adequate authority to protect this area from timber harvesting, hunting, and off road vehicle use.

Sugarloaf :

This area is eroded due to illegal use of ORVs and all management practices have failed to end it.

Inholding:

An inholding between the park and Dow road has represented the

State's number one acquisition priority for the last 10 years. The property contains a portion of a lime sink which contains unique and undisturbed hydrologic characteristics and the unusual plant and animal life which depends on these conditions. This lime sink, as well as the biolgical resources of the park would be severely damaged if this property is not acquired and allowed to be developed.

Erosion/Compaction:

The campground is showing a high degree of soil compaction and erosion. There are also signs of vegetation trampling.

Visitor Impacts:

Vandalism of the Venus fly trap is an ongoing problem despite signs stressing the rareness of the plants. 
Inadequate Parking:

There is inadequate parking spaces for the picnic area during peak periods and cars are being parked anywhere in the area that space can be found.

Controlled Burning:

A 15 to 20 acre longleaf pine-wiregrass savannah which supports the Venus Flytrap is in danger of unnatural succession to a community type unfavorable to the Flytrap because of the absence of natural fire. A draft prescribed burn plan has been prepared.

\section{External Threats:}

Development :

Encroachment requests concerning the Sunny Point buffer lands have been denied in the past: airport, sewer lines, and land for town facilities.

\section{Infestation:}

There has been an infestation of gypsy moths at the KOA located just south of the park.

Top 3 Visitor Impacts Identified by Superintendent:

1. Erosion/soil compaction

2. OVR Use

3. Inadequate parking

\section{Facility Condition:}

There are 12 buildings located on the park and all are in need of repair. Needs include:

Concrete foundations that are deteriorating

Poor lighting in some of the buildings

Weakening roofs and ceiling (especially one of the ranger's home)

Overloaded electrical outlets (need more in every building)

Pier foundations of the storage building are deteriorating

No handicap access

The main project in progress is in conjunction with LWCF to dredge the boat basin. The second phase of the project is to replace the bulkhead and slips at the marina. 
Carolina Beach State Park (Continued)

\section{Capital Improvements:}

Current Projects:

$\begin{array}{ll}\text { Boat basin dredging } & \$ 186,224 \\ \text { Marina renovation } & \$ 900,000\end{array}$

Documented needs: $\$ 1,891,933$

Projects: New water supply system

Repave roads and parking

Visitor center complex

Access road maintenance yard

Ranger residences (4)

Renovate ranger residence (1)

Warehouse

Maintenance building renovation

Land Acquisition:

\begin{tabular}{ccl}
\hline Tract $\#^{\prime}$ & Acres & \multicolumn{1}{c}{ Reason } \\
\hline 1 & 23.7 & $\begin{array}{l}\text { Inholding surrounded by } 3 \\
\text { sides by park }\end{array}$
\end{tabular}

Boundary Marking Status:

\begin{tabular}{cccc}
\hline $\begin{array}{c}\text { Total } \\
\text { Boundary } \\
\text { Mile }\end{array}$ & $\begin{array}{c}\text { Well } \\
\text { Marked }\end{array}$ & $\begin{array}{c}\text { Poorly } \\
\text { Marked }\end{array}$ & $\begin{array}{c}\text { Indef. } \\
\text { or } \\
\text { Unknown }\end{array}$ \\
\hline 18.5 & 4.2 & 14.3 & $-0-$
\end{tabular}

Expenditures and Attendance:

\begin{tabular}{lccc}
\hline Year & Attendance $($ Calendar Yr.) & Current $\$($ Fiscal Yr.) & $1977 \$$ (Fiscal Yr.) \\
\hline & & & \\
1977 & 178,321 & $\$ 91,980$ & $\$ 91,980$ \\
1978 & 147,036 & 87,377 & 81,281 \\
1979 & 98,147 & 86,775 & 73,851 \\
1980 & 135,240 & 114,349 & 87,691 \\
1981 & 151,410 & 136,785 & 96,805 \\
1982 & 184,287 & 125,022 & 82,687 \\
1983 & 170,896 & 147,787 & 93,359 \\
1984 & 162,526 & 149,349 & 89,861 \\
1985 & 195,940 & 165,540 & 94,865 \\
1986 & 198,448 & 170,257 & 94,377 \\
1987 & 180,756 & 177,264 & 93,940 \\
1988 & & 164,119 & 83,392
\end{tabular}


Carolina Beach State Park (Continued)

Repair and Renovations:

\begin{tabular}{crr}
\hline Fiscal Year & Current $\$$ & $1977 \$ *$ \\
1977 & $\$ 2,647$ & $\$ 2,647$ \\
1978 & 4,106 & 3,820 \\
1979 & 1,651 & 2,333 \\
1980 & 5,845 & 4,482 \\
1981 & 8,037 & 5,688 \\
1982 & 12,204 & 8,071 \\
1983 & 0 & 0 \\
1984 & 3,235 & 1,946 \\
1985 & 8,081 & 4,631 \\
1986 & 2,323 & 1,288
\end{tabular}

*1977 budget figures are adjusted to reflect inflation and are shown in 1977 dollars. Source: Office of State Budget.

Total Park Revenue: FY 1987: \$63,020

FY 1988: $\$ 55,853$ 


\section{CHOWAN SWAMP NATURAL ARRA}

Location: Gates County

Size: Three tracts of land consisting of 6,066 acres

\section{Reason for Establishment:}

This portion of the Chowan Swamp is a good representation of a freshwater estaurine swamp. In North Carolina, this type of natural community is generally limited to the tributaries and low land encircling the Albemarle Sound. Bordered by the Chowan River, the swamp contains notable species of wildlife.

\section{History of the Natural Area:}

The State purchased the property from The Nature Conservancy in 1974. The Nature Conservancy had served as a middleman between the Georgia Pacific Corporation and the State. The property is in three noncontiguous parcels. The three parcels have been designated as temporary game lands and are managed by the Wildlife Resources Commission.

\section{Existing Recreation Opportunities:}

The natural area is open to traditional hunting and fishing which is regulated by the Wildlife Resources Commission. Access, primarily by canoe or small boat, limits recreational use of the property.

\section{Threats :}

Effluents from a nearby fertilizer plant are likely responsible for recent algae blooms on the Chowan River.

\section{Land Acquisition:}

None planned.

\section{Staffing:}

None

\section{Budget:}

None 


\section{CLIFFS OF THE NEUSE STATE PARK}

Location: Wayne County

Size: 748 acres

\section{Reason for F stablishment:}

To protect a 90-foot cliff that rises above the Neuse River that was once a part of the Atlantic Coastline.

\section{History of the Park:}

Cliffs of the Neuse has been a park since 1945. Tuscarora Indians called the area Sapony Hills and used it as a base to begin their hunts into the Neuse wilderness.

\section{Facilities:}

Boating (row boats available for rent in summer)

Family campground ( 35 sites, restroom/shower, no hookups)

Group camp area (primitive)

Maintenance compound

Park office

Picnic area (100 tables, no shelter)

Residence ( 3 houses)

Swimming (lake with bathhouse and refreshment stand)

Trails (3-1/2 miles, hiking)

\section{Existing Staff:}

\section{Permanent:}

Park Superintendent

Park Ranger II

Park Ranger I

\section{Seasonal:}

Park Attendant (2)

Chief Lifeguard

Lifeguard (4)

Refreshment Stand Manager I

Refreshment Stand Clerk

Bathhouse Manager II

Bathhouse Operator

General Utility Worker

\section{Minimum Additional Staff Needs:}


Cliffs of the Neuse State Park (Continued)

\section{Staffing Over Last Ten Years:}

Permanent

1977 Park Superintendent

Chief Ranger II

Park Ranger I

1978 No change

1980-86 No change

No change

\section{Internal Threats:}

Hiking trail:

There has been a great deal of erosion on all the trails because of overuse.

Vegetation Destruction:

All areas show signs of vegetation destruction by visitors walking over various plants.

Pests:

The Southern Pine Beetle is killing several different sections of trees across the park.

\section{Litter:}

Litter has become a serious problem.

Boundaries:

The lack of marked boundaries has led to encroachments. There have also been clear-cuts on or near these unmarked boundaries. 
Capital Development:

The southern side of the park is reported to host a population of fox squirrel, a species in jeopardy due to habitat lose. The park's master plan proposes development which may further imperil this species' habitat.

\section{Internal Threats: (Continued)}

Erosion/Soil Compaction:

Soil compaction has resulted from overuse.

Top 3 Visitor Impacts Identified by Superintendent:

1. Erosion/Soil Compaction

2. Vegetation Destruction

3. Litter

\section{External Threats:}

Water Quality:

The water quality of the lake continues to be damaged because of an inadequately protected watershed.

Aesthetics :

The clear-cuts have disrupted the visual appearance of the park.

\section{Facility Condition:}

There are 26 buildings located in the park and all are in need of repair. The safety related problems are:

Lack of smoke detectors

Fire extinguishers missing or in poor condition

Electrical outlets overloaded (need more in every building)

Weakened roofs, floors, and foundations

Buildings that need to be demolished (a storage/garage, pack house, Crumpler House)

No handicap access.

\section{Capital Improvements:}

Current Projects:

Water system improvements

Dam Inlet structor repair

$\$ 166,208$

40,000 
Cliffs of the Neuse State Park (Continued)

Documented Needs: $\$ 2,590,900$

Projects: Septic tank renovations

Visitor center/district office

Picnic area renovatjon

Primitive campsites-; roup

Renovation of bathhouse

Renovation of the refreshment stand

Renovate ranger residences (3)

Electrical renovation of shop building

Sprinkler system for grounds (lake)

Repave parking lots, roads

Vehicular storage shed

Superintendent residence garage (1)

Land Acquisition:

\begin{tabular}{rrl}
\hline Tract $\#$ & Acres & \multicolumn{1}{c}{ Reason } \\
\hline 1 & 24.0000 & Resource Protection \\
2 & 23.0000 & $\begin{array}{l}\text { Inholding Bordered on } 3 \\
\text { sides by park }\end{array}$ \\
3 & 64.0000 & Buffer Zone \\
4 & 82.4000 & Resource Protection \\
8 & 29.2300 & Resource Protection \\
9 & 31.6000 & Resource Protection \\
11 & 9.8400 & Resource Protection \\
12 & 9.0400 & Scenic Protection \\
13 & 1.9700 & Entrance Protection \\
14 & 17.6100 & Buffer \\
15 & .7200 & Access (land development) \\
16 & 1.5600 & Access
\end{tabular}

Boundary Marking Status:

\begin{tabular}{cccc}
\hline $\begin{array}{c}\text { Total } \\
\text { Boundary } \\
\text { Mile }\end{array}$ & $\begin{array}{c}\text { Well } \\
\text { Marked }\end{array}$ & $\begin{array}{c}\text { Poorly } \\
\text { Marked }\end{array}$ & $\begin{array}{c}\text { Indef. } \\
\text { or } \\
\text { Unknown }\end{array}$ \\
\hline 5.5 & 5.5 & $-0-$ & $-0-$
\end{tabular}


Cliffs of the Neuse State Park (Continued)

Expenditures and Attendance:

\begin{tabular}{lcrc}
\hline Year & Attendance (Calendar Yr.) & Current $\$($ Fiscal Yr.) & $1977 \$$ (Fiscal Yr.) \\
\hline & & & \\
1977 & 129,097 & $\$ 88,406$ & $\$ 88,406$ \\
1978 & 179,250 & 102,851 & 95,675 \\
1979 & 143,737 & 107,368 & 91,377 \\
1980 & 112,161 & 119,850 & 91,910 \\
1981 & 85,437 & 130,735 & 92,523 \\
1982 & 123,078 & 94,069 & 62,215 \\
1983 & 127,674 & 154,194 & 97,406 \\
1984 & 153,062 & 154,194 & 92,764 \\
1985 & 145,986 & 178,027 & 102,021 \\
1986 & 137,218 & 197,720 & 109,601 \\
1987 & 150,633 & 201,460 & 106,762 \\
1988 & & 162,823 & 82,693
\end{tabular}

Repair and Renovations Over Last 10 Years:

\begin{tabular}{ccc}
\hline Fiscal Year & Current & $1977 \$ *$ \\
1977 & $\$ 3,795$ & $\$ 3,795$ \\
1978 & 6,198 & 5,766 \\
1979 & 5,273 & 4,390 \\
1980 & 5,660 & 4,340 \\
1981 & 7,203 & 5,098 \\
1982 & 4,091 & 2,706 \\
1983 & - & - \\
1984 & 3,774 & 2,271 \\
1985 & 3,681 & 2,109 \\
1986 & 7,039 & 3,902
\end{tabular}

*1977 Budget figures are adjusted to reflect inflation and are shown in 1977 dollars. Source: Office of State Budget.

Total Park Revenue: FY 1987: $\$ 27,529$

FY 1988: $\$ 43,046$ 


\section{CROWDERS MOUNTAIN STATE PARK}

Location: Gaston County

Size: 2,083 acres

\section{Reason for Establishment:}

This park is known for its rocky outcrops and the twin peaks of Crowders Mountain at 1,625 feet and Kings Pinnacle at 1,705 feet. The park was established to protect the peaks from destruction by mining.

\section{History of the Park:}

The park got its name from Ulrick Crowder, a German merchant who settled in the area in the $1780 \mathrm{~s}$. In 1779 a twelve-year old boy discovered a seventeen pound gold nugget in nearby Cabarrus County, and in 1803, a slave found another nugget, this time 28 pounds. The resulting North Carolina gold rush, which lasted until the California gold rush, at its height made the area the chief gold producer in the United States. There were sixty gold mines in Mecklenburg County, with another twenty-four in Gaston County. Workable quantities of gold were discovered near Crowders Mountain in 1829. Crowders Mountain became a state park in 1973.

\section{Pacilities:}

Camping (primitive)

Group camp area (primitive)

Maintenance area

Office

Picnic area (28 tables, 2 shelters)

Residence ( 3 houses)

Trails (10 miles, hiking)

\section{Existing Staff:}

Permanent:

Park Superintendent I

Park Ranger II (2)
Seasonal:

Park Attendant (2)

General Utility Worker

Minimum Additional Staff Needs:

Maintenance Mechanic

Clerk Typist III 
Crowders Mountain State Park (Continued)

Staffing Over Last Ten Years:

Permanent

1977

Park Superintendent II Chief Park Ranger

\begin{tabular}{lll}
1978 & No change & Park Attendant (2) \\
\hline 1979 & $\begin{array}{l}\text { Added: } \\
\text { Park Ranger I }\end{array}$ & No change \\
\hline 1980 & No change & No data available \\
1981 & No change & $\begin{array}{l}\text { Added: } \\
\text { Naturalist }\end{array}$ \\
\hline & No change & $\begin{array}{l}\text { Naturalist changed to } \\
\text { General Utility Worker } \\
\text { No change }\end{array}$ \\
\hline
\end{tabular}

\section{Seasonal}

No data available

\section{Internal Threats:}

Hiking Trails/Spur Trails:

There is a great deal of erosion on all 10 miles of hiking trails. The occurrence of bushwhacking is very apparent with the formation of new spur trails.

Fisheries Management:

There is a decline of game fish in the lake.

Endangered Species:

Managing the Bear Oak population is needed.

Visitor Impacts:

There is a high usage of the natural areas of the park. Encouraging the use of other areas has had little success. There has also been an increase in vegetation removal and destruction.

Top 3 Visitor Impacts Identified by Superintendent:

1. Spur trails

2. Erosion/soil compaction

3. Vegetation removal 
Crowders Mountain State Park (Continued)

\section{External Threats:}

Adjacent Development:

There has been an increase in the development of residential areas outside of the park. The fastest growing is a trailer park which is affecting the aesthetic view from the park. This development around the park has affected the water quality.

\section{Exotic Plants:}

Areas of the park are being engulfed in kudzu and honeysuckle plants.

Development:

Two major areas proposed for acquisition and development by the master plan have been lost to residential development. Other areas proposed for acquisition are similarly threatened.

\section{Facility Condition:}

There are 18 buildings located on the park and all are in need of repair. Safety related problems include:

Lack of smoke detectors in some buildings

Weakening floors and roofs

No lighting for exit signs

Concrete is breaking up on porches and decks

Ranger's home has a poorly constructed chimney

Tobacco barn should be condemned

No handicap access

\section{Capital Improvements:}

Current Projects:

Electrical Renovation

Documented Needs: $\$ 3,397,562$

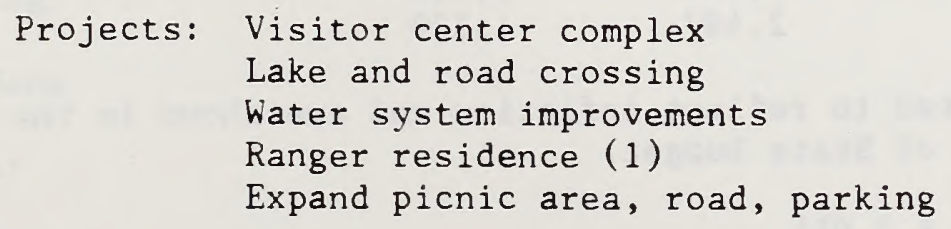

\section{Land Acquisition:}


Crowders Mountain State Park (Continued)

Boundary Marking Status:

\begin{tabular}{cccc}
\hline $\begin{array}{c}\text { Total } \\
\text { Boundary } \\
\text { Mile }\end{array}$ & $\begin{array}{c}\text { Well } \\
\text { Marked }\end{array}$ & $\begin{array}{c}\text { Poorly } \\
\text { Marked }\end{array}$ & $\begin{array}{c}\text { Indef. } \\
\text { or } \\
\text { Unknown }\end{array}$ \\
\hline 16.1 & $-0-$ & 14.6 & 1.5
\end{tabular}

Expenditures and attendance:

\begin{tabular}{lcrc}
\hline Year & Attendance (Calendar Yr.) & Current $\$($ Fiscal Yr.) & $1977 \$ *$ (Fiscal Yr.) \\
\hline & & & \\
1977 & 20,768 & $\$ 21,924$ & $\$ 21,924$ \\
1978 & 75,855 & 34,342 & 31,946 \\
1979 & 72,790 & 46,766 & 39,801 \\
1980 & 74,915 & 41,051 & 31,481 \\
1981 & 84,172 & 39,748 & 28,130 \\
1982 & 90,368 & 50,276 & 33,251 \\
1983 & 91,688 & 55,352 & 34,967 \\
1984 & 100,902 & 55,352 & 33,304 \\
1985 & 11,655 & 73,390 & 42,057 \\
1986 & 120,651 & 80,248 & 44,483 \\
1887 & 130,012 & 70,405 & 37,311 \\
1988 & & 89,182 & 45,293
\end{tabular}

Repair and Renovations:

\begin{tabular}{|c|c|c|c|c|}
\hline Fiscal Year & \multicolumn{2}{|c|}{ Current $\$$} & \multicolumn{2}{|c|}{$1977 \$ *$} \\
\hline 1977 & $\$$ & 5,424 & $\$$ & 5,424 \\
\hline 1978 & & 3,719 & & 3,46 \\
\hline 1979 & & 2,165 & & 1,84 \\
\hline 1980 & & 1,039 & & 79 \\
\hline 1981 & & 708 & & 501 \\
\hline 1982 & & 2,980 & & 1,97 \\
\hline 1983 & & 0 & & \\
\hline 1984 & & 4,647 & & 2,796 \\
\hline 1985 & & 5,428 & & 3,111 \\
\hline 1986 & & 2,487 & & 1,379 \\
\hline
\end{tabular}

$* 1977$ Budget figures are adjusted to reflect inflation and are shown in the 1977 dollars. Source: Office of State Budget.

Total Park Revenue: FY 1987: \$2,051

FY 1988: $\quad \$ 2,400$ 


\section{DISMAL SWAMP NATURAL AREA}

Location: Camden County

Size: $14,343.5$ acres

Reason for Establishment:

The State owned property, coupled with the federal refuge, together preserve one of the largest areas of swamp wilderness in the eastern United States. While the original character and size of the Great Dismal Swamp has been altered considerably as a result of drainage and timbering, the natural areas do contain regionally significant communities (white cedar, pocosin, and gum-cypress) and species.

\section{History:}

Timbering has been a major industry in the Dismal Swamp, and most of the natural area has been logged, diminishing the stands of Atlantic white cedar and mature hardwoods. Commercial timbering ceased with acquisition of the site by The Nature Conservancy, acting in the State's behalf. In 1974, the State received a Land and Water Conservation Fund grant of $\$ 1,179,342.50$ to purchase the property from The Nature Conservancy. Presently the State and the U.S. Fish and Wildlife Service are finalizing an annually renewable management agreement whereby the U.S. Fish and Wildlife Service will manage and provide access to the Division's lands.

\section{Existing Recreation Use:}

The natural area is presently undeveloped and is managed for protection of the wildife, plant, and other natural resources.

\section{Threats:}

Loss of the white cedar stand by wildfire. Invasion of the pocosin community by hardwoods due to lack of fire. Lowering of the water table from drainage.

\section{Land Acquisition:}

None planned.

\section{Staffing:}

None

Budget:

None 


\section{DUKE POWER STATE PARK}

Location: Iredell County

Size: 1,447 acres

\section{Reason for Establishment:}

Duke Power was required by the Federal Energy Regulatory Commission to provide recreation with its hydropower project.

\section{History of the Park:}

Lake Norman was created by damming the Catawba River and contains 32,510 acres of water with a $520-\mathrm{mile}$ shoreline. One of the early projects of the Duke Power Company, the lake produces power and water supply for the area. The park was created in 1962 with land donated by Duke Power.

\section{Facilities :}

Boat launch (Lake Norman)

Family camping ( 33 sites, restroom/shower, no hook-ups)

Group camping (primitive)

Picnic area ( 67 tables)

Residences ( 2 houses)

Swimming (lake, bathhouse, refreshment stand)

Trails ( 6 miles, hiking)

\section{Existing Staff:}

Permanent:

Park Superintendent II

Park Ranger II

Park Ranger I

General Utility Worker
Seasonal:

Park Attendant (2)

General Utility Worker

Chief Lifeguard

Lifeguard (4)

Refreshment Stand Manger I

Bathhouse Manager I

Refreshment Stand Clerk

Minimum Additional Staff Needs:

Clerk Typist III 
Duke Power State Park (Continued)

Staffing Over Last Ten Years:

Permanent

1977 Park Superintendent II

Chief Park Ranger

Park Ranger I

General Utility Worker

\section{Seasonal}

No data available

No change

Park Attendant (2)

Naturalist

Chief Lifeguard

Lifeguard (4)

Refreshment Stand Manager I

Bathhouse Manager I

Refreshment Stand Clerk

1979-1985 No change

No change

1986

No change

Changed Naturalist position

to General Utility Worker

\section{Internal Threats:}

Erosion/Soil Compaction:

The access trails are eroding through overuse and soil compaction. Shoreline Erosion:

The shoreline is eroding because of wave action from boating.

Vandalism:

There has been some vandalism in the youth tent camping area.

Pest Control:

There are Southern Pine beetle infestations in the park. 
Duke Power State Park (Continued)

Internal Threats: (Continued)

Boundaries/Vehicular Access

The boundaries need to be resurveyed. The inholdings, including a private residential inholding completely surrounded by park land, make 24 hour access into park necessary. The resulting noise disturbs the campers, and park operation and management are hindered.

Visitor Impacts:

Problems with litter and soil compaction at the campground areas are evidenced.

\section{External Threats:}

Air Quality:

A fly ash plant is located in nearby Stateville.

Adjacent Development:

Residential development of Hernwood and Hicks Creek is affecting the aesthetic view from the lake. "Critical" lands proposed for acquisition are threatened by residential development.

\section{Facility Condition:}

Bridge providing a major access to the park has been closed due to structural decline.

There are 23 buildings at the park and all are in need of repair. The list below includes the safety hazards which are the first priority:

Weakened roofs on the public buildings

Lacking fire extinguishers and smoke detectors

Exit signs are not illuminated

The wood decks are rotten

There are some repairs in progress including replacing the roofs at the swimming areas and filling the well at the Clark house.

Other projects are pending including repairing guardrails and replacing foot bridges.

\section{Capital Improvements:}

Current Projects: Replace roofs at swim area Emergency bridge repair 
Duke Power State Park (Continued)

Capital Improvements: (Continued)

Documented Needs: $\$ 7,509,728$

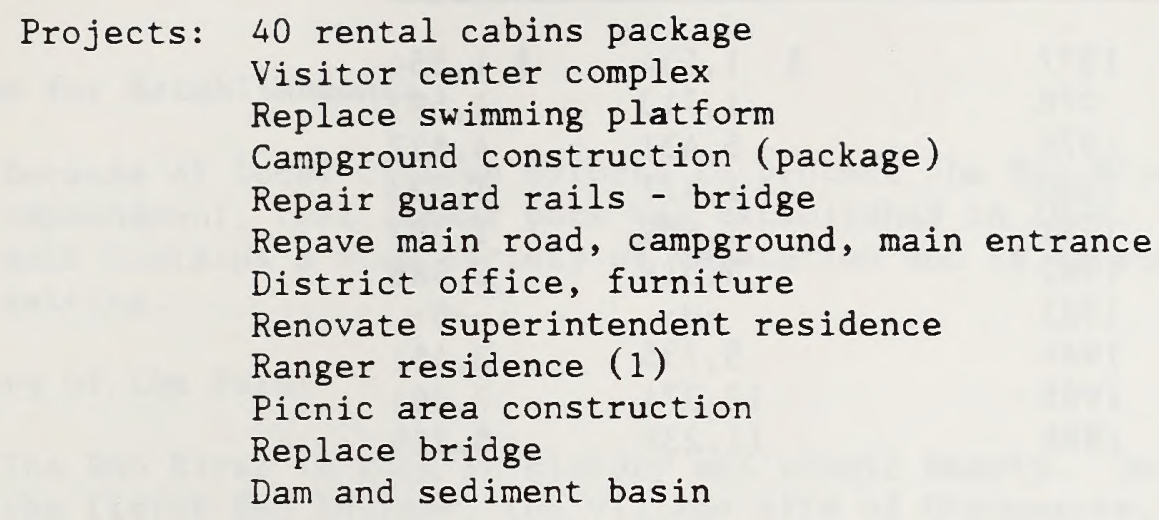

Land Acquisition: No acquisition in progress

\section{Boundary Marking Status:}

\begin{tabular}{cccc}
\hline $\begin{array}{c}\text { Total } \\
\text { Boundary } \\
\text { Mile }\end{array}$ & $\begin{array}{c}\text { Well } \\
\text { Marked }\end{array}$ & $\begin{array}{c}\text { Poorly } \\
\text { Marked }\end{array}$ & $\begin{array}{c}\text { Indef. } \\
\text { or } \\
\text { Unknown }\end{array}$ \\
\hline 12.7 & 1.0 & 10.7 & 1.0
\end{tabular}

Expenditures and Attendance:

\begin{tabular}{lcrc}
\hline Year & Attendance (Calendar Yr.) & Current $\$$ (Fiscal Yr.) & $1977 \$ *$ (Fiscal Yr.) \\
\hline & & & \\
1977 & 103,505 & $\$ 69,743$ & $\$ 69,743$ \\
1978 & 31,444 & 67,937 & 63,197 \\
1979 & 101,905 & 69,656 & 59,282 \\
1980 & 122,440 & 88,867 & 68,150 \\
1981 & 105,030 & 117,054 & 82,841 \\
1982 & 122,749 & 121,897 & 80,620 \\
1983 & 122,978 & 141,842 & 89,603 \\
1984 & 129,400 & 141,842 & 89,344 \\
1985 & 138,565 & 156,362 & 89,607 \\
1986 & 151,031 & 169,150 & 93,764 \\
1987 & 151,664 & 191,351 & 101,405 \\
1988 & & 152,308 & 77,353
\end{tabular}


Duke Power State Park (Continued)

Repair and Renovations:

\begin{tabular}{ccc}
\hline Fiscal Year & Current $\$$ & $1977 \$ *$ \\
\hline 1977 & $\$ 1,554$ & $\$ 1,554$ \\
-978 & $\$, 713$ & 1,593 \\
1979 & 5,431 & 4,622 \\
1980 & 1,477 & 1,033 \\
1981 & 1,969 & 1,393 \\
1982 & 4,518 & 2,988 \\
1983 & $-0-$ & $-0-$ \\
1984 & 5,735 & 3,451 \\
1985 & 12,374 & 7,091 \\
1986 & 11,238 & 6,229
\end{tabular}

*1977 Budget figures are adjusted to reflect inflation and are shown in 1977 dollars. Source: Office of State Budget.

Total Park Revenue: FY 1987: \$ 27,118

FY 1988: $\$ 31,099$ 


\section{ENO RIVER STATE PARK}

Location: Orange and Durham Counties

Size: 2,064 acres

\section{Reason for Establishment:}

Because of local citizen efforts to protect the Eno River area from impoundment, this linear park was established in 1973. The scenic park contains a wide variety of vegetation and is located in an urban setting.

\section{History of the Park:}

The Eno River is rich in history and scenic beauty. Once the home of the fierce Eno Indians, the village site of Occoneeche, which is east of present-day Hillsborough, has been excavated by archaeologists. Early settlers came into the area and stayed. Since 1750, river life has centered around the many grist mills using the river for power. There are at least thirty-two sites of old mills.

Efforts to save the river were led by Margaret and Holger Nygard. As early as 1965, they sponsored hikes along the river to show people the beauty of the area. An organization, the Association for the Preservation of the Eno, was formed to gather support for the river and is still active and strong today. As a result of citizen action, the Eno is one of the most protected rivers. Some land is in state parks, county and city parks, and some federal public lands. The river is a canoe trail. As with many of the other state parks, the Nature Conservancy was instrumental in obtaining several of the tracts along the Eno. (Runkle, John. A Guide to North Carolina State Parks. Tread Softly. 1983.)

\section{Facilities:}

Family Camping ( 5 primitive backpack sites)

Group camping ( 1 primitive backpack sites)

Maintenance building

Park office

Picnic area (29 tables)

Piper-Dixon House

Residence (one house)

Trail (19.9 miles, hiking)

\section{Existing Staff:}

Permanent:

Park Superintendent I

Park Ranger II

Park Ranger I

Clerk Typist (.5)

\section{Seasonal}

Park Attendant General Utility Worker Clerk Typist 
Eno River State Park (Continued)

\section{Minimum Additional Staff Needs:}

Clerk Typist III (.5)

Maintenance Machanic

Staffing Over Last Ten Years:

\begin{tabular}{|c|c|c|}
\hline & Permanent & Seasonal \\
\hline 1977 & $\begin{array}{l}\text { Chief Ranger II } \\
\text { Park Ranger I }\end{array}$ & No data available \\
\hline 1978 & No change & $\begin{array}{l}\text { Park Attendant } \\
\text { Naturalist }\end{array}$ \\
\hline 1979 & $\begin{array}{l}\text { Added: } \\
\text { Park Superintendent I }\end{array}$ & No change \\
\hline 1980 & No change & No change \\
\hline 1981 & No change & $\begin{array}{l}\text { Added: } \\
\text { Park Attendant }\end{array}$ \\
\hline 1982 & No change & No change \\
\hline 1983 & No change & $\begin{array}{l}\text { Added: } \\
\text { Clerk Typist III }\end{array}$ \\
\hline $1984-1985$ & No change & No change \\
\hline 1986 & $\begin{array}{l}\text { Added: } \\
\text { Clerk Typist III }(1 / 2)\end{array}$ & $\begin{array}{l}\text { Change Naturalist to } \\
\text { General Utility Worker }\end{array}$ \\
\hline
\end{tabular}

\section{Internal Threats:}

Erosion:

Trail erosion exists because of poor design and overuse. The off-road vehicles have only made the problem worse and repairs more difficult.

old Field Management:

A rotation schedule has been set up to mow the field. 
Eno River State Park (Continued)

\section{Internal Threats: (Continued)}

Boundaries :

The boundaries are not properly marked and hunting encroachments have been occurring. In addition, the park is accessible by the AT\&T and Duke rower rights-of-way. Cooperation between the State and th sse companies could close these easements, thereby lessening the hunting problem.

Horses on the Hiking Trails

The bridle trails are inadequate for the amount of demand, so the hiking trails are being used. This causes trail destruction and user conflicts.

\section{External Threats:}

Water Quality:

The river is threatened by artificial low flow conditions in the summer due to upstream water withdrawals and an impoundment. Water quality is further threatened by an upstream sewage treatment plant which discharges effluent received from a textile plant.

Pest Management:

Southern Pine Beetle infestation near State property has led to an initial presence on park land.

Adjacent Development:

The rapid urban growth of the Durham area is threatening to consume the unprotected banks of the Eno with residential development. On a statewide basis, completion of the park's acquisition program is within the most urgent category.

Top 3 Visitor Impacts Identified by Superintendent:

1. Erosion/compaction

2. Horses on hiking trails

3. Hunting 
Eno River State Park (Continued)

\section{Facility Condition:}

There are 17 buildings located in the park, and most are in need of repair. The safety related repairs are:

Need smoke detectors in maintenance building and office No handrails and replacement of broken board on the porch of the day cabin

Fire extinguishers are in poor condition

New roofs, floors, and porch needed on wilderness shelter

Demolish buildings on newly acquired land

New roof needed for maintenance building

\section{Capital Improvements:}

Current Projects: None

Documented Needs: $\$ 3,513,018$

Projects: Well, water system at Cole Mill road

Piper-Dickson House Museum

Restroom/septic field - Cates Ford

Trail development - Cates Ford

Picnic area-family - Cates Ford

Warehouse building

Pumpstation area develop parking lot, picnic, toilets, trails

Group camp - Cates Ford

Trail improvements - Cole Mill

Canoe launch, parking lot, park road -Pleasant Green Road

Maintenance building, residence renovation

Picnic area expansion - Cole Mill

Repave road, parking lot, park gate - Cole Mill

Renovate ranger residence (1)

Pave one mile of park road and parking lot area Cates Ford

Improve parking at canoe access area - Cates Ford 
Eno River State Park (Continued)

\section{Land Acquisition:}

\begin{tabular}{rrl}
\hline Tract \# & Acres & \multicolumn{1}{c}{ Reason } \\
1 & 41.00 & Resource Protection \\
2 & 7.25 & Resource Protectic. \\
3 & 27.10 & Resource Protectio: \\
4 & 6.70 & Resource Protection \\
5 & 12.00 & Resource Protection \\
6 & 9.20 & Watershed Protection \\
7 & 2.40 & Resource Protection \\
8 & 1.46 & Access \\
9 & 2.45 & Access \\
10 & 5.43 & Access \\
11 & 2.78 & Access \\
12 & 24.20 & Scenic Protection \\
14 & 5.00 & Watershed Protection \\
15 & 6.50 & Resource Protection \\
16 & 9.00 & Scenic Protection \\
17 & 11.00 & Scenic Protection \\
19 & 2.51 & Access \\
20 & .75 & Access
\end{tabular}

Boundary Marking Status:

\begin{tabular}{cccc}
\hline $\begin{array}{c}\text { Total } \\
\text { Boundary } \\
\text { Mile }\end{array}$ & $\begin{array}{c}\text { Well } \\
\text { Marked }\end{array}$ & $\begin{array}{c}\text { Poorly } \\
\text { Marked }\end{array}$ & $\begin{array}{c}\text { Indef. } \\
\text { or } \\
\text { Unknown }\end{array}$ \\
\hline 24.0 & 5.0 & 2.5 & 16.5
\end{tabular}

Expenditures and Attendance:

\begin{tabular}{lcrc}
\hline Year & Attendance (Calendar Yr.) & Current $\$($ Fiscal Yr.) & $1977 \$ *$ (Fiscal Yr.) \\
\hline & & & \\
1977 & 12,142 & $\$ 29,216$ & $\$ 29,216$ \\
1978 & 10,862 & 33,657 & 31,657 \\
1979 & 14,131 & 51,383 & 43,230 \\
1980 & 15,294 & 36,142 & 27,716 \\
1981 & 48,730 & 64,496 & 45,645 \\
1982 & 58,871 & 52,019 & 34,404 \\
1983 & 64,638 & 66,784 & 42,188 \\
1984 & 110,243 & 64,333 & 38,708 \\
1985 & 121,410 & 64,855 & 36,593 \\
1986 & 101,422 & 75,042 & 41,598 \\
1987 & 136,967 & 93,887 & 49,755 \\
1988 & & 105,062 & 53,358
\end{tabular}


Eno River State Park (Continued)

Repair and Renovations:

\begin{tabular}{crr}
\hline Fiscal Year & Current $\$$ & $1977 \$ *$ \\
\hline 1977 & $\$ 1,740$ & $\$ 1,740$ \\
1978 & 3,744 & 3,483 \\
1979 & 2.718 & 2,313 \\
1980 & 3,596 & 2,758 \\
1981 & 10,555 & 7,470 \\
1982 & 2,790 & 1,845 \\
1983 & 0 & 0 \\
1984 & 5,033 & 3,028 \\
1985 & 2,476 & 1,419 \\
1986 & 2,778 & 1,540
\end{tabular}

*1977 Budget figures are adjusted to reflect inflation and are shown in 1977 dollars. Source: Office of State Budget.

Total Park Revenue: FY 1987: \$ 880.60

FY 1988: $\$ 4,822.00$ 


\section{FALLS LAKE STATE RECREATION AREA}

Location: Wake and Durham Counties

Size: 2,183 acres leased from the Corps of Engineers

\section{Reason for Establishment:}

The Army Corps of Engineers built the reservoir for drinking water for both Raleigh and Durham. Recreational use of such reservoirs is required.

\section{History of the Park:}

Falls Lake began filling in January of 1983 and is the center of a controversy over development around the boundaries of the lake project and the effect of development on water quality. The lake is primarily used as a drinking water source for Raleigh and Durham and is managed in conjunction with the Army Corps of Engineers.

\section{Pacilities:}

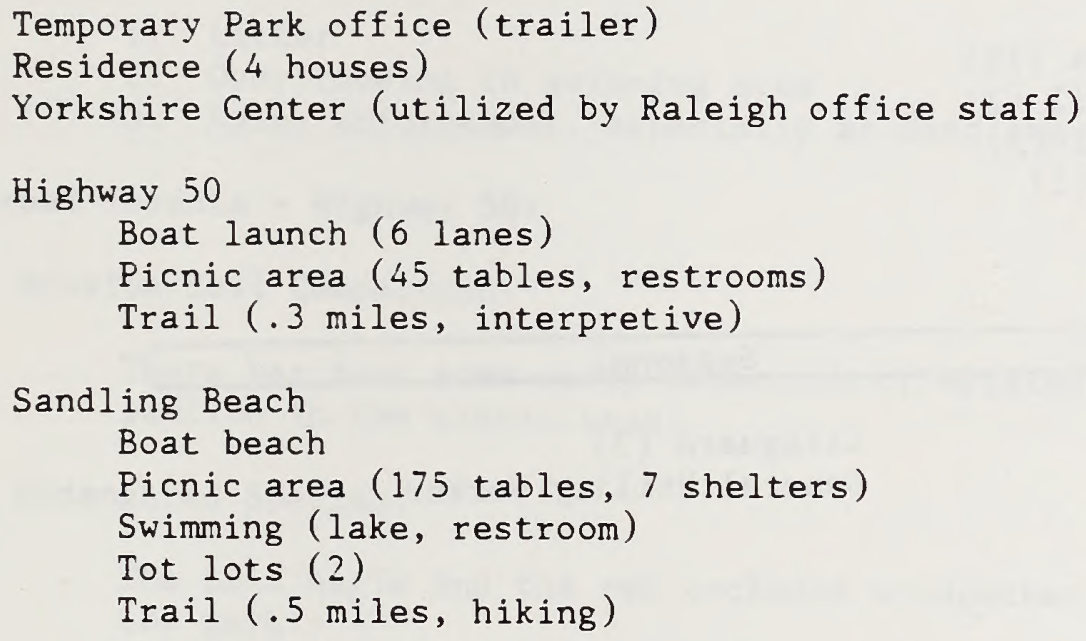

B. W. Wells

Trails ( 2 miles, hiking)

\section{Existing Staff:}

Permanent:

Park Superintendent I

Maintenance Mechanic II

General Utility Worker

Clerk Typist III (.5)

Maintenance Mechanic III
Seasonal:

Assistant Park Ranger

General Utility Worker (4)

Chief Lifeguard

Lifeguard (4)

Highway 50

Park Ranger I 
Falls Lake State Recreation Area (Continued)

Existing Staff: (Continued)

Rollingview

Park Ranger II

Park Ranger I

Sandlin Beach

Park Ranger II

Park Ranger I

Additional Staff Needs: (As per staffing plan recently developed by District Superintendent)

Park Superintendent III

Clerk Typist III (.5)

Ranger Naturalist

Maintenance Mechanic IV

Motor Mechanic

Waste Water Treatment Operator

Park Ranger II (3)

Park Ranger I (4)

General Utility Workers (10)

Maintenance Mechanic III (2)

Maintenance Mechanic II (3)

Park Superintendent I (2)

Staffing Over Last Five Years:

\section{Permanent}

1983 Park Superintendent I

Park Chief Ranger

Park Ranger II (2)

Park Ranger I (4)

Maintenance Mechanic III

Maintenance II

General Utility Worker

Clerk Typist III (.5)

1984 No change

1985 No change

1986 No change
Seasonal

Lifeguard (3)

General Utility Worker
No change

No Change

New changes:

General Utility Worker (3)

Assistant Park Ranger (3)

Chief Lifeguard

Lifeguard (4) 


\section{Falls Lake State Recreation Area (Continued)}

\section{Internal Threats:}

\section{Litter:}

Due to the large crowds, the litter of the recreation areas has become a problem.

Swimming :

One of the swimming areas is very popular, which causes an overcrowding problem.

Large Crowds:

During the summer months, heavy visitor use is a problem both on the lake and in the day use area. Rules and regulations are constantly being broken. The lack of staffing is not helping the situation.

Top 3 Visitor Impacts Identified by Superintendent:

1. Litter

2. Overcrowding in swimming area

3. Rules enforcement, especially at Sandling Beach

Internal Threats - Highway 50:

Erosion/Soil Compaction:

There has been some early detection of erosion and soil compaction in the picnic area.

Endangered Species:

The bald eagle and the red cockaded woodpecker are both present at the park.

Spur Trails:

Park visitors have created numerous new trails to the lake causing vegetation trampling.

Pest Management:

There have been some sections infested by the Southern Pine Beetle. Boundaries:

Some of the boundaries have not been adequately identified. 
Falls Lake State Recreation Area (Continued)

Internal Threats: (Continued)

Inadequate Septic System:

The facilities are overused which will shorten their lives.

Top 3 Visitor Impacts Identified by Superintendent:

1. Erosion/soil compaction

2. Spur trails

3. Inadequate septic system

Internal Threats - Rollingview Marina: No data available.

Internal Threats - Sandling Beach:

Erosion/Soil Compaction:

There are several areas where the overuse from visitors have caused soil compaction and trampling.

Litter:

There is a large amount of litter that can be found throughout the park.

Boundaries:

The park boundaries are not adequately identified.

Pest Management:

There are sections of the park that are infested with the Southern Pine Beetle.

Unrestrained Pets:

Several incidences of pets running freely in the park have caused some concern.

Top 3 Visitor Impacts Identified by Superintendent:

1. Litter

2. Erosion/soil compaction

3. Unrestrained pets

\section{External Threats:}

Water Quality:

There is new development along the Neuse River which may affect the water quality of all sections of the lake in the future. 
Falls Lake State Recreation Area (Continued)

\section{Pacility Condition:}

No building inventory or inspection program (FIIP) has been completed; however, there are several projects that have been listed for repairs including demolishing storage buildings or old houses on the park, reshingling several ranger residences, and installing smoke detectors in the park building. The major projects are the renovation of the Yorkshire building.

\section{Capital Improvements:}

Current Projects: Yorkshire Center Renovation \$154,600

Documented Needs: $\$ 103,300$

Projects: Repair to waste water treatment system at Highway 50 Warehouse at Sandling Beach

\section{Boundary Marking Status:}

\begin{tabular}{cccc}
\hline $\begin{array}{c}\text { Total } \\
\text { Boundary } \\
\text { Mile }\end{array}$ & $\begin{array}{c}\text { Well } \\
\text { Marked }\end{array}$ & $\begin{array}{c}\text { Poorly } \\
\text { Marked }\end{array}$ & $\begin{array}{c}\text { Indef. } \\
\text { or } \\
\text { Unknown }\end{array}$ \\
\hline 26.7 & 12.5 & 12.5 & 1.7
\end{tabular}

Expenditures and Attendance: :

\begin{tabular}{lrrrr}
\hline Year & Attendance (Calendar Yr.) & Current & $\$$ (Fiscal Yr.) & 1977 \\
\hline & & & (Fiscal Yr.) \\
1982 & 0 & $\$ 21,392$ & $\$ 14,148$ \\
1983 & 29,606 & 123,050 & 77,732 \\
1984 & 69,496 & 0 & 0 \\
1985 & 222,293 & 152,267 & 87,259 \\
1986 & 247,658 & 203,371 & 112,733 \\
1987 & 383,667 & 392,332 & 207,913 \\
1988 & & 364,270 & 185,003
\end{tabular}

Repair and Renovations:

\begin{tabular}{ccc}
\hline Fiscal Year & Current $\$$ & $1977 \$ *$ \\
1982 & $\$ 10,562$ & $\$ 6,985$ \\
1983 & $-0-$ & $-0-$ \\
1984 & 12,365 & 7,440 \\
1985 & 9,064 & 5,194 \\
1986 & 113,354 & 62,835
\end{tabular}

*1977 Budget figures are adjusted to reflect inflation and are shown in 1977 dollars. Source: Office of State Budget. 


\section{FORT FISHER STATE RECREATION AREA}

Location: New Hanover County

Size: 287 acres

\section{Reaso for Establishment:}

Fort Fisher State Recreation Area was originally part of a State Historic Site, the area having been the site of an important Civil War battle. The area is an excellent place for beach recreation. The recreation area was established to provide better management of existing State property used intensively for water based recreation and to provide managment of estuary access areas.

\section{History of the Park:}

A movement to develop the site of Fort Fisher as a State or National Park originated with the local citizens of New Hanover County in the early 1930s. The movement met with little success and died completely with the onset of World War II, when the fort site once again became an active military post. After the war, the site was abandoned by the Army. A landing strip had destroyed part of the land face and 100 years of sea erosion obliterated the corner bastion and much of the sea face, leaving the visitor with little to stimulate the imagination in picturing the massive earthworks and heroic battles which occurred at Fort Fisher.

In the late 1950s, local and state forces joined to revive the idea of restoring Fort Fisher. During the summer of 1960 , work commenced on a 180-acre tract held by the State of North Carolina under lease from the United States Government. Underbrush was cleared from the six mounds and seven gun emplacements which lie within the leased property. The mounds have been seeded and marked with interpretive signs and the fort is managed as a historic site by the Department of Cultural Resources.

An LWCF grant in 1969 allowed the State to purchase additional acreage, and this land was transferred to the Division in 1986 to provide a well managed beach recreation area.

\section{Facilities:}

Swim (ocean, bathhouse, refreshment stand) 
Fort Fisher State Park (Continued)

\section{Existing Staff:}

Permanent:

Park Ranger II

\section{Seasona1}

Park Attendant

Refreshment Stand Clerk (2)

Chief Lifeguard

Lifeguard (3)

\section{Minimum Additional Staff Needs:}

Park Superintendent I

Park Ranger

Maintenance Mechanic

Staffing Over Last Five Years:

Permanent

No Staff

No change

Park Ranger II
Seasonal

Park Attendant

No change

Park Attendant

Refreshment Stand Clerk II

Chief Lifeguard

Lifeguard (3)

\section{Internal Threats:}

Dune Buggies and Motorcycles:

There have been newly formed accesses by both vehicle types from the main road to the beaches. These vehicles cause damage to vegetation and erosion.

Shoreline Erosion:

This type of erosion is unavoidable. The natural beach erosion occurs continually.

Visitor Impacts:

The littering done by visitors negatively impacts the visual aesthetics of the beach area. 
Fort Fisher State Park (Continued)

\section{Internal Threats:}

Top 3 Visitor Impacts Identified by Superintendent:
1. ORV Use
2. Litter
3. Natural e cosion

\section{External Threats:}

No data available.

\section{Facility Condition:}

There are 2 buildings located at the park. The only problem is the lack of handicap access to each of them.

\section{Capital Improvements:}

Current Projects: None

Documented Needs: $\$ 458,488$

Projects: New water supply system, contact station, and paving of
lot

\section{Land Acquisition:}

No acquisition in progress.

\section{Boundary Marking Status:}

\begin{tabular}{cccc}
\hline $\begin{array}{c}\text { Total } \\
\text { Boundary } \\
\text { Mile }\end{array}$ & $\begin{array}{c}\text { Well } \\
\text { Marked }\end{array}$ & $\begin{array}{c}\text { Poorly } \\
\text { Marked }\end{array}$ & $\begin{array}{c}\text { Indef. } \\
\text { or } \\
\text { Unknown }\end{array}$ \\
\hline 16.6 & 0 & 7.6 & 9.0
\end{tabular}

Expenditures and Attendance:

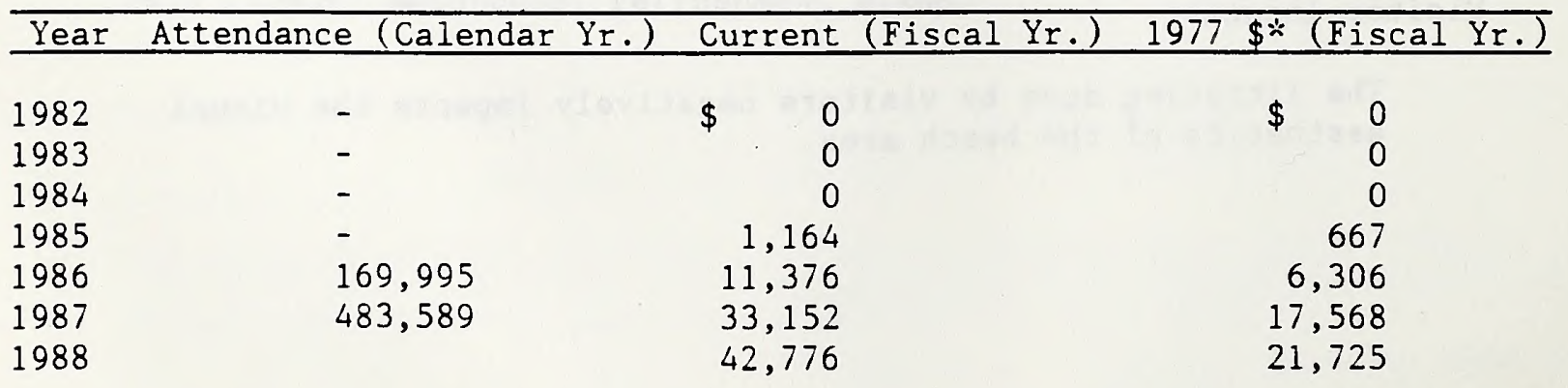


Fort Fisher State Park (Continued)

Repair and Renovations Over Last 5 Years: No data available.

*1977 Budget figures are adjusted to reflect inflation and are shown in 1977 dollars. Source: Office of State Budget.

Total Park Revenue: FY 1987: \$ 6,452

FY 1988: \$8:097 


\section{FORT MACON STATE PARK}

Location: Carteret County

Size: 389 acres

Reason for Establishment:

This historical fort was built in order to protect Beaufort Harbor. The Park offers outstanding vistas of the ocean, inlet, harbor, water craft, and beaches in addition to containing the historic fort.

\section{History of the Park:}

Fort Macon is North Carolina's second oldest state park, founded in 1924. The town of Beaufort is the third oldest town in North Carolina, settled in 1708. Fort Macon was built between 1826 and 1834 to replace an earlier fort which was abandoned when Beaufort Inlet shifted to the west. Robert $E$. Lee was the engineer for the stone jetties which were built in the 1840s. The fort was taken by Union forces in 1862 after a tremendous shelling. Abandoned for years, the fort has been painstakingly restored.

\section{Facilities:}

Historic fort (museum, bookstore, 5 restored rooms)

Maintenance area

Park office

Picnic area (30 tables, 16 shelters)

Residence ( 3 houses)

Swimming (ocean, bathhouse, refreshment stand)

Trail (.25 mile, hiking)

\section{Existing Staff:}

\section{Permanent:}

Park Superintendent III

Park Ranger II

Park Ranger I

Clerk Typist (.5)

Maintenance Mechanic

Historic Site Manager
Seasonal:

Park Attendant (3)

Chief Lifeguard

Lifeguard (5)

Refreshment Stand Manager I

Bathhouse Manager I

Refreshment Stand Clerk (2)

Historian

\section{Minimum Additional Staff Needs:}

Clèrk Typist (.5)

General Utility Worker

General Utility Worker (2) - Seasonal 
Fort Macon State Park (Continued)

\section{Staffing Over Last Ten Years:}

\section{Permanent}

1977 Park Superintendent III

Park Ranger I

Park Ranger II
Seasonal

No data available

Park Attendant (2)

Chief Lifeguard

Lifeguard (5)

Refreshment Stand Manager I

Bathhouse Manager I

Refreshment Stand Clerk (2)

Historian

1979 No Change

No change

1980-82 Added: Ranger Historian

No change

1983 Added: Clerk Typist $(1 / 2)$

No change

1984-1986 Added: Maintenance Mechanic Added: Park Attendant

Changed: Ranger Historian to Historic Site Manager

\section{Internal Threats:}

Erosion:

Erosion is occurring along the beach due to wave action.

Historic:

The fort has a long history. It needs repair work in order to enhance its interpretive value to the park.

Visitor Impacts:

Fort Macon is a very popular park which makes for an overcrowding problem. Damage can be seen on the dunes and the sensitive areas around them. There are also problems with overparking at both the fort and the bathhouse causing damage to the area and facilities. 
Fort Macon State Park (Continued)

Internal Threats: (Continued)

Top 3 Visitor Impacts Identified by Superintendent:

1. Overcrowding

2. Overparking

3. Dune Damage

\section{External Threats:}

Water Quality:

The development around the park has affected the water quality.

Adjacent Development:

The increase of condominiums on the barrier island has caused water pollution and a decline in the park's aesthetics. The integrity of the park is threatened by the proposal from the Town of Atlantic Beach to run a major sewer line through the park and develop an effluent dischage into the inlet.

\section{Facility Condition:}

There are 29 buildings located on the park and all are in need of repair. The safety problems are first priority and they include:

Lack of smoke detectors in several public buildings and the residences

Some of the buildings' foundations are deteriorating

The maintenance building's waste water pipes are still cast iron and need replacement

Weakened roofs

The fort has broken concrete floors, and the brick masonry is deteriorating

\section{Capital Improvements:}

Current Projects:

Barracks renovation

$\$ 155,320$

Maintenance building renovation $\$ 163,680$

Renovate int. restoration center $\$ 40,000$

Shelter renovations

$\$ 75,000$

Toilet building renovation

$\$ 142,500$

Waterline replacement utilities $\$ 101,631$ 
Fort Macon State Park (Continued)

Capital Improvements: (Continued)

Documented Needs: $\$ 7,546,221$

Projects: Fort restoration

Ranger residence garages (3)

Relocate fuel tanks

Renovate chief ranger residence (1)

75-yard expansion to rock jetty

Fort restoration study

Land Acquisition: No land acquisition in progress.

Boundary Marking Status:

\begin{tabular}{cccc}
\hline $\begin{array}{c}\text { Total } \\
\text { Boundary } \\
\text { Mile }\end{array}$ & $\begin{array}{c}\text { Well } \\
\text { Marked }\end{array}$ & $\begin{array}{c}\text { Poorly } \\
\text { Marked }\end{array}$ & $\begin{array}{c}\text { Indef. } \\
\text { or } \\
\text { Unknown }\end{array}$ \\
\hline 6.9 & 3.0 & 2.1 & 1.8
\end{tabular}

\section{Expenditures and Attendance:}

\begin{tabular}{|c|c|c|c|c|}
\hline Year & Attendance (Calendar Yr.) & Current \$ (Fiscal Yr.) & $1977 \$ *$ (Fiscal & $\mathrm{Yr})$. \\
\hline 1977 & 761,257 & $\$ 85,641$ & $\$ 85,641$ & \\
\hline 1978 & 957,239 & 100,297 & 93,886 & \\
\hline 1979 & 859,047 & 111,356 & 94,771 & \\
\hline 1980 & 879,426 & 106,602 & 81,750 & \\
\hline 1981 & 851,395 & 123,844 & 87,646 & \\
\hline 1982 & 925,084 & 133,563 & 88,335 & \\
\hline 1983 & $1,051,366$ & 185,605 & 117,249 & \\
\hline 1984 & $1,146,330$ & 185,605 & 111,676 & \\
\hline 1985 & $1,079,876$ & 180,553 & 103,469 & \\
\hline 1986 & $1,193,862$ & 192,380 & 106,641 & \\
\hline 1987 & $1,225,520$ & 213,820 & 113,312 & \\
\hline 1988 & & 257,157 & 130,603 & \\
\hline
\end{tabular}

Repair and Renovations:

\begin{tabular}{crr}
\hline Fiscal Year & Current $\$$ & $1977 \$ *$ \\
\hline 1977 & $\$ 10,541$ & $\$ 10,541$ \\
1978 & 12,111 & 11,266 \\
1979 & 27,386 & 23,307 \\
1980 & 19,290 & 14,793 \\
1981 & 12,823 & 9,075 \\
1982 & 14,605 & 9,659 \\
1983 & 0 & 0 \\
1984 & 25,109 & 15,108 \\
1985 & 22,186 & 12,714 \\
1986 & 19,334 & 10,717
\end{tabular}


Fort Macon State Park (Continued)

*1977 Budget figures are adjusted to reflect inflation and are shown in 1977 dollars. Source: Office of State Budget.

Total Park Revenue: FY 1987: \$41,898

FY 1988: $\$ 46,084$ 


\section{GOOSE CREEKK STATE PARK}

Location: Beaufort County

Size: 1,327 acres

\section{Reason for Establishment:}

The park contains biologic, scenic, and recreational resources in a setting not previously represented in the system. The unique marshy area forms a natural garden. It includes wetlands and river frontage along the Pamlico.

\section{History of the Park:}

Goose Creek was purchased in 1974 with funds appropriated by the General Assembly in the early 1970s. During this time twelve new parks and recreation areas, including Goose Creek, were established.

\section{Facilities:}

Boat launch

Camping (primitive)

Park office/maintenance building

Picnic area (20 tables, restrooms)

Residence (one house, one trailer)

Trail (6 miles, hiking)

\section{Existing Staff:}

\section{Permanent:}

Park Superintendent I

Park Ranger II

Park Ranger I

Minimum Additional Staff Needs:

Maintenance Mechanic

Clerk Typist III

Staffing Over Last Ten Years:
Seasonal

Park Attendant

Lifeguard (2)

General Utility Worker

Clerk Typist 
Goose Creek State Park (Continued)

Staffing Over Last Ten Years: (Continued)

Permanent Seasonal

1979-1980 No change

No change

1981 No change

Added: Lifeguards (2)

1982 No change

No change

1983 No change

Added: Clerk Typist

$1984-1985$ No change

No change

1986 No change

Change Naturalist Position to General Utility Worker

\section{Internal Threats:}

O1d Field Management:

The upkeep of fields has been on a year-to-year basis because of the areas growing over so quickly.

Endangered Species:

The red-cockaded woodpecker was once very active in the park, but because of growth around the park, fewer of them have been spotted. Control of wildfire is threatening the integrity of the red-cockaded woodpecker habitat. A buildup of fuels is posing a severe fire danger, and a draft prescribed burn plan has been prepared.

Pest Management:

Fire ants and Southern Pine Beetles have become management problems. Spraying for ticks has been necessary for the last few years in order to control them.

Soil Compaction:

The picnic area needs to be expanded in order to alleviate the concentration of picnicking in one area which is the main cause of the soil compaction.

Lack of Communication:

There is no bathhouse for the swimming area which leaves the lifeguards without a phone to contact rangers in case of emergency. 
Goose Creek State Park (Continued)

Internal Threats: (Continued)

Vandalism and Litter:

The boat landing is isolated from the rest of the park and that is where the vandalism and litter are occurring.

Top 3 Visitor Impacts Identified by Superintendent:

1. Soil compaction

2. Lack of communication

3. Vandalism and litter

\section{External Threats:}

Adjacent Development:

There is development of a residential area on the north side and homes are being constructed close to the park boundary. There has also been a lot of clear-cutting in the past few years which may have impacts in later years. The aesthetic view from the park has been negatively impacted by such developments.

\section{Facility Condition:}

There are 19 buildings in use at the park, some with serious problems. There is a storage building that needs to be replaced, and the concrete porches are beginning to crack. There has been some improvement made for the handicapped including more parking and easier access to restrooms. However, most projects for handicapped access remain. New flooring needs to be installed at the park office.

Storage and lumber storage buildings are needed. Older equipment needs rehabilitating, such as replacing the buoy and rope at the swimming area. Park boundary lines need to be cleared and marked.

\section{Capital Improvements:}

Current Projects: None

Documented Needs: $\$ 2,945,354$

Projects: Tent and trailer campground

Boat launch, pier, clean facilities and channel dredge

Vehicle storage shed

Warehouse

Group camp, road, utilities, beach, pier sites, parking lot

Visitor center complex

Picnic area-family day use, beach, bathhouse, parking lot, and sites 
Goose Creek State Park (Continued)

Capital Improvements - Projects (Continued)

Personnel barracks

Parking/access road - Dinah's Landing

Trails

Ranger residences (2)

Tent camping-boat dock-walk in

Primitive campsites - family

\section{Land Acquisition:}

The acquisition of one parcel is currently being pursued.

Boundary Marking \& Status:

\begin{tabular}{cccc}
\hline $\begin{array}{c}\text { Total } \\
\text { Boundary } \\
\text { Mile }\end{array}$ & $\begin{array}{c}\text { Well } \\
\text { Marked }\end{array}$ & $\begin{array}{c}\text { Poorly } \\
\text { Marked }\end{array}$ & $\begin{array}{c}\text { Indef. } \\
\text { or } \\
\text { Unknown }\end{array}$ \\
\hline 12.8 & 6.0 & 6.8 & $-0-$
\end{tabular}

Expenditures and Attendance:

\begin{tabular}{lccc}
\hline Year & Attendance (Calendar Yr.) & Current $\$$ (Fiscal Yr.) & $1977 \$ *$ (Fiscal Yr.) \\
\hline & & & \\
1977 & 40,844 & $\$ 21,755$ & $\$ 21,755$ \\
1978 & 36,767 & 40,980 & 38,121 \\
1979 & 27,157 & 66,912 & 56,946 \\
1980 & 28,792 & 67,180 & 51,518 \\
1981 & 53,800 & 70,231 & 49,703 \\
1982 & 98,849 & 66,456 & 43,952 \\
1983 & 112,042 & 77,584 & 49,011 \\
1984 & 117,050 & 77,584 & 46,681 \\
1985 & 110,391 & 81,704 & 46,822 \\
1986 & 109,798 & 91,430 & 50,682 \\
1987 & 113,225 & 95,851 & 50,795 \\
1988 & & 100,861 & 51,224
\end{tabular}

Repair and Renovations:

\begin{tabular}{|c|c|c|}
\hline Fiscal Year & Current \$ & $1977 \$ *$ \\
\hline 1977 & 1,360 & $\$ 1,36$ \\
\hline 1978 & 2,401 & 2,233 \\
\hline 1979 & 4,044 & 3,442 \\
\hline 1980 & 3,795 & 2,910 \\
\hline 1981 & 6,958 & 4,924 \\
\hline 1982 & 3,494 & 2,311 \\
\hline 1983 & 0 & 0 \\
\hline 1984 & 2,857 & 1,719 \\
\hline 1985 & 2,269 & 1,300 \\
\hline 1986 & 2,494 & 1,382 \\
\hline
\end{tabular}


Goose Creek State Park (Continued)

*1977 budget figures are adjusted to reflect inflation and are shown in the 1977 dollars. Source: Office of State Budget.

Total Park Revenue: FY 1987: \$2,593

FY 1988: $\$ 2,829$ 


\section{HAMMOCKS BEACH STATE PARK}

Location: Onslow County

Size: 892 acres

\section{Reason for Establishment:}

The beach is an undeveloped area that has examples of the natural proces; of dune migration. The island is also a nesting area for loggerhead sea turtles. The park contains outstanding biological, scenic, and recreational resources.

\section{History of the Park:}

Nearby Swansboro is one of the earliest known towns in North Carolina. It is listed in the Colonial Records. There are legends of Blackbeard and invasion by the Spanish. The beach was used by whalers and fishermen. It was owned for half a century by Dr. William Sharpe, a New York brain surgeon and friend of Franklin Delano Roosevelt. $\mathrm{Dr}$. Sharpe left the island to the black teachers' association for a retreat. It was given to the state for a park in 1961. (Runkle, John. A Guide to North Carolina State Parks. Tread Softly, 1983, p. 38.)

\section{Facilities:}

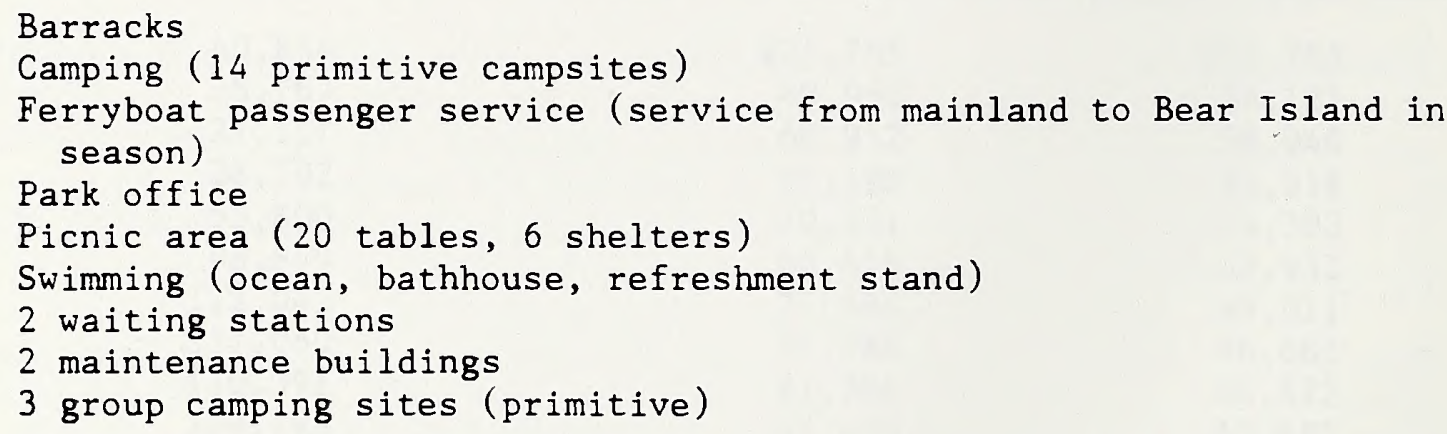

\section{Existing Staff:}

Permanent:

Park Superintendent II Park Ranger II

Maintenance Mechanic III

\section{Seasonal:}

Naturalist

Park Attendant

Chief Lifeguard

Lifeguard (3)

Refreshment Manager I

Bathhouse Manager

Deckhand (3)

Ferryboat Operator (3)

Assistant Ranger

Clerk Typist 
Hammocks Beach State Park (Continued)

\section{Minimum Additional Staff Needs:}

Permanent:

Park Interpreter and

Education Specialist

Park Ranger II

Clerk Typist III

\section{Staffing Over Last Ten Years:}

Permanent Seasonal

1977 Park Superintendent II No data available

Chief Park Ranger

1978 No Change

Park Attendant

Chief Lifeguard

Lifeguard (2)

Refreshment Stand Manager I

Bathhouse Manager I

Deckhand (2)

Ferrymen (2)

Park Ranger

Boat Operator

1979-80 No Change

No Change

1981 No Change

Added: Deckhand

Naturalist

Ferryboat Operator

1982 No Change No change

1983 No Change Added: Clerk Typist

1984 No Charge No Change

1985 Added: Maintenance Mechanic II

1986 No Change

Added: Lifeguard

\section{Internal Threats:}

Erosion:

Wave Action is causing beach erosion on the island and has required the construction of a new bulkhead. The main route from the bathhouse to the beach is heavily used and erosion and vegetation trampling are evident. 
Hammocks Beach State Park (Continued)

Internal Threats: (Continued)

Endangered Species:

Protection of the nesting sites on the island is needed for the Loggerhead Turtle.

Overuse:

The bathhouse on Bear Island shows signs of abuse in that it has little to no vegetation around it.

Wildlife Management:

The control of hunters on the park Boundary is needed.

Visitor Impact:

The increase of visitors during the summers may be disturbing nesting sea turtles.

Litter:

The beach is the area affected by the litter left behind from the swimmers and sunbathers.

Boundaries :

Only the popular access areas on Bear Island have been marked.

Top 3 Visitor Impacts Identified by Superintendent:

1. Erosion

2. Overuse

3. Litter

\section{External Threats:}

Military Overflights:

Bear Island is in close proximity to two military air bases and frequesnt over flights of jets and helicopters intrude on the serenity of the island. In addition, the island west of Bear Island, Browns Island, is a military bombing and artillery range.

Adjacent Development:

The islands close by are being developed and negatively affect the aesthetic view from the island. 
Hammocks Beach State Park (Continued)

\section{Facility Condition:}

There are 27 buildings including several covered wells, and there are many problems and safety hazards including: wooden steps to the rangers house are rotten; a rotting wooden porch is in need of being replaced; and there is a lack of handicapped access.

Installation of smoke detectors and fire extinguishers has been completed. The replacement of the main power cable and other electrical wiring repairs are completed. Replacement of the bulkhead on the mainland has just been completed.

\section{Capital Improvements:}

Current Projects:

$$
\begin{array}{ll}
\text { Sewer Improvements } & \$ 60,000 \\
\text { Power cable/electrical repair } & \$ 227,680 \\
\text { Mainland Bulkhead Replace } & \$ 176,645 \\
\text { Island Well-Water Improvement } & \$ 316,800
\end{array}
$$

Documented Needs: $\$ 1,617,252$

Projects: Nature study building, exhibit, and furniture

Maintenance building addition for park office, renovate existing ranger residence

Landing improvements, island

Ranger residence (1)

Office/visitor center

Renovate existing office to barracks

Picnic area development

Land Acquisition:

\begin{tabular}{cccc}
\hline Tract & Acres & Reason & Estimated Cost \\
\hline 2 & 43.600 & Mainland development & $\$ 610,000$
\end{tabular}

\section{Boundary Marking Status:}

\begin{tabular}{cccc}
\hline $\begin{array}{c}\text { Total } \\
\text { Boundary } \\
\text { Mile }\end{array}$ & $\begin{array}{c}\text { Well } \\
\text { Marked }\end{array}$ & $\begin{array}{c}\text { Poorly } \\
\text { Marked }\end{array}$ & $\begin{array}{c}\text { Indef. } \\
\text { or } \\
\text { Unknown }\end{array}$ \\
\hline 4.5 & 0.5 & 4.0 & $-0-$
\end{tabular}


Hammocks Beach State Park (Continued)

\section{Expenditures and Attendance:}

\begin{tabular}{|c|c|c|c|}
\hline Year & Attendance (Calendar $\mathrm{Yr}$. ) & Current \$ (Fiscal Yr.) & $1977 \$^{*}$ (Fiscal Yr.) \\
\hline 1977 & 29,051 & $\$ 74,561$ & $\$ 74,561$ \\
\hline 1978 & 29,442 & 81,517 & 75,830 \\
\hline 1979 & 29,653 & 95,979 & 81,684 \\
\hline 1980 & 29,038 & 96,088 & 73,687 \\
\hline 1981 & 32,889 & 124,159 & 87,869 \\
\hline 1982 & 32,117 & 112,582 & 74,459 \\
\hline 1983 & 33,938 & 133,357 & 84,243 \\
\hline 1984 & 29,133 & 132,388 & 79,656 \\
\hline 1985 & 29,628 & 140,641 & 80,597 \\
\hline 1986 & 29,942 & 164,142 & 90,988 \\
\hline 1987 & 47,280 & 212,602 & 112,666 \\
\hline 1988 & & 192,093 & 97,559 \\
\hline
\end{tabular}

\section{Repair/Renovations:}

\begin{tabular}{crr}
\hline Fiscal Year & Current $\$$ & $1977 \$^{*}$ \\
\hline & & \\
1977 & 2,455 & 2,455 \\
1978 & 11,583 & 10,775 \\
1979 & 8,068 & 6,866 \\
1980 & 6,602 & 5,063 \\
1981 & 6,548 & 4,634 \\
1982 & $4,605$. & 3,046 \\
1983 & 0 & 0 \\
1984 & 21,531 & 12,955 \\
1985 & 10,486 & 6,009 \\
1986 & 4,543 & 2,518
\end{tabular}

*1977 Budget figures are adjusted to reflect inflation and are shown in 1977 dollars. Source: Office of State Budget.

Total Park Revenue: FY 1987: \$13,186

FY 1988: \$13,372 


\section{HANGING ROCK STATE PARK}

Location: Stokes County

Size: $\quad 5,852$

\section{R ason for Establishment:}

This mountain is the most eastern of any mountain in the State. It offers outstanding scenic views, sparkling mountain streams, waterfalls and cascades. Over 300 species of rare and unusual mountain plants can be found.

\section{History of the Park:}

The Civilian Conservation Corps established a camp at Hanging Rock in 1935 and constructed various recreational facilities and made general improvements. Hanging Rock State Park developed through the public spiritedness of a committee set up by the citizens of Winston-Salem and Stokes County, who donated 3,000 acres to the State in 1936.

\section{Facilities:}

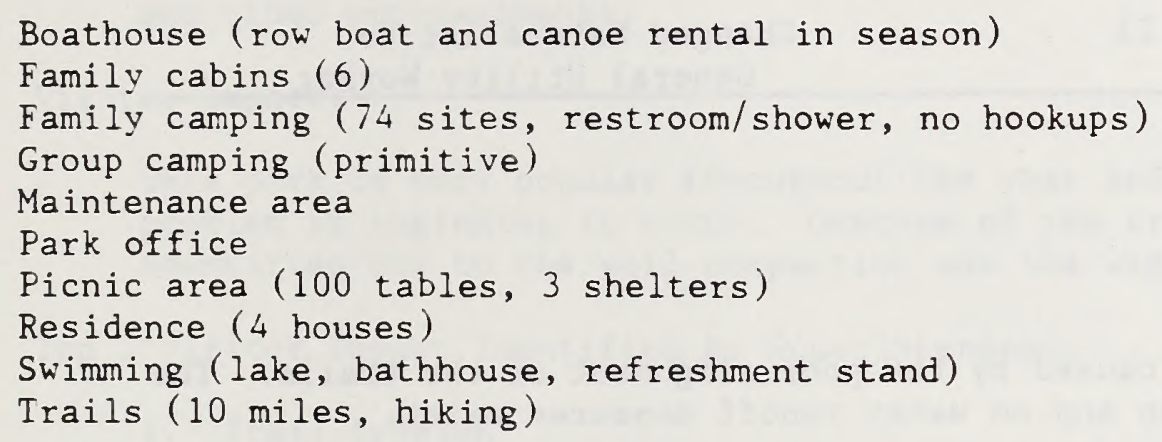

\section{Existing Staff:}

\section{Permanent:}

Park Superintendent III

Park Ranger II

Park Ranger II

Park Ranger I

Clerk-Typist III (.5)

Maintenance Mechanic II
Seasonal:

Park Attendant (2)

Bathhouse Operator

Chief Lifeguard

Lifeguard (4)

Refreshment Manager I

Bathhouse Manager

Refreshment Stand Clerk

General Utility Worker

Minimum Additional Staff Needs:

Clerk Typist III (.5) 
Hanging Rock State Park (Continued)

Staffing Over Last Ten Years:

Permanent

1977 Park Superintendent III

Park Ranger III

Park Ranger II

Park Panger I

1978 No Change
Seasonal

No data available

Park Attendant (2)

Chief Lifeguard

Lifeguard (4)

Refreshment Stand Manager I

Bathhouse Manager II

Refreshment Stand Clerk

Naturalist

No Change

Added:

1985 Clerk-Typist

No change

Added :

1986 Maintenance Mechanic II

Changed Naturalist to

General Utility Worker

\section{Internal Threats:}

Erosion:

Trail erosion is caused by the poor alignment of the trails. The grade is too steep and no water runoff measures exist.

The public use areas including the campground, picnic area, and other areas are heavily used causing extreme soil compaction.

Vegetation Damage:

The heavy public use areas are losing the forest overstory due to both soil compaction and vandalism.

Historic Sites:

There are some old buildings that are on the park that have historical significance. 
Hanging Rock State Park (Continued)

\section{Internal Threats: (Continued)}

Fisheries Management:

The small 12 acre lake provides fishing, and this is very popular at the park. Overcrowding has been a problem.

Endangered Species:

Several species of rare plants exist, including the Schweintz's Sunflower, the Sweet Pinsap, the Translucent Orthodontum, and the Bradley Spleenwort. The only rare animal found is the Wehrle's Salamander.

Pest Management:

There have been some minor outbreaks of Southern Pine Beetle.

Boundaries:

The unmarked boundaries are allowing major problems with poaching and other encroachments.

Visitor Impact:

This park is very popular throughout the year and an overcrowding problem is beginning to occur. Overuse of the trails can be identified due to the soil compaction and the width of the trails.

Top 3 Visitor Impact Identified by Superintendent:

1. Trail Erosion

2. Soil Compaction

3. Vegetation Damage

\section{External Threats:}

Adjacent Development:

Several zoning requests have been before the county zoning board concerning lands adjoining the park. Development around the park would greatly affect the aesthetic view from the mountain. Hanging Rock Ridge was threatened recently by a proposal to place a major communications tower on the ridge. Acquisition of the ridge is underway. 


\title{
Facility Condition:
}

The 45 buildings in the park all need repairs. Some safety hazards that need attention include:

Smoke detectors in all the cabins

The entire septic system needs to be redone

Overloaded electrical outlets and conductors

The concrete porch is cracking

The lack of fire extinguishers or existing one in poor condition

Waste water piping nteds replacing

The electrical power is not grounded

Cracking building foundations

Restroom lighting is in poor condition

Oil fired forced air furnace is in terrible condition

Ranger residence needs new attic stairs

Little to no handicap access.

There are several projects that are in progress at the park including renovation of 5 toilet buildings and total renovation of the observation tower.

\section{Capital Improvements:}

Current Projects:

Bathhouse renovation

Dan River canoe access

$\$ 346,080$

Hiking trail renovation

24,500

75,000

Observation tower/cabin renovation

335,920

Renovate main trail

23,942

Renovate 5 toilet buildings

Water system improvements

205,500

38,102

Documented Needs: $\$ 4,042,200$

\author{
Projects: Visitor center complex \\ 4 rental cabins package \\ Parking lot - lower cascades and Tory's Den \\ Improvements to beach \\ Entrance gate stone columns \\ Renovate grills in camping and picnic \\ Renovate ranger residences (3) \\ Renovation of maintenance area buildings \\ Renovate personnel barracks \\ 30 rental cabins at river site \\ River access and utilities
}


Hanging Rock State Park (Continued)

Land Acquisition:

Tract Acres $\quad$ Reason $\quad$ Estimated Cost

$1290.00 \quad$ Primary Resource Protection 180,000

Boundary Marking Status:

\begin{tabular}{cccc}
\hline $\begin{array}{c}\text { Total } \\
\text { Boundary } \\
\text { Miles }\end{array}$ & $\begin{array}{c}\text { Well } \\
\text { Marked }\end{array}$ & $\begin{array}{c}\text { Poorly } \\
\text { Marked }\end{array}$ & $\begin{array}{c}\text { Indef. } \\
\text { or } \\
\text { Unknown }\end{array}$ \\
\hline 27.6 & 10.8 & 3.4 & 13.4
\end{tabular}

Expenditures And Attendance:

\begin{tabular}{lccc}
\hline Year & Attendance (Calendar Yr.) & Current $\$($ Fiscal Yr.) & $1977 \$$ (Fiscal Yr.) \\
\hline & & & \\
1977 & 170,630 & $\$ 104,400$ & $\$ 104,400$ \\
1978 & 230,996 & 115,027 & 107,002 \\
1979 & 218,612 & 123,907 & 105,453 \\
1980 & 275,600 & 122,209 & 93,719 \\
1981 & 259,155 & 140,341 & 99,321 \\
1982 & 240,988 & 124,099 & 82,076 \\
1983 & 237,486 & 157,261 & 99,344 \\
1984 & 200,184 & 157,163 & 94,563 \\
1985 & 229,588 & 157,608 & 262,240 \\
1986 & 234,713 & 167,600 & 92,905 \\
1987 & 268,312 & 183,820 & 97,413 \\
1988 & & 245,353 & 124,608
\end{tabular}

Repair/Renovations:

\begin{tabular}{crr}
\hline Fiscal Year & Current $\$$ & $1977 \$^{*}$ \\
\hline & & \\
1977 & 7,805 & 7,805 \\
1978 & 12,299 & 11,441 \\
1979 & 8,160 & 6,945 \\
1980 & 13,466 & 10,327 \\
1981 & 8,837 & 6,254 \\
1982 & 8,410 & 5,562 \\
1983 & 0 & 0 \\
1984 & 8,084 & 4,864 \\
1985 & 15,895 & 9,112 \\
1986 & 10,595 & 5,873
\end{tabular}


Hanging Rock State Park (Continued)

*1977 Budget figures are adjusted to reflect inflation and are shown in 1977 dollars. Source: Office of State Budget.

Total Park Revenue: FY 1987: $\$ 95,562$

FY 1988: $\quad \$ 93,874$ 


\section{HEMLOCK BLUFFS NATURAL AREA}

Location: Wake County

Size: 84.72 acres

Reason for Establishment:

Hemlock Bluffs is a natural area that features flora and fauna unique to the mountain regions some 200 miles away. The cooler climate of the area allows the growth of hemlock trees on bluffs which face north over Swift Creek and which are never exposed to direct sunlight.

\section{History of the Natural Area:}

In 1961, the National Park Service recognized the Hemlock Bluffs as an area worthy of acquiring as a local nature preserve. The State purchased the property with Land and Water Conservation Fund assistance in 1976. Because the State had no staff or budget to manage the property, a lease agreement for management of the area has been made with the Town of Cary. In 1979, the Hemlock Bluffs were added to the State Registry of Natural Heritage Areas and classified as a State Nature and Historic Preserve by the General Assembly.

\section{Existing Recreation Opportunities:}

Access to the bluffs allows passive recreational opportunities such as nature study. On adjoining land, the Town of Cary plans to build a nature/visitor center with nature trails and interpretive signs in the natural area. Cary also will construct active recreation facilities on its adjacent land.

\section{Threats :}

Small hemlock trees, wildflowers, and other plants have been removed from from the area. Overuse has damaged the trails on the bluffs, ORV damage is present, and litter problems have also existed. Fire has already damaged the area, and the future threat of fire exists.

\section{Land Acquisition:}

None planned.

\section{Staffing:}

None

\section{Budget:}

None 


\section{HORSEPASTURE RIVER}

Location: Transylvania County

Length: That segment extending downstream from Bohaynee Road (N.C. 281) to Lake Jocassee, approximately four miles.

\section{Reason for Establishment:}

To preserve the outstanding natural and scenic qualities of the river and to maintain the river in a free-flowing state. The river has five very different and outstanding waterfalls within a two-mile segment. The variety of flows combines with the variety of waterfalls to guarantee an unusually large variety of scenic features in these waterfalls. The Horsepasture gorge is one of the most rugged gorges in the Blue Ridge escarpment.

\section{History of the River:}

The Horsepasture River was designated a Natural River by the General Assembly on June 7, 1985. Efforts to protect the river stemmed from plans by Carrasan Power and the Federal Energy Regulatory Commission that could have led to the impoundment of the river. The river corridor includes no State land ownership. Portions of the four mile designated Natural River flow through U.S. Forest Service lands, and part through private property.

\section{Existing Recreation Opportunities:}

Hiking Trail:

An 80-mile hiking trail known as the Foothills Trail crosses the lower portion of the Horsepasture. Other trails also exist along the river. The trails are not State owned property, but are maintained by Duke Power Company.

\section{Fishing:}

The Horsepasture is classified as a designated trout water and is managed primarily for brown trout which receive annual supplementary stocking. Catch success is not high because of low fish density and steep gradient. Access is also difficult.

\section{Picnicking :}

Picnicking is a popular activity on the rock outcroppings above and below the two upper falls due to the easy access.

\section{Staffing :}

The Horsepasture has never had any staff. 


\section{Threats:}

Water Quality:

Designation as a natural river does little to protect water quality as the greater watershed is not affected by designation.

Adjacent Land Use:

The State owns no land along the four mile segment designated as a component of the N.C. Natural and Scenic Rivers System. The river is not protected by land use controls. Timber could be cut, or land developed.

Litter:

Litter is evidenced along the river, especially in the popular falls areas.

Erosion:

The thin soils in much of the area and fragile ground cover can lead to erosion problems if disturbed.

Pacilities:

None

\section{Land Acquisition:}

The State owns no land along the river, nor are there any plans to purchase any. The U.S. Forest Service and Crescent Land and Timber Company are the primary landowners along the designated segment of the river. 


\section{JOCKEY'S RIDGE STATE PARK}

Location: Dare County

Size: 393 acres

\section{Reason for Establishment:}

The area contains the largest natural sand dunes on the east coast, and they extend to 140 feet in height.

\section{History of the Park:}

The name Jockey's Ridge comes from the use of the dune as a grandstand for horse-racing. Legend has it that the name Nags Head comes from the practice of the Outer Bankers tying a lantern to a horse's head and leading it up and down the beach, to lure ships to their destruction. The area is rich in history. The Elizabethean Gardens and the summer outdoor drama, "The Lost Colony," are also found on Roanoke Island. Near Jockey's Ridge is Kill Devil Hill, where the Wright brothers first flew their airplane on December 17, 1903. The Wright Brothers' Memorial and Museum stands on the spot where the flight took place.

The dunes at Jockey's Ridge were saved in the early 1970s by the efforts of the local residents, led by Carolista Fletcher, who stood in front of the bulldozers. Support throughout the state was mobilized to prevent the dunes from becoming developed.

\section{Facilities:}

Park office/museum/maintenance building Picnic area (16 tables with 8 shelters) Residence (one house)

\section{Existing Staff:}

Permanent:

Park Ranger II

Park Ranger I
Seasonal:

Park Attendant

\section{Minimum Additional Staff Needs:}

\section{Permanent:}

Maintenance Mechanic Park Superintendent Clerk Typist 
Jockey's Ridge State Park (Continued)

Staffing Over Last Ten Years:

Permanent

Seasonal

\section{7}

Park Ranger I

No Change

1978-1979 No Change

Park Attendant

1980 Added: Park Ranger I

No change

1981-1984 No change

No change

1985

No Change

No change

1986

No change

No change

\section{Internal Threats:}

Inholdings:

There are several inholdings in the park. Failure to acquire these parcels could result in their development for residential purposes, impacting the park's nationally signigicant visual resources.

\section{Staffing:}

The increase in visitation is requiring more overtime by the staff. More staff is needed.

\section{Visitor Impact:}

The park is closed in the evening to the public, but because of the Nags Head area being so close, there are people that stay on the park after hours. There is also a permit system used for hang gliders to provide management for the dunes and the various activities. The visitor concentration at the restrooms, parking lot, and picnic area is heavy.

Top 3 Visitor Impacts Identified by Superintendent:

1. Overcrowding in small areas

2. Conflict of recreational interests

3. Easy access to park

\section{External Threats:}

Crosswalk:

This has given unlimited access to the park from Nags Head. It also presents traffic safety problems. 
Jockey's Ridge State Park (Continued)

Adjacent Land Use:

Adjacent land use activities have threatened the natural movement of sands in the dune system. Sand mining that was occuring adjacent to the park and which was permanently removing sand from the system has stopped. Commercial and residential development near the park may be severely altering wind patterns and velocities that are important to the natural maintenance of the dune.

\section{Pacility Condition:}

Most of the 10 buildings on the park are picnic shelters.

The park has received money for general development including completion of the museum. The structures are in good condition.

\section{Capital Improvements:}

Current Projects:

General/museum development $\$ 436,615$

Documented Needs: $\$ 471,960$

Projects: Landscape - park

Repair parking area

Warehouse, pave lot

Renovate ranger residences (2)

Land Acquisition:

\begin{tabular}{|c|c|c|}
\hline Iract & Acres & Reason \\
\hline 1 & .2800 & Inholding intrudes into park \\
\hline 2 & .4480 & Inholding intrudes into park \\
\hline 4 & 3.8000 & $\begin{array}{l}\text { Inhoiding bordered on } 3 \text { sides } \\
\text { by park }\end{array}$ \\
\hline 7 & 1.3800 & Inholding intrudes into park \\
\hline 8 & 2.1650 & Inholding intrudes into park \\
\hline 9 & 1.6177 & Inholding intrudes into park \\
\hline $14 \mathrm{~A}$ & 1.8833 & Inholding intrudes into park \\
\hline 14 & 1.0212 & $\begin{array}{l}\text { Inholding completely surrounded } \\
\text { by park }\end{array}$ \\
\hline 19 & 1.3730 & Buffer \\
\hline 46 & 3.1100 & Inholding intrudes into park \\
\hline 47 & .0920 & Inholding intrudes into park \\
\hline 48 & .4500 & Inholding intrudes into park \\
\hline 49 & .0826 & Inholding intrudes into park \\
\hline $55-1$ & .1266 & Inholding completely surrounded \\
\hline
\end{tabular}


Jockey's Ridge State Park (Continued)

Land Acquisition: (continued)

\begin{tabular}{|c|c|c|}
\hline Iract 非 & Acres & Reason \\
\hline $55-2$ & .1266 & $\begin{array}{l}\text { Inholding completely surrounded } \\
\text { by park }\end{array}$ \\
\hline $55-3$ & .1266 & $\begin{array}{l}\text { Inholding completely surrounded } \\
\text { by park }\end{array}$ \\
\hline $55-4$ & .1298 & $\begin{array}{l}\text { Inholding completely surrounded } \\
\text { by park }\end{array}$ \\
\hline $55-5$ & .1894 & $\begin{array}{l}\text { Inholding completely surrounded } \\
\text { by park }\end{array}$ \\
\hline $55-6$ & .1891 & $\begin{array}{l}\text { Inholding completely surrounded } \\
\text { by park }\end{array}$ \\
\hline $55-7$ & .1292 & $\begin{array}{l}\text { Inholding completely surrounded } \\
\text { by park }\end{array}$ \\
\hline $56-1$ & .3807 & $\begin{array}{l}\text { Inholding completely surrounded } \\
\text { by park }\end{array}$ \\
\hline $56-2$ & .2526 & $\begin{array}{l}\text { Inholding completely surrounded } \\
\text { by park }\end{array}$ \\
\hline $56-3$ & .1253 & $\begin{array}{l}\text { Inholding completely surrounded } \\
\text { by park }\end{array}$ \\
\hline $56-4$ & .1256 & $\begin{array}{l}\text { Inholding completely surrounded } \\
\text { by park }\end{array}$ \\
\hline $56-5$ & .2510 & $\begin{array}{l}\text { Inholding completely surrounded } \\
\text { by park }\end{array}$ \\
\hline $57-3$ & .2025 & $\begin{array}{l}\text { Inholding completely surrounded } \\
\text { by park }\end{array}$ \\
\hline $57-4$ & .2025 & $\begin{array}{l}\text { Inholding completely surrounded } \\
\text { by park }\end{array}$ \\
\hline $57-5$ & .2025 & $\begin{array}{l}\text { Inholding completely surrounded } \\
\text { by park }\end{array}$ \\
\hline $57-6$ & .2020 & $\begin{array}{l}\text { Inholding completely surrounded } \\
\text { by park }\end{array}$ \\
\hline 58 & .1469 & Inholding intrudes into park \\
\hline 59 & .2847 & Inholding intrudes into park \\
\hline $\begin{array}{l}60 \\
61\end{array}$ & $\begin{array}{l}.4591 \\
.4591\end{array}$ & $\begin{array}{l}\text { Resource Management } \\
\text { Resource Management }\end{array}$ \\
\hline
\end{tabular}

\section{Boundary Marking Status:}

\begin{tabular}{cccc}
\hline $\begin{array}{c}\text { Total } \\
\text { Boundary } \\
\text { Mile }\end{array}$ & $\begin{array}{c}\text { Well } \\
\text { Marked }\end{array}$ & $\begin{array}{c}\text { Poorly } \\
\text { Marked }\end{array}$ & $\begin{array}{c}\text { Indef. } \\
\text { or } \\
\text { Unknown }\end{array}$ \\
\hline 4.2 & $-0-$ & 2.0 & 2.2
\end{tabular}


Jockey's Ridge State Park (Continued)

Expenditures and Attendances:

Year Attendance (Calendar Yr.) Current $\$$ (Fiscal Yr.) $1977 \quad \$^{*}$ (Fiscal Yr.)

1977

1978

1979

1980

1981

1982

1983

1984

1985

1986

1987

1988
32,370

182,473

192,309

187,784

229,738

286,394

275,822

304,250

325,867

350,092
$\$ 1,191$

14,502

13,498

14,064

31,425

36,630

36,531

36,531

36,244

38,661

38,692

89,352
$\$ 1,191$

13,490

11,488

10,785

22,240

24,226

23,077

21,980

20,770

21,431

20,504

45,379

Repair and Renovations:

\begin{tabular}{|c|c|c|}
\hline Fiscal Year & Current \$ & $1977 \$$ \\
\hline 1977 & 50 & 50 \\
\hline 1978 & 0 & 0 \\
\hline 1979 & 437 & 372 \\
\hline 1980 & 242 & 186 \\
\hline 1981 & 3,052 & 2,160 \\
\hline 1982 & 2,104 & 1,392 \\
\hline 1983 & 0 & 0 \\
\hline 1984 & 1,236 & 748 \\
\hline 1985 & 1,851 & 1,061 \\
\hline 1986 & 2,537 & 1,406 \\
\hline
\end{tabular}

*1977 Budget figures are adjusted to reflect inflation and are shown in 1977 dollars. Source: Office of State Budget.

Total Park Revenue: FY 1987: $\$ 23,765$

FY 1988: $\$ 25,511$ 


\section{JONES LAKE STATE PARK}

\section{Location: Bladen County}

Size: 1669 acres land

539 acres water

$\overline{2208}$ acres total

\section{Reason is is Establishment:}

Jones Lake is an excellent example of a Carolina Bay ecosystem whose geological origin is still unknown. It is a popular recreational lake that typlifies a Carolina Bay and its associated communities.

\section{History of the Park:}

Bladen County was settled by Scottish and English settlers in the 1730 s. Farming over the years depleted the marginal soils and, by the Depression, much of the population suffered or moved away. A Civilian Conservation Corps (CCC) camp in the Bladen Forest made possible the construction of the park's recreation area and trails. In 1911, the state took claim of all the lakes over 500 acres (later reduced to 50 acres) in the southern coastal area for "the use and benefit of the people." Jones Lake became a state park in 1939 and, although initially a segregated park, is now used by all segments of the population.

\section{Pacilities:}

Bathouse (rowboats for rent in season)

Boat ramp

Family camping ( 20 sites, restroom/shower, no hookups)

Maintenance building

Park office/barracks

Picnic area ( 60 tables, 6 shelters)

Residence (one house, one trailer)

Swimming area (lake, bathhouse, refreshment stand)

Trail ( 3.3 miles around lake shore)

\section{Existing Staff:}

Permanent:

Park Superintendent II

Park Ranger II

Park Ranger I
Seasonal:

Park Attendant (2)

Chief Lifeguard

Lifeguard (3)

Bathhouse Manager

Refreshment Stand Manager

Refreshment Stand Clerk

\section{Minimum Additional Staff Needs:}

Clerk Typist III

Maintenance Mechanic 
Jones Lake State Park (Continued)

Staffing Over Last Ten Years:

Permanent

Seasona 1

1977 Park Superintendent II

Chief Ranger II

1978 No Change

Park Attendants (3)

Chief Lifeguard

Lifeguard (3)

Refreshment Stand Manager I

Bathhouse Manager I

1979 No Change

Lost: 1 Park Attendant

1980-1984 No Change

No Change

1985 Added: Park Ranger I

No Change

1986 No Change

No Change

\section{Interna1 Threats:}

Boundary Marking:

Boundaries are unmarked and need to be identified.

Aging Facilities:

Water and sewer facilities are old and in poor condition.

Controlled Burning:

The natural fire regime which ordinarily maintains the pond pine, atlantic white cedar, red maple community, shrub bogg and other communities has been upset by the control of wildfire over the last two decades. In addition, fire control has allowed a dangerously high level of fuels to accumulate. A draft prescribed burn plan has been prepared.

Compaction/Erosion:

In the heavy use areas, especially the campground, there is a great deal of soil compaction and erosion.

Forest Management:

Management is needed to prevent or control Southern Pine Beetle infestation. 
Jones Lake State Park (Continued)

\section{Internal Threats: (Continued)}

Power Boat Overuse:

Power boat overuse presents a danger to the public renting row boats. The small size of the lake, especially at low water levels, makes power boating extremely dangerous due to overcrowdong. Large motors can cause damage in the shallow lake.

Vegetation Damage:

There is vegetation damage due to the cars that are parked or driven off the road.

Top 3 Visitor Impacts Identified by Superintendent:

1. Compaction/Erosion

2. Vegetation Damage

3. Unrestrained Pets

External Threats:

The park is surrounded by Forestry Games Lands and therefore hunting pressures exist in the park. Use of dogs to drive game from the park is a regular occurance and is difficult to enforce. The State has not been able to acquire certain land tracts that would act as natural hunting buffers. Cutting of trees for firewood is also a problem.

\section{Facility Condition:}

The 17 buildings located on the park are in need of repairs and the safety hazards include:

Electric outlets need new wiring because of overload voltages Weakened wooden steps and porches due to weathering and age Handicapped access has been put on hold

Some of the minor repairs are completed, but due to a lack of money, several major projects have been canceled. This includes replacement of a cracked patio and roof repairs.

\section{Capital Improvements:}

Current Projects: None

Documented Needs: $\$ 2,284,785$ 
Jones Lake State Park (Continued)

Projects: Boat launch facility

Water, electric, sewer repair

Visitor center complex

Dumping station

Ranger residences (2)

Trail improvements

Land Acquisitions: No future acquisjtion in progress.

Boundary Marking Status:

\begin{tabular}{cccc}
\hline $\begin{array}{c}\text { Total } \\
\text { Boundary } \\
\text { Mile }\end{array}$ & $\begin{array}{c}\text { Well } \\
\text { Marked }\end{array}$ & $\begin{array}{c}\text { Poorly } \\
\text { Marked }\end{array}$ & $\begin{array}{c}\text { Indef. } \\
\text { or } \\
\text { Unknown }\end{array}$ \\
\hline 9.2 & 4.4 & 2.7 & 2.1
\end{tabular}

Expenditures and Attendance:

\begin{tabular}{lcrc}
\hline Year & Attendance (Calendar Yr.) & Current $\$($ Fiscal Yr.) & $1977 \$ *$ (Fiscal Yr.) \\
\hline & & & \\
1977 & 60,382 & $\$ 49,620$ & $\$ 49,620$ \\
1978 & 73,281 & 49,985 & 46,498 \\
1979 & 89,889 & 56,644 & 48,208 \\
1980 & 65,508 & 69,139 & 53,021 \\
1981 & 63,426 & 77,268 & 54,684 \\
1982 & 57,104 & 83,761 & 55,397 \\
1983 & 61,872 & 70,865 & 44,766 \\
1984 & 58,962 & 70,865 & 42,638 \\
1985 & 67,429 & 71,794 & 41,143 \\
1986 & 87,033 & 93,762 & 51,975 \\
1987 & 97,103 & 92,763 & 49,158 \\
1988 & & 99,112 & 50,336
\end{tabular}

Repair/Renovations:

\begin{tabular}{ccr}
\hline Fiscal Year & Current $\$$ & $1977 \$^{*}$ \\
\hline & & \\
1977 & $\$ 3,444$ & $\$ 3,444$ \\
1978 & 4,815 & 4,479 \\
1979 & 2,673 & 2,275 \\
1980 & 13,679 & 10,490 \\
1981 & 15,038 & 10,642 \\
1982 & 5,723 & 3,785 \\
1983 & $-0-$ & $-0-$ \\
1984 & 7,926 & 4,769 \\
1985 & 3,617 & 2,073 \\
1986 & 5,754 & 3,190
\end{tabular}

*1977 Budget figures are adjusted to reflect inflation and are shown in 1977 dollars. Source: Office of State Budget.

Total Park Revenue: FY 1987: \$13,029

FY 1988: $\$ 14,022$ 


\section{JORDAN LAKE STATE RECREATION AREA}

Location: Chatham, Durham, and Wake Counties

Size: 1925 acres leased from the Corps of Engineers

\section{Reason for Establishment:}

The Army Corps of Engineers built the project to create a reservoir for Durham, Chapel Hill, and other surrounding areas.

\section{History of the Park:}

Jordan Lake is a State Recreation Area which is managed in conjunction with the Army Corps of Engineers. The lake was open to the public in 1982. Several areas at Jordan are planned to open in 1989 and 90 , including Crosswinds Campground, Poplar Point Campground, and Seaforth Day Use Area.

Facilities:

Crosswinds:

Boat ramp (6 lanes)

Maintenance area

Park office

Existing Staff:

Permanent:

Park Superintendent III

Clerk Typist

Crosswinds

Maintenance Mechanic II

General Utility Worker

Park Ranger I

Ebenezer Church

Park Ranger II

Park Ranger I

Maintenance Mechanic II

General Utility Worker
Seasonal:

Park Attendant (6)

Chief Lifeguard

Lifeguard (11)

Assistant Park Ranger (4)

Refreshment Stand Clerk

General Utility Worker (6) 
Jordan Lake State Recreation Area (Continued)

Existing Staff: (Continued)

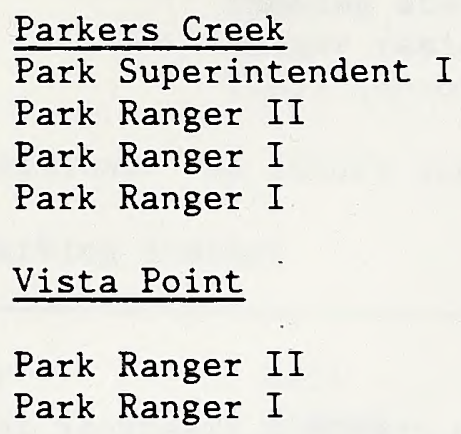

Additional Staff Needs: (As per staffing plan recently developed by District Superintendent)

Permanent:

Wastewater Treatment Plant Operator Maintenance Mechanic III (2)

Park Ranger I (9)

Permanent:

General Utility Worker (2)

Park Superintendent I

Park Ranger II (3)
Seasonal:

Park Attendants (4)

General Utility Workers (11)

Park Rangers (4)

Seasona1:

Refreshment Stand Clerk

\section{Staffing Over Last Four Years:}

\section{Permanent}

1983

Park Superintendent

Park Chief Ranger

General Utility Worker

\begin{tabular}{lll}
\hline 1984 & No change & Park Ranger (2) \\
1985 & No change & Park Attendant (2) \\
& & $\begin{array}{l}\text { Added: } \\
\text { Park Attendant (2) } \\
\text { Assistant Park Ranger (2) } \\
\text { Refreshment Stand Clerk }\end{array}$ \\
\hline \multirow{2}{*}{ No change } & $\begin{array}{l}\text { Park Attendant (2) } \\
\text { Chief Lifeguard } \\
\text { Lifeguard (11) } \\
\text { General Utility Worker (6) }\end{array}$ \\
\hline
\end{tabular}

\section{Seasonal}

No data available 
Jordan Lake State Recreation Area (Continued)

\section{Internal Threats:}

\section{Crosswinds Boat Ramp}

Shoreline Erosion/Compaction:

Due to the wave action from the lake, the shoreline : $s$ becoming eroded. There is also soil compaction from overuse by fishermen.

Spur Trails:

Several new trails have been created from the parking lot to the lake.

Vandalism:

There is evidence of destruction to the restrooms.

Top 3 Visitor Impacts Identified by Superintendent:

1. Soil compaction

2. Spur trails

3. Vandalism

\section{Ebenezer Church}

Shoreline Erosion/Compaction:

The wave action from the lake is causing some erosion, and soil compaction can be found at the swimming beach.

Vegetation Trampling:

There is a large amount of vegetation being trampled near the shoreline fishing area because of visitors creating their own trails.

Pest Management:

There have been small sections of the park infested with Southern Pine Beetles.

\section{Litter:}

There are several facility areas that have major litter problems.

Top 3 Visitor Impacts Identified by Superintendent:

1. Soil compaction

2. Spur trails

3. Litter 
Jordan Lake State Recreation Area (Continued)

Internal Threats: (Continued)

Parkers Creek

Soil Compaction/Erosion:

Heavy camper use is causing soil compaction and erosion.

Spur Trails:

There are areas where visitors have created trails and caused vegetation trampling and soil compaction.

Vandalism:

After hour entries are resulting in damage to park facilities.

Top 3 Visitor Impacts Identified by Superintendent:

1. Soil compaction/erosion

2. Spur trails

3. Vandalism

\section{Vista Point}

Shoreline Erosion/Compaction:

There are several areas where compaction and erosion are occurring.

Spur Trails:

There are several areas where visitors have made their own trails to the park facilities.

Unrestrained Pets:

Several incidents of pets roaming freely have caused major concerns for the park management. 
Jordan Lake State Recreation Area (Continued)

Internal Threats: (Continued)

Endangered Species:

The bald eagle has been spotted in the area and is known to roost in the area.

Top 3 Visitor Impacts Identified by Superintendent:

1. Erosion/soil compaction

2. Spur trails

3. Unrestrained pets

\section{Externa1 Threats:}

The lake is relatively new, so external problems at this time are few. The future may hold problems concomitant with surrounding land development. Water quality concerns regarding the Haw River and Jordan Lake prompted the creation of a Legislative study commission.

\section{Facility Condition:}

There is no BIIP information because the park is relatively new.

There have been some smoke detectors installed in several of the buildings. The major project for the park is to construct two new ranger residences.

Projects that have been canceled or placed on hold include placing electrical wiring in a building that does not have any, and reanchoring and repairing the floating docks.

\section{Capital Improvements:}

Current Project:

Ranger Residence: $\$ 80,000$

Documented Needs: $\$ 2,880,241$

Projects: Warehouse at Parkers Creek
23 rental cabins package
Ranger residences

Land Acquisition: No data available 
Jordan Lake State Recreation Area (Continued)

\section{Boundary Marking Status:}

\begin{tabular}{cccc}
\hline $\begin{array}{c}\text { Total } \\
\text { Boundary } \\
\text { Mile }\end{array}$ & $\begin{array}{c}\text { Well } \\
\text { Marked }\end{array}$ & $\begin{array}{c}\text { Poorly } \\
\text { Marked }\end{array}$ & $\begin{array}{c}\text { Indef. } \\
\text { or } \\
\text { Unknown }\end{array}$ \\
\hline 21.5 & 14.5 & 6.0 & 1.0
\end{tabular}

Expenditures and Attendance:

\begin{tabular}{|c|c|c|c|}
\hline ear & Attendance (Calendar $\mathrm{Yr}_{\text {. }}$ ) & Current $\$$ (Fiscal Yr.) & $1977 \${ }^{*}$ (Fiscal Yr.) \\
\hline 1982 & 90,454 & $\$ 24,998$ & $\$ 16,533$ \\
\hline 1983 & 80,778 & 69,845 & 44,122 \\
\hline 1984 & 163,797 & 0 & 0 \\
\hline 1985 & 474,646 & 148,720 & 85,226 \\
\hline 1986 & 546,722 & 275,236 & 152,570 \\
\hline 1987 & 779,658 & 407,662 & 216,037 \\
\hline 1988 & & 594,795 & 302,080 \\
\hline
\end{tabular}

Repair and Renovations:

\begin{tabular}{crr}
\hline Fiscal Year & Current $\$$ & \multicolumn{1}{c}{$1977 \$^{*}$} \\
\hline 1982 & $\$ 9,148$ & $\$ 6,050$ \\
1983 & 0 & 0 \\
1984 & 13,263 & 7,980 \\
1985 & 13,909 & 7,971 \\
1986 & 13,653 & 7,568
\end{tabular}

*1977 Budget figures are adjusted to reflect inflation and are shown in 1977 dollars. Source: Office of State Budget.

Total Park Revenue: FY 1987: \$182,795

FY 1988: \$199,716 


\section{KERR LAKE STATE RECREATION AREA}

Location: Vance and Warren Counties

Size: Bullocksville: 455 acres

County Line: 285 acres

Henderson Point: 329 acres

Hibernia: 446 acres

Kimball Point: 93 acres

Nutbush Bridge: 363 acres

Satterwhite Point: 282 acres

Satterwhite Marina: 28 acres

Steele Creek Marina: 282 acres

\section{Reason for Establishment:}

The reservoir was constructed by the Army Corps of Engineers to provide water for both North Carolina and Virginia. Recreation areas were built around the reservoir to provide public recreation.

\section{History of the Park:}

The Army Corps of Engineers finished construction on the dam in 1951, the year it was opened to the public. The Kerr Reservoir Commission operated the recreational activities until 1971 when the Division of State Parks and the Commission were combined.

\section{Facilities :}

Bullocksville:

Boat ramp (one lane)

Community building

Family camping ( 68 sites, no hookups, toilet/showers)

Picnic area (32 tables, 2 shelters)

Refreshment stand

Residence (one house)

County Line:

Boat ramp ( 2 lanes)

Family camping (12 sites with hookups, 70 sites without hookups, restroom/shower)

Picnic area ( 4 tables, one shelter)

Residence (one house) 
Kerr Lake State Recreation Area (Continued)

\section{Facilities: (Continued)}

Henderson Point:

Boat ramp ( 3 , one lane)

Community building

Family campground ( 24 sites with hookups, 55 without hookups, restroom/shower)

Group camp (primitive)

Picnic area ( 24 tables, 3 shelters)

Residence (one house)

Hibernia

Boat ramp (2, 2 lane)

Family campground ( 30 sites with hookups, 120 without hookups, restroom/shower

Group camp (primitive)

Maintenance area

Picnic ( 9 tables, one shelter

Residence (two houses)

Kimball Point:

Boat ramp (single lane)

Family campground ( 23 sites with hookups, 65 without hookups), restroom/shower)

Picnic area (11 tables, one shelter)

Residence (one house)

Nutbush:

Boat ramp (2, one lane)

Family campground ( 28 sites with hookups, 71 without hookups, restroom/shower)

Residence (one house)

Satterwhite:

Boat ramp (2, one lane)

Community building

Family campground ( 24 sites with hookups, 99 without hookups, restrooms/shower)

Group camp (restroom/shower)

Maintenance area

Picnic area ( 36 tables, 3 shelters)

Residence (two houses) 
Kerr Lake State Recreation Area (Continued)

\section{Existing Staff:}

Permanent:

Park Superintendent III

Park Superintendent I

Clerk IV

Maintenance Mechanic III

Maintenance Mechanic II

Mechanic I

Machine Operator II

General Utility (3)

Bxisting Staff: (Continued)

$\underline{\text { Permanent }}$

Bullocksville

Park Ranger II

County Line

Park Ranger II

Henderson Point

Park Ranger II

Hibernia

Park Ranger II (2)

Kimbal1 Point

Park Ranger II

Nutbush Bridge

Park Ranger II

Satterwhite Point

Park Ranger II
Seasonal:

General Laborers (4)
Seasonal:

Bullocksville

Park Attendant (2)

County Line

Park Attendant (3)

Henderson Point

Park Attendant (4)

Hibernia

Park Attendant (6)

Kimball Point

Park Attendant (3)

Nutbush Bridge

Park Attendant (3)

Satterwhite Point

Park Attendant (5) 
Kerr Lake State Recreation Area (Continued)

Additional Staff Needs: (As per staffing plan recently developed by District Superintendent)

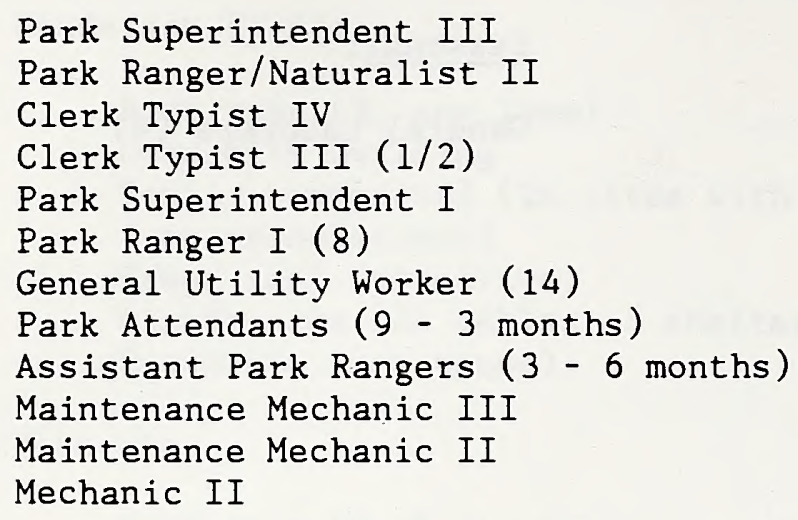

Staffing Over Last Five Years: No change in permanent staffing over last five years.

\section{Internal Threats:}

\section{Bullocksville}

Shoreline Erosion/Soil Compaction:

The wave action from motor boat wakes is eroding the bank. There are also soil compaction problems in the campground areas.

\section{Litter:}

There is a large amount of litter in the public use areas.

\section{Hunting :}

There is a problem with hunters encroaching on park property due in part to the boundaries not being properly marked.

Unrestrained Pets:

There have been several incidents of pets running freely in the park.

Pest Management:

The Southern Pine Beetle is present in the area.

Crowds:

This area is very popular, and large crowds, often exceeding desirable numbers, are present at peak periods. 
Kerr Lake State Recreation Area (Continued)

Internal Threats: (Continued)

Bullocksville (Continued)

Top 3 Problems Identified by Superintendent:

1. Erosion/soil compaction

2. Hunting

3. Unrestrained pets

\section{County Line}

Shoreline Erosion/Soil Compaction

The high water levels have washed away the bank. There is also a bad problem of soil compaction in the campground.

Pest Management:

The Southern Pine Beetle is present in the area.

\section{Litter:}

There is a large problem with litter, especially in the high usage areas.

Boundaries/Hunting:

Due to the unmarked boundaries, there have been both timber cutting and hunting encroachments.

Crowds :

The park has a major overcrowding problem.

Top 3 Problems Identified by Superintendent:

1. Erosion/Soil compaction

2. Litter

3. Hunting

\section{Henderson Point}

Trail Erosion/Trampling:

Overuse and soil compaction are the main cause for the erosion. There has also been a great deal of vegetation trampling. 
Kerr Lake State Recreation Area (Continued)

Internal Threats: (Continued)

Henderson Point: (Continued)

Shoreline Erosion:

The higl water and wave action has caused the shoreline to erode.

Pest Management:

The Southern Pine Beetle is killing trees throughout the area.

Unrestrained Pets:

There have been many cases of pets running freely in the recreation area.

Hunting :

There is major concern about the problems of hunters crossing onto park lands due to a lack of boundary markers.

Visitor Impacts:

Overuse from visitors is visible through the litter and overcrowding problems.

Top 3 Problems Identified by Superintendent:

1. Erosion/trampling

2. Unrestrained pets

3. Hunting

\section{Hibernia}

Erosion/Soil Compaction:

There is an erosion problem along the shoreline and in the high usage areas. Soil compaction problems also exist in these high usage areas.

Historic:

A plantation site exists, but needs to be surveyed.

Litter:

There is a great deal of litter left behind in the high usage areas. 
Kerr Lake State Recreation Area (Continued)

\section{Internal Threats: (Continued)}

Hibernia: (Continued)

Pest Management:

There is Pine Bertle infestation.

Hunting:

There have been several incidences of hunters found on the park property.

Visitor Impacts:

An overcrowding problem is occurring for day use visitors and campers.

Top 3 Problems Identified by Superintendent:

1. Erosion/Soil Compaction

2. Litter

3. Hunting

\section{Kimball Point}

Shoreline Erosion:

The fluctuations in the lake level and wave action contribute to shoreline erosion.

Litter:

There is a great deal of litter left behind in the high usage areas. The soil compaction problem also exists in these high usage areas.

Unrestrained Pets:

There have been several family pets found running freely in the park.

Hunting:

There have been several incidences of hunters found on the park property.

Visitor Impacts:

There is a tremendous overcrowding among the campers and day use visitors. 
Kerr Lake State Recreation Area (Continued)

Internal Threats: (Continued)

Kimball Point: (Continued)

Top 3 Problems Identified by Superintendent:

1. Erosion/soil Compaction

2. Litter

3. Hunting

\section{Nutbush Bridge}

Water Quality:

There are known sewage disposal drains that go into the lake.

Erosion/soil Compaction:

Soil compaction from overuse has caused erosion of the hiking trails and other heavy usage areas. Major damage has been done to the campsites that are along the lake with the fluctuations in the water levels.

\section{Litter:}

There is a great deal of litter left behind in the high usage areas.

Hunting :

There have been several incidences of hunters found on the park property.

Pest Management:

The Southern Pine Beetle is present in the area.

Unrestrained Pets:

There have been several family pets found running freely in the park. 
Kerr Lake State Recreation Area (Continued)

Nutbush Bridge: (Continued)

Visitor Impacts:

There is an excessive amount of use by visitors.

Top 3 Problems Identified by Superintendent:

1. Erosion/Soil Compaction

2. Litter

3. Hunting

\section{Satterwhite Point}

Trail Erosion:

The overuse of the trails has cause soil compaction and erosion.

Shoreline Erosion:

The water fluctuation has caused extensive shoreline erosion.

Historic:

A pre-colonial house foundation exists and needs to be surveyed for archaeological significance.

Pest Management:

An infestation of the Pine Beetle has affected approximately 7 acres.

Litter:

There is a great deal of litter left behind in the high usage areas.

Hunting:

There have been several incidences of hunters found on the park property.

Visitor Impact/Vandalism

This is a very high usage area which suffers from erosion and destruction of facilities.

Top 3 Problems Identified by Superintendent:

1. Erosion/Soil Compaction

2. Litter

3. Hunting 
Kerr Lake State Recreation Area (Continued)

\section{External Threats:}

Henderson Point

Adjacent Development:

The area is surrounded by a trailer park.

\section{Hibernia}

Adjacent Development:

The trailer park adjacent to the area is expanding in size. This also affects the aesthetic view from the recreation area.

\section{Kimball Point}

Adjacent Development:

Beyond the state boundaries are residential areas that are causing an aesthetic problem for the park.

\section{Nutbush Bridge}

Adjacent Development:

The adjacent development and growth is causing an aesthetic problem around around the lake.

\section{Satterwhite Point}

Adjacent Development:

The amusement park and a trailer park are causing problems in that they can be seen from the park. Encroachments may occur in the near future.

\section{Pacility Condition:}

The Bullocksville area has 18 buildings, all needing repair. Existing safety hazards include:

Electrical supply not sufficient for underground use needs to be replaced

No fire extinguishers

Plumbing needs to be replaced

Overloaded electrical outlets

No handicapped accesses 
Kerr Lake State Recreation Area (Continued)

Facility Condition: (Continued)

The County Line area has 13 buildings which all need repairs. Problems include:

The equipment shed needs to be demolished

Electrical wiring hanging out of wall

and power has been cut

Lack of fire extinguishers

Weakened roofs

The Henderson Point area contains 11 buildings all needing repairs, and the safety hazards include:

No smoke detectors

No fire extinguishers

Lacking stair handrails

Poor lighting

The Hibernia area has 26 buildings in need of repair and the safety hazards that are in need include:

Lack of smoke detectors

Lack of fire extinguishers

Overloaded electrical outlets

A reinforced concrete roof that is cracking;

No electrical grounding

Poor lighting in restrooms

Cracking concrete porch

The Kimball Point has 17 buildings, all in need of repair. The safety hazards that require attention include:

No smoke detectors and fire extinguishers

A rotten wooden deck

No protection from an electrical overload

No electrical grounding

One building should be repaired or just demolished.

The Nutbush Bridge area contains 15 buildings which are generally in good shape. There are some safety hazards that need attention including:

New septic tank replacement and new drain field

Lack of grounding of electrical wiring

Overloaded outlets

Lack of smoke detectors and extinguishers 
Kerr Lake State Recreation Area (Continued)

\section{Facility Condition: (Continued)}

The Satterwhite Point area has 48 buildings all needing repairs. Safety hazards that need attention include:

No fire extinguishers

Overloaded electrical outlets

No smoke detectors

Worn out electrical switches

old oil fired furnace

Several wooden stoves

Cast iron piping needs to be replaced

Poorly lighted restrooms

Electrical overload protection is worn

out and needing total replacement

Steps have no tread to protect from

slipping

The wooden storage platform is rotting away

All areas have little or no handicapped

accesses

Some improvements for the park have been started including placement of smoke detectors in the public use buildings. Well improvements at Nutbush and Kimball Point are underway. The entire shoreline is under erosion control measures.

Picnic areas at the various sites need improvements and repairs.

Projects that are to be finished in 1989 include a water system at Nutbush, Hibernia, and County Line. Toilet buildings are to be renovated at Bullocksville and road improvements made at Satterwhite Point.

\section{Capital Improvements:}

Current Projects:

Well improvements - Nutbush, Kimball Point Shoreline stabilization, erosion control Water system improvements - Hibernia,

Nutbush, County Line

Toilet building renovation - Bullocksville

Road improvements - Satterwhite Point Dump station - County Line, Henderson Point, Bullocksville
$\$ 260,000$

$\$ 81,000$

$\$ 346,368$

$\$ 62,002$

$\$ 97,337$

$\$ 95,669$

Documented Needs: $\$ 17,125,565$

Projects: Renovate 700 tent and trailer sites - 7 areas Visitor center complex - Satterwhite Point Repave roads - Satterwhite Point Restroom building - Hibernia Water and electricity - 200 sites 
Kerr Lake State Recreation Area (Continued)

\section{Capital Improvements: (Continued)}

Documented Needs:

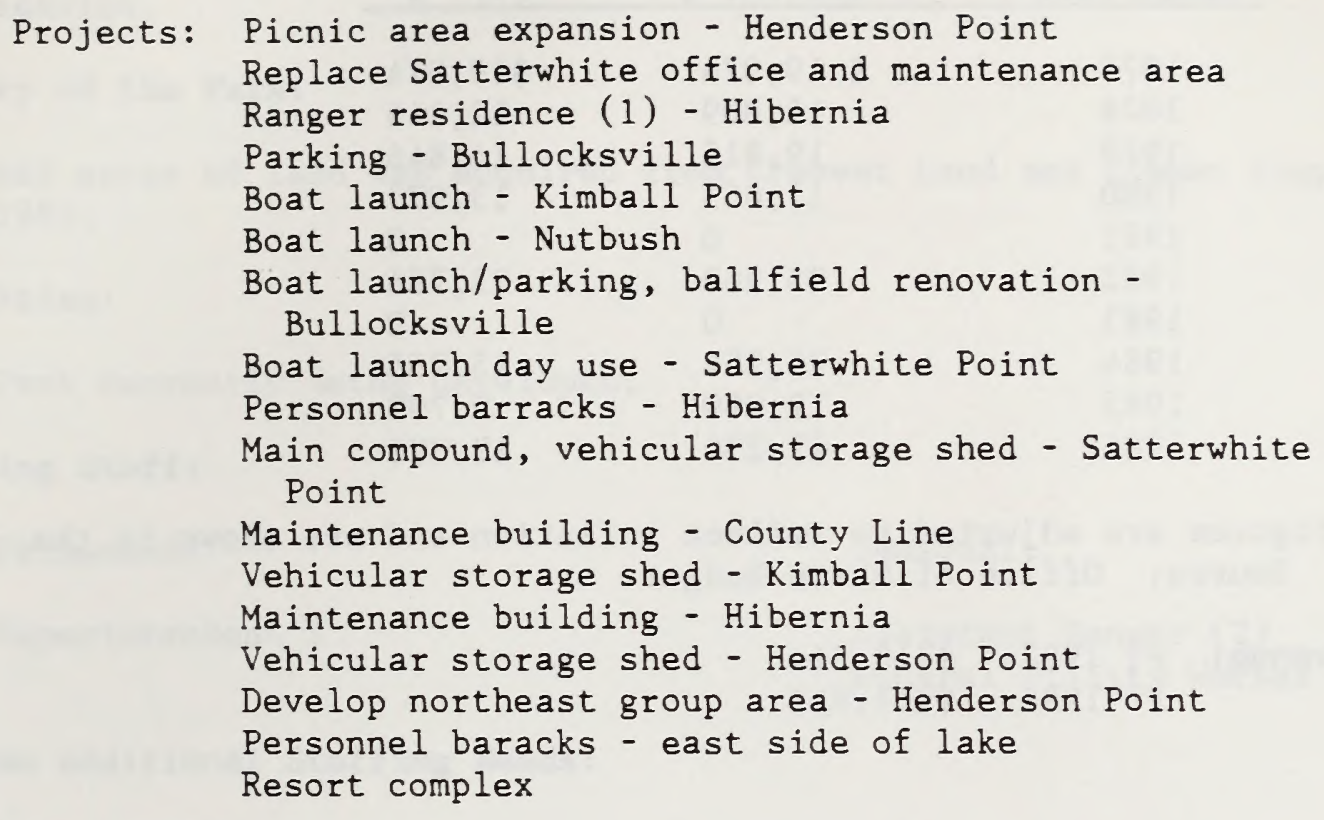

\section{Land Acquisition:}

No acquisition in progress.

\section{Boundary Marking Status:}

\begin{tabular}{cccc}
\hline $\begin{array}{c}\text { Total } \\
\text { Boundary } \\
\text { Mile }\end{array}$ & $\begin{array}{c}\text { Well } \\
\text { Marked }\end{array}$ & $\begin{array}{c}\text { Poorly } \\
\text { Marked }\end{array}$ & $\begin{array}{c}\text { Indef. } \\
\text { or } \\
\text { Unknown }\end{array}$ \\
\hline 50.0 & 20.0 & 3.0 & 27.0
\end{tabular}

Expenditures and Attendance:

\begin{tabular}{lcrr}
\hline Year & Attendance (Calendar Yr.) & Current $\$($ Fiscal Yr.) & $1977 \$$ (Fiscal Yr.) \\
\hline & & & \\
1977 & $1,285,043$ & $\$ 320,588$ & $\$ 320,588$ \\
1978 & $1,432,025$ & 359,863 & 334,256 \\
1980 & $1,233,051$ & 368,980 & 314,026 \\
1981 & $1,595,279$ & 418,104 & 320,632 \\
1982 & $1,344,902$ & 0 & 0 \\
1983 & $1,366,161$ & 503,829 & 333,220 \\
1984 & $1,387,384$ & 527,807 & 333,422 \\
1985 & $1,330,784$ & 720,740 & 433,658 \\
1986 & $1,545,797$ & 607,689 & 348,246 \\
1987 & $1,426,041$ & 760,115 & 421,350 \\
1988 & $1,116,827$ & 600,520 & 318,278 \\
& & 678,021 & 344,348
\end{tabular}


Kerr Lake State Recreation Area (Continued)

\section{Repair and Renovations:}

\begin{tabular}{crr}
\hline Fiscal Year & Current $\$$ & \multicolumn{1}{c}{$1977 \$ *$} \\
\hline 1977 & $\$ 19,074$ & $\$ 19,074$ \\
1978 & 13,809 & 12,846 \\
1979 & 19,815 & 16,846 \\
1980 & 17,053 & 13,077 \\
1981 & 0 & 0 \\
1982 & 35,963 & 23,785 \\
1983 & 0 & 0 \\
1984 & 25,354 & 15,255 \\
1985 & 17,099 & 9,799 \\
1986 & 22,236 & 12,326
\end{tabular}

*1977 budget figures are adjusted to reflect inflation and are shown in the 1977 dollars. Source: Office of State Budget.

Total Park Revenue: FY 1987: $\$ 310,514$ FY 1988: $\$ 264,813$ 


\section{LAKE JAMES STATE RECREATION AREA}

Location: McDowell \& Burke Counties

Size: 565 acres

\section{Reason for Establishment:}

The North Carolina Legislature established the park during the 1987 session.

\section{History of the Park:}

565 acres of land was acquired from Cresent Land and Timber Company in 1987.

\section{Facilities:}

Park currently being developed.

\section{Existing Staff:}

Permanent:

Superintendent I
Seasonal:

Assistant Ranger (2)

General Utility Worker

Minimum Additional Staffing Needs:

Clerk Typist

Park Ranger I (2)

Maintenance Mechanic

\section{Internal Threats:}

Erosion of bluffs along the shoreline continues. Several inholdings prevent the efficient and adequate management and protection of the park's resources.

\section{Capital Improvements:}

Current Projects:

$$
\begin{array}{ll}
\text { General Development } & \$ 500,000 \\
\text { Phase II } & \$ 250,000
\end{array}
$$

Documented Needs: (Park being developed)

\section{Facility Expansion:}

New roads

Ranger residence

\section{Land Acquisition:}

The major acquisition, purchase of the 565 acres, has been completed. 
Lake James State Recreation Area (Continued)

Boundary Marking Status: No data available.

Repairs/Renovation: Not applicable. 


\section{LAKE WACCAMAW STATE PARK}

Location: Columbus County

Size: 1,508 acres land $\frac{8,938}{10,446}$ total acres

\section{Reason for Establishment:}

Lake Waccamaw, one of North Carolina's largest natural lakes and the nation's largest Carolina bay, is recognized as a unique and fragile resource of State and national significance. It is home to several endemic fish and mollucs species. It is also a popular recreational lake. The park was established in response to strong local support which continues. The park also provides recreational opportunities for this part of the State.

\section{History of the Park:}

The State purchased land to establish Lake Waccamaw State Park in 1976. In 1983, the State and Columbus County matched Land and Water Conservation Fund assistance to provide initial development at the park.

\section{Pacilities:}

Group camping (primitive)

Picnic area (30 tables)

Pit toilet

\section{Existing Staff:}

Permanent:

Ranger I
Seasonal:

None

Minimum Additional Staff Needs:

Park Superintendent I

Park Ranger I

Maintenance Mechanic

Staffing Over Last Ten Years:

\section{Permanent}

1981 No permanent personnel

$1982-85$ No change Ranger I

\section{Seasonal}

None

None 
Lake Waccamaw State Park (Continued)

\section{Internal Threats:}

Water Quality:

The several endemic fish and mollusc species depend on maintenance of t.'e lake's water quality. Accidental untreated discharges from the Tuwn's sewage treatment plant threaten water quality.

Controlled Burns:

Fire dependent/tolerant areas (longleaf/turkey oak/wiregrass; xeric sand ridges; open shrub pocosin; and pine pocosin) are threatened by the preclusion of natural fire. In addition, dangerous fuel levels are accumulating in some of these areas. A draft prescribed burn plan has been developed.

Off-Road Vehicles:

ORVs are causing destruction of the vegetation and wooded areas.

Endangered Species:

Management for the Venus Fly Trap and the Lake Waccamaw Silverside is needed.

Vandalism:

There has been destruction of the pit toilets, tables, signs, and pier.

Boundaries:

The unmarked boundaries are making control of poachers very difficult.

Pier Construction:

The new piers constructed on the lake by private residents have caused destruction of vegetation and a reduction of the aesthetic quality of the lake.

Visitor Impact:

Visitors have negatively impacted water quality through the use of boating.

Top 3 Visitor Impacts Identified by Superintendent:

1. Off-road vehicle

2. Vandalism

3. Pier construction 
Lake Waccamaw State Park (Continued)

\section{External Threats:}

Adjacent Development:

Development of land adjacent to the lake and park continues to threaten water quality and near-shore habitats. Potential residential development of a "critical" waterfront tract for which acquisition :s now being attempted threatens the last undeveloped section of sioreline habitat for the endemic species, and an important natural area.

\section{Facility Condition:}

There are 6 buildings on the park, most of which are in good condition. The major problems of the park include no handicapped access for the buildings.

\section{Capital Improvements:}

Current Projects:

$$
\text { Toilet building, water supply } \$ 284,000
$$

Documented Needs: $\$ 4,242,227$

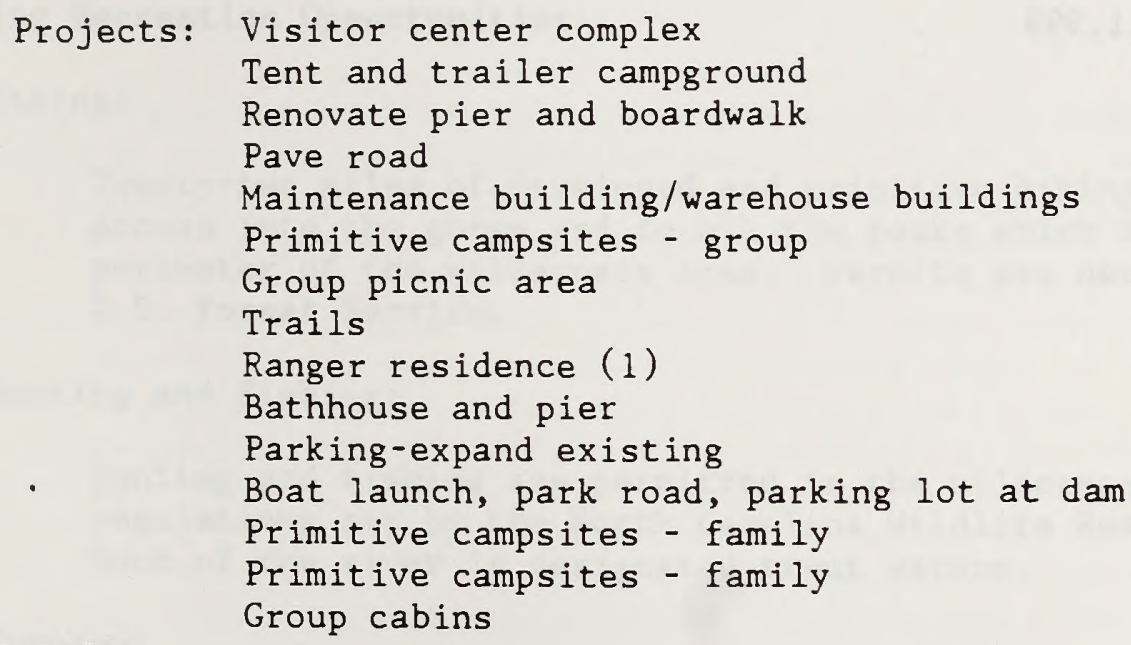

Land Acquisition:

$\begin{array}{lrl}\text { Tract \# } & \text { Acres } & \text { Reason } \\ \text { 1A } & & \\ \text { 1B } & 8.00 & \text { Primary Resource } \\ 2 & 217.00 & \text { Primary Resource } \\ 3 & 1.65 & \text { Land Development } \\ 4 & 227.00 & \text { Land Development } \\ 5 & 117.88 & \text { Primary Resource }\end{array}$


Lake Waccamaw State Park (Continued)

Boundary Marking Status:

\begin{tabular}{cccc}
\hline $\begin{array}{c}\text { Total } \\
\text { Boundary } \\
\text { Mile }\end{array}$ & $\begin{array}{c}\text { Well } \\
\text { Mar' ed }\end{array}$ & $\begin{array}{c}\text { Poorly } \\
\text { Marked }\end{array}$ & $\begin{array}{c}\text { Indef. } \\
\text { or } \\
\text { Unknown }\end{array}$ \\
\hline 5.0 & 0 & 5.0 & 0
\end{tabular}

Repair and Renovations: No data available.

Expenditures and Attendance:

Year Attendance (Calendar Yr.) Current \$ (Fiscal Yr.) 1977 \$* (Fiscal Yr.)

1982

1983

1984

1985

1986

1987

1988

$$
\begin{array}{r}
992 \\
1,209 \\
2,357 \\
17,643 \\
30,308 \\
55,397
\end{array}
$$

$\$ 29,519$

$\$ 33,009$

$\$ 15,643$

$\$ 16,764$

Total Park Revenue: $\$ 11,999$ 


\section{LINVILLE RIVER}

Location: Burke County

Length: That segment beginning at the State Highway 183 bridge and extending approximately 13 miles downstream to the boundary between the U.S. Forest Service lands and lands of Duke Power Company (latitude $\left.35^{\circ} 50^{\prime} 20^{\prime \prime}\right)$.

\section{Reason for Establishment:}

To recognize the outstanding natural and scenic qualities of the river. Linville Gorge is the deepest gorge east of the Mississippi, its rocky walls falling almost 2,800 feet.

\section{History of the River:}

The U.S. Forest Service acquired Linville Gorge in 1938 under authority of the Weeks Act which authorized the acquisition of federal lands for timber production and to protect the headwaters and watersheds of navigable streams. The Forest Service recognized the uniqueness of the area, designating it a "wild area" in the 1950s. In September of 1964, the area was designated as a wilderness area by Congress. The North Carolina General Assembly designated the 13-mile segment a scenic river in June of 1975 .

\section{Existing Recreation Opportunities:}

Hiking :

Twenty-two miles of developed and primitive hiking trails provide access into the gorge and to all the peaks which form the eastern perimeter of the wilderness area. Permits are necessary from the U.S. Forest Service.

Hunting and Fishing:

Hurting and fishing are permitted in the wilderness area under regulations set by the North Carolina Wildlife Resources Commission. Much of the river is designated trout waters.

Camping :

A permit from the U.S. Forest Service is required for camping in Linville Gorge on weekends and holidays.

Linville Falls:

The falls area is designated a recreation area and is administered by the National Park Service. A variety of trails carry park visitors to the falls offering some of the most scenic views of the area. 


\section{Staffing:}

The Linville River is administered by the National Park Service and U.S.

Forest Service. No Division staffing exists.

\section{Threats:}

Overuse:

To prevent overuse of the wilderness , rea, overnight camping is limited to 50 visitors and time limits are set.

Water Quality:

Water quality has been negatively affected by septic tanks upstream and runoff from gas stations in the Newland area. Sedimentation problems also exist.

\section{Litter:}

Trash floats down the river during storms and accumulates. Litter from hikers and campers is also evident.

Solid Waste:

Unburied fecal matter is often seen along the trails.

\section{Facilities:}

The Linville Falls area has some improved overlooks for viewing the falls and a gorge. A rough dirt road parallels the wilderness boundaries south from N.C. 183, and a gorge information station, staffed during the summer, provides information about campsites, fishing opportunities, trail conditions and plant and animal life.

\section{Land Acquisition:}

The State owns no land along the 13 miles designated as a scenic river, nor are there any plans to purchase any. 


\section{MASONBORO ISLAND STATE NATURAL AREA}

Location: New Hanover County

Size: 106 acres of the approximately 5,000 acres are State owned.

\section{Reason for Establishment:}

Masonboro Island is one of very few undeveloped barrier islands in the State and stands as a relict undisturbed island in an area which has received intensive development pressures. It is an excellent example of the barrier island/estuarine system that protects much of the North Carolina coastline from the direct erosive forces of the ocean. Portions of the marshes have been declared a National Estuarine Sanctuary.

\section{History of the Natural Area:}

Genesis of the original island is thought to have occurred by mainland beach detachment which took place during the last 5,000 years when the Holocene sea rise slowed down. Dune ridges formed along a seashore that was some distance seaward to the present coast. The rising sea then isolated the dune ridges from the mainland forming barrier islands separated from the mainland by sounds. Masonboro Island remains undeveloped and is accessible only by boat. Other than a few primitive wood shelters, no permanent dwellings are found on the island.

\section{Existing Recreation Use:}

Primary uses of the island by visitors are beach recreation, overnight camping, hunting, and fishing.

\section{Threats:}

Because the majority of the island is in private ownership, development is a possibility. However, the high overwash rate on the island would tend to preclude all but the most temporary dwellings. Any vehicular traffic on the island would be disastrous to the fragile dune and grassland communities. Erosion of the north end of Masonboro Island is likely due to the newly constructed jetty which impedes the longshore current sand supply. Nesting colonial shorebirds are disrupted and eggs and nestlings destroyed by unknowing visitors and vandals.

\section{Land Acquisition:}

The Division has no land acquisition plans at this time.

\section{Staffing:}

None

\section{Budget:}

None 


\section{MEDOC MOUNTAIN STATE PARK}

Location: Halifax County

Size: 2287

\section{Reason for Establishment:}

This is uniquely located between the fault line of the Piedmont and the Coastal Plains. The mountain is 325 feet high and is a biotite granite formation. The park contains unique biological, geological, and scenic resources.

\section{History of the Park:}

Sidney Weller, an early farmer and educator, developed the "American system" of grape culture in the area. The name of the mountain was taken from the Medoc grape area in France. The forests in the park's immediate vicinity were cut extensively in the $1930^{\prime} \mathrm{s}$. Boy Scouts have a camp nearby, and there are several old homesteads in the area. A rich molybdenum deposit was discovered under the mountain in 1940, and several explorations have taken place since then. The land was sold to the state in 1973 for use as a state park. (Runkle, John. A Guide to North Carolina State Parks. Tread Softly, 1983, p.44.)

\section{Pacilities:}

Group camping (tent, restroom/shower)

Picnic area ( 32 tables, one shelter)

Residence (one house)

Trails ( 8 miles, hiking)

\section{Existing Staff:}

Permanent:

Park Superintendent I

Park Ranger II
Seasonal:

Park Attendant (2)

General Utility Worker

\section{Minimum Additional Staff Needs:}

Park Ranger I

Clerk Typist III

Maintenance Mechanic 
Medoc Mountain State Park (Continued)

Staffing Over Last Ten Years:

Permanent Seasonal

1977 Park Superintendent I

No data available

1978 No thange

Park Attendant (2)

Secretary

Maintenance Mechanic

1979 Added:

Chief Park Ranger

No Change

1980 No Change

No data available

1981 Added:

Park Ranger I

Lost: Secretary and

Maintenance Mechanic

Added: Naturalist

1982-1985 No Change

No Change

1986 Lost: Park Ranger I

Change: Naturalist to

General Utility Worker

\section{Internal Threats:}

Old Field Management:

Fields are mowed to maintain a successional stage.

Endangered Species:

The Neuse River Waterdog is rare and is found in Little Fishing Creek. Its habitat must be kept well maintained in order for it to survive.

Fires:

There have been several fires (mostly by arson) which have burned several acres.

Best Management:

There are approximately 3 acres of forested area which is infested with Pine Beetles.

\section{Litter:}

The northern boundary is located along a main road where litter is found daily. 
Medoc Mountain State Park (Continued)

Internal Threats: (Continued)

Boundaries :

The unmarked boundaries allow encroachments by hunters and their dogs especially on the western border.

Top Three Visitor Impacts Identified by Superintendent:

1. Hunting

2. Fires

3. Litter

\section{External Threats:}

Adjacent Development:

There is a nearby race track that causes litter and noise pollution problems. There is also a proposed molybdenum mine which will be on Medoc Mountain. Mining rights expire in September of 1989 .

\section{Pacility Condition:}

The eight (8) buildings located on the park are in relatively good condition, but the safety hazards that exist include: no smoke detectors; no fire extinguishers; overloaded outlets; little handicap access to the facilities; and weakened roofs.

There have been some repairs done on the roofs of the buildings. Plans also include placing both smoke detectors and fire extinguishers in the buildings where needed.

\section{Capital Improvements:}

Current Projects: None

Documented Needs: $\$ 5,546,866$

Projects: Tent and trailer campground Trail improvements, footbridges

Pave road, 2.2 miles

Visitor center complex

Lake development

Maintenance building

Ranger residences (2)

Dam, bridge and road

Land Acquisition: No Acquisition in progress. 
Medoc Mountain State Park (Continued)

Boundary Marking Status:

\begin{tabular}{cccc}
\hline $\begin{array}{c}\text { Total } \\
\text { Boundary } \\
\text { Mile }\end{array}$ & $\begin{array}{c}\text { Well } \\
\text { Marked }\end{array}$ & $\begin{array}{c}\text { Poorly } \\
\text { Marked }\end{array}$ & $\begin{array}{c}\text { Indef. } \\
\text { or } \\
\text { Unknown }\end{array}$ \\
\hline 8.1 & 8.1 & $-0-$ & $-0-$
\end{tabular}

\section{Expenditures And Attendance:}

Year Attendance (Calendar Yr.) Current \$ (Fiscal Yr.) 1977 \$* (Fiscal Yr.)

$\begin{array}{lrrr}1977 & 9,204 & \$ 37,533 & \$ 37,533 \\ 1978 & 6,449 & 46,135 & 42,916 \\ 1979 & 7,077 & 54,805 & 46,643 \\ 1980 & 5,527 & 53,931 & 41,358 \\ 1981 & 6,207 & 57,306 & 40,556 \\ 1982 & 8,533 & 54,990 & 36,369 \\ 1983 & 18,382 & 62,341 & 39,382 \\ 1984 & 22,228 & 62,341 & 37,510 \\ 1985 & 17,728 & 63,121 & 36,172 \\ 1986 & 31,238 & 77,125 & 42,752 \\ 1987 & 29,696 & 80,731 & 42,783 \\ 1988 & & 104,959 & 53,306\end{array}$

*1977 Budget figures are adjusted to reflect inflation and are shown in 1977 dollars. Source: Office of State Budget.

Repair and Renovations:

\begin{tabular}{ccc}
\hline Fiscal Year & Current $\$$ & $1977 \$ *$ \\
\hline 1977 & $\$ 4,096$ & $\$ 4,096$ \\
1978 & 2,370 & 2,205 \\
1979 & 4,699 & 3,999 \\
1980 & 2,412 & 1,847 \\
1981 & 3,381 & 2,393 \\
1982 & 4,869 & 3,220 \\
1983 & 0 & 0 \\
1984 & 5,521 & 3,322 \\
1985 & 5,553 & 3,182 \\
1986 & 2,748 & 1,523
\end{tabular}

*1977 Budget figures are adjusted to reflect inflation and are shown in 1977 dollars. Source: Office of State Budget

Total Park Revenue - FY 1987: \$915.00.

FY 1988: $\$ 420.00$ 


\section{MERCHANTS MILLPOND STATE PARR}

Location: Gates County

Size: 1,809 acres land

850 acres water

$\overline{2,659}$ acres total

\section{Reason for Establishment:}

While the mill pond is man-made, this area is unique in that nature has reclaimed it to form some of the rarest ecological communities in the State. The scenic millpond also offers excellent recreation opportunities.

\section{History of the Park:}

Bennett's Creek, named after the governor of Virginia in the 1650s, was dammed in 1811 to operate a grist mill. A store was built on the mill site in 1910, and the park derived its name from the merchant on the mill pond. The mill was in operation until shortly before World War II. The Millpond area was sold to developers whose scheme failed to materialize. In 1973, A. B. Coleman of Moyock, North Carolina, donated the site and some adjacent land to the State for a park. The Nature Conservancy during the same year conveyed the title to 925 acres of woodlands on the north side of the Millpond to the State.

\section{Facilities:}

Boathouse (canoe rental in season)

Family camping (20 sites, no hookups, restroom/shower)

Group camping (primitive)

Park office/maintenance building

Picnic area ( 7 tables)

Primitive camping (canoe access)

Residence (one house, one trailer)

Trails ( 9 miles, hiking)

\section{Existing Staff:}

Permanent:

Park Superintendent I

Park Chief Ranger

Park Ranger I
Seasonal:

Park Attendant General Utility Worker 
Merchants Millpond State Park (Continued)

\section{Minimum Additional Staff Needs:}

Maintenance Mechanic II

Clerk Typist III

\section{Staffing Over Last Ten Years:}

\section{Permanent}

1977 General Utility Worker

Park Ranger II

1978 Same
Seasonal

No data available

Park Attendant

Naturalist

No Change

No Change

No Change

$\underline{1982-1984}$

Changed: Park Ranger II to Park Chief Ranger No Change

\section{Internal Threats:}

Water Quality:

The water is tested by the N. C. Division of Environmental Management periodically and monitored by the park staff daily. The Millpond is eutrophicating quickly due to sediment and fertilizer laden runoff in the millpond's unprotected watershed.

Overcrowding/Overuse:

During the peak periods, there are so many canoes on the millpond that there is no wilderness experience. There is also a problem with this overuse having an effect on the resource.

Old Field Management:

The fields are on a mowing schedule that the Park Superintendent and the District Naturalist developed.

Erosion/Soil Compaction:

Soil compaction has become a problem in the 7 family canoe campsites. 
Merchants Millpond State Park (Continued)

Internal Threats: (Continued)

Land Acquisition:

Portions of the millpond shoreline and lower section of Lassiter Swamp are not yet in State ownership and protection. These areas are threatened by timber harvesting.

Pest Control:

In dry years, aquatic vegetation in the millpond increases and interferes with canoeing and fishing. Studies are underway to determine what action would best manage the problem.

Hunting Dogs:

During deer season the dogs cross over onto park boundaries and chase deer, especially on the north side. The campers are also bothered by barking dogs.

Top Three (3) Visitor Impacts Identified by Superintendent:

1. Overcrowding/overuse of canoe campsites, particularly in the family camping area.

2. Erosion/Soil Compaction

3. Hunting Dogs

Endangered Species:

The park is habitat for many different species of plants that need proper management.

External Threats:

Filling in of the pond:

Due to farming being done in and around the watershed of the pond, the successional process is being hastened

\section{Pacility Condition:}

The 17 buildings in the park are structurally sound, although there are a few safety hazards including: electrical outlets in the barracks that need new wiring and weakened floors in the storage building. Installation of smoke detectors has been completed. New sewer improvements have been funded and should be underway soon.

\section{Capital Improvements:}

Current Projects: 
Merchants Millpond State Park (Continued)

\section{Capital Improvements: (Continued)}

Documented Needs: $\$ 2,566,200$

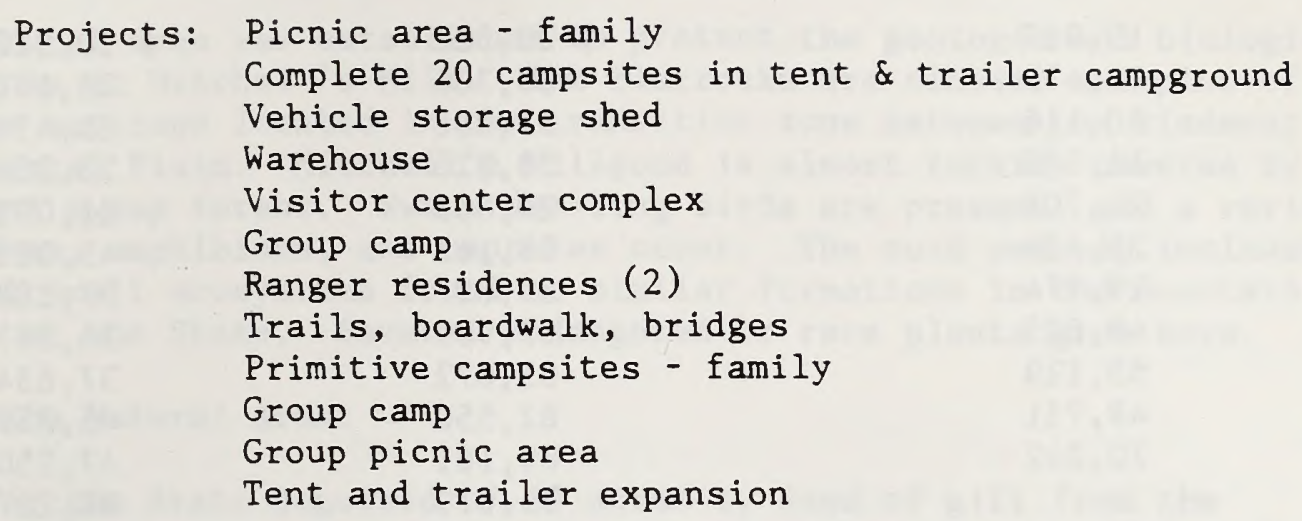

Land Acquisition:

\begin{tabular}{|c|c|c|c|}
\hline Tract & Acres & Reason & Estimated Cost \\
\hline 6 & 25.5920 & Primary Resource & $\$ 15,600$ \\
\hline 7 & 84.830 & Resource Protection & 68,340 \\
\hline 8 & 35.000 & Scenic Protection & 28,000 \\
\hline 11 & 43.300 & Resource Protection & 36,640 \\
\hline 14 & 113.600 & Resource Protection & 51,700 \\
\hline 15 & 52.500 & Primary Resource & 60,900 \\
\hline 16 & 38.882 & Primary Resource & 35,700 \\
\hline 28 & 56.200 & Resource Protection & 48,100 \\
\hline 30 & 39.600 & Resource Protection & 59,400 \\
\hline $35-A$ & 17.700 & $\begin{array}{l}\text { Inholding bordered on } 3 \\
\text { sides by park }\end{array}$ & 25,500 \\
\hline $35-B$ & 2.500 & $\begin{array}{l}\text { Inholding bordered on } 3 \\
\text { sides by park }\end{array}$ & 2,500 \\
\hline $35-C$ & 2.800 & $\begin{array}{l}\text { Inholding bordered on } 3 \\
\text { sides by park }\end{array}$ & 2,800 \\
\hline 39 & 3.000 & Entrance Protection & 21,000 \\
\hline
\end{tabular}

Boundary Marking Status:

\begin{tabular}{cccc}
\hline $\begin{array}{c}\text { Total } \\
\text { Boundary } \\
\text { Mile }\end{array}$ & $\begin{array}{l}\text { Well } \\
\text { Marked }\end{array}$ & $\begin{array}{c}\text { Poorly } \\
\text { Marked }\end{array}$ & $\begin{array}{c}\text { Indef. } \\
\text { or } \\
\text { Unknown }\end{array}$ \\
\hline 18.0 & 0.2 & 17.5 & 0.3
\end{tabular}


Merchants Millpond State Park (Continued)

Bxpenditures and Attendance:

Year Attendance (Calendar Yr.) Current \$ (Fiscal Yr.) 1977 \$* (Fiscal Yr.)

$\begin{array}{ll}1977 & 10,987 \\ 1978 & 1,, 477 \\ 1979 & 30,116 \\ 1980 & 16,589 \\ 1981 & 20,708 \\ 1982 & 25,454 \\ 1983 & 29,974 \\ 1984 & 49,605 \\ 1985 & 55,129 \\ 1986 & 48,731 \\ 1987 & 70,242\end{array}$

$\$ 20,522$

$\$ 20,522$

30,306

28,192

31,056

26,431

30,326

23,256

29,803

21,092

68,165

45,083

59,027

57,999

37,288

65,672

34,897

82,550

37,634

45,759

89,161

95,019

47,250

48,257

Repair and Renovations:

\begin{tabular}{ccr}
\hline Fiscal Year & Current $\$$ & $1977 \$ *$ \\
\hline 1977 & $\$ 3,728$ & $\$ 3,728$ \\
1978 & 3,506 & 3,261 \\
1979 & 1,579 & 1,344 \\
1980 & 707 & 542 \\
1981 & 2,408 & 1,704 \\
1982 & 25,664 & 16,974 \\
1983 & 0 & 0 \\
1984 & 4,411 & 2,654 \\
1985 & 6,934 & 3,974 \\
1986 & 4,955 & 2,747
\end{tabular}

$* 1977$ Budget figures are adjusted to reflect inflation and are shown in 1977 dollars. Source: Office of State Budget.

Total Park Revenue: FY 1987: \$11,841

FY 1988: $\$ 17,522$ 


\section{MITCHELL'S MILL STATE NATURAL AREA}

Location: Wake County

Size: 67.28 acres (including the millpond)

\section{Reason for Establishment:}

The natural area was established to protect the geologic and biologic resources at Mitchel.'s Mill. The flatrocks are classic examples of granite outcrops located in the transition zone between the Piedmont and the Coastal Plain. Mitchell's Millpond is almost totally covered by am emergent swamp forest. Swamp dwelling birds are present, and a variety of fishes, amphibians, and reptiles occur. The rock outcrop includes several small ecosystems found at similar formations in the mountain region of the State. Several endangered or rare plants grow here.

\section{History of the Natural Area:}

In 1976, the State acquired 67.28 acres by deed of gift from the Martin-Marietta Corporation which included the millpond and several of the flatrock granite outcrops. Traditional land use in the vicinity of Mitchell's Mill has been family farming.

\section{Existing Recreation Use:}

There is no recreational development at the site. Because the site is fragile and easily damaged, unguided visitation should not be taken. Still, the site is used for walking and picnicking.

\section{Threats:}

Traditional farming of the surrounding area is giving way to small acreage home development, subdivision development, and land speculation, and increased residential development threatens the area. The fragile site is subject to damage from use. Damage to outcrop ecosystems by vehicles and trash dumping also take place.

\section{Land Acquisition:}

The 1985 State Parks Study Commission identified 83 critical acres. The Division is presently involved with acquiring 25 of these acres, leaving 58 more critical acres remaining to be acquired.

\section{Staffing:}

None

\section{Budget:}

None 


\section{MORROW MOUNTAIN STATE PARK}

Location: Stanly County

Size: 4,693 acres

\section{Reason for Establishment:}

The mountain is part of the Uwharrie Mountains which were formed by volcanic action.

\section{History of the Park:}

Morrow Mountain has been a State park since 1935. Indians quarried the rhyolite rocks for arrowheads and tools. Some relics can still be found. The last group of Indians to live nearby were the Keyauwees, who had a fishing camp at the foot of the Great Falls of the Yadkin (where the Falls Dam is now located). In the 19th century, Morrow Mountain was called Naked Mountain after being ravaged by tornadoes and forest fires.

Dr. Kron lived on a plantation here from 1843-83 and grew over one hundred different kinds of grapes. The Kron House is now restored and open to the public. A ferry went regularly across the Pee Dee River until the 1920s, linking the towns of Salisbury with Fayetteville and the coastal plain.

Much of the early construction work at the park was undertaken by the Civilian Conservation Corps during the Depression.

\section{Facilities:}

\section{Barracks}

Boathouse (row boat \& canoe rental in season)

Boat launch (one lane, Lake Tillery)

Family cabins (6)

Family camping (106 sites, no hookups, restroom/shower)

Group camping (primitive)

Maintenance area

Park office/lodge

Picnic area ( 85 tables, 2 shelters)

Residence ( 3 houses)

Swimming (pool, bathhouse, refreshment stand)

Trails ( 16 miles, hiking and 12 miles, bridle) 
Morrow Mountain State Park (Continued)

\section{Existing Staff:}

Permanent:

Seasonal

Park Superintendent III

Park Attendant (2)

Park Ranger II

Park Ranger II

Chief Lifeguard

Park Ranger I

Clerk Typist III (.5)

Lifeguard (3)

Refreshment Stand Manager I

Refreshment Stand Clerk (2)

Bathhouse Manager II

General Utility Worker

\section{Minimum Additional Staff Needs:}

Permanent

Maintenance Mechanic IV

Clerk Typist III (.5)
Seasonal

None

\section{Staffing Over Last Ten Years:}

\section{Permanent}

Park Superintendent III

Park Ranger II

Park Ranger II

Clerk Typist

$$
\text { Added: }
$$

1978

Park Ranger I
Seasonal

No data available

Park Attendant

Naturalist

Chief Lifeguard

Lifeguard (3)

Refreshment Stand Mgr. I

Refreshment Stand Clerk

Bathhouse Manager II

Clerk Typist II

No change

Abolish Clerk Typist

Naturalist changed to

General Utility Worker

Add 1 Park Attendant

1 Refreshment Stand Clerk 
Morrow Mountain State Park (Continued)

\section{Internal Threats:}

Trail Erosion:

The soil compaction and poor trail design have caused the erosion problem. Two trails have been rerouted to avoid any more destruction.

Shoreline Erosion:

Wave action on Lake Tillery has caused some erosion, but another cause is visitors launching canoes from undesignated shoreline.

\section{Litter:}

There is a great deal of litter found in the high usage areas.

Old Field Management:

There is one field mowed periodically.

Vegetation Damage:

There is a lack of adequate parking and facilities to handle the heavy visitor use on the weekends. Visitors park on the grass, bringing about vegetation damage.

\section{Historic:}

The Kron family graveyard is in need of being identified and protected.

\section{Wildlife Management:}

The deer population is quite large and is a temptation for poachers.

Pest Management:

There is a problem with Southern Pine Beetles.

Visitor Impacts:

Soil compaction and overuse in the campgrounds, on the trails, and in the picnic area is prevalent.

Top 3 Visitor Impact Identified by Superintendent:

1. Erosion/compaction

2. Litter

3. Vegetation damage 
Morrow Mountain State Park (Continued)

\section{External Threats:}

Adjacent Development:

A sewage treatment plant, which was to be located near the entrance to the park and which would have discharged into the creek forming one boundary of the park, was stopped by a strong local effort.

\section{Facility Condition:}

There are 57 buildings on the park which need many repairs. Safety concerns include:

Smoke detectors needed in all the cabins

No fire extinguishers

No emergency phone at the pool

Weakened roofs

The lack of lighted exit signs

A wooden porch is rotten

The outlets are overloaded

No lighting at the boathouse

Little handicap access

The projects that are underway include guardrails and water supply

improvements. Projects that are to be completed by 1989 include

renovations to the bathhouse and pool, water-system improvements, and

the renovation of toilet buildings.

\section{Capital Improvements:}

Current Projects:

Bathhouse \& pool renovations

Family campground, water supply road improvements

Toilet building ( 3 ) renovations

Water system improvements
$\$ 750,000$

$\$ 280,000$

$\$ 165,000$

$\$ 116,407$

Documented Needs: $\$ 7,321,056$

Projects: Renovation to shoreline, trails, summit area

27 rental cabin package

Repave road

Kron grave yard restoration

Electrical renovation

Trail renovation, fire and bridle

Renovate lodge to restaurant complex

Visitor center complex

Land Acquisition: No acquisition in progress. 
Morrow Mountain State Park (Continued)

Boundary Marking Status:

\begin{tabular}{cccc}
\hline $\begin{array}{c}\text { Total } \\
\text { Boundary } \\
\text { Mile }\end{array}$ & $\begin{array}{c}\text { Well } \\
\text { Marked }\end{array}$ & $\begin{array}{c}\text { Poorly } \\
\text { Marked }\end{array}$ & $\begin{array}{c}\text { Indef. } \\
\text { or } \\
\text { Unknown }\end{array}$ \\
\hline 20.0 & 20.0 & $-0-$ & $-0-$
\end{tabular}

Expenditures and Attendance:

\begin{tabular}{|c|c|c|c|}
\hline Year & Attendance (Calendar Yr.) & Current $\$$ (Fiscal Yr.) & 1977 \$* (Fiscal Yr.) \\
\hline 1977 & 354,699 & $\$ 100,859$ & $\$ 100,859$ \\
\hline 1978 & 381,164 & 107,250 & 99,767 \\
\hline 1979 & 344,204 & 134,668 & 114,611 \\
\hline 1980 & 332,837 & 131,797 & 101,071 \\
\hline 1981 & 286,587 & 140,202 & 99,223 \\
\hline 1982 & 275,443 & 140,460 & 92,897 \\
\hline 1983 & 273,898 & 153,622 & 97,045 \\
\hline 1984 & 267,315 & 153,622 & 92,432 \\
\hline 1985 & 291,080 & 172,999 & 99,140 \\
\hline 1986 & 307,195 & 174,330 & 96,635 \\
\hline 1987 & 303,245 & 179,324 & 95,031 \\
\hline 1988 & & 186,116 & 94,523 \\
\hline
\end{tabular}

Repair and Renovations:

\begin{tabular}{crr}
\hline Fiscal Year & Current $\$$ & $1977 \$ *$ \\
\hline 1977 & 10,217 & 10,217 \\
1978 & 13,306 & 12,378 \\
1979 & 11,198 & 9,530 \\
1980 & 7,008 & 5,374 \\
1981 & 14,481 & 10,248 \\
1982 & 7,584 & 5,016 \\
1983 & 0 & 0 \\
1984 & 13,667 & 8,223 \\
1985 & 13,153 & 7,538 \\
1986 & 13,078 & 2,249
\end{tabular}

$* 1977$ budget figures are adjusted to reflect inflation and are shown in 1977 . dollars. Source: Office of State Budget.

TOTAL PARK REVENUE: FY 1987: \$76,111.19

FY 1988: $\$ 74,425.00$ 


\section{Location: Ashe County}

Size: 555 acres

\section{Reason for Establishment:}

This park is 4,683 feet above sea level and has a panoramic view of three itates. The park offers scenic vistas, colorful displays of purple rhododendron, mountain laurel, and azaleas. It has been selected as a National Natural Landmark due to its magnificent oak hickory forests.

\section{History of the Park:}

Mt. Jefferson became a park in 1956. The mountain was once called Panther Mountain, but is now named after the Jeffersons: the father, Peter, who surveyed and explored much of the region; and the son, Thomas, who became president of the United States. Daniel Boone hunted and explored in the region and came through on his way to Kentucky. The cave near the top was part of the Underground Railroad, helping slaves escape to the North.

\section{Facilities:}

Park office/maintenance building

Picnic area ( 32 tables)

Trails ( 1.5 miles, hiking)

\section{Rxisting Staff:}

Permanent:

Park Superintendent I

Park Ranger II
Seasonal:

Park Attendant

Park Ranger

\section{Minimum Additional Staff Needs:}

Park Ranger I

Maintenance Mechanic II

Clerk Typist

\section{Staffing Over Last Ten Years:}

\section{Permanent}

\section{Park Ranger II}

1978 No change
Seasona 1

No data available 
Mount Jefferson State Park (Continued)

Staffing Over Last Ten Years: (Continued)

\begin{tabular}{lll}
\hline \multicolumn{1}{c}{ Permanent } & \multicolumn{1}{c}{ Seasonal } \\
\hline Added: & Added: \\
Park Superintendent I & Park Ranger \\
& \\
\hline
\end{tabular}

1980-86 No change No change

\section{Internal Threats:}

Trail Erosion \& Vandalism:

The design of the trails, plus the soil compaction from visitors, causes erosion. There is also a tremendous amount of vandalism on the trails with the destruction of signs, self-guide booklets and vegetation.

Vista Management:

Pruning and selective herbicidal control are used to control the invading species of trees at the overlooks.

Top 3 Visitor Impacts Identified by Superintendent:

1. Soil Compaction

2. Presence of Human Waste

3. Vandalism

\section{External Threats:}

F1y-overs:

The military uses the mountains for target points and they fly directly over the park. This affects the serenity for the park visitors. 
Mount Jefferson State Park (Continued)

External Threats: (Continued)

Adjacent Development:

There is some development along the road going to and from the park.

\section{Pacility Condition:}

There are 3 buildings located on the park and all are in need of repairs. Some of the safety hazards in the buildings include:

Weakened roofing

Lack of smoke detectors

No fire extinguishers

The maintenance building has a suspended gas heater that is in bad condition

A lack of handicapped access

Some of the repairs that have been started include reroofing and replacing the floor in the park office, and installing smoke detectors and fire extinguishers where needed.

\section{Capital Improvements:}

Current Projects: None

Documented Needs: $\$ 1,486,198$

Projects: Visitor center complex

Well, pumphouse \& piping for water system

Replace septic systems

Picnic shelter

Repave road

Ranger residence (1)

Land Acquisition:

\begin{tabular}{lrl} 
Tract \# & \multicolumn{1}{c}{ Acres } & Reason \\
$1-\mathrm{A}$ & 1.1149 & Entrance Protection \\
1 & 22.1120 & Entrance Protection \\
2 & .4210 & Entrance Protection \\
3 & 13.6400 & Entrance Protection
\end{tabular}


Mount Jefferson State Park (Continued)

\section{Boundary Marking Status:}

\begin{tabular}{cccc}
\hline $\begin{array}{c}\text { Total } \\
\text { Boundary } \\
\text { Mile }\end{array}$ & $\begin{array}{c}\text { Well } \\
\text { Marked }\end{array}$ & $\begin{array}{c}\text { Poorly } \\
\text { Marked }\end{array}$ & $\begin{array}{c}\text { Indef. } \\
\text { or } \\
\text { Unknown }\end{array}$ \\
\hline 3.7 & 0.5 & $-0-$ & 3.2
\end{tabular}

Expenditures and Attendance:

\begin{tabular}{lcrc}
\hline Year & Attendance (Calendar Yr.) & Current $\$$ (Fiscal Yr.) & 1977 \$* (Fiscal Yr.) \\
\hline & & & \\
1977 & 51,595 & $\$ 9,836$ & $\$ 9,836$ \\
1978 & 35,499 & 10,163 & 9,454 \\
1979 & 39,920 & 10,443 & 8,888 \\
1980 & 28,557 & 28,945 & 22,197 \\
1981 & 44,217 & 64,125 & 45,382 \\
1982 & 60,659 & 54,838 & 36,269 \\
1983 & 63,032 & 73,485 & 46,421 \\
1984 & 88,755 & 73,485 & 44,215 \\
1985 & 90,249 & 73,371 & 42,046 \\
1986 & 104,211 & 82,985 & 46,001 \\
1987 & 157,148 & 99,737 & 52,855 \\
1988 & & 38,521 & 19,564
\end{tabular}

Repair and Renovations:

\begin{tabular}{crr}
\hline Fiscal Year & Current $\$$ & 1977\$* \\
\hline 1977 & $\$ 1,249$ & $\$ 1,249$ \\
1978 & 1,841 & 1,687 \\
1979 & 2,253 & 1,917 \\
1980 & 3,437 & 2,636 \\
1981 & 6,829 & 4,833 \\
1982 & 4,728 & 3,127 \\
1983 & 0 & 0 \\
1984 & 4,345 & 2,614 \\
1985 & 5,115 & 2,931 \\
1986 & 7,057 & 3,912
\end{tabular}

*1977 Budget figures are adjusted to reflect inflation and are shown in 1977 dollars. Source: Office of State Budget.

Total Park Revenue: FY 1987: \$2,907

FY 1988: $\$ 0$ 


\section{MOUNT MITCHELL STATE PARK}

Location: Yancey County

Size: 1,677 acres

\section{Reason for Establishment:}

Mount Mitchell is the highest mountain east of the Mississippi River $(6,684$ feet). Its unique geologic, biologic, and scenic values were recognized, and it was established as a park in 1916 to prevent it from being clear-cut.

\section{History of the Park:}

Mount Mitchell was named in honor of Dr. Elisha Mitchell, a clergyman and University of North Carolina geology professor who explored the mountain. Dr. Mitchell is credited with determining the height of the mountain using barometric measurements. He fell to his death there in 1857 .

\section{Existing Staff:}

\section{Permanent:}

Park Superintendent III

Park Chief Ranger

Maintenance Mechanic

\section{Seasonal:}

Park Attendant (3)

Refreshment Stand Manager

Refreshment Stand Clerk (5)

Clerk Typist

General Utility Worker

\section{Minimum Additional Staff Needs:}

Park Ranger I

Clerk Typist III ( $1 / 2)$

\section{Staffing Over Last Ten Years:}


Mount Mitchell State Park (Continued)

Staffing Over Last Ten Years: (Continued)

Permanent

Seasonal

1979-1980 No Change

No Change

1981 No Change

Added:

1 Refreshment Stand Clerk

1982-1986 No Change

Change Naturalist to

General Utility Worker

\section{Internal Threats:}

Endangered Species

Flying squirrel

Saw-whet ow 1

Blackcapped chickadee

Mount Mitchell spider

Spreading avens

Arctic bent grass

Mountain paper birch

Hiking Trail Erosion

The observation tower trail was constructed on a steep grade with a poor drainage system. There are many dead and uprooted trees along some portions of the trails causing large amounts of soil to wash out.

Researchers

Research projects bring many researchers to the park which causes overcrowding, especially on the test plot areas.

Boundaries

Unmarked boundaries at the park are allowing encroachments from poachers and land developers.

Pests

Balsam Wooley Aphid is a parasitic insect that is suspected of killing trees. 
Mount Mitchell State Park (Continued)

\section{Internal Threats: (Continued)}

\section{Litter}

The concessions at the park contribute to problems with trash in heavy use areas.

Top 3 Visitor Impacts Identified by Superintendent:

1. Hunting

2. Erosion/Compaction

3. Litter

\section{External Threats:}

Adjacent Developments

Beyond the west boundary there are some primitive cabins in view. Air Quality

There has been a sharp decline in the Red Spruce and Fraser Fir on top of the mountain. Acid deposition and $f \circ g$ is one of the main causes for the stunted growth.

\section{Facility Condition:}

There are 22 buildings located on the park, most needing repairs. Safety related repairs are:

sprinklers not working in restaurant old and frayed wiring underground storage tanks leaking deteriorating highway railings deteriorating oil furnaces crumbling porches and decks weakening floors and roofs weather beaten tower in need of repair

Some projects are underway, such as repairs to the the water system and septic system. Because of the lack of funds, problems will have to be addressed by repairs rather than renovation.

A new septic system is completed, but the area at the summit was only repaired and will need additional work. Access for the handicapped is also being completed at the park. 
Mount Mitchell State Park (Continued)

\section{Capital Improvements:}

Current Projects:

$\begin{array}{ll}\text { Renovate concession building } & \$ 22,400 \\ \text { Repair lodge and personnel barracks } & \$ 182,000 \\ \text { Sewer repairs } & \$ 29,000 \\ \text { Water system improvements } & \$ 94,500 \\ \text { Water system, Phase II } & \$ 179,314\end{array}$

Documented Needs: $\$ 1,712,500$

Projects: Tower and concession building renovations

Trail improvements

Repave roads

Renovate personnel barracks

Office/visitor center

Ranger residences (3)

Land Acquisition:

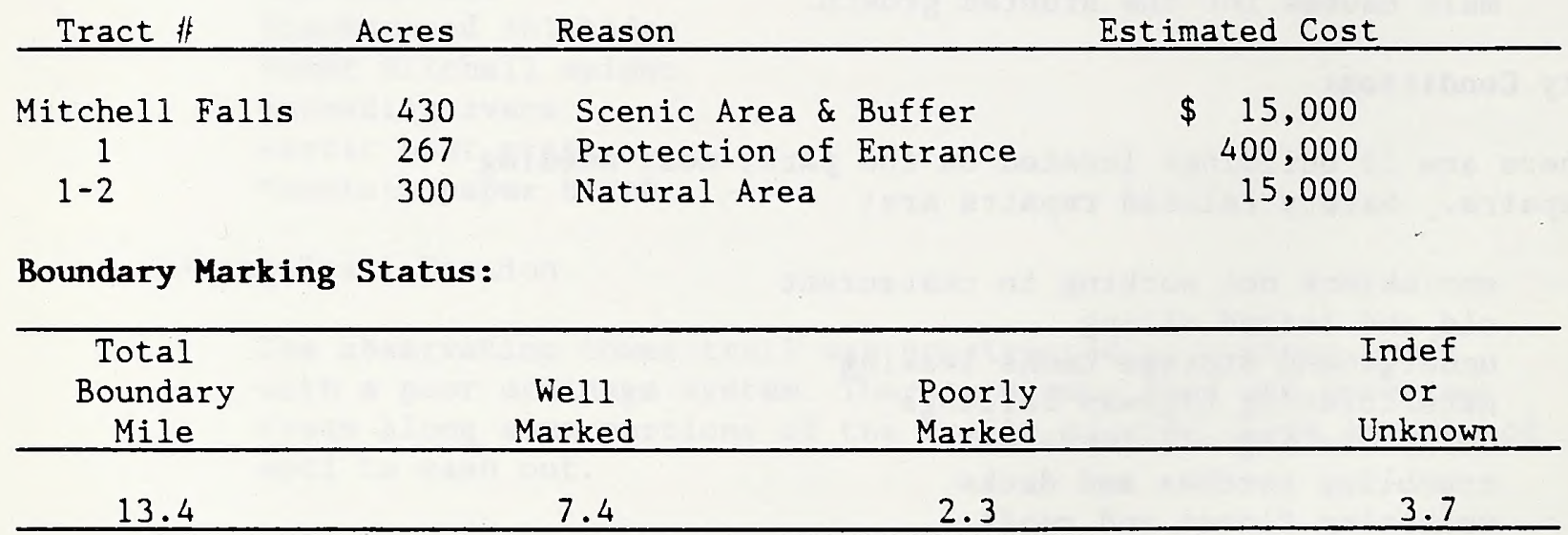

\section{Expenditures and Attendance:}

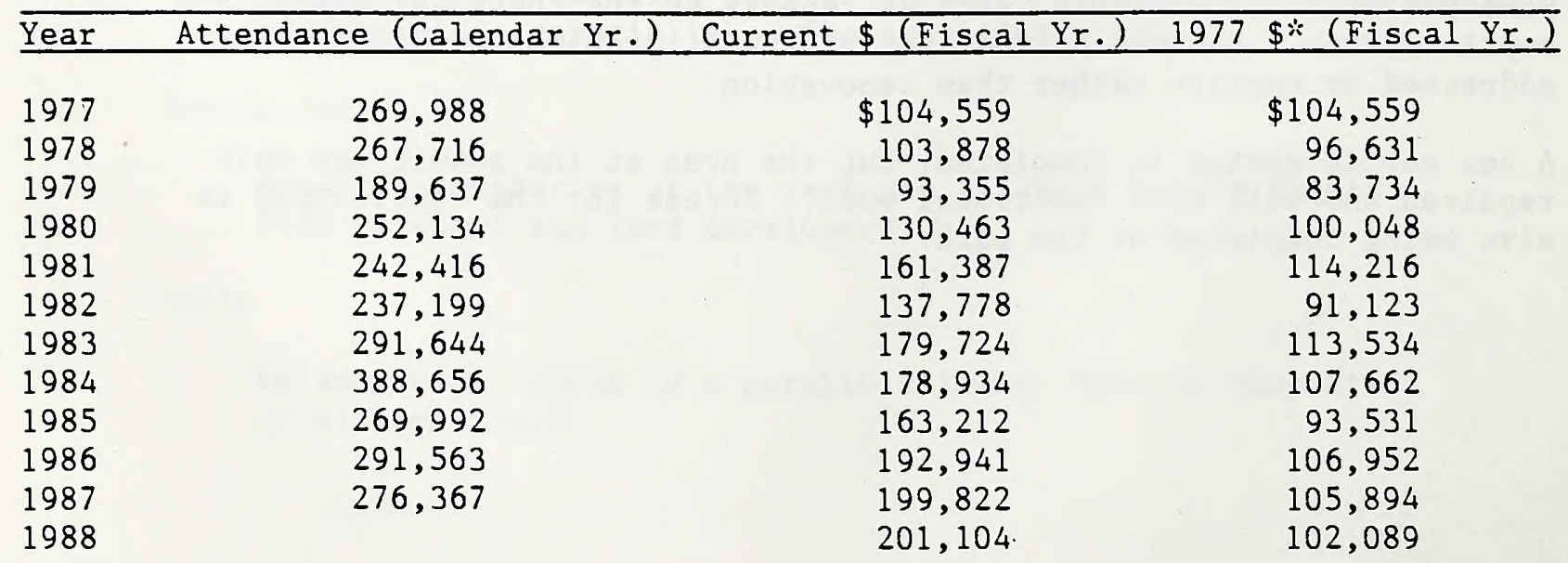


Mount Mitchell State Park (Continued)

\section{Repair and Renovations:}

\begin{tabular}{crr}
\hline Fiscal Year & Current $\$$ & $1977 \$$ \$ \\
\hline & & \\
1977 & $\$, 971$ & $\$ 8,971$ \\
1978 & 9,567 & 8,910 \\
1979 & 5,480 & 4,664 \\
1980 & 11,944 & 9,160 \\
1981 & 30,017 & 21,243 \\
1982 & 8,907 & 5,891 \\
1983 & 0 & 0 \\
1984 & 24,399 & 14,681 \\
1985 & 16,157 & 9,259 \\
1986 & 13,423 & 7,441
\end{tabular}

*1977 budget figures are adjusted to reflect inflation and are shown in 1977 dollars. Source: Office of State Budget.

Total Park Revenue: FY 1987: \$115,546

FY 1988: $\$ 122,402$ 


\section{NEW RIVER STATE PARK}

Location: Ashe and Alleghany Counties

\section{Size:}

531 acres are owned by the State. A segment $26-1 / 2 \mathrm{miles}$ in length, from the confluence of the south fork of the New River and Dog Creek. downstream to the state line, is designated a scenic river.

\section{Reason for Establishment:}

The New River is the oldest river in North America and it is a component of the Natural and Scenic Rivers System.

\section{History of the Park:}

The New River was an early Indian migration route. Artifacts found in the river valley span the entire range of aboriginal occupation of the eastern United States. Like much of the area in northwest North Carolina, New River was surveyed in the early 1700 s by Peter Jefferson, the father of President Thomas Jefferson. Early settlers found the area ideal for farming.

In the late 1960s, the Appalachian Power Company of Virginia was granted a permit to begin construction on a pumped storage, hydro-electric facility on the New River. A pumped storage facility releases water during the day when electricity demand is high and pumps it back during the night (the system is a net energy consumer rather than producer). The series of dams would have flooded the New River valley and displaced over 3,000 people, destroying rich farms, communities, and the unique natural areas. After a long fight that galvanized support from across the country, the New River was included in the Wild and Scenic River system. It is now protected from dams. The state sections of the New River are presently under construction. The Wagoner Road area was opened in 1982. (Runkle, John. A Guide to North Carolina State Parks. Tread Softly, 1983, p. 49.) The park was established in 1977.

\section{Facilities:}

Picnic area (14 tables)

Primitive camping

\section{Existing Staff:}

\section{Permanent:}

Park Ranger II
Seasonal:

Park Attendant (2) 
New River State Park (Continued)

Minimum Additional Staff Needs:

Superintendent

Park Ranger I

Maintenance Mechanic

Clerk Typist

Staffing Over the Last Five Years:

\begin{tabular}{lll}
\hline & Permanent & Seasonal \\
\hline 1984 No Staff & Park Attendant \\
\hline 1985 No Change & No Change \\
\hline 1986 Park Ranger II & Added: Park Attendant
\end{tabular}

\section{Internal Threats:}

Water Quality:

Threats to the river's water quality include the malfunctioning of the Town of Jefferson sewage treatment plant which discharges upstream from the designated section, a proposed major water supply withdrawal, and sedimentation from rapid increase in unregulated residential subdivision development.

Soil Compaction:

The campground is showing signs of soil compaction damage.

Shoreline Erosion:

The bank is eroding in areas where trampling of the vegetation has occurred.

\section{Litter:}

The amount of litter has increased in and around the river.

Old Field Management:

There are a few old fields in the park that are maintained by mowing them once a year. 
New River State Park (Continued)

Internal Threats: (Continued)

Endangered Species:

The river is home for a rare $\mathrm{fish}$ species known as the Bluntnose Minnow.

\section{External Threats:}

Adjacent Development:

There has been an increase in development along the river since the designation. Some of the areas are to be future land acquisitions for the State. This development affects the aesthetic view from the river, and the visual quality of the river's corridor which led to State Scenic River designation is being destroyed by uncontrolled residential development.

Top 3 Visitor Impacts Identified by Superintendent:

1. Shoreline Erosion;

2. Soil Compaction; and

3. Litter

\section{Facility Condition:}

The one main building on the park is the park office, and it is being renovated. A major project in the works at the park is the construction of a toilet building.

\section{Capital Improvements:}

Current Projects:

$$
\begin{array}{ll}
\text { Meeting shelter } & \$ 60,000 \\
\text { Toilet building/contact station } & \$ 141,000
\end{array}
$$

Documented Needs: $\$ 3,411,995$

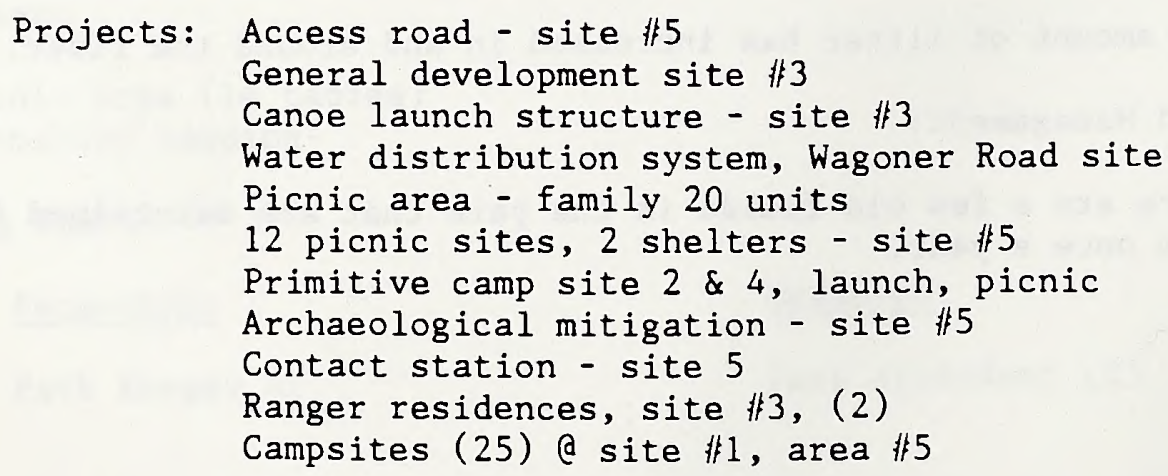


New River State Park (Continued)

\section{Land Acquisition:}

\begin{tabular}{cclr}
\hline Tract & Acres & \multicolumn{1}{c}{ Reason } & Estimated Cost \\
\hline 1 & 15.00 & $\begin{array}{l}\text { Land Development } \\
\text { Inholding bordered on } 3 \\
\text { sides by park }\end{array}$ & $\$ 37,500$ \\
3 & 35.00 & $\begin{array}{l}\text { Buffer } \\
\text { Land Development }\end{array}$ & 35,460 \\
4 & 19.70 & Primary Resource & 108,000 \\
5 & 75.00 & Primary Resource & 39,300 \\
6 & 26.00 & Primary Resource & 50,700 \\
7 & 72.00 & 180,190
\end{tabular}

Boundary Marking Status:

\begin{tabular}{cccc}
\hline $\begin{array}{c}\text { Total } \\
\text { Boundary } \\
\text { Mile }\end{array}$ & $\begin{array}{l}\text { Well } \\
\text { Marked }\end{array}$ & $\begin{array}{c}\text { Poorly } \\
\text { Marked }\end{array}$ & $\begin{array}{c}\text { Indef. } \\
\text { or } \\
\text { Unknown }\end{array}$ \\
\hline 9.6 & 7.0 & 0.9 & 1.7
\end{tabular}

Expenditures and Attendance:

Year Attendance (Calendar Yr.) Current \$ (Fiscal Yr.) 1977 \$* (Fiscal Yr.)

$\begin{array}{ll}1985 & 17,915 \\ 1986 & 18,670 \\ 1987 & 25,942\end{array}$

1988

$\$ 62,159 \quad \$ 31,569$

Repairs/Renovation: No data available

Total Park Revenue: FY 1988: \$4,159 


\section{PETTIGREW STATE PARK}

Location: Washington County and Tyrell County

Size: 16,600 acres water

$\frac{850}{17,450}$ acres land

\section{Reason for Establishment:}

The historic plantation, Somerset Place State Historic Site which is adjacent to the park, gives the park added interest to its natural beauty. Lake Phelps, a 16,600 acre angler's paradise, provides excellent fishing. Lake and wind conditions are ideal for shallow-draft sailboats and windsurfing. Pettigrew's origin as a park stems from Federal public works programs of the depression era.

\section{History of the Park:}

Pettigrew became a state park in 1939, and with the addition of Lake Phelps, which is owned by the state, is North Carolina's largest state park. The lake was considered worthless in colonial times as part of the Great Dismal Swamp. The first syndicate to drain the lake for farming was created in 1780 . The Pettigrew family built the nearby Bonarva Plantation in 1789 and lived there until it burned in 1860 . Somerset Place, now a state historic site open to the public, was built in the 1830 s and was the center of a rich rice plantation. With the lower lake levels of recent years, Indian dugout canoes have been found and preserved, evidence of a once thriving Indian population.

\section{Facilities:}

Information Building

Boat ramp (one lane, Lake Phelps)

Family camping (13 sites, no hookups, restroom/shower)

Group camp

Information building

Park office/maintenance building

Picnic area (17 tables)

Residence (one house)

Trails ( 5.5 miles, hiking)

Group Camp

\section{Existing Staff:}

Permanent:

Park Superintendent I

Chief Park Ranger

Maintenance Mechanic I
Seasonal

Park Attendant

Minimum Additional Staff Needs:

Park Ranger I

Clerk-Typist III 
Pettigrew State Park (Continued)

Staffing Over last Ten Years:

\begin{tabular}{lll}
\hline & Permanent & Seasonal \\
\hline 1977 & $\begin{array}{l}\text { Park Superintendent I } \\
\text { Chief Park Ranger }\end{array}$ & No data available \\
\hline 1978 No Change & $\begin{array}{l}\text { Park Attendant } \\
\text { General Laborer }\end{array}$ \\
\hline 1979 No Change & $\begin{array}{l}\text { Lost } \\
\text { General Laborer }\end{array}$ \\
\hline $1980-1985$ No Change & No Change \\
\hline 1986 & Added: Maintenance Mechanic I & No Change \\
\hline
\end{tabular}

\section{Internal Threats:}

Water Quality:

Some siltation is effecting the lake water level, and management of the problem will be needed in the near future.

Archaeological Resources:

Recent discoveries have revealed several very significant prehistoric resource areas. These areas are threatened by looting.

Endangered Species:

The Waccamaw killifish is being studied at the lake. Bald eagles have also been spotted in the park. 


\section{Internal Threats: (Continued)}

Boundaries :

The lines are cleared at least once every other year.

Visitor Impact:

An interpretive center is needed to aid in visitor understanding of the area.

Aesthetics:

There are some unattractive areas in the park that need to be hidden from view with trees or shrubs.

Top three Visitor Impacts Identified by Superintendent

1. Litter

2. Lakeshore Cleanup

3. Erosion

\section{External Threats:}

Adjacent Development:

Wind easements were a verbal agreement given to a few land owners adjacent to the lake, but it was not given to everyone. Clearing the underbrush on property in order to obtain wind from the lake is now prohibited. Some of the land owned by First Colony Farms is land that the State wants to acquire. However, First Colony is planning to develop the area.

\section{Facility Condition:}

The park is in need of increased parking facilities at pier boat ramp, additional picnicking areas, a new maintenance area, a new ranger residence, and a new entrance and access road.

\section{Capital Improvements:}

Current Projects: None

Documented Needs: $\$ 3,733,284$

Projects: Visitor center complex Boat launch area - Bee Tree

Roadside parking - Big Point Development

Concession stand and pier

Picnic area group - Big Point

Ranger residence (1)

Boat launch marina - Big Point development

Tent and trailer - 70 sites

Warehouse building 
Pettigrew State Park (Continued)

Land Acquisition

Tract 非 Acres Reasons

\begin{tabular}{lll}
\hline 1 & 43.09 & Primary resource \\
2 & 87.00 & Primary resource
\end{tabular}

Boundary Marking Status:

\begin{tabular}{lrcc}
\hline $\begin{array}{l}\text { Total } \\
\text { Boundary } \\
\text { Mile }\end{array}$ & $\begin{array}{r}\text { Well } \\
\text { Marked }\end{array}$ & $\begin{array}{c}\text { Poorly } \\
\text { Marked }\end{array}$ & $\begin{array}{c}\text { Indef. } \\
\text { or } \\
\text { Unknown }\end{array}$ \\
\hline 8.9 & 8.5 & 0.4 & 0
\end{tabular}

\section{Expenditures and Attendance:}

\begin{tabular}{lccc}
\hline Year & Attendance (Calendar Yr.) & Current $\$$ (Fiscal Yr.) & $1977 \$ *$ (Fiscal Yr.) \\
\hline & & & \\
1977 & 50,974 & $\$ 38,400$ & $\$ 38,400$ \\
1978 & 50,682 & 40,227 & 37,420 \\
1979 & 51,546 & 44,875 & 38,191 \\
1980 & 38,011 & 43,431 & 33,306 \\
1981 & 54,052 & 48,557 & 34,364 \\
1982 & 60,430 & 42,063 & 27,819 \\
1983 & 61,763 & 57,484 & 36,313 \\
1984 & 59,170 & 53,380 & 32,118 \\
1985 & 63,744 & 74,777 & 42,852 \\
1986 & 45,197 & 64,549 & 35,781 \\
1987 & 52,875 & 85,016 & 45,054 \\
1988 & & 104,289 & 52,965
\end{tabular}

Repair/Renovation Over Last Ten Years:

\begin{tabular}{crr}
\hline Fiscal Year & Current $\$$ & $1977 \$^{*}$ \\
\hline 1977 & 3,183 & 3,183 \\
1978 & 898 & 835 \\
1979 & 1,897 & 1,614 \\
1980 & 1,867 & 1,431 \\
1981 & 5,730 & 4,055 \\
1982 & 843 & 557 \\
1983 & 0 & 0 \\
1984 & 2,812 & 1,692 \\
1985 & 6,522 & 3,738 \\
1986 & 3,956 & 2,193
\end{tabular}


Pettigrew State Park (Continued)

*1977 budget figures are adjusted to reflect inflation and are shown in 1977 dollars. Source: Office of State Budget.

TOTAL PARK REVENUE: FY 1987: \$5,937

FY 1988: $\$ 7,862$ 


\section{PILOT MOUNTAIN STATE PARK}

Location: Yadkin \& Surry Counties

Size: 3,703 acres

\section{Reason for Establishment:}

The mountain has a unique quartzite monadnock that rises 200 feet from the top of the mountain.

\section{History of the Park:}

The Saura Indians called the mountain "Jo-me-o-kee," which translates into "pilot." Thomas Jefferson's father, Peter, mapped the region in 1751, naming the mountain Ararat. It was first measured by Joseph Caldwell, the first president of the University of North Carolina, who made it a practice to climb the mountain at all seasons of the year. The Pinnacle served as the outdoor pulpit for the Reverend Lorenzo Dow.

It has been a park since 1968 and was dedicated as a National Natural Landmark in 1976.

\section{Facilities:}

Family camping ( 49 sites, no hookups, restroom/shower)

Group camping (primitive)

Maintenance area

Park office

Picnic area (45 tables, one shelter)

Primitive camping (Yadkin River)

Residence ( 3 houses)

Trails ( 21 miles, hiking and 12 miles, bridle)

\section{Existing Staff:}

Permanent

Park Superintendent I

Park Ranger II

Park Ranger II

Clerk-Typist III (.5)
Seasonal

Park Attendant (2)

General Utility Worker

Clerk-Typist III

Minimum Additional Staff Needs:

Seasonal

Clerk-Typist (.5)

Maintenance Mechanic 
Pilot Mountain State Park (Continued)

Staffing Over Last Ten Years:

\begin{tabular}{lll}
\hline \multicolumn{1}{c}{ Permanent } & Seasonal \\
\hline 1977 & $\begin{array}{l}\text { Park Superintendent I } \\
\text { Park Ranger II } \\
\text { Park Ranger II }\end{array}$ & No data available \\
\hline 1978 No Change & $\begin{array}{l}\text { Park Attendant } \\
\text { Naturalist } \\
\text { (2) General Laborers }\end{array}$ \\
\hline 1979 & No Change & Lost General Laborers \\
\hline 1980 & No Change & No data available \\
\hline 1981 & No Change & $\begin{array}{l}\text { Add Park Attendant } \\
\text { Clerk-Typist III }\end{array}$ \\
\hline $1982-1985$ No Change & No Change \\
\hline 1986 Add Clerk-Typist & $\begin{array}{l}\text { Naturalist changed to } \\
\text { General Utility Worker }\end{array}$ \\
\hline
\end{tabular}

\section{Internal Threats:}

Trail Erosion:

Several years of ATV use on the trails has caused erosion, soil compaction and destruction of vegetation.

Old Field Management:

There are a few old fields in the park. The only management technique is mowing the grass once a year.

Historic Site:

The Hauser Farm and the Bean Shoals Canal need to be surveyed.

Endangered Species:

The top of the Big Pinnacle is a nesting area for ravens and hawks which was threatened in the past by a proposal to provide visitor access to the top. 
Pilot Mountain State Park (Continued)

Internal Threats: (continued)

Boundaries:

The lack of markers on the boundaries is resulting in encroachment from hunters and adjacent land owners.

Visitor Impacts:

The visitation is very heavy and causes an overcrowding problem during the fall foliage season. This also causes a litter problem at the summit of the mountain.

Top 3 Visitor Impacts Identified by Superintendent:

1. Litter

2. Compaction/erosion

3. Vegetation trampling/destruction

\section{Facility Condition:}

The 45 buildings on the park are all in need of many repairs, but the safety hazards that are a major concern include:

No smoke detectors

Weakened roofs

The Hauser homestead and out buildings.

A new electrical system is needed to replace the old ones in several buildings.

The concrete sidewalk to the park office is cracked and becoming hazardous.

Few repairs have been completed at the park. The one safety hazard repaired was the roof repair to the bathhouse. The other repairs have been listed, but due to a lack of money and staff, they have been placed on hold.

\section{Capital Improvements:}

Current Projects:

Safety park and landscaping $\$ 75,000$ 
Pilot Mountain State Park (Continued)

Capital Improvements: (Continued)

Documented Needs: $\$ 8,055,603$

Projects: Lake development - Grassy Creek, parking lot, dam, park road Restroom building - river section

Trail improvements

Picnic area/Grassy Creek, park road, sites, shelters, toilet Water system improvements

Renovate ranger residence (1), river section

Visitor center complex

Pave access road \& parking lot - river section

Maintenance building - river section

Warehouse - river section

Picnic area expansion (package) - mountain top

Demolition

Picnic area/shelter - river section

Land Acquisition: No acquisition in progress

Boundary Marking Status:

\begin{tabular}{cccc}
\hline $\begin{array}{c}\text { Total } \\
\text { Boundary } \\
\text { Miles }\end{array}$ & $\begin{array}{l}\text { Well } \\
\text { Marked }\end{array}$ & $\begin{array}{c}\text { Poorly } \\
\text { Marked }\end{array}$ & $\begin{array}{c}\text { Indef. } \\
\text { or } \\
\text { Unknown }\end{array}$ \\
\hline 36.6 & 0 & 36.6 & 0
\end{tabular}

Expenditures and Attendance:

Year Attendance (Calendar Yr.) Current \$ (Fiscal Yr.) 1977 \$* (Fiscal Yr.)

$\begin{array}{rrrr}1977 & 171,432 & \$ 58,540 & \$ 58,540 \\ 1978 & 194,246 & 70,307 & 65,402 \\ 1979 & 174,356 & 79,104 & 67,323 \\ 1980 & 189,064 & 86,045 & 65,985 \\ 1981 & 179,976 & 85,389 & 60,431 \\ 1982 & 142,524 & 84,039 & 55,581 \\ 1983 & 180,981 & 89,753 & 56,698 \\ 1984 & 198,696 & 87,753 & 54,003 \\ 1985 & 236,678 & 95,173 & 54,540 \\ 1986 & 216,842 & 114,368 & 63,397 \\ 1987 & 264,752 & 120,790 & 64,011 \\ 1988 & & 133,328 & 67,714\end{array}$


Pilot Mountain State Park (Continued)

\section{Repair/Renovations:}

\begin{tabular}{crr}
\hline Fiscal Year & Current $\$$ & $1977 \$ *$ \\
1977 & 5,879 & 5,879 \\
978 & 8,344 & 7,762 \\
1979 & 9,053 & 7,705 \\
1980 & 8,307 & 6,370 \\
1981 & 13,878 & 9,822 \\
1982 & 14,812 & 9,796 \\
1983 & 0 & 0 \\
1984 & 4,504 & 2,710 \\
1985 & 5,704 & 3,269 \\
1986 & 7,251 & 4,019
\end{tabular}

*1977 budget figures are adjusted to reflect inflation and are shown in the 1977 dollars. Source: Office of State Budget.

Total Park Revenue: FY 1987: \$9,735

FY 1988: $\$ 10,197$ 


\section{RAVEN ROCK STATE PARK}

Location: Harnett County

Size: 2,847 acres

Reason for Establishment:

There is a 152 foot high quartzite rock formation that juts out over the river and the park receives its name from this formation. A rich assemblange of habitats supports many plants and animals. There is also excellent river and creek fishing for catfish, largemouth bass and a variety of sunfish.

History of the park:

Raven Rock has been a state park since 1970. It was originally known as Patterson's Rock, named after an early settler who was injured while canoeing along the Cape Fear River. At the point of starvation, he was saved when a deer fell off the cliff at his feet. The name was changed in honor of the many ravens that once nested there. In the $1850 \mathrm{~s}$, a series of locks and dams were built on the Cape Fear River at this point to facilitate trade upriver to Raleigh. Much of the area was timbered in early 1900s.

The park was acquired by the State using donations and Federal LWCF assistance.

Pacilities:

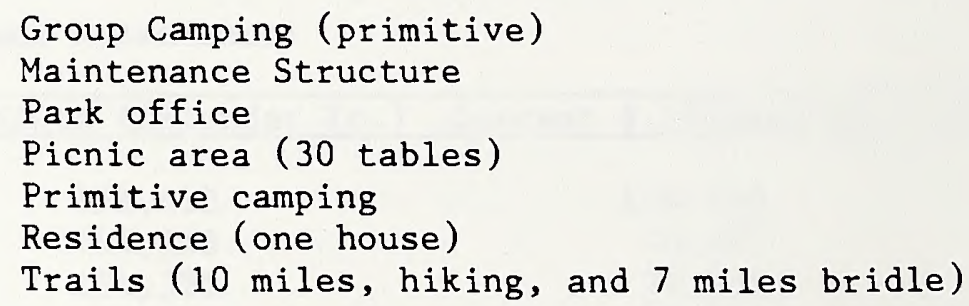

\section{Existing Staff:}

Permanent:

Park Superintendent I

Chief Park Ranger

Park Ranger I
Seasonal:

General Utility Worker

Park Attendant (2)

\section{Minimum Additional Staff Needs:}

Clerk-Typist III

Maintenance Mechanic 
Raven Rock State Park (Continued)

\section{Staffing Over Last Ten Years:}

\begin{tabular}{lll}
\hline \multicolumn{1}{c}{ Permanent } & Seasonal \\
\hline $1977 \begin{array}{l}\text { Park Superintendent I } \\
\text { Chief Park Ranger } \\
\text { Park RangerI }\end{array}$ & No data available \\
\hline 1978 No Change & $\begin{array}{l}\text { Park Attendant } 2 \\
\text { Naturalist } \\
\text { General Utility Worker }\end{array}$ \\
\hline 1979 No Change & Lost: General Utility Worker \\
\hline 1980 No Change & No data available \\
\hline 1981 No Change & Add: Refreshment Stand Clerk \\
\hline
\end{tabular}

1982

- 83 No Change

No Change

1984 No Change

Lost: Refreshment Stand

Clerk

\begin{tabular}{ll}
\hline 1985 No Change & No Change \\
\hline 1986 No Change & $\begin{array}{c}\text { Naturalist changed to a } \\
\text { general utility worker }\end{array}$ \\
\hline
\end{tabular}

\section{Internal Threats:}

Trail Erosion/Compaction

Visitors are not staying on the marked trails and are forming spur trails. No managment technique seems to stop this practice.

Climbing/Rappelling

Rock climbing and rappelling has had an impact on the rocks by causing erosion to occur more quickly. Plants are also being damaged by this practice.

Bridle Trails

Erosion damage is occuring on steep sections of the trails. Damage is occuring in wet areas along the river floodplain. 
Raven Rock State Park (Continued)

Internal Threats: (Continued)

Vandalism

Painting and carving on the softer rock formations and on trees has been a problem.

ATV Control

There have been ATV's found being used in creeks and on the river. banks. The gates and signs are having little effect on preventing this type of abuse.

Top three Visitor Impacts Identified by Superintendent

1. Erosion/Compaction

2. Climbing and Rappelling

3. Vandalism

\section{External Threats}

Adjacent Development

A clear cut area that is adjacent to the park is causing both water quality problems and an asthetic view problem. This property is also to be eventually acquired by the State for the park. Many of the lands proposed for acquisition and development have yet to be acquired.

\section{Facility Condition:}

Most of the 22 buildings in the park are in fair condition, but most have several safety hazards including:

-- no smoke detectors

- weakened roofs

- handrails needed around porches and along stairs

-- the Mckoy House needs to be demolished and cleared.

-- lack of handicap access to the public use buildings.

There is a new toilet building and parking lot completed at the park. Access for the handicapped has been put on hold pending availability of funds for renovations.

\section{Capital Improvements:}

Current Projects: None 
Raven Rock State Park (Continued)

\section{Capital Improvements: (Continued)}

Documented Needs: $\$ 12,067,429$

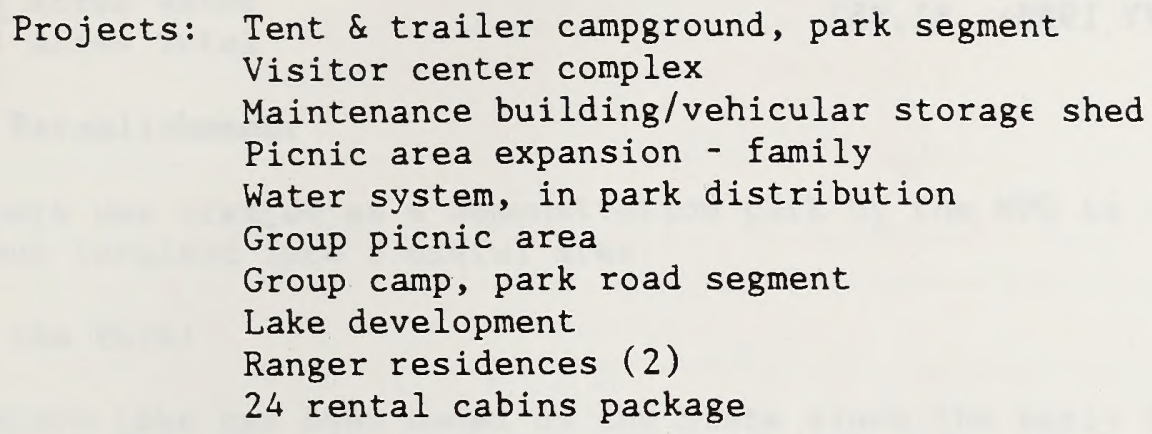

Land Acquisition: No acquisition in progress.

Boundary Marking Status:

\begin{tabular}{crcc}
\hline $\begin{array}{c}\text { Total } \\
\text { Boundary } \\
\text { Miles }\end{array}$ & $\begin{array}{r}\text { Well } \\
\text { Marked }\end{array}$ & $\begin{array}{c}\text { Poorly } \\
\text { Marked }\end{array}$ & $\begin{array}{c}\text { Indef } \\
\text { or } \\
\text { Unknown }\end{array}$ \\
\hline 10.8 & 4.4 & 6.4 & 0
\end{tabular}

Bxpenditures and Attendance:

\begin{tabular}{lcrcc}
\hline Year & Attendance (Calendar Yr.) & Current $\$($ Fiscal Yr.) & 1977 \$* (Fiscal Yr.) \\
\hline & & & \\
1977 & 68,424 & $\$ 47,814$ & $\$ 4,814$ \\
1978 & 67,065 & 44,804 & 41,678 \\
1979 & 59,744 & 56,395 & 47,996 \\
1980 & 56,665 & 66,543 & 51,030 \\
1981 & 53,763 & 64,371 & 45,556 \\
1982 & 58,555 & 59,710 & 39,497 \\
1983 & 54,603 & 74,053 & 46,780 \\
1984 & 58,975 & 74,053 & 44,557 \\
1985 & 39,126 & 65,405 & 37,481 \\
1986 & 52,144 & 79,470 & 44,052 \\
1987 & 54,801 & 81,298 & 43,083 \\
1988 & & 123,477 & 62,711
\end{tabular}

Repair/Renovation:

\begin{tabular}{crrr}
\hline Fiscal Year & Current & 1977 & $\$ *$ \\
\hline & & & \\
1977 & $\$ 3,085$ & $\$$ & 3,085 \\
1978 & 7,601 & & 7,071 \\
1979 & 3,395 & & 2,889 \\
1980 & 5,415 & &
\end{tabular}


Raven Rock State Park (Continued)

*1977 Budget figures are adjusted to reflect inflation and are shown in 1977 dollars. Source: Office of State Budget.

Total Park Revenue: FY 1987: $\$ 2,862$

FY 1988: $\$ 1,952$ 


\section{SINGLETARY LAKE STATE PARK}

Location: Bladen County

Size: 649 Acres Land

572 Acres Water

1221 Acres Total

\section{Reason for Establishment:}

This park was created as a demonstration park by the NPS to convert worn-out farmland into a useful area.

\section{History of the Park:}

Singletary Lake has been owned by the State since the early 1900s. The Civilian Conservation Corps had a camp operation at the site.

Singletary Lake has been a state park since 1939 when it was donated to the State by the Federal government.

\section{Facilities:}

Group camp (two units, cabins, restroom/showers, and mess halls)

Maintenance area

Park office

Residence (one house)

Trail (1 mile, hiking)

\section{Existing Staff:}

\section{Permanent}

Park Superintendent II Chief Park Ranger

Park Ranger I

Clerk-Typist

\section{Minimum Additional Staff Needs:}

Maintenance Mechanic II

Clerk-Typist (.5)

Staffing Over the Last Ten Years:

\section{Seasonal}

General Utility Worker 
Singletary Lake State Park (Continued)

Staffing Over the Last Ten Years: (Continued)

Permanent

Seasonal

\begin{tabular}{lll}
\hline 1978 No Change & $\begin{array}{l}\text { Naturalist } \\
\text { General Laborer }\end{array}$ \\
\hline 1979 No Change & Dropped General Laborer \\
\hline $1980-1986$ No Change & $\begin{array}{l}\text { Naturalist changed to } \\
\text { General Utility Worker }\end{array}$ \\
\hline
\end{tabular}

\section{Internal Threats:}

Fire

Fire dependent/tolerant areas (longleaf/turkey oak/wiregrass; xeric sand ridges; open shrub pocosin; and pine pocosin) are threatened by the preclusion of natural fire. In addition, dangerous fuel levels are accumulating in come of these areas. A draft prescribed burn has been developed.

\section{Litter}

There is a great deal of litter in the group campgrounds.

Endangred Species

The Venus flytrap and Red cockaded woodpecker are both found in the park.

Vegetation Destruction

Along the trails there is a continous problem of visitors digging for bait.

Pest Managment

The Southern Pine beetle has infested several areas.

Soil Compaction

There is a problem of compaction along the lake shore.

Boundaries

The unmarked boundaries have caused encroachment from hunters and local residents. 
Singletary Lake State Park (continued)

\section{Internal Threats: (Continued)}

Top 3 Visitor Impacts Identified by Superintendent

1. Litter

2. Vegatation Destruction

3. Soil Compaction

\section{Facility Condition:}

The 29 buildings located at the park are in relatively good condition. There are some safety hazards that need to be taken care of including:

- all cabins need smoke detectors

- new electrical receptacles are needed in several buildings

- one of the storage buildings need to be destroyed

- the wooden stairs are in need of new treads

- handicap accesses are needed for the public buildings.

Some of the projects that have been listed to do include roof repairs, redecking and replacement of rotten supports of the pier, and construction of handicapped access ramps.

\section{Capital Improvements:}

Current Projects: None

Documented Needs: $\$ 4,536,065$

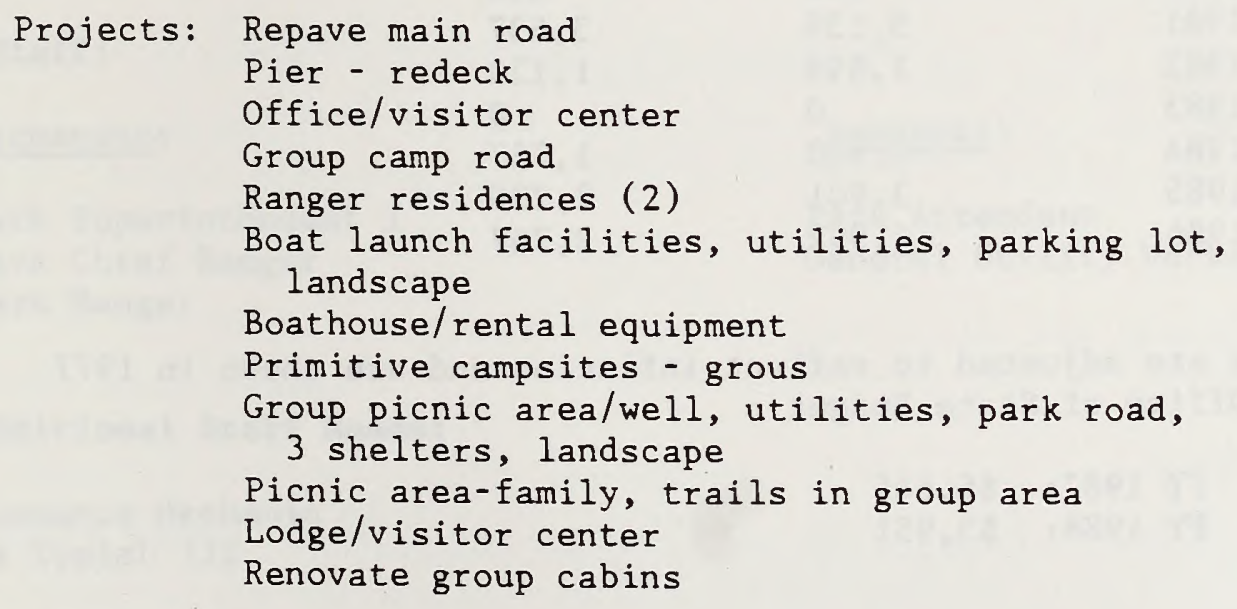

\section{Land Acquisition:}

No acquisition in progress

\section{Boundary Marking Status:}

\begin{tabular}{lccc}
\hline $\begin{array}{l}\text { Total } \\
\text { Boundary }\end{array}$ & $\begin{array}{c}\text { Well } \\
\text { Marked }\end{array}$ & $\begin{array}{c}\text { Poorly } \\
\text { Marked }\end{array}$ & $\begin{array}{c}\text { Indef. } \\
\text { or } \\
\text { Unknown }\end{array}$ \\
\hline 23.2 & 6.8 & 5.4 & 11.0
\end{tabular}


Singletary Lake State Park (Continued)

\section{Expenditures and Attendance:}

\begin{tabular}{lcrc}
\hline Year & Attendance (Calendar Yr.) & Current $\$$ (Fiscal Yr.) & 1977 \\
\hline 1977 & 12,845 & $\$ 25,192$ & (Fiscal Yr.) \\
1978 & 12,174 & 35,567 & $\$ 25,192$ \\
1979 & 5,464 & 27,466 & 32,155 \\
1980 & 8,320 & 27,115 & 23,375 \\
1981 & 9,022 & 48,288 & 20,794 \\
1982 & 10,047 & 46,462 & 34,174 \\
1983 & 10,532 & 73,070 & 30,729 \\
1984 & 12,260 & 73,070 & 46,159 \\
1985 & 14,418 & 81,600 & 43,965 \\
1986 & 17,189 & 85,707 & 46,762 \\
1987 & 12,022 & 97,302 & 47,509 \\
1988 & & 124,908 & 51,564 \\
& & & 63,437
\end{tabular}

\section{Repair/Renovation:}

\begin{tabular}{crr}
\hline Fiscal Year & Current $\$$ & \multicolumn{1}{c}{$1977 \$ *$} \\
\hline & & \\
1977 & $\$ 3,974$ & $\$ 3,974$ \\
1978 & 10,629 & 9,887 \\
1979 & 1,558 & 1,326 \\
1980 & 551 & 443 \\
1981 & 5,139 & 3,637 \\
1982 & 1,698 & 1,123 \\
1983 & 0 & 0 \\
1984 & 2,920 & 1,757 \\
1985 & 3,901 & 2,236 \\
1986 & 4,992 & 2,767
\end{tabular}

*1977 Budget figures are adjusted to reflect inflation and are shown in 1977 dollars. Source: Office of State Budget

Total Park Revenue: FY 1987: \$6,645

FY 1988: $\$ 3,951$ 


\section{SOUTH MOUNTAIN STATE PARK}

Location: Burke County

Size: 6,586 acres

\section{Reason for Establishment:}

This park has good examples of the upper Piedmont ecology.

\section{History of the Park:}

The state park is part of the South Mountains Wildlife Management Area and includes surrounding timber lands with many Forest Service roads. The State purchased the first parcel at South Mountain in December of 1975. The area is rich in minerals; gold was discovered in 1828 as part of the North Carolina Gold Rush. William Earl Hidden, the geologist for Thomas Edison, explored the area in search of new minerals. Hiddenite, named after him, is a yellow-green gem stone found only in the area.

\section{Facilities:}

Park office/maintenance building

Primitive camping

Residence ( 2 houses)

Restroom

Trails ( 32 miles, hiking and 25 miles bridle)

\section{Existing Staff:}

Permanent:

Park Superintendent I

Park Chief Ranger

Park Ranger
Seasonal:

Park Attendant

General Utility Worker

\section{Minimum Additional Staff Needs:}

Maintenance Mechanic

Clerk Typist III

Staffing Over Last Ten Years:

Permanent

Park Chief Ranger

No change

Added:
Seasonal

No data available

Park Attendant

General Utility Worker

Lost: 
South Mountains State Park (Continued)

Staffing Over Last Ten Years: (Continued)

\begin{tabular}{lll}
\hline & Permanent & \multicolumn{1}{c}{ Seasonal } \\
\hline 1979 & Park Superintendent I & General Utility Worker \\
1980 & No change & No data available \\
\hline 1981 & No change & $\begin{array}{l}\text { Added: } \\
\text { Naturalist }\end{array}$ \\
\hline $1982-84$ & No change & No change \\
\hline 1985 & Added: & No change \\
1986 & Park Ranger I & $\begin{array}{l}\text { Naturalist changed to } \\
\text { General Utility Worker }\end{array}$ \\
\hline
\end{tabular}

\section{Internal Threats:}

Water Quality:

Jacobs Fork, with the cleanest surface waters in the State Parks System, has been nominated for outstanding Resource Water

Designation. The last privately owned inholding property in the Park's section of the watershed, through vacation cabin development, is threatening the water quality of Jacob Fork.

Trail Erosion:

Poor trail design has been the main cause of most of the erosion problems. The grade is too steep, and the lack of water bars has sped up the erosion process.

Parking:

The parking area and the entrances are inadequate to handle the visitation, causing management problems.

Old Field Management:

There are several fields on the park. properly. They are being mowed once or twice a year at the present time.

Bridle/Hiking Trails:

More trails are needed to keep up with the demand.

Habitat Management:

In the natural area is a Bear Oak site. 
South Mountains State Park (Continued)

Internal Threats: (Continued)

Backpacking:

The backpacking campground has an inadequate water supply.

Encं angered Species:

The Bear Oak is an endangered tree species, and the park has other rare plants that need to be managed properly.

Pest Management:

Southern Pine Beetles have infested approximately one acre.

Boundaries:

The unmarked boundaries have caused problems with encroachment occurring from hunters and local residents.

Visitor Impacts:

There have been some minor impacts from visitors including

trampling, soil compaction, and litter. Heavy visitor use of the

High Shoals Falls area, and undesirable access to the top of the

falls is seriously impacting the fragile vegetation in this area.

Top 3 Visitor Impacts Identified by Superintendent:

1. Parking

2. Bridle/Hiking Trails

3. Backpacking

\section{External Threats:}

Adjacent Development:

There is a potential for development in the watershed which may lead to pollutants in the water. Also, land proposed for acquisition and master planned for development of a lake and swimning/day use area is threatened by subdivision and residential development.

\section{Facility Condition:}

There are 5 buildings located in the park and all are in need of repair. The safety related repairs needed include new electrical receptacles to replace the old ones. Handicap access for the public buildings is also needed. 
South Mountains State Park (Continued)

\section{Capital Improvements:}

Current Projects: None

Documented Needs: $\$ 2,183,689$

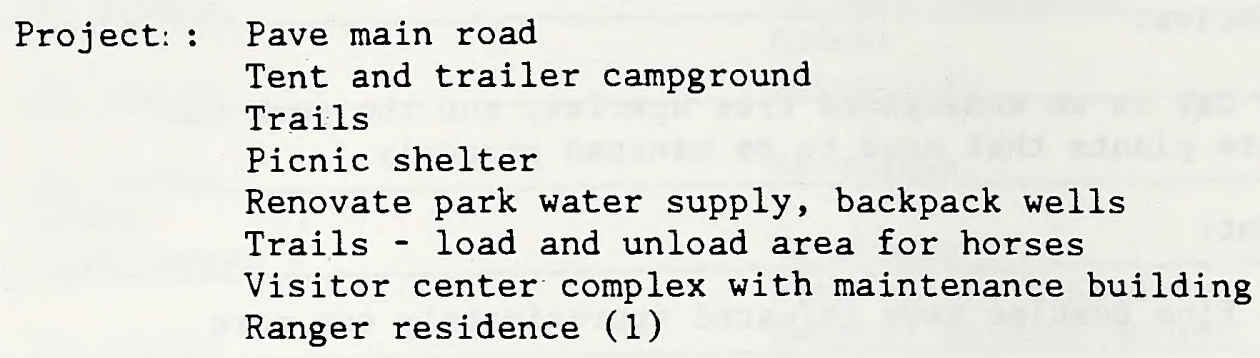

Land Acquisition:

\begin{tabular}{crl}
\hline Tract \# & Acres & Reason \\
\hline 1 & 538.706 & Primary Resource \\
2 & 806.000 & Inholding intrudes into park \\
4 & 44.000 & Primary Resource \\
5 & 1.990 & Land Development \\
6 & 31.500 & Primary Resource
\end{tabular}

Boundary Marking Status:

\begin{tabular}{cccc}
\hline $\begin{array}{c}\text { Total } \\
\text { Boundary } \\
\text { Mile }\end{array}$ & $\begin{array}{c}\text { Well } \\
\text { Marked }\end{array}$ & $\begin{array}{c}\text { Poorly } \\
\text { Marked }\end{array}$ & $\begin{array}{c}\text { Indef. } \\
\text { or } \\
\text { Unknown }\end{array}$ \\
\hline 26.5 & 14.0 & 10.0 & 2.5
\end{tabular}

Expenditures and Attendance:

\begin{tabular}{|c|c|c|c|}
\hline Year & Attendance (Calendar $\mathrm{Yr}$. ) & Current $\$$ (Fiscal & Yr.) $1977 \$ *$ (Fiscal Yr.) \\
\hline 1977 & 7,329 & $\$ 7,329$ & $\$ 7,327$ \\
\hline 1978 & 5,992 & 34,798 & 32,370 \\
\hline 1979 & 9,918 & 35,394 & 30,123 \\
\hline 1980 & 11,912 & 31,264 & 23,975 \\
\hline 1981 & 10,576 & 43,149 & 30,537 \\
\hline 1982 & 11,714 & 43,450 & 28,737 \\
\hline 1983 & 30,908 & 62,212 & 39,300 \\
\hline 1984 & 40,976 & 67,105 & 40,376 \\
\hline 1985 & 43,301 & 77,474 & 44,398 \\
\hline 1986 & 49,413 & 95,700 & 53,053 \\
\hline 1987 & 40,484 & 101,985 & 54,046 \\
\hline 1988 & & 80,023 & 40,461 \\
\hline
\end{tabular}


South Mountains State Park (Continued)

Repair and Renovations:

\begin{tabular}{crr}
\hline Fiscal Year & Current $\$$ & $\$ 1977 \$ \%$ \\
\hline 1577 & $\$ 1,821$ & $\$ 1,821$ \\
198 & 4,702 & 4,374 \\
1979 & 6,116 & 5,205 \\
1980 & 834 & 640 \\
1981 & 1,147 & 812 \\
1982 & 1,353 & 895 \\
1983 & 0 & 0 \\
1984 & 9,550 & 5,746 \\
1985 & 11,612 & 6,654 \\
1986 & 4,860 & 2,694
\end{tabular}

*1977 Budget figures are adjusted to reflect inflation and are shown in 1977 dollars. Source: Office of State Budget.

Total Park Revenue: FY 1987: \$2,516

FY 1988: $\quad \$ 1,988$ 


\section{STONE MOUNTAIN STATE PARK}

Location: Wilkes \& Allegheny Counties

Size: 13,378 acres

\section{Reason for Rstablishment:}

The mountain is on the eastern dge of the Blue Ridge. It has a dome-shaped granite mass that rises 600 feet above its base and makes the mountain very distinctive.

\section{History of the Park:}

Stone Mountain has been a state park since 1969 and is also listed in the National Registry of Natural Landmarks. The area was originally the hunting grounds of the Catawba Indians. Abandoned homesteads can be found on the outskirts of the park.

\section{Facilities:}

Family camping (35 sites, no hookups, restroom/shower)

Group camping (primitive)

Maintenance area

Park office

Picnic area (12 tables, 1 shelter)

Primitive camping

Residence ( 3 houses)

Trails ( 10 miles, hiking and 3 miles, bridle)

Staff: Current

Permanent:

Park Superintendent I Chief Park Ranger

Park Ranger I

General Utility Worker

Clerk-Typist III (.5)
Seasonal:

Park Attendant (2)

Refreshment Clerk

\section{Minimum Additional Staff Needs:}

Park Interpreter and Education Specialist

Clerk-Typist III (.5)

\section{Staffing Over Last Ten Years:}




\section{Stone Mountain State Park (Continued)}

Staffing Over Last Ten Years:

Permanent

Seasonal

1978 No Change

Park Attendant

Refreshment Stand Clerk

Naturalist

1979 Add General Utility worker

No Change

1980-1984 No Change

No Change

1985 Add Clerk-Typist

No Change

1986 No Change

Changed Naturalist to

Park Attendant

\section{Internal Threats:}

Water Quality

The State does not own the entire watershed. As a result, protecting the water quality is difficult.

Trail Erosion

The trails design and over use are the main causes for the erosion.

Old Field Management

There are 12 fields maintained by cutting the grass and once in a while several are bush cut. Three of the fields are maintained for turkey population.

Historic Site

There is one residence with an out building that could be restored and used in interpretation.

Endangered Species

Possible cougar sightings have occurred in the park and the rare Table Mountain Pine needs proper management.

ORV Use

ORV use is occurring in the newly acquired areas and has made poaching easier. There is a particular problem of road side litter. 
Internal Threats: (Continued)

Pest Management

The gypsy moth has been discovered on the park. There is also approximately 2 acres of Kudzu in the park.

Boundaries

These is very little knowledge of the lines or both eastern and south sides of the park. This is allowing hunting encroachment.

Traffic Control

Vandalism is occurring after park hours to the traffic counter. Thefts are also a problem. The lack of gates on the main roads contributes to the vandalism and theft.

Top Three Visitor Impacts Identified by Superintendent

1. Deer Hunting

2. ORV Use

3. Litter

\section{External Threats:}

Adjacent Development

At the completion of the current land acquisition program, approximately 4,400 additional acres will remain to be acquired. The high scenic quality of the park, the clean waters of the park's streams and waters, and the wilderness recreational opportunities are threatened as long as these lands remain in private ownership. The proposed Wolf Rock Quarry could severely damage many of the park's resources. The State does not own the mineral rights to a 125 acre tract underlying Wolf Rock. Mining would destroy this important natural, scenic, recreational, and geological feature and disrupt recreational use. This is a critical acquisition which must be completed.

\section{Facility Condition:}

The 68 building on the park needing many repairs and the safety hazards that include:

no smoke detectors

wooden foundations are rotten and need replaced

replacement of electrical wiring and circuit

breakers

the plumbing needs repairing

there is no telephone at the maintenance building 
Stone Mountain State Park (Continued)

there is very little handicap access to the public use buildings

The ongoing repairs include the demolition of 3 buildings replacement of shingles on several roofs, and repairs to the plumbing. The other needed repairs have been placed on hold. There is a major project in the works that includes constructing an office and Visitor Center for the park.

\section{Capital Improvements:}

Current Projects: Office/visitor center $\$ 296,000$

Hiking trail renovation $\$ 75,000$

Documented Needs: $\$ 2,683,213$

Projects: Picnic area developed, park road parking lot, sites, shelters, toilets

Water system improvements, utilities

Furniture, exhibits in visitor center

Warehouse

Bury underground electric

Renovation of Hutchinson homestead

Renovate ranger residences (4)

Landscaping-park office, visitors center, and picnic areas

Land Acquisition:

\begin{tabular}{|c|c|c|}
\hline ract 非 & Acres & Reason \\
\hline 77 & 303.8700 & Scenic Protection \\
\hline 84 & 3.8000 & Inholding bordered on 3 sides by park \\
\hline 113 & 70.1110 & Primary Resource \\
\hline 126 & 57.0900 & Inholding completely surrounded by park \\
\hline $150-151$ & 2.1480 & Scenic Protection \\
\hline 152 & 32.7500 & Primary Resource \\
\hline 153-A & 11.7000 & Scenic Protection \\
\hline 153 & 53.8850 & Primary Resource \\
\hline $152-B$ & 2.3300 & Scenic Protection \\
\hline 163 & 151.4510 & Primary Resource \\
\hline $168-\mathrm{A}$ & 60.000 & Entrance Protection \\
\hline 168. TNC & 128.000 & Inholding bordered on 3 sides by park \\
\hline $176-\mathrm{A}$ & 2.1600 & Scenic Protection \\
\hline 183 & 57.4720 & Scenic Protection \\
\hline 184 & 12.5300 & Entrance Protection \\
\hline 185 & 0.4000 & Entrance Protection \\
\hline 186. & 19.6000 & Entrance Protection \\
\hline
\end{tabular}


Stone Mountain State Park (Continued)

Land Acquisition: (Continued)

\begin{tabular}{lcl} 
Tract \# & Acres & \multicolumn{1}{c}{ Reason } \\
187 & 1.4500 & Entrance Protection \\
195 & 61.5000 & Inholding bordered on 3 sides by park \\
207 & 34.2900 & Entrance Protection \\
209 & 5.7200 & Primary Resource \\
210 & 0.6800 & Primary Resource \\
211 & 0.6800 & Primary Resource \\
212 & 1.9600 & Primary Resource \\
$624-\mathrm{A}$ & 20.100 & Primary Resource \\
$224-\mathrm{F}$ & 5.8190 & Primary Resource \\
$224-\mathrm{FG}$ & 8.7550 & Primary Resource \\
$233-\mathrm{NC}$ & 125.3800 & Inholding completely surround by park \\
116 & 45.3810 & Scenic Protection \\
118 & 23,6000 & Scenic Protection
\end{tabular}

Boundary Marking Status:

\begin{tabular}{cccc}
\hline $\begin{array}{c}\text { Total } \\
\text { Boundary }\end{array}$ & $\begin{array}{c}\text { Well } \\
\text { Marked }\end{array}$ & $\begin{array}{c}\text { Poorly } \\
\text { Marked }\end{array}$ & $\begin{array}{c}\text { Indef. } \\
\text { or } \\
\text { Unknown }\end{array}$ \\
\hline 38.0 & 15.0 & 4.0 & 19.0
\end{tabular}

\section{Expenditures and Attendance:}

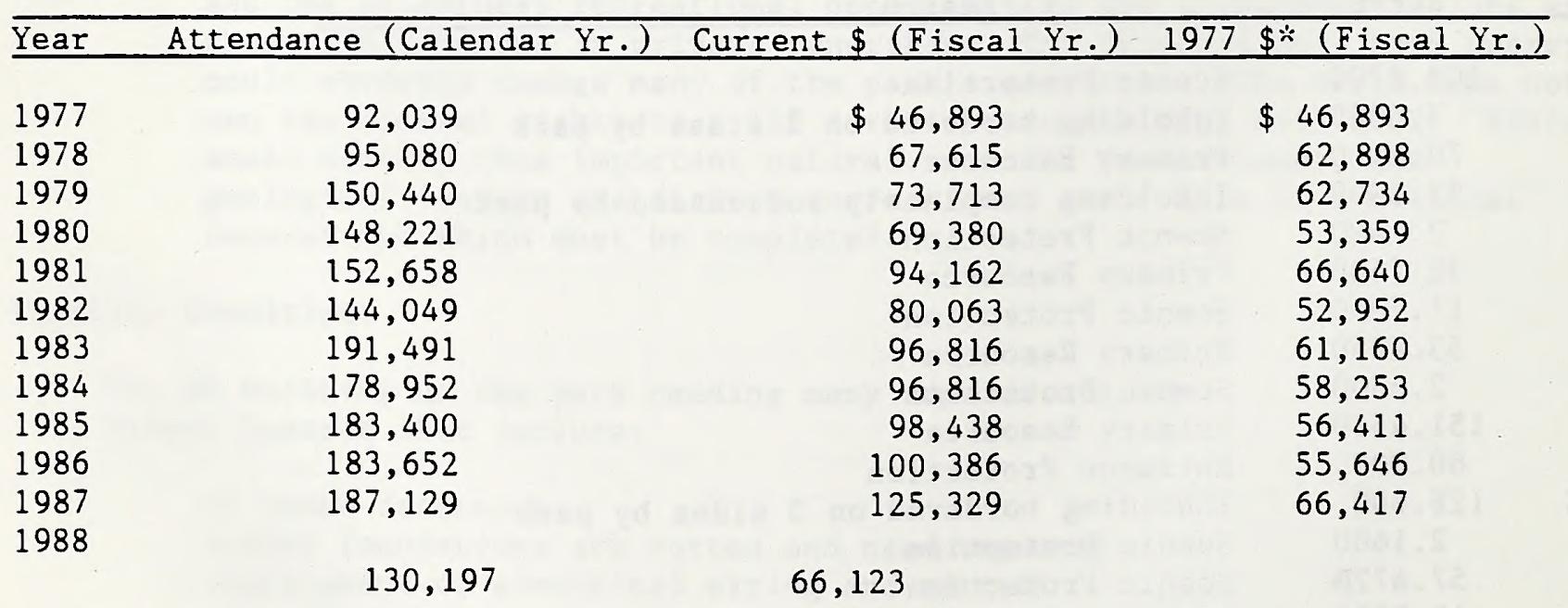


Stone Mountain State Park (Continued)

Repair/Renovation:

\begin{tabular}{crr}
\hline Fiscal Year & Current $\$$ & 1977 $\$ *$ \\
\hline 1977 & $\$ 3,125$ & $\$ 3,125$ \\
1978 & 7,769 & 7,227 \\
1979 & 7,985 & 6,796 \\
1980 & 10,197 & 7,820 \\
1981 & 15,889 & 11,245 \\
1982 & 4,271 & 2,824 \\
1983 & 0 & 0 \\
1984 & 4,458 & 2,682 \\
1985 & 6,043 & 3,463 \\
1986 & 12,887 & 7,143
\end{tabular}

*1977 Budget figures are adjusted to reflect inflation and are shown in 1977 dollars. Source: Office of State Budget.

Total Park Revenue: FY 1987: \$21,761

FY 1988: $\$ 28,547$ 
Location: Carteret County

Size: 265 Acres

\section{Reason for Establishment:}

This area is one of the few portions of Bogue Banks still left undisturbed. It contains excellent biological and scenic resources.

History of the Park:

The park was presented to North Carolina by the grandchildren of Theodore Roosevelt in 1771 .

\section{Existing Recreation Opportunities:}

Hiking Trail:

The $1 / 4$ mile trail travels through areas that were once a beach ridges.

Interpretive Study:

Guided hikes are provided by the Marine Resource Center.

Special Interest:

The State Natural Area and the Marine Resource Center provide programming all year round.

Additional Recreation Needs: No data available.

\section{Existing Staff:}

The park has no permanent staff, but it is regularly monitored by the staff at Fort Macon.

\section{Internal Threats:}

Water Quality:

There is monitoring of the water run-off from an adjacent construction project. 
Theodore Roosevelt Natural Area (cont.)

External Threats:

Adjacent Development:

A shopping center planned adjacent to the park will cause run-off problems and aesthetic problems.

\section{Facility Condition:}

There are no buildings, but the trails at the park are well maintained.

Facility Expansion: No data available.

Land Acquisition: No data available.

Boundary Marking Status: No data available.

Operating Budget and Attendance Over Last 10 Years: No staff, budget, or attendance figures.

Repair and Renovations Over Last 10 Years: Not applicable. 


\section{WAYNESBOROUGH STATE PARK}

Location: Wayne County

Size: 142 acres

\section{Reason for Establishment:}

The City of Goldsboro and Wayne County donated the park site to the State to recognize the location of Waynesborough. Local civic organizations promoted a're-creation of the abandoned city and received State support in 1979.

\section{History of the Park:}

The Waynesborough ferry existed as early as 1712 when John Barnwell crossed the Neuse River as he fought against the Tuscarora Indians. Lord Cornwallis crossed the river at the same point during the American Revolution as the British Army marched to Yorktown where he eventually conceded to the Americans.

Waynesborough was incorporated in 1787 and served as a center of activity for both stage coach and steamboat travel. Because city was half way between New Bern and Raleigh on a two-day stage coach journey, travelers would stay overnight in Waynesborough. The town was the furtherest point along the Neuse River navigated by early steamboat travel and thus served as a transportation center between the coast and inland areas.

Waynesborough was gradually abandoned and replaced by Goldsboro because the town was subject to flooding. The park was previously the site of a 50-acre landfill which has been capped.

\section{Facilities:}

Gazebo

Picnic area (20 tables, one shelter)

Pier (Neuse River)

Residence (one house)

Trail (one mile, hiking)

\section{Existing Staff:}

\section{Permanent:}

Park Ranger II
Seasonal:

None

\section{Minimum Additional Staff Needs:}

Park Superintendent I

Park Ranger

Maintenance Mechanic 
Waynesborough State Park (Continued)

Staffing Over Last Pive Years:

\section{Permanent}

Permanent

1981-85 General Utility Worker (.5)

1986 Added:

Park Ranger II

Lost :

General Utility Worker (.5)

\section{Internal Threats:}

Escaping Gases:

The landfill creates methane gas that leaks into the restroom.

Uneven Settling:

The landfill site is not stabilized enough to lay a concrete foundation. The buildings that have been constructed have large cracks in foundations and walls.

External Threats: No Data Available

\section{Facility Condition:}

The four buildings located on the park were constructed recently, but problems have mounted very quickly including: lack of fire extinguishers; large cracks in the concrete floors; plumbing not meeting safety standards; electrical wiring not meeting safety standards; restroom floor drain needing caulking periodically to keep the methane gas out of the restroom; and lack of handicap access at the park.

A major concern at the park is the restroom facility. Due to the uneven settling, the building has been declared structurally unsafe for public use.

\section{Capital Improvements:}

Current Projects:

$$
\text { Visitor Center } \$ 330,000
$$

Documented Needs: $\quad \$ 195,776$

Projects: Maintenance building/warehouse buildings 
Waynesborough State Park (Continued)

Land Acquisition: No acquisition in progress.

\section{Boundary Marking Status:}

\begin{tabular}{cccc}
\hline $\begin{array}{c}\text { Total } \\
\begin{array}{c}\text { Bourdary } \\
\text { Mile le }\end{array}\end{array}$ & $\begin{array}{l}\text { Well } \\
\text { Marked }\end{array}$ & $\begin{array}{c}\text { Poorly } \\
\text { Marked }\end{array}$ & $\begin{array}{c}\text { Indef. } \\
\text { or } \\
\text { Unknown }\end{array}$ \\
\hline 0.8 & 0 & 0 & 0.8 \\
\hline
\end{tabular}

\section{Expenditures and Attendance:}

Year Attendance (Calendar Yr.) Current \$ (Fiscal Yr.) 1977 \$* (Fiscal Yr.

1984

1985

1986

1987

1988

$$
\begin{array}{r}
00 \\
00 \\
40,373 \\
27,376
\end{array}
$$

$\$ 14,956$
11,960

$\$ 7,946$

6,074

\section{Repair/Renovation:}

\begin{tabular}{crr}
\hline Fiscal Year & Current $\$$ & $1977 \$ *$ \\
1984 & 00 & 00 \\
1985 & 00 & 00 \\
1986 & 810 & 449
\end{tabular}

Total Park Revenue: FY 1988: \$ 270

*1977 Budget figures are adjusted to reflect inflation and are shown in 1977 dollars. Source: Office of State Budget. 


\section{WEYMOUTH WOODS NATURAL AREA}

Location: Moore County

Size: 676 acres

\section{Reason for Establishment:}

The area is unique because of the longleaf pines found there.

\section{History of the Park:}

Weymouth Woods became a State natural area in 1963. As far back as the late 1600 s, maps showed the sandhills region, calling it the Pine Barrens or the Sahara of North Carolina. It once covered one million acres in south central North Carolina. Scottish Highlanders settled the region around 1740 and began the cultivation of the longleaf pines they found there. The tall straight longleaf was ideal for most timbers and the tar and resin was used for naval stores. Most of the longleaf was cut between 1875 and 1895 .

Around the turn of the century, James Boyd of Harrisburg, Pennsylvania, stopped at Southern Pines and fell in love with the "most beautiful trees" he had ever seen. He purchased the land and saved the trees. His descendants generously donated the land to the State for a park and nature preserve. The surrounding Pinehurst-Southern Pines area is called the golfing capital of the world.

\section{Facilities:}

Maintenance building

Museum/office building

Trail ( 4 miles, hiking)

\section{Existing Staff:}

\section{Permanent:}

Park Superintendent II

Park Chief Ranger

Clerk Typist III (.5)

\section{Minimum Additional Staff Needs:}

Maintenance Mechanic

Park Ranger

Clerk Typist (.5)

Staffing Over Last Ten Years:

\section{Seasonal}

Park Attendant 
Weymouth Woods Natural Area (Continued)

Permanent Seasonal

\begin{tabular}{lll}
1977 & $\begin{array}{l}\text { Park Superintendent II } \\
\text { Park Chief Ranger } \\
\text { Clerk Typist }\end{array}$ & No data available \\
\hline 1978 & No change & General Laborer \\
\hline 1979 & No change & $\begin{array}{l}\text { Lost } \\
\text { General Laborer }\end{array}$ \\
1980 & No change & No data available \\
\hline 1981 & No change & $\begin{array}{l}\text { Added: } \\
\text { Park Attendant }\end{array}$ \\
\hline $1982-86$ & No change & No change \\
\hline
\end{tabular}

\section{Internal Threats:}

Water Quality:

The adjacent development may cause the water quality to deteriorate.

Trail Erosion:

The soil compaction and the loss of the tread material is causing erosion. Horse use is eroding some trails.

Controlled Burns:

Controlled burning has been a critical part of the plant management program for the past 12 years. It is behind schedule.

Vandalism:

There have been many types of vandalism including ORVs, damaged trail signs and stray dogs.

Habitat Management:

Maintaining the wet areas is a critical part of the park ecosystem.

Overuse:

The museum exhibits are beginning to show wear and tear from their twelve years of continuous use. 
Weymouth Woods Natural Area (Continued)

\section{Internal Threats: (Continued)}

Endangered Species:

The area is home for the Red cockaded woodpecker and the Well's Pixie Moss, both needing management. There are several other threatened plant species all needing different types of management.

Pest Management:

There are problems with exotic vegetation.

Boundaries:

The unmarked boundaries are causing encroachments from local hunters. This has caused visitor conflicts and a massive movement by the deer population.

Top 3 Visitor Impacts Identified by Superintendent:
1. Hunting
2. Vandalism
3. Overuse

\section{External Threats:}

Adjacent Development:

The increase of noise pollution has occurred with the increase of adjacent development. There has also been an increase in vandalism.

\section{Facility Condition:}

The two buildings on the park are relatively new so they are in good condition. The only problem with the structures is the lack of handicap accesses.

\section{Capital Improvements:}

Current Projects: None

Documented Needs: $\$ 435,935$

$$
\begin{aligned}
& \text { Projects: Visitor center exhibit renovation } \\
& \text { Repave parking, road entrance } \\
& \text { Trails - boardwalk } 300 \mathrm{ft} . \\
& \text { Ranger residences (2) }
\end{aligned}
$$


Weymouth Woods Natural Area (Continued)

\section{Land Acquisition:}

\begin{tabular}{lrl}
\hline Tract & Acres & \multicolumn{1}{c}{ Reason } \\
\hline 54 & 8.00 & Buffer \\
55 & 19.15 & Inholding bordered on 3 sides by park \\
$55-2 \mathrm{~A}$ & 3.83 & Inholding intrudes into park \\
$55-2 \mathrm{~B}$ & 3.83 & Inholding intrudes into park \\
$55-2 \mathrm{C}$ & 3.83 & Inholding intrudes into park \\
$55-2 \mathrm{D}$ & 3.83 & Inholding intrudes into park \\
$55-2 \mathrm{E}$ & 3.83 & Inholding intrudes into park \\
$55-5 \mathrm{~A}$ & 3.00 & Buffer \\
82 & 6.80 & Entrance Protection
\end{tabular}

Boundary Marking Status:

\begin{tabular}{cccc}
\hline $\begin{array}{c}\text { Total } \\
\text { Boundary } \\
\text { Mile }\end{array}$ & $\begin{array}{c}\text { Well } \\
\text { Marked }\end{array}$ & $\begin{array}{c}\text { Poorly } \\
\text { Marked }\end{array}$ & $\begin{array}{c}\text { Indef. } \\
\text { or } \\
\text { Unknown }\end{array}$ \\
\hline 8.8 & 5.5 & 2.4 & 0.9
\end{tabular}

\section{Expenditures and Attendance:}

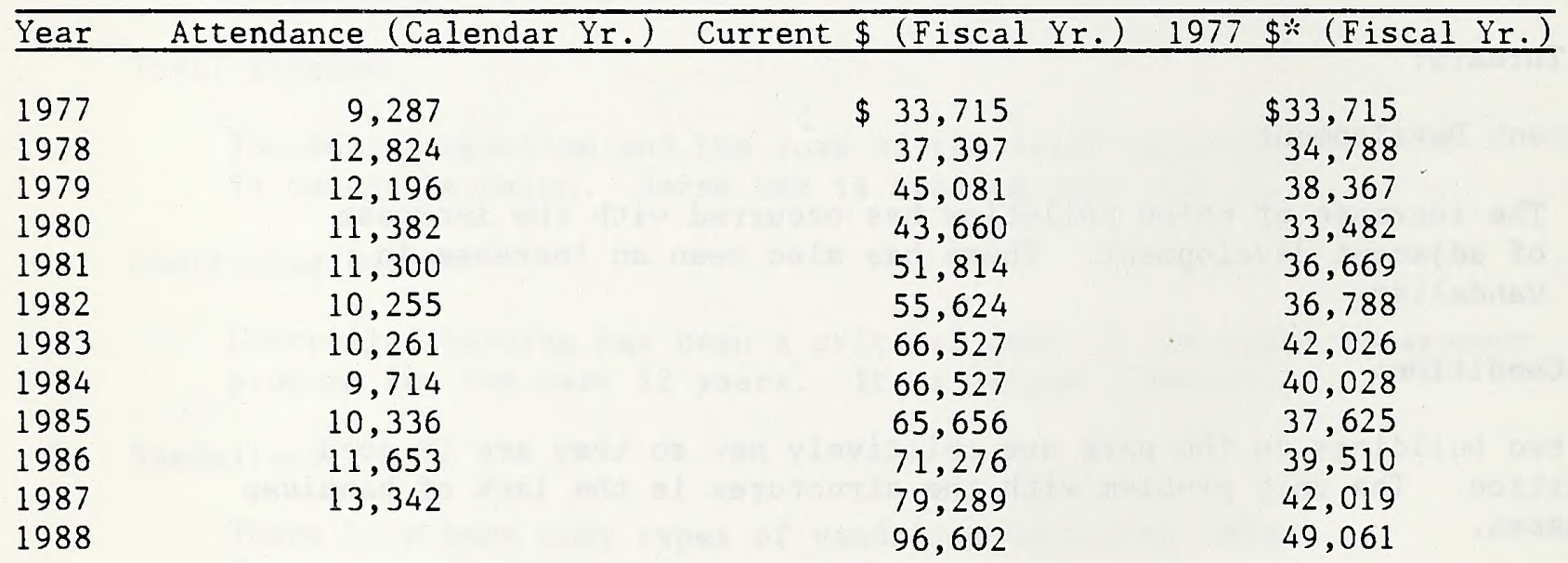

Repair and Renovations:

\begin{tabular}{crr}
\hline Fiscal Year & Current $\$$ & $1977 \$ *$ \\
1977 & $\$ 1,825$ & $\$ 1,825$ \\
1978 & 1,443 & 1,342 \\
1979 & 1,491 & 1,269 \\
1980 & 1,134 & 870 \\
1981 & 3,179 & 2,250 \\
1982 & 8,653 & 5,723 \\
1983 & 0 & 0 \\
1984 & 3,520 & 2,118 \\
1985 & 3,027 & 1,735 \\
1986 & 2,256 & 1,251
\end{tabular}


Weymouth Woods Natural Area (Continued)

*1977 budget figures are adjusted to reflect inflation and are shown in the 1977 dollars. Source: Office of State Budget.

Total Park Revenue: - 0 - 
Location: Wake County

Size: 5337 acres

\section{Reason for Establishment:}

This park was developed as a demonstration park in the 930 s by the National Park Service to prove that worn-out farm land could be productive for recreation. The Park was given to the State by the Federal government in 1943.

History of the Park:

In the 1700 s and 1800 s, the land was covered with many farms and there are ruins of mills on several of the creeks. The camp that was constructed by the Civilian Conservation Corps in the 1930s was used for foreign troops in World War II. Umstead has been a park since 1943; in 1955, it was renamed in honor of William B. Umstead, Congressman and Governor during the 1930s.

\section{Pacilities:}

Boathouse (rowboat and canoe rental in season)

Family camping ( 28 sites, no hookups, restroom/shower)

Group camping ( 4 units, cabins, restroom/shower, mess halls)

Maintenance area (2)

Park office

Picnic area ( 2 areas, 65 tables, 3 shelters)

Residences ( 6 houses)

Trails ( 15 miles, hiking and 15 miles bridle)

Warehouse

\section{Existing Staff:}

Permanent:

Park Superintendent III

Park Ranger II (2)

Park Ranger I (2)

Clerk Typist III (.5)

Maintenance Mechanic II

\section{Minimum Additional Staff Needs:}

General Utility Worker

Clerk Typist (.5)

Seasonal:

Park Attendant (6)

General Utility Worker 
William B. Umstead State Park (Continued)

Staff Over Last 10 Years:

\begin{tabular}{|c|c|c|}
\hline & Permanent & Seasonal \\
\hline 1977 & $\begin{array}{l}\text { Park Superintendent III } \\
\text { Chief Park Ranger (2) } \\
\text { Park Ranger I ( } 2) \\
\text { Clerk Typist III (5) } \\
\text { Maintenance Mechanic II }\end{array}$ & No data available \\
\hline 1978 & No change & $\begin{array}{l}\text { Park Attendant ( } 4) \\
\text { Naturalist ( } 2) \\
\text { Boathouse laborer ( } 2 \text { ) }\end{array}$ \\
\hline $1979-1980$ & No change & No change \\
\hline 1981 & No change & $\begin{array}{l}\text { Dropped: } \\
2 \text { Park Attendants }\end{array}$ \\
\hline 1982 & No change & No change \\
\hline 1983 & No change & $\begin{array}{l}\text { Dropped: } \\
1 \text { Naturalist } \\
1 \text { Boathouse Laborer }\end{array}$ \\
\hline 1984 & No change & $\begin{array}{l}\text { Dropped: } \\
\text { Other Boathouse Laborer }\end{array}$ \\
\hline $1985-1986$ & No change & $\begin{array}{l}\text { Naturalist changed to } \\
\text { General Utility Worker }\end{array}$ \\
\hline
\end{tabular}

Internal Threats:

Air Quality:

The low-flying air traffic is causing air quality problems and noise pollution.

Water Quality:

The extensive development around the park is generating large amounts of run-off into watershed.

Trail Erosion:

The major erosion problems are caused by horses on undeveloped trails. Additional causes include trail bicycles, all terrain motorized vehicles, and large numbers of hikers.

Campground Degradation:

There are many problems in both the family and group campgrounds including soil compaction, litter, destruction of vegetation and facility damage. 
William B. Umstead State Park (Continued)

Internal Threats: (Continued)

Habitat Management:

The beaver habitat is at risk due to the future development plans for the park.

Sewage and Water System Usage:

The overuse of both the water and sewage systems is beginning to cause problems. Both systems need to be replaced.

Top 3 Visitor Impacts Identified by Superintendent:

1. Trail erosion

2. Campground degradation

3. Sewage and water system usage

Boundaries:

The unmarked boundaries contribute to encroachments from hunters and local residents.

Visitor Impacts:

The day use area is overcrowded and understaffed, and the facilities have become worn out.

External Threats:

Adjacent Development:

There are several adjacent problems including high use hotels, commercial and residental development, and an airport. All this development is affecting the aesthetics of the park with noise and unsightly buildings.

\section{Facility Condition:}

In the Crabtree Section, 133 buildings are located within the section and all need repair. Maintenance and safety problems that need attention include:

Smoke detectors in all cabins

New roofing needed on most of the buildings

Step treads need replacing

New handrails along stairs

The wooden porches are rotten and need to be replaced

New incandescent exit signs should be placed in the public use buildings

Replace the restroom ceramic tile floor

Stock fire extinguishers in some of the buildings 
William B. Umstead State Park (Continued)

\section{Facility Condition: (Continued)}

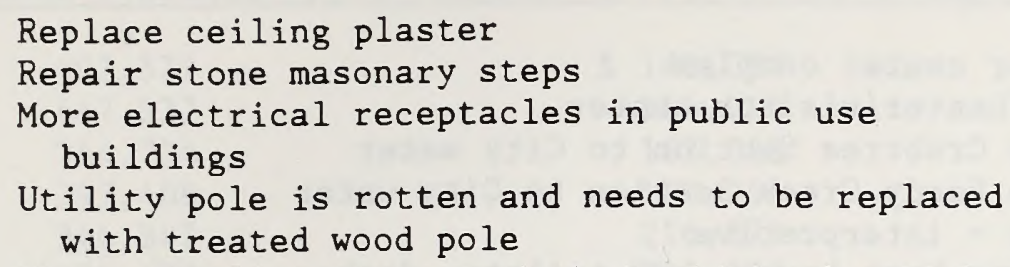

The naturalist storage shed should be demolished.

Handicapped accesses are needed for the public use buildings.

The Reedy Creek Section contains 33 buildings and many have some safety hazard problems including:

Lacking smoke detectors

Lacking fire extinguishers

Weak roofs that need to be replaced

New handrails for the steps and around the porches are needing to be replaced

The steps need new treads

The Crabtree repairs include:

Installing smoke detectors

Repairing porches and railings

Replacing old plumbing

There have been some reroofing projects that have been completed. The major project that is ongoing is to drain the lake and clean the plant growth from the bottom.

The Reedy Creek Section needs some of the same repairs including:

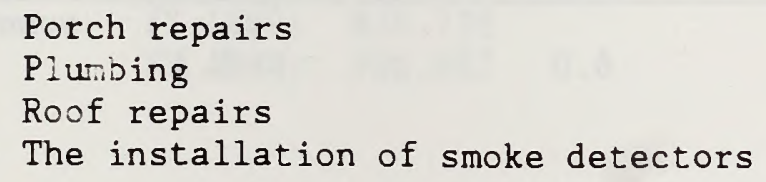

\section{Capital Improvements:}

Current Projects:

Clean Lakes Grant $\$ 616,000$

Hiking trail renovations 
William B. Umstead State Park (Continued)

Capital Improvements: (Continued)

Documented Needs: $\$ 7,618,645$

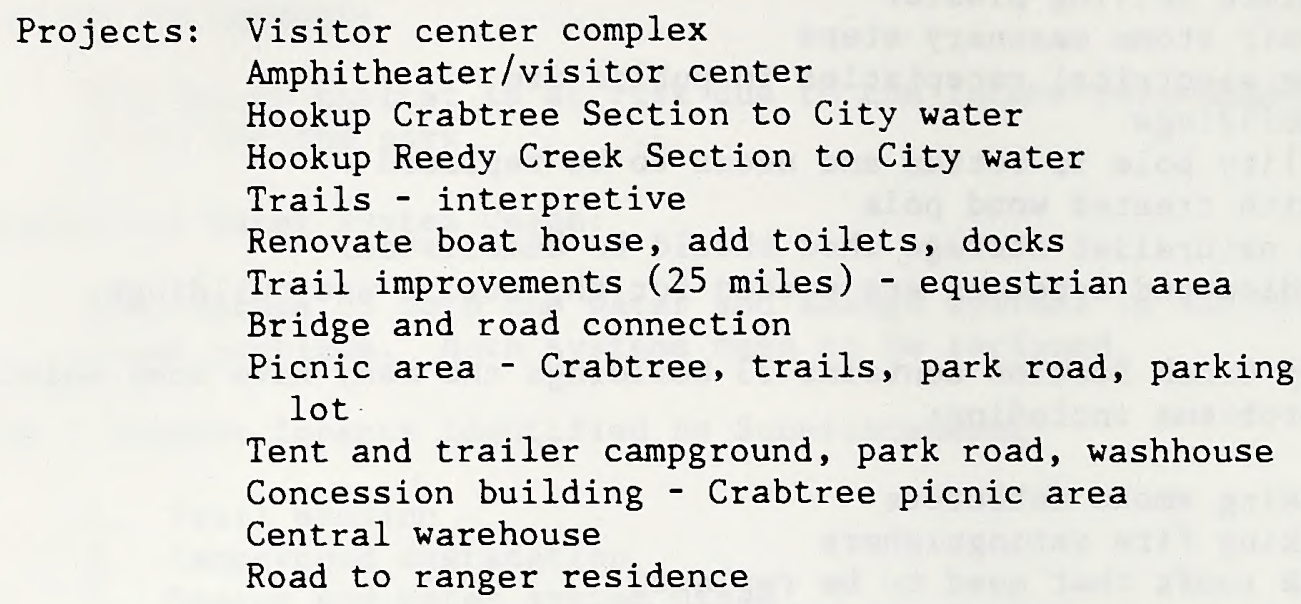

\section{Land Acquisition:}

\begin{tabular}{ccc}
\hline Tract \# & Acres & Reason \\
\hline 54 & 33.200 & $\begin{array}{r}\text { Inholding bordered on } 3 \\
\text { sides by park }\end{array}$ \\
$56 \mathrm{p}$ & 11.107 & $\begin{array}{c}\text { Inholding intrudes into park } \\
\text { intel }\end{array}$
\end{tabular}

Boundary Marking Status:

\begin{tabular}{cccc}
$\begin{array}{c}\text { Total } \\
\text { Boundary } \\
\text { Mile }\end{array}$ & $\begin{array}{c}\text { We11 } \\
\text { Marked }\end{array}$ & $\begin{array}{c}\text { Poorly } \\
\text { Marked }\end{array}$ & $\begin{array}{c}\text { Indef. } \\
\text { or } \\
\text { Unknown }\end{array}$ \\
\hline 20.3 & 11.0 & 6.0 & 3.3
\end{tabular}


William B. Umstead State Park (Continued)

\begin{tabular}{lcrc}
\hline Year & Attendance (Calendar Yr.) & Current $\$$ (Fiscal Yr.) & $1977 \$ *$ (Fiscal Yr.) \\
\hline & & & \\
1977 & 407,577 & 143,033 & $\$ 143,033$ \\
1978 & 447,337 & 116,112 & 154,523 \\
1979 & 344,734 & 167,062 & 148,989 \\
1980 & 397,406 & 190,954 & 146,437 \\
1981 & 346,347 & 216,873 & 153,484 \\
1982 & 376,478 & 212,229 & 140,363 \\
1983 & 381,296 & 216,460 & 136,740 \\
1984 & 443,620 & 212,939 & 128,122 \\
1985 & 574,495 & 248,243 & 142,260 \\
1986 & 499,378 & 266,464 & 147,707 \\
1987 & 369,382 & 304,701 & 161,473 \\
1988 & & 340,104 & 172,729
\end{tabular}

Repair and Renovations:

\begin{tabular}{|c|c|c|}
\hline Fiscal Year & Current $\$(F Y)$ & $1977 \$ *(\mathrm{FY})$ \\
\hline 1977 & $\$ 15,912$ & $\$ 15,912$ \\
\hline 1978 & 22,046 & 20,507 \\
\hline 1979 & 14,292 & 12,163 \\
\hline 1980 & 10,744 & 8,239 \\
\hline 1981 & 15,516 & 10,980 \\
\hline 1982 & 12,025 & 7,953 \\
\hline 1983 & 0 & 0 \\
\hline 1984 & 30,438 & 18,314 \\
\hline 1985 & 44,793 & 25,669 \\
\hline 1986 & 30,379 & 16,839 \\
\hline
\end{tabular}

*1977 Budget figures are adjusted to reflect inflation and are shown in 1977 dollars. Source: Office of State Budget.

Total Park Revenue: FY 1987: \$26,735

FY 1988: $\$ 26,807$ 

APPENDIX IV-1

RESOURCE EVALUATION COMMITTEE MEMBERS 


\section{COMMITTER MEMBERSHIPS}

\section{ARCHAEOLOGY COMMTTEE}

Dr. Martin Botkin

Parks and Recreation Planning

Officer

Division of Parks and Recreation NRCD

Ms. Loyld Childers

Grants Administrator

Administrative Brand

State Historic Preservation Office

Division of Archives and History

Department of Cultural Resources

Ms. Terry Harper

Staff Archaeologists

Historic Sites Section

Division of Archives and History

Department of Cultural Resources

Ms. Carol Tingley

Natural Resource Specialist

Division of Parks and Recreation NRCD

Mr. Jack Wilson

Staff Archaeologist

Historic Sites Section

Division of Archives and History

Department of Cultural Resources
Mr. Mark Mathis

Staff Archaeologists

Office of State Archaeology

Division of Archives and History

Department of Cultural

Resources

Mr. Larry Misenheimer

Assistant Director

Division of Archieves and History

Department of Cultural

Resources

Mr. Michael Southern

Chief

Survey Planning Branch

State Historic

Preservation Office

Division of Archives and History

Department of Cultural Resources 


\section{BIOLOGY COMMITTEE}

Mr. Frederick Annind

Associate Director

North Carolina Nature Conservancy

Dr. Michael Baranski

Professor

Catawba College

Mr. Carl Betsill

Small Game and Migratory Bird Program Coordinator

Wildife Resources Commission

NRCD

Dr. Mike Corcoran

Executive Director

North Carolina Wildlife Federation

Mr. Jack Donnelly

Nongame Program Coordinator

Wildlife Resources Commission

NRCD

Dr. Albert Radford

Professor Emeritus

University of North Carolina

at Chapel Hill
Mr. Robert Sutter

Coordinator and Endangered Species Botanist

NC Plant Conservation

Program

Mr. John Taggart

Estuarine Reserve

Coordinator

Division of Coastal

Management

NRCD

Ms. Carol Tingley

Natural Resources Specialist

Division of Parks and Rec. NRCD

Mr. Alan Weakley

Biologist

Division of Parks and Rec. NRCD

Dr. Peter Weigl

Professor

Wake Forest University 


\section{GEOLOGY COMMITEE}

Mr. Steve Benton

Coordinator

Division of Coastal Management NRCD

Mr. Fred Beyer

Science Supervisor

Cumberland County School System

Dr. Robert Butler

Professor

Department of Geology

University of North Carolina

at Chapel Hill

Mr. Albert Carpenter

Senior Geologist

North Carolina Geological Survey
Dr. Duncan Heron

Professor

Department of Geology

Duke University

Mr. Michael Schafale

Community Ecologist

Division of Parks and Recreation NRCD

Dr. Steven Yurkovich

Professor

Department of Earth Sciences

Western Carolina University 


\section{RECREATION COMMITTEE}

Mr. Bayard Alcorn

Parks and Recreation Planner

Division of Parks and Recreation NRCD

Mr. Tom Hartman

Superintendent

Cape Hatteras National Seashore

National Park Service

Mr. Ray Kisiah, Jr.

Regional Consultant

Division of Parks and Recreation NRCD

Mr. Joe Mickey

District Fisheries Biologist

Wildlife Resources Commission

NRCD

Dr. Doug Sessoms

Chair

Recreation Curriculum

University of North Carolina
Mr. Ron Tietgen

Director

Garner Parks and Recreation Dept.

Mr. Larry Warlick

District Wildlife Biologist

Wildlife Resources Commission NRCD

Dr. Roger Warren

Professor

Department of Recreation

Resources Administration NCSU

Mr. Tom Wells

Director

Recreation Resource Services NCSU

Ms. Kathy White

Regional Consultant

Division of Parks and Recreation NRCD 


\section{SCENIC COMITTEE}

Dr. Martin Botkin

Parks and Recreation Planning officer

Division of Parks and Recreation NRCD

Mr. and Mrs. Robert Conner

Representative,

Friends of State Parks

Dr. Hugh Devine

Professor

Department of Recreation

Resources Administration

NCSU

Mr. Jack Frauson

Parks and Recreation Consultant

Division of Parks and Recreation NRCD

Mr. Tom Harper

Director of Inquiry

North Carolina Department of

Trave1 and Tourism
Mr. Allen deHart

Director

Public Affairs

Louisburg College

Mr. Bill Noonan

Representative, Friends of State Parks

Dr. Denis Wood Associate Professor School of Design NCSU 
APPENDIX IV-2

DEFINITION OF NATURAL HERITAGE THEMES 


\section{DEFINITION OF THERS}

\section{ARCHAEOLOGIC RRSOURCES}

The resource themes used in this study are general statements of the various kinds of past human activity that are represented by sites or features within the State Parks System. These sites and features can be organized into three thematic categories--prehistoric archaeological resources, historic archaeological resources, and standing structures and other .boveground features.

\section{Prehistoric Archaeological Themes}

For purposes of this planning document, the term prehistory refers to the period of time beginning with the initial entry of the Native Americans into what is now North Carolina (sometime prior to ca. 10,000 years ago) until ca. 1670 A.D., by which time European settlement of the North Carolina coast was well underway. A prehistoric archaeological site is therefore defined as any location of prehistoric human activity. As such, a site may be identified by one or more artifacts or features made, modified, or used by prehistoric people. These sites can be divided into a series of generalized site types that reflect differing forms of human activity which can be identified by specific artifact patterns and features. These site types or themes (for consistency with the State Parks planning process) are defined as follows:

\section{VILLAGE}

Sites that possess the remains of domestic, ceremonial, subsistence and economic activities, and shelters indicative of year round habitation.

\section{CAMPSITE/ACTIVITY AREA}

Sites that consist of the remains of domestic, subsistence and economic activities, and shelters indicative of short-term habitation, or of behavior associated with specific domestic, subsistence, or economic activities. Examples include, but are not limited to, temporary habitation sites, hunting sites, butchery sites, and wild plant gathering sites such as those associated with harvesting nut resources.

\section{SHRILL MUDDEN}

Sites that consist of the remains of shellfish gathering mixed with the remains of other domestic, subsistence and economic activities, with the mussel shell being the primary component of the remains.

\section{BURIAL/CEMIETERY}

Sites that consist of one or more human burials, and the material remains placed with the individual interments. Usually, but not always, prehistoric burials/cemeteries exist as part of some other archaeological site, especially villages and campsites. 


\section{QUARRY/SOAPSTONE}

A specialized economic site that shows evidence of activity directed toward the extraction of soapstone from the ground for trade or for later fashioning into artifacts such as bowls and ornaments. This site could show evidence of the the actual sources of the soapstone mined, and/or the artifacts used to extract the soapstone. The habitation area used by the soapstone miners would be classified as a Campsite/Activity Area, or possibly a Village.

\section{QUARRY/OTHER}

A specialized economic site that shows evidence of activity directed toward the extraction of some stone (excluding soapstone), such as quartz, rhyolite, or slate, from the ground for trade or for later fashioning into artifacts such as projectile points, scrapers, and blades. This site could consist of the actual source of the stone mined, the artifacts used to extract the stone, and examples of the stone actually mined. The habitation area used by the stone miners would be classified as a Campsite/Activity Area or possibly a Village.

\section{SHELTER/CAVE}

A site that consists of a natural rock shelter, rock overhang or cave showing evidence of having been used as a temporary or permanent habitation area. The remains of domestic, economic and subsistence activities would be present.

\section{ROCK ART}

A site that consists of drawings, sketches, or engravings executed by prehistoric peoples on stone (such as rock outcrops and the walls of rock shelters and caves).

\section{TRAIL/PATH}

A site used by prehistoric peoples as a route of land travel. A good example is the Occaneechi Trail that can be tentatively identified with certain existing roads in the Eno River State Park. The Occaneechi Trail connected the prehistoric and historic Indian groups of the North Carolina Piedmiont with the Indians of the Chesapeake, the North Carolina Coast, and the South Carolina Piedmont. It was also a trail used by European traders during early historic times, approximately A.D. 1670 to 1750, to conduct trade with the Indians of the interior of the Southeastern United States.

\section{UNDERWATER}

A preserved underwater site that shows evidence of any prehistoric human behavior associated with habitation, subsistence and/or economic activities. Examples include, but are not limited to, the submerged prehistoric canoes and other artifacts including pottery recovered from Lake Phelps.

\section{OTHIER}

Any site that shows evidence of human activity that can not be associated with any of the the other prehistoric themes. 


\section{Historic Archaeological and Standing Structure Themes}

For purposes of this planning document the term "historic" refers to the period of time beginning with the European settlement of what is now North Carolina (about the mid-seventeenth century). A historic archaeological site is defined as any location of past human activity associated with historic Indians, Afro-Americans, and Euro-Americans and are generally identified by the material remains (artifacts and features) associated with them. These sites can be divided into a series of generali ed site types that reflect differing forms of human activity that can be ideltified by specific artifact patterns and features. The theme definitions used for Standing Structures (which are the result of a specific type of human activity) are the same as those used for historic archaeological resources. The themes in this case reflect different building types. These site types and building types or themes (for consistency with the State Parks planning process) are defined below:

\section{RECREATION}

Structures and/or sites related to the early development of the State parks System or to earlier private or local parks that preceded the state system, including but not limited to camp structures, sleeping cabins, picnic shelters, lodge halls, bathhouses, and related facilities. Also included would be early Euro-american and Afro-american structures or sites used for leisure or amusement activities such as race tracks, baseball fields, mineral springs, fishing cabins, and any landscaping associated with these features.

\section{PUBLIC WORKS}

Facilities or the archaeological remains of facilities constructed by local, state, and federal governments as part of public works projects, particularly the CCC, including but not limited to dams and other engineering facilities and including support facilities such as barracks, mess halls, bath houses, etc. not subsequently used for public recreation, and any associated landscape features.

\section{PUBLIC/CIVIC/RFLIGIOUS}

Standing structures and/or sites built for community purposes, including but not limited to churches, lodge/fraternal halls, schools, post offices, and other government facilities, and any associated landscape features.

\section{COMERCIAL}

Structures and/or sites related to the exchange of goods including but not limited to store buildings, wharfs, and any associated landscape features.

\section{URBAN/DOMESTIC}

Dwelling houses and/or the archaeological remains of dwelling houses in a town or village setting, including all support structures such as sheds, garages, garden or animal facilities and any associated landscape features such as fences, plantings, walls, arbors, etc. 


\section{RURAL/DOMESTIC}

Dwelling structures and sites associated primarily with the agricultural economy, including farm and plantation houses and all their support facilities, including but not limited to barns, granaries, privies, smokehouses, cribs, sheds, spring houses, and similar structures. Also included would be irrigation canals and ditches, trappers cabins and their support structures and any associated landscape features such as fences, plantings, walls, etc.

\section{CEMETERY}

Burial sites with associated above-ground features, including stones and markers, fences and walls, and associated landscaping.

\section{INDUSTRTAL}

Structures or sites associated with the extraction of resources or the manufacture of materials or goods, including but not limited to mines, furnaces, distilleries, and factories. (Excepting mill sites - see below)

\section{MILLS}

Structures and/or sites associated with the the grinding of corn and grains or the cutting of lumber including but not limited to mill buildings, dams, sluices, storage buildings, related support structures and any associated landscape features.

\section{TRANSPORTATION}

Roadbeds, bridges, landing docks, canals, lighthouses, and similar features or sites related to transportation.

\section{MILITARY}

Forts and fortifications, earthworks, battlefields, barracks, magazines, commissaries, and other features and sites related to defense of territory.

\section{UNDERWATER}

Lost or abandoned vessels or structural part of these vessels and structures built in the water such as docks, wharfs, dams, bridges, mill sites, lighthouses, and fish traps. Also included are inundated land sites and cultural material that is intentionally or accidentally deposited in the water particularly in areas such as river crossings, landing sites and city or town water fronts.

\section{OTHER}

Any structure or site that shows evidence of human activity that cannot be associated with any of the other historic themes. 


\section{BIOLOGIC RESOURCES}

\section{SPRUCE-FIR FORESTS}

Boreal forest types, dominated by Fraser fir (Abies fraseri) and red spruce (Picea rubens), are found at high elevations in the Blue Ridge province. They are a distinctive and important part of the montane landscape of the Southern Appalachians, and are habitat for large numbers of both Southern Appalachian endemic and northern disjunct species of plants and animals.

Natural Communities: Fraser Fir Forest

Red Spruce--Fraser Fir Forest

Red Spruce Forest

\section{GRASS AND HEATH BALDS}

These two kinds of balds are grouped together, although they are not closely related. They occur at high elevations in the mountains, primarily associated with Spruce-Fir Forests and Montane Mixed Hardwood Forests. Included are all high elevation terrestrial communities dominated by grasses, forbs, or shrubs.

Natural Communities: Grassy Bald

Heath Bald

\section{MONTANE MIXED HARDWOOD FORESTS}

These forests are primarily dominated by a diverse mixture of hardwood trees, such as yellow birch (Betula alleghaniensis), beech (Fagus grandifolia), buckeye (Aesculus flava), sugar maple (Acer saccharum), red oak (Quercus rubra), American ash (Fraxinus americana), basswood (Tilia heterophylla), and others. The shrub layer is often sparse, but can be composed of dense thickets of great rosebay (Rhododendron maximum). Typically the herb layer is dense and very diverse, but is locally sparse, particularly under rosebay. This category also includes forests with Canada hemlock (Tsuga canadensis) as a major component, or even dominant, since these forests are generally closely associated with mixed hardwood forests.

Natural Communities: Wind Forest

Northern Hardwoods Forest

Cove Forest

Canada Hemlock Forest

\section{PIEDMONT AND COASTAL PLAIN MIXED HARDWOOD FORESTS}

This theme includes a variety of hardwood-dominated communities, found primarily on moist slopes in the Piedmont and Coastal Plain. Although oaks and hickories are often present, they are minor components of the forest; such trees as tulip tree (Liriodendron tulipifera), beech (Fagus grandifolia), red maple (Acer rubrum), southern sugar maple (Acer floridanum), red oak (Quercus rubra), and ash (Fraxinus spp.) are common canopy trees. Typical subcanopy trees are ironwood (Carpinus caroliniana) and hop-hornbeam (Ostrya virginiana). Shrub and herb layers are often fairly diverse. Forests of drier sites, dominated by oaks and hickories, are excluded. 
Natural Communities: Mesic Mixed Hardwoods Forest

Basic Mesic Forest

\section{OAK-HICKORY FORESTS}

This theme once covered a greater portion of the state than any other, and included most of the uplands of the Piedmont, as well as substantial areas of the Mountains and Coastal Plain. These forests are dominated by a mixture of oaks (Quercus spp.) and hickories (Carya spp.), with lesser amounts of pin: $s$ (Pinus spp.) and mixed hardwoods. Dogwond (Cornus florida), sourwood (Oxydendrum arboreum), and red maple (Acer rubrum) are common subcanopy trees. Shrub layers are generally sparse, but blueberries (Vaccinium spp.) can be locally abundant on strongly acidic soils, viburnums (Viburnum spp.) on less acidic soils. Herb layers are generally fairly sparse.

Natural Communities: High Elevation Red Oak Forest

Montane White Oak Forest

Chestnut Oak Forest

Chestnut Oak--Scarlet Oak Forest

Dry Oak--Hickory Forest

Dry-Mesic Oak--Hickory Forest

Basic Oak--Hickory Forest

Montmorillonite Forest

\section{ROCK OUTCROPS}

This theme is a very heterogeneous grouping, consisting of all pioneer communities growing on bare rock or on shallow soil over a rocky substrate. It includes such different features as high elevation cliffs and granitic domes, Piedmont granitic flatrocks, and Coastal Plain marl outcrops. Generally, this theme occurs as minor inclusions within other themes. As a pioneer system, it is characterized by a flora consisting primarily of herbs, lichens, and mosses adapted to the unusual and stressful environment that shallow soils of rock outcrops provide (extremes of dryness and moisture, heat and cold). Because of the peculiar conditions prevailing, these sunny, shallow-soil communities have many endemic and disjunct plant species.

Natural Communities: High Elevation Rocky Summit

High Elevation Granitic Dome

Low Elevation Rocky Summit

Low Elevation Granitic Dome

Acidic Cliff

Basic Cliff

Coastal Plain Marl Outcrop

Granitic Flatrock

Mafic Bedrock Glade

Ultramafic Outcrop Barren

Diabase Glade 


\section{DRY CONIPEROUS FORESTS}

This theme includes a heterogeneous grouping of coniferous forests which grow in dry settings, in rocky or sandy soils, often in positions in the landscape prone to droughtiness and fire. In the mountains this theme occurs primarily on dry ridge crests, and is usually dominated by pitch pine (Pinus rigida), table mountain pine (Pinus pungens), shortleaf pine (Pinus echinata), scrub pine (Pinus virginiana), or, less commonly and in areas less subject to fire, Carolina hemlock (Tsuga caroliniana). On deep sands in the Sandhills Region of the state and in settings such as Carolina Bay rims and relict dune ridges in other parts of the coastal plain occur dry, fire-adapted forests. A sparse canopy of longleaf pine (Pinus palustris) overtops an often dense subcanopy of turkey oak (Quercus laevis), blackjack oak (Quercus marilandica), bastard post oak (Quercus margaretta), and bluejack oak (Quercus incana). Herbs and shrubs are generally very sparse, and are of species specialized for the very droughty, sandy soils. In somewhat moister situations in the Coastal Plain, longleaf pine (Pinus palustris) and loblolly pine (Pinus taeda) dominate forests with frequent to occasional fire. A combination of edaphic conditions and fire disturbance prevents succession to hardwood forests.

Natural Communities: Pine--Oak / Heath

$$
\begin{aligned}
& \text { Carolina Hemlock Bluff } \\
& \text { White Pine Forest } \\
& \text { Pine Flatwoods } \\
& \text { Pine/Scrub Oak Sandhill } \\
& \text { Xeric Sandhill Scrub }
\end{aligned}
$$

\section{MARITTIE GRASSLANDS}

This theme includes the unforested, non-tidal parts of the barrier islands. These areas are too dynamic, too recently formed, or receive too much salt spray to support woody vegetation. They are dominated by such species as sea oats (Uniola paniculata), cordgrass (Spartina patens), sand grass (Triplasis americana), hog spurge (Croton punctatus), beach grass (Ammophila breviligulata), beach pea (Strophostyles helvola), pennywort (Hydrocotyle bonariensis), and many others. Wet swales, so long as they are dominated by herbaceous vegetation and are not connected to the estuary (except during extraordinary storm events), are included. This theme excludes beaches, $a$ marine and predominantly faunal community, and salt and brackish marshes, which are tidal wetlands.

Natural Communities: Dune Grass

Maritime Dry Grassland

Maritime Wet Grassland

\section{MARITIME FORESTS}

Maritime forests are characterized by a highly distinctive suite of shrubs and trees, including live oak (Quercus virginiana), laurel oak (Quercus laurifolia), wax myrtle (Myrica cerifera), wild olive (Osmanthus americana), yaupon (Ilex vomitoria), Hercules' club (Zanthoxylum clava-herculis), red cedar (Juniperus spp.), loblolly pine (Pinus taeda), and others. This category 
includes well-developed forests, as well as scrubby woody growth, on the barrier islands. It also includes a few areas on the mainland shore of the sounds which share characteristic species, such as live oak (Quercus virginiana) and yaupon (Ilex vomitoria), with barrier island maritime forests. Locally it also includes atypical forests on the barrier islands, such as those including beech, American holly, sweet gum, and cypress on the northern barrier islands, or those with cabbage palm (Sabal palmetto), at Cape Fear.

Natural Communities: Maritime Shrub

Maritime Forest

Marit.ime Mesophytic Forest

Maritime Swamp Forest

\section{BLACKWATER RIVERS AND SWAMP PORESTS}

This theme is restricted to the Coastal Plain; it includes blackwater rivers and streams themselves, as well as the forests on the adjoining floodplains of those watercourses. Blackwater rivers have their headwaters in the Coastal Plain, carry very little particulate sediment but large amounts of dissolved tannic, humic, and fulvic acids (derived from decaying organic matter), which give them their characteristic tea-colored waters. Vegetation ranges from submersed aquatic herbs in deeper waters, through shrubs and herbs occurring on temporary bars of the river, to wetland forests with various hydroperiods. Typical trees include swamp black gum (Nyssa biflora), pond cypress (Taxodium ascendens), bald cypress (Taxodium distichum), water ash (Fraxinus caroliniana), sweet bay (Persea borbonia), green ash (Fraxinus pennsylvanica), water hickory (Carya aquatica), red maple (Acer rubrum), overcup oak (Quercus lyrata), American elm (Ulmus americana), ironwood (Carpinus caroliniana), and others. Shrub and herb layers are generally sparse.

Natural Communities:Sand and Mud Bar

Coastal Plain Levee Forest, Blackwater

Cypress--Gum Swamp, Blackwater

Coastal Plain Bottomland Hardwoods,

Blackwater

Oxbow Lake

Coastal Plain Small Stream Swamp,

Blackwater

\section{BROWNWATER RIVERS AND SWAMP FORESTS}

This theme is also limited to the Coastal Plain, but occurs along brownwater rivers -- rivers with headwaters in the Piedmont or Mountains, which carry a heavy sediment load. Excluded from this theme are the parts of these rivers in the Piedmont and Mountains (see next theme). Typical tree species of the alluvial floodplains include bald cypress (Taxodium distichum), swamp tupelo (Nyssa aquatica), sweet gum (Liquidambar styraciflua), green ash (Fraxinus pennsylvanica), basket oak (Quercus michauxii), willow oak (Quercus phellos), laurel oak (Quercus laurifolia), overcup oak (Quercus lyrata), cherrybark oak (Quercus pagoda), and many others. Shrub and herb layers (except on the stream banks and bars) are sparse. 
Natural Communities: Sand and Mud Bar

Coastal Plain Levee Forest, Brownwater

Cypress--Gum Swamp, Brownwater

Coastal Plain Bottomland Hardwoods,

Brownwater

Coastal Plain Small Stream Swamp,

Brownwater

\section{PIEDMONT/MOUNTATN RIVERS AND ALLUVIAL FORESTS}

This theme is related to the Brownwater Rivers and Swamp Forests Theme, but differs in being located in the Piedmont and Mountains and having narrower and less frequently inundated floodplains. Cypress and tupelo are absent. Typical species include river birch (Betula nigra), box elder (Acer negundo), hackberry (Celtis laevigata), southern sugar maple (Acer floridanum), sycamore (Platanus occidentalis), red maple (Acer rubrum), bitternut hickory (Carya cordiformis), black walnut (Juglans nigra), green ash (Fraxinus pennsylvanica), and American elm (Ulmus americana). The most common subcanopy tree is ironwood (Carpinus caroliniana). Alder (Alnus serrulata) is often abundant in thickets along the banks.

Natural Communities: Rocky Bar and Shore

Piedmont/Mountain Levee Forest

Piedmont/Mountain Swamp Forest

Piedmont/Mountain Bottomland Forest

Piedmont/Mountain Alluvial Forest

\section{NONRTVERINE SWAMP FORESTS}

This theme consists of wetland forests occurring in wet flats not associated with a river. Many of the tree species are also found in riverine wetlands, but the nonalluvial nature of these forests allows greater development of shrub and herb layers. Dominant trees are primarily a diversity of wetland oaks (Quercus spp.) and hickories (Carya spp.). In the coastal plain, nonriverine swamp forests contain a wide mixture of wetland trees and shrubs.

Natural Communities: Wet Mar1 Forest

Nonriverine Wet Hardwood Forest

Nonriverine Swamp Forest

Upland Depression Swamp Forest

BOGS, FENS, AND SEEPS

This theme consists of small areas of shrub- and herb-dominated wetland vegetation in the Mountains and Piedmont. Such areas can occur in a wide variety of settings, including stream floodplains, seepage slopes, and so forth. Frequently encountered shrubs are alder (Alnus serrulata), hardhack (Spiraea tomentosa), silky willow (Salix sericea), and a variety of heaths. Sedges (Carex spp. and Scirpus spp.) are often diverse and dominant. Peat mosses (Sphagnum spp.) generally form mats which help maintain the high water table. This wetland theme occurs in small areas of the landscape, generally surrounded by other, upland themes. 
Natural Communities: Swamp Forest-Bog Complex

Marsh-Bog Complex

Southern Appalachian Bog

Southern Appalachian Fen

High Elevation Seep

Spray Cliff

Piedmont Hardpan Bog

Hillside Seepage Bog

\section{SAVANNAS}

The Savanna theme covers wetlands in the Coastal Plain and Tidewater, with very frequent fire, characterized by an open canopy of longleaf pine (Pinus palustris) or pond cypress (Taxodium ascendens) over a diverse herbaceous layer composed primarily of grasses, sedges, composites, lilies, and orchids. This theme occurs just "upslope" from pocosins, and in small Carolina bays.

Natural Communities: Pine Savanna

Cypress Savanna

\section{POCOSTNS}

The pocosin theme occurs in a variety of landscape settings in the Coastal Plain and Tidewater Regions. Most characteristic is a dense layer of shrubs, many of them wetland heaths, including staggerbush (Lyonia lucida), titi (Cyrilla racemiflora), leatherleaf (Chamaedaphne calyculata), honeycup (Zenobia pulverulenta), gallberry (Ilex glabra), inkberry (Ilex coriacea), sweet pepperbush (Clethra alnifolia), and others. Catbrier (Smilax laurifolia) occurs in dense tangles. Depending on hydroperiod, fire frequency, and depth of peat, there may be an open to dense canopy of one or more of the following tree species: pond pine (Pinus serotina), loblolly bay (Gordonia lasianthus), sweet bay (Magnolia virginiana), Atlantic white cedar (Chamaecyparis thyoides), red maple (Acer rubrum), black gum (Nyssa biflora), and pond cypress (Taxodium ascendens). Some of the largest occurrences of this theme are large peat domes, but it also occurs in much smaller sites, such as streamheads and Carolina bays.

Natural Communities: Low Pocosin

High Pocosin

Streamhead Pocosin

Small Depression Pocosin

Seepage Pocosin

Pond Pine Woodland

Atlantic White Cedar Forest

Bay Forest 


\section{SALT AND BRACKISH MARSHES}

This theme consists of the estuarine marshes of the sounds, dominated by saltmarsh cordgrass (Spartina alterniflora) and black needlerush (Juncus roemarianus). These areas are biologically very productive.

Natural Communities: Salt Marsh

Brackish Marsh

Salt Flat

Salt Shrub

\section{TIDAL FRESHWATER MARSHES AND SWAMPS}

This theme is limited to the Tidewater Region, and consists of forested and unforested wetlands subject to tidal influence. It occurs primarily on the mainland shores of .Pamlico, Albemarle, and Currituck Sounds. Common tree species are cypress (Taxodium distichum), and water gums (Nyssa aquatica and N. biflora). Common herbs are cattails (Typha angustifolia and T. latifolia), and wild rices (Zizania aquatica and Zizaniopsis miliacea).

Natural Communities: Tidal Freshwater Marsh

Tidal Cypress--Gum Swamp

\section{NATURAL PONDS, POOLS, AND LAKES}

This category includes all natural bodies of fresh water. North Carolina's natural lakes, which all occur in the Coastal Plain, have diverse origins; "bay lakes" in large Carolina Bays (such as those in Bladen County), and "peat-burn lakes" created by fire in a peat dome (such as the lakes in Croatan National Forest). The theme also includes smaller bodies of permanent or semipermanent water, such as dolines in the Tidewater Region and interdune ponds on barrier islands in the Tidewater.

Natural Communities: Vernal Pool

Interdune Pond

Semipermanent Impoundment

Small Depression Pond

Natural Lake Shoreline

Other lacustrine communities have not

yet been classified in North

Carolina

\section{BEACHRS, INTERTIDAL AND SUBTIDAL FLATS}

This theme contains estuarine and marine intertidal and subtidal communities, including beaches up to the highest annual tide (foot of the foredune). In faunistic diversity and productivity, this is a rich system.

Natural Communities: These Communities have not yet been classified in North Carolina. 


\section{GEOLOGIC RESOURCES}

\section{BARRIER ISLANDS AND SHORELINE}

Geomorphic features created by wind and waves at the coast during Holocene times, both on barrier islands and on sections of the mainland coast where barriers are absent. They include beach, foredunes, active and stabilized rear dunes, overwash deposits, interdune ponds and swamps, inlets, sand spits, capes, relict inlets, active flood and ebb tidal deltas.

\section{ESTUARIES}

Geomorphic features associated with tidally influenced areas in lagoons behind barrier islands and in drowned river mouths. They include regularly and irregularly flooded tidal marshes, estuarine swamps, tidal channels, open water with sand and mud bottom, shell beds, relict flood tidal deltas, and estuarine beaches.

\section{CONTINEINTAL SHEILF}

Geomorphic features of offshore areas. They include soft bottom areas and erosional marl outcrops characterized by low scarps.

\section{REIIICT COASTAL FEATURES}

Geomorphic features created by coastal processes before the Holocene, at higher stands of sea level than at present. They include Coastal Plain scarps and terraces, relict beach ridges, and dune systems.

\section{CAROLINA BAYS}

Oriented elliptical depressions. They include water-filled, peat-filled, sandy, and clay-based bay interiors, sand rims, and associated aeolian sand deposits.

\section{FLUVIAL DEPOSITIONAL FEATURES}

Geomorphic features produced by alluvial processes of streams and rivers on floodplains and in river channels, primarily in areas of relatively non-resistant rock. They include mud, sand, and gravel bars, natural levees, point bars, sloughs, ridge and swale systems, oxbows, relict terraces with ridge and swale systems, sloughs, etc., terrace slopes, and coastal plain blackwater stream swamps. 


\section{PEATLANDS AND INTERSTREAM WETLANDS}

Areas saturated by non-flowing water for large parts of the year, because of blocked drainage or flat topography without drainage. They include peat domes, other peatlands, upland swamps, and peat deposits in Carolina bays.

\section{NATURAL LAKRS AND PONDS}

Natural bodies of fresh water in depressions of various origin. They include lakes in peatlands and Carolina bays and ponds in naturally blocked drainage systems and sinkholes or dolines, with associated shallow nearshore areas, beaches, and erosional shorelines.

\section{CAVES, SINRS, AND SPRINGS}

Features produced by solution of rock and other effects of ground water. They include solution caves, speleothems, sinkholes, dolines, natural bridges, and other karst features, and flowing and seeping springs produced by ground water flow in solution cavities, fractured bedrock, saprolite, and sand.

\section{DISSECTED UPLANDS}

Upland areas with well-developed drainage, showing the effects of the common surface geomorphic processes operating on most of the state's landscape. They include upland ridges, ravines, and slopes along streams, underlain by bedrock, saprolite, or colluvium.

\section{INSELBBERGS (MONADNOCKS)}

Isolated erosional remnants. They include isolated hills and mountains of unusually resistant rocks and outliers of the Blue Ridge escarpment.

\section{CLIFPS}

Steep to vertical or overhanging slopes of exposed rock. They include cliffs of resistant rock on high peaks and ridges, and cliffs produced by streams and rivers.

\section{EXFOLIATION FEATURES}

Geomorphic features produced by exfoliation or spalling in hard, generally granite-like rocks. They include flatrocks, dome-shaped mountains and rock faces, and weathering pits which are most commonly formed on exfoliation surfaces. 


\section{GORGES, RAPIDS, AND WATERPALLS}

Features produced by stream erosion in high to moderate relief terrain or resistant rock. They include steep-walled gorges, waterfalls, waterfall pools, rapids over bedrock, rapids over boulder deposits, and potholes.

\section{MASS WASTING FEATURES}

Landforms illustrating $f$ satures produced by mass wasting phenomena. They include debris avalanches, tracks, and deposits, earth flows, slumps, talus slopes, and relict periglacial features such as boulder fields and nivation cirques.

\section{FAULTS, JOINTS, AND RELATED FEATURES}

Areas illustrating results of faulting and jointing, either directly or indirectly. They include visible high angle and thrust faults, sheared and cataclastic rocks, large fault-produced features such as windows, fault zones, horsts, and grabens, fissure caves, joint or fault-controlled drainage, and other landforms showing effects of faults or joints.

\section{FOLDS AND RELATED FEATURES}

Areas illustrating results of folding, either directly or indirectly. They include folds visible in outcrops and series of outcrops, and landforms produced by differential erosion in folded rocks.

\section{INTRUSIONS}

Areas illustrating intrusive igneous bodies. They include batholiths, dikes, sills, ring dikes, and other kinds of plutons, of granitic rocks, syenite, diorite, diabase, gabbro, and ultramafic rocks.

\section{VOLCANIC FEATURES}

Areas illustrating features produced by extrusive igneous activity. They include lava flows, breccias, tuffs, lahars, pillow lavas, and other features visible in outcrops or expressed in landforms.

\section{METAMORPHIC FEATURES}

Areas illustrating characteristic minerals, textures, and structures produced by metamorphic processes. They include rocks of different initial composition, metamorphosed to different degrees. 


\section{SEDIMENTARY PEATURES}

Areas illustrating sedimentary stratigraphy, rock types, sedimentary structures, and depostional environments. They include sandstone, dolomite, mudstone, graywacke, fanglomerate, arkose, lake shale, coastal plain sand and shale, marl, coquina, representative strata of different ages or formations of the Coastal Plain, Triassic Basins, Carolina Slate Belt, and windows in the Blue Ridge.

\section{FOSSILS}

They include representatives of the range of fossil types, animal and plant, marine and terrestrial, different types of preservation, and different ages.

\section{UNUSUAL ROCK TYPES}

Outcrops of rock types rare in North Carolina or in the region. They include ultramafic rocks, dolomite, marble, limestone, and orbicular diorite and noteable occurrences of unusual minerals.

\section{GLOSSARY OF GEOLOGIC TERMS}

Aeolian: Deposited or reworked by wind.

Batholith: A large body of intrusive rock frequently covering many square miles of area and extending to great depth.

Breccia (volcanic): A rock consisting of brocken rock fragments produced by volcanic eruptions, with rock fragments greater than 32 millimeters in size.

Dike: A narrow vertical body of intrusive rock, appearing in outcrop as a narrow line.

Doline: A depression on the land surface caused by collapse of surficial sediments into a void created by solution of limestone underground.

Drowned river mouth: Lower reach of a river valley, now occupied by tidal estuarine waters. These valleys were formed when sea level was lower and were inundated when sea level rose.

Graben: A block of rock lowered relative to adjacent areas by vertical fault movement.

Holocene: The most recent period of geologic time, extending from the end of the last ice age $(10,000$ years ago) to the present. 
Horst: A block of rock uplifted relative to adjacent areas by vertical fault movement.

Lahar: A deposit produced by landslides of volcanic ash on the flank of a volcano.

Mar1: A sedimentary rock consisting of clay with abundant calcium carbonate material in the form of shells or shell fragments. The term is also frequently used in North Carolina to refer to rocks madr up largely of shells.

Mass wasting: A series of geomorphic processes involving movement of larke masses of earth material by gravity, either slowly or quickly.

Nivation cirque: A rounded basin-like landform produced by periglacial processes around permanent snowfields.

Periglacial: A series of geomorphic processes resulting from repeated freezing and thawing under cold climate, as occurred during the ice age.

Pluton: General term for bodies of intrusive igneous rock.

Ring dike: A narrow, ring-shaped body of intrusive rock, as in the syenite ring dike in Cabarrus County.

Sand spit: A small point of land or narrow shoal projecting from the shore.

Saprolite: A soft, earthy, clay-rich, thoroughly decomposed rock formed in place by weathering.

Scarp (Coastal Plain): A relatively steeply sloping area on the Coastal Piain or Continental Shelf, believed to have been formed by coastal processes in the past.

Sill: A thin, horizonal body of intrusive rock. Unlike a dike, it may cover a large area in outcrop.

Slough: An elongate depression in a floodplain that occurs at a former location of a river channel.

Spalling: Breaking in layers parallel to the surface, as sometimes occurs in granite and related rocks.

Speleothem: A cave formation, such as a stalactite or stalagmite.

Tuff: A volcanic rock consisting of broken rock fragments produced by volcanic eruptions, with fragments generally less than four millimeters in size. 


\section{BOATING}

Opportunity to operate or ride in a boat in a natural outdoor setting. The water resources required can range from whitewater streams and flat water rivers to large lakes, reservoirs and oceans. Types of boating vary according to the boat used and the water resource. Examples of activities in the boating theme include flatwater canoeing (including other small craft), whitewater canoeing, powerboating, sailing, surfboarding, water skiing and wi id surfing.

\section{SWIMIING}

Opportunity to swim, wade, stand or float in water in a natural outdoor setting. Resources vary with the water resources which range from rivers to lakes to oceans. Examples of activities in the swimming theme include ocean swimming, lake swimming, river swimming and scuba diving.

\section{FISHING}

Opportunity to catch fish in a natural outdoor setting. Fishing resources vary according to the type of fish available and the water resource available. Types of fishing also vary according to the equipment used, the bait used and whether a boat is used. Fish management practices should be maintained where practical to enhance and maintain fish populations. Examples of activities in the fishing theme include warm water fishing, cold water fishing and saltwater fishing.

\section{BEACH ACTIVITIES}

Opportunity to participate in a variety of leisure activities at a fresh water or salt water beach in a natural outdoor setting. A sandy beach is the primary resource for these activities. Support facilities like bath houses and parking could be available. Examples of activities in the beach activities theme include shell collecting and sun bathing.

\section{SNOW AND ICE ACTIVITIES}

Opportunity to participate in a variety of leisure activities and winter sports in a natural environment where snow and ice are available. A wide range of terrains is preferable for a variety of snow activities. Examples of activities in the snow and ice activities theme include skating, cross country skiing, downhill skiing and sledding.

\section{SCENIC RESOURCES}

\section{SCENIC VISTAS}

The view from a natural or man-made resource. 


\section{RECREATION RESOURCES}

\section{CAMPING}

Opportunity to stay overnight in a natural outdoor setting. Facilities can provide a wide range of comforts from primitive to modern depending upon the preferences of the user and the equipment used. Examples of activities for the camping theme include backpacking, tent and trailer camping, primitive camping, organized group camping, youth group camping and cabin camping.

\section{NATURE STUDY}

Opportunity to observe and learn about the natural environment through a variety of means. The resource is generally an undisturbed natural area. Examples of activities for the nature study theme include interpretive programs or exhibits, bird watching, nature hikes or tours, individual nature study and photography.

\section{TRAIL USE}

Opportunity to travel along a trail located in a natural outdoor setting. Different resources provide for various types of travel such as hiking, jogging or horseback. Trail use can also vary widely in the distances traveled and physical endurance required. Examples of activities for the trail use theme include bicycling, hiking, horseback riding, walking and jogging.

\section{PICNICKING}

Opportunity to consume a meal in a natural outdoor setting. Picnicking can involve one person or a large group. Facilities to accommodate groups of different sizes are required to meet these different user preferences. Examples of activities for the picnicking theme include small group picnicking and large group picnicking.

\section{OPEN SPACE ACTIVITIES}

Opportunity to participate in a wide variety of leisure activities in an open natural outdoor setting. The resource provides the space needed for active uses as well as places to sit or rest. Examples of activities for the open space activities theme include kite flying, frisbee, touch football and sitting.

\section{ADVENTURE}

Opportunity to test physical endurance and skills in a natural outdoor setting where the combination of the activity and the natural resource provide an obvious challenge and risk for the participant. Examples of activities for the adventure theme include hang gliding, off road vehicle driving, rapelling, rock climbing, orienteering and spelunking. 


\section{RESERVOIRS/LAKES}

The view of a body of flat water.

\section{WATERFALLS}

The view of a steep descent of water from a height.

\section{RIVERS}

The view of a large natural stream of water emptying into an ocean, lake, or other body of water, and usually fed along its course by converging tributaries.

\section{WHITEWATER STREAMS}

The view of a cascading body of running water.

\section{BAYS AND ESTUARIES}

The view of either a coastal flat body of water enclosed by land but having an outlet to the ocean or the lower portion of a river where its current is met and influenced by the tides.

\section{SEASHORES}

The view of a tract of land adjacent to the ocean.

\section{FORESTS}

The view of a dense growth of trees, together with other plants, covering a large area.

\section{MRADOWS AND GRASSLANDS}

The view of a tract of grass covered land.

\section{SWAMPS}

The view of a lowland region saturated with water and primarily vegetated with trees.

\section{POCOSINS}

The view of a shallow swampy depression vegetated chiefly with shrubs. 


\section{MARSHES}

The view of a low lying wetland vegetated primarily with grasses.

\section{GORGES}

The view of a deep, narrow passage with precipitous rocky sides often enclosed between mountains.

\section{ROCK OUTCROPPINGS}

The view of an expansive natural stone formation occurring either vertically or horizontally.

\section{ISLANDS}

The view of a body of land surrounded on all sides by salt or fresh water.

\section{CAVES AND CLIFFS}

The view of geologic formations of either a hollow beneath the earth's surface or of a vertical rock wall.

\section{SCENIC HIGHWAYS}

The view from a highway or road of visually diverse and natural or man-made phenomena. 

APPENDIX IV-3

COMMITTEE RATINGS FOR SIGNIFICANCE OF THEMES WITHIN REGIONS 
$m m \mathbb{Z} m m m m m m 0 \quad m m m m 0 m m 00 m 000$

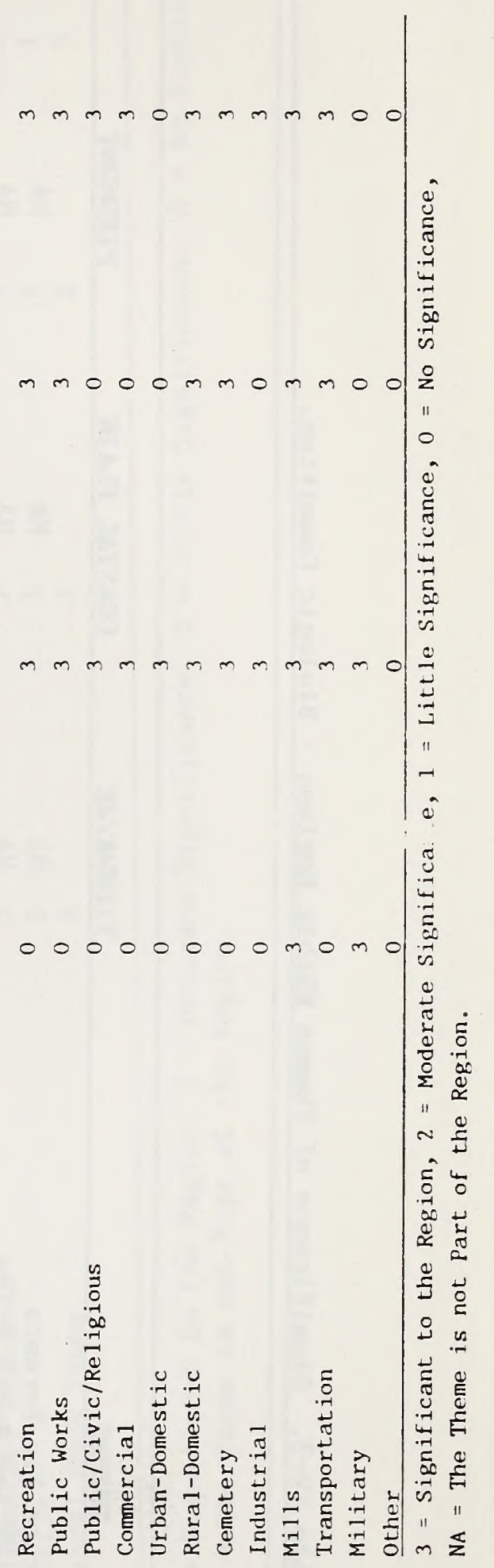




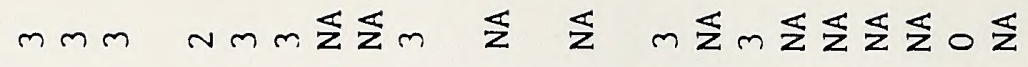

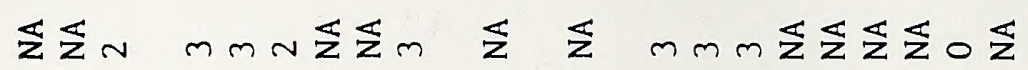

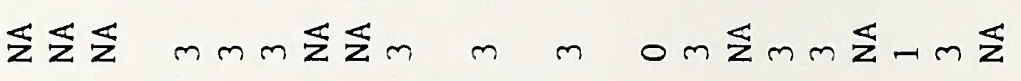

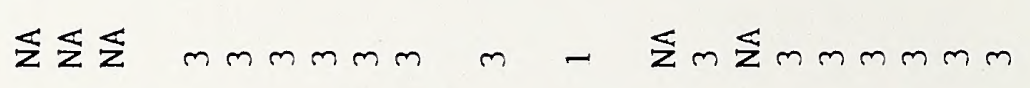

\section{$\sum_{\substack{n \\ 0}}^{\substack{d \\ 0}}$ \\ $\operatorname{lin}_{0.1}^{\infty}$}

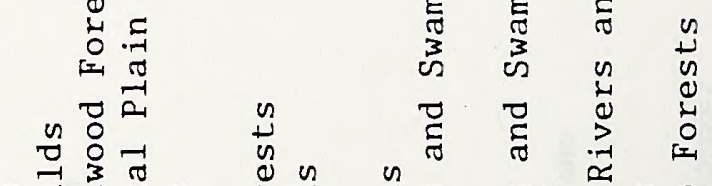

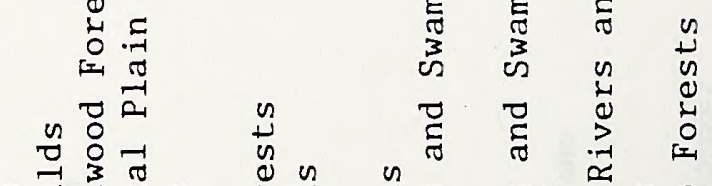

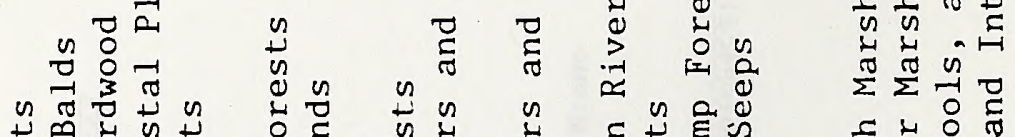
许

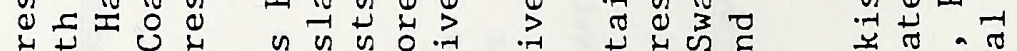

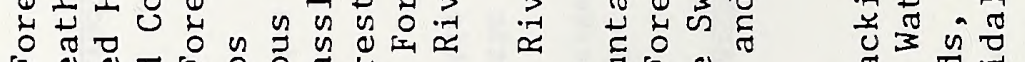

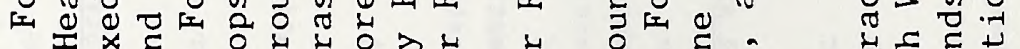

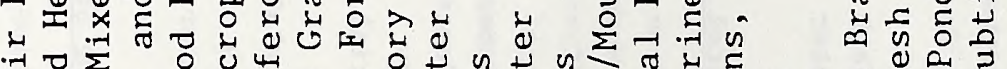

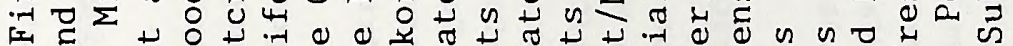

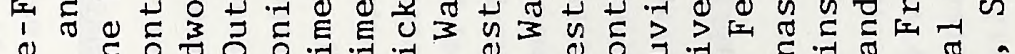
४ U थ

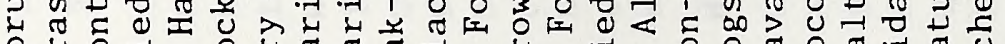

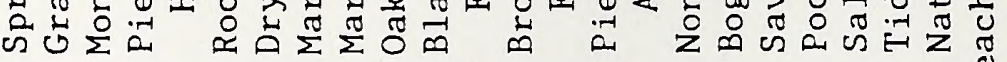




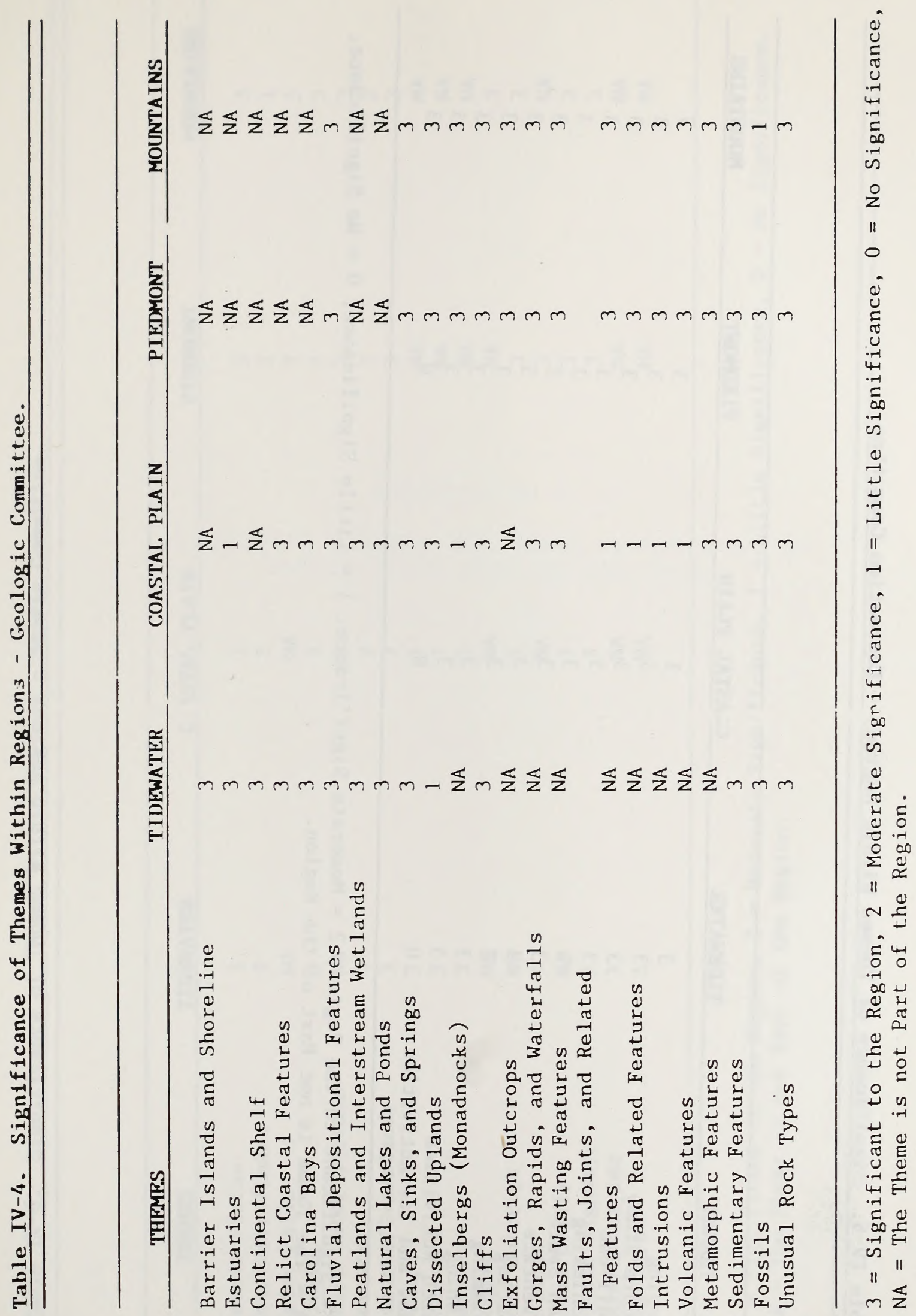




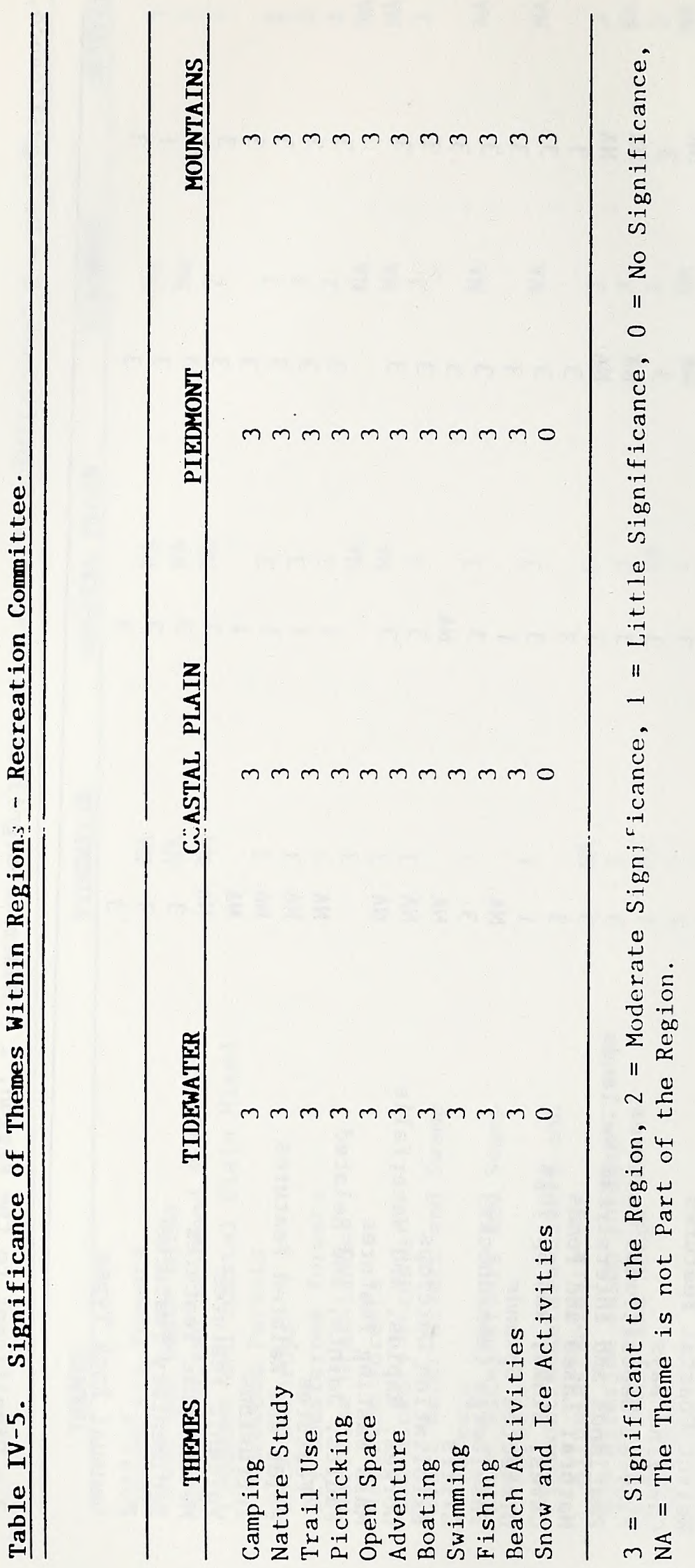




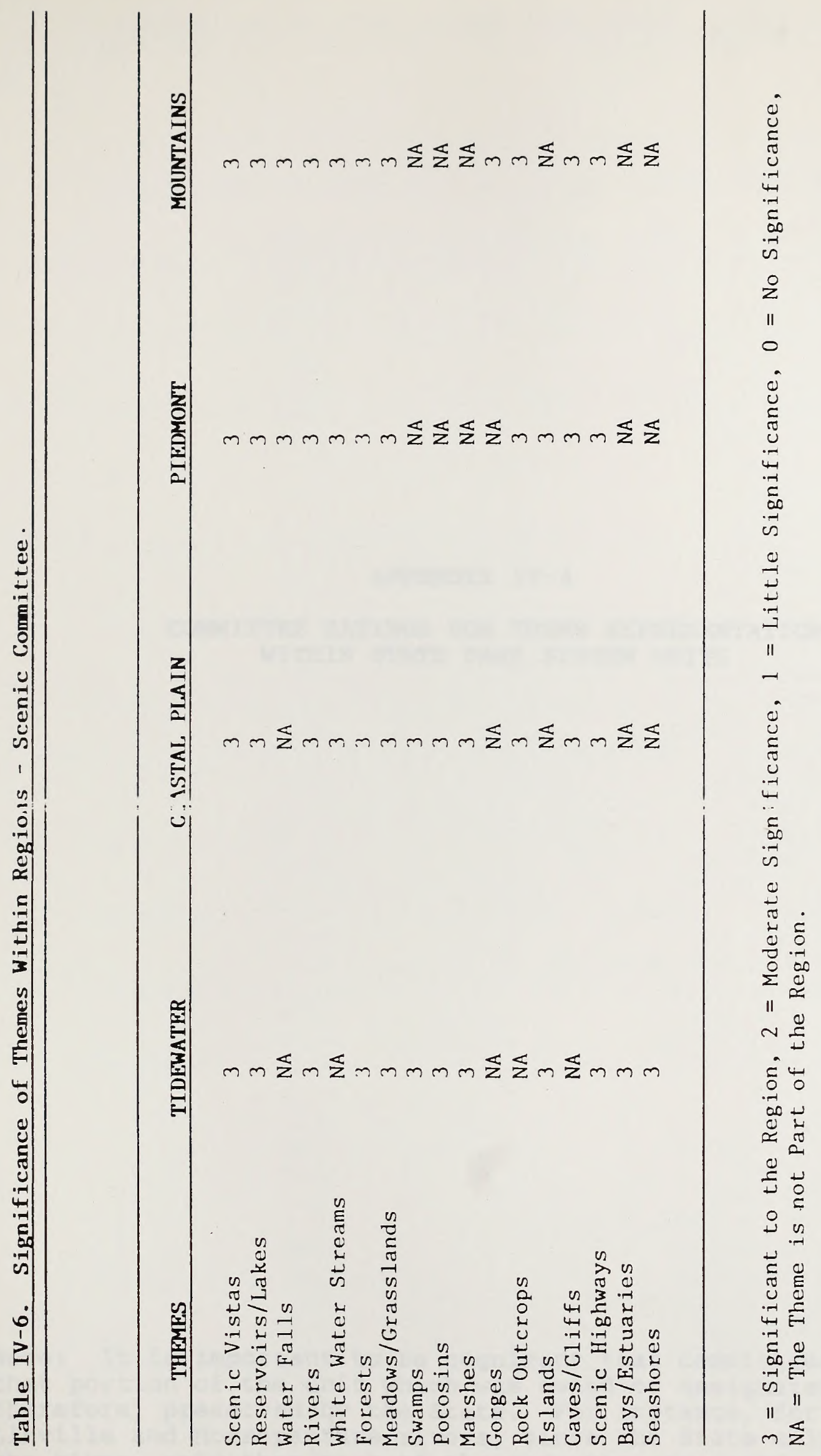





\section{APPENDIX IV-4 \\ COMMITTEE RATINGS FOR THEME REPRESENTATION WITHIN STATE PARR SYSTEM UNITS}

Note: It is important to be cognizant that committees only rated that portion of the unit which was owned or designated and, therefore, preserved by the state. For instance, for the Linville and Horsepasture rivers, since the state only designated the river, only that part of the resource was rated. 
Table IV-7. State Park System Unit Abbreviations.

State Park Unit

Matrix Code

Baldhead Island

Baytree Lake

Boones Cave

Bushy Lake

Carolina Beach

Chowan Swamp

Cliffs of the Neuse

Crowders Mountain

Dismal Swamp

Duke Power

Eno River

Falls Lake

Fort Fisher

Fort Macon

Goose Creek

Hammocks Beach

Hanging Rock

Hemlock Bluffs

Horsepasture River

Jockey's Ridge

Jones Lake

Jordan Lake

Kerr Lake

Lake James

Lake Waccamaw

Linville River

Masonboro Island

Medoc Mountain

Merchants Millpond

Mitchells Mill

Morrow Mountain

Mount Jefferson

Mount Mitchell

New River

Pettigrew

Pilot Mountain

Raven Rock

Salters Lake

Singletary Lake

South Mountain

Stone Mountain

BAIS

BALA

BOCA

BULA

CABE

CHSW

CLNE

CRMO

DISW

DUPO

ENRI

FALA

FOFI

FOMA

GOCR

HABE

HARO

HEBL

HORI

JORI

JONE

JORD

KELA

LAJA

LAWA

IIRI

MAIS

MEMO

MEMI

MIMI

MOMO

MOJE

MOMI

NERI

PETT

PIMO

RARO

SALA

SILA

SOMO

STMO

THRO

WAYN

WEWO

WHLA

WIUM 


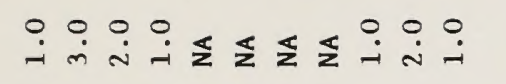

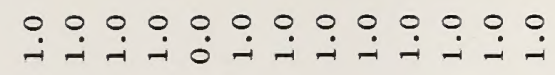

욱연

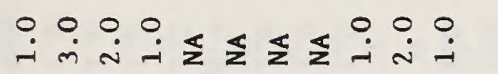

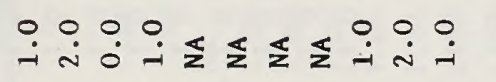

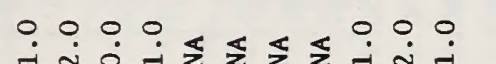

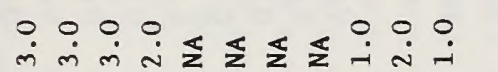

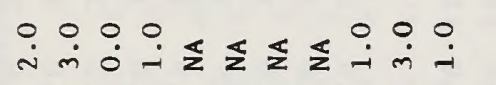

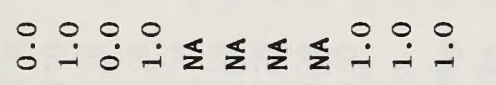

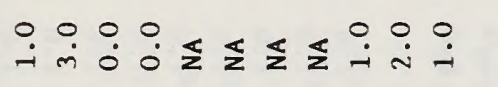

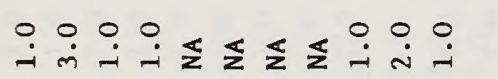

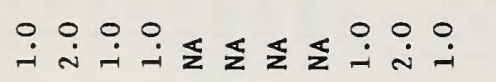

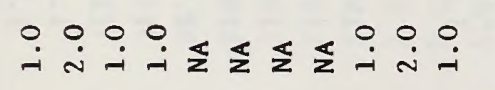

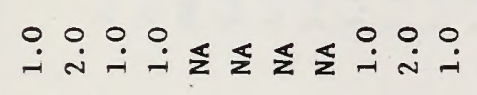

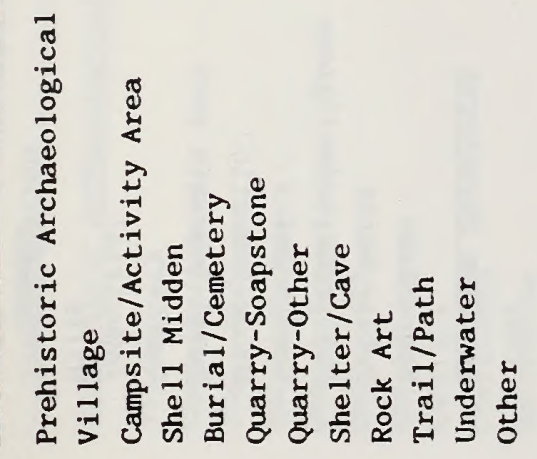

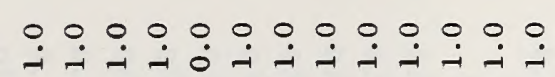

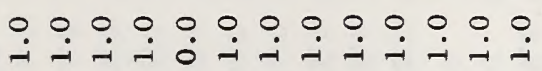

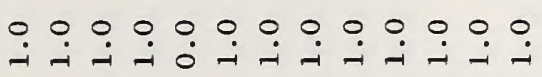

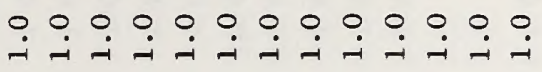

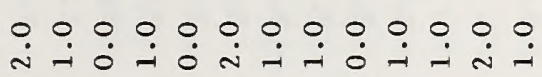

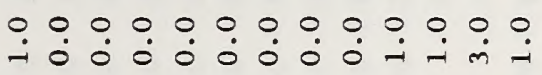

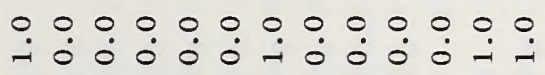

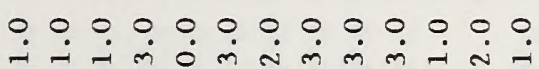

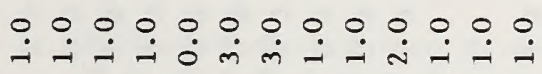

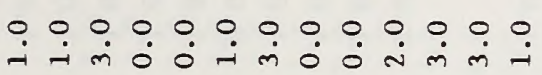

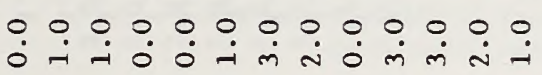

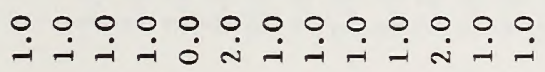

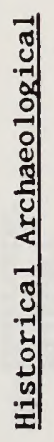

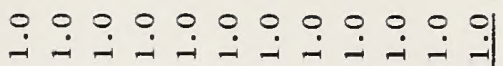

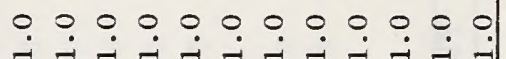

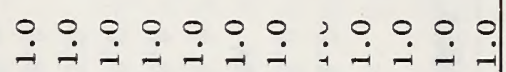

0.0000000000

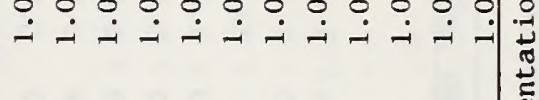

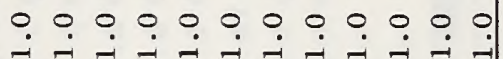

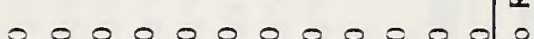

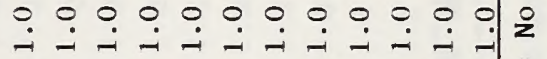

000000000000

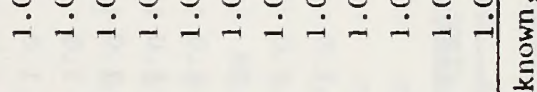

0.00000000005

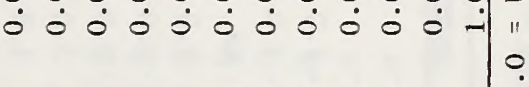

0.000 .000000

$\dot{-} \dot{-} \dot{-} \dot{-} \dot{-} \dot{-} \dot{-} \dot{m} \dot{-} \dot{-} \dot{\vec{U}}$

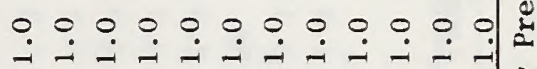

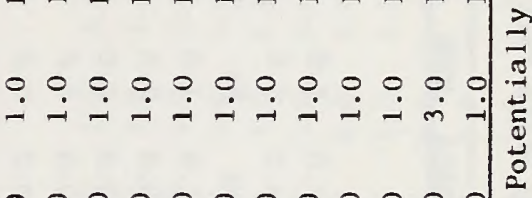

우우우우우우울

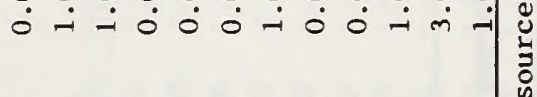

언

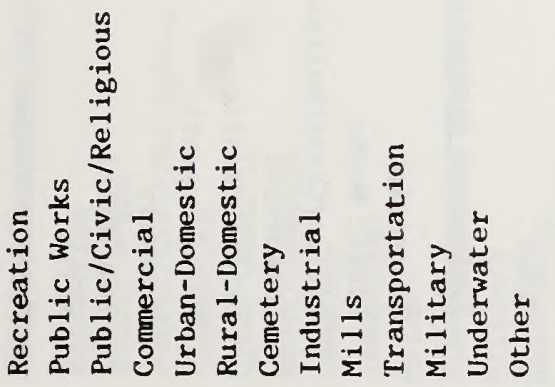

ปี่

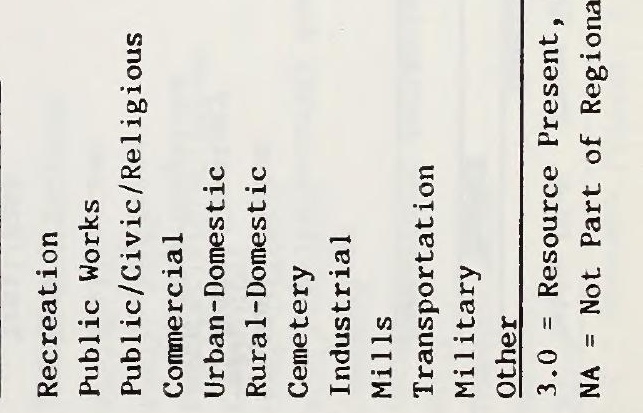




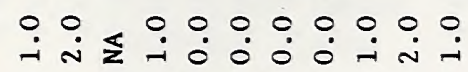

$\circ 0000000.00 \% 0$

0.0000 .00000

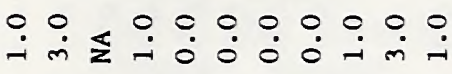

$\circ 00000000000 \%$

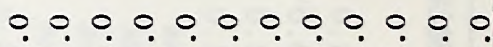

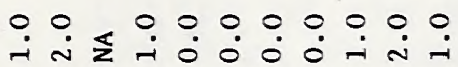

000000000000000

0.0000000000

苗

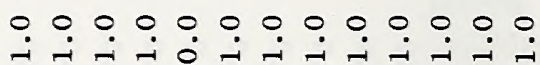

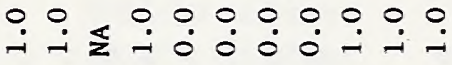

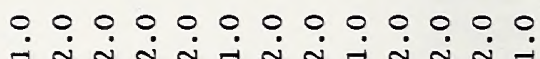

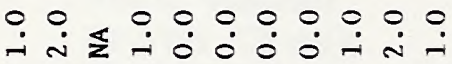

000000000000

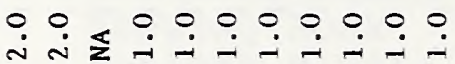

0.00000000000

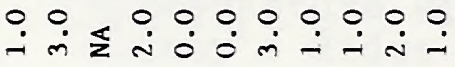

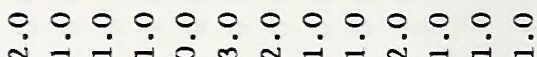

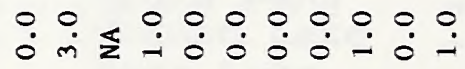

00.0000000000

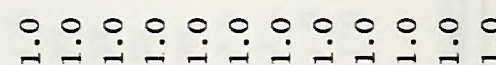

$00 \leq 000000000$

0.00000000000

000000000000

인

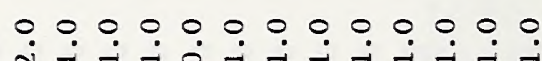

00000000000

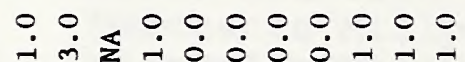

0000000000000

?

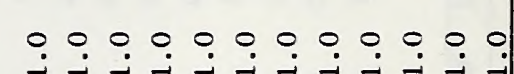
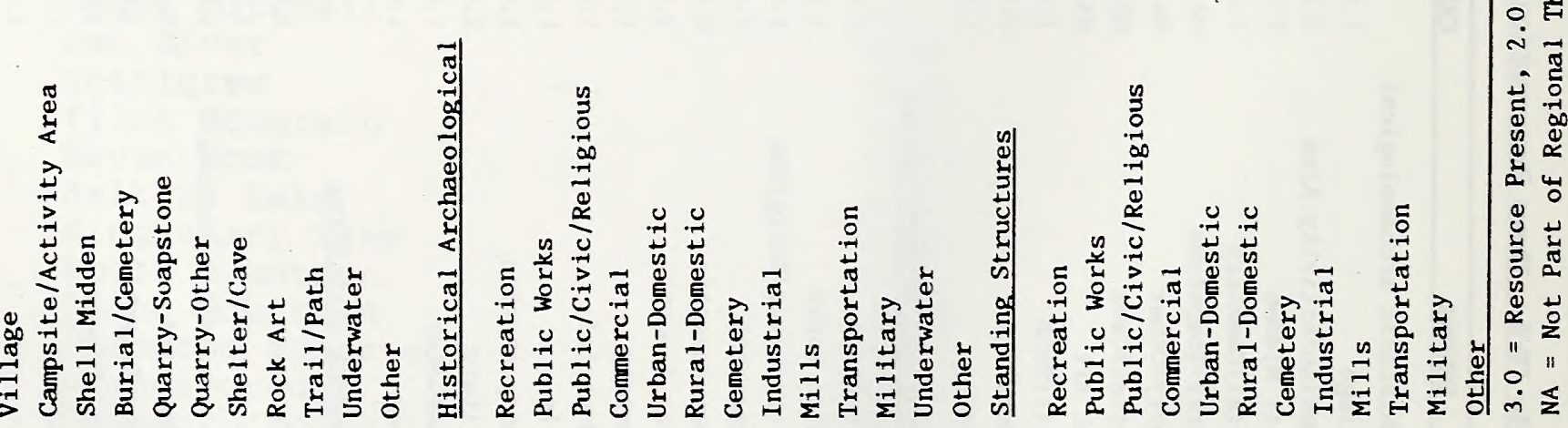


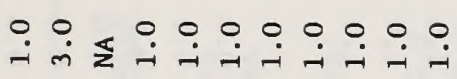

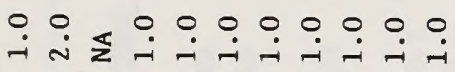

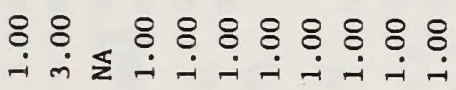

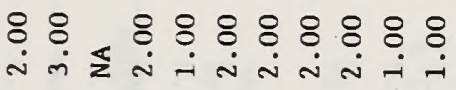

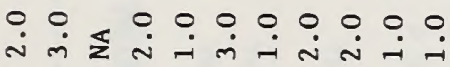

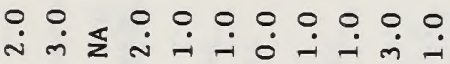

운

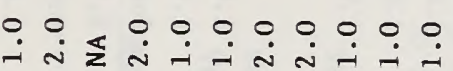

운

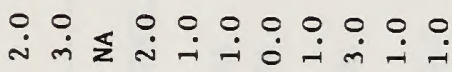

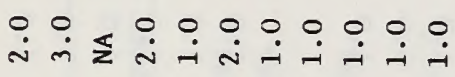

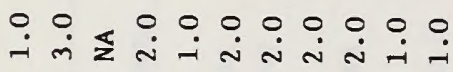

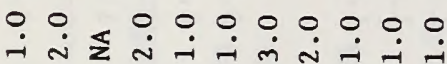

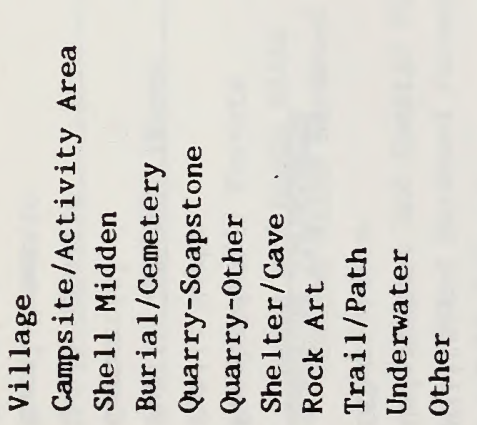

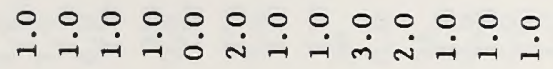

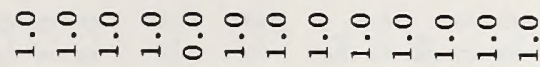

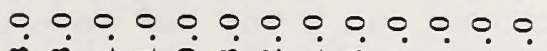

우우우우웅․

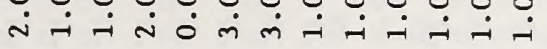



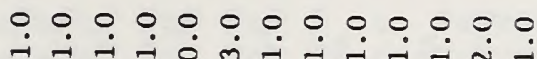

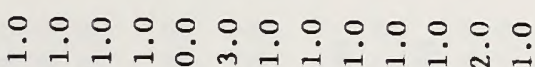

m

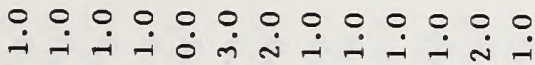

i்

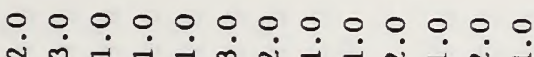

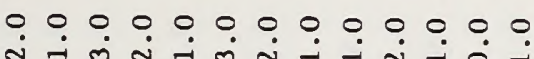



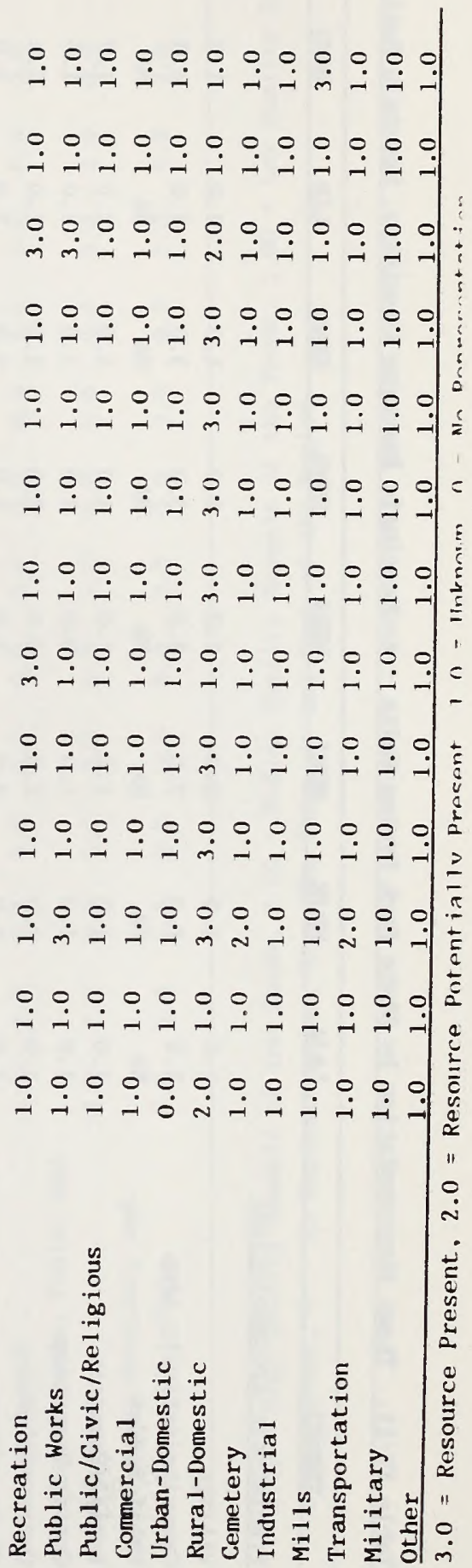




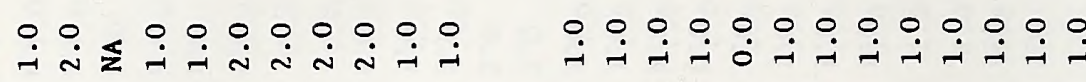

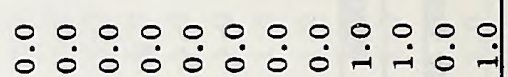

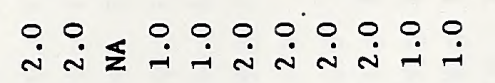

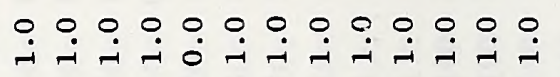

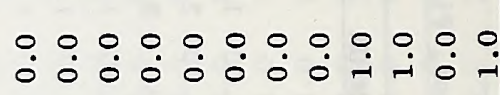

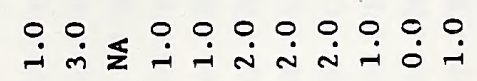

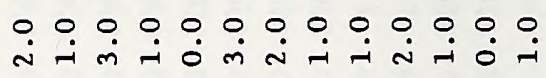

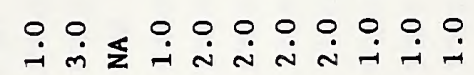

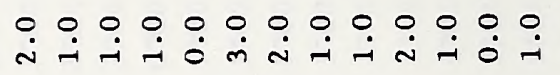

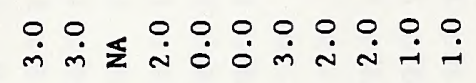

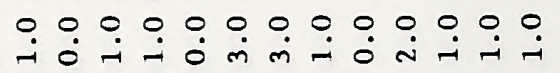

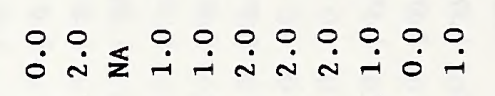

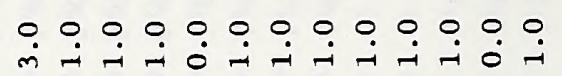

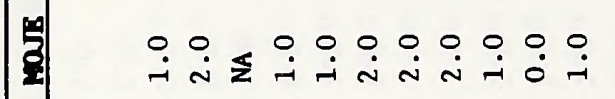

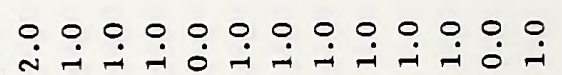

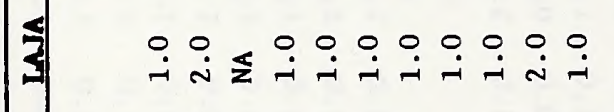

m업

$\ln (20$

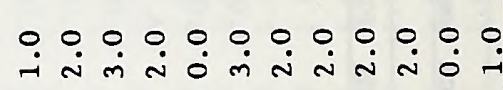

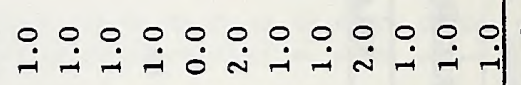

$\because \div \% \because \because \because \% \div$

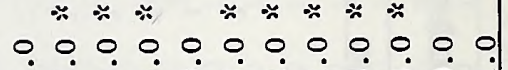

造
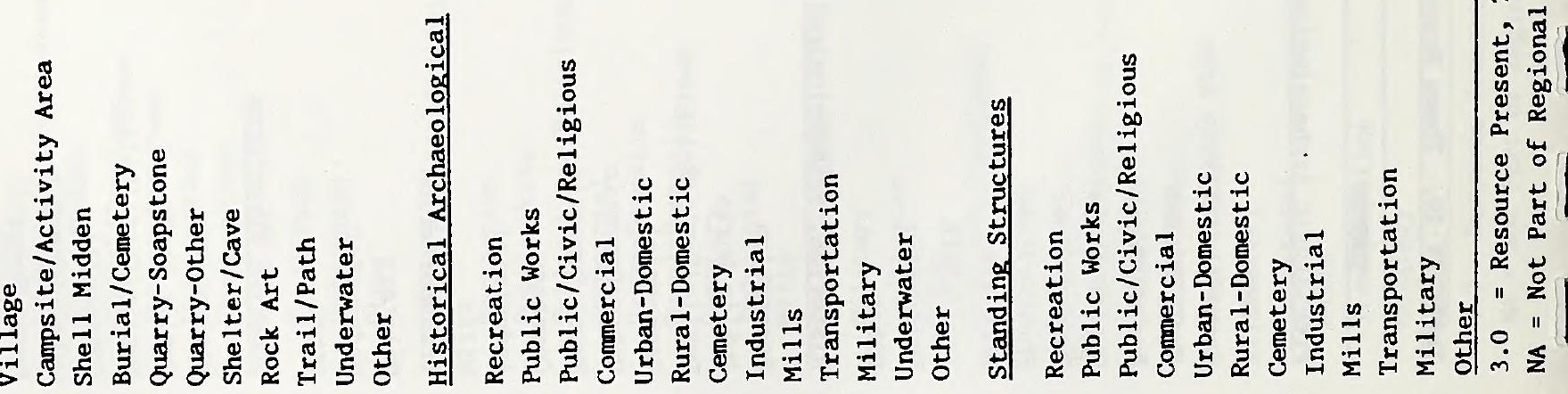


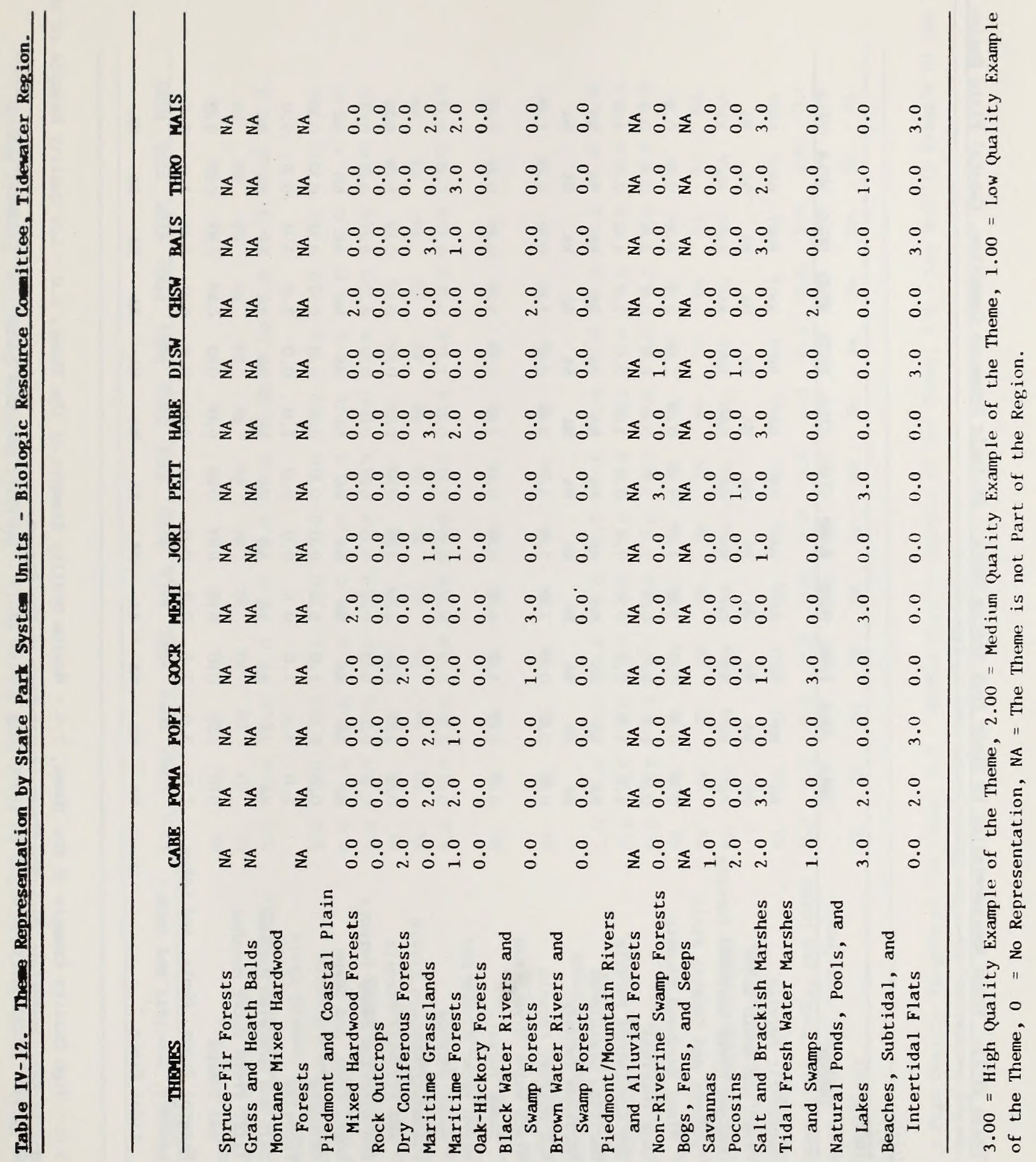




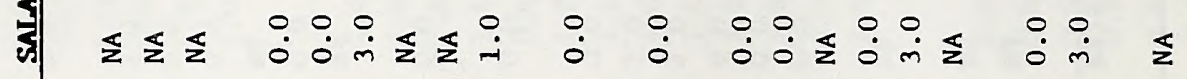

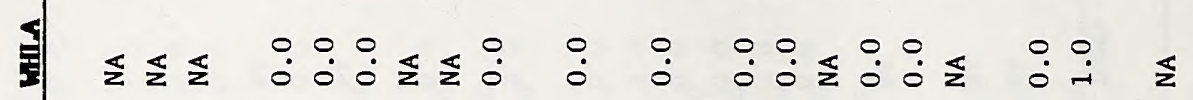

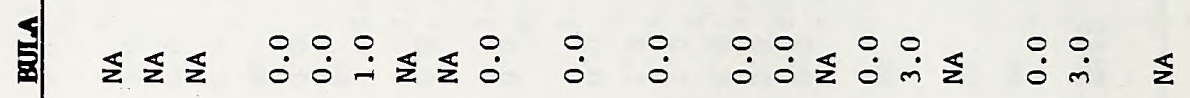

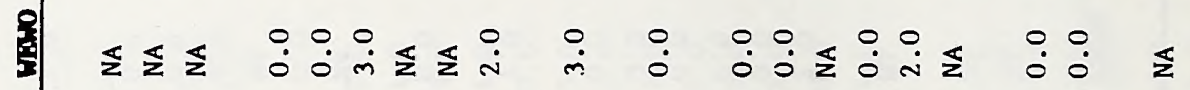

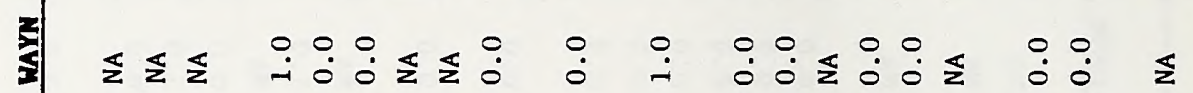

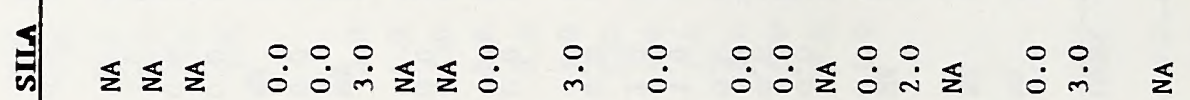

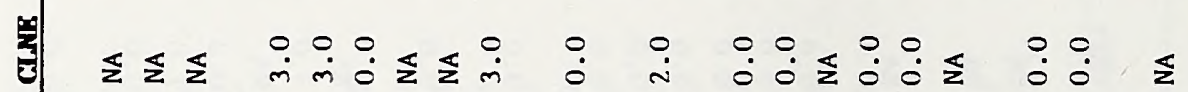

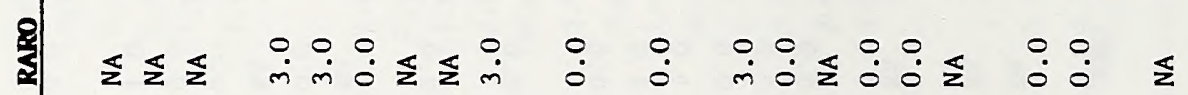

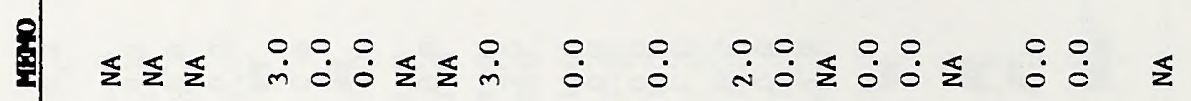

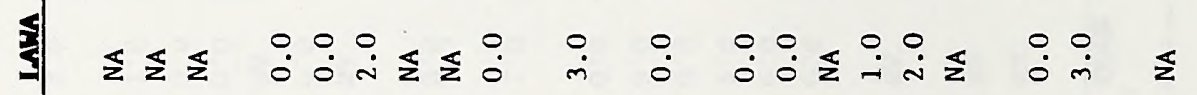

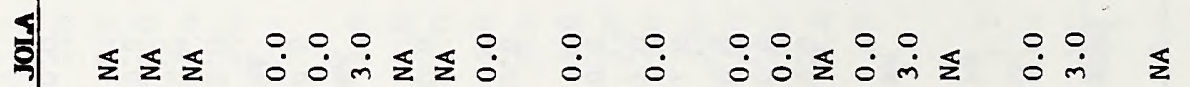

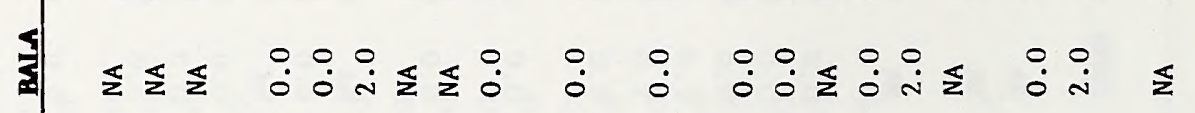

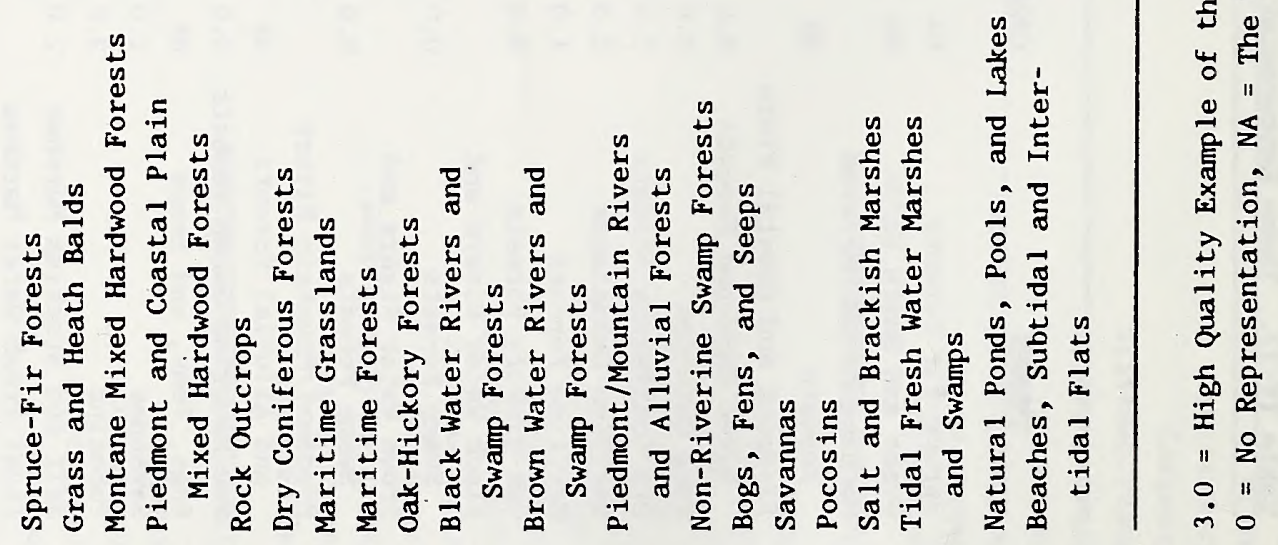




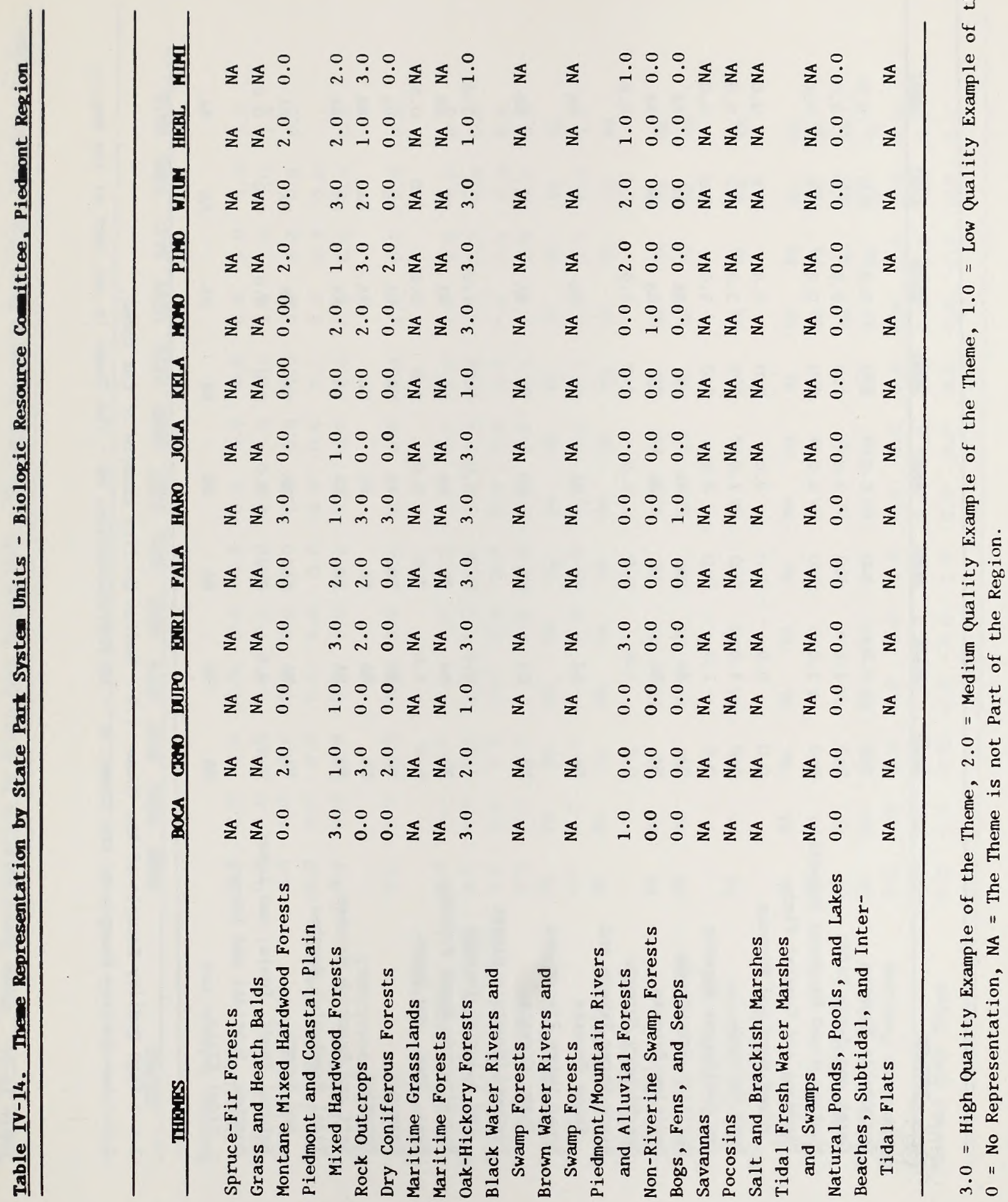




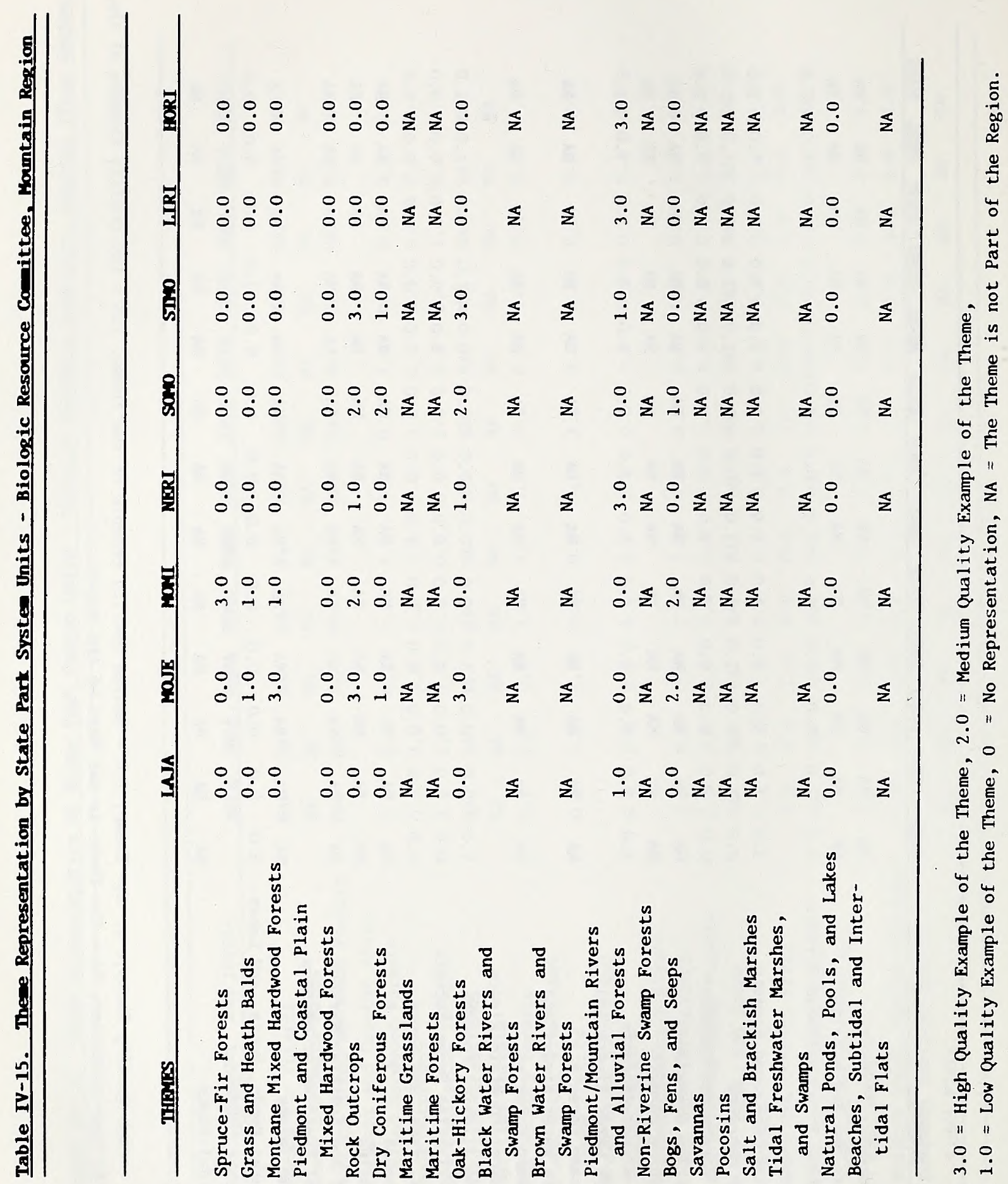




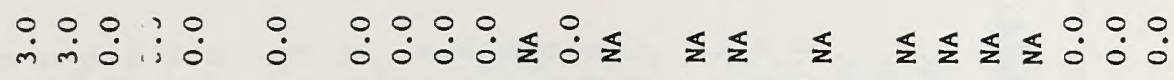

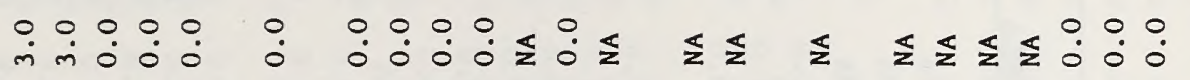

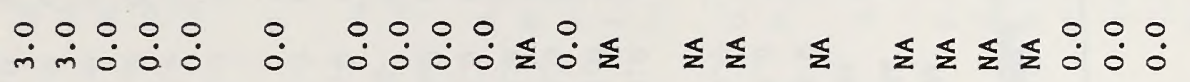

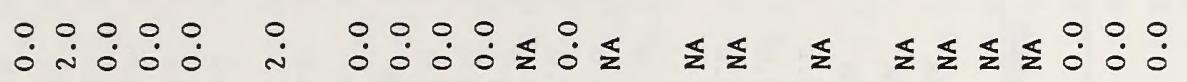

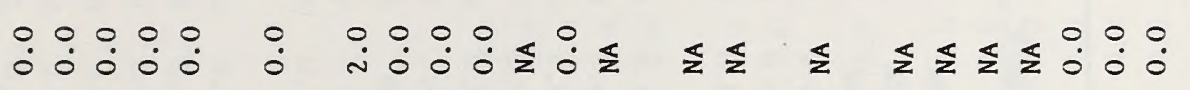

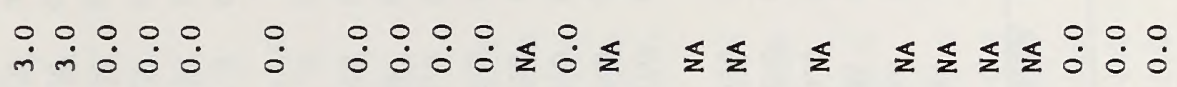

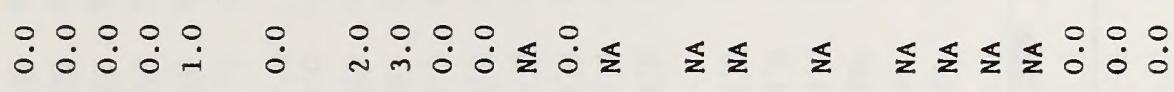

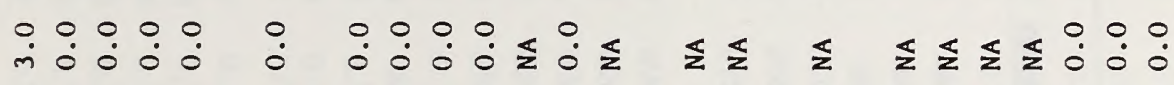

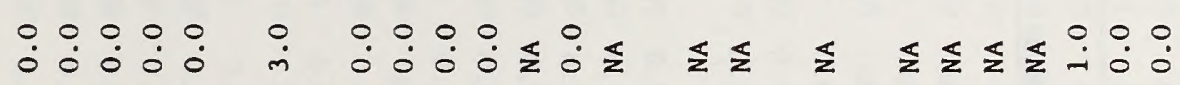

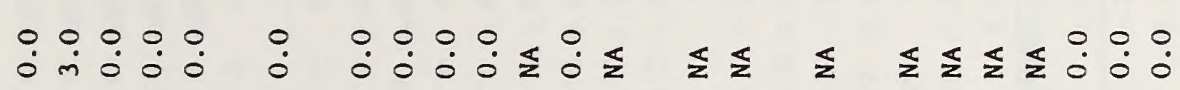

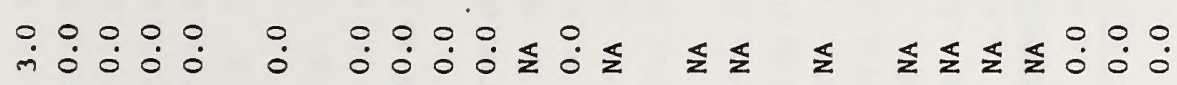

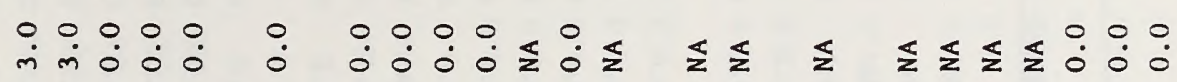

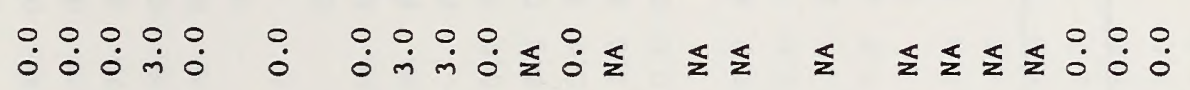

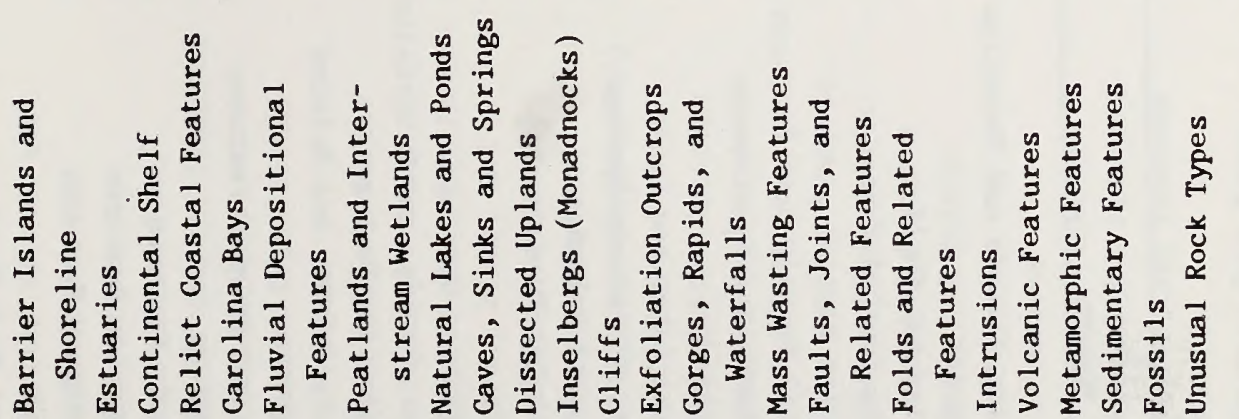




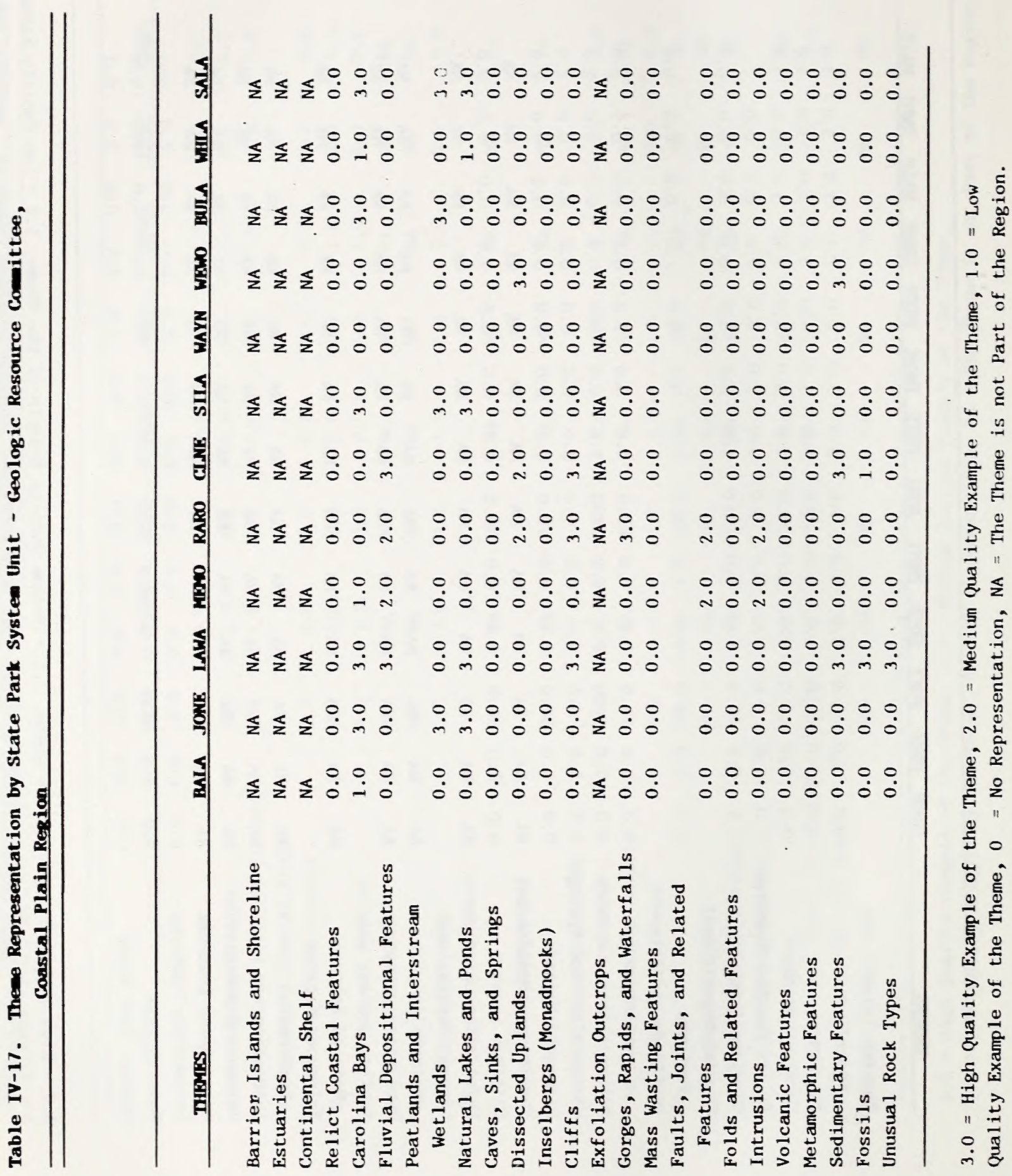




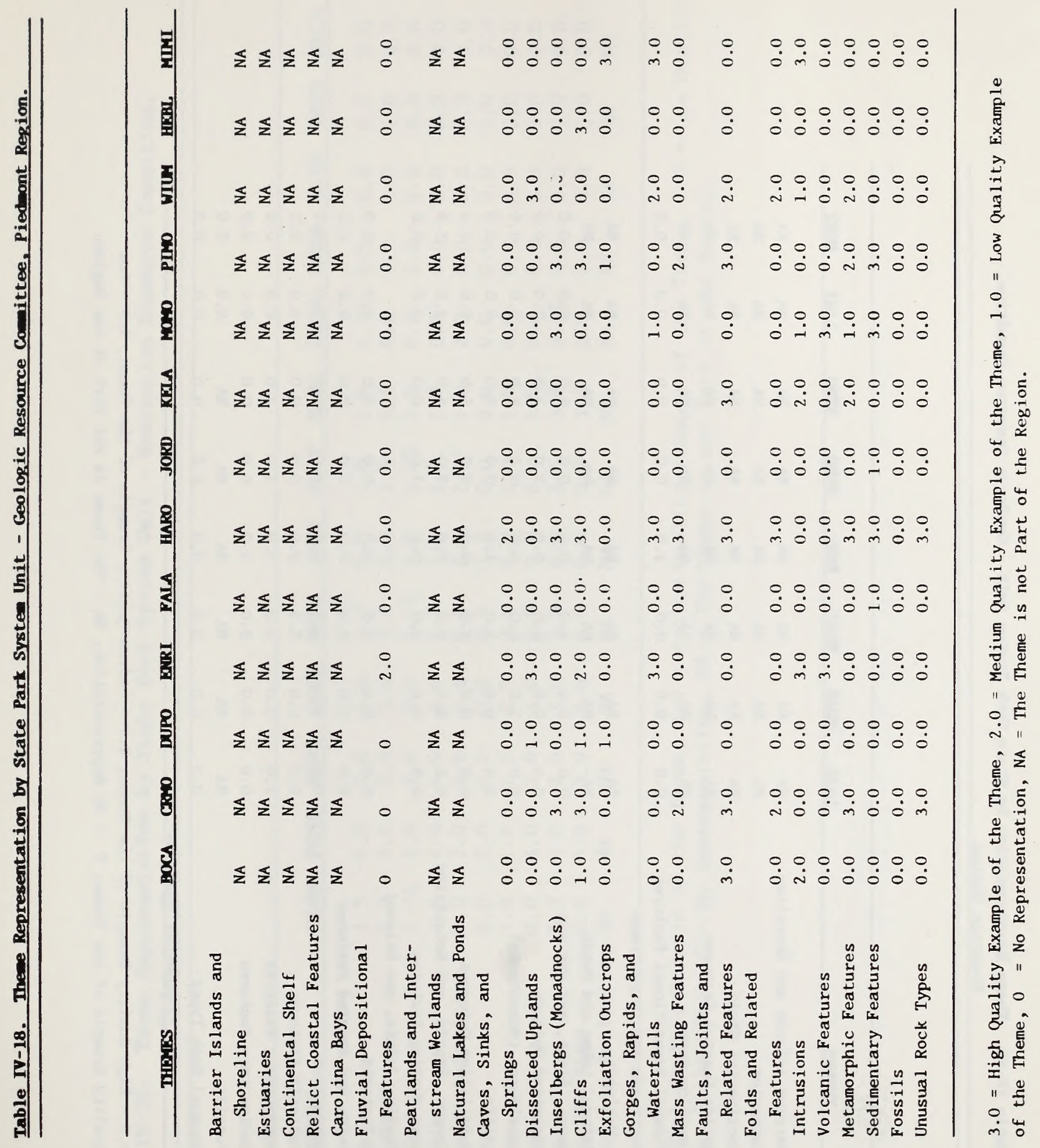




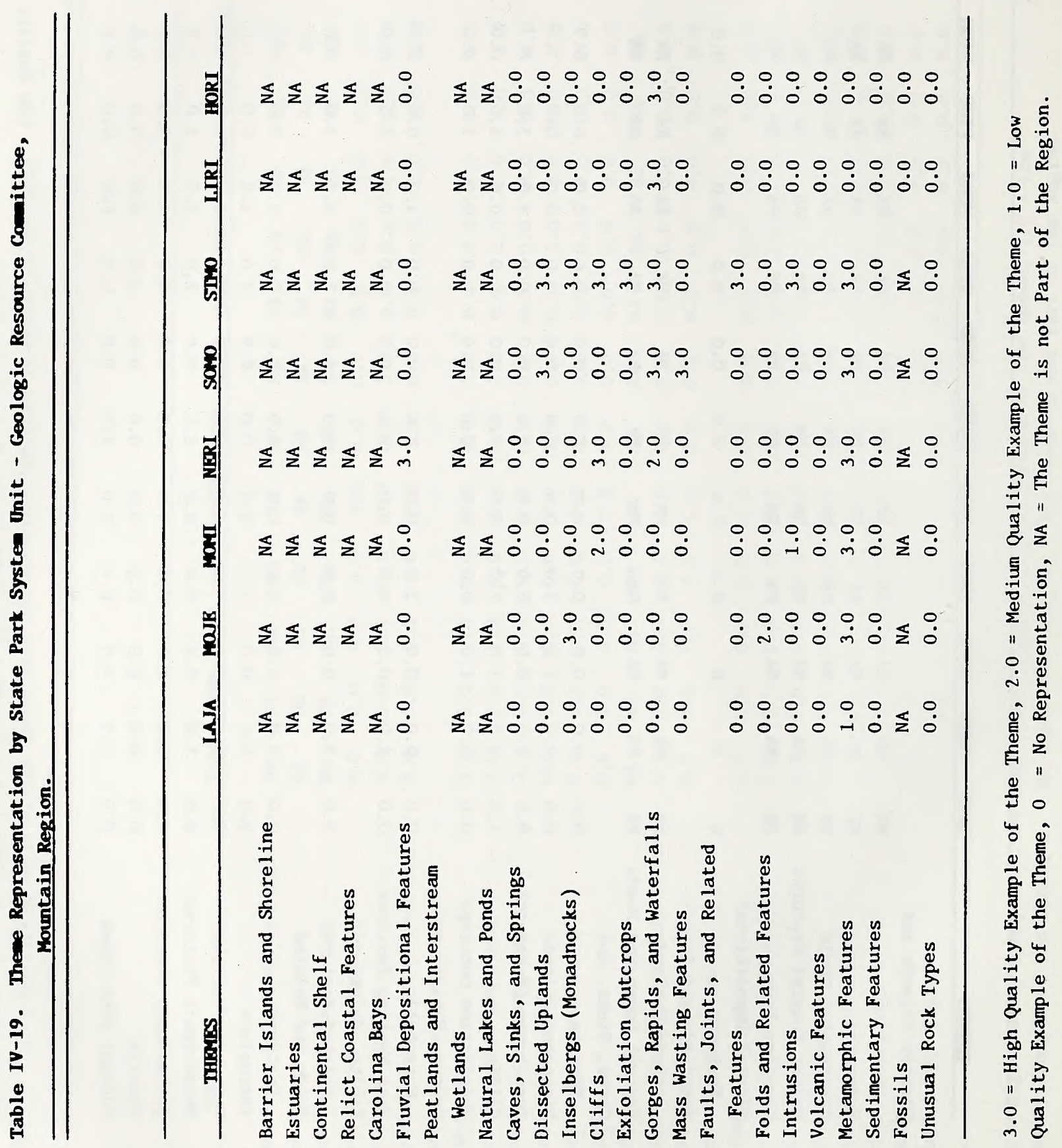




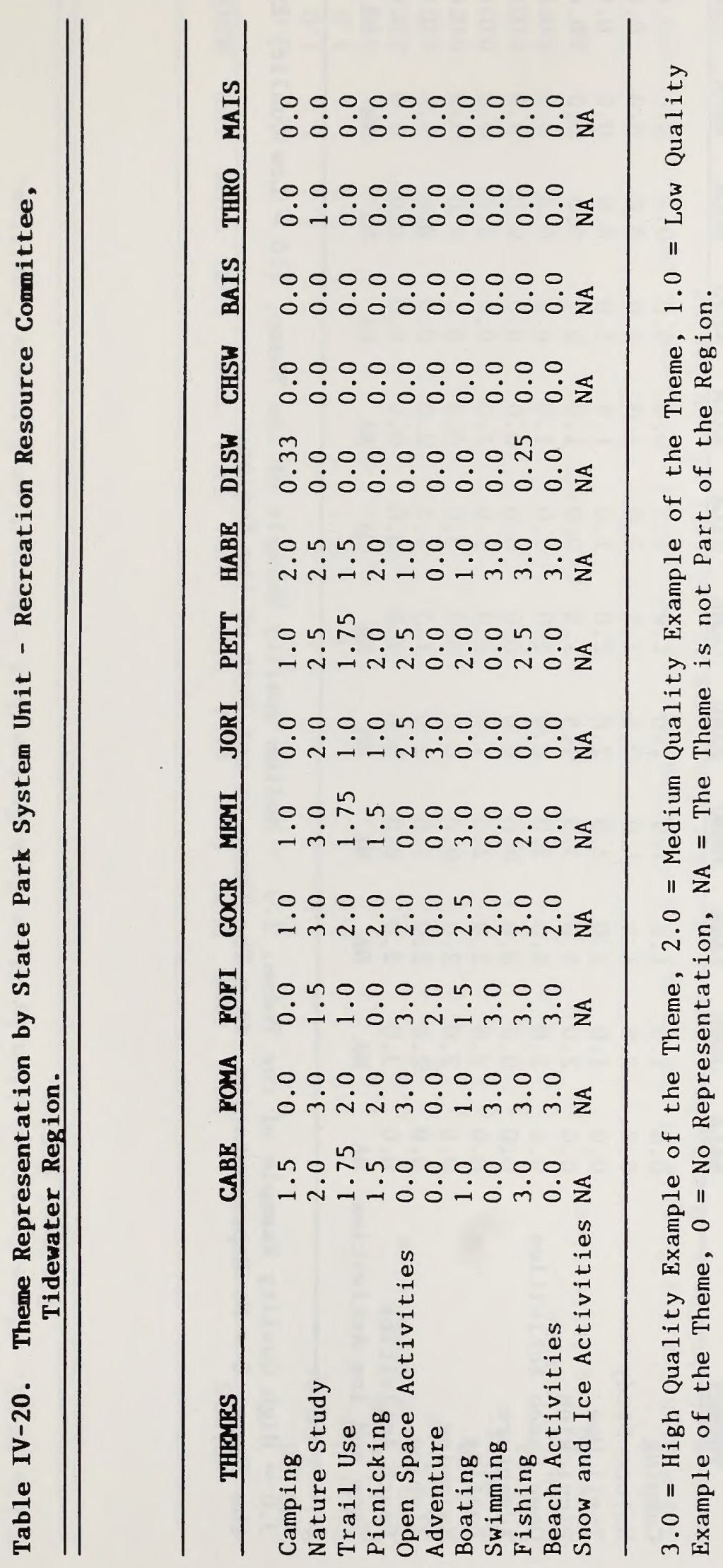




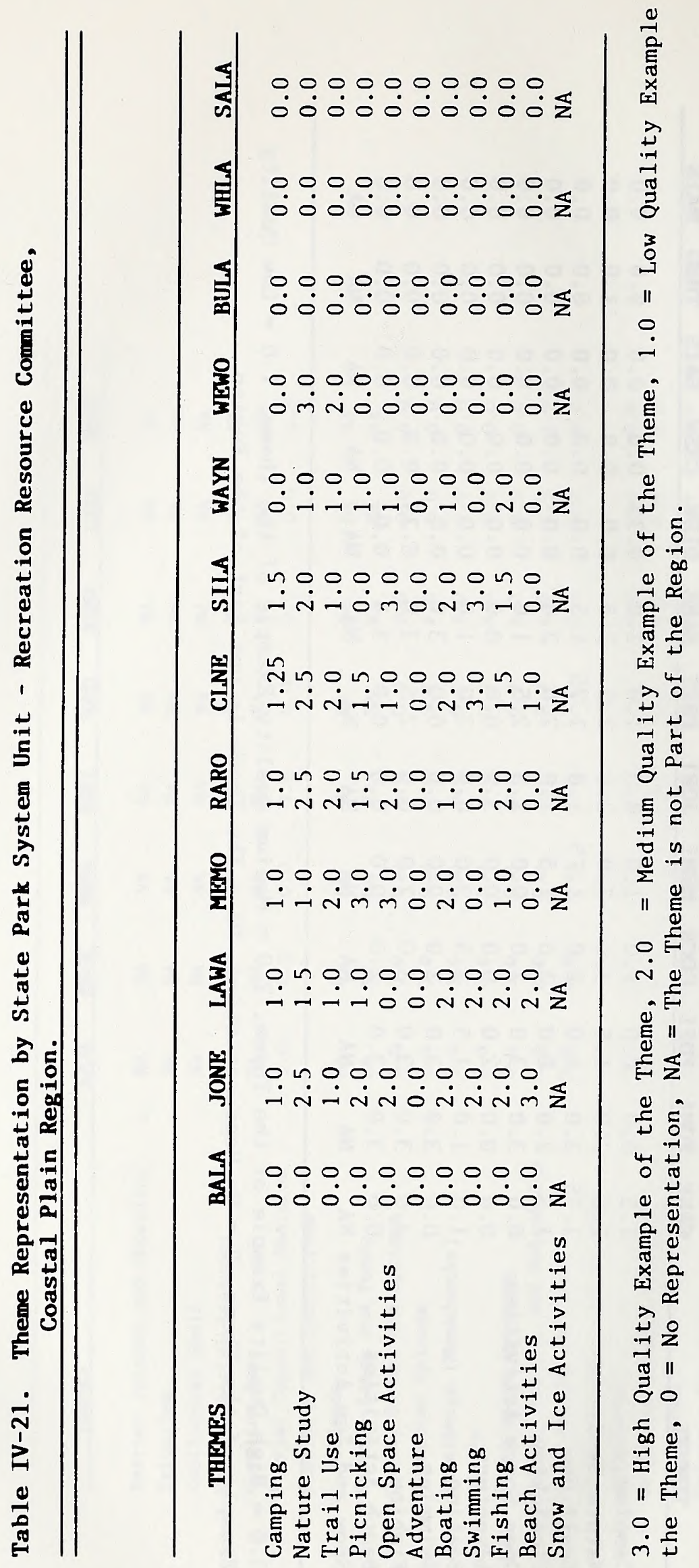




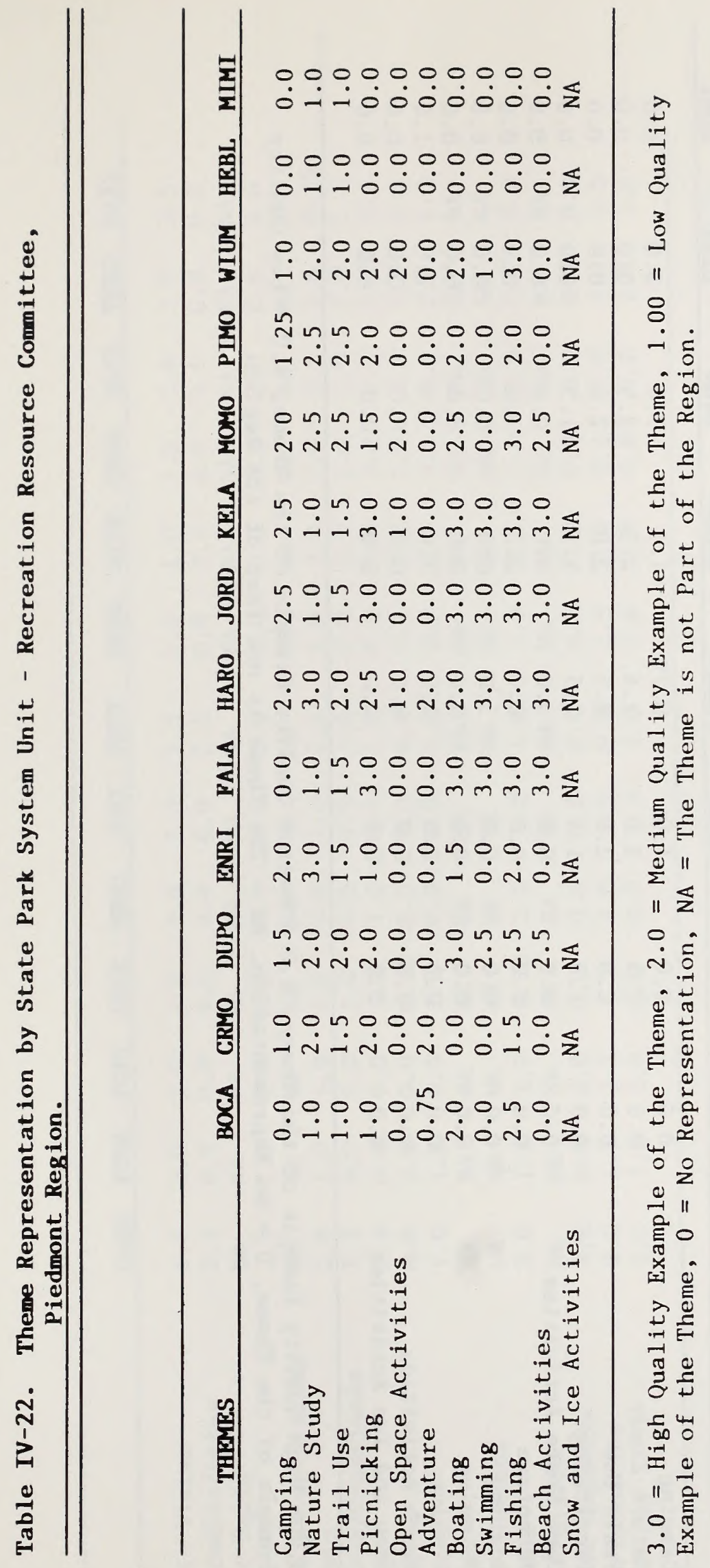




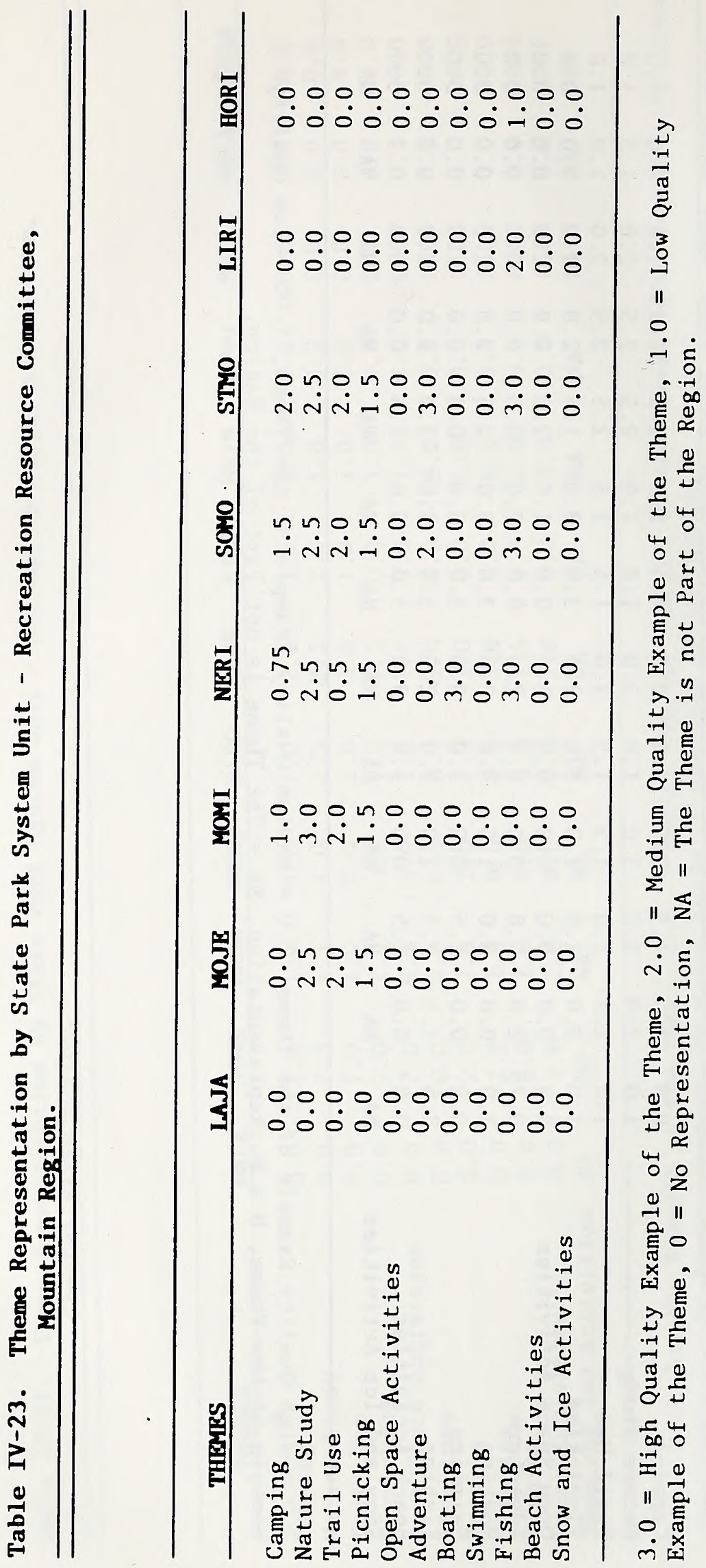




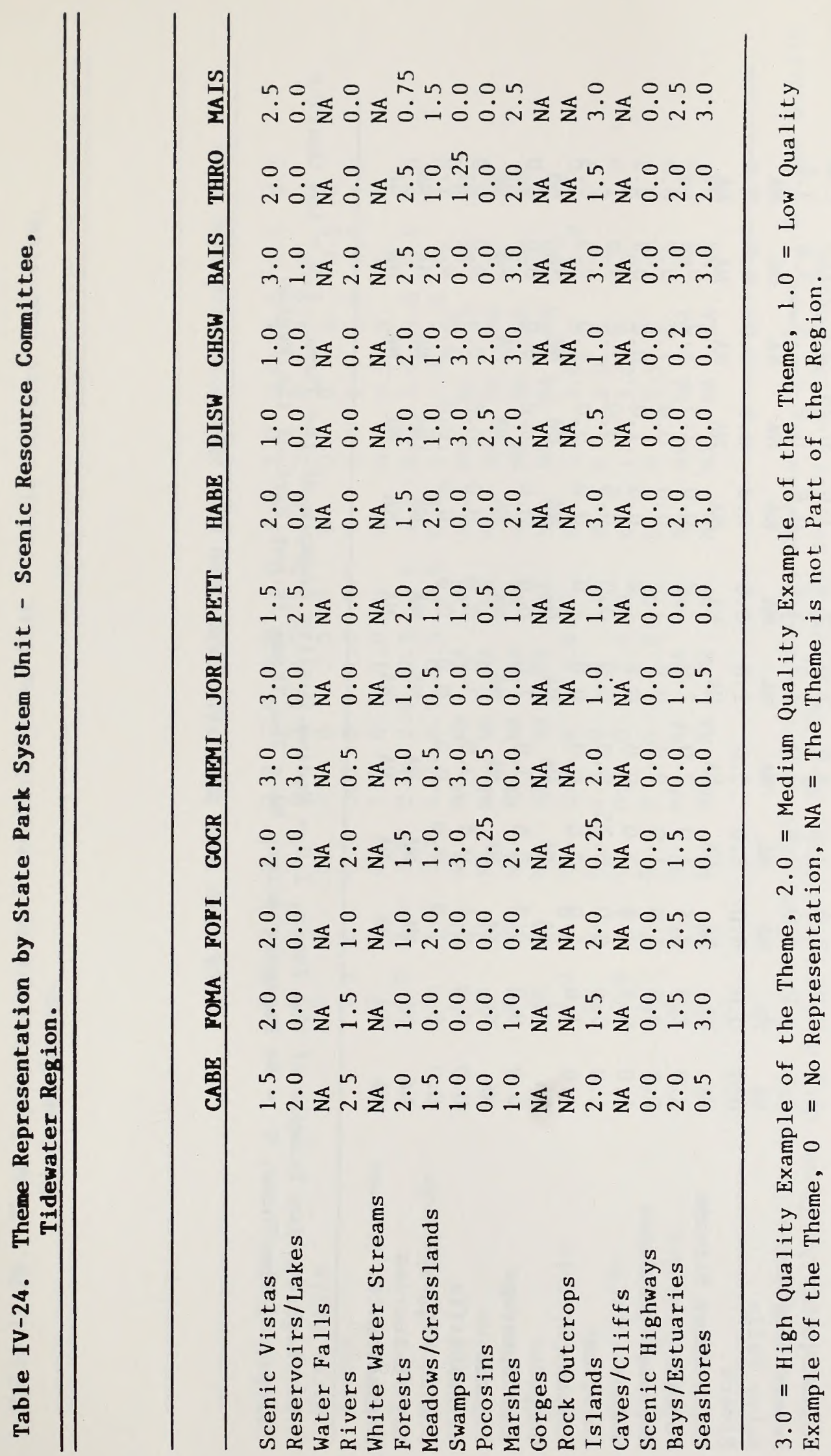




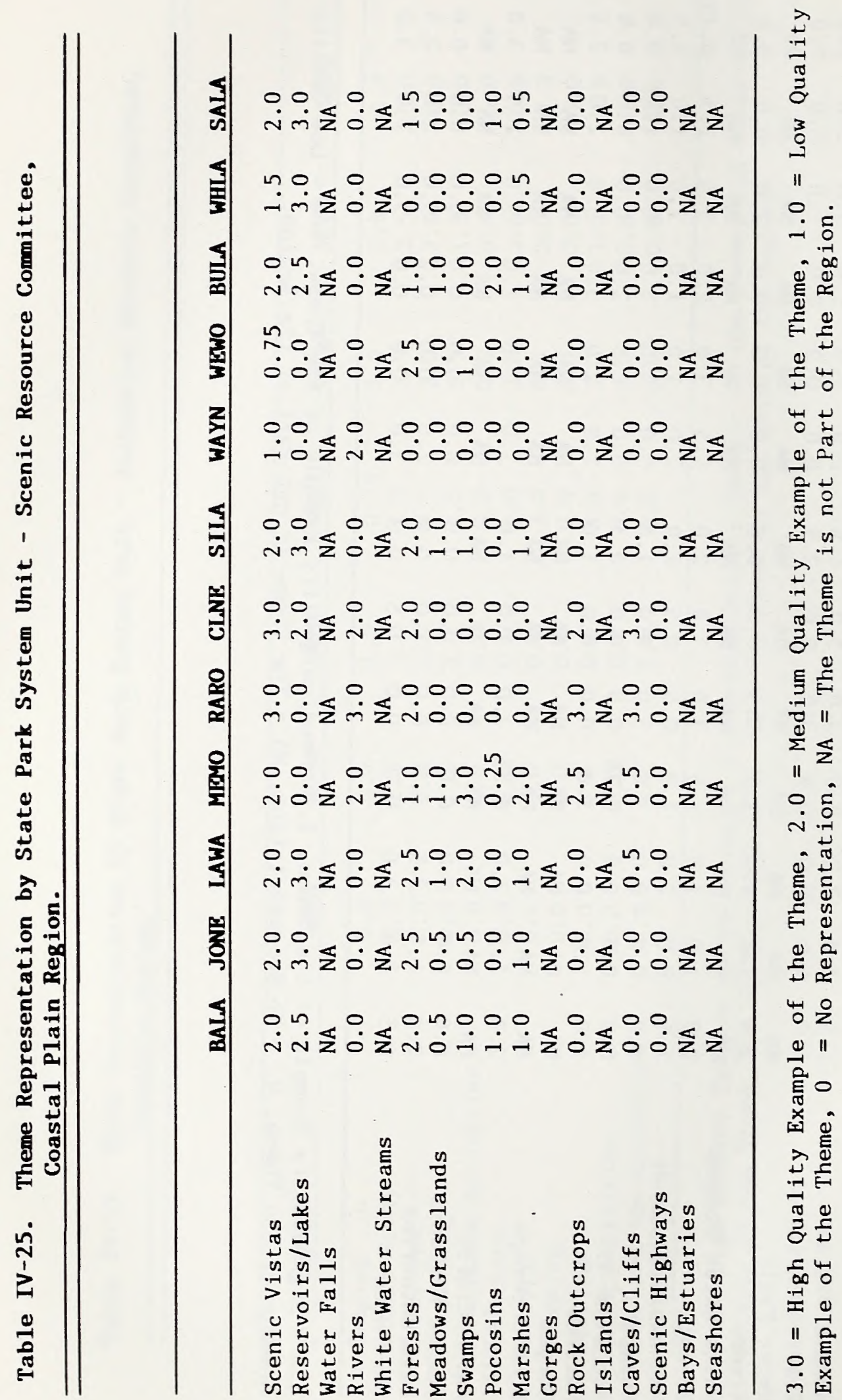


眨

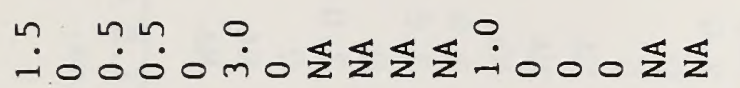

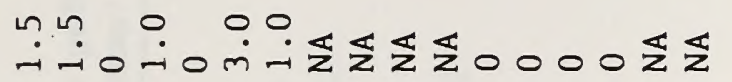

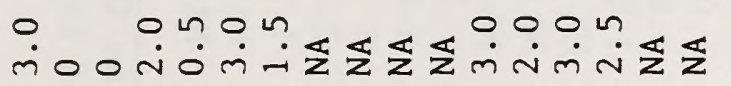

婇o

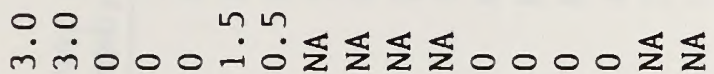

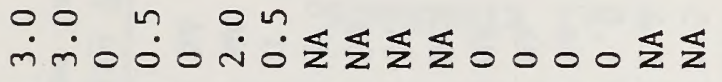

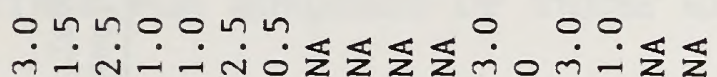

iñ

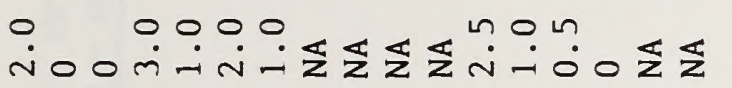

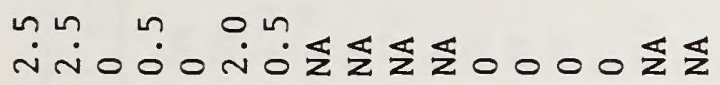

ñं0

iooño î.

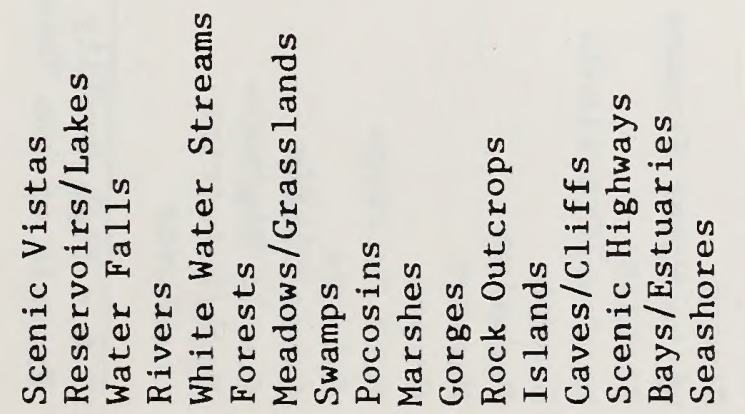

3
-1
-1
3
0
3
0

II

?

$-5$

$\stackrel{0}{0} \cdot \stackrel{0}{0}$

$\stackrel{2}{E}$

ขِ

40

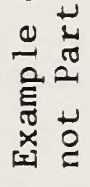

त)

Эั

ว

声

$\sum^{\infty} \|$

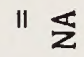

도

赵

है

ป

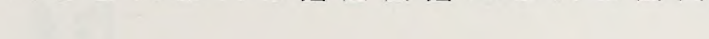

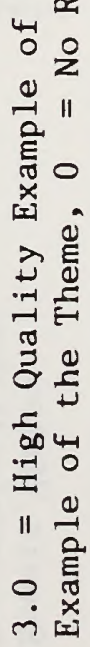




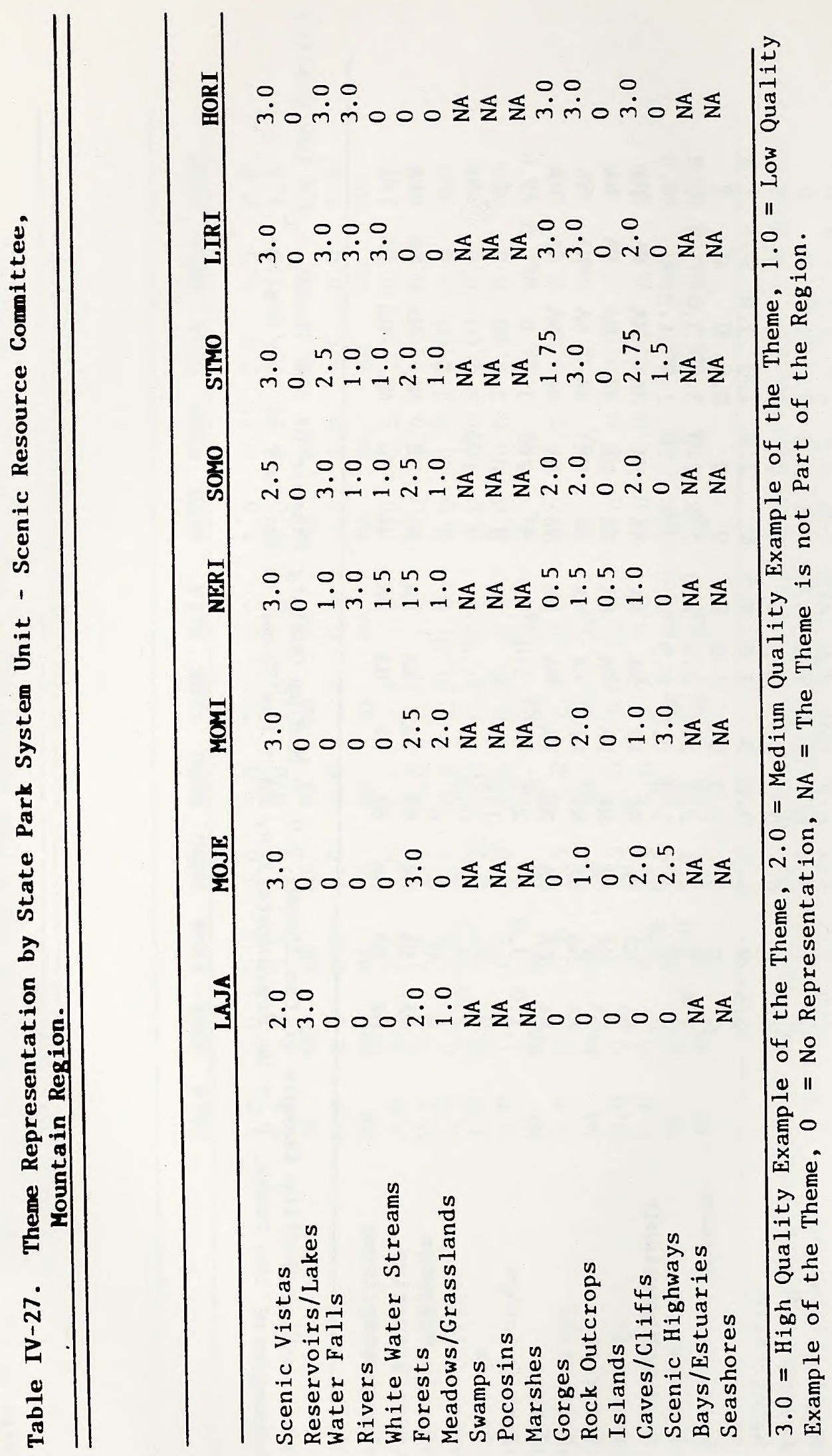


APPENDIX IV-5

COMMITTEE RATINGS FOR ADEQUACY OF THEME REPRESENTATION BY REGION 


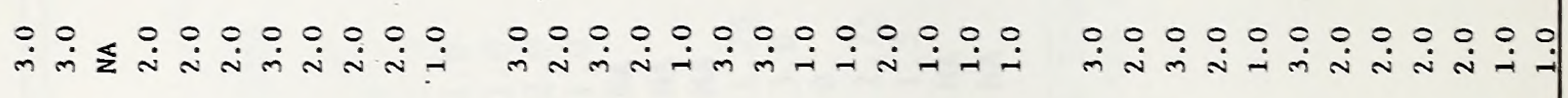

$\sqrt{20}$

(1)

(1)

$\sqrt{3}$

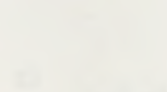

$\sqrt{2}$

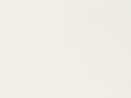

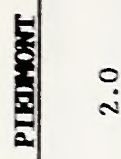

울 $+2$

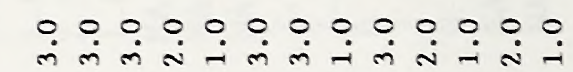

ம்

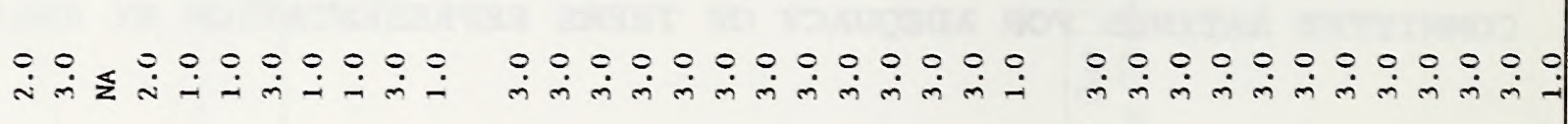

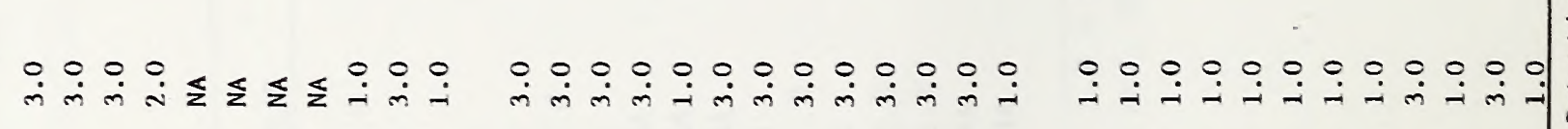

논
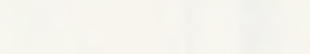

aี

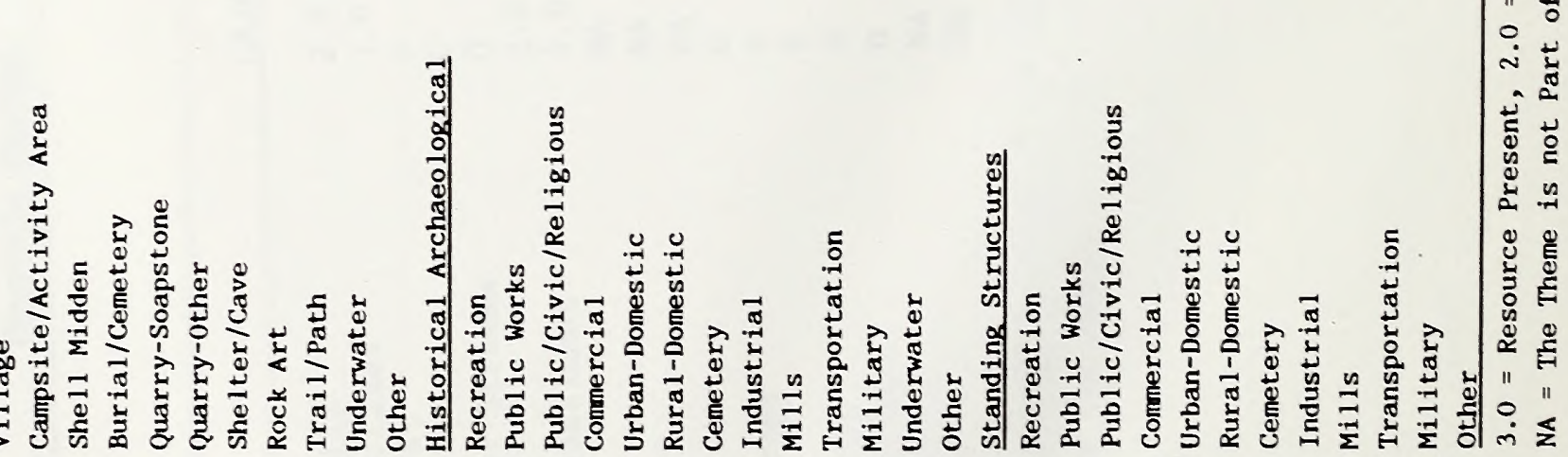




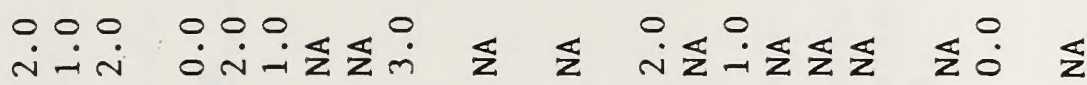

ż⿺辶்

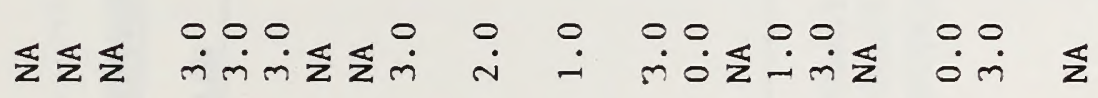

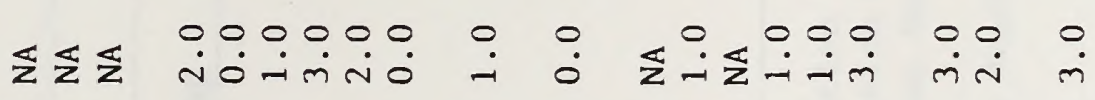

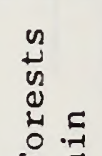

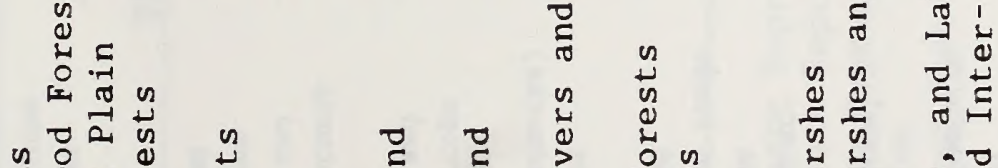

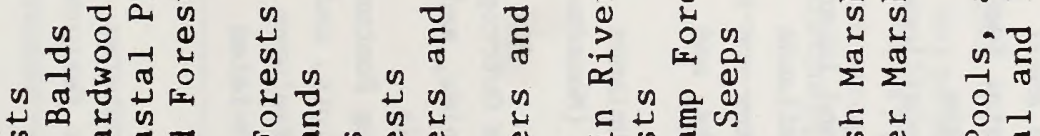
a

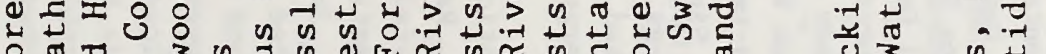

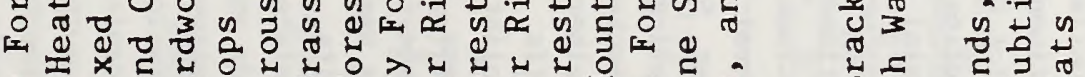

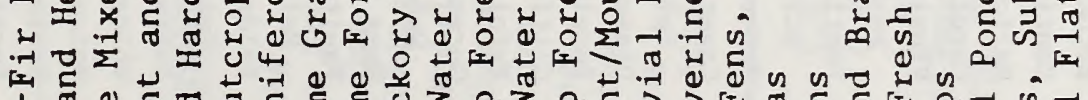
1 U

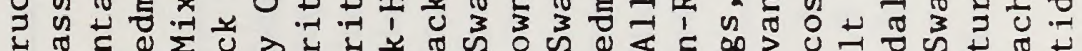

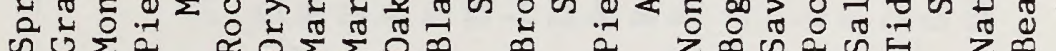

$\prod_{i=1} \prod_{i=1}$

is uे

कृ

$>>2$

$\ddot{\theta} \ddot{\circ} \geq$

믈

สิ สิ

$\lambda>$

$\pm \pm>$

$\Xi \pm$

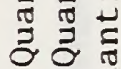

-

$\therefore>0$

$\pm \pm>$

苋券 $\frac{\pi}{\pi}$

$5 \div 3$

ڤ̊ํํㅇํㅇ

$\nabla \stackrel{0}{\supset}$

U)

$\begin{array}{lll}n & n & 0 \\ \pi & 0 & 0 \\ n & 0 & n\end{array}$

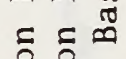

○

出

$\pi$ \%

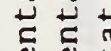

a

का जै ह ए

$\rightarrow$ u

वे क्षे

(1) \&

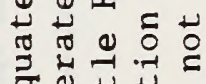

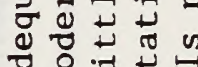

< $\frac{0}{2}$

II II II

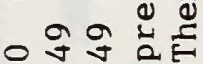

$\dot{\sim} \dot{\sim} \dot{\sim}$

m-1, 造

n n $\overrightarrow{0}$ "

ㄱं 


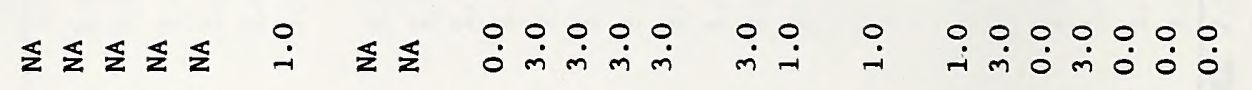

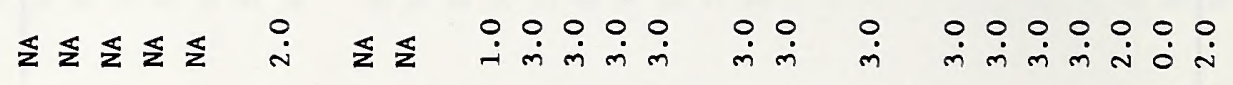

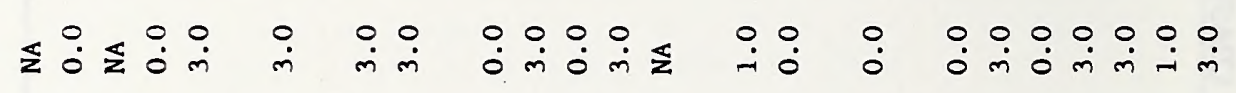

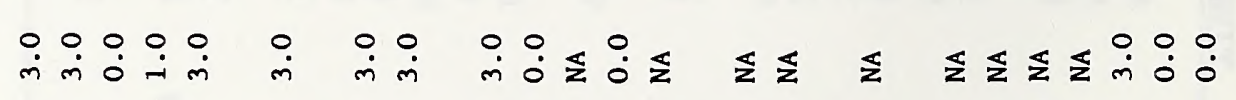

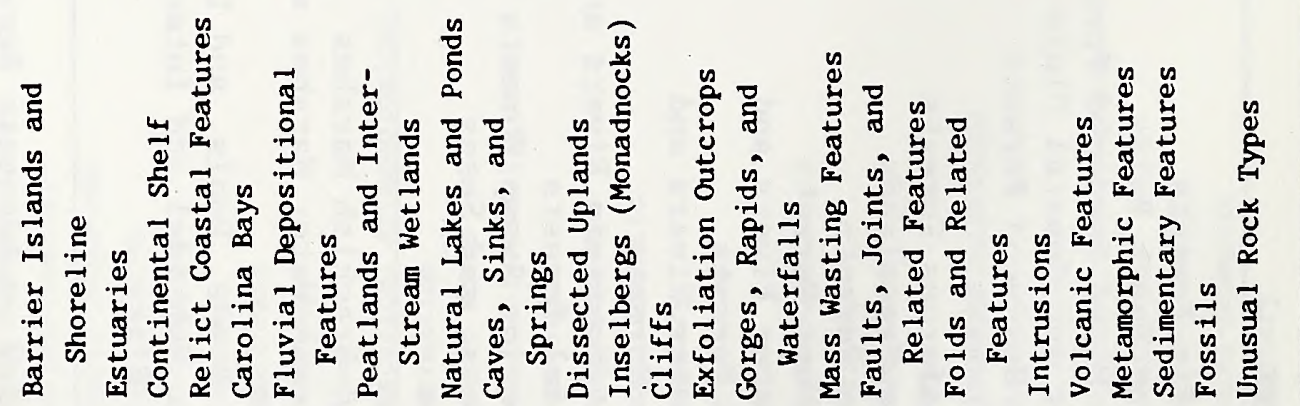

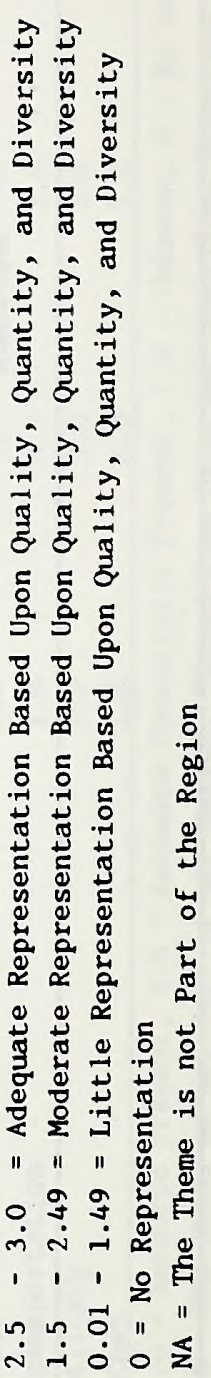




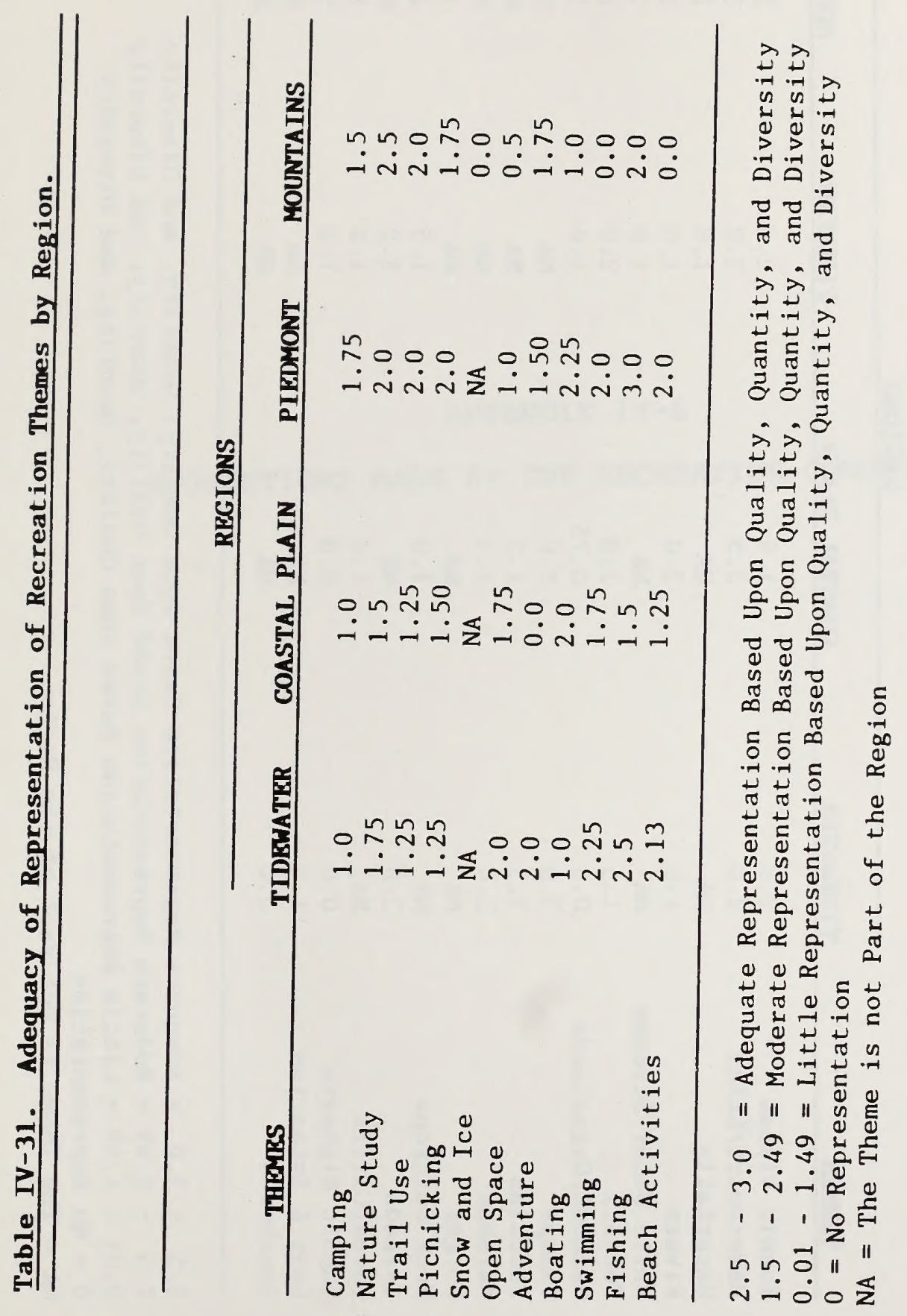




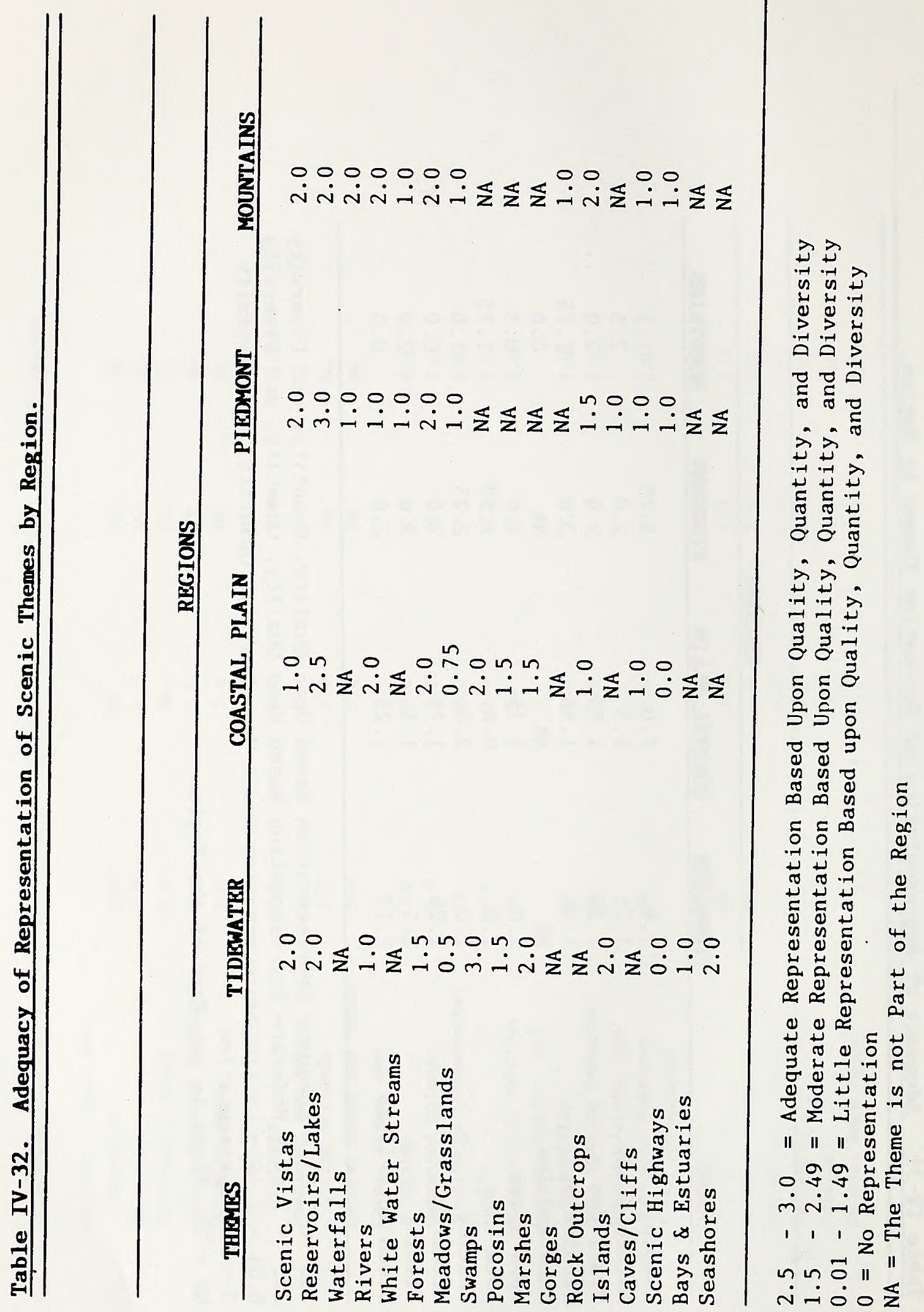


APPENDIX IV-6

SUGGESTIONS MADE BY THE RECREATION COMMITTEE 
In addition to evaluating state Parks System coverage of recreation resources, the recreation committee made additional suggestions for improving the system. Their suggestions are listed below.

Committee recommendations (20) are listed below:

1. Develop systemwide management policies applicable to all park units.

2. Develop a general management plan for each park unit establishing the purpose for the park unit and describing compatible recreation uses.

3. Produce a resource management plan, development plan and interpretation plan for each park units.

4. Plan for the continuing education of state park personnel in current state park management practices and provide travel and training budgets to implement the plan.

5. Plan for greater demands by municipal and county governments on state parks to provide areas and services that local governments cannot support, such as regional parks near metropolitan areas.

6. Track trends affecting outdoor recreation, including Federal legislation and policy.

7. Produce an operations manual for each park unit in cooperation with park field staff.

8. Describe a model park for each park-site classification identified in the state Parks Act (state parks, state natural areas, state recreation areas, state trails, state rivers and state lakes), perhaps including existing local, state and federal parks as examples.

9. Recommend a state role in meeting outdoor recreation needs in areas that are not currently being served by any other public recreation agency.

10. Use private concessioners to develop expensive capital improvement projects, if the development provides legitimate recreation activities for the visitor that are not appropriate for the state to supply.

11. Study the feasibility of resort parks in the recreation area site classification.

12. Develop policies describing appropriate recreation activities for each site classification identified in the state Parks Act. 
13. Develop a policy on hunting in the state Parks System.

14. Define quality standards for each recreation activity offered in the State Parks System.

15. Evaluate new activities that could occur in the state Parks System and track trends for new forms of recreation.

16. Evaluate the recreation needs of North Carolinians and the role of the State Parks system in meeting those needs.

17. Evaluate demographic trends affecting outdoor recreation preferences, including the growing number of senior citizens.

18. Ensure that the Recreation Committee that participates in the five-year update of the State Parks Systemwide Plan performs on-site evaluations of the State Parks System units.

19. Improve opportunities for nature study and interpretation through increased staffing, programming and literature.

20. Perform a thorough management study of the park system, including a review of staffing, hours of operation, visitor services and facilities, and maintenance practices. Consider using a consultant to perform the management study. 
STATE LIBRARY OF NORTH CAROLINA

||||||||||||||||||||||||||||||||||||||||||||||||

3 3091007954209 
Date Due

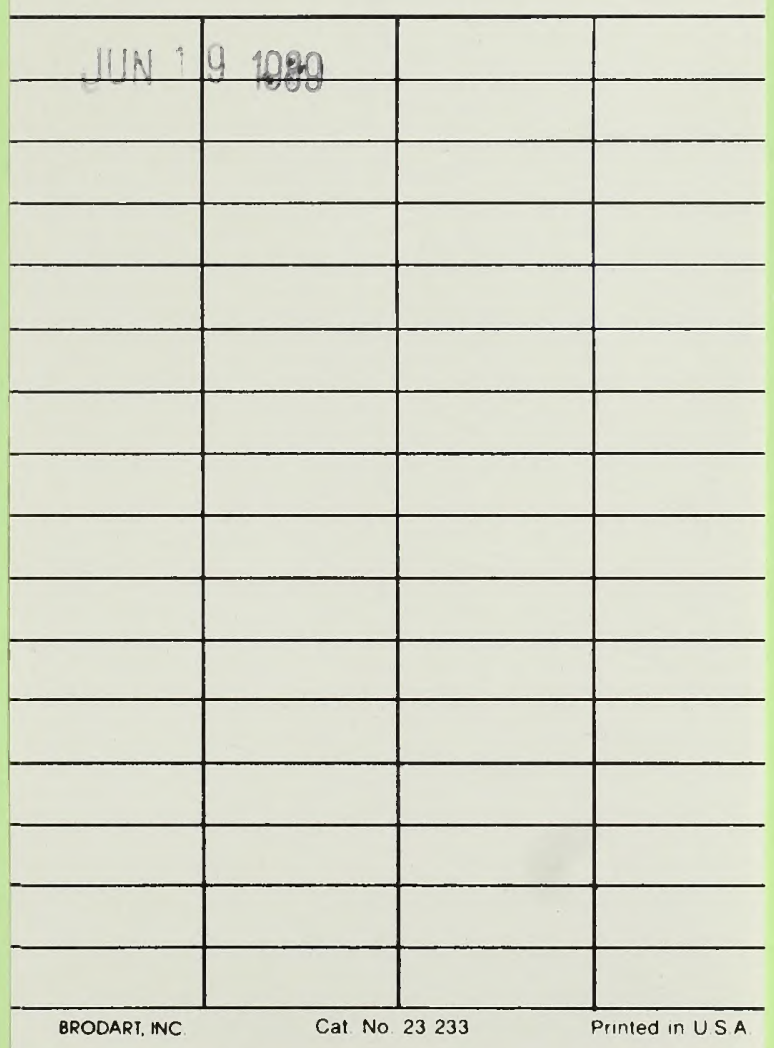

uU coples or tnis aocument were printed at the cost of $\$ 4200$ or $\$ 7.00$ per copy. 
